ROBERTO MATTA:

VISIONES E INFLUENCIAS DE UN GRABADOR DESCONOCIDO

Presentada por

Ana Gabriela Moreno Campos

Director

Fernando Evangelio Rodríguez

- Enero de 2014 - 

RESUMEN EN CASTELLANO: visiones e influencias de un grabador desconocido 1

RESUMEN EN VALENCIANO: visions i influències d'un gravador desconegut 3

RESUMEN EN INGLES: visions and influences of an unknown engraver. 5

AGRADECIMIENTOS .8

I. INTRODUCCIÓN 10

II. BIOGRAFÍA ROBERTO MATTA 16

II.1. Introducción 16

II.2. Vida y obra 17

II.3. Gráfico Familiar .50

III. VISIONES E INFLUENCIAS DE UN GRABADOR DESCONOCIDO 51

III.1. Matta y el arte. 52

III.2. El grabado y Matta 56

III.3. Realización de los grabados de Roberto Matta. 58

III.4. El contacto con los impresores en la realización de los grabados 58

III.5. Cómo se plantea el proceso del grabado Roberto Matta 59

III.6. Tradición en los atelieres de grabado 59

III.7. Que sucedió con las matrices utilizadas por Roberto Matta 60

III.8. Qué sucedió con los dibujos de Roberto Matta? 60

IV. ROBERTO MATTA EN LOS ATELIERES DE GRABADO. 61

IV.1. Atelier George Visat - Albert Dupont. 61

IV.2. Atelier Fernand Mourlot - Frank Bordas 63

IV.3. Relación Matta-Bordas: Atelier Frank Bordas. 66 


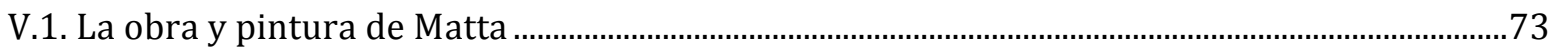

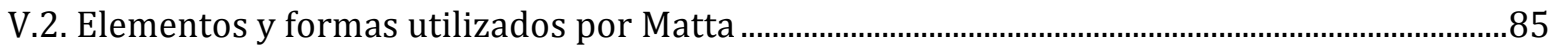

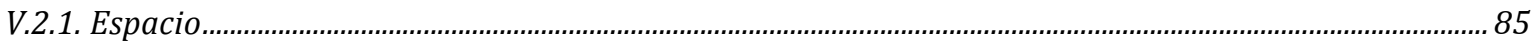

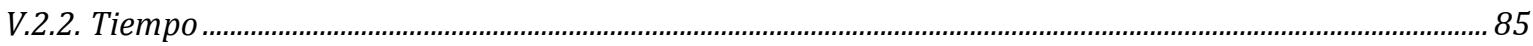

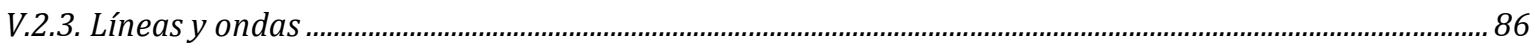

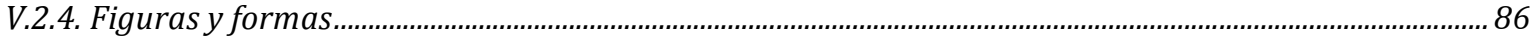

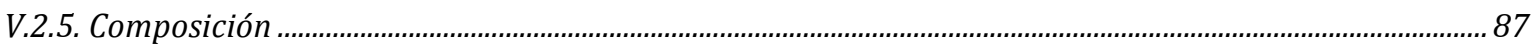

V.2.6. Los colores

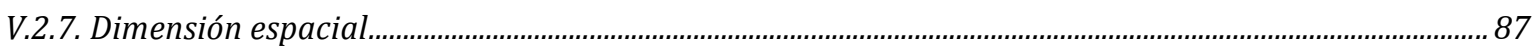

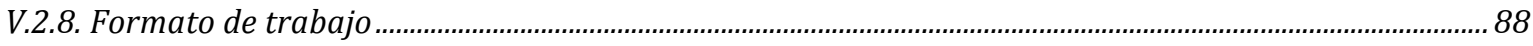

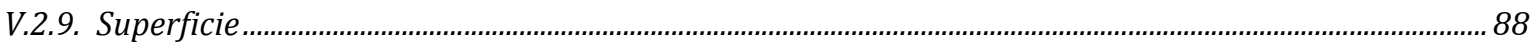

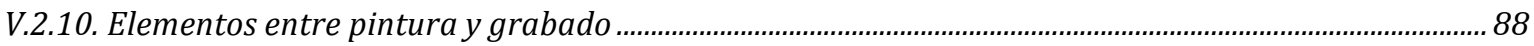

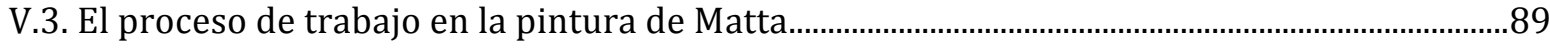

V.4. Periodos pictóricos y gráficos (grabados) de Matta.........................................................................91

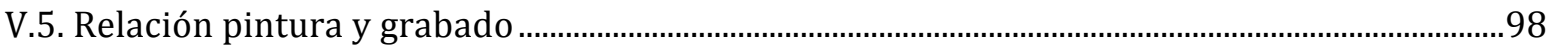

VI. OBRA GRAFICA DE ROBERTO MATTA : CATALOGACIÓN DE GRABADOS.....................103

VII. ANÁLISIS Y COMENTARIOS PARA LA COMPRENSIÓN DE LAS SERIES MÁS RELEVANTES DE LA OBRA GRÁFICA DE ROBERTO MATTA ……..........................................108

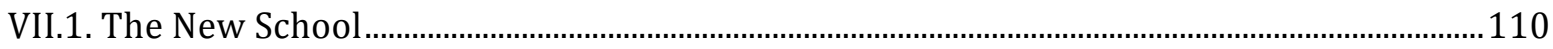

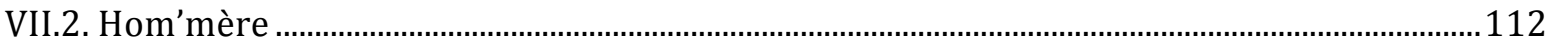

VII.3. El verbo Hommérica ……………..........................................................................................113

VII.3. El Gran Burundu-Burunda ha muerto ………….......................................................................115

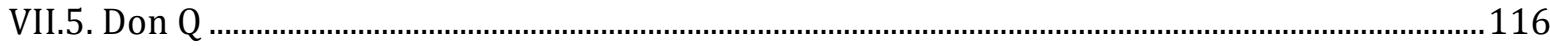

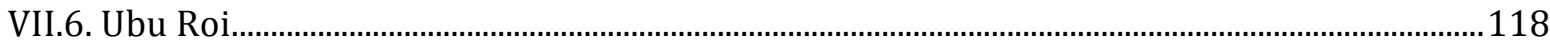


VIII. CATALOGACIÓN OBRAS GRAFICAS. ROBERTO SEBASTIAN MATTA ECHAURREN120 IX. CRONOLOGÍA DE LA VIDA Y OBRA DE ROBERTO MATTA ..................................................122

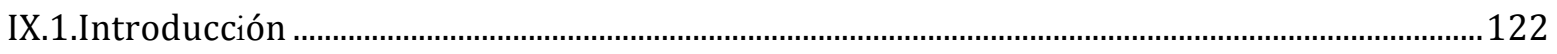

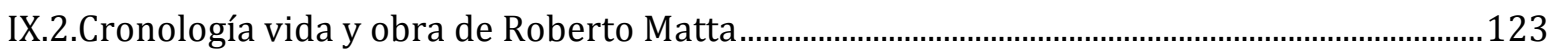

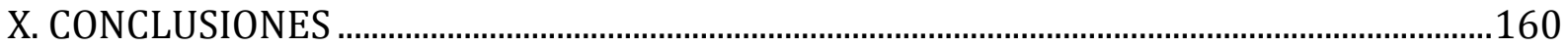

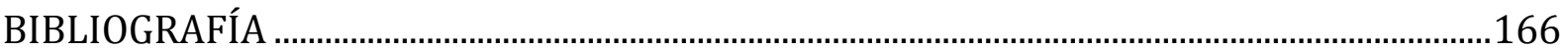





\section{Visiones e influencias de un grabador desconocido}

Roberto Sebastian Matta Echaurren, artista chileno surrealista, se conoce principalmente por su trabajo pictórico. Hoy, con la presente tesis se desea mostrar, explorar, investigar y deducir cómo este artista plástico principalmente pictórico, encuentra en el grabado un camino paralelo en el desarrollo de su obra, un camino bastante desconocido hasta este momento.

La tesis que se presenta parte desde los inicios de su vida y relata el transcurso en ella. Ya que todos estos factores históricos y personales son los que nos ayudarán a conocer y comprender quién es Roberto Sebastian Matta Echaurren, un artista que nunca se consideró chileno, un artista universal y un pintor al que nunca se le consideró grabador, a pesar de la cantidad y calidad de su obra gráfica. Estas últimas ideas se expresan y se exponen en profundidad posteriormente dentro de la presente tesis.

Luego, la investigación presenta una explicación del por qué es el título "Visiones e influencias de un grabador desconocido" para así poder vislumbrar cómo Matta entiende y vive el arte. Y lo más relevante cómo Matta descubre el grabado, dónde, cómo, cuándo, y por qué desea expresarse en esta área artística. Y se enuncia algo muy relevante que son los reconocidos “atelieres” de grabado en los que Matta eligió trabajar.

Posteriormente se indican los dos atelieres más significativos donde trabajó Matta que son: Atelier George Visat - Albert Dupont y Atelier Fernand Mourlot - Frank Bordas, haciendo un énfasis en la relación de Roberto Matta y Frank Bordas ya que es a partir de esta relación y los datos que nos entregaron las fuentes directas que podremos entender y comprender cómo Matta ve el grabado.

Todo lo descrito son las bases que nos guiarán a un segmento esencial de esta tesis que es el capítulo titulado "Pintura y Grabado". Dentro de este capítulo se aborda la pintura de Matta, su obra finalizada y su proceso dentro de ella. Con el resultado de toda esta información, hacemos un paralelo pictórico y gráfico, siendo lo fundamental establecer y esclarecer si existe o no una relación entre la pintura y el grabado de Roberto 
Matta.

La catalogación de los grabados es el núcleo de la presente tesis, siendo el primer catálogo técnico de la obra de Matta, a pesar de que esta investigación se comenzó hace mas de 5 años, aún no existe un catálogo técnico y razonado completo de su obra. Hoy se presenta un catálogo más completo que los existentes aunque no se posee aún la totalidad de su obra.

Posteriormente a la catalogación de sus grabados se presenta un análisis y comentarios para comprender la obra gráfica de este artista, en ella se eligen por grado de relevancia, a nivel histórico, personal o plástico seis obras gráficas, que son: The New School, Hom'mere, El verbo hommerica, El gran Burundi-burunda ha muerto, Don Q y Ubu Roi.

Para finalizar se ha considerado interesante presentar una cronología de la vida y obra de Roberto Matta que estarán unidas a los hechos históricos chilenos y mundiales para darnos un contexto político y social importante que se ve reflejado en las obras plásticas del artista.

Deseo mencionar que las "Visiones e influencias de un grabador desconocido" no es una investigación completa ni acabada, ya que, la finalización de este trabajo fue truncado por una integrante relevante de la familia del artista, no obstante se logra presentar casi un $80 \%$ de su trabajo gráfico. Siendo esta tesis el destape hacia esa parte que el artista escondía y protegía como un secreto y de la cual actualmente solo conocemos fragmentos para su comercialización.

Posteriormente a la primera revisión de la presente tesis por los investigadores externos, se han realizado ciertos cambios, uno es sobre la presentación del gráfico familiar y de la presentación de las fichas, todos los cambios son a nivel gráfico de la presente tesis.

Finalmente aquí esta!, se la presento hoy "Visiones e influencias para un grabador desconocido" un trabajo contra el miedo, contra el olvido, contra el secreto. 


\section{Visions i influències d'un gravador desconegut}

Roberto Sebastian Matta Echaurren, artista xilè surrealista, és conegut principalment pel seu treball pictòric. Avui, amb aquesta tesi es desitja mostrar, explorar, investigar i deduir com aquest artista plàstic, principalment pictòric, troba en el gravat un camí paral-lel en el desenvolupament de la seva obra, un camí bastant desconegut fins aquest moment.

La tesi que es presenta part des dels inicis de la seva vida i relata el transcurs en ella. Ja que tots aquestos factors històrics i personals són els que ens ajudaran a conéixer i comprendre qui és Roberto Sebastian Matta Echaurren, un artista que mai es considerà xilè, un artista universal i un pintor a qui mai s'ha considerat gravador, malgrat la quantitat i qualitat de la seva obra gràfica. Aquestes darreres idees s'expressen i s'exposen en profunditat posteriorment dins d'aquesta tesi.

Després, la investigació presenta una explicació de perquè el títol és Visions $i$ influències d'un gravador desconegut, per així poder entreveure com Matta entén i viu l'art. I allò més rellevant és com Matta descobreix el gravat, on, com, quan i perquè desitja expressar-se en aquesta àrea artística. I s'enuncia quelcom molt rellevant que són els reconeguts atelieres de gravat on Matta va elegir treballar.

Posteriorment s'indiquen els dos atelieres més significatius on treballà Matta, que són: Atelier George Visat-Albert Dupont i Atelier Fernand Mourlot-Frank Bordas, fent èmfasi en la relació de Roberto Matta i Frank Bordas, ja que a partir d'aquesta relació i de les dades que ens oferiren les fonts directes podrem entendre i comprendre com Matta veu el gravat.

Tot allò descrit són les bases que ens guiaran a un segment essencial d'aquesta tesi i que és el capítol "Pintura i Gravat". Dins d’aquest capítol veurem la pintura de Matta, la seva obra finalitzada i el seu procés dins d'aquesta. Amb el resultat de tota aquesta informació, fem un paral·lel pictòric i gràfic, sent fonamental establir i esclarir si existeix o no una relació entre la pintura i el gravat de Roberto Matta. 
La catalogació dels gravats és el nucli d'aquesta tesi, sent el primer catàleg tècnic de l'obra de Matta. Malgrat que aquesta tesi va començar fa més de cinc anys, encara no existeix un catàleg tècnic i raonat complet de la seva obra. Avui es presenta un catàleg més complet que els existents, encara que no es posseeix la totalitat de la seva obra.

Posteriorment a la catalogació dels seus gravats, es presenta una anàlisi i uns comentaris per a comprendre l'obra gràfica d'aquest artista. En ella s'elegixen per grau de rellevància a nivell històric, personal o plàstic sis obres gràfiques, que són: The New School, Hom'mere, El verbo hommerica, El gran Burundi-burunda ha muerto, Don Q i Ubu Roi.

Per finalitzar, s'ha considerat interessant presentar una cronologia de la vida i l'obra de Roberto Matta, que estaran unides als fets històrics xilens i mundials per a donar-nos un context polític i social important que es veu reflectit en les obres plàstiques de l'artista.

Desitge mencionar que les Visions i influències d'un gravador desconegut no és una investigació completa ni acabada, ja que la finalització d'aquest treball fou truncat per una integrant rellevant de la família de l'artista; no obstant això, s'aconsegueix presentar quasi un $80 \%$ del seu treball gràfic. Aquesta tesi destapa eixa part que l'artista amagava i protegia com un secret i de la que actualment sols coneguem fragments per a la seva comercialització.

Posteriorment a la primera revisió d'aquesta tesi per part dels investigadors externs, s'han realitzat certs canvis: un d'ells té a veure amb la presentació del gràfic familiar i de la presentació de les fitxes; tots els canvis són a nivell gràfic d'aquesta tesi.

Finalment ací està, presento avui Visions i influències d'un gravador desconegut, un treball contra la por, contra l'oblit, contra el secret. 


\section{Visions and Influences of an Unknown Engraver}

Roberto Sebastian Matta Echaurren, Chilean surrealist artist, is principally known for his painting. Today, through this thesis, I wish to show, explore, investigate and deduce how this artist, primarily a painter, is found to have developed his engraving skills in parallel, in a manner unknown until now.

The thesis begins by studying the early period of his life and relates what course it took. Since all of these historical and personal elements help us to know and understand who Roberto Sebastian Matta Echaurren, an artist who did not consider himself Chilean, a universal artist and painter, never considered as an engraver - despite the quantity and quality of his artwork. These ideas are expressed and investigated in depth later in the thesis.

From then onwards, the investigation presents an explanation for the title "Visions and Influences of an Unknown Engraver" providing an understanding of how Matta understood and lived art. The most relevant is how Matta discovered engraving, where, how and when and why he wanted to express himself through this medium. Highlighted here is an important point, the "Atelieres" of engraving where Matta chose to work.

Later, we look at the most significant of the Atelieres where Matta worked, who are: Atelier George Visat - Albert Dupont and Atelier Fernand Mourlot, with particular attention paid to the relationship between Roberto Matta and Frank Bordas, from where we begin to understand how, through direct sources, Matta approached his engraving.

Everything described up to this point is the foundation that guides us to an essential part of the thesis, the chapter entitled "Painting and Printmaking." In this chapter we will look at Matta's painting, his finished work and the process within. By correlating all of this data, we construct a parallel between the pictorial and graphic, establishing and clarifying if there genuinely existed a direct relation between the painting and engraving of Roberto Matta. 
The engravings catalogue is the heart of the thesis; being the first technical catalogue of Matta's work, despite this thesis having been started more than five years ago. Until now there has not existed a complete, technical and reasoned catalogue of his work. Through this thesis is presented the most comprehensive study of his work, although it does not yet contain the entirety of his artwork.

After the documentation and study of his engravings, an analysis is presented with commentary in order to understand the graphic work of this artist, within which we choose by relevance, in a historical context, either personal or public, six graphic artworks, which are; The New School, Hom'mere, El Verbo Hommerica, El Gran BurundiBurunda ha Muerto, Don Q y Ubu Roi.

To conclude it was considered noteworthy to present a chronology of the life and work of Roberto Matta, linked to Chilean and global historical events, to give us a social political context which reflects directly upon his artwork.

I want to mention that "Visions and Influences of an Unknown Engraver" is not a completely comprehensive investigation, since the completion of this work was cut short by a member of the artist's family. It does however manager to present roughly $80 \%$ of his artwork. Since the objective of this thesis was to uncover work that the artist himself hid and protected as a secret, we can only know fragments of the total body of work created.

Following the first external review of the thesis by external researchers, we have made some changes, one being the graphical presentation and display of the works. To date, all of the changes have been at the graphical level.

Finally, here it is! Today is presented "Visions and Influences of an Unknown Engraver" a work against fear, against loss, against secrecy. 



\section{AGRADECIMIENTOS}

1 mi papá y mi mamá, Javier Moreno y Blanca Campos, por haberme incentivado
desde pequeña a perseguir mis sueños y a luchar por ellos. Gracias por creer en mi y dejarme perseguir mis anhelos!.

A mi esposo, Odon Thiébeauld por su paciencia, su compañía y sus constantes motivaciones para finalizar esta tesis, sobre todo al final de este proceso.

A mis hermanos, Daniel y María José por su paciencia cuando utilicé el computador en la casa de los papas y por dejarme tranquila estudiar.

A Humberto Nilo, por creer en mi y en mi trabajo, apoyarme a dar este gran paso de dejar Chile.

A Guillermo Nunez, por darme las primeras herramientas artísticas sociales.

A Carlos Plascencia por haberme incentivado a venir a Valencia, a seguir estudiando y por su puesto a encontrar tantos caminos nuevos que he aprovechado al máximo.

A Franck Bordas por haber creído en mi, y porque sin conocerme, abrió sus puertas para recibirme y darme las primeras herramientas, las bases de esta investigación y los contactos, muchas gracias Franck, sin ti nada hubiese sido posible.

A Ramuntcho Matta, por su humildad y generosidad ante una desconocida como yo, que quiere saberlo todo, gracias infinitas por darme la posibilidad de ver, observar e investigar el trabajo de tu padre, y por supuesto muchas gracias por darme la posibilidad de conocerte y reencontrarme contigo.

A Gino Diomaiuto, porque no solo tus palabras sobre Matta Gino me han ayudado, sino tus palabras de vida, nuestras conversaciones y tu cariño gratuito hacia una desconocida. Muchas, muchísimas gracias.

A Albert Dupont, por la sinceridad y franqueza en tus sentimientos hacia la relación que tuviste con Matta, y por haberme enseñado no tan solo los grabados de Matta, sino la esencia de este artista, la poesía que genera su obra. Gracias Albert por abrirme y enseñarme tu taller, un taller que llevaré en mi memoria muy a mi pesar de su cierre. 
A Michael Woolworth, por sus declaraciones que sin ellas no hubiese dado en el clavo de esta investigación, que fueron vitales para posteriores reflexiones y conclusiones.

A Pititi y Geoffroy por su preocupación sin limites, su disponibilidad en todos los ámbitos y su paciencia, ante la vaca chilena.

A Verónica Ariza y Cándido Valadez, por su amistad, generosidad sin limites, su paciencia y la disponibilidad inmediata para resolver trámites.

A mis compañeros de U.P.V., Vero, Cándido, Chi-Chang, Xaro, Carles, Horte, Waldo, Tania, y Cano porque sin las conversaciones y comentarios hubiese sido imposible tener ganas de finalizar este periodo.

A Guido Garaycochea, por las búsquedas de información en EE.UU. y su afecto!!

A Rosita y a Pilar las secretarias de la U.P.V., por todos los dolores de cabeza que les provoque y por todos los papeles que debía de llenar y entregar.

A Lara Gogollos por su traducción al Valenciano, en un ultimo minuto, miles de gracias!.

A Louis Mannig, por la gentileza de hacer la traducción en inglés a miles de kilómetros!!, gracias Louis!.

Y con especial dedicación a mi profesor tutor, FERNANDO EVANGELIO RODRIGUEZ, porque sin su compañía, disponibilidad, gentileza y franqueza no hubiese podido terminar esta tesis. Y por sobre todo, por su labor de profesor, por recordarme lo que significa nuestra profesión y porque de todos, debería ser el mejor profesor del mundo, gracias Fernando por todooooooo. 


\section{Introducción}

l plantearse trabajar sobre Roberto Matta, desde la perspectiva del grabador, se
pensó que la búsqueda sería fácil y segura, ya que se encuentra suficiente bibliografía sobre su obra gráfica y aún más sobre su vida y su trayectoria artística. Sin embargo el investigar va más allá, según se entiende, del solo hecho de recabar información y reescribirla asimilando o reflexionando acerca de lo encontrado. El investigar es, para este proyecto, el buscar los orígenes de la bibliografía encontrada, es ir en la búsqueda de los datos, fechas, procesos, formas de expresión, comentarios y verificarlos, siendo la verificación lo más relevante en un proceso que pretenda tener rigor científico ya que se puede ver con profundidad lo que hay dentro de estos escritos, porque en ellos mismos existe un grado, a veces fascinante y otras muchas más veces pernicioso, de querer mitificar a un artista, su obra y en especial, su vida personal que se entrelaza con el trabajo plástico. En el caso de Matta, prácticamente totalidad de la bibliografía existente pretende colaborar con el mito, esto, en términos prácticos implica la anulación o invención de datos.

El por qué se desea entonces aclarar que la verificación es relevante en esta investigación es porque esta tesis no pretende colaborar con el mito que rodeó y que fue Matta, ni tampoco el desmitificarlo. Se pretende, sí, ser lo más claro y objetivo con la información entregada. La que se encuentra verificada, que es la mayoría, y la que no se encuentra verificada, o de la que no se poseen datos claros, todo ello se especifica y se hace mención en este trabajo.

Pues bien, se hace esta tesis sobre Roberto Matta con la idea de valorarlo como artista, y sobre todo como grabador, ya que en su país de origen se desconoce gran parte de su vida y obra desde su partida de Chile, quizás causado por el hecho de que él no se sintiese chileno. 
En este trabajo se investiga su obra gráfica con el objetivo de desvelar a Matta grabador en un mismo campo común, que me otorga un grado de seguridad para comenzar a conocerlo en profundidad, pero sobre todo el grabado se investiga porque se desconocen sus creaciones en esta área, tanto a nivel artístico como popular, es entonces un área virgen a nivel de investigación, puesto que bibliográficamente sólo se poseen los catálogos de las exposiciones gráficas del artista, lo que es sumamente atrayente, ya que me obliga a buscar los orígenes de las creaciones de sus obras, para conocer y comprender al grabador y al artista que es él, y me otorga también las armas o la posibilidad para definir o citar a Matta como un grabador además de como pintor, que es el área por la que ha sido más conocido y reconocido. Del mismo modo, el provecho que me da el investigar sus grabados y hacer una catalogación es amplísimo no tan solo para dar otra visión de Matta, sino también en el mundo del grabado, ya que a mi parecer las obras de Matta contribuyen técnicamente al grabado en sí, y plásticamente al mundo del arte.

De esta manera la investigación intenta ser un aporte hacia el mundo del grabado y del arte en general, ya que se entrega una nueva visión sobre el artista y se pretende mostrar que Matta hizo aportes al mundo del grabado hasta ahora desconocidos. Del mismo modo esta tesis pretende ser útil no tan solo a las personas que deseen saber más de este artista o más del grabado en sí, sino que de ella pueda obtener provecho también cualquier lector que desee informarse, tanto sobre Matta como de su obra gráfica.

Una parte fundamental de esta tesis tanto a nivel de aporte como de utilidad es el catálogo técnico de sus obras, que pretende servir en especial a investigadores y coleccionistas de la obra gráfica de Matta, pero también a lectores que tengan interés en informarse de este artista, ya que en este catálogo se presentan datos muy precisos y poco conocidos de sus obras de los que se podrían deducir, por ejemplo, la forma de trabajo de Matta, la relación de ello con su vida, el modus operandi de sus creaciones 
gráficas, que también abre la posibilidad de establecer una relación ente sus grabados y su obra pictórica, pudiendo apreciar si existen influencias mutuas entre ambas formas de expresión.

La tesis que se presenta es el resultado de una metodología compleja en la que ha sido decisiva la recopilación de antecedentes acumulados, fundamentalmente, a través de entrevistas realizadas a las personas que tuvieron alguna relación con Matta y que en algunos casos trabajaron para y con el artista, además de las entrevistas que él otorgó durante su vida. Cabe resaltar como algo especialmente apreciable, los encuentros realizados en los talleres en los que Matta trabajó y participó activamente, como el taller de Franck Bordas, Albert Dupont y Michel Woolworth, de los que se obtuvo información práctica sobre las estampas, así como acerca de la actitud de Matta frente al grabado. A esto se le une las informaciones obtenidas de su hijo Ramuntcho Matta, quien aporta una serie importante de datos personales del artista, como también la apreciación de un buen número de estampas que no se encontraban en los talleres anteriormente mencionados. Por último, los datos prácticos de la forma cómo Matta trabajó en la litografía fueron estudiados en las reuniones con Gino Diomaiuto. Estas fuentes de información son, sin lugar a dudas, de primera mano, lo que le da a este trabajo un respaldo interesante, ya que todas estas personas no solo colaboraron con sus testimonios para la elaboración de esta tesis, sino que generosamente fueron ellas mismas quienes me dieron la posibilidad de ver, observar, apreciar y acceder a toda la información necesaria de cada uno de los grabados, afiches, libros de artistas y asimismo el asistir a los atelieres en que creó e imprimió el artista.

A toda esta información se le anexó todo lo encontrado en los dos únicos libroscatálogos que existen sobre sus grabados, más los libros biográficos y los dedicados a su obra pictórica, como también todos los catálogos de las exposiciones realizadas por este artista. El conjunto de la información fue encontrada en numerosas bibliotecas públicas y privadas, entre las que cabe destacar como más relevantes la Biblioteca del Instituto 
Valenciano de Arte Moderno en Valencia (España,) la Biblioteca Richelieu en París (Francia) y la Biblioteca del Museo de Bellas Artes de Santiago de Chile.

En su formato definitivo la investigación se ha estructurado en siete capítulos. El primero entrega la vida y obra del de Roberto Matta Echaurren, incluyendo reflexiones del artista sobre los acontecimientos de su vida, más un gráfico familiar. En el segundo y tercer capítulo, se propone en forma general ver y rescatar a Roberto Matta como grabador, no como pintor, haciendo mención que dentro del transcurso emprendido por Matta en el grabado, se estudiaron las influencias recibidas y las visiones que el artista desarrolló dentro de la especialidad, las que resultan particularmente interesantes, dado que fue un artista dedicado la mayor parte de su vida a la pintura, y que en un momento se plantea como grabador. ¿Qué lleva o gatilla a Matta a trabajar con una técnica tan diferente y poco masiva como lo es el grabado? Es una de las interrogantes propuestas en la investigación. Asimismo, en el tercer capítulo se hace una referencia a cada uno de los atelieres en que trabajó Matta una gran parte de su obra gráfica.

El cuarto capítulo presenta una visión global de la pintura y grabado de Matta que será un referente aún mas sólido para poder entender las obras gráficas del artista, haciendo énfasis en los elementos utilizados por Matta, el cómo los proyecta sobre las superficies y los periodos de creación ambas técnicas. Estableciéndose la intención del saber si, por una parte hubo una influencia desde la pintura hacia el grabado o viceversa, y a la vez tratar de responder la interrogante más importante: saber si Matta es realmente un grabador en un mundo plástico donde su obra pictórica es la más conocida y valorada.

El quinto capítulo, aborda la realización de la primera catalogación de la obra gráfica de Roberto Sebastián Matta, en la que además, se anexa una ficha técnica para cada una de las series gráficas realizadas por el artista. Sin embargo, se debe señalar que estas fichas no contienen la totalidad de su obra grabada, aunque sí la inmensa mayoría, ya que, a pesar de las intensas búsquedas hechas, nos encontramos frente a las barreras 
impuestas por una fuerza mayor, que nos amenaza en esta búsqueda seriamente y que en términos prácticos no se puede hoy encontrar más información sobre los grabados de Matta, ya que su última esposa, Germana Ferrari, se encuentra realizando un catalogo técnico. Sintiendo entonces que este trabajo es una competencia para su propio catálogo comercial.

El sexto capítulo comenta algunas de las series gráficas más relevantes en el área del grabado, poniendo énfasis en la motivación que tuvo el artista para generar la creación de cada serie.

Finalmente, el séptimo capítulo entrega una cronología de la vida y obra de Roberto Sebastián Matta Echaurren, para proporcionar una información general sobre él, su obra y sobre los hitos relevantes en la historia de Chile y en la del mundo. Con la idea de que el lector pueda situarse en la contingencia social que rodeo al artista y que es lo que motiva su creación, logrando establecer así un nexo entre la historia, la vida personal y artística de Roberto Matta.

En último lugar, se desea hacer referencia al título propuesto “ Matta: Visiones e Influencias de un grabador desconocido" que fue creado con la idea de plantear primeramente que Roberto Sebastián Matta Echaurren fue un grabador además de pintor, y así poder rescatar la obra gráfica (grabados) del artista. Para ello se utilizaron las palabras visiones e influencias, porque se piensa que bajo estos dos términos se puede llegar a entender el desarrollo y creación de sus obras gráficas, como también el transcurso a nivel personal y artístico que tiene Matta con respecto a sus pares, los artistas e impresores.

Asimismo, se quiere aclarar que la tesis que se presenta no trata de ninguna forma o modo, de ser enfocada hacia una investigación sobre y en la línea de un historiador del arte. Ya que se comprende que una Tesis Doctoral en Grabado y Estampación, debe 
proponer y desarrollar la innovación en el tema y entregar un escrito nuevo, diferente, y que en lo posible sea un aporte hacia otros. Es por ello que sabemos de la probabilidad que en la primera lectura pensemos que el trabajo entregado es solo una base histórica de Matta y de su obra gráfica. No obstante, el planteamiento de la tesis es innovador porque no existe bibliográficamente ningún escrito completo que pretenda rescatar a Matta como grabador por medio de su obra gráfica. Sólo existen actualmente dos catálogos como se ha mencionado anteriormente, en los que se recopila parte de su obra gráfica, que fueron realizados en diferentes periodos de creación del artista y desarrollados principalmente de una manera cualitativa, centrada solo en el grabado sin crear relaciones con su desarrollo pictórico. Entonces, lo que contiene esta investigación es el propósito de crear el primer catálogo técnico completo de las obras gráficas de Roberto Sebastián Matta Echaurren, inexistente hasta hoy, el que se presenta acompañado de un análisis de parte de sus obras, de la relación entre la pintura y el grabado, así como el proceso de creación, los modos empleados, los tiempos, las decisiones y el aporte que hizo como artista hacia el mundo del grabado, todo ello en conjunto pretende ser una contribución artística y educacional en el descubrimiento global de Roberto Sebastián Matta Echaurren. 


\section{Biografía Roberto Matta \\ II.1. Introducción}

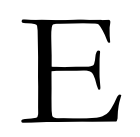

scribir sobre la vida de Roberto Matta a lo menos es algo extenuante no solo por el hecho de recabar información y tratar de escribirla lo mejor posible para que otros la lean de forma clara y precisa, sino porque el nivel de información que se tiene o que se pueda recabar de él es extensa y algunas veces dudosa. El por qué nos atrevemos a decir tan abiertamente y casi tan livianamente dudosa es por lo que el mismo Matta decía a los periodistas que lo entrevistaban, o a sus amigos cuando contaba anécdotas, ya que cuando Matta terminaba la conversación solía decir "Alentador, no le creas a un surrealista”, y así todo lo anterior quedaba en una extensa nebulosa. Del mismo modo nos atrevemos a decir dudosa, porque al investigar la vida y obra de Matta se ha recabado primeramente información de los libros y catálogos que se encuentran sobre el artista. Sin embargo, estos datos son al parecer en algunos casos inciertos porque al ir en busca de las fuentes de los datos correspondientes hay un cambio algunas veces profundo entre lo escrito y lo que realmente aconteció. ¿Por qué existen entonces estos cambios? ¿Por qué se escribe algo distinto a lo que realmente aconteció? la respuesta pudiese ir en dos direcciones, la primera es que se ha creado durante toda la vida de Matta un mito sobre él, que él mismo aceptó, y la segunda, quizás la más compleja de explicar, es el mundo que rodeaba a Matta y que rodea su figura hasta hoy a pesar de su muerte. Este mundo que es solo un grupo de personas, las que podríamos identificar como familiares, amigos y conocidos que han hecho que abunden los secretos y que lo que piensas que es real por haberlo leído lo dudes en algunas ocasiones al máximo.

La investigación biográfica que se presenta intenta y desea entregar al lector todo lo recabado bibliográficamente. Se pretende que el lector reciba con la mayor claridad y fidelidad posible al Matta persona y artista, que son solo uno finalmente, porque no 
podría existir un Matta artista sin el Matta persona, reflexivo, político y poeta que coexisten en un espacio de vida plástica, social y personal común.

Se desea del mismo modo que la fidelidad y veracidad de esta biografía se hace concreta muchas veces en las citas de Matta expuestas, que corroboran y dan certeza a los hechos mencionados. Asimismo es relevante decir que esta biografía no pretende romper ni establecer más mitos alrededor de Roberto Matta pero pretende introducirnos en Matta y en lo que él ha sido en vida, escrito lo más objetivamente posible.

\section{II.2. Vida y obra}

Así fue Roberto Sebastián Antonio Matta Echaurren, quien se consideró durante toda su vida ciudadano del mundo, nacido el once de noviembre de mil novecientos once, es decir 11/11/1911, en Santiago de Chile. La cifra convierte así al número 1 en un símbolo que se repetirá luego, cuando es admitido al grupo surrealista, teniendo la palabra surrealista 11 letras, que coincidentemente marcan un hito inconsciente en la historia personal de Matta.

Matta nace en el seno de una familia de clase media alta, de origen vasco-francés. Siendo el mayor de cuatro hermanos: Roberto, Mario, Sergio y Mercedes.

Su padre fue don Roberto Matta, agricultor y dueño de un fundo en el barrio las Condes, situado en la ciudad de Santiago. Su madre fue Doña Mercedes Echaurren, quien nació y fue educada en Francia. El padre de doña Mercedes fue don Víctor Echaurren, hombre de gran fortuna en la época.

Es importante mencionar lo relevante en la vida de Matta que fue la figura de su nana Mercedes Villarroel y Soto. Mujer de origen vasco, por la cual siempre tuvo un gran cariño, puesto que lo crió desde niño, ya que él nunca tuvo una relación estrecha con sus 
padres. Así él llamaba a Mercedes Villarroel cariñosamente con el seudónimo de "mama" siendo para él el único nexo con Chile y la única relación de familia con su país natal, como él mismo lo describiría posteriormente : "Pero si no hubiese habido esa mama, yo no tendría ningún contacto con Chile. La "mama” es el único pedacito de raíz que hace que, por ejemplo, si veo una fotografía de Pinochet matando al pueblo chileno, es a mi “mama" a la que están matando...¿me entiendes? Entonces, ahí hay una reacción, porque me la tocan" ${ }^{1}$. Así de fuerte fue para Matta su relación con esta mujer, la que más que ser una cuidadora fue una madre para el artista.

En 1928, Roberto Matta finaliza sus estudios en el Colegio Sagrado Corazón de Jesús y María, Congregación de los Jesuitas Marianos en Santiago de Chile. Siendo este lugar el centro de estudios de las familias más acomodadas de la época y en el cual aprende el idioma Francés.

Con posterioridad, a los 16 años, comienza a estudiar arquitectura en la Pontificia Universidad Católica de Chile, lo que genera que comience a vivir solo junto a su hermano Mario en un departamento en el centro de la ciudad.

En la universidad conoce a los profesores Sergio Larraín y al "señor Rivera”². Larraín será uno de los chilenos con quién mantendrá amistad por toda su vida y a quién Matta describe como "un tipo de muy buen gusto y que sabía lo que enseñaba" ${ }^{3}$ y el señor Rivera será como menciona Matta, el "que se dio cuenta que yo era quizás un artista"4. Este profesor lo toma como su ayudante en el primer año de sus estudios y a la vez le solicita administrar el negocio (una mueblería) que poseía, mientras él se iba a Europa a cantar. Esta anécdota será relevante en las decisiones de vida de Matta, siendo descrita

\footnotetext{
1 Palabras de Roberto Matta recogidas en: CARRASCO, Eduardo, Autorretrato-nuevas conversaciones con Matta. Santiago de Chile 2002.p.34

2 Se menciona como "Señor Rivera", ya que en las bibliografías encontradas, Matta recuerda al profesor solo por su apellido.

${ }^{3}$ Carrasco, Eduardo. Op. Cit., p. 55

${ }^{4}$ Ibidem, p. 22
} 
por él de la siguiente forma "él era un arquitecto tenor y yo me quedé administrando su negocio", será a través de este negocio como Matta se dará cuenta de que él no deseaba ser un hombre rico, a pesar de que a través de lo ganado en la mueblería pudo subsistir los dos primeros años en Europa.

La vida de Matta entonces, transcurría, entre la mueblería y la universidad como él muy bien describe

"todo esto, yo tenía que hacerlo entre los cursos de la universidad, lo que prueba que estos cursos eran de lo más flojo del mundo. Entre clase y clase, yo iba donde el tapicero y donde el carpintero y al banco y etc."

Por lo tanto, Matta no dedicaba todo el tiempo a sus estudios como lo harían durante esa época los niños de buenas familias. A la vez, Matta colabora en algunas propuestas como el hacer caricaturas para la revista Topaze de gran circulación en ese tiempo y pintar algunos cuadros al óleo. De estas pinturas solo se conservan algunas, entre las que destaca el retrato a su nana Mercedes. Es así como los hechos que van aconteciendo con él en su juventud irán marcando una personalidad, una forma de vida y de espíritu que se verá posteriormente en su vida artística y personal, las cuales se entrelazan y coexisten en él mismo.

A pesar del poco tiempo dedicado a sus estudios, Matta se titula en diciembre del año 1933 presentando como proyecto anterior a su tesis, "La Liga de religiones-valle de Jeaspeat, la Isla de elefante", un templo para 147 religiones con dibujos realizados en el ya inexistente, "Taller de los olmos" en el cual ingresó como alumno libre dadas sus aptitudes e inquietudes, a la clase de dibujo a mano alzada con el profesor Hernán Gazmuri, quien influye no solo en su soltura artística, sino a la vez, en sus pensamientos un poco revolucionarios y opuestos al catolicismo de la sociedad chilena de esa época. 
Matta termina sus estudios universitarios en diciembre de 1933, coincidiendo este hecho con el quiebre personal ante la sociedad chilena que él venía sintiendo años antes y que se acentúa ante la sorpresiva huelga de los trabajadores de la mueblería contra Matta, lo que provoca que él se aleje furtivamente de su familia y de Chile. Decidió, entonces, partir a Europa con su amigo Manuel Marchant. Viajaron seis meses en el barco "Merchant Marine Compagnie Transatlantique”. En este periodo visitaría, con destino final en Francia, varios puertos de Italia, España, Alemania, Yugoslavia, Grecia e Inglaterra. De este acontecimiento Matta describe lo siguiente "me metí en un barco y me mandé a cambiar. Yo me recibí en diciembre de arquitecto y como eran las vacaciones me fui a "Viña del mar" . "Como todo el mundo andaba de vacaciones, nadie se dio cuenta de mi ausencia hasta después. Yo tomé mi barco y desaparecí”. Las causas de la partida de Matta hoy no son ninguna incógnita, él escapa de lo que observaba en su familia y de lo que lo rodeaba, ya que encontraba que ambos contextos formaban una sociedad bastante colonial durante esa época, más aún, pensaba estar viviendo en el 1800. Y es por esas posturas que se fundan y realzan en esta sociedad, que se acentuaban dentro de su familia de clase alta o con un sentido burgués, lo que provoca que Matta finalmente se distancie. Matta diría posteriormente "Yo no me fui de Chile, porque yo no conocí Chile, yo me fui de esto que estamos hablando" refiriéndose a lo anteriormente mencionando, que es el sentirse ajeno a seguir esta sociedad conservadoramente colonial que él conocía como Chile y que durante todo el tiempo que vivió en Chile lo mantuvo en un estado de inconsciencia referente al todo que lo rodeaba, sin poder sentirse libre. Por lo tanto, las razones del por qué se distancia de Chile son conscientes muchos años después y es así como él puede explicarnos a nosotros a través de entrevistas el hecho de su partida.

\footnotetext{
5 Ciudad que se sitúa en la costa de la Quinta región de Chile, y que es aún frecuentada por familias económicamente privilegiadas.

${ }^{6}$ CARRASCO, Eduardo. Op. Cit., p. 56

${ }^{7}$ CARRASCO, Eduardo. Op. Cit., p. 22
} 
Luego de visitar varios puertos en Europa dentro del barco con el que partió desde Chile, se establece primeramente en Liverpool con la idea de radicarse un tiempo en Londres. Y se siente allí en un verdadero cambio como él lo describiría

“'Cuánto tiempo tomó en mí para pasar del siglo 17, que era el de los "huasos” de Chile, al siglo 20 que se vivía aquí...! Eso fue una verdadera metamorfosis, como la de las cuncunas y las mariposas" 9

El siglo XVII y los huasos a los que se refiere Matta era esa sociedad en la que vivía en Chile, esa sociedad y huasos burgueses que lo rodeaban. Sin embargo, en Londres, no obtiene la ayuda esperada y se traslada a Francia antes de lo presupuestado. En París arrienda una pieza de hotel en el barrio latino, ubicado en el Boulevard Saint Germain y es allí donde comienza a organizar su vida.

Mientras tanto, en Santiago, su hermano Mario, quien se queda a cargo de la mueblería que administraba él, es el primero en enterarse de su huída a través de una carta que le envía Roberto Matta varias semanas después. El por qué Matta le escribe esa carta es quizás porque con él vivió desde que entraron a la universidad, "lejos de la casa de sus padres", ${ }^{10}$ y quizás también porque con Mario había una cercanía con respecto a la edad que cada uno tenía. El otro hermano, Sergio, era menor que ellos y para esa época aún vivía con sus padres. Posteriormente, ambos hermanos, Mario y Sergio, visitarían Europa separadamente. Mario se queda solo por un tiempo y luego se estableció definitivamente en Chile, en cambio Sergio o Serge como le dice Matta, vivió en Europa toda su vida. El artista recuerda a Serge de la siguiente manera

\footnotetext{
${ }^{8}$ Huasos, es el nombre que tienen los hombres que trabajan en el campo de Chile.

${ }^{9}$ CARRASCO, Eduardo. Op. Cit., p. 25

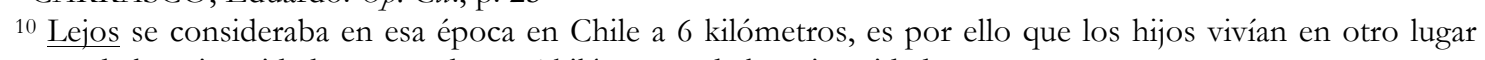
cerca de la universidad, y sus padres a 6 kilómetros de la universidad.
} 
"Serge era un tipo curioso. Era muy buen mozo, y actor, y bailarín, y trabajó con Marceau al principio. Y después empezó, poco a poco, por razones de vida y cosas así, a hacer cosas de moda"11.

Se puede decir que hubo algo entonces, algo indescribible que hizo que los hermanos tuviesen ganas de conocer mundo de salir de ese pequeño y lejano Chile. Hubo algo que los hizo tomar la decisión y partir sin importar la opción final de quedarse o regresar. Lo relevante es que los tres partieron por el impulso de lo que encontrarían. Sin embargo, no hubo nunca una relación entre los hermanos ya sea de amistad o familiar. Quizás fue originado por cómo les habían enseñado a vivir y hacer frente a los otros, siempre con distancia y con mucha educación de por medio ; es por ello lo que diría Matta posteriormente "Serge era dos o tres años menor que yo. Pero nunca lo conocí verdaderamente....." ${ }^{12}$, “Él vivía en otro mundo. En el fondo, yo no lo conocí bien”, y ese otro mundo al que se refiere el artista en el que vivía Serge, era el de la costura rodeado de amigos como Max Schiaparelli, Pierre Cardin y Jacques Fath, diseñadores y costureros relevantes. Siendo Serge un costurero y consejero de algunas de estas grandes figuras.

En París, en el año 1934, Matta conoce al arquitecto suizo-francés Le Corbusier, con quien trabajó como ayudante. De esta experiencia Matta relata lo siguiente

"Yo trabajaba con él, me levantaba a las seis de la mañana, y a las nueve estaba donde Le Corbu, como le decíamos, donde trabajaba todo el día sin descansar...no tenía dinero, podía ir dos veces a la semana a un cinema y comía pésimo; pero este trabajo con Le Corbusier no era un verdadero trabajo, porque no ganábamos nada....."13

\footnotetext{
${ }^{11}$ CARRASCO, Eduardo. Op Cit.,p.43

12 Ibidem,p.43

${ }^{13}$ CARRASCO, Eduardo. Op. Cit.p...25
} 
Refiriéndose al no ganar nada económicamente, ya que en este atelier Matta ganó el conocer no tan solo personas o personalidades, sino también tuvo la oportunidad de realizar un viaje a la Unión Soviética en 1936.

Cabe aclarar que el artista al partir de Chile solo se fue con los ahorros que había obtenido de la mueblería y con ese dinero pudo vivir los 2 primeros años en Europa. Sin embargo, el mes de diciembre era en el que más economizaba ya que visitaba a sus tíos en Madrid (España) para disfrutar con ellos la navidad. En 1934-1935 es la primera vez que Matta está en la casa de su tía apodada Bebé y su tío Carlos Morla Linch quien, en esos momentos, cumple funciones como Agregado Cultural de la Embajada de Chile en Madrid, y de quien se dice en algunos libros que fue eje de reuniones entre artistas e intelectuales. Estas relaciones permitieron a Matta conocer a Rafael Alberti, Maruja Mallo, Manuel Ángeles Ortiz, Pablo Neruda y Federico García Lorca.

Para Matta el ir a visitar a sus tíos en navidad no solo era una visita familiar en la cual de alguna forma se sentía cómodo sino que a la vez era un lugar para establecer nuevos contactos y fundamentalmente era un tiempo de ahorro, del que podría disfrutar después viajando por Europa.

En 1935, con el dinero ahorrado, Matta realiza diversos viajes, entre tantos Finlandia y Alemania. Posteriormente, en 1936, viaja a la Unión Soviética donde residirá por dos meses.

El motivo por el cual viaja a este país es que, según sus propias palabras 
"en el estudio de Le Corbusier se había construido una cosa en Moscú, un edificio de oficinas con aire acondicionado, pero como ellos respondieron que no tenían presupuesto para el aire acondicionado, hubo que ir allí y re dibujar los planos" 14

La cosa en Moscú a la que se refiere Matta es el Centro Soyouez. No obstante, como él mismo relataría, este viaje no era pagado por el arquitecto por lo tanto todo lo que se realizaba en el atelier tenía un carácter de voluntariedad y fue ésta la razón por la que viajó a Moscú, ya que él se ofreció para ir junto a un holandés que trabajaba también en el atelier. Ambos con sus propios dineros viajaron de ciudad en ciudad con los medios de transporte más económicos, como menciona Matta "hicimos toda la Alemania, la Polonia, Moscú, Leningrado, Finlandia, Suecia, Dinamarca, Alemania de nuevo, Bélgica, París y después partí de nuevo a España"15. Visitando en Lisboa, durante el verano de ese mismo año, a la poetisa chilena Gabriela Mistral, quien lo incentiva a interesarse por los postulados de las "Brigadas Culturales" de México, las que fueron escritas por los poetas José Martí (cubano) y el mexicano José Vasconcelos. Gabriela Mistral también ayudó a Matta a cambiar de residencia reubicándose en Londres, donde conocerá y trabajará con los profesores de la Bauhaus, Walter Groupius, Moholy-Nagy y los artistas Henry Moore y Roland Penrose.

En algún momento de estos viajes, Matta conoce al arquitecto finlandés Alvar Aalto.

En el ínter tanto, el mundo conoce las dramáticas noticias del inicio de la Guerra Civil Española.

Posteriormente, Matta descubre en la Librería de la Galería Zwemmer, en París, la revista Cahiers d'art, que presenta como tema en los números 1 y 2, El Objeto visual. El creador encuentra en estas revistas dos artículos que le llaman la atención ; uno ilustrado

\footnotetext{
${ }^{14}$ Ibidem,p. 25

${ }^{15}$ Ibidem, p. 25
} 
por Marcel Duchamp y otro ilustrado por Man Ray. Ambos artistas pasan a ser fuentes esenciales para su desarrollo artístico en el futuro.

Ya el 31 de diciembre del año 1936, al regreso de su viaje por la Unión Soviética, Matta se encuentra en Estocolmo (Suecia) y comienza a escribir el proyecto fílmico La tierra es un hombre inspirado en la muerte de Federico García Lorca asesinado en agosto de ese año por los franquistas en España.

Se puede decir entonces que el caminar por el mundo para Matta nunca se detiene.

Durante el verano del año 1937, Matta, se encuentra en Gran Bretaña y comienza a pintar nuevamente ya que se supone que desde que llegó a Europa solo dedicó su tiempo a trabajar en arquitectura, a hacer bocetos y a escribir. El pintar quizás fue motivado, en aquel momento, por el joven oficial de la marina inglesa Gordon Onslow Ford quién al ver sus dibujos, lo incita a pintar. Trabajando juntos en la obra basada en el automatismo guiados por la intuición poética.

En ese período Roberto Matta es contratado por el arquitecto español Josep Lluis Sert para que trabajara posiblemente como arquitecto en el pabellón español de la "Feria mundial de París"16 ya que es muy probable que Sert conociese con anterioridad a Matta, pues ambos trabajaron en el atelier de Le Corbusier años antes. En la "Feria mundial de París” (la cual en Biografías sobre Matta se menciona como la Exposición Internacional) tiene la oportunidad de ver el montaje del Guernica de Picasso.

Conoce entonces a Picasso y a Dora Maar, visitando el atelier del artista español al menos 15 veces.

${ }^{16}$ ANONIMO, Alexander(Sandy)Calder, Colección Síntesis de las Artes Mayores, Ciudad Universitaria de Caracas. en http:www.centenariovillanueva.web.ve/CUC/Sintesis_Artes/Artistas_Extranjeros/Arp/Frames_Arp.htm, junio 2004 p.2. (Web visitada el 14/06/2004) 
Además conoce a Salvador Dalí a partir de una nota de presentación que le había proporcionado Federico García Lorca, escrita en la última parte de un libro del poeta que Matta entregó a Dalí a petición suya. Dalí lo lleva a conocer a André Bretón quién había inaugurado recientemente una galería de arte. Bretón se impresiona con los trabajos de Matta y le compra dos de sus dibujos.

Entretanto, este mismo año Matta conoce en España a Delia del Carril apodada "La hormiguita”, en el momento en que Pablo Neruda, comienza su relación sentimental con ella, dejando a su mujer María Antonieta Agenaar.

En 1938, el grupo surrealista invita a Matta a integrarse a éste como miembro activo, lo que perdura hasta 1948. En el mismo año participa, ya como integrante del grupo, en la exposición Internacional del Surrealismo en la Galería de Bellas Artes de París, en la que Matta expone 4 dibujos realizados el año anterior. Matta y Ann Clark visitan durante este lapso a Gordon Onslow-Ford en Suiza donde experimenta con la pintura.

Estimulado por Gordon Onslow-Ford, Matta trabaja en Trevignon, Bretaña. Realiza durante este tiempo las obras pictóricas que llamó primeramente "Morfologías Psicológicas" y que luego más tarde se llamarán "Inscapes”, realizando 9 cuadros en los cuales desarrolla la técnica del automatismo en la pintura. De regreso a París conoce a Marcel Duchamp con quien mantendrá siempre un contacto regular. Desde México, André Bretón recomienda la intervención de Matta en un ensayo sobre la arquitectura para la revista francesa Minotaure, que es redactado por Georges Hugnet (poeta y escritor francés) y en el que, finalmente, Matta participará con notas y con cuatro dibujos que dieron lugar al ensayo "Matemática sensible, arquitectura del tiempo", en respuesta "Matemática razonable" escrito por Le Corbusier.

Adquiere en ese mismo tiempo una edición de la Caja Verde de Duchamp a quién visitará regularmente para efectuar los pagos de esta obra. En una de esas visitas, Matta le 
comentará a Duchamp su decisión de dejar la arquitectura y dedicarse por completo a la pintura.

Sus frutos como pintor comienzan a surgir rápidamente. Durante ese mismo año (1938), ilustra, junto con los surrealistas Max Ernst, Brauner y Yves Tanguy, la reedición de los "Cantos de Maldoror" del Conde de Lautréamont.

En 1939, año en que se inicia la Segunda Guerra Mundial, Matta pasa el verano en Chemilieu en compañía de André Bretón, su esposa Jacqueline y su hija Aube, OnslowFord, Yves Tanguy, Marcel Jean (pintor surrealista canadiense), Ann Matta-Clark, Kay Sage (pintor surrealista norteamericano) y Esteban Francés en un castillo que les alquila Gertrude Stein.

De regreso a París, vive con Pablo Neruda en la Roche-Guyon hasta que se traslada a Nueva York junto a su esposa Ann Clark e Yves Tanguy por invitación de Marcel Duchamp. Cruza en barco el Atlántico y llega a Nueva York a finales de 1939. En esta ciudad comenzará a trabajar, llegando con el tiempo a convertirse en el mentor de los artistas americanos de la pintura abstracta expresionista Robert Motherwell, Jackson Pollock, William Baziotes y de manera más intensa, de Arshille Gorky, a quienes conoce entre los años 1940-1941.

Roberto Matta y su esposa viven en un departamento en Greenwich Village hasta mayo de 1940, en 9 gay street. Durante este mismo tiempo habitan en una casa de campo fuera de la ciudad.

En 1940, Matta realiza su primera exposición individual (abril-mayo) con The-Litchew y Walt Disney en la Julien Levi Gallery de Nueva York. Al mismo tiempo, participa en muestras colectivas del arte surrealista: Exposición Internacional del Surrealismo en la Galería de Arte Mexicano y en la exposición Surrealismo hoy en la Gallery Zwemmer, ubicada en Londres. Frecuenta en este mismo período el loft de los diseñadores Francis Lee y Edison Price donde conoce a Jackson Pollock, William Baziotes y Peter Busa. 
Participa, además, en la exposición organizada por Howard Putzel para acompañar las conferencias impartidas sobre el surrealismo por Gordon Onslow-Ford en el New School For Social Research dirigida por Meyer Schapiro (historiador del arte). Conoce en este año al escritor Lionel Abel.

En el año 1941, viaja a México con los pintores Baziotes, David Hare, María Ferrero, Motherwell y su esposa, Bárbara Reis y Ann Clark ; coinciden con Wolfgang Paalen, pintor surrealista afincado en México desde 1939. En el viaje, Matta descubre el inagotable talento del arte precolombino. Más tarde en Cuba incorporaría, como Wifredo Lam, las raíces afroamericanas a su producción artística. Matta ejerce el automatismo y emplea la escala monumental, revolucionando de esta manera la obra de William Baziotes.

Asimismo Matta constituye la futura Escuela de Nueva York con Pollock, Motherwell y otros artistas.

Al mismo tiempo Pinta durante este año Invasión of the night cuadro considerado fundamental en su trayectoria.

Al siguiente año, realiza su primera exposición individual en la Galería Pierre Matisse de Nueva York con él título "La tierra es un hombre". Con posterioridad participa, en el mismo lugar, con una muestra colectiva titulada Artists in exils (artistas en exilios). Participará, asimismo, en la exposición montada por Duchamp, First papers of surrealism (primeros papeles del surrealismo).

Junto a Motherwell, organiza reuniones con jóvenes artistas norteamericanos entre los cuales se encuentran Baziotes, Pollok y Gorky, quienes practican la pintura automática. Estas reuniones serán fundamentales pues sustentan las bases del expresionismo abstracto. Desarrolla el concepto "Los grandes transparentes" que traspasa a sus dibujos y pinturas. La obra Les vitreurs inspira a André Bretón a escribir The great transparent 
ones y Surrealisme, ou non y a plantear la idea de los grandes transparentes en el tercer manifiesto del surrealismo escrito por el mismo Bretón y en el que colabora Matta ilustrando el prólogo del manifiesto, que es publicado en la revista VVV.

Durante este mismo año, Matta aprende las técnicas del grabado en el estudio de Stanley William Hayter (pintor y grabador) quien es incorporado al surrealismo. Stanley William Hayter, ayuda a un grupo de pintores a incursionar en las técnicas gráficas aportando soluciones a los planteamientos del automatismo.

En 1943, Matta ilustra El día es un atentado del poeta Charles Duits y adquiere una escultura de Giacometti L'objet invisible en la Galería Julien Levy. Participa en importantes exposiciones de arte contemporáneo.

Nacen sus hijos mellizos Sebastián (Batán) y Gordon Matta Clark en Nueva York, fruto de la relación del artista con Ann Clark. Ambos hijos se desarrollarán en el ámbito plástico durante el transcurso de sus vidas. Destacándose especialmente en el mundo arquitectónico-artístico. Siendo Gordon considerado "uno de los artistas conceptuales más importantes de hoy"17.

Posteriormente, Sebastián (Batán) muere en el año 1977 (sin tener esta actual biografía datos concretos sobre su muerte). Sin embargo, como todo lo que rodea a Matta está lleno de mitos, del mismo modo esta lleno de mitos los por qué de la muerte de Sebastián. Seguidamente, en el año 1978, muere Gordon de un cáncer fulminante.

Meses más tarde del nacimiento de sus hijos en 1943, Ann Clark y Roberto Matta se separan, sin saber en la actualidad los motivos de la ruptura, de la cual no se crean mitos, solo tremendos secretos.

17 AREVALO, Antonio. Opiniones: Aferrar el mundo del ser en el ser en el mundo en http://laventana.casa.cult.cu/modules.php?name=News\&file=article\&sid=735 Diciembre 2002 p.1 (web visitada el 14/05/2004) 
Durante el año 1944, expone en la Galería Pierre Matisse de Nueva York, ocasión en la cual Bretón escribe Le perle est gatee à mes yeux, texto que será publicado en 1950. Matta ilustra la portada del volumen IV y último de la revista $V V V$. Contribuye, además, con 4 láminas del tarot para el libro Arcano 17 de André Bretón. Participa, entretanto, en importantes exposiciones colectivas de arte contemporáneo. Estrecha su relación con Gorky quien se interesa por el automatismo y por la concepción espacial de Duchamp. Escribe junto a Catherine S. Dreier una reflexión sobre la obra de Marcel Duchamp que titula "Le verre de Duchamp: La mariée mise a un ses célibataires", publicada en Nueva York por la Sociedad Anónima.

En 1945 expone Le Poête (El poeta) en Galería Pierre Matisse y expone sus esculturas por primera vez, en la exposición Imagery of chess. Participa igualmente en numerosas exposiciones colectivas.

Ya en el año 1946 Roberto Matta se encuentra en París. En sus obras se hace cada vez mas evidente la representación de personajes en situaciones sadomasoquistas. En este mismo momento se encuentra con Wilfredo Lam, que viene desde Haití.

Marcel Duchamp escribe el texto Matta peintre (Matta pintor) que será publicado en 1950, para el catálogo de la Collection of the Société Anonyme.

Entretanto, en 1947, participa en diversas exposiciones colectivas entre las que destacan: la Exposición Internacional del Surrealismo realizada en la Galería Maeght en París, donde expone un Altar dedicado a Marcel Duchamp y en la exposición Large Scale Modern Painting, organizada por el Museo de Arte Moderno de Nueva York donde expone junto a Pablo Picasso, Fernand Léger y Henri Matisse.

París es el escenario en que presenta su primera muestra individual, en la Galería Rene Drouin, ubicada en Place Vendôme. Entre los textos del catálogo se publica una reflexión 
de Bretón bajo el título "Il y a trois ans" (Hace tres años). Realiza, conjuntamente la escenografía de una pieza teatral del poeta Henri Pichette.

Es importante destacar que durante este periodo recibe su primer premio en Norteamérica el San Francisco Annual por el cuadro Séparés Vivants (separados vivos), que es una pintura que refleja la vida sobre la gran ciudad neoyorkina.

Matta durante este año se casa con la norteamericana Patricia Kane quien será su segunda esposa y con la que no tendrá hijos. Años más tarde se separarán. Roberto Matta se casará después con la norteamericana Mallite Pope y Patricia Kane se casará con Pierre Matisse.

En el año 1948, Matta decide regresar definitivamente a Europa para reestablecerse en París. La partida desde Nueva York se origina por "La dirección que toma la pintura de Matta al dirigirse hacia la representación y cada vez más hacia lo exterior”"18, lo que provoca un alejamiento de los artistas norteamericanos que ya habían comenzado su desarrollo artístico gestual y abstracto por lo que es un camino contrario a lo que plantea Matta. Llegando este hecho incluso a dañar las relaciones humanas, transformándose el mundo que rodeaba al artista en Nueva York, en un lugar bastante egoísta y en el que se comienza a desprestigiar su obra por considerarse retórico en su discurso visual. Son entonces estos hechos los que producen que Matta parta desde Nueva York a Europa, no obstante, su alejamiento será solamente físico ya que estará en constante comunicación con las galerías y algunos artistas norteamericanos.

Al llegar a Europa, específicamente a París, es expulsado del grupo surrealista y excluido de la escuela de Nueva York y de las Galerías Pierre Matisse, Sydney Janis, Maeght, etc. La expulsión se causa principalmente por el suicidio de Arshille Gorky, ya

\footnotetext{
${ }^{18}$ Ministerio de Educación de Chile y el Ministerio de la Cultura de Venezuela, "Catalogo exposición Matta Uni-Verso" Santiago de Chile 1991 e inicios de 1992. P.35
} 
que se acusa a Matta de haber tenido un amorío con la esposa de este artista y se piensa en ese momento, equivocadamente, que este hecho habría provocado la muerte de Gorky. André Bretón, entonces, expulsa a Matta del grupo surrealista acusándolo de "descalificación intelectual e ignominia moral”"19. Sin embargo esta acusación tendría sus opositores, como Marcel Duchamp e Ives Tanguy quienes decidieron también dejar el grupo surrealista. Tiempo más tarde se aclararon los episodios y se ha sabido que en junio de 1948 Gorky habría tenido un accidente automovilístico, lo que habría provocado un quiebre en su cuello y una paralización temporal del brazo que utilizaba para pintar. Este hecho provocó en él un dolor insoportable y angustioso que lo llevó a la depresión y que influyó en que la relación con su esposa empeorase "y ésta decidió llevarse a sus hijas y abandonarlo"20, por lo tanto Matta no es la causa de la decisión de Gorky. Finalmente hay que mencionar como dato que el artista armenio dejó "a modo de carta, una inscripción tallada en una caja de madera que decía : "Good bye my loveds" (Adiós mis amores), refiriéndose posiblemente a su mujer y sus hijas.

Se piensa entonces que, por todos estos acontecimientos, Matta decide cambiar su residencia en París para instalarse en las cercanías de Roma en Italia. Siendo en este lugar, donde entra en contacto con jóvenes artistas desconocidos, científicos con nuevas ideas revolucionarias e inéditas. Este año participa por primera vez en la XXIV Bienal de Venecia, que hasta estos días es un evento mundial de suma importancia para el mundo artístico.

A finales de 1948, Matta vuelve a Chile por primera vez desde su partida, convertido en un artista del mundo. Su infatigable trabajo lo lleva a exponer en la Galería Dédalo, ubicada en el centro de la capital. La revista chilena Proarte publica su texto

\footnotetext{
${ }^{19}$ Ibidem,p.35

20 ALBARRACIN, M de la Paz. Arschile Gorky: una experiencia Armenia en la diáspora en http:// www.transoxiana.com.ar/0101/gorki.html, junio 2000 p.7 (Web visitada 16/05/2004)

21 ALBARRACIN, M de la Paz. Arschile Gorky: una experiencia Armenia en la diáspora en http:// www.transoxiana.com.ar/0101/gorki.html, junio 2000 p.7 (Web visitada 16/05/2004)
} 
"Reorganimación de la afectividad". No es posible escribir con exactitud por cuanto tiempo duró la estadía de Matta en Chile, sin embargo se sabe que fueron varias semanas.

Contribuye durante este año con algunos artistas que conoció en Norteamérica con los que sigue en contacto. Ellos son Asger Jorn y los "Situacionistas" ${ }^{22}$ con los que Matta expone y Robert Motherwell quien edita el texto Infernallucinations sobre Max Ernst en el que contribuye Matta. No obstante esta última información sobre Asger Jorn y los Situacionistas bibliográficamente no es tan clara con respecto al año, por lo tanto se puede decir que este último hecho pudo realizarse en 1948 o 1949.

En 1949 se establece en Roma, donde permanecerá hasta 1954. Viajará, sin embargo, frecuentemente a París para seguir sus contactos con galerías y artistas, lo que origina su participación en la exposición Les Grands courants de la peinture contemporaine (Las grandes corrientes de la pintura contemporánea) en el Museo de Lyon.

Asimismo, por estos años pinta por primera vez el concepto del cubo abierto que venía desarrollando desde 1942, con el cual intenta expresar el espacio múltiple en una superficie bidimensional.

En 1950 Matta reside en dos ciudades italianas Roma y Bolonia.

Presenta sus primeras exposiciones individuales en Italia: Matta. fostore sciamo en la Galería del Obelisco y en la Galería del Secolo, en Roma. Luego expone en Milán y en Venecia. Entre las muestras colectivas en que participa, destaca una confrontación entre los jóvenes artistas franceses y norteamericanos presentada en la Galería Sydney Janis en Nueva York. Michel Tapié (critico de arte) pública, entretanto, el texto The space of Matta (El espacio de Matta), en la revista Paris Post de París.

\footnotetext{
${ }^{22}$ Los Situacionistas son un grupo artístico, con raíces del surrealismo y de la filosofía existencialista, mofándose igualmente de estas dos vertientes.
} 
Durante 1951, Matta expone en el Institut of Contemporany Art de Londres. Esta muestra se exhibe posteriormente en la Galería Sydney Janis, Nueva York, ocasión en que se publican algunos textos artísticos en diversas revistas norteamericanas.

Nace en Roma el 22 de enero este mismo año, su hijo Pablo Echaurren (Paino), producto de la fugaz relación entre Matta con la actriz italiana Angela Faranda. El por qué de la utilización del segundo apellido de Roberto Matta, que proviene de su abuela vasca, en el nombre de Pablo, es según se menciona "que no fue un resentimiento contra el autor de sus días sino la búsqueda de un camino propio"²3, ya que Pablo, igual que sus otros medios hermanos, se desarrolla en el área artística siendo actualmente un dibujante y pintor relevante en Italia.

A partir de 1952, Matta participa en diversas muestras colectivas en el Museo Nacional de Arte Moderno en París. Termina Les roses son belles (una alusión al proceso Rosenberg), su primera obra dedicada a un hecho histórico relevante, la ejecución del matrimonio Julius y Ethel Rosenberg, "acusados de vender secretos atómicos a la Unión Soviética”24. Fue un acontecimiento que a escala mundial causó conmoción y, de alguna forma, motivó a Matta para comunicar visualmente su visión frente a este acto.

En 1953, Matta presenta dos exposiciones individuales: en Galería Iolas de Nueva York y en la Sala Napoleónica de Venecia. Asimismo se publican en este año varios textos que analizan el espacio en la obra de Matta: "Le réalisme ouvert de Matta" (El realismo abierto de Matta) de Alain Jouffroy, escritor surrealista, en Cahiers d'arts; "El espacio de Matta" de Stanley William Hayter, en la revista italiana Número; y "Espace continu espace vécu", de Max Clarac Sérou, en la revista parisina Position.

\footnotetext{
${ }^{23}$ JOUFFé, André. Matta, el lado oscuro del corazón, en http: // www.vertice2000.cl/nacion29.html, junio 2004, p.1 ( Web visitada 28/06/2004)

${ }^{24}$ CERON, Pablo. El caso Rosenberg, la ejecución que conmociono al mundo en http://old.clarin.com/diario/2003/06/19/i-02501.htm, junio 2003, p.1.(Web visitada 19/06/2004)
} 
Roberto Matta Echaurren viaja en 1954 a Perú y a Chile presentando exposiciones individuales en la Galería Lima de Lima y en el Museo Nacional de Bellas Artes de Santiago de Chile. La visita a Chile solo duró 2 semanas y fue originada porque uno de los hermanos del artista quería un automóvil Cadillac, ya que de este tipo de autos no había en Chile, solo era posible traerlos por chilenos que viviesen "en el exterior" ${ }^{25}$ por mucho tiempo, fue así como uno de los hermanos de Matta (bibliográficamente no se sabe si fue Mario o Sergio, aunque se supone que fue Mario) lo trae a Chile, pagándole el pasaje a Matta, mientras éste realiza todas las gestiones para traer este auto a Chile. Fue durante esta estadía donde por primera vez se tomó un trago con su padre, como él mismo lo describe "Y en esta estadía, un día, en el bar del Hotel Carrera, por primera en mi vida me tomé un trago con mi padre...Él tendría unos 73 o 74 años y nos tomamos esta fotografía que salió en El Mercurio"26, siendo este acontecimiento un hito relevante en la vida de Matta quien había visto durante toda su niñez y juventud un padre ausente.

Expone a la vez en Galerías de Venecia, Chicago, Roma y en la Universidad de Washington.

Participa paralelamente por primera vez en el Salón de Mayo, en la isla de Paros donde a partir de ese momento expondrá regularmente. La revista Reality publica durante ese mismo año un artículo sobre Matta, que se establece nuevamente en París. Colabora en Attulima, obra del escritor, poeta surrealista Alain Jouffroy, en la que Matta acompaña su texto con una litografía y tres grabados calcográficos realizados en aguafuerte con aguatinta, lamentablemente no se poseen imágenes de estos grabados.

En 1955, se presenta una muestra individual en la Galería Sydney Janis en Nueva York, sobre la obra del artista, la que luego se exhibirá en la Pan America Unión en Washington. Recibió el segundo premio de su vida, en el "Pittsburg International", con el óleo 
Interrogation. Paralelamente expone esculturas realizadas en cerámica con los artistas del grupo $C O B R A^{27}$ : Karel Appel, Corneille y Jorn.

Nace el 8 de julio de este mismo año, en Neuilly-sur-Seine, Francia, su hija Federica, fruto del matrimonio con la norteamericana Mallite Pope. Federica durante su vida ha tenido una trayectoria artística destacada tanto en Latinoamérica como en Europa ; actualmente Federica vive en París.

Al año siguiente Matta pinta para la UNESCO el mural Las dudas de tres mundos. Colabora con Víctor Brauner en las pinturas y dibujos que expondrían juntos en la Galería del Dragón, (París) sobre el tema "La televisión”. Tele-invitation es de los primeros cuadros retransmitidos en la televisión francesa en París. De esta exposición se publican variados textos en las revistas parisinas destacando el que escribe Edouard Glissant (escritor, poeta y ensayista francés) sobre la obra reciente del artista.

Posteriormente, en 1957, realiza su primera retrospectiva en EE.UU. en el Museo de arte de moderno de Nueva York, coordinada por William Rubin. Se presentan en la Galería Ruth Moskin (Nueva York) y en la Galería del Dragón (París), exposiciones de su trayectoria en el área del dibujo que abarcan desde 1937 hasta 1957. La sala de exposiciones de la Fundación Eugenio Mendoza en Caracas, Venezuela, presenta una muestra individual de sus obras de los años cincuenta, momento en que establece contactos con Alejo Carpentier quien escribió en el catálogo de esta exposición un texto y a quien "se le considera el primer representante del Realismo Mágico"28.

En el año 1958, Matta presenta exposiciones individuales en la Galería Iolas (Nueva York) y en la Galería del Dragón (París). Entre los textos publicados este año sobre el

${ }_{27}$ COBRA, grupo artístico fundado en 1948 por Jorn, Noiret, Appel, Constant y Corneille, el cual duró sólo tres años. El nombre obedece a la combinación de las primeras letras de Copenhague, Bruselas y Ámsterdam.

28 ANONIMO, Premio Cervantes, Alejo Carpentier en http://www.portal-local.com/occu-cer-carp-vid.asp, junio 2004, p.1.(Web visitada 19/06/2004) 
artista destacan "La Question" de Alain Jouffroy y "Matta, l'aube et le vertige" de Patrick Waldberg. Pinta La cuestión de Djamila, en respuesta al libro Cuestión de Henri Alleg sobre la tortura en la Guerra de Independencia en Argelia. Colabora en la obra literaria de Henri Michaux, poeta francés, Vigies sur Cibles acompañando los escritos de Michaux con 8 grabados realizados por medio del aguafuerte y aguatinta (véase página 4 del catalogo razonado.

Expone en 1959 en Alemania en la Galería de Daniel Cordier (Frankfurt). Se organiza por primera vez en Europa la primera retrospectiva del artista por Pontus Hultenen en el Moderna Museet de Estocolmo, bajo el título "Quince formas de dudas". Sobre la trascendencia de esta exposición, Hurbert Juin (escritor y periodista belga) publica en la revista parisina Combat "Estocolmo consagra a Matta", refiriéndose a la importancia de la obra de Matta no tan solo en el mundo artístico sino a la vez en la relación de su obra con el espectador.

Durante este mismo año Matta es reincorporado al movimiento surrealista "en consideración a su fidelidad por el espíritu surrealista”29.

Expone en la XII Documenta de Kassel y comienza a trabajar en L'espace de l'espace, políptico sobre el cual trabajará hasta 1968.

Matta colabora entretanto en la obra literaria de Alain Bosquet Paroles Peintes junto a Max Ernst, Jacques Hérold, Wilfredo Lam y Dorotea Tanning. Obra en la que colaboró con el grabado calcográfico titulado "Paroles Peintes" que es realizado por medio del aguafuerte con aguatinta (Lamentablemente no se poseen imágenes de estos grabados).

29 ANONIMO, Periódico el Sur, Cultura. Roberto Matta: El último gran surrealista en http://www.elsur.cl/gen/25102002/A_CULTURA/, noviembre 2002, p.1.(Web visitada 20/05/2004) 
En 1960 Matta expone por primera vez sus esculturas en la Galería del Dragón en París. Alain Jouffroy (escritor y poeta surrealista) publica un artículo en la revista Combat en París, en el que plantea la revolucionaria postura política del artista.

Nace durante este mismo año, su hijo Ramuntcho Matta, el que será el segundo y último hijo de la relación entre Matta y Mallite Pope. Ramuntcho se desenvuelve laboralmente en el mundo de la música y el arte a lo que se dedica hasta hoy. Actualmente Ramuntcho vive en París.

Posteriormente, Matta viaja a Chile, en 1961, y da inicio a un mural para la Universidad Técnica del Estado en Santiago de Chile, titulado “Vivir enfrentando las flechas", que será concluido en 1971. El mural mide 7 metros de largo. Durante su permanencia en Chile los periódicos publican varias entrevistas y artículos sobre el artista. En diversos lugares del mundo como en Nueva York, Londres, Paris, Frankfurt y Chicago, se presentan diversas muestras de sus obras, destacando la muestra colectiva en la que participa Matta en el Guggenheim Museum de Nueva York, titulada “Abstract Expressionist Imagists”.

Durante el año 1962 se presenta una exposición de sus grabados en la Galería Punto Cardinal, en París. Como representante del arte latinoamericano, Matta participa en una exposición presentada en el Museo de Arte Moderno de la Villa de París y recibe el premio Mazotto, siendo Mazotto a la vez un en evento expositivo, en donde las obras de Matta serán expuestas, en varias ciudades europeas.

Posteriormente, en 1963, se organizan más de 12 exposiciones del artista en diferentes ciudades europeas. Entre ellas destaca una gran retrospectiva que presenta el Museo Cívico de Bolonia, que luego itineraria por Viena y Dusseldorf. En el catálogo de Bolonia se publica una conversación entre Matta, Guttuso (pintor), Giulio Carlo Argan (crítico de arte y político) y Mario Micheli (historiador del arte), bajo el titulo "El arte y la revolución”. La Galería del Dragón, en París, complementa esta muestra con una selección de dibujos que 
abarcan la producción del artista desde 1937 hasta 1957. Matta viaja a Cuba en ese mismo año y crea el grabado Scogliatole realizado con una plancha que nunca fue editada, y del cual existe solo una prueba de ensayo.

En 1964, Matta viaja nuevamente a Cuba con el motivo de presentar una exposición en la Casa de las Américas. Su estadía en la Habana le inspira una serie de pinturas que exhibirá en la Galería Ático, en Roma.

Participa luego, en la XXXII Bienal de Venecia, en la tercera edición de la Documenta en Kassel y en la muestra de 10 años de arte actual, en el Museo de Arte Moderno de la Villa de París.

A continuación, Matta crea un libro de arte titulado "Les voix" con un texto inédito de Michel Fardoulis Lagrange (escritor) ilustrado con 10 grabados de Matta, de los que no poseemos ninguna información.

Durante el año 1965 presenta la exposición Cubo abierto en el Kunstmuseum en Lucerna Suiza, ocasión en la cual publica dos textos que plantean -en rasgos generales- su concepción estética: L'espace de l'espace y Cosa è la cosa mentale. Participa en diversas colectivas entre las cuales destaca la XI Exposición International del Surrealismo, en la Galería Loeil, en París.

Roberto Matta Echaurren, expone en Milán, Nueva York, París, Lima y en Minneapolis durante el año 1966. F. C. Toussaint realiza una extensa entrevista al artista sobre "El surrealismo y la revolución" publicada en Les Lettres Francaises en París. Crea la serie de once grabados para acompañar la obra literaria del escritor Joyce Mansour Les Damnations .

Posteriormente, en 1967, viaja a La Habana y expone en la Galería Latinoamericana. En el mismo año va a Chile por 26 horas, durante el gobierno de Eduardo Frei Montalva, para participar en la celebración del $14^{\mathrm{a}}$ aniversario de la revolución cubana. En esta oportunidad presenta la exposición Grimau o las pujanzas del desorden, en la Universidad 
Técnica del Estado, en Santiago de Chile. Muere André Bretón y Matta escribe, como homenaje póstumo "L'illumination", publicado en la Nouvelle Revue Francaise, en París. Adquiere un viejo convento en Tarquinia (Italia) que se convierte en su casa-estudio.

Entre los años 1967-1968 (se utilizan ambos años, ya que este hecho relevante aparece sin claridad en las bibliografías utilizadas) visita Cuba y Preside el II Congreso Cultural de la Habana, allí expone un discurso titulado "La guerra interior" y realiza en esta misma ocasión un mural junto a los estudiantes de la Escuela de Bellas Artes titulado "Para que la libertad no se convierta en estatua".

En París en el año 1968, la obra de Matta se incluye en la muestra "Totems et Tabous", presentada en el Museo de Arte Moderno de la Villa de París. Esta exposición es traslada luego a la fábrica de la Nord Aviation, ocupada entonces por la huelga general de Mayo. Matta participa simultáneamente en las manifestaciones del mayo francés. Se organizan en ese mismo tiempo, numerosas exposiciones de su obra en diferentes galerías europeas y neoyorquinas.

En el año 1969 Matta realiza variadas exposiciones entre las que destaca La revolución y la arquitectura, presentada en el Centro Cultural de Villa de París.

Posteriormente, en 1970, realiza una retrospectiva en la National galerie de Berlín. Visita Chile por dos días donde se encuentra con Salvador Allende y Fidel Castro, siendo invitado por la Universidad de Concepción a participar en una conferencia titulada: “Diálogo sobre la tradición del futuro". En el Museo de Bellas Artes de Santiago se inicia la construcción de una moderna sala de exposiciones que será bautizada "Sala Matta" y que culminará el año siguiente. Durante este mismo año es invitado por el periódico Al Arma en Egipto donde se reunió con intelectuales árabes. Viaja a Zambia, Tanzania y Angola, en esos países realiza obras para el movimiento de liberación de Angola. Conoce al político y poeta Agostino Neto. Viaja durante este mismo tiempo a Cuba para participar en la reunión internacional de artistas gráficos. 
Nace su hija Alisée, fruto de la unión con la Italiana Germana Ferrari (no se encuentran datos sobre la fecha en la que Matta y Germana Ferrari se unieron). El nacimiento de su última hija será motivación para realizar la obra Dar a la vida una luz. Alisée, al igual que sus otros medios hermanos, emprenderá su desarrollo personal y laboral en el área artística, más específicamente en la publicidad y el diseño, en lo que trabaja actualmente en Italia.

Vuelve a Chile en 1971 invitado por Salvador Allende a realizar un mural en la Universidad Técnica del estado (hoy USACH), participando en diversas acciones de la Brigada Ramona Parra, entre las cuales destaca la elaboración del mural Primer gol del pueblo chileno, en la Municipalidad de la Granja de Santiago de Chile. Durante ese mismo año, es considerado uno de los 10 mejores pintores del mundo en base a una encuesta realizada a 104 personalidades artísticas internacionales, y que publicó la revista francesa Connaissance des Arts. Termina ese año realizando una retrospectiva de su obra en la villa francesa de Sochaux y en el Museo de Bellas Artes de le Havre.

Durante 1972 Matta sigue desarrollando el concepto espacial del cubo abierto y realiza una serie de obras que expone en la Galería Nueva York. Entre las exhibiciones colectivas en que participa destaca el Surrealismo, presentada en Haus der Kunst de Munich y en el Museo de Artes decorativas de París. Dona al pueblo chileno las obras Hagámonos la guerrilla interior para parir el hombre nuevo y Ojo con los desarrolladores.

En 1973, luego del golpe de estado del 11 de septiembre en Chile, las municipalidades italianas de Livorno, Bolonia y Rávena, en solidaridad con el pueblo chileno, organizan la exposición Por Chile con Matta. Presenta una gran muestra de sus obras recientes en la Galería Cívica de Arte Moderno, en Ferrara.

Empieza a crear Hom'mére, un diario autobiográfico e inédito, realizado por medio del grabado y editado por Ediciones Polígrafa, en Barcelona. 
En 1974 Matta realiza diversas exposiciones en Europa entre las que destacan: Bella Ciao, en la sala XX Settembre de Terni, y una retrospectiva organizada por la Kestner Gesellschaft, en Hannover. Participa en los eventos de la Bienal de Venecia, y se organiza la muestra del artista El gran burundún burundá ha muerto (véase página...del catálogo) homenaje a Jorge Zalamea, en la Galería Aele de Madrid. Durante el año siguiente esta muestra itineraria por varias instituciones latinoamericanas como el Museo de Arte Moderno de Bogotá y el Museo de Bellas Artes, en Caracas. Roland Sabatier ilustrador, publica Matta: Catálogo razonado de la obra gráfica 1943-1974, que es el primer catálogo donde se presenta la obra gráfica de Roberto Matta.

Durante el año 1975 realiza la exposición itinerante del El gran burundún-burundá ha muerto para apoyar la declaración del tribunal Russel sobre los crímenes de la junta militar en Chile. Se organizan además diversas exposiciones de su obra, entre las cuales destaca: El Hombre desciende del signo en la Galería de la Oca de Roma, constituida por pasteles inspirados en los códices mexicanos.

Posteriormente, en 1976, presenta gran parte de su obra gráfica en la Galería Latinoamericana, en la Habana y exhibe una serie de pinturas y pasteles realizados como homenaje a los Pirineos, en el Chateau de Castellnou.

Durante los años 1976-1977 (no se tiene un antecedente claro sobre la fecha de realización) Matta acaba la construcción iniciada en 1973 con un colectivo de obreros y artesanos de Tarquinia, que se titula "L'autoapocalypse", que es una estructura construida con componentes de desechos de automóviles pertenecientes a la fábrica Fiat, intentando esta construcción recrear una casa . Matta dirá "No es una máquina para habitar, sino un intento de humanizar la máquina" ${ }^{30}$. Esta pieza se exhibe posteriormente en diferentes ciudades italianas.

\footnotetext{
${ }^{30}$ Ministerio de Educacion de Chile y el Ministerio de la Cultura de Venezuela. Op. Cit.,p.35
} 
Durante el año 1977 Matta ilustra por medio del grabado, el poema de Arthur Rimbaud Un Saison en Enfer, editado por Ediciones Polígrafa, en Barcelona. Presenta al mismo tiempo la muestra Coigitum, en la Galería Hayward, en Londres.

En 1978 expone en la Galería Minotauro en Caracas. En el año siguiente Matta ilustra con una serie de litografías El canto I de la Araucana, libro escrito por Alonso de Ercilla en el 1500, trabajando nuevamente en un hecho histórico que trata sobre la llegada de los españoles a América. De esta obra se hace una edición de 125 ejemplares que se presenta en el Palazzo Vecchio de Florencia.

Luego, en 1980 se realiza la presentación del catálogo Matta: Índice de la obra gráfica entre 1959-1980 dirigido por Germana Ferrari, esposa de Matta, el cual es el segundo catálogo donde se presenta la obra gráfica de Roberto Matta. La presentación de este catálogo se realiza en la exposición El corazón es un ojo, en el Palazzo Degli Alessandri, en Viterbo.

Durante el año 1981 expone en el Palazzo Reale, en Nápoles, ocasión en que se publican dos textos inéditos. Entre las exhibiciones colectivas en que participa, destaca Un nuevo espíritu de pintura, en la Real Academia de Londres. En Florencia presenta la muestra Gargantatua como interpretación gráfica del cuento Gargantúa de Rabelais.

Posteriormente, en 1982, Matta presenta la muestra Arquitectura del tiempo en el Teatro de Ivry, en París. Se organiza, a la vez, una exposición en la Galería Ático, en Roma. Viaja a Nicaragua con ocasión del Congreso Interamericano donde participó con Gabriel García Márquez y Julio Cortazar, el cual trata sobre la "Autonomía cultural de nuestra América”, ocasión en que se publica su texto Reorganización de la razón, porque la historia es redonda como la tierra. En Cuba colabora con la formación del Museo de Arte del Hombre Latino africano, con la donación de una serie de esculturas africanas. Dona al 
programa ambiental de las Naciones Unidas (UNEP) con sede en Nairobi, el proyecto de energía solar.

Realiza los grabados para acompañar el libro Ubu-Roi (véase página 18 del catalogo ) de Alfred Jarry.

El centro municipal cultural Jacques Prévert de la Villa de París presenta la muestra Adiós al Burundún.

Realizando luego, en 1983, estudios en Riverside, en Londres, donde presenta una exposición de pasteles y grabados inspirados en la tempestad de Shakespeare, que intenta crear un paralelismo con la epopeya precolombina. Se organiza una gran retrospectiva del artista titulada Mediterráneo verbo América que se presenta en Valencia, Barcelona, y posteriormente, en el Palacio de Cristal en Madrid, y en el Museo de Bellas Artes, en Bilbao.

Durante 1984, exhibe una muestra de pasteles de 1983, titulada Verbo América, en el Museo de Bellas Artes de la Habana. La Galería Samy Kynge, en París, presenta la exposición Punto de Apoyo. El Arts Council de Londres organiza una exhibición de dibujos titulada La lógica de la alucinación, que itineraria por varias ciudades inglesas. En Sevilla se realiza durante este año la presentación de grabados Declaración Universal de los derechos Humanos, homenaje Fray Bartolomé de las Casas. Esta obra había sido realizada con Rufino Tamayo, Robert Motherwell, Antoni Tàpies y otros artistas.

En el año 1985, se realiza una gran retrospectiva de la obra del artista en el Centro de Arte Georges Pompidou- Museo de Arte Moderno, en París. Recibiendo Roberto Matta en ese mismo año, la medalla de oro de las Bellas Artes Españolas. Siendo esta condecoración entregada por el Rey Juan Carlos de España, en un acto celebrado en el Museo del Prado en Madrid. 
A continuación, en 1986, exhibe parte de su extensa obra en la Galería Totah-Stelling y en el Instituto Hispánico en Nueva York.

En Chile se expone parte de la obra de Matta en la Galería de arte El caballo verde en Concepción y en el Museo Nacional de Bellas Artes de Santiago con motivo de la IV Bienal de arquitectura. En Santiago se publica el libro Matta-conversaciones de Eduardo Carrasco, que es fundamental para comprender a Matta artista y persona.

Posteriormente, en 1988, presenta una exposición en el Palasso Venecia, en Italia.

En 1989 en el Museo Nacional de Bellas Artes de Santiago de Chile, se cambia el nombre de la "Sala Matta" por "Sala Chile", por solicitud expresa del artista. Al año siguiente se le restituirá el nombre original, en honor a Matta, cuando Nemesio Antúnez (pintor chileno) asuma la dirección del museo.

Durante el año 1990 Roberto Sebastián Matta reside en París, pasando temporadas de verano en Tarquinia, Italia, donde ha instalado su taller, una escuela de cerámica y una sala de exposiciones. El 27 de agosto, de este mismo año, recibe el Premio Nacional de Arte, en Chile, a los setenta y nueve años de edad.

En la subasta anual realizada en la casa Sotheby's las obras del artista alcanzan altos precios ubicándose entre los diez artistas latinoamericanos más cotizados. Se organiza una exposición en el Palazzo Reale, en Milán.

En agosto del año 1991, se inaugura el mural alegórico al descubrimiento de América, en San Salvador. Esta obra pertenece a la serie titulada "Verbo América" (véase página...del catálogo), en la cual también se incluye el mural que se realizará al año siguiente en la entrada de la Exposición Universal de Sevilla, de 1992. El Museo Nacional de Bellas Artes de Santiago de Chile y el Museo de Bellas Artes de Caracas organizan la 
exposición Matta Uni Verso 11-11-11 como homenaje a los 50 años de vida artística y a los ochenta años de existencia del pintor.

En 1992 realiza el encargo la Junta de Andalucía del mural de cerámica en la Exposición Universal, Sevilla. En esta misma cuidad se realiza la exposición Verbo América, auspiciada por la Caja San Fernando de Sevilla, que se expondrá en 7 ciudades españolas. Y se realiza la exposición de escultura y pintura, patrocinada por la Caja de Ahorros de Asturias en Oviedo.

Recibe en este mismo periodo, el Premio Príncipe de Asturias de las Artes, en España.

En 1993 se realiza la primera exposición individual sobre la obra de Roberto Sebastián Matta Echaurren en el Yokohoma Museum of Art., Japón.

Entre 1994 -1999 se realizan varias exposiciones sobre la obra de Matta, siendo algunas de estas realizadas en la Galería Artespacio y Galería AMS, ambas en Santiago de Chile, en la Galería Almirante y en el Museo Nacional Centro de Arte Reina Sofía, ambas en Madrid, siendo estas dos ultimas instituciones donde se presentó una gran retrospectiva sobre una gran parte de su obra en el año 1999.

Durante este mismo periodo de años, 1994-1999, Matta gana dos premios relevantes en su trayectoria el Premium Imperiale for Lifetime Achievement in the Arts en Japón 1995, y es nombrado Artista de Honor en el Art Miami 98, en Miami 1998.

En el año 2000 se realiza una exposición homenaje en el Museo Reina Sofía de Madrid, en estos momentos los Reyes de España le conceden la nacionalidad española a Matta.

Los últimos 30 años del artista los vivió entre Paris e Italia.

Roberto Sebastián Matta Echaurren fallece en Tarquinia, una localidad italiana cercana a Roma, el sábado 26 de noviembre del 2002, a los 91 años. En Tarquinia Matta pasa los 
últimos momentos de su vida, en el convento de padres pasionistas, del siglo XVIII, comprado por él mismo, años antes. Roberto Matta es acompañado durante el termino de su vida por su última esposa Germana Ferrari, a pocos días de haber inaugurado personalmente su última exposición en la Galería Ulises en Roma.

Algunos meses antes de morir, Roberto Sebastián Matta estuvo con el presidente de Chile, de ese entonces Ricardo Lagos y su esposa Luisa Duran, a quién le obsequio la serie de grabados El gran burundú-burundá ha muerto para que fuese una ayuda concreta, en la última etapa del proyecto Sonrisa de mujer ${ }^{31}$, el cual tiene por objetivo, ayudar a la mujer chilena para que tenga una dentadura en buen estado, esperando que se sientan más dignas e integrándose así de mejor manera a la sociedad.

Luego de la visita del ex presidente Ricardo Lagos, Roberto Sebastián Matta otorgó algunas entrevistas, siendo una de ellas a una radio en Chile, la radio Cooperativa, en la cual le preguntaron al artista por la visita del presidente chileno, a lo que Matta respondió "el encuentro fue muy bueno, Lagos tiene algo de roto chileno, como yo" ${ }^{32}$. Comentando posteriormente en esa conversación Radial, que la muerte no existe, que él no iba a poder decir personalmente "yo me morí”

Al momento de conocer mundialmente la noticia de la muerte de Roberto Sebastián Matta Echaurren, muchos personajes de todo el mundo quisieron rendirle un homenaje, pudiendo algunos ir a su despedida en la cual la señora Luisa Duran leyó las siguientes palabras como parte del discurso mandado por el ex presidente chileno Ricardo Lagos en el funeral de Roberto Matta:

\footnotetext{
31 Sonrisa de mujer, fue un programa del gobierno chileno, entre los años 2000-2006 para mejorar las dentaduras de las mujeres chilenas.

32 CAMPOS, Sergio, El diario de Cooperativa. Programa radial Radio Cooperativa. Diciembre 2002.

33 CAMPOS, Sergio, El diario de Cooperativa. Programa radial Radio Cooperativa. Diciembre 2002.
} 
"Vengo a decir adiós a un chileno, es cierto, pero también a uno de los más grandes artistas contemporáneos, a alguien quien fue uno de los nuestros, pero que fue también un consumado artista del mundo.

Vengo a decir adiós a la imaginación, a la inteligencia, a la gracia y a la libertad que pusiste tanto en tu vida como en tu obra, dejándonos un legado tan rico y diverso que nunca podremos hacer caber en solo un catálogo.

Vengo decir adiós a nuestro Premio Nacional de Arte, que cuando recibió de mis manos esa distinción, preguntó entre distraído y jocoso, qué era eso que le dábamos y para que servía.

Vengo a decir adiós a Roberto Matta y a celebrar que hace poco mas de un año, en París, me dijera que se encogía con el paso de los años, que estaba cada vez mas pequeño y que esa era seguramente la manera de irse acostumbrando a la tierra.

En fin, vengo a decirte que ahora estarás definitivamente en la tierra, pero también en nuestra memoria y en nuestro recuerdo, y que en Chile continuaremos esforzándonos para que vivir juntos entre la cordillera de los Andes y el Océano Pacífico continúe siendo algo bello, emocionante y digno como tu siempre lo quisiste. $^{34}$

Asimismo, en Francia, el ministro de cultura Jean- Jacques Aillagon, se despidió de Matta con las siguientes palabras :

"Este gran artista chileno que escogió desde muy temprano Francia para vivir y estudiar con Le Corbusier y pasar aquí la mayor parte de su vida, era un espíritu

\footnotetext{
${ }^{34}$ CAMPOS, Sergio, El diario de Cooperativa. Programa radial Radio Cooperativa. Diciembre 2002.
} 
muy innovador que influyó ampliamente en las corrientes pictóricas de la postguerra ${ }^{35}$.

Se escogen estos textos para relatar el cómo fue visto y apreciado Roberto Sebastián Matta Echaurren hasta en los últimos momentos, y por qué su legado no sólo está en su obra, donde tenemos pinturas y grabados además de dibujos, esculturas, artefactos, versos, frases y algunos textos, sino que dejó lo más importante, su lucidez y su gran humanidad, que estará presente, siempre cada vez que se recuerde.

Finalmente, la ceremonia fúnebre se realizó en la iglesia de la Anunciación de la localidad italiana de Tarquinia en donde se entonó "la canción Volare, de Domenico Mogdugno, se brindó con vino del lugar de sus orígenes, como dijo su viuda, Germana Ferrari, levantando un vino hecho en Chile"36, enterrando sus restos en el jardín de este lugar.

La realización de la biografía que se presenta se basa en la información recabada en los siguientes catálogos: Matta Hoy, Matta Uni-Verso y Matta el año de los tres 000, más el apoyo fundamental de los libros Conversaciones con Matta de Eduardo Carrasco y Autorretrato del mismo autor.

35 ANONIMO, Periódico El Sur, Cultura. Roberto Matta: El ultimo gran surrealista en http: // www.elsur.cl/gen/25102002/A_CULTURA/, noviembre 2002, p.1 (web visitada 20/05/2004)

36AREVALO, Antonio. Opiniones: Aferrar el mundo del ser en el ser en el mundo en http:/ / laventana.casa.cult.cu/modules.php?name $=$ News $\&$ file $=$ article $\&$ sid $=735$ diciembre 2002, p. 1 (web visitada 14/05/2004) 


\section{II.3. Gráfico Familiar}

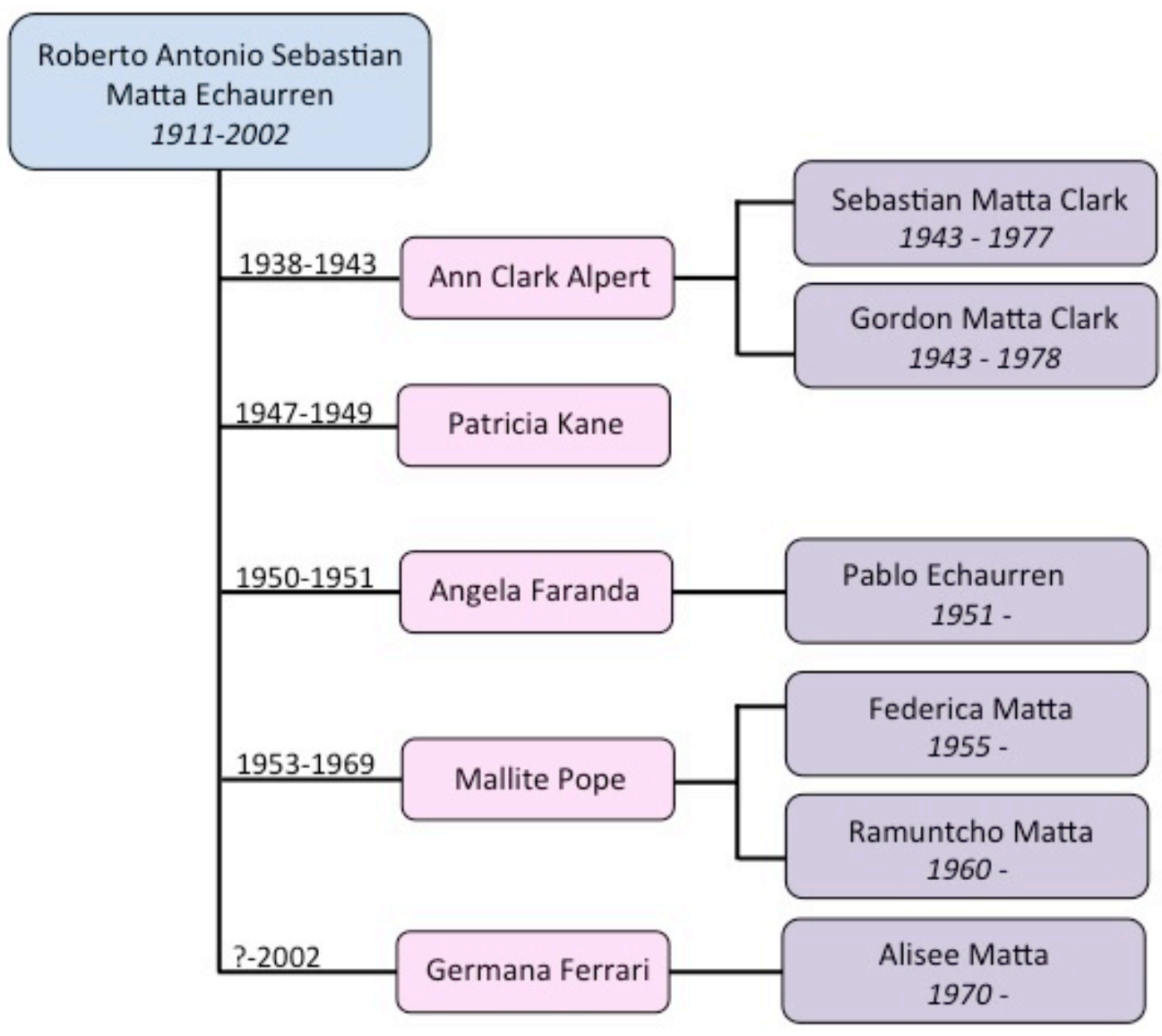




\section{Visiones e influencias de un grabador desconocido}

$\mathrm{E}$ scribir sobre Matta, desde la perspectiva de grabador, no es tan fácil ni claro como se puede pensar en un primer momento, ya que se tiende a creer que el artista traspasa lo realizado en el ámbito pictórico al ámbito gráfico. Siendo estas dos formas de expresión distintas y no pueden ni deben ser concebidas, en el caso de Matta, como si una fuese el resultado de la otra. Debemos comprender que ambas formas de expresión son realizadas por él, lo que genera en un principio las mismas búsquedas y las mismas ganas de utilizar el espacio, de crear personajes, etc., siendo diferente el resultado del proceso y del producto que finalmente es la obra. Porque en cada una de las áreas Matta se encuentra y se enfrenta a lo azaroso del desarrollo, a lo que cada área (pintura-grabado) le entrega en sí misma, siendo por ello que las diferencias entre ambos campos artísticos al nivel de realización y resultado no permitan pensar que el artista traspasa lo mismo entre lo pictórico y lo gráfico en su obra.

Entonces, para poder rescatar a Matta como un grabador y descubrir las influencias y visiones del artista en el grabado, debemos situarnos en las visiones que tiene él con respecto al arte en general, lo que consecutivamente nos llevará al camino de cómo Matta entiende y expresa el grabado en su obra plástica. Poniendo un especial interés en cómo Matta llega al grabado y en quienes lo introducen en sus técnicas, en sus diferentes disciplinas y aplicaciones.

Debiendo tener cuenta que Matta es un arquitecto que se identifica como tal frente a los artistas e impresores, y que él es innatamente un surrealista en su totalidad, siendo este parámetro el que de alguna forma lo autoriza a establecer múltiples relaciones no tan solo artísticas sino también desde los ámbitos más diversos del hombre, que lo plasma no solo en su obra, sino en su forma de hablar con los otros, y en el esquema previo de creación de la obra el que va ligado intrínsicamente a él como ser humano. 


\section{III.1. Matta y el arte}

Cuando Matta partió de Chile, no tenía ninguna visión sobre los grandes artistas vanguardistas de la época o lo que se desarrolla en Europa por esos años, él estaba sumergido en otro arte, otra forma de realización, ya que en Chile, como según él mismo lo relata, se estaba viviendo en una década atrás, en una época colonial, por lo que uno se puede imaginar entonces, que sólo esa noción tenía de lo que es el arte y lo que se difundía como tal. Matta mencionaría más tarde que él nunca supo de arte ni de nada que lo relacionara, sin embargo se puede dudar un poco de esta declaración, porque es impensable que alguien que en esos años estudiara arquitectura y participara en talleres artísticos, estuviese tan ajeno a lo que acontecía, como si no tuviese una idea real, como si estuviese en una burbuja tan personal de crecimiento, que hasta lo que veía y lo que se le enseñaba era ajeno de su ser, de sus conocimientos. Se puede también decir que Matta siempre menciona el no saber, en sus conversaciones y entrevistas, si se le pregunta por Chile, por la segunda guerra mundial, por las muertes, por la dictaduras, él nunca sabe, nos hace creer que no tiene conciencia real de lo que acontece, en un primer instante, por supuesto, ya que ese discurso es un escudo, es por ello entonces que resulta tan difícil de estudiar y/o entender a un artista en que en el "no saber" formó una parte del discurso oral de su obra, no obstante, tanto en sus grabados como en sus pinturas vemos claramente que sí sabía sobre muchos temas, que tenía más que una idea sobre ellos y que reaccionaba a través de sus obras sobre estos conocimientos y acontecimientos. Para clarificar aún más este punto, Matta mencionaba que no sabía de ciertas cosas o temas, porque indudablemente le aburrían las preguntas que le hacían y así decir "no sé" era una salida de escape rápida para finalizar una conversación.

Al llegar a París, Matta comienza a sentir y a ver el arte, siendo en este transcurso donde comienza de parte de él una gran admiración hacia algunos artistas, en especial a Marcel Duchamp. El por qué se menciona a Duchamp, es porque la admiración no se refiere a su obra o al proceso, sino porque lo considera como un ser extraordinario por su 
forma de pensar, y de ver más allá que todos los otros artistas, hasta de él mismo. Según nos cuenta Gino Diomaiuto (artista plástico), mientras caminaba con Matta por el Louvre, tuvieron una conversación sobre Duchamp en la que recuerda que Matta "admiraba la inteligencia de Duchamp, la percepción, una inteligencia capaz y superior con un espíritu propio" ${ }^{37}$. Así, para Matta, Duchamp era un artista, una persona que podía ver más allá que él, pero no en el mismo sentido, es decir, mientras Matta buscaba llegar a ver el origen de las cosas y llegar hasta lo esencial de las formas y de los sentimientos o de algo más concreto, Duchamp llegaba a lo que el objeto era en si mismo y lo convertía en otro concepto, lo enviaba a otro plano. Duchamp reflexionaba sobre el objeto y luego lo transformaba en obra con otra concepción, se interesaba principalmente en la cuarta dimensión y en el arte interpretado por la mente en lugar de por la retina, lo que sin lugar a dudas fue una influencia a lo que Matta quiso lograr y logró en sus obras, ya que reflexionaba constantemente sobre qué había detrás de nuestros ojos, siendo un tema de gran interés para él y de grandes pensamientos, fue axial como algunas exposiciones llevarían títulos relacionados a esto como "El corazón es un ojo" y algunos poemas como "El reino de los ojos", asimismo Matta trabajaría posteriormente como Duchamp en la cuarta dimensión y sobre todo en el juego de palabras en sus obras, tal como lo hacía Duchamp en sus creaciones, axial se puede decir que Matta sí tuvo algunas influencias de su parte, siendo la más importante el proceso de reflexión en torno a la creación, pero de una reflexión quizás más especial a la que todos podemos tener, un tipo de pensamiento superior y extraordinario que solo algunos logran desarrollar o simplemente poseen, pero que sin lugar a dudas es excepcional.

Por lo que se puede deducir entonces que Matta recoge influencias conceptuales de un gran artista como lo es Marcel Duchamp, así como también es de suponer que él recogió puntos de vistas de otros artistas e impresores, de los que no se sabe a ciencia cierta si tuvo verdaderas influencias de ellos, es por esto que solo se menciona la influencia de Duchamp, porque tenemos datos certeros de que así fue y más aún los años de 37 Conversación con Gino Diomaiuto. Paris, diciembre 2003. 
creaciones, de proposiciones, de reflexiones nos avalan esta afirmación. Del mismo modo quiero decir que esta influencia que tuvo Matta no fue solo en una sola área de creación, es decir, no solo se quedó en la pintura o en el grabado, sino que esta influencia fue el punto de partida para que conceptualmente Matta desarrollase su trabajo en todos los ámbitos, y quizás fue una motivación en el tiempo, al observar el trabajo de Duchamp, al leer sus escritos, así como las conversaciones que tuvo con este artista, ya que no debemos de olvidar que fue por la petición de Marcel Duchamp por la que Matta decide irse a Estados Unidos de Norteamérica, para huir de la guerra. Entonces podemos concluir que para Matta, Duchamp era un artista relevante por todo lo anteriormente mencionado y el cual tenía palabras de peso para Roberto Matta.

Posteriormente, cuando Matta comienza a viajar y a habitar en diversos países como EE.UU., Inglaterra, Francia o Italia, entabla relaciones con diversos artistas, siendo eje de reuniones y conversaciones en las que no solo se generan ideas, se proponen proyectos o se discuten pensamientos, sino que se generan grupos de nuevos creadores, como fue el caso de lo que posteriormente se llamarían expresionistas abstractos, en el que participaron Jackson Pollock (1912-1956), Willem de Kooning (1904-1997), Barnett Newman (1905-1970), Arshile Gorky (1904-1948), William Baziotes, Franz Kline (19101962), Mark Tobey (1890-1976), Mark Rothko (1903-1970), Ad Reinhardt (1913-1967) Adolph Gottlieb (1903-1974), Robert Motherwell (1915-1992), Clyfford Still (1904-1980), Hans Hofmann (1880-1966), Philip Guston (1913-1980), Morris Louis (1912-1962), Helen Frankenthaler (1928-2011), Walker Tomlin (1899-1953), Joan Mitchell (1926-1992), Esteban Vicente (España,1903-2000), siendo Matta quien dio el impulso para que éstos, en su mayoría jóvenes creadores, siguiesen realizando su obra en conjunto, motivados por el automatismo que él realizaba, siendo entonces Matta una influencia para este grupo de artistas. No obstante, al paso del tiempo en una conversación entre Diomaiuto y Matta, este último se referiría a Pollok, uno de estos jóvenes artistas, que recibió la influencia de Matta, como un creador que se envolvió en su pintura "convirtiéndose en un sordo mudo, 
el que solo gesticula, no habla" ${ }^{38}$, concluyendo de esta descripción que Pollok tiene un discurso pero que es difícil de sacarlo fuera. Así Matta toma el arte, el arte era su vida, no fue un concepto, no fue una idea, fue poesía, y fue esa misma poesía lo que provocó que el fuese el generador y motivador de este grupo artístico de la abstracción, nacido en Norteamérica.

Otro punto relevante a destacar es que tanto las influencias como las visiones de Matta, pareciesen que fuesen una seguidilla de acciones unidas como si fuesen finalmente una cadena, esto lo decimos porque las visiones de Matta solo son tales y reales con los conceptos que Duchamp maneja, y es en base a esto que Matta crea sus propios conceptos, los que son seguidos por este grupo de jóvenes artistas norteamericanos, basándose principalmente la influencia sobre ellos en la idea del automatismo que "era un elemento dominante del movimiento surrealista, que acentuó la supresión del control consciente sobre uno dominado por la composición libre de las imágenes y de las asociaciones inconscientes" ${ }^{39}$. Pero Matta utilizó el automatismo de modo que una forma daba lugar a otra hasta que la unificación fuera lograda o hasta que la creación a posteriori destruyera toda la composición. Y fue Matta quien introdujo el automatismo en ese grupo de artistas que posteriormente definiríamos como expresionistas abstractos.

Hay que destacar, sin lugar a dudas un dato interesante que merece ser rescatado, si no hubiese sido por Duchamp quizás Matta nunca hubiese conocido el grabado, porque fue gracias a la motivación de Duchamp de partir a EE.UU. que Matta se introduce por primera vez en el mundo del grabado en los talleres de Stanley William Hayter, no sabemos si de él tuvo influencias específicamente en el mundo del grabado, pero creemos que de alguna forma no solo aprendió técnicas en ese taller, sino también puntos de vistas y reflexiones que harán por cierto las bases de Matta en el mundo del grabado, que

\footnotetext{
38 Conversación con Gino Diomaiuto. Paris, diciembre 2003.

${ }^{39}$ http://209.85.135.104/search?q=cache:mLikK7MbiwQJ:www.wallpapers.cl/pintores/biografia_roberto_matta . php+Automatismo+Matta\&hl=fr\&ct $=$ clnk\&cd=6\&client $=$ safari , visitado en abril 2008.
} 
se nutrirán en el camino con otras influencias como las de George Visat sobre la técnica del grabado empírico (Pág.47) que Matta intentó y desarrolló en su obra.

Se piensa que finalmente se debe mencionar, después de todas las entrevistas realizadas a las personas cercanas al trabajo de Matta, que la concepción del arte para Matta es poesía, y eso es algo muy relevante en el discurso artístico de Matta y en su vida, nada se generaba sin ella, entendiéndose la poesía como "encanto indefinible que en personas y cosas halaga y suspende, conmueve y deleita el ánimo"*0 lo que a través de su propia energía y vitalidad traspasaba no sólo a su obra plástica sino, a la vez, a las personas, promoviendo un encanto muy particular en el hacer y en el ser, que según él mismo no tiene ninguna relación con el tener, ya que no importa lo que tengamos sino lo que somos y hacemos. Como corrobora Diomaiuto quien menciona que el "espíritu de Matta, era el de un niño que juega, muy intenso, la imaginación en él era muy bella"*1 .

\section{III.2. El grabado y Matta}

El grabado a lo largo de la historia siempre ha estado presente en el hombre, si se entiende el grabado en su idea más general, las huellas de los yacimientos rupestres ya son grabados. Sin embargo, si se sitúa en el hecho de la reproductibilidad múltiple, se está en pleno en el concepto actual de grabado aunque se cuestionará siempre el por qué el grabado es hasta hoy tan poco conocido y comercializado como es la pintura. Es verdad que la imprenta y la fotografía han sido hechos que han opacado a esta área, pero sin embargo hay algo aún que motiva a los artistas a participar, involucrarse e indagar en el grabado, siendo quizás el hecho de ser un sistema de reproducción múltiple con factores azarosos y desconocidos para un artista que desarrolla principalmente su creación dentro de otra área. Lo que conlleva un reconocimiento de casi la totalidad de los pintores, e incluso de los escultores, que desean y quieren hacer grabados ya que les permite, como

\footnotetext{
${ }^{40}$ Diccionario Sopena Aristos 3. Editorial Ramón Sopena, S.A., Barcelona, Novena Edición 1992.p.485

${ }^{41}$ Conversación con Gino Diomaiuto. París, diciembre de 2003.
} 
técnica, trazar un discurso paralelo a su campo habitual, llevándolo a peculiaridades o a aproximaciones de su trabajo, temática y problemáticas habituales y el uso de la multiplicidad un diálogo y nexo entre toda la obra del artista que le permite establecer una interlocución permanente entre toda ella, obteniendo de las técnicas recursos, para dar prioridad a sus inquietudes. Y así el artista desarrolla entonces sus inquietudes a través de las diversas alternativas que brinda el grabado, en relación con los formatos, el relieve o el plano, el dibujo, el color y las diversas gamas de tonalidades que se pueden obtener. Lo que facilita al creador el indagar en esta área y el desarrollar su trabajo, más aligerado de las limitaciones materiales. (Que pudiesen encontrarse en las otras áreas de desarrollo plásticas).

Asimismo, las amplias y diversas posibilidades técnicas que posee el grabado permiten al artista experimentar y elegir un camino propio que se adapte y que favorezca de la mejor forma posible a sus propias necesidades. Siendo por ello que algunos creadores plásticos se dediquen sólo a un campo del grabado, que les satisface, ya que llegan dentro de él a lo buscado y/o anhelado, como puede ser la litografía o serigrafía para desarrollar más el uso del color, o en calcografía para desarrollar más la utilización de las líneas profundas o ligeras y texturas de todo tipo, o xilografía que permite conseguir imágenes a base de líneas negras sobre fondo blanco o bien líneas blancas sobre fondo negro, así como tintas planas. Entre otras de las muchas posibilidades que permiten desarrollar cada una de estas técnicas.

Ofreciendo, a la vez, cada una de estas técnicas, sub-técnicas que desarrollan además procesos más específicos, lo que genera no tan solo un aporte a nivel de creación y desarrollo sino también de resultado.

El resultado del proceso del grabado algo es quizás aún mas motivador y atrayente hacia los artistas, ya que el resultado al no ser una obra única los posibilita a acercarse a un público mucho más amplio y de distintos niveles sociales, porque la obra final en 
grabado se entiende como una cantidad determinada de obra, numerada, es decir una edición, lo que equivale a tener una cantidad de imágenes idénticas, siendo a la vez cada una única. Esta incongruencia se da porque cada obra a pesar de ser visualmente igual a las demás posee una entidad propia, y esta individualizada mediante un número distinto en el tiraje.

\section{III.3. Realización de los grabados de Roberto Matta}

En la realización de sus grabados, Matta casi nunca se introduce en las técnicas, es decir en la realización de la obra, solo en el calcográfico y litográfico él dibuja sobre las matrices al igual como pone manchas para realizar el aguafuerte, aguatinta o técnicas del azúcar, él no realiza el proceso, para ello existe una cadena numerosa de personas que trabajan para la realización de su grabados. Sin embargo esto no quiere decir que a Matta no le gustase o no le atrajese el trabajar en el proceso del grabado, por el contrario, él siempre deseaba realizarlo. No obstante el grupo que rodeaba a Matta impedía con fuerza que Matta trabajase él mismo toda la obra, por un asunto monetario principalmente, ya que ¿Qué pasaría entonces si todas esas personas dejasen de trabajar para Matta?, ¿Qué pasaría con el tiempo de Matta?, ¿Qué pasaría con las ganancias de Matta? muchas son las interrogantes, sin embargo se sabe que Matta trabajó litográficamente por él mismo, motivado por dos jóvenes impresores litográficos: Frank Bordas y Michael Woolworth. Durante las noches secretamente Matta realizó sus propias litografías. Este hecho para estos dos impresores ha sido un gran logro en el trabajo con Matta, al saber que el artista se sintió partícipe completamente de su obra, sintiéndose comprometidas ambas partes durante la complicidad en el desarrollo de esta serie litográfica.

\section{III.4. El contacto con los impresores en la realización de los grabados}

El contacto con los impresores en París es casi inmediato, Matta logra llegar a ellos y deambula entre el atelier de Fernand Mourlot y el atelier de George Visat realizando su 
trabajo, sin embargo las relaciones con ellos son primera y principalmente artísticas, ellos son los que ayudan a Matta desde una elección de color hasta la elección del papel, aun sabiendo que deben servir a un Matta exigente, el cual tiene una idea clara de lo que desea como obra. No obstante, le gusta mucho experimentar durante el desarrollo de la obra, la cual se va transformando, siempre que exista una concordancia con sus ideas y con su problemática artística.

\section{III.5. Cómo se plantea el proceso del grabado Roberto Matta}

El trabajo de Matta en obra gráfica se plantea técnicamente en dos líneas básicas, una en grabado calcográfico y la otra litografía, en ambos procesos Matta llega en un primer momento con bocetos realizados sobre hojas de dibujos, que en algunas oportunidades se encontraban coloreados, según nos relataron Albert Dupont y Gino Diomaiuto. Consiguientemente, en ambos procesos, se dibujaba sobre las matrices, que luego trabajaban los colaboradores del atelier. En litografía llevaba el boceto y desde ese momento comenzaban a hacer su trabajo otros artistas, que empezaban a pasar el dibujo a la piedra ya que muy pocas veces Matta dibujaba sobre esta matriz. Siendo este procedimiento realizado principalmente a mano, aunque hubo series litográficas que se realizaron por medio de transferencias, según lo relatado por Frank Bordas.

En ambas técnicas Matta se introduce como un espectador de una gran parte del proceso.

\section{III.6. Tradición en los atelieres de grabado}

En los atelieres existe como tradición, cuando un artista trabaja con un colaborador, dibujante o impresor, se regala siempre una prueba de artista con una frase con cariño al amigo, o al colaborador, esto es una tradición en los atelieres. 
En el caso de Matta dejó obras en los atelieres en los que trabajó, sin embargo hubo algunas obras que no deseó firmar, para él, ese asunto era (eso) un chiste, una broma, por eso Matta también era un ser especial, muchas veces su rapidez iba a pasos agigantados con respecto a las obligadas tradiciones de los talleres gráficos que hasta hoy perduran.

\section{III.7. Que sucedió con las matrices utilizadas por Roberto Matta}

De lo que sucedió con las matrices, ya sean placas metálicas o piedras litográficas, en las que trabajó Matta se sabe que muchas placas se han eliminado, perdido, han sido extraviadas, o trabajadas nuevamente, reutilizadas, no pudiendo ver ninguna de las existentes para la realización de esta tesis. Y con respecto a las litografías, en su gran mayoría son piedras botadas, es decir eliminadas, ya que el atelier Bordas tuvo traslados y en esos traslados muchas piedras se botaron y otras están extraviadas, sin embargo aún el impresor Michael Woolworth, con quien Matta realizo toda la serie de Don $Q$ tiene en su poder algunas de estas piedras y matrices de aluminio, y aunque en su momento no se pudo ver ninguna de forma directa, se sabe de su existencia, y de la invitación generada para poderlas apreciar en algún próximo momento.

\section{III.8. Qué sucedió con los dibujos de Roberto Matta?}

Los únicos dibujos que se puede ver en base de esta investigación, los posee Michael Woolworth, siendo éstos dibujos de pequeño formato, realizados con lápiz mina y coloreados con lápices de colores de madera. No se tiene información de qué sucedió con todos los otros dibujos realizados por Matta, se supone que muchos de ellos los tendrá parte de su familia y su última esposa Germana Ferrari. 


\section{Roberto Matta en los atelieres de Grabado}

$\mathrm{M}$ atta conoce el grabado en el año 1942 en el atelier de Stanley William Hayter en

Nueva York, siendo éste el primer acercamiento al grabado que tiene Matta, de este hecho se sabe bastante poco, solo que fue allí donde conoció las técnicas gráficas por primera vez, donde desarrolló principalmente técnicas calcográficas, y en donde realizó sus primeros trabajos en grabado, imprimiéndose allí la serie The new school (véase página...del catálogo), una de las primeras series gráficas realizadas por Matta.

\section{IV.1. Atelier George Visat - Albert Dupont}

Sin embargo será durante la década de 1960 cuando comienza a desarrollar el grabado calcográfico en el atelier de George Visat en París, el cual se sitúa en la rue del Dragón, muy cerca del Café de Flore, donde se reunían los surrealistas liderados por André Bretón. El atelier de Visat se constituye, así, en un eje principal, no tan solo para Matta, sino también para otros artistas surrealistas como Chagall, Miró, Picasso, Bellmer, Ernst.

George Visat, quien era poeta, editor y grabador, motivó a los surrealistas a desarrollar lo que él llamó el "Grabado Empírico", que es una técnica donde se deja que el azar sea un espacio de juego en el proceso del grabado, siendo esta técnica muy utilizada en las obras calcográficas de Matta, ya que cada uno de los fondos calcográficos están realizados por medio de las técnicas de aguafuerte, aguatinta y técnica del azúcar, que son trabajadas por medio del ácido de manera que éste produzca imágenes azarosas, es decir, es decir el Grabado Empírico, que realizaba Visat en su taller y que promovía realizar para y con otros artistas, y así, por medio de este proceso, se constituyen los fondos de Matta como si fuesen grandes manchas en el espacio. Asimismo cada obra calcográfica de Matta se constituye con más de una matriz, utilizándose entre 3 y hasta 6 planchas diferentes, ya que para cada color se utilizó una placa distinta. Así existe solo una matriz para el fondo que, como mencionamos anteriormente, se deja a la acción azarosa producida por las 
corrosiones del ácido; dejando otra matriz solo para el dibujo, donde destaca la figura de los personajes realizados por Matta, y por último, cada uno de los colores utilizados ocupa una matriz distinta, al igual que los gofrados utilizados por el artista. Por lo tanto, el imprimir una sola obra, o una serie, era un gran trabajo, porque el calzar no tan solo el tamaño y las formas dentro de los espacios sino también los colores era un trabajo a lo menos extenuante. Cada color se realiza en una matriz diferente, como hemos mencionado, sin embargo hay que añadir que la elección del color es un primer momento seleccionado por el artista, luego Matta conversaba con el impresor para cambiar colores, aumentar tonalidades y ver los resultados azarosos que pueden producirse en el momento de la impresión, y los que pueden de alguna forma colaborar con la obra.

Posteriormente a la muerte de George Visat, asumirá por completo el atelier su hija, Christine Visat y su esposo Albert Dupont, artista que conoció a Matta y trabajó con él en el atelier Visat desde que Dupont tenía alrededor de 18-19 años. Matta siguió, luego de la muerte de Visat, trabajando en el mismo atelier, ahora a cargo de Dupont con quien no solo terminó de realizar toda su obra gráfica sino que también fue con quien fomentó una amistad y una relación especial. Para Dupont, Matta no solo fue un gran artista sino también una persona que hasta hoy los inunda de poesía y de ese espíritu que no tiene que ver con lo mercantil, sino con lo de sentirse alegres, libres, enamorados de las cosas, de las situaciones de la vida. Matta influyó en él en ese sentido y en el sentido del crear poéticamente al mismo tiempo, del como quiere y desea seguir relacionándose con artistas. Hoy Dupont trabaja con artistas como Baselitz, Kupper, y varios otros, pero para Dupont nada es igual sin Matta ya que él llenaba un espacio con su pragmatismo que pocos artistas pueden entregar y dar gratuitamente a ellos. Dupont se siente agradecido, porque hasta en sus decisiones personales Matta influyó activamente y de eso, según el propio Dupont relató, no hay más que agradecerle. 


\section{IV.2. Atelier Fernand Mourlot - Frank Bordas}

Asimismo, Matta comienza a integrarse en el atelier de Fernand Mourlot en París, atelier en el que se trabaja solamente las técnicas litográficas, será en este atelier donde conocerá a Gino Diomaiuto en el año 1967, quien será el hombre que traspasará por más de 15 años los dibujos de Matta a las piedras litográficas.

Hay que mencionar que Matta, desde que entra en contacto con los atelieres de grabado, muy pocas veces realiza el proceso técnico de esta área plástica, ya sea litográfico, calcográfico o serigráfico, él no participa en el proceso de realización. Es decir, en términos prácticos, Matta llega con su dibujo realizado en una hoja de papel normal, de dibujo, y con los colores en su mente, como idea; solo algunos de estos bocetos llegan coloreados, así, es Diomaiuto quien traspasa a mano el dibujo a la piedra litográfica. Esto se da, según lo describe el mismo Diomaiuto, porque el área del grabado le hace tener menores preocupaciones al artista, en este caso a Matta, ya que son creadores que desarrollan su trabajo en otra área plástica, como en el caso de Matta a la pintura. En el grabado, los artistas provenientes de otras áreas, son ayudados por varios colaboradores, dibujantes, impresores y editores, lo que permite una gran despreocupación al artista en el desarrollo de su trabajo, ya que esta colaboración es una participación diversa, dado que el artesano, el dibujante, el editor y el impresor, cada uno de ellos aporta su visión a cada uno de los trabajos emprendidos. En cambio en la pintura, Matta se enfrentaba solo a un tela o soporte y él mismo es quien se encuentra con las dificultades del proceso, debiendo hacerse cargo por sí mismo, sin ayudas. Es quizás por ello que existe una mayor preocupación del artista en el área que desarrolla fundamentalmente su obra. Asimismo, el por qué Matta se introduce y desea desarrollar parte de su obra en el área del grabado, ya sea calcográfico, litográfico o serigráfico, es porque realizar un grabado para Matta era, una experiencia diferente, un descanso de la pintura, ya que tenía una relación frente al proceso del grabado diferente, produciéndose entonces una creación paralela a la pintura. El que le daba más libertad en el proceso técnico, ya que no era él el que se encargaba del 
proceso eran solo sus ideas que debían ser plasmadas por otros en una matriz, y esto se puede deducir de las conversaciones que se ha tenido con los colaboradores de Matta, sin embargo algunos de sus amigos ven el impulso de Matta hacia el grabado, naturalmente, sin tanta conciencia de el hecho que lo aproxima a este proceso artístico.

El trabajo litográfico entre Matta y Diomaiuto se desarrolla en un ambiente de suma colaboración entre ambos; Gino tenía el espíritu de interpretar el trabajo de Matta. Un trabajo realizado bajo una estricta comunión entre ambos en el acto no tan solo de traspasar sus dibujos sino también en la relación nacida entre los dos, que era muy apasionada, con mucha simpatía como nos relata el mismo Diomaiuto. Gino trata, en todo su trascurso laboral con Matta, de traspasar siempre sus dibujos con la mayor fidelidad posible, desde el primer instante cuando Matta le entrega el dibujo original en una hoja simple y él debe traspasarlo. Sin embargo Diomaiuto aclara que para él no existe ninguna influencia de él mismo en el traspaso del dibujo a la piedra, no obstante, se cree que de alguna forma la hay, porque cada artista tiene características propias para expresar su trabajo, en una forma personal y única que va desde cómo toma el lápiz a cómo escribe, Cómo dibuja y cómo pinta. En este caso, por más que Gino tratase de realizar una fidedigna copia del dibujo de Matta sobre la piedra, siempre habrá algo del propio Gino en ese dibujo, a pesar de que él mismo no desee admitirlo.

Para el traspaso, entonces, del dibujo a la piedra, Diomaiuto utilizó diversos lápices como en las siguientes obras: "les coinvaincus", "Affiche pour le théâtre municipal musical, France culture, Festival d'Avignon", ya que debió realizar distintas líneas con diferentes grosores y calidades, dibujando de 2 ó 3 maneras diferentes. Así, para el traspaso utilizó los lápices N$^{0} 4$ William Kornis, Litho Crayón made U.S.A., Nº5 Philiphe Garel/ Luis Garel, los lápices crayons №2, Copal / № 1 duro, con el cual se logra una línea muy fina, además de la utilización de una pequeña pluma Brandon ${ }^{\circledR}$. 
Las piedras sobre las que trabajó Diomaiuto para realizar las obras de Matta eran piedras calcáreas litográficas que pesaban entre 200-250 kilos, asimismo, dibujó sobre placas de zinc y aluminio que eran las otras matrices con las que le gustaba trabajar a Matta en litografía. Finalmente, las litografías de Matta se imprimieron utilizando la tinta litográfica de Charbonnel, sobre distintos soportes y calidades de papel, en los que podemos mencionar la utilización de papel Arches, Japón Nacré, Canson y Fabriano en diferentes gramajes que van desde los 125 hasta 225 gramos.

Con respecto a cómo se incluye el color en las obras, es una parte del proceso que Matta trabajaba en un primer instante con Fernand Mourlot y posteriormente con su nieto Frank Bordas. No obstante, como nos relata Bordas, Matta tenía la idea de ir siempre cambiando su trabajo, por ello "siempre deseaba transformar el color siendo una exigencia, pero también un problema” ${ }^{\star 2}$. La litografía, como sabemos, es una técnica que aporta posibilidades diversas utilizando 5 colores como máximo (los que se utilizaban en el atelier, en ese tiempo, según nos explica Diomaiuto), la paleta de colores es, entonces, una síntesis. Para los pintores que buscaban una copia fidedigna de su obra y no una síntesis, (como es el grabado), era un gran problema (cosa que para Diomaiuto es una exigencia estúpida). En cambio Matta, quien se nutría de los accidentes producidos en las diferentes fases del proceso técnico y creativo, esta exigencia no la planteaba, ya que consideraba, como toda la gente relacionada al grabado, que el grabado es un proceso que desarrolla principalmente el dibujo, añadiendo Matta a su obra, los aportes involuntarios que nacen durante la realización.

Siendo en esta elaboración donde existe una parte del proceso que es la indicación de los colores. Matta, en algunas oportunidades, como relata Diomaiuto, era un poco cambiante, ya que en un principio indicaba realizar la obra con solo tres colores y luego quería otros dos más, siendo imposible realizar este proceso en la etapa posterior, lo que generaba un diálogo, o a veces discusiones, entre Diomaiuto y Matta sobre los colores seleccionados y el proceso de realización. El impresor en este instante es relevante porque aporta su 42 Conversaciones con Frank Bordas. Paris, enero del 2004. 
visión al artista, en este caso a Matta, ayudándolo con su opinión, para así establecer en conjunto la selección y elección no solo de colores sino también de papel, calidad, dimensiones, etc.

\section{IV.3. Relación Matta-Bordas: Atelier Frank Bordas}

La conexión entre Matta y Frank Bordas se inicia en París cuando éste último tenía 20 años, en el año 1979. Bordas estaba comenzando con su atelier y, en el inicio de este, invita a participar Matta, quién ya entonces era una estrella en París. Bordas recuerda el primer encuentro de ambos, en donde estuvieron conversando una hora, Bordas nos relata que se sintió un poco intimidado por este artista, siendo en esta primera conversación donde Bordas se da cuenta que Matta era un poeta de la vida. Después de este primer encuentro, Matta comienza a trabajar con Bordas y Michael Woolworth, impresor norteamericano radicado en Francia, socio y amigo de Bordas durante esa época. No obstante Frank no sabía cómo manejar un atelier de impresiones comerciales, como él mismo nos declara "no estaba estructurado para ello. Yo trabajaba por amor al arte" ${ }^{43} \mathrm{y}$ así, por amor al arte, trabajó durante un año y seis meses casi gratuitamente para Matta. Durante este periodo de trabajo, Matta nunca firmó nada y así muchas estampas y matrices se tiraron, y las que no, al cambiar el domicilio del atelier, años después, fueron extraviadas en el intertanto, o reutilizadas por otros artistas.

Para Bordas, Matta entendía la litografía como un laboratorio de experimentación, lo que era muy estimulante, sobre todo para unos jóvenes como él y Woolworth. Sin embargo esto a veces era un poco confuso, ya que Bordas algunas veces consideraba terminada la obra y Matta no, por lo tanto Bordas tenía que seguir trabajando, siendo eso complicado por el asunto del enigma y porque, según lo que percibía Bordas, para Matta nunca la obra estaba terminada (véase página....capitulo pintura y grabado). O, como lo

\footnotetext{
${ }^{43}$ Conversaciones con Frank Bordas. París, enero del 2004.
} 
describe Gino, Matta tenía la misma metodología tanto en el grabado como en la pintura: un orden en el desorden ya que él era un "desordenado en el orden" ${ }^{4}$.

Refiriéndonos al proceso de trabajo de Matta, Bordas nos cuenta que Matta busca los accidentes de la tinta, del agua, del color, todo es un accidente provocado por su rapidez, ya que Matta tenía una velocidad increíble, mucho mayor que la de un hombre de 20 años.

Por último, Matta ejerció una relevante influencia sobre Bordas como él mismo lo describe

“Matta me ha dado muchas llaves para entender la poesía y la pintura, sobre todo esta ultima, ver las galerías, las exposiciones, el todo, la política, lo artístico, lo cultural, absolutamente todo con mucha velocidad" ${ }^{15}$

Y agrega que Matta "sobre todo me ha dado mucha energía" ${ }^{46}$. Siendo esta energía la que posiblemente motive a contar todos estos acontecimientos.

Para terminar este capítulo, podemos escribir que Matta influye en otros artistas fundamentalmente en como él ve el arte, como él concibe la vida, y en una posición quizás menos importante a nivel técnico, ya que son los conceptos que él posee de el arte y la vida en conjunto los que influyen en otros y esto sin importar de que área artística uno sea o se desarrolle. Por otro lado las visiones que tiene sobre el grabado son las mismas que tiene a nivel artístico general, el automatismo que él desarrolla y que se ve apoyado y acentuado con el grabado empírico, que hasta hoy sigue casi en su totalidad desconocido, porque a pesar de conocerse hoy una parte de sus grabados, aún no conocemos la totalidad de su obra, y es por eso que esta tesis se planteó ese objetivo, de

\footnotetext{
${ }^{44}$ Conversaciones Gino Diomaiuto.Paris, febrero del 2004.

45 Conversaciones con Frank Bordas. Paris, enero del 2004.

${ }^{46}$ Conversaciones con Frank Bordas. Paris, enero del 2004.
} 
rescatar no sólo la obra gráfica de Matta sino a un Matta grabador, que al solo conocer la forma de trabajo y sus planteamientos en el mundo del grabado se podría reconocer como tal. 


\section{Pintura y grabado}

$\mathrm{L}$ a obra gráfica de Roberto Matta se ha presentado hasta ahora en esta tesis como un área artística ajena a las otras disciplinas plásticas en que las que ha trabajado este artista. Esto se debe a la voluntad de rescatar apasionadamente los grabados de Matta, puesto que ese es nuestro interés y el tema central de la tesis, pero ello no quiere decir que se olvide su importancia en otras áreas. Es por ello, que se llega a un punto de este estudio, en que hay que hacer una pausa profunda y seria. Mirar hacia el lado y darse cuenta de que realmente no se puede finalizar este proyecto, llamado tesis, sin antes hacer una relación con el área plástica de más desarrollo en profundidad de este artista que fue y es la pintura.

Las razones del por qué se elige la pintura y no otra técnica de expresión, para comparar y guiar el estudio previo que se ha realizado sobre el grabado, se dará a conocer un poco más adelante, ya que es interesante antes mencionar que Matta no solo hizo grabados y pinturas sino también fue prolífico escultor y ceramista, asimismo, y quizás en mayor medida, dibujante. Entonces el por qué se elige la pintura y no otra técnica de expresión, sabiendo que se podría obtener bastante información de la escultura, por ejemplo. Se basa esencialmente en tres razones primordiales: una, porque el comienzo de Matta como artista es a través de la pintura, que es su primer medio de expresión, el cual desarrolló desde sus inicios hasta los últimos años de vida, siendo la pintura la columna vertebral del artista; dos, porque su obra pictórica fue tan extensa, fértil y a la vez de tan grandes dimensiones, que se encuentra un número bastante mayor de pinturas que obras realizadas en otras técnicas; y tres, la obra pictórica de Matta al ser tan extensa ha sido estudiada con bastante profundidad desde sus inicios, cabe recordar que fue por una de sus obras por la que es invitado a participar en el movimiento surrealista. 
Entonces la base de datos que se puede obtener es amplia a nivel de desarrollo de obra, de definiciones teóricas sobre su pintura y del mismo modo a nivel de clasificación temática. Encontrando así información asertiva y constructiva que de alguna forma se piensa, puede ayudar a concluir esta tesis, ya que se puede decir que la pintura y las bases de ésta en el trabajo de Matta nos darán las herramientas necesarias para terminar a cabalidad nuestro tema central que es el grabado.

Siendo nuestro anhelo tomar la pintura para avanzar en esta investigación, no tan solo con una idea comparativa entre ambas técnicas (grabado y pintura), sino como la excusa o el peldaño que faltaba para poder terminar la escalera. Y se dice para terminar esta escalera, porque no se puede estar ciego y fingir que el grabado fue todo para Matta, porque en términos prácticos no lo fue y es esta causa más otras que ya se han mencionado, del por qué se estudia la pintura para rescatar el grabado de este artista.

Y se toma la pintura para definir, clasificar e indicar etapas de Matta en el grabado, ya que no existe un estudio en este sentido gráficamente, entonces se piensa que a través de la pintura, como medio y herramienta se pueden establecer estas categorías para así, con profundidad y certeza, poder esclarecer aún más el desarrollo de su obra en el grabado. Considerando esencial la observación de obras gráficas y obras pictóricas del mismo año o periodo para así esclarecer aún más, las etapas de creación y desarrollo gráfico en los grabados del artista.

En la misma línea, se pretende expresar que la información que se obtenga sobre el desarrollo pictórico de la obra de Matta, será una referencia más para esta investigación sobre el grabado de este artista.

Asimismo, se incluirá la mirada de Matta hacia sus obras, su proceso de trabajo general en relación a todas las técnicas y, sobre todo, se desea recuperar y valorar los acontecimientos ajenos a su vida personal, que motivaron la creación, que son los 
hechos históricos. Siendo éstos el inicio para transferir sus ideas, reflexiones y pensamientos, frente a lo que estaba aconteciendo. Y es aquí donde se puede citar la idea del poeta y escritor francés Alain Jouffroy sobre Matta, que expresa en su libro "MATTA" que la obra del artista, si se quiere, es una propaganda de un hombre que tiene la necesidad de contaminar a los otros con sus ideas, sus entusiasmos y sus angustias "la propagande d`un homme seul, la propagande d`un poète et d'un amoureux, jamais celle d'un homme de parti". ${ }^{47}$ siendo entonces su obra lo contrario de un juego, porque las ideas son pensamientos internos reflexivos y al utilizarlos para transmitir su posición sobre un hecho, debe ser mínimamente astuto para no caer en el juego de lo sin sentido, de lo obvio, de lo inmediato, que Matta por supuesto no tiene, y que por el contrario, utiliza su astucia, inteligencia y habilidad como una propaganda para impregnarnos de lo acontecido y hacerlo de alguna forma, algo propio en nosotros.

Finalmente, se desea aclarar que el capítulo que se presenta no es tan solo un cuadro comparativo entre dos áreas, ya que para ello se presenta en la última parte de este capítulo una línea de tiempo en la que fácilmente el lector podrá ver y comparar las diferentes obras y etapas desarrolladas por este artista, sino que se presenta en un primer momento claramente todo lo que se refiere a la pintura de Matta, cuál es su definición, cuáles son las etapas de trabajo, qué veía Matta en sus obras, qué nos dio él como teoría sobre sus obras, ya que se piensa que si no se presentara esto como base, bastante poco se entendería posteriormente su obra en general y el grabado en específico.

Al concluir esta primera fase de definición de la pintura de Matta, se presenta la primera comparación o mejor dicho, el primer diálogo entre pintura y grabado, donde se pretende resolver interrogantes, como si realmente la pintura influyó en sus grabados, en qué obras podemos ver esta influencia, si existiese, y si realmente a veces ${ }^{47}$ JOUFFROY Alain, MATTA, Galerie, 19 rue du dragón Paris 6. Francia 1958. p.8. 
el espacio de la pintura se le hizo pequeño y tuvo que recurrir al grabado para desarrollar más un tema o viceversa. Se cree que este primer diálogo es esencialmente un diálogo entre dos disciplinas y no dos disciplinas ajenas. Por último se planteará la interrogante de si Matta fue un grabador o no, siendo estas últimas páginas las que darán, por decirlo de alguna manera, el habeas corpus de este trabajo o por el contrario una conclusión diferente a la esperada.

Con espíritu crítico y análisis precisos se desea tener una visión singular, entregando una nueva y única información sobre grabado, de este artista. 


\section{V.1. La obra y pintura de Matta}

"Si se pudiera pensar en ir más lejos, más profundo en el estado mental, en la geología de la mente, se vería un increíble hervor de energías que funcionan eternamente en cada especie. [....] . Las llamamos cólera, voluntad, pero yo veo una imagen que se parece más a la energía del sol. [...]. En cada ser hay un núcleo del que deriva la energía y que, al mismo tiempo, ritma y modifica. Este núcleo no podemos sino llamarlo sol, a falta de otra palabra, pero podríamos denominarlo umbral. La energía humana es un sistema en expansión en un universo similar a un $\operatorname{cosmos}^{48}$

R. Matta, la tierra es un hombre.

Lo primero que hay que saber de Matta, para comprender lo que el mismo artista nos explica de su obra a través de la pintura, es que él no es sólo un artista plástico, sino que es un filósofo y un metafísico. Y hay muchos pensamientos de estas dos grandes áreas humanistas que motivan, generan y se entrelazan con y en su obra.

Siendo la pintura y sus pinturas el mejor sonido por el que Matta logra expresar verbalmente su pensamiento, respecto a lo que el desea y transmite plásticamente en sus obras. Presentando igual discurso, en todas las técnicas, solo que Matta lo logra explicar por medio de su pintura, quizás porque es más conocida y así es más fácil de comprender para los interlocutores que realizaron conversaciones o entrevistas con él, ya que probablemente se han sentido hablando en un mismo campo común de conocimiento, para luego transcribirlo y hacerlo presente hacia los que no logramos conocer a Matta en vida, y por lo cual, solo nos queda por una parte ese registro escrito y por otra los testimonios orales de quienes convivieron con él y lo guardan aún en su memoria. De este modo hemos podido enterarnos de lo que Matta pensaba y reflexionaba sobre su propio trabajo.

48 ACCATINO, Sandra. "Historia, imaginación, aventura", en Oyarzun, P.; Álvarez, G.; Muñoz, M.E. y Accatino, S.: Tentativas sobre Matta, Editorial Delirio Poético, Santiago, 2002. p.64. 
Para adentrarse en el trabajo de Matta debe uno situarse, en lo que a primera vista se observa, como espectador, cuando se está frente a su obra, que es el espacio que nos presenta, se podría decir, que es un área en la que intenta representar justamente la idea de la dimensión y de tiempo, en conjunto y en el mismo momento, ¿pero qué es el espacio en la obra de Matta?, según Pablo Oyarzún en el libro Tentativas sobre Matta es "la plasmación de la fuerza de la imaginación en la génesis de un continuum de espacio-tiempo" ${ }^{* 9}$ siendo a la vez esa combinación entre espacio y tiempo una "crítica del espacio plástico convencional” ${ }^{5_{0}}$, que se realiza en la práctica introduciendo sistemáticamente la dimensión temporal a través de líneas y figuras con un sin número de velocidades, que los ojos difícilmente logran captar, para posteriormente analizar en el cerebro -en la psique- ya que el ojo en sí esta sólo preparado para una determinada velocidad. Para expresarlo de mejor forma, nos situaremos en las figuras surrealistas (típicas) en las que solo se veía un tiempo lento, dejando la posibilidad para que los ojos descansasen, no obstante Matta no nos permite eso y nos exige más, presentándonos un tiempo veloz y a la vez yuxtaposiciones, basadas y generadas en el origen de las figuras que en esencia son sus morfologías determinadas por su continuum de psique y mundo, ya que cada objeto o figura se encuentra en el mundo, en un momento preciso, histórico, y psíquicamente correcto. No obstante esto pertenece al origen, la génesis de los objetos o de las figuras y no a lo que el espectador o nosotros mismos consideramos, por decirlo de alguna forma, cuerdo, siendo los orígenes de cada uno de los objetos o las figuras y sus morfologías lo que nos lleva a ver conscientemente un espacio en las obras de Matta. Un espacio en el que siempre intenta representar la relatividad y el que finalmente trata de recrear o crear proyecciones geométricas.

Es importante decir de dónde nace este interés de Matta por querer mostrar primero un espacio, luego la relatividad y las ondas que se presentan dentro de ese espacio y 49 OYARZUN, Pablo. "Pintura y posibilidad", en Accatino, S.; Álvarez, G.; Muñoz, M.E. y Oyarzun, Pablo. Tentativas sobre Matta, Editorial Delirio Poético, Santiago, 2002. p.15.

${ }^{50}$ Ibidem. p.15. 
dentro de cada cuerpo, ya sea activo o estático (inactivo). Pero antes de saber de dónde nace su interés, habrá que decir que lo relevante en sus obras es justamente este juego entre el espacio de la relatividad y ondas que muestra y desarrolla en toda su larga trayectoria artística. Ya que para él las líneas trazadas son una proyección de las ondas creadas por un cuerpo, sin importar el tema o sujeto que trate en cada una de sus pinturas o grabados, él siempre presenta todo con su relatividad a partir de las ondas generadas por lo esencial del cuerpo, al artista no le interesa pintar figurativamente, es cierto que él pinta figuras, pero lo que busca es lo esencial de cada una de ellas, por ejemplo el pie que es una parte del cuerpo a la que Matta ha recurrido para explicar como él crea un espacio, y la búsqueda en lo relativo de un cuerpo y sus ondas. Cuando ve un pie no le interesa dibujar su contorno, lo que encuentra relevante es descubrir qué hay dentro del mismo pie, es la intención, el anhelo por llegar a su origen, que es un núcleo de espacio, dentro de si mismo y dentro del gran espacio donde se sitúa.

Dicho de otra manera, él buscó lo esencial del pie y es allí, en lo esencial, donde se encuentra el núcleo del sistema de onda, que producirá finalmente lo que se ve concreta y objetivamente, que es un pie, pero que Matta lo presenta como una búsqueda o un estudio por lo esencial, dentro del objeto, siendo esta búsqueda representativa de hechos, figuras o situaciones iniciadas a partir de la propia esencia de ellas y no de su apariencia, llegando a ello por medio de un cuestionamiento y del tiempo en que se sitúa tanto él como lo que desea presentar o mostrar, es decir un continuum de psique y mundo, pero nos hemos salido un poco de lo que se está explicando, que es el momento justo cuando Matta se interesa por las ondas y la relatividad, que nace a partir de la idea de espacio y tiempo, para poder luego llegar a lo esencial de cada una de las figuras, cosas o acontecimientos que presenta en sus obras. La motivación, el inicio del interés de Matta hacia el espacio, la relatividad y las ondas se produjo durante el año 1937, cuando en París asiste a una exposición sobre la geometría no Euclidiana y luego, en 1942, a la gran exhibición surrealista de la Red 
Mansión en Nueva York, produciéndole ambas exposiciones una gran motivación hacia el estudio de nuevas figuras espaciales.

Posteriormente llega a encontrar "las hondas de Hertz y en él, las concepciones del espacio-tiempo surgidas a partir de la física moderna, un modelo de la materia, del espacio y del tiempo para la pintura" ${ }^{\text {11 }}$ pero sobre todo Matta es un artista con una fuerte influencia del modelo construido en la física moderna a partir de la relatividad de Einstein, “donde el tiempo de un acontecimiento no es absoluto, sino dependiente de la masa y de la posición en el espacio" ${ }^{52}$ es por ello que en la obra de Matta vemos el espacio y el tiempo tratados en conjunto y es con todos estos encuentros teóricos y plásticos que descubrió, buscó y aprovechó Matta cuando quizás él le encuentra un sentido a su trabajo, que en ese entonces se estaba iniciando. Posiblemente es allí cuando descubre un justificativo válido para su trabajo, para de cierta forma no solo definirlo, sino también para explicarlo; no obstante estas exposiciones se realizaron entre los años 1939-1942, cuando Matta no llevaba gran parte de su obra pictórica realizada, entonces no fue solo un justificativo a su obra sino también se puede decir que fue una motivación por aprender y desarrollar más algo que estaba dentro de él sin definiciones y que cobra un sentido relevante en toda y a lo largo de su obra, ya que es a partir del espacio, del tiempo, del sistema de ondas y la relatividad que él logra explicar sus obras.

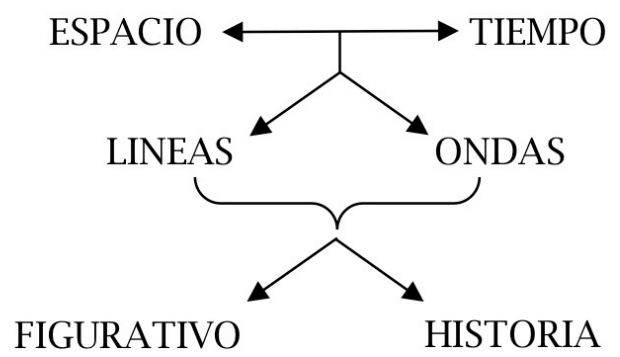

51 ACCATINO, Sandra. "Historia, imaginación, aventura", en Oyarzun, P.; Álvarez, G.; Muñoz, M.E. y Accatino, S.: Tentativas sobre Matta, Editorial Delirio Poético, Santiago, 2002. p.68.

52 Ibidem. p. 68. 
Habría que añadir que la espacialidad y las superficies que muestra y que impregna Matta en sus trabajos se cree que nace por la fuerte influencia, quizás inconsciente, que tiene de sus estudios de arquitectura y del desarrollo de espacios arquitectónicos.

Pero bien, ¿Qué es la relatividad y el sistema de ondas o las ondas producidas tanto por objetos como por personas para Matta?, él lo explica de esta forma: "el sistema de ondas hertzianas, las hondas térmicas, la forma que asume el viento en un ciclón, los rayos que envían luz al interior de una bombilla, son grandes transparentes... especie no estará nunca más acabada, definida, de lo que pudiera estar el sistema solar." ${ }^{54}$ Con estas dos citas Matta nos dice que cada forma en su interior posee tantas ondas que es imposible acabar de definir o crear una figura, porque todo lo que su origen produce es tan inmenso y tan transparente que va a hacer un centro de creación y motivación permanente en su obra.

Y así veremos en sus obras que las líneas serán fundamentales para trazar las ondas que generan figuras y posteriormente el espacio-tiempo en la pintura de Matta, representando su fuerza tanto en el trazo provocado por él, como la fuerza que llevan por si mismas las figuras representadas, siendo entonces su pintura una pintura energética, con un dinamismo gestual que se expresa sobre la inmensidad, traducida a través del espacio casi cósmico en el que están representados sus temas y en las grandes dimensiones de sus obras. Siendo aquí importante destacar que el espacio que presenta es tan amplio, con tantas perspectivas, nacidas quizás inconscientemente, como ya se ha mencionado, por sus influencias, sus estudios de arquitectura, su tratamiento del sistema de ondas que Matta desplegó continuamente en sus obras y por lo relativo que se presentan estos conceptos, que el espacio parece que lo limitase y tratase como él mismo ha manifestado de salir "de los espacios convencionales

${ }^{3}$ Citado por: ACCATINO, Sandra. "Historia, imaginación, aventura”, en Oyarzun, P.; Álvarez, G.; Muñoz, M.E. y Accatino, S.: Tentativas sobre Matta, Editorial Delirio Poético, Santiago, 2002. p.68.

${ }^{54} \mathrm{Ibidem}$, p.68 
multiplicando los horizontes...”55, y como espacios convencionales se podría entender en una primera lectura el formato al que recurre en sus obras, quizás por ello utiliza constantemente los grandes formatos, porque parece que ese espacio es tan inmenso, galáctico y cósmico que pudiese salirse en cualquier momento de su propio límite y es esa una invitación sugerente que pone en evidencia en todos sus trabajos.

No obstante, hay que mencionar como un alcance, que a pesar de que sus grabados no poseen dimensiones gigantescas o fuera de los “cánones" formales del grabado, su idea de mostrar un espacio tan inmenso que es un tanto cósmico se transmite igualmente sobre el papel, como en su pintura, produciendo el mismo sentimiento de limitación que aparece en sus obras pictóricas sobre el formato, se podría decir entonces que para Matta nunca un formato va a ser suficientemente grande para desarrollar sus creaciones, es por ello que recurre a la herramienta que mejor sabe utilizar, que es la creatividad, para podernos presentar un espacio sin limites y sin convenciones.

Y también se pudiese pensar que el salirse de los espacios convencionales y multiplicar los horizontes que ha dicho Matta, se podría referir más fuertemente a la idea de presentar un espacio-tiempo artístico, que no existía hasta ese momento en la historia del arte, o en los artistas que en esos momentos él frecuentaba o conocía. Matta lo expresa hablando así de los únicos artistas que vio como precedentes a su trabajo, en relación general a su obra:

“Cézanne tenía un sentimiento de vibraciones, y Van Gogh; y probablemente antes de ellos lo tenía El Greco. Miguel Ángel lo tenía eso con la piedra...y Leonardo tenía algunas veces ese interés en las manchas ${ }^{156}$

\footnotetext{
55 Citado por: ACCATINO, Sandra. "Historia, imaginación, aventura”, en Oyarzun, P.; Álvarez, G.; Muñoz, M.E. y Accatino, S.: Tentativas sobre Matta, Editorial Delirio Poético, Santiago, 2002. p.72.

${ }^{56}$ CARRASCO Eduardo, Autorretrato nuevas conversaciones con Matta, Santiago de Chile 2002. p. 203.
} 
Es quizás también por ello, por verse realizando algo que muy pocos creaban o investigaban y por encontrarse ante esas ideas y motivaciones que inconscientemente estaban en él, que quizás él desea salir de lo que imperaba.

Un convencionalismo que poseía el arte clásico y realista que venía desarrollándose en la práctica desde los siglos XIV y XIX respectivamente, a través de la representación histórica figurativa y real, que Matta desarrolla igualmente en sus trabajos, pero que en la práctica-resultado no tiene ninguna connotación concreta de la figura o la historia que proponía el arte clásico y el arte realista. No obstante, Matta presenta como tema central en sus obras la historia, (lo que se explicará con mayor fuerza en los párrafos posteriores), siendo ambas (la historia y las figuras) las que en conjunto provocan un gran cambio a nivel plástico, ya que por un lado le toca lidiar con la vanguardia en el sentido de que ésta había excluido de sí la pintura de historia, y que a la vez se enfrenta con lo que fue un paradigma de la pintura clásica, entonces ¿Qué hacia un Matta con ideas tan avanzadas a nivel de la relatividad, de ondas, de espacio queriendo mezclarlo con algo tan concreto como la historia?.

Aquí se genera un cambio importante no tan solo a nivel plástico, ya que él con sus formas no figurativas nos lleva a situarnos aún más que en los propios hechos históricos en sus sentimientos y su postura sobre esos hechos, y es este conjunto lo que lo enfrenta sin lugar a dudas a una sociedad artística que buscaba casi huir de su propia historia y regocijarse en sí mismos, como quizás un medio de protección ante lo externo.

A la vez, se debe recalcar que Matta se sale sobre todo de los cánones, éstos que ya hemos establecido, según sus propias palabras, como convencionales, al expresar como se ha mencionado en el párrafo anterior- el motivo preferido, su leitmotiv, que lo impulsa a trabajar primordialmente en ellas, que son los hechos históricos: la historia 
que ha acontecido, siendo interesante este punto, porque por una parte no tiene nada de aventurero y por el contrario pudiésemos pensar que es hasta un gran convencional.

Aunque las obras de Matta se escapan de ese realismo al que se está habituado, a ese ambiente de la pintura realista que las costumbres visuales de nuestro inconsciente colectivo nos hacen pensar inmediatamente en un hecho histórico representado figurativamente y lo más parecido a las circunstancias para relatar el hecho, no obstante a esto, la mayoría de las pinturas de Matta, por no decir que son todas, tienen su tema central situado en la historia -la historia real- pero no son características de la realidad concreta, la historia acontecida y narrada, sucesos, nacionales o mundiales, que hicieron eco en todas las personas entre ellas en Matta, quien quizás inconcientemente toma parte de la realidad y la expresa en sus obras, y quizás inconsciente porque siente tanta pasión ante los hechos que necesita dejarlos como un registro de lo acontecido, porque no se siente ajeno a lo que sucede a su alrededor y es por ello que se cree que nos desea traspasar su postura sobre la realidad en sus obras, y no como los artistas justamente de su misma época, que prefieren aislarse y casi huir de la historia, tanto personal como colectiva. Por el contrario Matta sale más y más de ese convencionalismo sobre todo al tratar y trabajar la historia no como un registro fiel de lo sucedido fuera de él. Dicho de otro modo, él no plantea estos acontecimientos como un mero narrador u observador, por el contrario es el hecho absorbido por su persona y expulsado con tanta fuerza hacia el exterior, con tanta pasión, que su obra no es reconocida tan solo por su técnica y por su desplazamiento, sino más por su expresividad, que refleja su postura ante los hechos, lo que es una diferencia esencial, entre muchas, que Matta tiene con los otros artistas realistas e históricos.

Para que quede aún más claro, se menciona la obra La balsa de la medusa de T. Géricault. Esta obra presenta un hecho histórico que fue el hundimiento de la fragata Medusa, enviada a Senegal por el gobierno Francés el año 1816 bajo el mando del conde de Chaumareix, a quien se le atribuye posteriormente el hecho del desastre. Es 
cierto que el año del acontecimiento de este hecho y de la creación de esta obra en especifico, 1818-1819, no tienen ninguna relación con la vida y obra de Matta, solo mencionamos esta obra, La balsa de la medusa, para así, con un carácter general (es decir, como un mero espectador) poder entender las diferencias entre el tratamiento realista de la pintura y las obras de Matta, definidas como surrealistas.

Pues bien La balsa de la medusa fue un hecho escondido por los gobernantes de la época y, más aún, como no se contaba con los medios de información que hoy se posee, la información que se obtuvo acerca de este hundimiento fue limitada con respecto a lo que hoy ya se sabe sobre el naufragio y que es que el capitán y los oficiales usaron los barcos salvavidas y abandonaron a los marineros, a los que se consideraba socialmente inferiores, entonces un grupo de 149 personas improvisó una balsa y, para subsistir, se vieron obligados a practicar el canibalismo. Solo 15 personas sobrevivieron cuando la balsa fue encontrada una semana más tarde a la catástrofe por la fragata Aarhus. Guericault realizó esta pintura para comunicarle a la sociedad lo que había acontecido, evidentemente el asunto -el tema- pasó por él, es decir, lo que él pudo saber, luego pudo magnificarlo o minimizarlo a nivel de desarrollo de imagen, pero fue un hecho que él deseo transmitir de una forma realista a primera vista, para comunicar lo acontecido. En relación a Matta, el interés principal es el de relatar lo acontecido históricamente por medio de su persona y personalidad, es decir no le interesa presentar algo realista en las primeras lecturas o miradas hacia su obra, lo que le importa es que la realidad se haga parte en él y se traduzca por medio de él, es por ello que en sus obras no vemos la auténtica realidad, sino una realidad expresiva apasionada presentada a través de la búsqueda del origen y la fuerza lineal del espacio, de la relatividad y de las ondas sobre la superficie presente en sus obras.

Aunque sabemos que es difícil realizar una explicación teórica de la obra de Matta y a la vez tratar de explicar lo que la motivó, se puede decir que Géricault se convierte en un intérprete de un sentimiento popular, que polarizó a la sociedad francesa de la época, y que Matta es un creador de la historia acontecida fuera y dentro de él. 


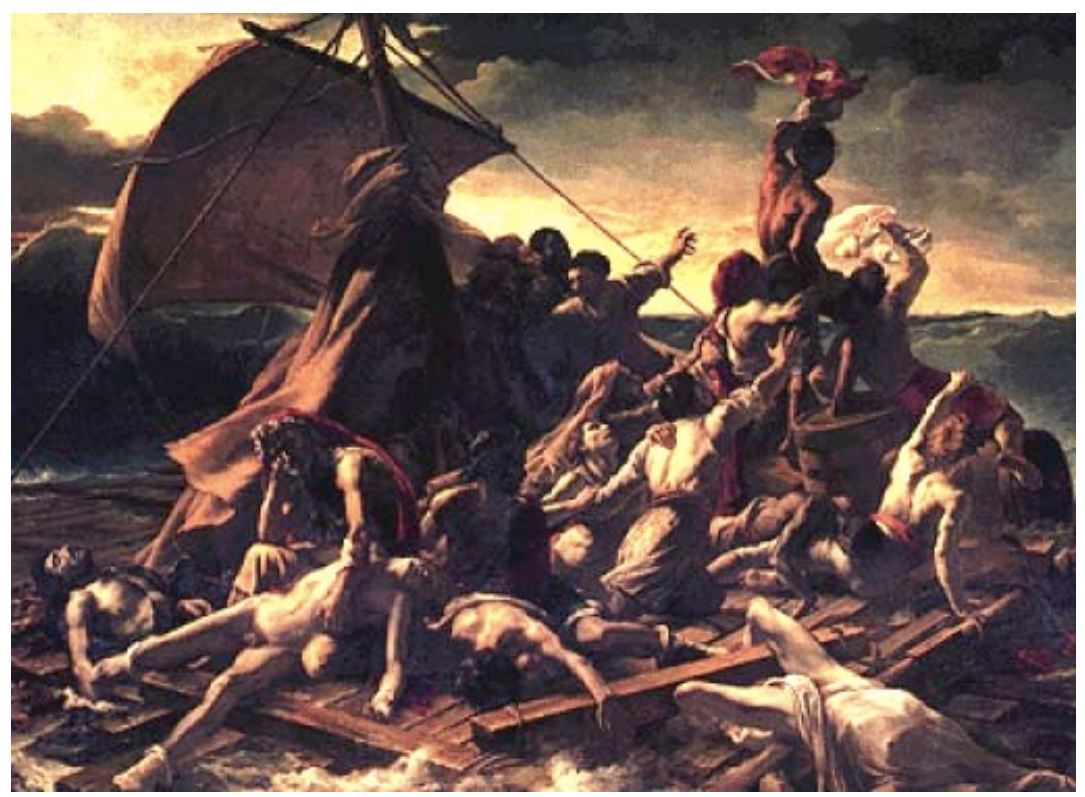

Géricault La balsa de la medusa 1819

Y más allá de todo el desarrollo existe un compromiso personal de Matta entre él y su obra, entre él y la historia y su postura sobre todo ello, que lo distancia de los artistas de la época y que por el contrario ese compromiso abierto y directo lo diferencia positivamente, ya que sale como muy pocos artistas de esos círculos y se involucra con la historia y los acontecimientos de los pueblos.

Siendo entonces relevante decir, que la incorporación de la historia en la pintura de Matta se expresa explícitamente por su compromiso personal y fuertemente político. Esto es algo patente para los espectadores, pero también para el mismo Matta que en contadas oportunidades lo expresó de este modo: “Así como la experiencia del universo es individual, la experiencia de ser individuo es universal" ${ }^{57}$ o como lo describió Octavio Paz

"Hay, además, otro elemento en esos cuadros de Matta que no ha dejado de manifestarse en su obra subsecuente: la historia. Con razón nunca ha querido

57 MATTA, Roberto. Catalogo de la exposición Matta. El año de los tres ceros. Santiago de Chile, Fundación Telefónica 2000. p.66. 
separar el mundo íntimo social y ambos de las fuerzas naturales y físicas. Para Matta la revolución y el amor, los cataclismos sociales y las explosiones de la galaxia, son parte de la misma realidad y, en un sentido profundo, riman (...). Pero lo que cuenta su pintura no es lo que pasa en la actualidad sino abajo y arriba de ella, el juego de las fuerzas e impulsos que nos hacen, deshacen $y$ rehacen" $"$ s8.

Y a la vez fue esto una puerta que le abrió nuevos caminos de expresión y conocimientos, sus viajes a Cuba, su relación con los estudiantes, el mural hecho en Santiago de Chile con la brigada Ramona Parra, en fin, son innumerables los acontecimientos iniciados por ese compromiso político que es en inicio y fin, plástico, donde nuevamente muestra y expresa una parte de la historia, su posición y sentimientos sobre no solo lo acontecido, sino lo que pasa dentro y fuera de esa actualidad.

Del mismo modo, no se puede olvidar que a Matta no solo lo motiva la historia vivida en primera persona; aunque éste fue su mayor impulso creativo, también lo fue, quizás en menor medida, su objetivo en crear, recrear y presentar su concepción de episodios de la historia, ya acontecidos en los que él no estuvo presente, pero que sintió profundamente como suyos, al igual su singular pasión por recrear obras literarias como "su particular modo de recrear las narraciones de Homero, de Cervantes, de Ercilla" ${ }^{59}$ en fin, se podría mencionar a muchos más literatos y obras, en las que Matta basó su trabajo, aunque se considera mucho más enriquecedor observar directamente estas obras en el catálogo confeccionado en esta tesis.

Sin embargo, no se puede intentar terminar este capítulo sobre la pintura y la obra de Matta, sin antes saber el cómo nace esta pasión o interés por pintar y narrarnos su 58 PAZ, Octavio. Catálogo del Centre George Pompidou, Musee Nacional d’art Moderne, París, 1985. p. 84. 59 ACCATINO, Sandra. "Historia, imaginación, aventura", en Oyarzun, P.; Álvarez, G.; Muñoz, M.E. y Accatino, S.: Tentativas sobre Matta, Editorial Delirio Poético, Santiago, 2002. p.64. 
percepción ante lo acontecido, narrarnos la historia, esto nace quizás en los años en que Matta está en EE.UU., después de irse a Norteamérica por el estallido de la segunda guerra mundial en Europa. En esos momentos Matta reflexionaría sobre cómo describir pictóricamente lo que siente y ve en esos acontecimientos a través de estas palabras: “como representar el campo de batalla, no físicamente, sino en su esencia, miedo contra coraje, crítica y odio, recelo y confianza?" ${ }^{60}$ y es en ese cómo, que Matta reflexiona, se sumerge y comienza a crear poco a poco, para luego en medio de todas estas reflexiones y quizás una cantidad importante de dibujos y bocetos, realizar otra reflexión muy substancial que la transmitiría de esta forma: “...asimismo deberíamos de tener cuadros que nos ayuden a combatir contra la oscuridad. Luz negra contra la noche negra de la ignorancia y de la guerra" ${ }^{61}$ siendo esta reflexión nacida de su observación a través de las ventanas, sobre las luces que invadían Nueva York en el año 1940.

Es así entonces, que en la pintura de Matta y en su obra en general se expresan con fuerza su visión y su postura frente a los acontecimientos históricos. Quizás, a modo de conclusión general, se podría decir que el tema central tratado en la obra de Matta fue la historia, incluida su historia personal, y su historia literaria, que es plasmada no tan solo como un hecho sino con toda esa angustia, esa pasión y ese frenesí de haberlo vivido y haberlo sentido aunque sea como un lector o a miles de kilómetros reales de lo que ha acontecido. Para enfrentarnos como espectadores a su propia búsqueda, la de "superponer, relacionar, abrir un fragmento de un acontecimiento"62 y hacernos participes de lo generado, de lo abierto.

Finalmente quiero hacerme eco de las palabras del escritor francés Alain Jouffroy sobre Matta, que expresa en su libro MATTA, donde explica que la pintura de este artista es la traducción de estados de conciencia recibida profundamente en la vida ${ }^{60}$ ACCATINO, Sandra. Op. Cit., p.65.

61 Ibidem, p.65.

62 Ibidem, p.65. 
cotidiana de cada hombre, ella es también y sobre todo una protesta contra la amenaza cotidiana que pesa sobre lo maravilloso. Y es el contenido original de su obra que ha determinado la originalidad de su forma. En la tesis que se presenta se cree fuertemente en esta percepción y definición de Alain Jouffroy porque con Matta se ve aún la vida y la realidad con la originalidad de su mirada y de su propia historia.

\section{V.2. Elementos y formas utilizados por Matta}

Existen tanto en las pinturas como en los grabados de Matta elementos que se repiten y que pueden aclarar algunas épocas o que por el contrario pueden ocultar o mostrar algo tan cerrado y oscuro dentro de ellas que se puede llegar a pensar que el artista pasaba por un mal momento o hubo algo que en ese instante lo agobiaba.

En esta parte se ha decido justamente ver esos elementos y definirlos, con y a través de Matta porque se considera oportuno aclarar cuáles son estos elementos y qué función cumplen dentro de su obra, para así entender sus creaciones con un mismo hilo conductor.

\section{V.2.1. Espacio}

En sus obras lo primero a lo que se enfrenta el espectador es a un gran espacio, ya que "Matta vuelve a situar al hombre al centro del universo, aunque éste haya perdido su estabilidad y su forma precisa." ${ }^{\prime 3}$, es decir, Matta utiliza un espacio que para él es el universo y es donde sitúa al espectador y que va más allá de nuestro campo de visión hasta lo imperceptible.

\section{V.2.2. Tiempo}

El tiempo que representa plásticamente en sus obras, Matta lo define de esta forma: “el tiempo sería para nosotros un ambiente comparable a un agua gelatinosa que 63S. ACCATINO, Sandra Tentativas sobre Matta, Editorial Delirio Poético, Santiago, 2002. p.72. 
acepta rítmicamente las transformaciones producidas con una velocidad más o menos grande” ${ }^{{ }_{4}}$, esto en la práctica se ve reflejado en cómo van a interactuar las líneas y las ondas en el espacio que él presenta, siendo el resultado de estas uniones el tiempo complejo al cual nos enfrenta.

\section{V.2.3. Líneas y ondas}

Ese gran espacio que hemos definido anteriormente se encuentra siempre repleto de líneas y de ondas que lo atraviesan o, como las define Eduardo Carrasco, “trayectorias lineales” ${ }^{\prime 5}$. Matta las identifica como ondas, ya que para él las ondas son la constitución de todas las cosas, tanto de lo material como lo sonoro, y en cada una de ellas él cree que hay distintas velocidades de ondas que constituyen estos elementos, por lo tanto lo que hace en sus pinturas y grabados es, a través de la línea, describir las ondas del objeto o el sonido que trata de representar. También Matta intenta explicar qué es la onda y cómo ésta se expresa, yendo un poco más lejos al decir que "la realidad social es una vibración" refiriéndose con ello a una vibración de onda. Y el por qué existe esa vibración y ese movimiento dinámico en sus obras, es porque Matta plantea que todo está en un estado de gestación de energía por nacer.

\section{V.2.4. Figuras y formas}

A partir entonces, de las líneas y las ondas creadas, se comienza a introducir las figuras y formas que son, según Matta: "recreaciones de los procesos anímicos y espirituales que impulsan y fuerzan la acción, establecen, al interior del cuadro, analogías formales y temáticas con otras realidades concomitantes” ${ }^{67}$, lo que nos invita a generar nuestras propias lecturas ya que nuestras analogías con la realidad varían, entonces las figuras y formas creadas a través de las líneas y ondas serán el eje para que el espectador a través de su ojo pueda acercarse a la obra de Matta.

\footnotetext{
64 ibidem p.69.

${ }^{65}$ CARRASCO Eduardo, Autorretrato nuevas conversaciones con Matta, Santiago de Chile 2002. p.191.

66 ibidem, p.192.

${ }^{67}$ OYARZU, Pablo, Tentativas sobre Matta, Editorial Delirio Poético, Santiago, 2002. p.17.
} 


\section{V.2.5. Composición}

En sus obras existe una arquitectura de cada cuadro que se basa en la composición, a la que él define diciendo "una cosa se relaciona a otra, y ésta me hace vincularla a otra, y ésta con la otra y ésta con la otra y no miro el cuadro” ${ }^{\circ 8}$, es así entonces como nace una composición armónica dentro de sus obras, en esa vinculación inconsciente que nace desde su interior.

\section{V.2.6. Los colores}

Los colores son variables en el trabajo de Matta porque dependen de varios factores, pero al mismo tiempo son fórmulas que se aplican en sus obras. A nivel de colores en la práctica lo que él hace es poner todos los colores que le interesa sobre la paleta, luego los empasta y los deja secar, para cuando ya están un poco secos comienza a elegir qué colores desea de toda esa mazamorra, y comienza a pintar. Al contrario de lo que él mismo realiza en grabado, ya que en este ámbito imagina los colores pero ellos luego cambian en el momento de la impresión, llegando a un resultado bastante dirigido entre Matta y el impresor, sin pasar mucho por el espacio azaroso del color que él mismo propone y encuentra en su pintura.

\section{V.2.7. Dimensión espacial}

La dimensión espacial en los cuadros de Matta nace primero por la variable de dónde se sitúe a pintar, de su posición física frente a un formato, siendo ese el punto de partida de la dimensión espacial en donde él, como artista, se encuentra para posteriormente en el resultado plantear una dimensión espacial que es la consecuencia de todas las líneas, ondas, figuras y formas dentro de un espacio en el que nos sitúa como espectadores en un momento determinado, es decir, una dimensión dentro de una situación precisa. Siendo esto la dimensión espacial.

${ }^{68}$ CARRASCO Eduardo. Op. Cit., p.200. 


\section{V.2.8. Formato de trabajo}

Las telas de gran tamaño que utiliza Matta son como menciona Alain Jouffroy en el libro MATTA para invadirnos con sus ideas, utilizando su seducción como un medio y no como un fin, para así ser el centro de la noche, es decir situarse el mismo Matta como el centro del universo y ubicar a los espectadores dentro de ese centro del universo del cual él se siente parte.

\section{V.2.9. Superficie}

El otro elemento esencial es la superficie, que no se puede explicar sin antes hablar sobre sus líneas, ya que las líneas interactúan en estas zonas y a veces, quizás en el mayor de los casos, son las propias líneas las que forman las áreas que algunas veces Matta presenta a través de trasparencias. Matta entonces, define la superficie como "obstáculos, que a veces se encajan y a veces se encogen y se descajan, desgajan", ya que, según él, la superficie será la situación precisa, el momento justo donde las líneas, figuras y formas se comunican dentro de la obra del artista.

Ahora, según Matta, al unir ambas cosas, las superficies más las ondas de vibración, se puede obtener el espacio que le permitirá representar las ideas que desea. Siendo tanto las ondas como las superficies constantes dentro de su trabajo y el desarrollo de éste, sin embargo los colores son los variables.

\section{V.2.10. Elementos entre pintura y grabado}

Finalmente se debe mencionar que los elementos que utiliza Matta en sus obras tanto pictóricas como gráficas (grabados) son los mismos, la diferencia principal es cómo estos elementos en la práctica se desarrollan, y esto se puede explicar de mejor forma en la puesta en marcha de su desarrollo plástico.

\footnotetext{
${ }^{69}$ CARRASCO Eduardo. Op. Cit., p.192.
} 
En la pintura Matta se encuentra solo frente a un proceso personal, por el contrario en el grabado el proceso es compartido con los dibujantes e impresores, de los que escucha aportes, siendo a veces estos aportes los que motivan en ciertos momentos su propias tomas de decisiones para finalizar sus obras graficas.

\section{V.3. El proceso de trabajo en la pintura de Matta}

Lo primero que realiza Matta antes de enfrentarse o comenzar a crear una pintura, es partir con ideas de muchos dibujos, muchísimos dibujos que finalmente serán la motivación para comenzar su pintura.

Pero antes de seguir relatando su proceso de trabajo, es interesante recalcar el por qué Matta dibuja antes de comenzar sus obras ya sean pictóricas o gráficas. La razón es que Matta posee un gusto por contar historias o por contar nuevamente lo ya acontecido, siendo ese gustito por el relato con el que comienza ya en 1941, durante un viaje a México, a esbozar un relato en forma de comic sobre "un perro cañón, centauros y autómatas"70 que serán las bases para las pinturas luminosas realizadas durante este viaje y que luego serán expuestas en el siguiente año en Nueva York.

Posteriormente a la realización de sus bocetos que le proporcionan ideas, incorpora todos los colores que desea sobre la tela, como si ésta fuese una gran paleta para mezclar, a posteriori deja secar un poco esta "mezcolanza" como él mismo la define y comienza poco a poco a sacar los colores que desea y empieza a parecer la pintura, el espacio, las ondas, para luego incorporar las figuras, pero perdón, según el mismo Matta, las figuras no se incorporan, ya están allí, entonces lo que él hace no es introducirlas sino sacarlas de su estado latente y darles la importancia que tienen para luego proporcionarles coordenadas, que serán en muchos casos transparentes. Siendo

${ }^{70}$ ACCATINO, Sandra. Op. Cit., p.64.

${ }^{71}$ MEZCOLANZA en Chile se utiliza esta palabra para definir una mezcla de cosas sin orden y posiblemente sin sentido. 
las transparencias las que juegan un rol importantísimo en el espacio que plantea Matta, ya que nos abren otros espacios dentro de la misma obra.

Ahora bien, hay que destacar que las mezcolanzas de colores con las que trabaja Matta dan lugar a las chorreras de colores que para él son parte del proceso, ya que, al contrario de muchos pintores que normalmente comienzan a pintar sobre una tela o superficie blanca, Matta chorrea el espacio de colores y luego comienza a escarbar, y es eso lo que da origen a su pintura, es por ello que de cierto modo él se define mucho más escultor que pintor en ese sentido.

Siendo su trabajo, como él lo explica, un proceso pectoral que es ir desde la pintura al sentido y volver desde el sentido a la pintura, siendo el sentido la esencia del objeto, figura o forma y todo lo que se generara dentro del microespacio de esos elementos.

Es interesante mencionar que en la fase final de la creación pictórica, Matta manifestó en algún momento que cada vez que pintaba un cuadro nunca más volvía a verlo, no lo miraba finalizado. Siendo difícil de alguna forma creer en esto, porque Matta es un hombre tan centrado en sí mismo, quizás un gran egocéntrico como muchos artistas, que resulta un poco difícil creer en su afirmación, no obstante, se cree mucho más fuertemente en una expresión de Matta cuando dice que, ya finalizada su obra, que para él sería muy difícil dibujar el mismo cuadro de nuevo y eso realmente se cree, porque la explosión, la intensidad de cada una de sus obras es única, y eso único no se encuentra en una copia.

Finalmente se desea aclarar que es muy diferente el proceso de Matta pintor y grabador ya que la forma en que se involucra como persona es absolutamente contraria. Por un lado, en la pintura está él solo frente a un espacio de creación y por el otro con el grabado su proceso es compartido y relacionado con otros artistas e impresores, como ya se ha explicado en el capítulo "El grabado y Matta". Siendo entonces ambos procesos de creación absolutamente distintos, y solo concuerdan en 
el resultado, donde se ve a un Matta quizás en algunos casos más libre, quizás en otros mucho más restringido.

\section{V.4. Periodos pictóricos y gráficos (grabados) de Matta}

Al comenzar este subcapítulo, es difícil de mencionar tan explícita y tácitamente los periodos o las etapas de Matta, ya que no se ha logrado obtener periodos o definiciones claras en sus obras pictóricas y esto ha nacido no por falta de fuentes bibliográficas sino, por el contrario, se ha tenido acceso a esto, no obstante no hay claridad de fechas entre estas fuentes y así se cree difícil relacionar estas fechas (que indican como se ha mencionado anteriormente periodos y etapas) con su vida personal y artística. Si embargo, esta tesis se atreve a crear una propia definición de periodos, ya que se considera oportuno y necesario definir estas etapas, aclarando antes que la definición de estos periodos se hace bajo la base de la observación sobre cada pintura realizada en los diferentes años de creación del artista desde 1938 hasta 2002, así mismo como la observación de sus grabados desde el año 1942. Añadiendo, por cierto, citas y reflexiones personales que aporten a estas definiciones de etapas. Se espera con esto finalmente no tan sólo clasificar la obra de este artista, sino ser el punto inicial para aclarar posteriormente la relación entre pintura y grabado, si existió o no, y por supuesto la relación que hubo entre creación y desarrollo de obra con su vida personal tanto de artista, como marido, padre y amigo.

El primer periodo de Matta se puede definir como su primera lucha contra la pintura, se dice en una "lucha" y en "contra" por todos los obstáculos que tuvo con la pintura al óleo, ya que ésta es la técnica con la que comienza por primera vez a indagar y que sin lugar a dudas le produjo en un primer instante esa lucha por la búsqueda del conocimiento. Siendo entonces, en el año 1938, cuando Matta hace su primer esquema o boceto pictórico, que el escritor Pablo Oyarzun en el libro Tentativas sobre Matta lo define como "la plasmación de la fuerza de la imaginación en la génesis de un 
continuum de espacio - tiempo"72 y es a partir de estos esquemas más las motivaciones que inician sus amigos, principalmente de Gordon Onslow-Ford, que Matta realiza durante este mismo año su primera pintura, la que evidentemente es su primer acercamiento al óleo. Titulándose esta obra "Morphology of desire", en la que visiblemente se nos muestra un juego de caracteres psicológicos. Es importante decir que durante estos primeros años, cuando nace su primera obra pictórica y su acercamiento a este tema, Matta comienza por primera vez a utilizar las palabras y todo el sentido de "morphologie psychologique" que serán la base filosófica de toda su obra. No obstante la idea primera cambiará un poco a lo largo de su trayectoria plástica, como el mismo Matta lo menciona:

"Las primeras cosas que hice, yo las llamaba "morfologías sicológicas". Entonces eran más bien cósmicas; en lugar de eso, esto es más lógico, es más como un ser que piensa, no sólo como un ser que funciona. Y las otras cosas eran un poco como la naturaleza de la materia funcionando" ${ }^{m 3}$.

Este primer periodo ocupa, según nuestro parecer, desde 1938 hasta 1942, en él Matta presenta en sus pinturas un espacio derritiéndose casi desintegrándose, un poco, quizás solo un poco, su obra parece tener una influencia de Dalí. Existiendo durante este tiempo cuatro obras más la primera realizada por Matta que son relevantes, y es por ello que se mencionan a continuación: Invasion of the nigth realizada en 1941, cuando Matta se encuentra en Nueva York, en la que presenta por primera vez las gotas o mejor dicho los primeros círculos blancos pequeños, que precisamente en esta obra poseen colores dentro de ellos, y es importante destacar este elemento porque será recurrente tanto en sus pinturas como en sus grabados. Asimismo la pintura El prisionero de la luz realizada en 1941, siendo Matta -según lo menciona su última esposa Germana Ferrari en el libro DUOTTO- él mismo el

\footnotetext{
72 Oyarzun, Pablo. "Pintura y posibilidad", en Tentativas sobre Matta, Editorial Delirio Poético, Op. Cit., p.15.

${ }^{73}$ CARRASCO Eduardo, Conversaciones con Matta, Santiago de Chile p.193-194.
} 
prisionero de la luz. Luego viene su obra Locus solus realizada entre los años 19411942, donde vemos el primer gran cambio hacia la especialidad de la perspectiva y nos aleja por un instante de esa percepción un poco triste, tenebrosa y trágica que habíamos visto en sus obras desde 1938. Posteriormente nacerá su obra L `anne 44 realizada en 1942, y en donde aparece por primera vez un incipiente indicio de las transparencias en la parte izquierda superior de esta obra y que desarrollará posteriormente con recurrencia.

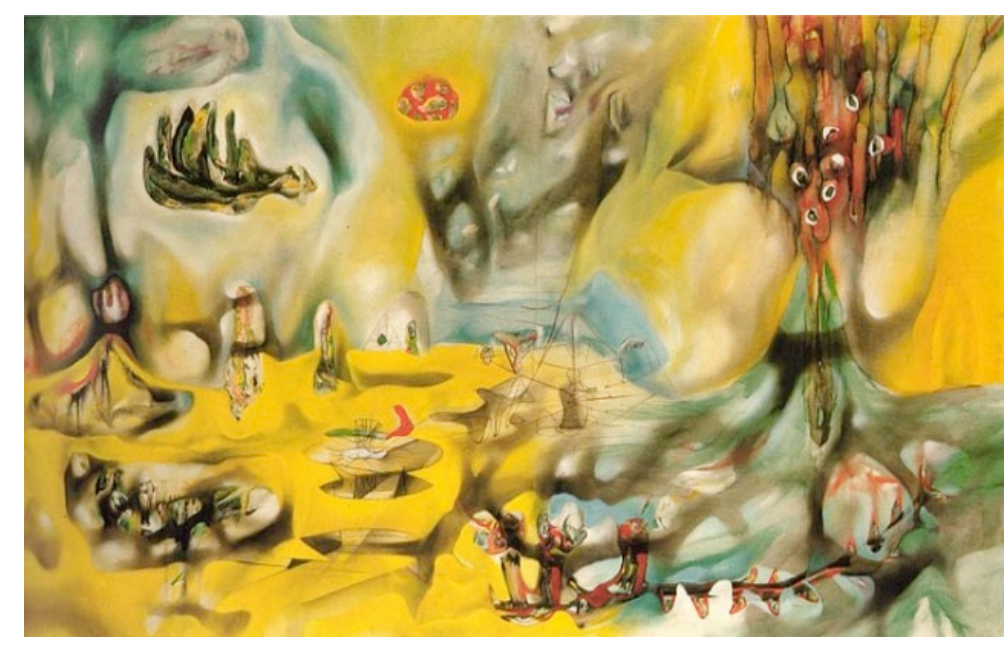

Invasión of the night 1941

Luego vendrá, entre los años 1942-1943, lo que se ha definido como el proceso de transición, sus primeras obras que iniciarán la exploración dentro de su pintura a lo que será por definitiva las bases pictóricas de su obra, las que creemos se comienzan a desarrollar durante el año 1943. Asimismo crea en el año 1942 El día es un atentado en relación a cómo cada persona se enfrenta al día, a la cotidianidad, entendiendo el día como un atentado, como una amenaza, como el riesgo diario.

A partir de 1943, se ve que la obra pictórica de Matta es más limpia y más clara a nivel de composición, ya que las formas, las líneas y las figuras se buscan, se entrelazan y dan respiros. Es así como vemos en las obras Eronisme, realizada durante este mismo año, o Le vertige d'eros, creada en 1944, que las figuras geométricas son 
claras y precisas, así como el espacio y una todavía incipiente utilización de las transparencias nos darán el paso para comenzar en profundidad la creación pictórica, que a nuestro parecer tiene su origen entre los años 1944-1945.

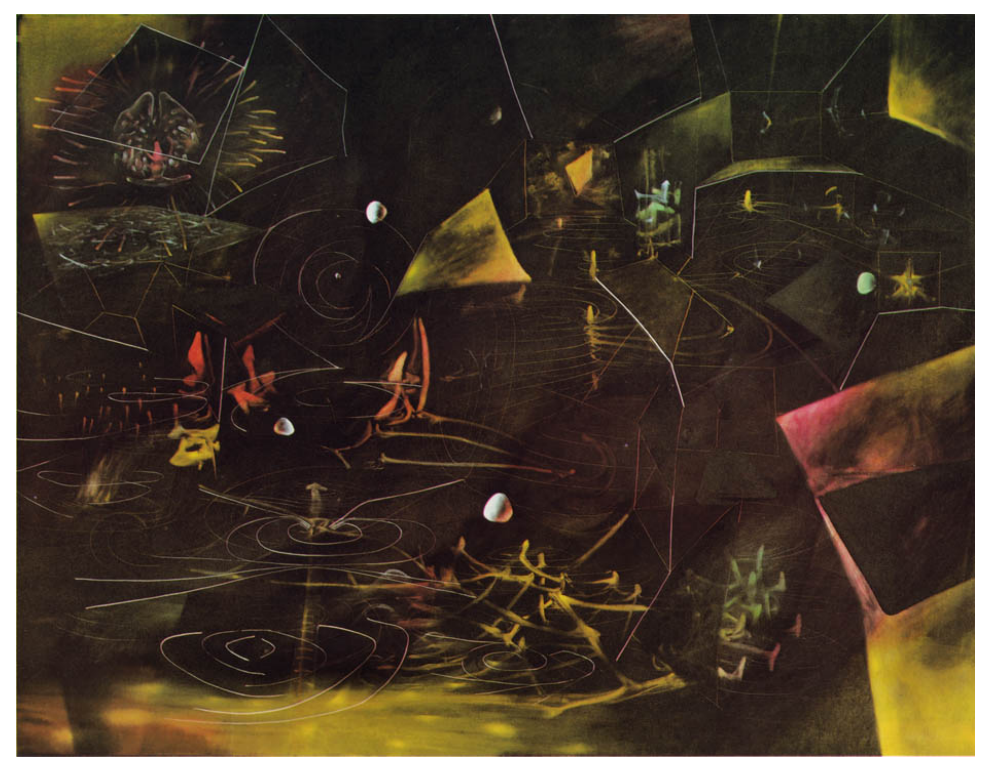

Vertige d'eros 1944

Es importante mencionar que dentro de este periodo nace el primer personaje de Matta que se aprecia claramente en la obra Le poete (Un poete de notre connaissance), realizada entre 1944-1945 esta obra presenta un personaje central y único que ocupa todo el espacio, se piensa que es el primer personaje, no porque antes en la obra de Matta no hayan existido sino porque aquí se plantea de una forma quizás más común a lo visto anteriormente, y con esto se quiere decir que no es que la figura presentada sea común sino es el cómo esta hecha consciente e inconscientemente, hace ver un personaje concreto, delineado en su contorno y definido con brazos, cabeza, tronco, y más precisamente con ojos, nariz y boca, es por ello que es el primer personaje de Matta explícitamente creado en sus obras.

Luego es importantísimo destacar la obra X-space and the Ego realizada en 1945, con la que se presenta por primera vez un acercamiento hacia el grabado en la obra de Matta. En ella se ve un espacio abierto, cósmico pero marcado por las líneas espaciales, 
de personajes, de una historia, que visiblemente se aproxima a los grabados que Matta ha realizado. Por supuesto, hay que destacar el uso de los pequeños puntos negros que son ahora fuertes y limpios en el espacio presentado. Asimismo, en 1946, Matta crea la obra Splitting the ergo donde se muestra un espacio mucho más libre, suelto y que define su obra, así como también su pintura How Ever la que proyecta una tensión explícita, fuerte y con una clara evidencia de la proyección o el recuento de un suceso histórico. No obstante a estas obras, existe una que es Sophyte que je m'utile, realizada en 1949, que parece una obra mucho más pensada, reflexionada y hasta mecanizada, una estructura sin vacilaciones o invitaciones, una composición cerrada dentro de todo este primer periodo de creación y de asentamiento de bases.

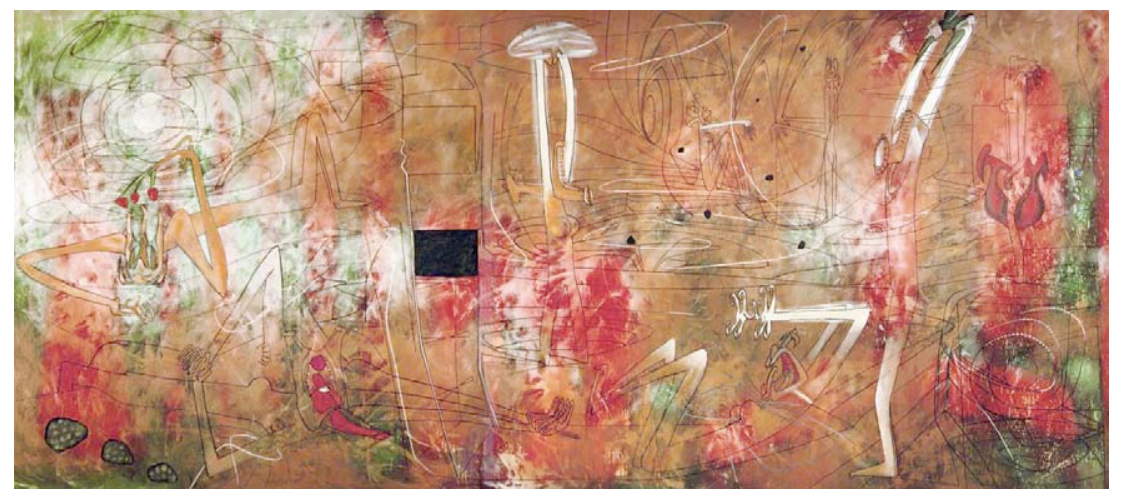

$X$-space and the ego 1945

Posteriormente, a partir de 1950, se observan obras relacionadas con hechos históricos donde Matta manifiesta a través de su pintura, clara y explícitamente, su posición frente a estos hechos, entre ellas mencionamos Contra vosotros asesinos de palomas creada en 1950 y Les roses sont belles, comenzada en 1951 y terminada en 1952, que fue su postura y una alusión frente al proceso Rosenberg, estas dos obras adquieren mayor fuerza porque son el inicio de la motivación principal en las obras de Matta, el inicio del tratamiento de la historia y su postura frente a ella, y más aún, estas dos obras son ya concretamente Matta, un artista que será inconfundible, único y original. 


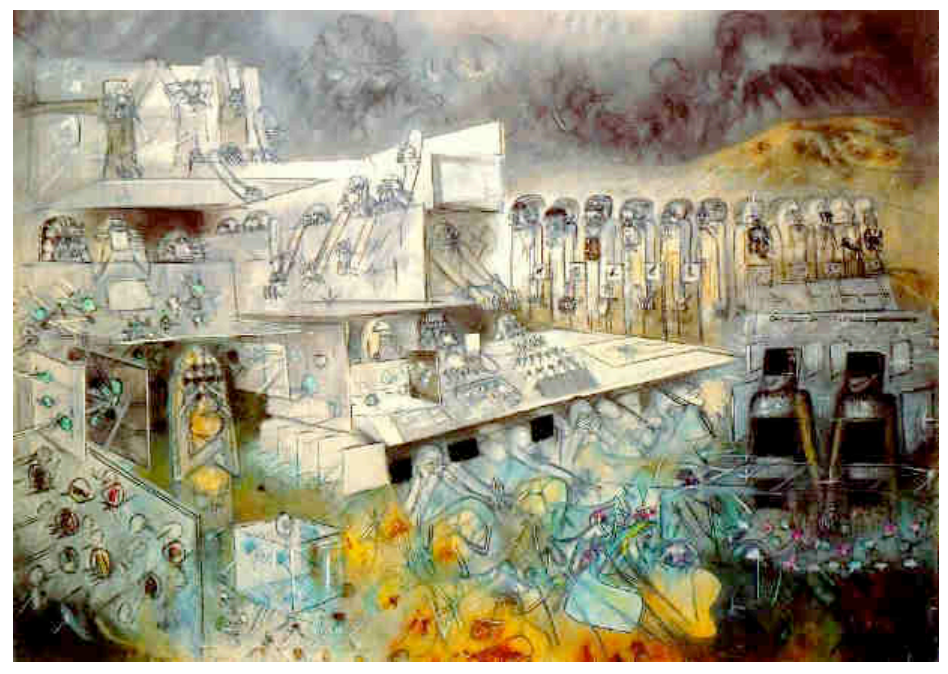

Les roses sont belles 1951

Desde el inicio de este capítulo se ha mencionado que la postura personal de Matta, expresada en sus obras generalmente es motivada por los acontecimientos, sobre todo históricos. No obstante, cabe destacar su postura también hacia temas plásticos, es así como en el año 1956 nos muestra la obra La banale de Venise como una protesta a la bienal de Venecia, que en ese entonces nos presentaba a artistas como Braque, Matisse, Dufy, Ernst, Arp, Pollock, Gorky, De Kooning y Calder a los que Matta consideraba por una parte grandes artistas y por otra, a algunos de ellos, artistas que no lograban comunicar nada.

La década de los 50 es la que realmente definirá al Matta que se verá posteriormente, donde sólo se mencionará obras relevantes por su relación o quizás influencia con sus propios grabados; es así como en Odisseano, obra pictórica realizada en 1971, existe ya una idea de oleaje, de mar, que expresa también Matta en el grabado L'odycean de la serie Hom'mère I Chaosmos realizada durante el año 1973. Estas obras no solo tienen por semejanza la forma de oleaje sino también de colores que se intensifican en el grabado. 


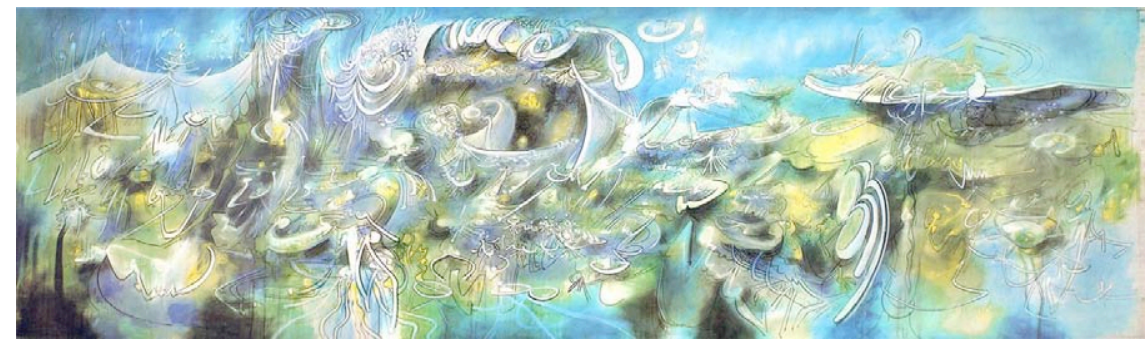

Odisseano 1971

Cabe mencionar que la década que continúa en los años 60 será un periodo de gran convulsión en todo el mundo, principalmente por los horrores de la guerra de Vietnam y esto se ve reflejado en las obras de Matta, como por ejemplo se observa en la pinturamural titulada Vivir enfrentando las flechas comenzada posiblemente en el año 1959 en gran formato y que posteriormente será donada a la Universidad Técnica del Estado hoy USACH en Santiago de Chile.

Asimismo existen obras, tanto pictóricas como de grabados, que poseen los mismos nombres, así se puede decir que Centre noeuds es la primera creación en ambas técnicas que posee el mismo título y que fue realizada en el año 1974 en grabado y en el año 1978 en pintura. Abordando Matta a finales de la década de los 70 el tema de la identidad del ser humano. Cabe destacar que en el año 1970 con motivo del nacimiento de su hija Alissé crea la que podríamos decir, la primera obra palpable y objetiva en relación a un hecho personal que es la obra Dar a la vida una luz que fue realizada por su fuerte motivación al nacimiento de su hija Alisee.

Posteriormente, ya en los años 80, Matta comienza a internarse en el uso gráfico que proporcionan los computadores, desde allí creará una parte de sus obras, tratando de ir en contra de la máquina. Sin Embargo, no deja de lado las otras áreas de expresión, ni su acercamiento entre ellas. Por ejemplo se menciona la serie de grabados Hom'mere Point d'appui creada en 1983, en la que existe un acercamiento con las obras pictóricas 
El mediterráneo es el verbo América realizada el mismo año y La brise du gene creada en 1991.

Finalizando la clasificación de las etapas de trabajo de Matta, se puede decir que en el último periodo de su vida siguió desarrollando su trabajo artístico pictóricamente, ya que alrededor de 1995 deja de realizar grabados y solo sigue un poco el nexo a esta área plástica a través de los afiches para sus exposiciones o para organizaciones que se lo pedían, trabajo que desarrolló desde sus inicios a la par con todo su trabajo plástico. Y se cree que ambas técnicas se influyeron entre sí, al darnos cuenta del desarrollo de ambas a nivel de años, de títulos y de hechos acontecidos alrededor del artista. Pareciendo a veces que el desarrollo del tema le quedase limitado en una técnica y necesitase de la otra para llegar al pleno desarrollo, como ejemplo de ello se menciona Verbo América realizada pictóricamente en el año 1981 y realizada en grabado en el año 1983 (ver páginas 22 del catalogo técnico razonado).

\section{V.5. Relación pintura y grabado}

Al finalizar este capítulo se deben resolver varias interrogantes que se efectuaron en la introducción del mismo, siendo una de ellas si hubo ciertamente una relación entre la pintura y el grabado en la obra de Matta. Esta pregunta se puede responder desde varias aristas, una es que se puede decir que sí hubo una relación, ya que en casi todos los periodos creativos de Matta se vio una creación similar en ambas técnicas, por ejemplo en los años 1980 y 1982 con las obras Don Q en grabado y La palais du soleil en pintura, en ellas se puede ver claramente, la utilización de líneas, ondas, formas y figuras dentro del espacio que el artista nos presenta. También bajo la arista de la utilización de los mismos títulos, existe allí otro tipo de relación entre pintura y grabado, ya que hay obras que poseen los mismos títulos en ambas técnicas, a pesar de que algunas no fueron desarrolladas en los mismos años, como por ejemplo Centre noeuds, realizada en grabado durante el año 1974 y pictóricamente en el año 1978, 
entre las que, no obstante, a pesar de ser obras realizadas en épocas diferentes, se aprecia una relación a nivel plástico, y una concordancia entre ambas por tratar el mismo tema central. Y, como última arista, no se ve casi ninguna relación entre la pintura y el grabado a nivel de realización, es decir, de puesta en práctica, la idea, el origen, y la motivación de cómo se llevan a cabo, ya que en la pintura Matta se encuentra solo frente a la creación y es él quien define su propio proceso es decir, el cómo lo lleva a cabo, qué elementos sacará y cuáles utilizará, asimismo la definición de tamaño, colores y la utilización de su tiempo. Por el contrario en grabado debe compartir parte de su proceso de trabajo, por no decir todo, con los impresores y ayudantes, quienes de una forma u otra influyen en su trabajo, no en la totalidad por cierto, pero en detalles que harán que el proceso sea bastante distinto a lo que vemos a nivel de proceso en la pintura, y dentro de esta gran diferencia que existe en el desarrollo de ambas técnicas, habrá que repetir que Matta en la pintura se enfrenta solo a su obra, a su proceso, a sus propias interrogantes, mientras que en el grabado se ve a un Matta quizás un poco más huérfano, ya que como se ha mencionado anteriormente, la idea inicial es suya pero la puesta en práctica es y será un proceso de los profesionales del grabado y la estampación, del cual él sólo forma parte como un espectador activo y no como el actor principal que es en la pintura.

No obstante, se desea mencionar que se cree que la obra gráfica de Matta es mucho más rica a nivel de colores, y mucho más limpia a nivel de formas y figuras, lo que no deja indiferente, ya que el mensaje logra ser mucho más elocuente en los grabados que en la pintura.

Otra de las interrogantes que se debe resolver es saber si hubo una relación o no entre creación y desarrollo de obra, ya sea pintura o grabado, con su vida como artista, marido, padre y amigo. De este punto se puede decir que en la obra de Matta vemos una relación efectiva entre los aconteceres históricos y el artista, no tanto así en su relación en la vida personal, solo se puede añadir que en varias entrevistas se hace 
entender que Matta observaba los materiales de trabajo de sus hijos, los que en algunas oportunidades utilizó, como por ejemplo en la serie de grabados del Quijote, donde recurrió a las grillas que le daban en el colegio a su última hija Alisee, para realizar los fondos de esta serie. No se si será un poco atrevido de nuestra parte decir que a Matta más que importarle su familia, sus hijos, le importó el mundo que rodeaba todo lo que él creaba. Se dice esto, porque él paso malos momentos en su vida, por ejemplo, las perdidas de sus primeros hijos Sebastián y Gordon Matta Clark que se produjeron en 1977 y 1978 y durante ese periodo no se ve ninguna obra de Matta que refleje un sentimiento de dolor, frente a la paternidad, aunque sí vemos un sentimiento de tristeza y de dolor, cuando debe trasladarse a EE.UU. por el inicio de la segunda guerra mundial en Europa. Durante esa época se ve claramente en sus pinturas un dolor, una rabia, y una sensación de no estar tan bien, lo que específicamente se puede apreciar en la pintura Inscape realizada durante el año 1939. Del mismo modo se puede apreciar que durante los años de las muertes de sus dos hijos ocurridas en 1977 y 1978 respectivamente, sus obras no tienen ninguna relación con el hecho o con algún sentimiento de tristeza, dolor, o amargura, como ejemplo de ello se menciona la obra pictórica Carré-four realizada durante 1978 y la serie de grabados que forman un libro de artista Une Saison en enfer realizada durante el mismo año, es por ello que se dice que a Matta le importaba mucho más el mundo que lo rodeaba que el ámbito familiar. Entonces se puede apreciar que no hubo relación entre el desarrollo o creación de obra con el aspecto familiar de este artista.

Por último debemos resolver una cuestión crucial para esta tesis que es saber si Matta fue un grabador o un pintor. Se cree definitivamente que fue mucho más un pintor que un grabador. El por qué se determina con tanta fuerza esta respuesta es por cómo se concibe en esta tesis quien es un pintor. Siendo el pintor no el que tan solo tiene una idea y la da para que otros lo realicen, sino es el que se involucra, es el que tiene una idea y por si mismo y solo la lleva a cabo y Matta cumple con creces estas ideas, ya que es solo él quien realiza sus pinturas, quien toma el pincel y se lanza en el 
espacio que él mismo anteriormente ha elegido. Ahora el por qué no se cree que Matta forma parte del mundo del grabado, es porque él no se interna en el mismo, no experimenta en todos sus periodos artísticos con el área gráfica, se piensa sí que fue un grabador frustrado, porque en los primeros años artísticos se involucró bastante con las técnicas que esta área posee y aprovechó esos periodos, con mejores resultados plásticos que la pintura a nuestro parecer, y es así como lo podemos ver por ejemplo en su primera serie de aguafuertes The new school. No obstante, vemos un artista que dirige sus obras gráficas y se cree que no las realiza efectivamente al 100\% como ocurrió con sus primeros grabados, ya que no realiza el proceso en su totalidad. En cuanto al por qué se dice que fue frustrado es porque se sabe por medio de las entrevistas que se realizaron a los impresores que trabajaron con él, que Matta tenía muchas ganas de entrar en el proceso, ese proceso que vivió y experimentó en su primer encuentro con esta área, pero eso estuvo prohibido para él por personas y factores ajenos que involucran su vida privada, de hecho off de record a las entrevistas realizadas se dijo que en una serie gráfica realizada por el artista durante la década de los 80, Matta estuvo escondido en un taller imprimiendo y trabajando él por si mismo y solo en esta serie, con la que se sintió bastante satisfecho y alegre. Por ello nos atrevemos a decir que Matta tuvo un espíritu de grabador que lamentablemente se vio un poco limitado por hechos ajenos a su obra, que tienen relación con su vida personal y comercial.

Se desea decir de todas formas, que es evidente que en lo relativo al proceso Matta no es un grabador, no obstante no se quiere dejar ese pensamiento en esta tesis, es por ello que se ha querido rescatar con fuerza la idea que él fue un grabador y desconocido por muchos. ¿Y por qué grabador aún sabiendo que en el desarrollo de esta técnica estuvo un poco ajeno?, porque él no eligió ese destino, y porque se sabe que él siempre tuvo las ganas y el ímpetu interno de querer realizar sus grabados, así como realizó todas sus obras en todas las otras técnicas. El grabado para Matta estuvo prohibido y 
en esto se quiere hacer énfasis, porque no fue su opción y fue la única técnica artística en la que no pudo expresar libremente todo su ser. 


\section{Obra grafica de Roberto Matta : catalogación de grabados}

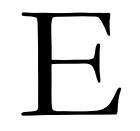

l primer interés por investigar sobre los grabados realizados por Roberto Matta, se origina en que no existe ningún estudio, ningún catálogo completo o que intente serlo, con todas las obras gráficas del artista, esto dio el primer impulso de la búsqueda, ya que para un estudiante de arte con especialidad en grabado resulta a lo menos tentador poder abrir un nuevo camino de investigación y de resultados, ante un artista del cual mayoritariamente se le conoce solo por su obra pictórica.

Por otra parte el interés de catalogar los grabados de Matta, es para esta investigación un aporte, ya que es aquí donde se obtiene la mayor información para poder descubrir toda su obra gráfica, comentarla, analizarla y llegar a posibles conclusiones, que muy probablemente nos abrirán nuevos caminos de entendimiento hacia este artista.

Fue así como el planteamiento de la creación del catálogo parte primero por descubrir cuales son los grabados de Matta, cómo se presentan, si poseen colores o son mayoritariamente monocromos, si se deben a una sola técnica o una variedad de ellas, qué formatos son los más abundantes etc., para luego, con toda esta información recabada construir un catálogo que se presenta no tan solo con las obras y su título, sino más bien con fichas para cada una de las obras, libros de artista y series presentadas.

Luego se han definido los campos de investigación para la realización de las fichas, de modo que en la presentación de las fichas nos encontramos con el título, la fecha, las dimensiones (del papel), la técnica empleada, y un poco más abajo la descripción de la obra. Fue así como para cada una de las fichas se construyeron campos de investigación, los que señalamos a continuación: 
- $\quad$ Autor (en todas las fichas es Roberto Sebastián Matta Echaurren)

- $\quad$ Titulo (de la obra)

- $\quad$ Fecha de realización

- $\quad$ Tamaño del papel

- Tamaño de la mancha

- $\quad \underline{\text { Técnica }}$

- $\quad$ Procedimiento y recursos complementarios, ( se explica si es una carpeta, libro o estampa, cómo esta compuesta, y datos anexos de relevancia)

- $\quad$ Matriz

- $\quad$ Numero de planchas-utilizadas

- $\quad$ Material de las planchas

- Datos complementarios ( se refiere a datos complementarios sobre la matriz, en ese punto solo existe un aporte que se repite en cada ficha, el cual es: la cantidad de planchas utilizadas en cada obra, se refiere a la función que cumplen dentro de la obra, ya que Matta utilizaba una plancha para el fondo, otra plancha para los personajes y varias planchas más para los colores utilizados en cada una de sus obras).

- Estampación

- Se especifica si se realizó en hueco, en relieve, planigráfica, o permeografica.

- $\quad$ Numero de tintas

- Colores

- $\quad$ Papel

- $\quad$ Marca

- Gramaje

- Color

- Edición

- Números de ejemplares

- $\quad$ Numero de P.A.

- $\quad$ Numero de H.C.

- B.A.T. 
- Otras pruebas

- $\quad$ Taller en que se realizó

- Estampador

- La estampa observada es la número

- Estampa observada directamente si o no

- Contemplada a través de reproducción si o no

- $\quad$ Colección

- Colección en la que se encuentra la estampa

- Colección en la que se encuentra la plancha

- Otras colecciones que tengan ejemplares de este trabajo

- $\quad$ Libros

- Libros o catálogos localizados

- Otros catálogos que la contengan

- Registros gráficos obtenidos, diapositiva o imagen digital

Toda esta información nos da en definitiva las bases de esta investigación, ya que a partir de ella podemos deducir bastantes aspectos relacionados tanto del proceso como del resultado, así como lo que Matta buscaba expresar a través del grabado.

Es así como podemos decir que Matta trabajó esencialmente en dos sistemas de impresión, la calcografía o grabado en hueco y la litografía, y, en menor medida, la serigrafía. Con los dos primeros sistemas, es decir, el grabado calcográfico y la litografía, realizó no solo estampas sino también libros de artista. El grabado en hueco fue la primera técnica que aprendió, de la que más obtuvo y aprovechó los frutos, sobre todo con el proceso mencionado en el capitulo sobre el grabado empírico, de ello podemos decir que el mayor provecho técnico se expresa en los fondos, que se pueden apreciar en sus obras y que nos da el espacio. 
Tanto en el grabado en hueco como en la litografía podemos ver el volumen otorgado por las texturas que se funcionan con los colores, como ejemplo de ello son las estampas del libro de artista Ubu Roi o las estampas de Hom'mére II “L'autre”. Asimismo podemos decir que la litografía le otorgó una claridad en color, es decir una pureza y limpieza a nivel de tonos, pero al mismo tiempo con la litografía juega en dimensiones haciendo por ejemplo la estampa mas grande que mide 1,20 X 2,00 mts. de la serie el Quijote, que fue realizada con la prensa litográfica mas grande que existe en el mundo.

Con respecto a la serigrafía, Matta la utilizó como medio para hacer los afiches de sus exposiciones o para ayudar como hemos sabido a algunas instituciones benéficas para sus campañas (reunir adherentes, colecta de dinero etc.).

También se deduce que a través de la recolección y observación de todas estas obras, Matta se atrevió en el uso del color, para la época fue alguien innovador ya que en varios de su grabados y en algunos libros de artista se pueden apreciar colores fluorescentes muy fuertes, pero como se encuentran acompañados de diferentes colores da una sensación muy rica a nivel cromático, lo que permite al contrario de lo que se pudiese pensar una relación tonal calida al ojo humano.

Es importante mencionar también sobre los papeles que utilizó Matta para imprimir sus grabados, uno de ellos es el tradicional papel Arches de 250 a 300 gramos, que según los entrevistados que participaron en esta tesis, es de muy buena calidad, pero aquí solo poseemos una información, lo interesante está en el otro papel utilizado por Matta que fue un papel Japón Nácar que no posee un alto gramaje, tiene una textura y una delicadeza a nivel de fibras que es evidente y al parecer, al ser nácar, le da una brillosidad muy sutil. Este papel Matta lo utilizo únicamente en el grabado calcográfico, desconocemos el por qué lo utilizó, en base a nuestras entrevistas podríamos deducir que fue un capricho del artista. Lo que es relevante es que se trata de un papel muy difícil de 
trabajar, no obstante se realizaron varios libros de artista por ejemplo Le verbo homérica que es un álbum y Une saison en enfer por mencionar algunos, como del mismo modo imprimió series de grabados (carpetas) en ambos tipos de papeles, desconocemos el por qué de esta elección.

Siendo todas estas deducciones posibles conclusiones que nos aportarán las bases para situar a Matta dentro del mundo del grabado, y en qué lugar de esta área artística se sintió más a gusto realizando su trabajo. 


\section{Análisis y comentarios para la comprensión de las series más relevantes de la obra gráfica de Roberto Matta}

$\mathrm{L}$ os análisis y comentarios que se escriben a continuación, son sobre solo seis series gráficas que hemos considerado las más relevantes en el proceso de grabado de Matta. Siendo estas seis series, elegidas a partir de diferentes parámetros como, por ejemplo, año de creación, cantidad de grabados en la serie, importancia de estos grabados en la vida del artista y la repercusión que tuvieron en su momento, por nombrar algunos de los parámetros utilizados en esta selección. No obstante quizás esta selección pudiese ser un poco injusta, si nos hubiésemos centrado solo en la relación de su obra gráfica con su obra pictórica, o su extensión hacia la pintura, ya que esta selección solo desea darle una importancia mayor a las series gráficas que realizó Matta en sí mismas y no en la proyección pictórica que pudiesen tener. Asimismo hemos solo seleccionado series que forman parte de libros de artista, porque el trabajo graficó de Matta se realizó fundamentalmente en series, álbumes, carpetas y libros de artista, entonces muy excepcionalmente encontramos estampas solitarias en su trabajo, no obstante hay que decir que si hubiese estampas solas, éstas no tuvieron tanta relevancia como las series. Se quiere aclarar también, que hoy tristemente se exponen y venden grabados de Matta pertenecientes a series, pero se presentan como estampas sueltas, y eso lleva a muchas personas a la confusión, ya que en algunos casos no se hace mención que tal u otro grabado pertenecen a una serie.

Antes de comenzar nuestro análisis particular de estas seis series, se ha querido hacer un balance general sobre las obras de Matta. De esto podemos decir que muy probablemente en este catálogo encontremos alrededor de un 75 \% de la totalidad su obra grafica, existiendo una mayor concentración de obra desde la década del 40 hasta la década de los 80, constatando un desarrollo continuo durante todos estos años en el tratamiento de las técnicas calcográficas, en cambio en la técnica litográfica se ve una 
mayor creación en la década de los 50 y en la de los 70, con Fernand Mourlot y en los 80 pocas creaciones pero importantes con Bordas y Woolworth. Asimismo podemos decir que serigráficamente no tuvo ningún proceso largo o importante, ya que solo realizó estampas sueltas y muy pocas, dado que su trabajo lo focalizó principalmente en la calcografía y luego en la litografía, desarrollando en diferentes formatos todas estas técnicas, sin tener un formato predilecto para imprimirlas. Se puede decir también, que la trayectoria en el proceso gráfico de Matta es suave y continuo, que se va expresando con más claridad, limpieza y de mejor forma a través de los años. Además se puede indicar que las obras de Matta fueron realizadas mayoritariamente en color, siendo los colores más utilizados rojo, azul, amarillo, negro, café, gris, verde y naranja, que son los mismos utilizados en su pintura, pero lo interesante en este punto es que en grabado Matta utiliza el color rosado y el dorado para lograr estampas valiosas a nivel cromático, ya que esta combinación aporta a su dibujos una sutilidad, delicadeza y finura que sobresalen e impactan como en la serie FMR donde se destacan mucho más los personajes por el carácter que le otorga este juego cromático. Asimismo los temas tratados por Matta en su obra gráfica, son por una parte realizados a partir de textos de poetas, escritores y/o textos propios, existiendo también grabados con implicación social y histórica como en los grabados de La Auracana y del mismo modo también existen en sus grabados temáticas espaciales y filosóficas. Siendo todas estas temáticas coherentes con su vida y su discurso, tanto artístico como personal.

De todo lo investigado se puede decir además que casi la totalidad de los grabados de Matta en las diferentes técnicas, fueron realizados en los talleres que mencionamos anteriormente en el capítulo "Roberto Matta en los talleres de grabado" de esta tesis. Pudiendo ser un $80 \%$ a un 85 \% de los grabados aquí catalogados realizados en estos talleres, siendo las tiradas a mi parecer grandes, hasta 300 ejemplares en algunas series.

Este balance general es una parte de lo que hemos podido concluir de las fichas que se encuentran en este catálogo. 
Las series que continuación pasamos a analizar y a comentar son de diferentes periodos de creación, asimismo son un aporte no tan solo para conocer a Matta grabador y reconocer a Matta como artista, sino para darnos cuenta del aporte que Matta hizo hacia el mundo gráfico.

\section{VII.1. The New School}

Fue creada entre 1943-1944, siendo impresa entre 1978-1979. Es una de las primeras series creadas por Roberto Matta en grabado. Realizada primeramente en el atelier de Stanley William Hayter en Nueva York y finalizada en París en las Ediciones Sabatier Satié. La obra esta compuesta por 10 grabados realizados a través del aguafuerte y la punta seca sobre placas de cobre. Presentándonos personajes desgarrados, exponiendo tensiones y a la vez actitudes eróticas tácitas dentro del dibujo y las formas. Esta serie es una de las mas importantes porque es el primer acercamiento que tuvo Matta hacia el grabado y es por ello que tiene un gran significado en su obra, son sus primeras estampas y son las que nos muestran, al contrario de lo que sucede con la pintura de Matta donde el espacio es lo mas relevante, la presencia de los personajes, que son los ejes y protagonistas. Existiendo gofrados en unas minúsculas partes de estos personajes. Las líneas son limpias y puras, los personajes presentados son muy sexuales, casi todos con penes erectos en diferentes partes de su cuerpo, representan tensión y hasta rabia, no tan solo por el movimiento o posición en que se encuentran, sino también por la profundidad del trazo sobre la placa de cobre, trazos profundos repetitivos, pareciese que algo lo hubiese molestado o ahogado a Matta al crear esta serie, necesitaba decir algo pero estaba muy presionado, ya que todos estos personajes nos expresan eso, la sensación de lucha, tensión, ahogo, como si hubiese un grito a evitar que nos ahoga y sobre todo la tensión de los personajes, que dejan de serlo para transformarse en animales salvajes que luchan entre ellos y con ellos mismos. Hay que escribir que, como lo dijo el mismo Roberto Matta y lo expresamos en el capítulo la obra y la pintura de Matta, las figuras y forma son las recreaciones de procesos anímicos y espirituales, y en relación a ello a lo mejor este sentimiento de angustia, tensión, rabia que expresan estos personajes se debe al hecho de 
llegar a EE.UU. por motivo de la guerra en Europa y al no ser una decisión espontánea del mismo artista, podría ser que tuviese estas emociones y sentimientos al estar allí en ese nuevo país de acogida de adopción.

Lo interesante a la vez en esta serie es ver una dualidad entre estos personajes desgarrados con los colores y el papel elegido para la impresión, tonos suaves, pasteles, rosas acompañan esta ira lineal negra, podría pensarse que es una serie de inicio, soltura, aventura a lo nuevo que es el grabado hacia él, todo cubierto con un manto de protección que se puede sentir en la contención del grabado por el papel Japón Nacré que lo cobija dulcemente a estos trazos negros, puros, con sus personajes infinitamente luchadores.

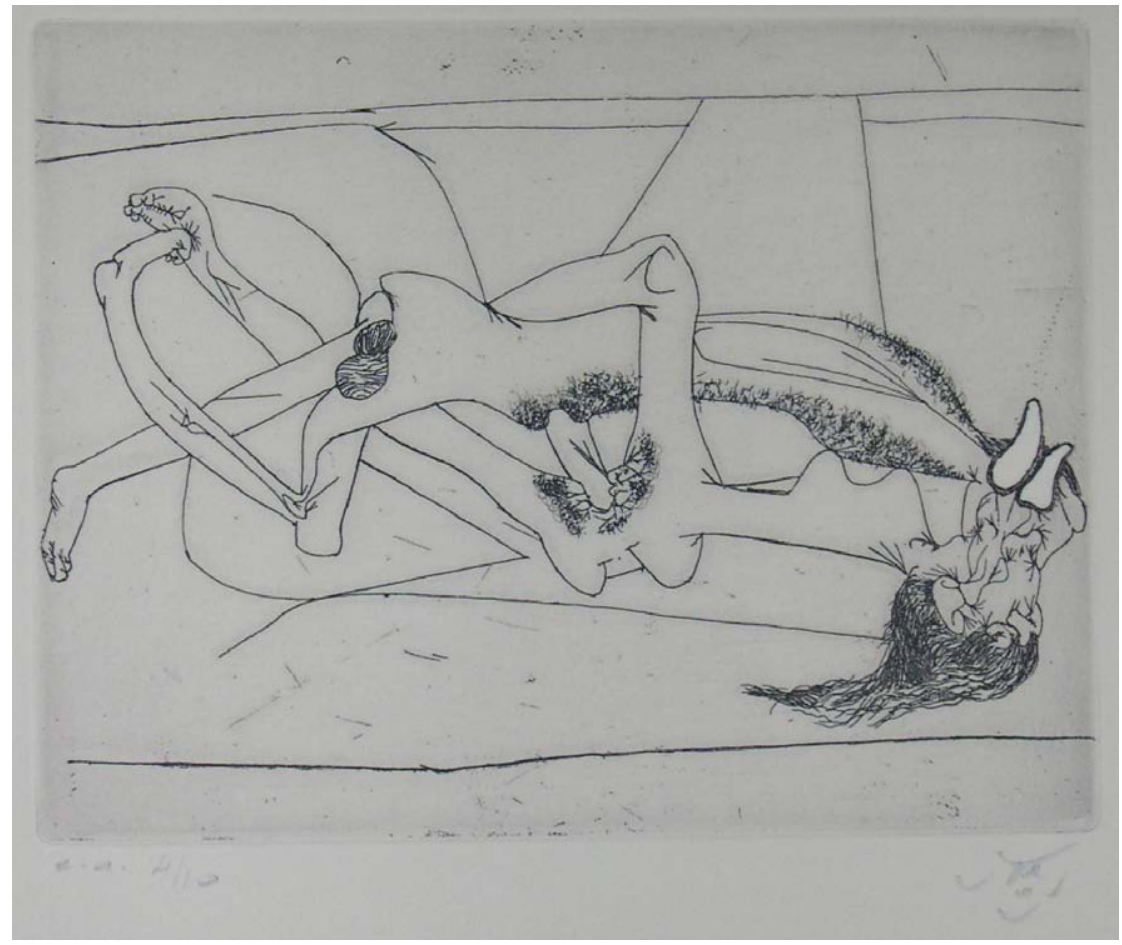

The new school 1943-1944 


\section{VII.2. Hom'mère}

Es una serie de grabados, que comenzó como un libro autobiográfico de Roberto Matta, siendo a su finalización una de las series más extensas en la obra grafica del artista, ya que posee cuatro tomos, que se titulan: Hom'mère “Chaosmos” (1973), Hom'mère “L'autre” (1975), Hom'mère “L'ergonaute” (1977) y Hom'mère "Point d'appui” (1983). Y el significado dentro de su obra es muy relevante principalmente porque comienza como un libro autobiográfico y termina expresando problemas y temas universales, un libro de artista que parte de un momento poéticamente personal hasta llegar a transmitirnos temas muy globales. Presentándonos un espacio visual importante en cada una de las obras, donde existe un tiempo cronológico e histórico importantísimo. Vibraciones lineales, personajes y una dimensión espacial muy similar a la que podemos encontrar en su obra pictórica, siendo estas series de grabados los más cercanos a lo que encontramos en su obra pictórica. Asimismo se constata el tema sobre la identidad del ser humano que él comienza a realizar en la década de los años 70, así como el título de estos cuatro tomos es "Hom' mére" que es la combinación de la primera sílaba de las palabras en francés de hombre y mujer, dándonos a entender que a partir de un hombre y una mujer nace la vida, y aquí en cada uno de estos tomos nace un nuevo tema, una nueva motivación de creación. Del mismo modo hay que recalcar que esta serie es una o quizás la más rica a nivel de técnica y desarrollo gráfico, el relieve, las profundidades lineales que encontramos en sus estampas con las combinaciones de colores magníficas que no dejan indiferente a nadie, y es sobre todo por el relieve logrado en las líneas que poseen estas obras por lo que atraen e invitan no solo a observarlas sino también a acariciarlas. Finalmente se puede decir que es una serie que aporta el lado mas humano de Matta de padre madre y creación, lo que quizás tiene relación al nacimiento de su ultima hija Alisee(1970) y, por otro lado, el golpe de estado en Chile(1973) hiciese quizás, sólo quizás, poner a Matta en una situación de observación entre la vida y la muerte y decidiese hacer esta serie autobiográfica. Que es y será la única definida así por el artista. 


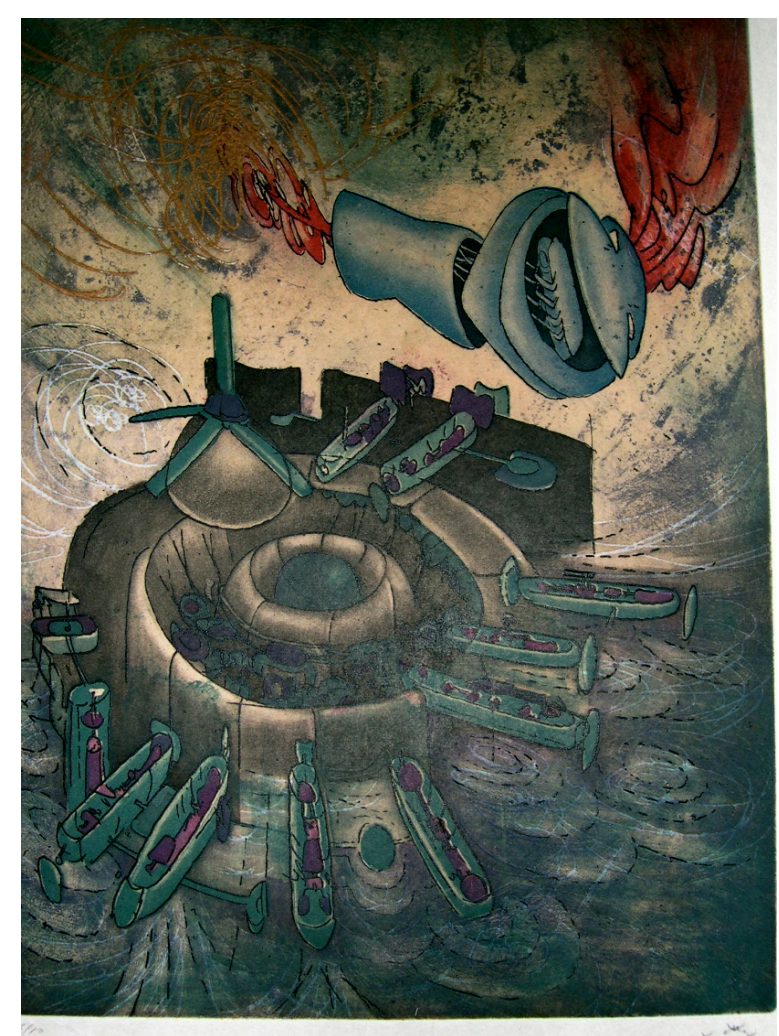

Hom'mere

\section{VII.3. El verbo Hommérica}

Fue creada y editada en 1987. Siendo una serie que trata sobre la idea de que América es un continente descubierto y que posee todas las culturas allí mismo, en la misma tierra “están todas como una especie de Arca de Noé”74. Y quizás por ello Matta decidió expresar en dos formatos diferentes todas estas culturas encontradas por él en América. Es así como la serie se nos presenta en dos formatos, primero como un álbum y segundo en forma de acordeón siendo su extensión total de 3 metros de largo. Ambas series creadas a la par y al mismo tiempo. Ellas fueron realizadas a través de la calcografía en el taller de Albert Dupont y se nos muestra lo que América posee para Matta que es una identidad diversa, lo que, según define el mismo artista, no tiene un europeo o un africano, es por ello que Matta dice que para él América es un verbo.

${ }^{74}$ CARRASCO, Eduardo, Autorretrato-nuevas conversaciones con Matta. Santiago de Chile 2002. p. 219 
Asimismo se quiere mencionar que el periodo de creación de esta obra se desarrolla en el mismo momento en que Matta comienza a trabajar sus obras pictóricas con ordenadores, abriendo un nuevo camino en el proceso de su trabajo con múltiples posibilidades y resultados. Esto es muy relevante porque a pesar de todo lo nuevo que descubre a través del ordenador, en el grabado y en especial en esta serie parece que quisiese volver a los orígenes, volviendo al uso del blanco, negro y gris, sin la utilización del color, pero existiendo un trabajo a nivel de tonalidad muy relevante a pesar de solo utilizar una monocromía cromática, éste logra una fuerza figurativa y espacial sin necesidad del color y es por ello de su riqueza en esta obra, el espacio es muy trabajado, como lo son también las figuras que acompañan este espacio, una obra cercana a su mundo pictórico espacial y lineal pero no cromático.

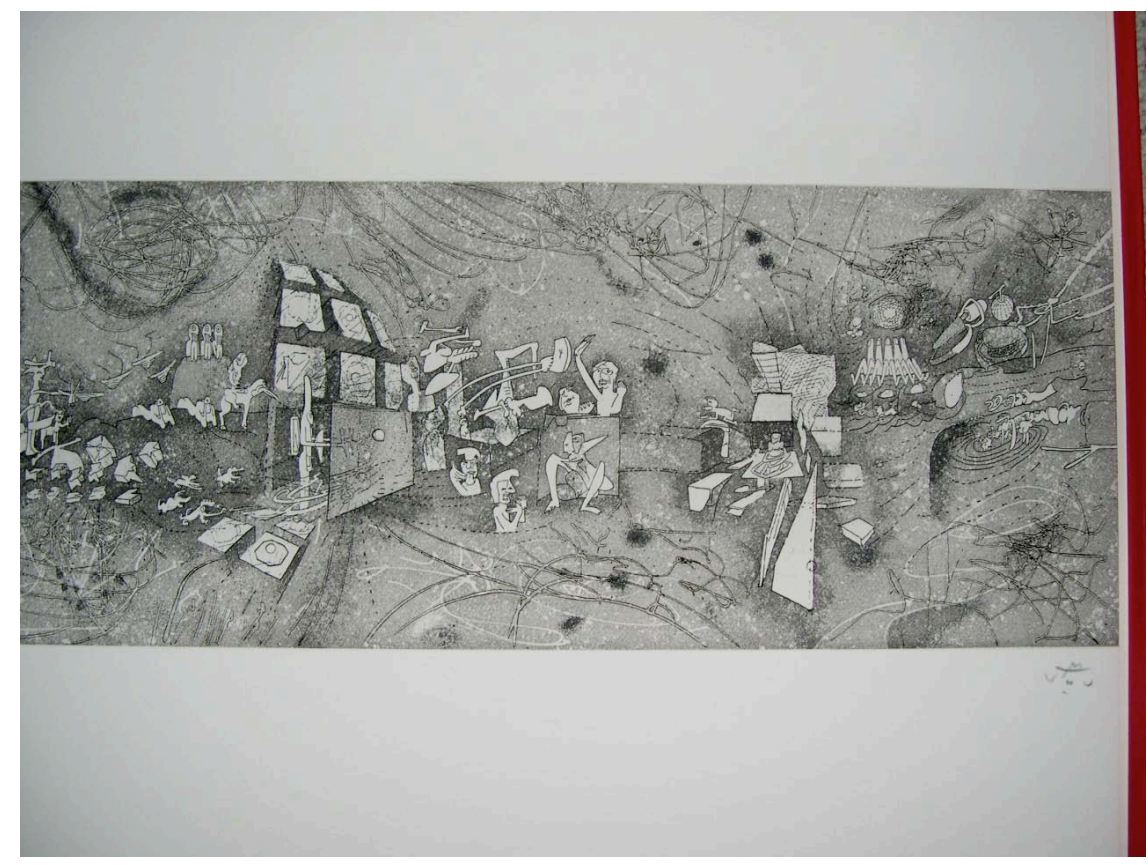

Le verbo Hommérica 1987 


\section{VII.3. El Gran Burundu-Burunda ha muerto}

Fue creado y editado en 1975. Es una serie litográfica realizada en el año 1975 en el atelier de Fernand Mourlot. La cual corresponde a una interpretación de la obra literaria Burundún-Burundá de Jorge Zalamea escrita en el año 1952, que es un relato satírico de la historia de un dictador, su poder y el gran espectáculo de su funeral, previsto por el mismo dictador. La serie litográfica trata a modo de relato, el funeral del tirano acompañado por todos los regimientos creados por él. El relato se constituye describiendo el funeral y todos los personajes que van a su entierro de una forma satírica y humorística. Vemos personajes que van al funeral del dictador con trompetas y banderas. Los grabados que forman parte de este álbum, tienen títulos que juegan a la vez con la obra impresa como "Trompetopeya" en el que se ve una escolta de personas que más parecen oficiales o personajes con formación militar por la estructura que poseen, pero a la vez esta estructura es lo que parece humorístico, porque es esto justamente, las posiciones de los personajes más la coherencia con el título elegido lo que nos otorga la risa, hacia un dictador que creó y obligó a hacer como era su deseo su propio funeral. También existe otra estampa de esta serie donde vemos estos mismos personajes oficiales sobre círculos óvalos, que con el título de la obra que se llama "Guevones" podemos deducir quizás superficialmente que ellos están justo sobre los huevos del hombre, es decir sobre sus propios testículos, y en Chile la palabra "huevones" es según el tono como se utilice alguien tonto, torpe.

Siendo probablemente la motivación un poco escondida de esta serie el golpe de estado de 1973 en Chile y la idea que describe Jorge Zalamea en su libro, la muerte del dictador, quizás como un anhelo de la parte de Matta hacia el dictador chileno, demostrando lo bufonesco del personaje-dictador en si mismo.

El Burundú consta de 7 litografías realizadas en blanco, gris y negro e impresas en el taller de Franck Bordas, gráficamente la obra completa esta centrada en los personajes, las figuras, no hay un espacio trabajado ni a nivel de colores, ni a nivel de líneas, sino solo 
son los personajes centrales que tienen una relevancia dentro de un espacio limpio que entrega así una mayor relevancia a estos personajes en el relato de esta historia.

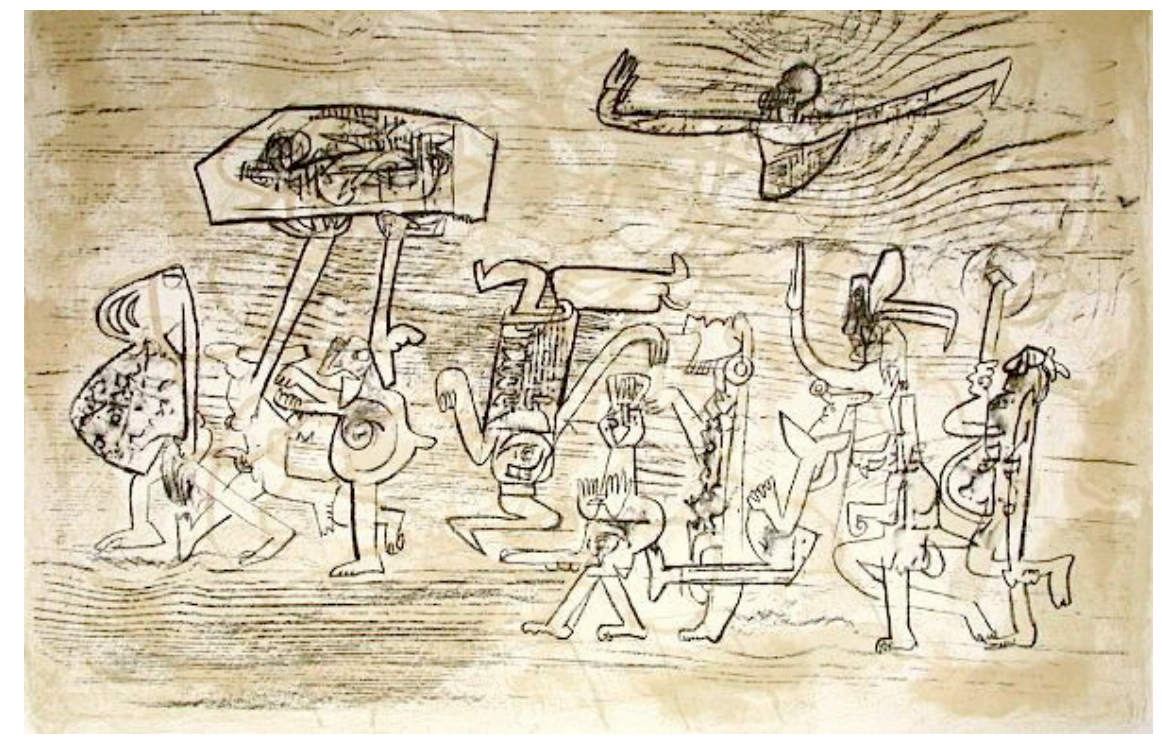

El gran Burundu Burunda ha muerto 1975

\section{VII.5. Don Q}

Es la serie litográfica editada por Matta en el año 1980 en el atelier de Michael Woolworth y Frank Bordas, desconociéndose aún la fecha de creación de la obra. Siendo esta obra gráfica una interpretación de la obra literaria Don quijote de la Mancha de Miguel de Cervantes.

Matta, durante su estancia en Londres en la década del setenta, comenzó a leer este libro (releyéndolo más de 4 veces) y ello lo inspira a realizar la gran serie litográfica Don $Q$ que consta de estampas de pequeño formato, más otras impresiones realizadas en un formato portafolio, es decir medio mercurio $(52 \times 72 \mathrm{~cm}$.), y una última realizada en un gran formato. Por último, hay que mencionar que con el libro Don quijote de la mancha Matta se apasionó por lo que Cervantes quería contar, con Don Quijote, un héroe, un caballero, que deseaba salirse de los deseos y cánones superficiales de todos los tiempos, un hombre que luchaba por la justicia y el amor. Tratando la obra sobre la literatura 
caballeresca en forma de caricatura por medio de sus dos personajes principales Don Quijote y Sancho Panza, quienes encarnan el alma española: el idealista, el soñador que olvida todas las necesidades del mundo material, que corre y sigue las fantasías.

Del mismo modo hay que destacar en esta serie el uso del color que parece que fuese una prolongación de todo lo que Matta ha ido encontrando a nivel cromático con el uso del ordenador, los colores en esta serie, al igual como lo que sucede en la serie Une saison en enfer, son una explosión de energía cromática que invita al ojo humano a pasearse no tan solo por la obra sino por el color y sus matices en sí mismos, se podría decir que es una obra que se acerca muchísimo a la pintura de Matta a nivel de los colores y la forma, incluso las líneas en estas litografías dejan de ser totalmente negras y adquieren color, una explosión de colores que se conjugan espléndidamente bien, son acordes, tanto al espacio, como a la historia que se desea encontrar, es una obra muy completa en ese sentido ya que hay un equilibrio pleno entre espacio y persona.

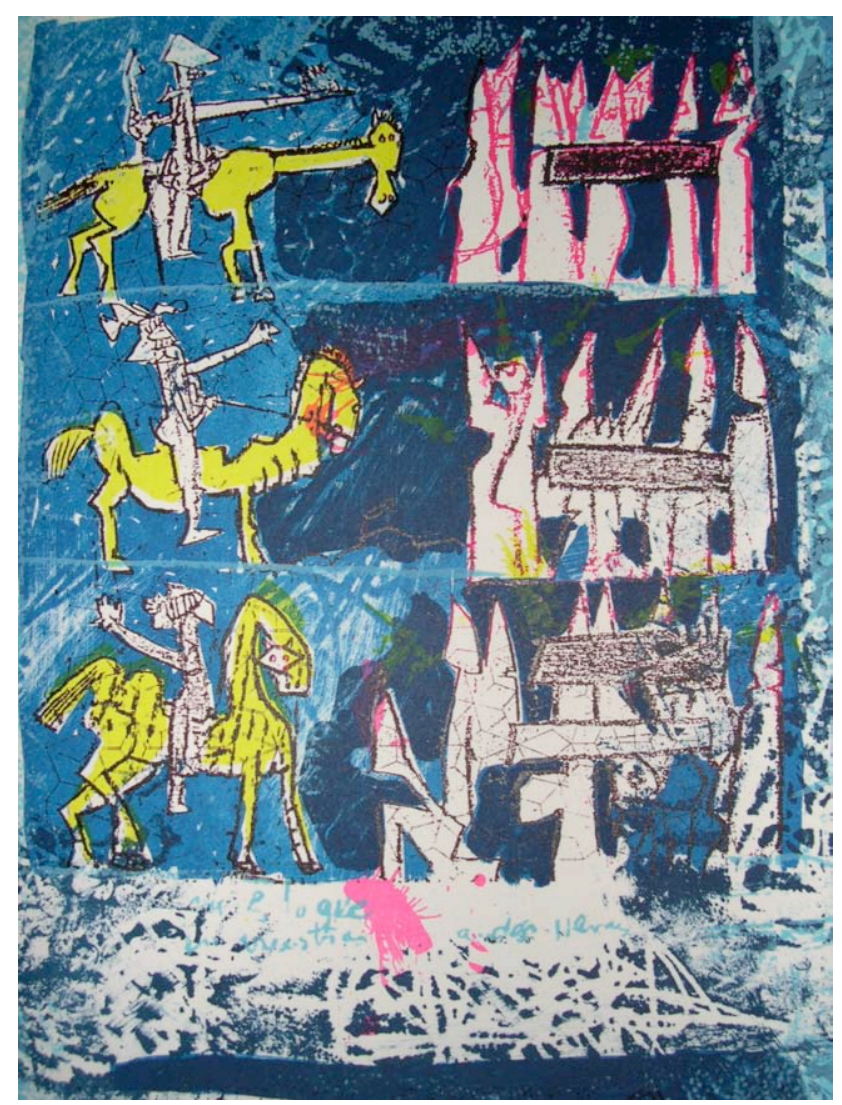

Don Q 1980 


\section{VII.6. Ubu Roi}

Fue creado y editado en 1982. Siendo obra del escritor francés Alfred Harry (18731907), que tuvo en un primer momento el nombre Les Polonais. La cual es una pieza de teatro que se divide en 5 actos, donde se reconoce como uno de los primeros escritos que luego formarían parte de lo que llamamos teatro de lo absurdo. La obra es representada por primera vez en 1889 por el grupo "Marionnettes des Phynances" en el departamento de la madre de Harry, Ubu Roi se publicará por primera vez en 1896 en Les Editions du Mercure en Francia. Posteriormente esta obra pasará a ser de culto para el grupo surrealista. Matta colabora con la realización del libro de artista Ubu Roi, donde está escrito todo el texto acompañados con dibujos y 10 grabados de Matta realizados con aguafuerte y aguatinta.

Ubu Roi trata de la experiencia escolar de Harry con un fastidioso profesor de física, que en el texto es ridiculizado dándole diversos apodos, esta obra fascina al grupo dadaísta por su carga irónica y contestataria. Y certeramente también fascinó a Matta, ya que la creación de los personajes son expresivos, directos y elocuentes al texto. Sus grabados son un apoyo a la historia, siendo solo 8 placas de cobre las que fueron técnicamente tratadas por medio del agua fuerte en el taller de Albert Dupont y que a nivel de resultado, pareciesen que ellas mismas nos contaran su propia historia, siendo personajes, satíricos y humorísticos, muy reales, muy claros a nivel lineal y de una composición limpia y quizás hasta básica, pero que poseen como todos los grabados y creaciones de Matta un nivel de atracción, de resultado, de interés hacia al espectador que creo que casi nunca, por no decir nunca, nos dejaran indiferentes.

En el trabajo técnico de $U b u$ Roi, hay que destacar que no existe el espacio, el personaje es la figura central ocupa el formato al máximo, el espacio que lo rodea no esta trabajado se deja limpio e intacto, pero en la practica es mínimo, ya que el personaje ocupa el eje central, y en el resultado solo podemos ver al personaje. Siendo esta obra bastante lejana a lo que podemos apreciar en la pinturas de Matta, aquí no hay un trabajo 
de color extenso, sí existe un trabajo lineal profundo, pero no se trabaja el espacio y los personajes son, al contrario de lo que vemos en pintura, personajes robustos hasta grotescos. Generalmente en sus pinturas, como en sus grabados, los personajes son más estilizados de los que se aprecian en esta obra. Y es por ello su importancia ya que se aleja en cierta forma de lo que hemos visto en la obra de Matta y nos hace explorar otro camino, continuamos a ver su trazo, su forma de hacer pero con una soltura diferente y eso es lo interesante a nivel gráfico en esta obra.

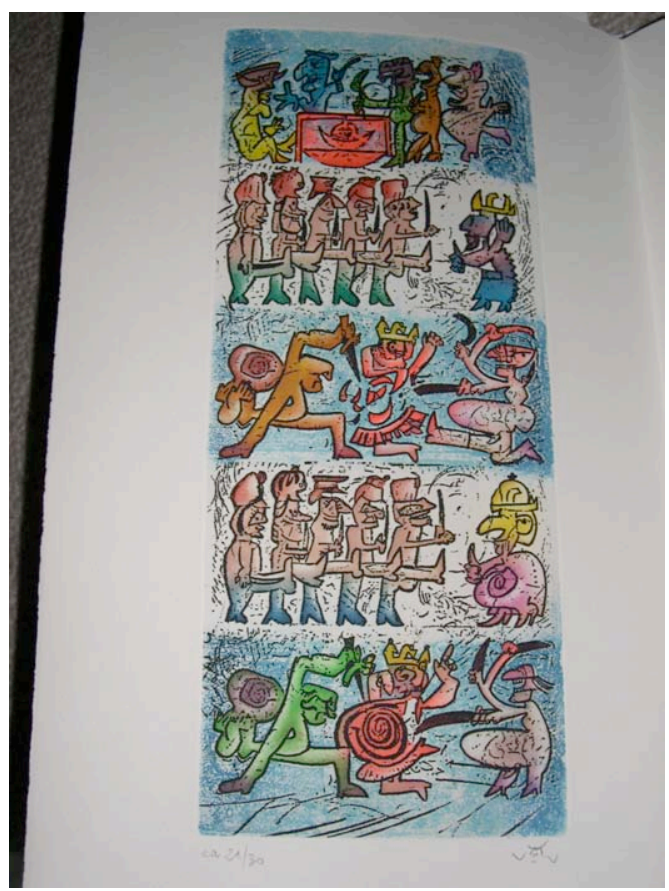

Ubu Roi 1982 
VIII. Catalogación obras graficas. Roberto Sebastian Matta Echaurren 



\section{Obra grafica Roberto Sebastian Matta Echaurren}

Ficha número : 1

Titulo de la obra : The New School.

Fecha de realización : 1943 - 1944 / 1978 - 1979

\section{Dimensiones}

Tamaño del papel : 23,7 x $17,5 \mathrm{~cm}$.

Tamaño de la mancha : $20 \times 15 \mathrm{~cm}$.

\section{Técnica}

Técnica : Punta seca, aguafuerte y aguatinta

\section{Procedimientos y recursos complementarios :}

The New School es un libro de artista compuesto por 10 grabados, los que fueron realizados a través de aguafuerte, aguatinta y punta seca por Roberto Matta en Estados unidos.

Las primeras cinco pruebas de ensayo realizadas por el artista, se crearon en el año 1944 en el atelier de William Hayter por petición de M. Bernard Reis.

Posteriormente en 1978 Matta reencuentra estas 5 pruebas de ensayo y al año siguiente 1979 adjunta algunos grabados inéditos a esta serie, formando así los 10 grabados que constituyen este libro de artista.

Del mismo modo, Matta a coloreado a mano un grabado que es la portada de The new school.

\section{Matriz}

Número de planchas : $\quad$ Entre 1 y 2.

Material de las planchas : Metal - Cobre.

\section{Datos complementarios :}

En esta serie existen planchas solo de dibujo y a las que se le añaden en ciertas ocasiones goffrados, pertenecientes a otras planchas.

\section{Estampación}

En hueco

En relieve

Planigrafica

Permeografica

Número de tintas :

Se utilizó una tinta para cada una de las planchas.

Colores :

Negro

\section{Papel}

Marca : $\quad$ Papel Arches Vélin.

Gramaje : 250 gramos.

Color : Blanco. 


\section{Edición}

Número de ejemplares :

70 ejemplares, numerados del 1 al 70 + X H.C. + 10 E.A. los que están numerados del I al X, exceptuando el grabado que se encuentra en la portada de este libro de artista.

Presentándose en un contenedor que es un papel negro plegaba tamaño $31 \times 40 \mathrm{~cm}$. unido por 4 hilos de colores pareados, siendo el primer par de color verde y celeste y el segundo de color amarillo y rojo.

En el lomo del papel plegado existe un papel blanco pegado que dice:

Matta - The new school.

$\mathbf{N}^{\circ}$ de P.A. (Prueba de Artista): Se desconoce.

$\mathbf{N}^{\circ}$ de H.C. (Hors Commerce) : X H.C.

B.A.T.: $\quad$ Se desconoce.

Otras Pruebas : Se desconoce.

Taller en el que se realizó :

La realización de las planchas se efectuó en el atelier de William Hayter y en el atelier Satié.

La cobertura del libro fue realizada por Sotar y la tipografía fue realizada con Caslon cuerpo 16 y de FequetBaudier.

La impresión final de The New School fue realizada el 15 de septiembre de 1980, por las Ediciones SabatierSatié en Paris.

\section{Estampador}

Ediciones Sabatier - Satie en Paris, el 15 de septiembre de 1980.

Número de la estampa observada : 4/10 E.A.

$\begin{array}{llll}\text { Estampa observada directamente : } & \mathrm{Si} & \mathrm{X} \quad \mathrm{No}\end{array}$

Contemplada a través de reproducción : $\mathrm{Si} \square \quad$ No $\mathrm{X}$

\section{Colección}

Colección en la que se encuentra : El destino de las planchas es desconocido.

Colección en la que se encuentra la plancha : El destino de las planchas es desconocido.

Otras colecciones que tengan ejemplares de este trabajo :

Se desconoce. 

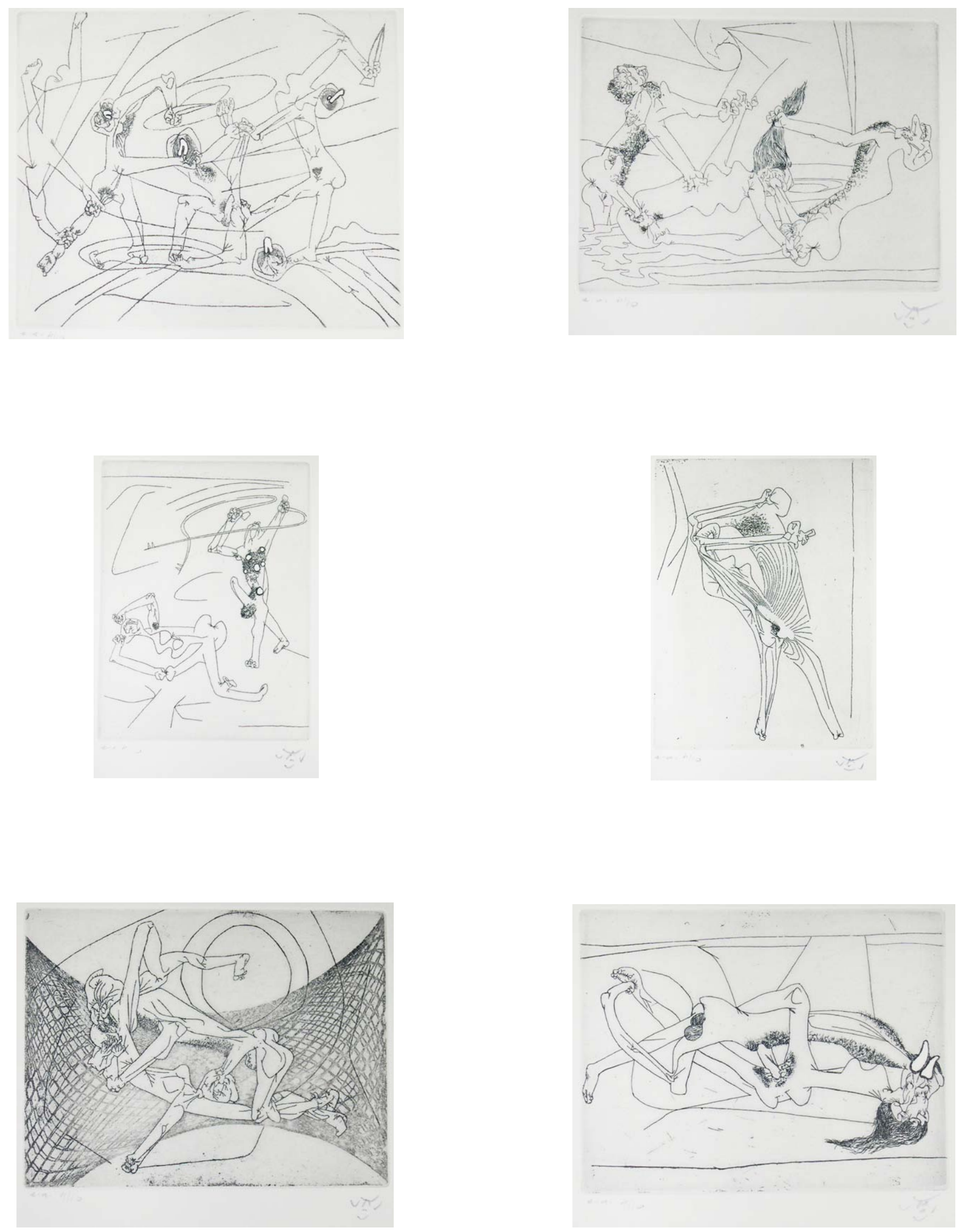

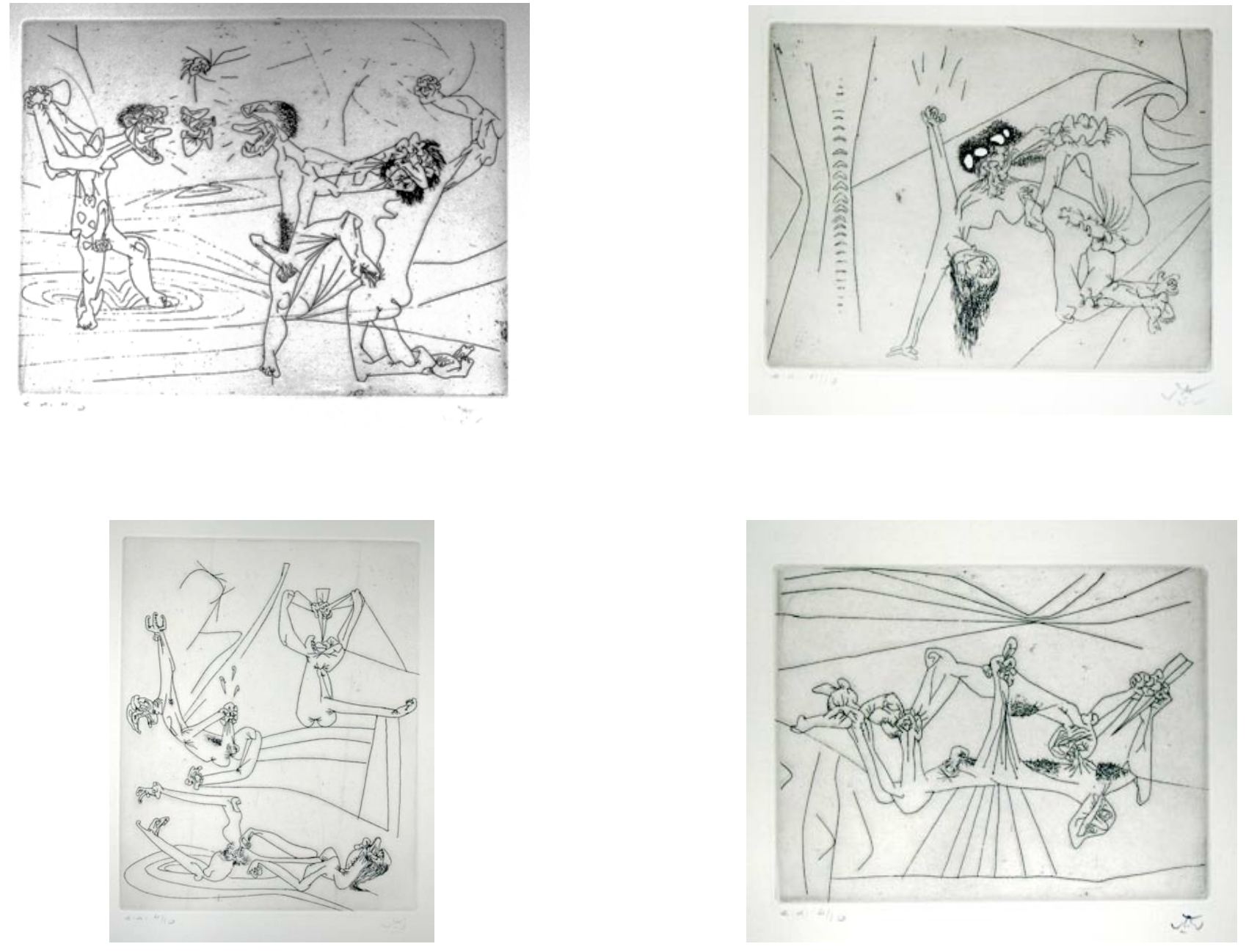

\section{Libros}

\section{Localización del libro o catalogo :}

Catalogo Razonado de G. Visat “L’oeuvre gravé de Matta”, editado por Sonet y George Visat, en 1975.

\section{Otros catologos que lo contengan :}

"Matta, index dell'Opera grafica dal 1969 al 1980", editado por Admministrazione Provinciali di Viterbo en 1980, realizado por Germana Ferrari.

Registros gráficos obtenidos

Diapositiva

$\square$

Imagén digital 
Ficha número : 2

Titulo de la obra : Bruñidor Portafolio

Fecha de realización : 1947

Dimensiones

Tamaño del papel :

Tamaño de la mancha : $31 \times 32 \mathrm{~cm}$.

\section{Técnica}

Técnica : Litografia y grabado en metal a traves de la punta seca.

\section{Procedimientos y recursos complementarios :}

Brunidor Portafolio es una carpeta colectiva realizada por diversos artistas: Roberto Matta, Y. Tanguy, Marx Ernst, Wilfrido Lam, S. Hayter, K. Seligmamn y Joan Miro.

Acompañado por un texto inedito de N. Calas titulado : "Saper vedere".

\section{Matriz}

Número de planchas : $\quad$ Se desconoce.

Material de las planchas : Metal y piedra.

\section{Datos complementarios :}

La cantidad de planchas utilizadas en cada obra, se refiere a la función que cumplen dentro de la misma, ya que Matta utilizaba una plancha para el fondo, otra plancha para los personajes y varias planchas mas para los colores utilizados en la(s) obra(s).

\section{Estampación}

En hueco

En relieve

Planigrafica

Permeografica

Número de tintas :

Se utilizaron 3 tintas.

Colores :

Negro, celeste y amarillo.

Papel

Marca : $\quad$ Papel Arches.

Gramaje : Se desconoce.

Color : Blanco. 


\section{Edición}

Número de ejemplares :

70 ejemplares sobre papel Arches 43 x $34 \mathrm{~cm}$. Firmados y numerados del 1 al 70 + 10 P.A., sobre papel Arches, numerados y firmados.

$\mathbf{N}^{\circ}$ de P.A. (Prueba de Artista) : 10 P.A.

$\mathbf{N}^{\circ}$ de H.C. (Hors Commerce) : Se desconoce.

B.A.T. : $\quad$ Se desconoce.

Otras Pruebas : Se desconoce.

Taller en el que se realizó :

Edición Robert Altmann.

\section{Estampador}

Se desconoce.

Número de la estampa observada : $11 / 70$

$\begin{array}{llll}\text { Estampa observada directamente : } & \mathrm{Si} & \mathrm{X} & \text { No } \mathrm{X}\end{array}$

$\begin{array}{lllll}\text { Contemplada a través de reproducción : } & \mathrm{Si} & \mathrm{X} & \text { No } & \mathrm{X}\end{array}$

Colección

Colección en la que se encuentra : Colección particular en Paris.

Colección en la que se encuentra la plancha : Colección particular en Paris.

Otras colecciones que tengan ejemplares de este trabajo :

Se desconoce. 


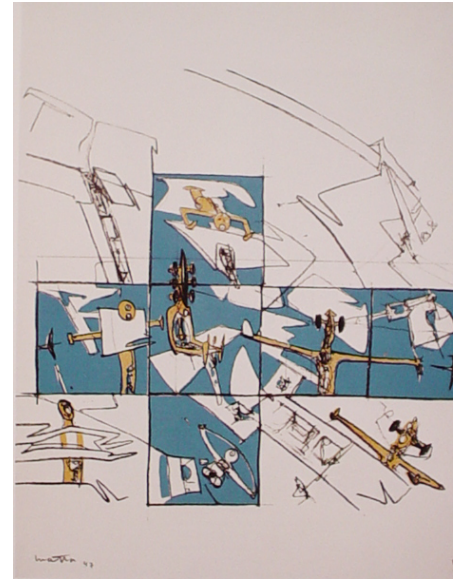




\section{Libros}

\section{Localización del libro o catalogo :}

Catalogo Razonado de G. Visat “L'oeuvre gravé de Matta”, editado por Sonet y George Visat, en 1975.

\section{Otros catologos que lo contengan :}

Se desconoce.

Registros gráficos obtenidos

Diapositiva

Imagén digital 


\section{Obra grafica Roberto Sebastian Matta Echaurren}

Ficha número : 3

Titulo de la obra : Droites liberees.

Fecha de realización : 1958 , impreso en 1971

Dimensiones

Tamaño del papel : $\quad 44.5 \times 32.5 \mathrm{~cm}$

Tamaño de la mancha : $18 \times 27.5 \mathrm{~cm}$

\section{Técnica}

Técnica : Aguafuerte y aguatinta.

\section{Procedimientos y recursos complementarios :}

Droites Libérées es un libro de artista compuesto por un poema inédito de Henry Michaux acompañado por 14 grabados de Roberto Matta a través del aguafuerte y la aguatinta.

\section{Matriz}

Número de planchas : $\quad$ Entre 3 a 7 planchas

Material de las planchas : Metal cobre y Zinc.

\section{Datos complementarios :}

La cantidad de planchas utilizadas en cada obra, se refiere a la función que cumplen dentro de la misma, ya que Matta utilizaba una plancha para el fondo, otra plancha para los personajes y varias planchas mas para los colores utilizados en la(s) obra(s).

\section{Estampación}

En hueco

En relieve

Planigrafica

Permeografica
Número de tintas :

Desde 3 hasta 7 tintas.

Colores :

Amarillo, negro, rojo, naranjo, celeste, verde y gris.

Papel

Marca : $\quad$ Papel Arches y Papel Japón Nacré.

Gramaje : 250 gramos. 
Color :

\section{Edición}

\section{Número de ejemplares :}

100 ejemplares en papel Arches tamaño $44.5 \times 32.5 \mathrm{~cm}$, firmados y numerados en cifras árabes mas XXV ejemplares numerados del I al XXV reservado a los colaboradores y al deposito legal. 100 ejemplares en papel japonés tamaño 44.5 x $32 \mathrm{~cm}$, firmados y numerados en cifras árabes + XXV ejemplares numerados del I al XXV reservado a los colaboradores y al deposito legal. Presentándose en una caja de 34,5 x 47,5 cm. cubierta de tela(algodón) color crema escrito en su lomo el titulo y la firma de Matta con color negro.

$\mathbf{N}^{\circ}$ de P.A. (Prueba de Artista): Se desconoce.

$\mathbf{N}^{\circ}$ de H.C. (Hors Commerce) : Se desconoce.

\section{B.A.T.: $\quad$ Se desconoce.}

Otras Pruebas : Se desconoce.

Taller en el que se realizó :

Atelier George Visat siendo la tipografía realizada en caslon Romain cuerpo 24 de Fequet y Baudier.

\section{Estampador}

George Visat.

Número de la estampa observada : 
Estampa observada directamente :

$\mathrm{Si}$

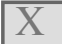

No

Contemplada a través de reproducción :

$\mathrm{Si}$

$\mathrm{X}$

No

\section{Colección}

Colección en la que se encuentra : El destino de las planchas es desconocido.

Colección en la que se encuentra la plancha : El destino de las planchas es desconocido.

Otras colecciones que tengan ejemplares de este trabajo :

Se desconoce.
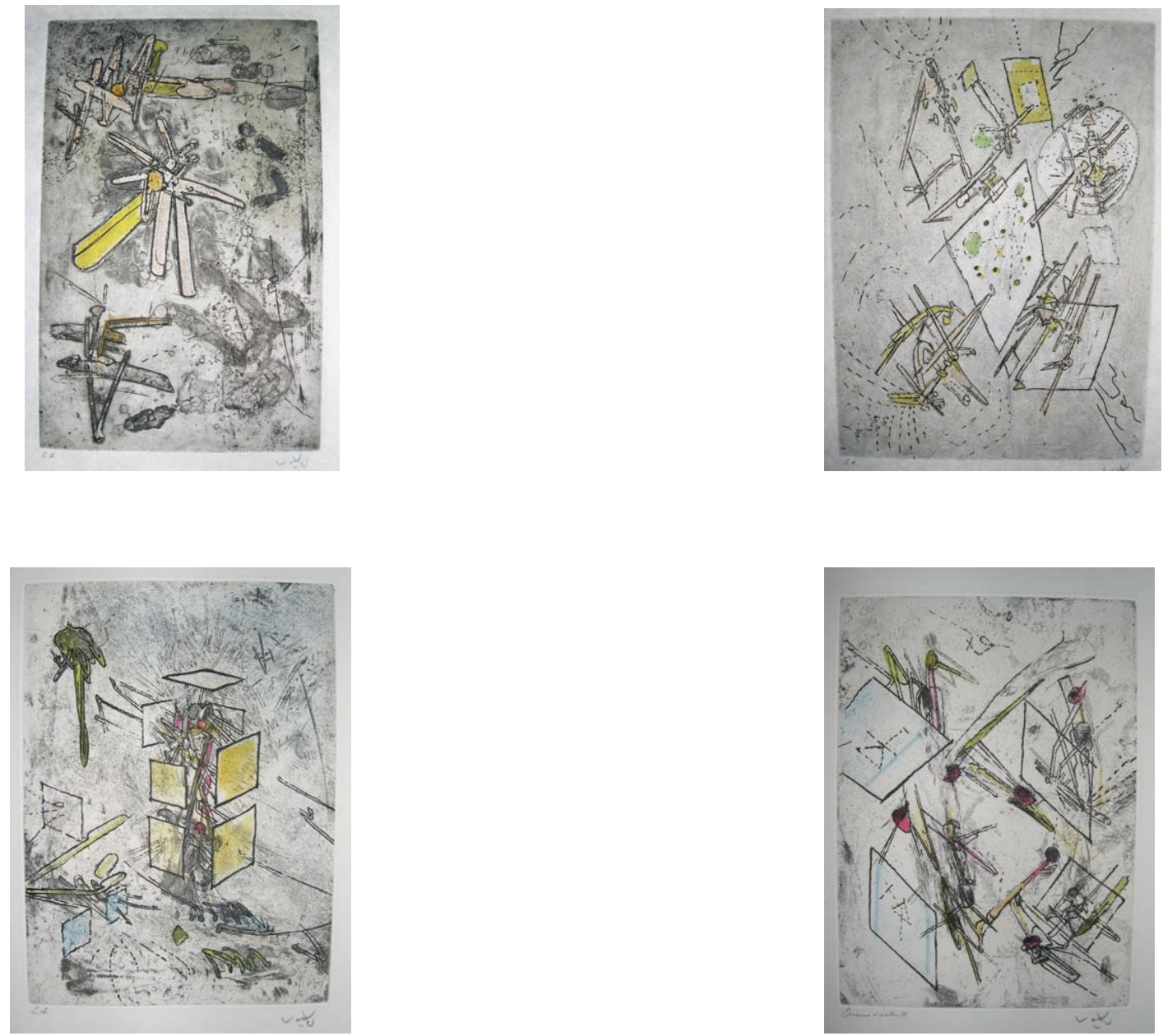

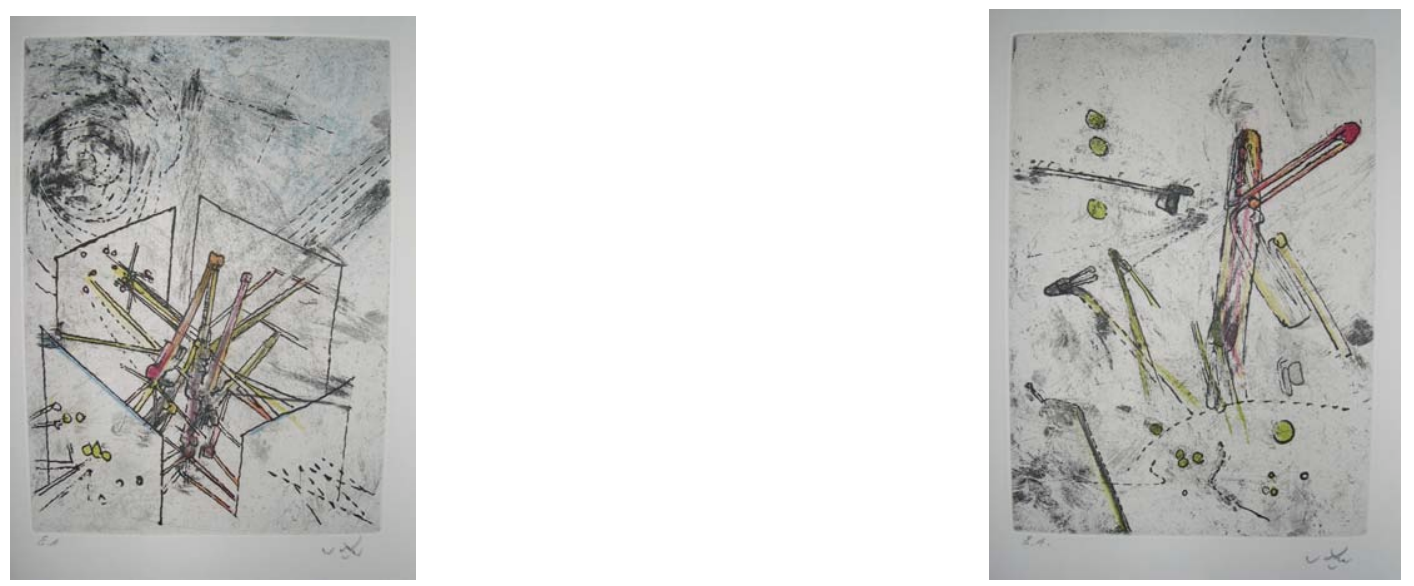

\section{Libros}

\section{Localización del libro o catalogo :}

Catalogo Razonado de G. Visat "L'oeuvre gravé de Matta", editado por Sonet y George Visat, en 1975.

\section{Otros catologos que lo contengan :}

"Matta: Estampas y poemas", editado por la casa de la Moneda para la exposicion realizada en el Museo Casa de la Moneda entre Diciembre 2001 hasta enero 2002.

"Matta, index dell'Opera grafica dal 1969 al 1980", editado por Admministrazione Provinciali di Viterbo en 1980, realizado por Germana Ferrari.

Registros gráficos obtenidos Diapositiva $\square$ Imagén digital $\quad \mathrm{X}$ 
Ficha número : 4

Titulo de la obra : Vigies sur Cibles.

Fecha de realización : 1958

Dimensiones

Tamaño del papel :

Tamaño de la mancha : $34 \times 26 \mathrm{~cm}$.

\section{Técnica}

Técnica : Aguafuerte y Aguatinta.

Procedimientos y recursos complementarios :

Vigies sur Cibles es un libro artístico compuesto por los escritos de Henry Michaux, los que se acompañan con 9 grabados realizados por Roberto Matta.

\section{Matriz}

Número de planchas : $\quad$ Entre 4 a 6 planchas.

Material de las planchas : Metal Cobre y Zinc.

\section{Datos complementarios :}

La cantidad de planchas utilizadas en cada obra, se refiere a la función que cumplen dentro de la misma, ya que Matta utilizaba una plancha para el fondo, otra plancha para los personajes y varias planchas mas para los colores utilizados en la(s) obra(s).

\section{Estampación}

En hueco

En relieve

Planigrafica

Permeografica

\section{Número de tintas :}

Entre 4 a 6 tintas.

\section{Colores :}

Negro, gris, naranja, rojo, celeste, amarillo, verde y rosado.

Papel

Marca : $\quad$ El papel utilizado fue especialmente hecho a mano por el maestro papelero A.G.Carbol.

Gramaje : 250 gramos.

Color : Blanco. 


\section{Edición}

\section{Número de ejemplares :}

99 ejemplares firmados por los autores, con un doble embalaje. las planchas de cobre fueron firmadas posteriormente al tiraje de este libro de artista. Dentro de estos 99 ejemplares existen 9 que se diferencian del resto de la serie, así existen: I ejemplar único nominativo el cual contiene 9 dibujos preparatorios de Matta, 7 planchas trabajadas a mano, y 9 grabados a color mas una serie realizada en negro. Luego existen 8 ejemplares numerados del I al VIII los que contienen 7 planchas realizadas en negro, mas 9 grabados a color y una serie realizada en negro. Presentándose en un contenedor de madera con doble cubierta de tamaño 26,5 x $34 \mathrm{~cm}$. cubierta exterior e interior $26 \times 33 \mathrm{~cm}$.

$N^{\circ}$ de P.A. (Prueba de Artista): Se desconoce.

$\mathbf{N}^{\circ}$ de H.C. (Hors Commerce) : Se desconoce.

B.A.T.: $\quad$ Se desconoce.

Otras Pruebas : Se desconoce.

Taller en el que se realizó :

Ediciones del Dragón en Paris.

Teniendo el cargo de director de esta obra Max Clarac-Sérou. La tipografía fue realizada en Platin Romain cuerpo 18.

\section{Estampador}

George Visat.

Número de la estampa observada : 70/99.

Estampa observada directamente :

$\mathrm{Si}$

$\mathrm{X}$

No

Contemplada a través de reproducción :

$\mathrm{Si}$

No

\section{Colección}

Colección en la que se encuentra : Colección particular en Paris.

Colección en la que se encuentra la plancha : Colección particular en Paris.

Otras colecciones que tengan ejemplares de este trabajo :

Se desconoce. 

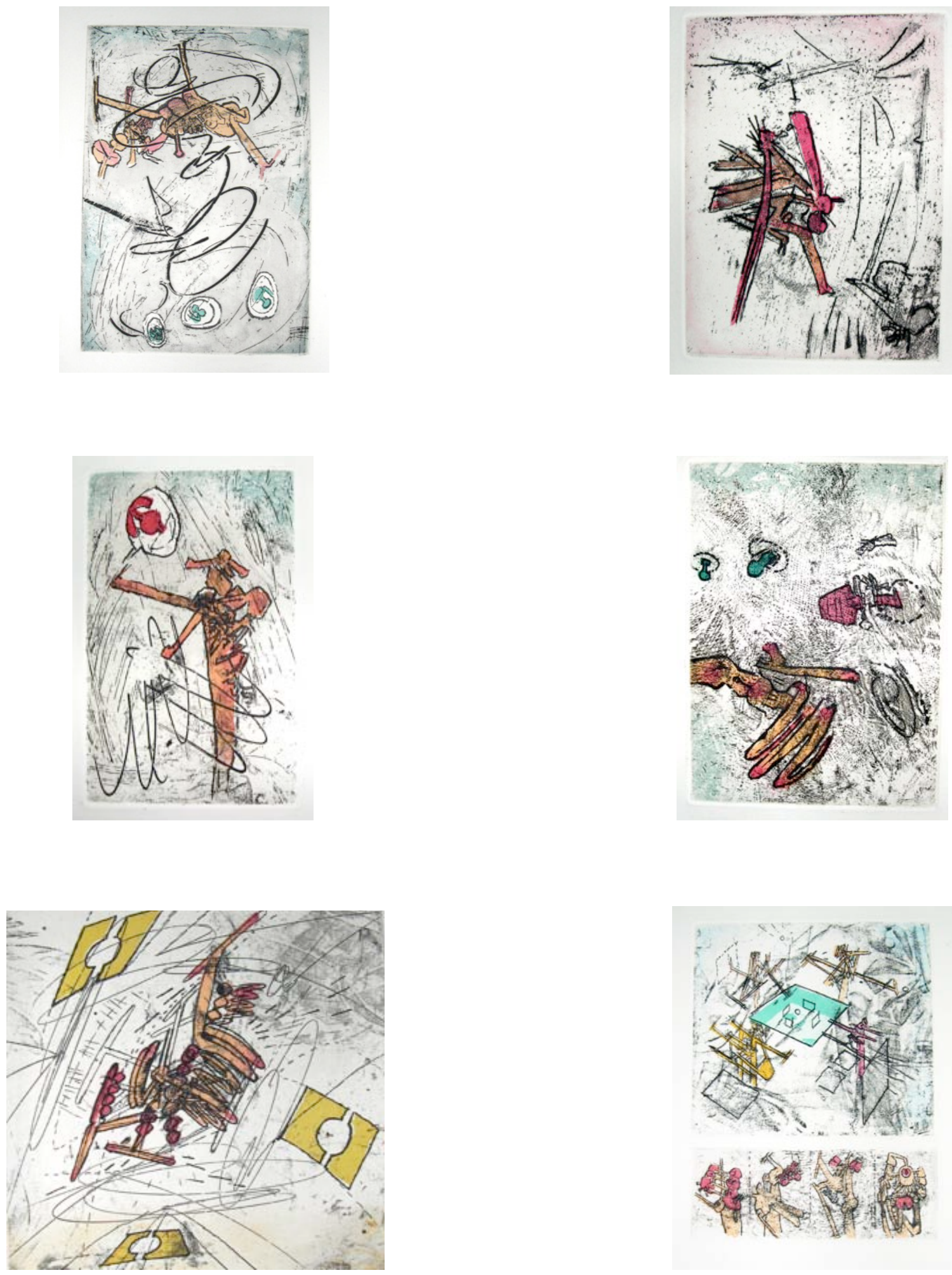

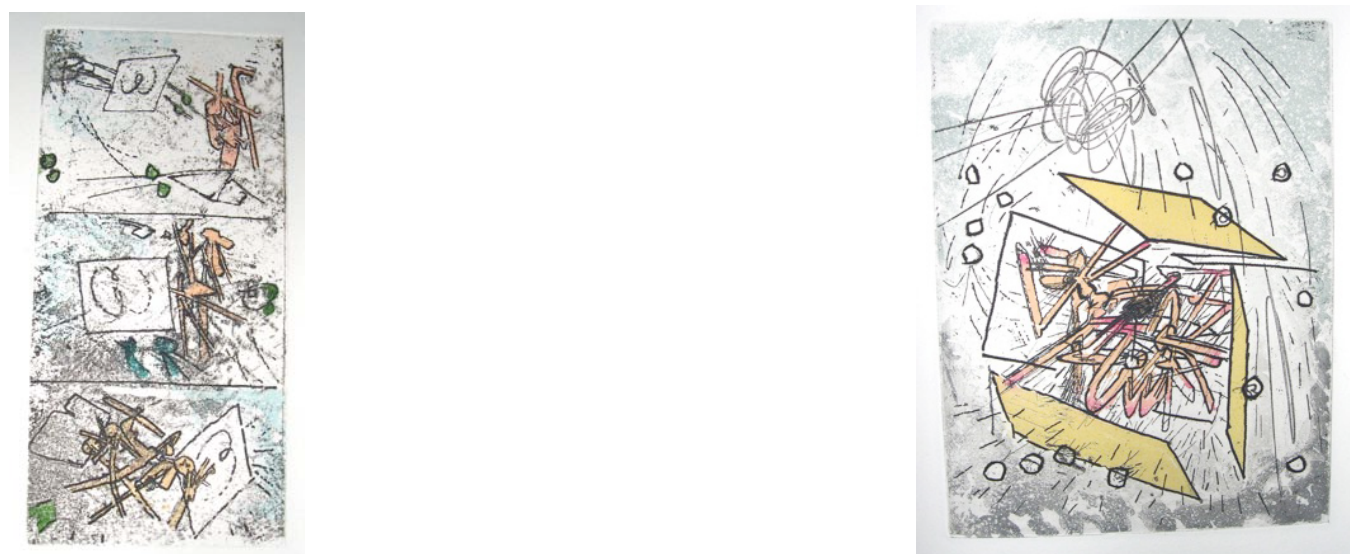

\section{Libros}

\section{Localización del libro o catalogo :}

Catalogo Razonado de G. Visat "L'oeuvre gravé de Matta”, editado por Sonet y George Visat, en 1975.

\section{Otros catologos que lo contengan :}

"Matta: Estampas y poemas", editado por la casa de la Moneda para la exposicion realizada en el Museo Casa de la Moneda entre Diciembre 2001 hasta enero 2002.

Registros gráficos obtenidos

Diapositiva

Imagén digital 


\section{Obra grafica Roberto Sebastian Matta Echaurren}

Ficha número : 5

Titulo de la obra : Come Detta dentro vo significando.

Fecha de realización : 1962

Dimensiones

Tamaño del papel : $46.5 \times 38.5 \mathrm{~cm}$.

Tamaño de la mancha : $28 \times 37.5 \mathrm{~cm}$.

\section{Técnica}

Técnica : Aguafuerte.

Procedimientos y recursos complementarios :

Come Detta dentro vo significando es una carpeta artística la que esta compuesta por un texto inédito de Roberto Matta el que esta acompañado por 16 grabados realizados por el mismo artista.

\section{Matriz}

Número de planchas : Entre 3 a 8 planchas.

Material de las planchas : Metal-Cobre.

\section{Datos complementarios :}

La cantidad de planchas utilizadas en cada obra, se refiere a la función que cumplen dentro de la misma, ya que Matta utilizaba una plancha para el fondo, otra plancha para los personajes y varias planchas mas para los colores utilizados en la(s) obra(s).

\section{Estampación}

En hueco

En relieve

Planigrafica

Permeografica

Número de tintas :

Se utilizaron 8 tintas.

\section{Colores :}

Rojo, rosado, gris, verde, naranjo, amarillo, violeta y negro.

Papel

Marca : $\quad$ Papel Arches.

Gramaje : Se desconoce. 
Color :

Se desconoce.

\section{Edición}

Número de ejemplares :

125 ejemplares sobre papel Arches de tamaño 46.5 x $38.5 \mathrm{~cm}$, firmados y numerados del 1 al 125 mas IV H.C. Existiendo un tiraje anterior que corresponde al afiche para la exposición de Matta

Come Detta dentro vo significando en la galería Point Cardinal en octubre de 1962 para la que se realizaron 190 pruebas sobre papel Arches, 40 han sido firmadas y numeradas del 1 al 40.

$\mathbf{N}^{\circ}$ de P.A. (Prueba de Artista): Se desconoce.

$\mathbf{N}^{\circ}$ de H.C. (Hors Commerce) : IV H.C.

B.A.T.: $\quad$ Se desconoce.

Otras Pruebas : Se desconoce.

Taller en el que se realizó :

Ediciones Point Cardinal en Paris. Realizacion de la talla dulce Ediciones Meyer, Lausanne.

Estampador

George Visat.

Número de la estampa observada : 
Estampa observada directamente :

Contemplada a través de reproducción :
$\mathrm{Si}$

$\mathrm{Si}$
No

No

Colección

Colección en la que se encuentra : Colección particular en Paris.

Colección en la que se encuentra la plancha : Colección particular en Paris.

Otras colecciones que tengan ejemplares de este trabajo :

Se desconoce.
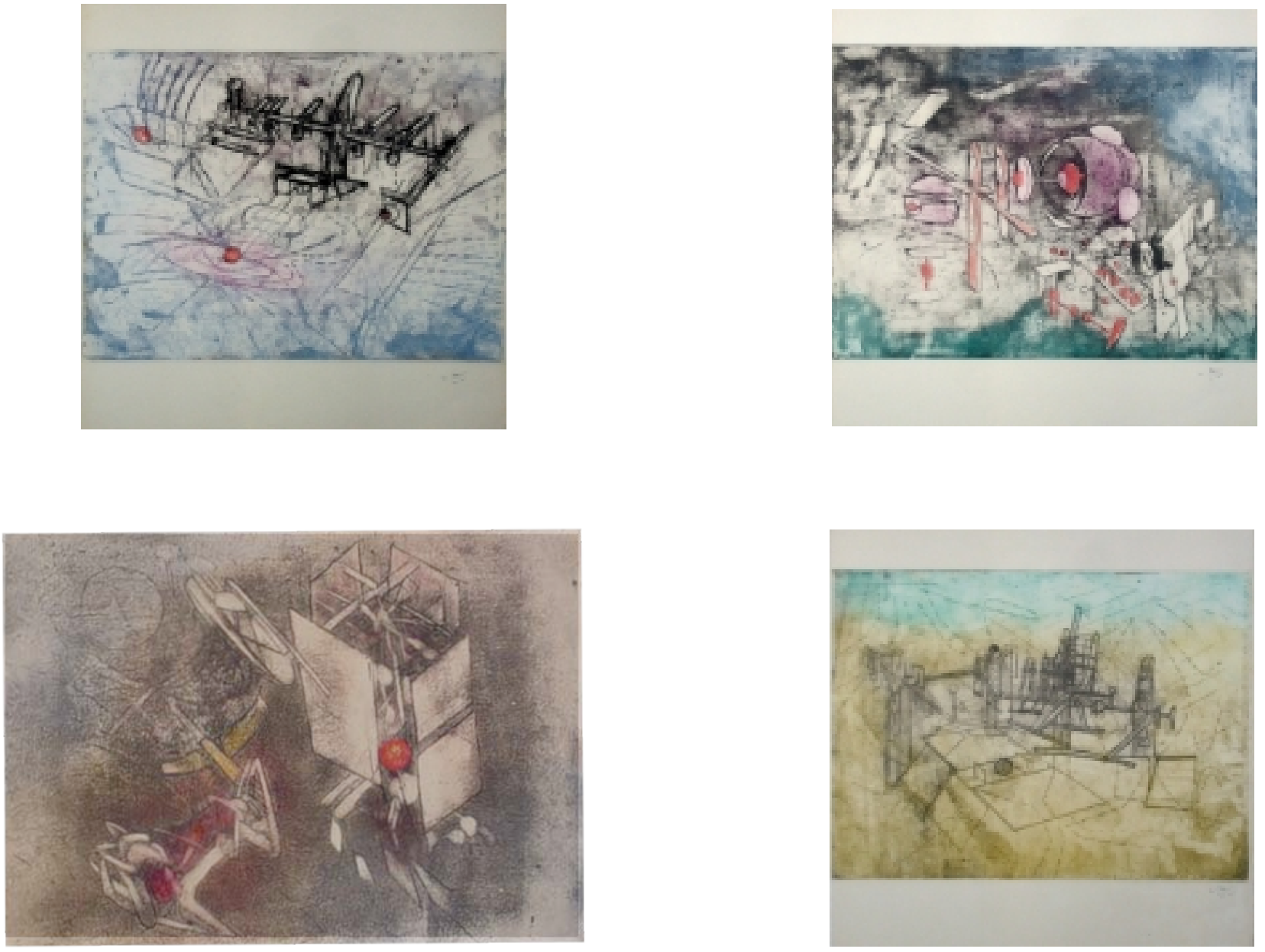


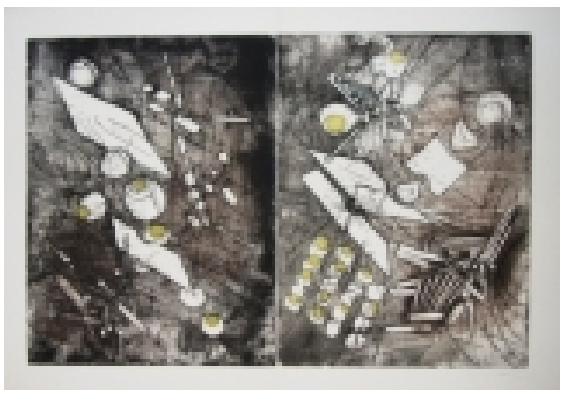

\section{Libros}

\section{Localización del libro o catalogo :}

Catalogo Razonado de G. Visat “L’oeuvre gravé de Matta”, editado por Sonet y George Visat, en 1975.

\section{Otros catologos que lo contengan :}

Se desconoce.

Registros gráficos obtenidos Diapositiva $\square$ Imagén digital $\mathrm{X}$ 


\section{Obra grafica Roberto Sebastian Matta Echaurren}

Ficha número : 6

Titulo de la obra : Les Damnations.

Fecha de realización : 1966

\section{Dimensiones}

Tamaño del papel : $\quad$ Se desconoce.

Tamaño de la mancha : $42 \times 33 \mathrm{~cm}$.

\section{Técnica}

Técnica : Aguafuerte y Aguatinta.

\section{Procedimientos y recursos complementarios :}

Les Damnations es un libro de artista el que contiene un texto de Joyce Mansour, el cual es acompañado por 11 grabados de Roberto Matta.

\section{Matriz}

Número de planchas : $\quad$ Entre 3 y 6 planchas.

Material de las planchas : Metal-Cobre.

\section{Datos complementarios :}

La cantidad de planchas utilizadas en cada obra, se refiere a la funcion que cumplen dentro de la misma, ya que Matta utilizaba una plancha para el fondo, otra plancha para los personajes y varias planchas mas para los colores utilizados en la(s) obra(s).

\section{Estampación}

En hueco

En relieve

Planigrafica

Permeografica

\section{Número de tintas :}

Dependiendo de cada obra varia entre 3 a 6 tintas.

\section{Colores :}

Negro, dorado, rojo, azul, celeste, blanco, cafe y naranjo.

\section{Papel}

Marca : $\quad$ Papel Japon Nacre/ Papel sur Velin de Arches.

Gramaje : 250 gramos.

Color :

$$
\text { Blanco. }
$$




\section{Edición}

\section{Número de ejemplares :}

75 ejemplares numerados y firmados del 1 al $75+10$ ejemplares numerados del 1 al 10 reservados para los colaboradores de este libro. Presentado en un contenedor caja tamaño 35 x $44,5 \mathrm{~cm}$. forrado en tela de seda blanca un poco brillante. Escribiéndose en el lomo del contenedor el titulo del libro en letras doradas.

$\mathbf{N}^{\circ}$ de P.A. (Prueba de Artista) : Se desconoce. Albert Dupont sabe de su existencia.

$\mathbf{N}^{\circ}$ de H.C. (Hors Commerce) : X a XXV H.C.

B.A.T. : 10 B.A.T.

Otras Pruebas : Se desconoce.

Taller en el que se realizó :

Atelier George Visat terminado de imprimir el 22 de noviembre de 1966. Tipografía en Montaigne itálica c.14 de Fequet et Baudier.

\section{Estampador}

George Visat.

Número de la estampa observada : Es la numero 74 de la serie 1 al 75.

Estampa observada directamente : $\quad \mathrm{Si} X \quad$ No $X$

Contemplada a través de reproducción : $\mathrm{Si} \square \quad$ No $\mathrm{X}$

Colección

Colección en la que se encuentra : Coleccion particular en Paris.

Colección en la que se encuentra la plancha : Coleccion particular en Paris.

Otras colecciones que tengan ejemplares de este trabajo :

Se desconoce. 

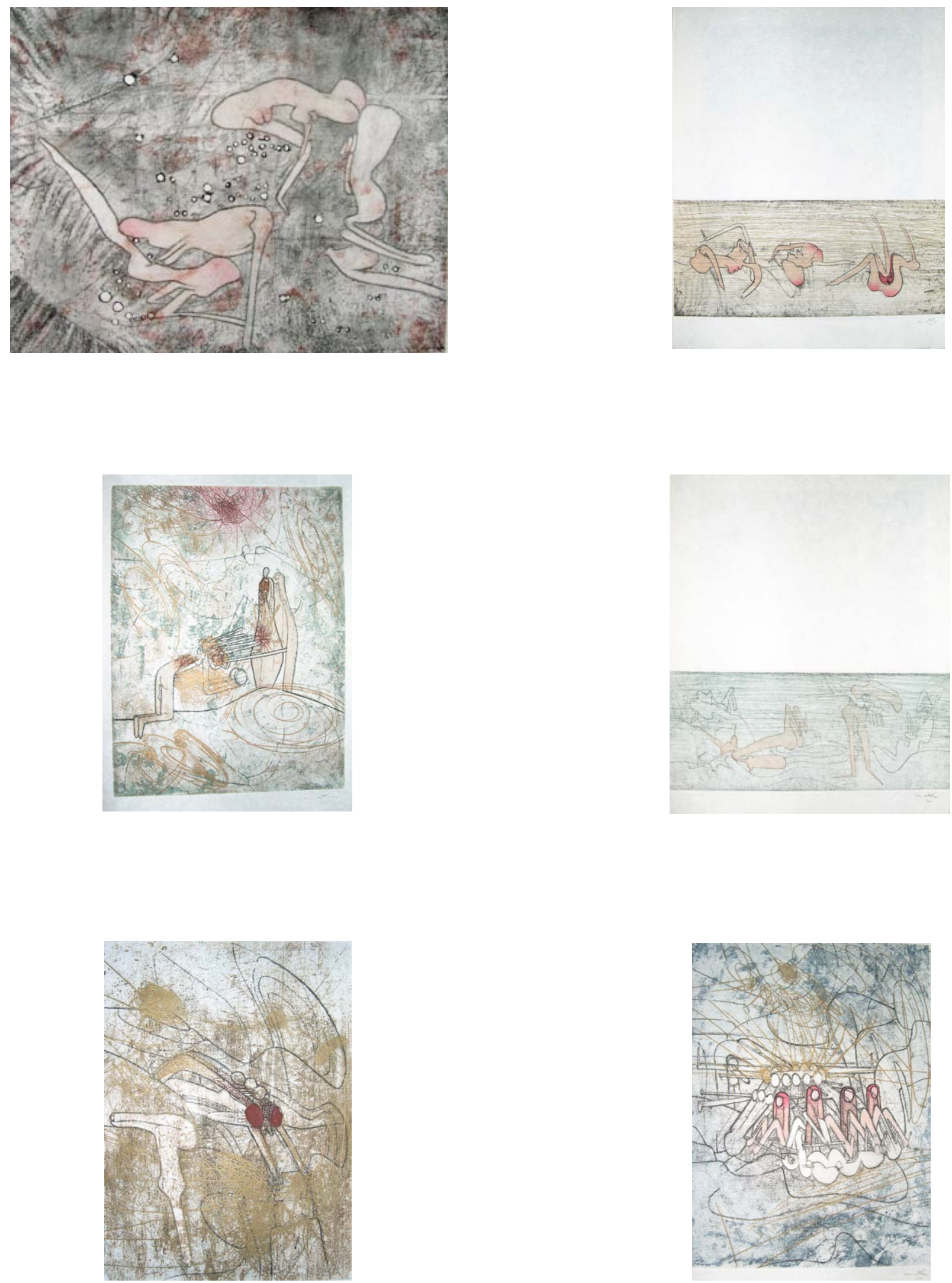

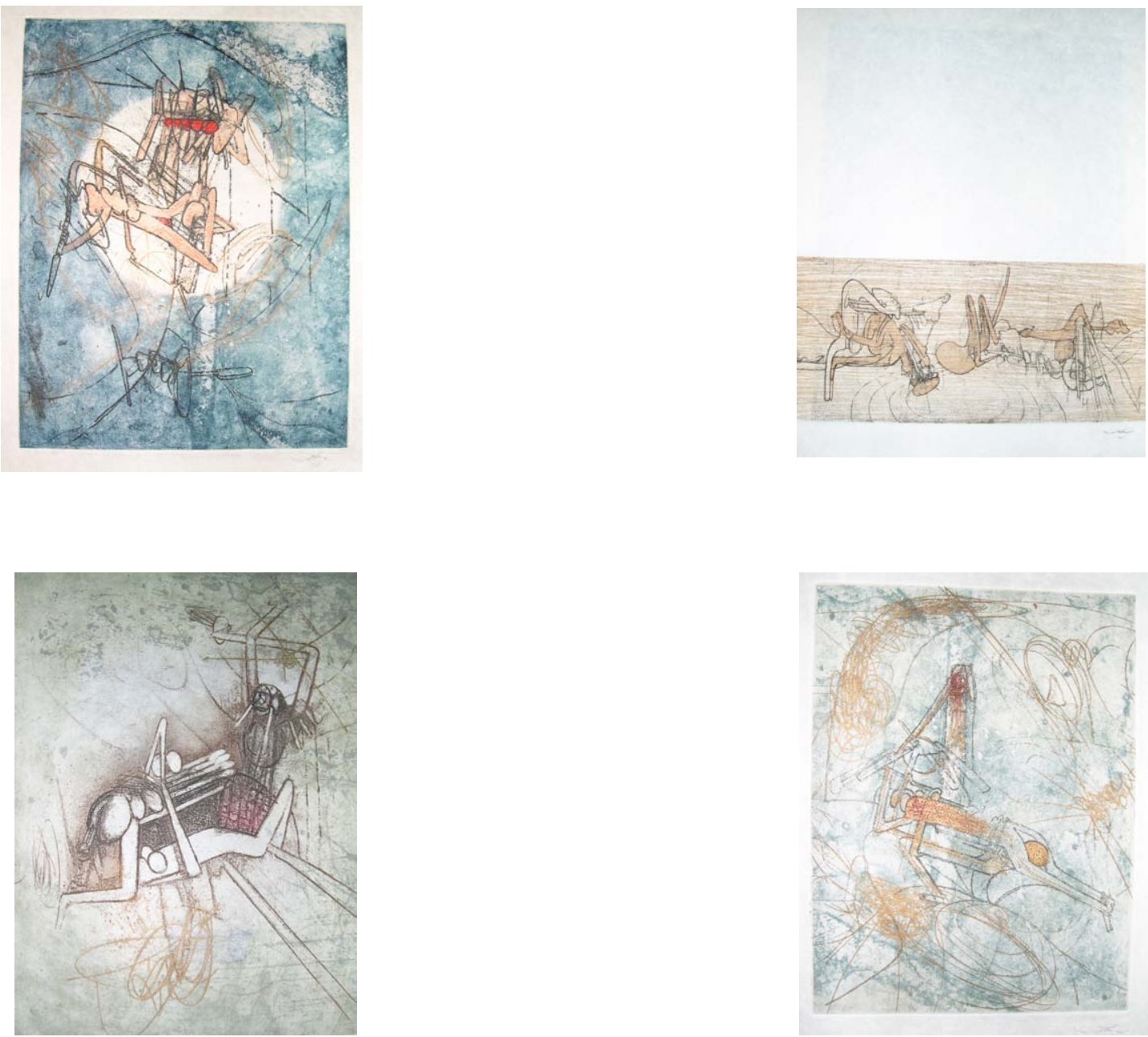

\section{Libros}

\section{Localización del libro o catalogo :}

Catalogo Razonado de G. Visat “L’oeuvre gravé de Matta”, editado por Sonet y George Visat, en 1975.

\section{Otros catologos que lo contengan :}

Se desconoce.

Registros gráficos obtenidos

Diapositiva

Imagén digital 


\section{Obra grafica Roberto Sebastian Matta Echaurren}

Ficha número : 7

Titulo de la obra : FMR.

Fecha de realización : $1968 / 1971$.

\section{Dimensiones}

Tamaño del papel : $28 \times 38 \mathrm{~cm}$.

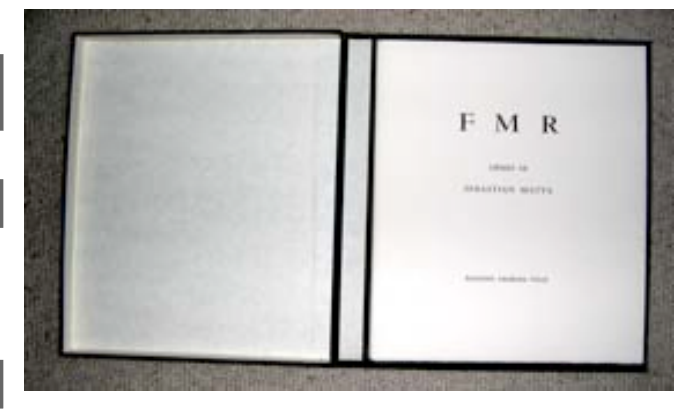

Tamaño de la mancha : $23.7 \times 17.5 \mathrm{~cm}$.

\section{Técnica}

Técnica : Aguafuerte y aguatinta.

\section{Procedimientos y recursos complementarios :}

FMR es un libro de artista compuesto por poemas inéditos de Roberto Matta acompañados por 10 grabados realizados por el mismo artista. En algunos catálogos se va a definir como un álbum.

Siendo los grabados realizados en 1968 y su edición mas la creación del libro FMR en el año 1971.

\section{Matriz}

Número de planchas : $\quad$ Entre 4 y 5 planchas en cada una de las obras.

Material de las planchas : Metal-Cobre.

\section{Datos complementarios :}

La cantidad de planchas utilizadas en cada obra, se refiere a la funcion que cumplen dentro de la misma, ya que Matta utilizaba una plancha para el fondo, otra plancha para los personajes y varias planchas mas para los colores utilizados en la(s) obra(s).

\section{Estampación}

En hueco

En relieve

Planigrafica

Permeografica

Número de tintas :

Entre 4 y 5 tintas.

Colores :

Dorado, negro rosado naranjo y rojo.

\section{Papel}

Marca : $\quad$ Papel Velin de lana/Papel Japon Nacre.

Gramaje : 250 gramos.

Color: Blanco. 


\section{Edición}

\section{Número de ejemplares :}

85 ejemplares sobre papel arches firmados y numerados en cifras árabes desde el 1 al $85+\mathrm{XV}$ ejemplares numerados desde el I al XV H.C. destinado a sus colaboradores y al deposito legal. Mas 85 ejemplares sobre papel Japón nacre firmados y numerados en cifras árabes desde el 1 al $85+X V$ ejemplares numerados desde el I al XV H.C. destinado a sus colaboradores y al deposito legal.

La presentación del libro se hace con un contenedor caja forrado en tela negra tamaño 31 x 41,5 cm. Impreso un grabado de Matta en la portada mas su firma.

$\mathbf{N}^{\circ}$ de P.A. (Prueba de Artista) : Se desconoce. Albert Dupont se sabe de su existencia.

$\mathbf{N}^{\circ}$ de H.C. (Hors Commerce) : X a XXV H.C.

B.A.T.: 10 B.A.T.

Otras Pruebas : Se desconoce.

Taller en el que se realizó :

Atelier George Visat. Siendo la tipografía realizada en Garamont Romain cuerpo 20 y de Fequet y Baudier.

\section{Estampador}

George Visat.

Número de la estampa observada : XIII.

\begin{tabular}{lllll} 
Estampa observada directamente : & $\mathrm{Si}$ & $\mathrm{X}$ & No $\mathrm{X}$ \\
\hline
\end{tabular}

Contemplada a través de reproducción : $\mathrm{Si}_{\square} \quad$ No $\mathrm{X}$

Colección

Colección en la que se encuentra : Coleccion particular en Paris.

Colección en la que se encuentra la plancha : Coleccion particular en Paris.

Otras colecciones que tengan ejemplares de este trabajo :

Se desconoce. 

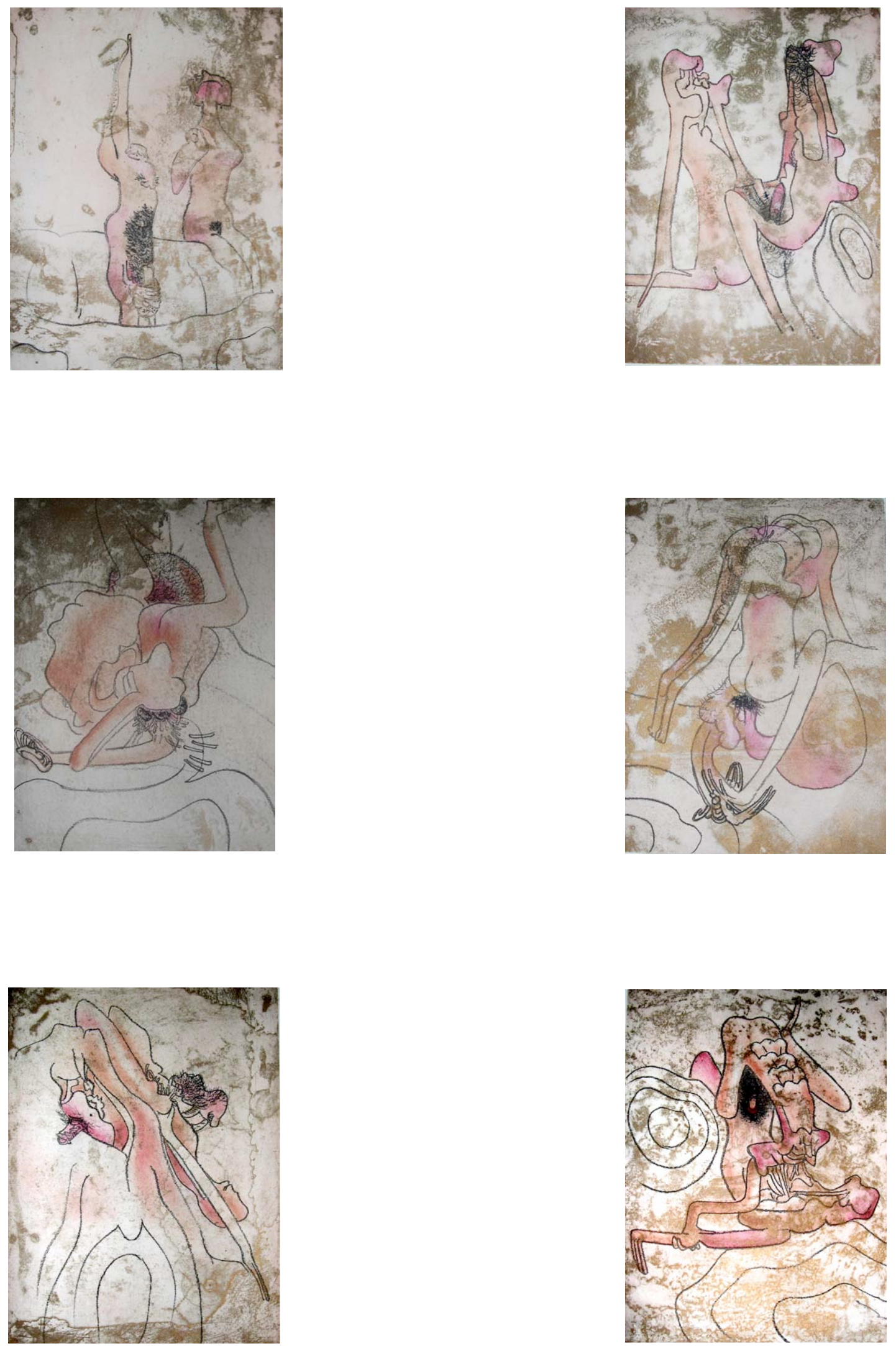

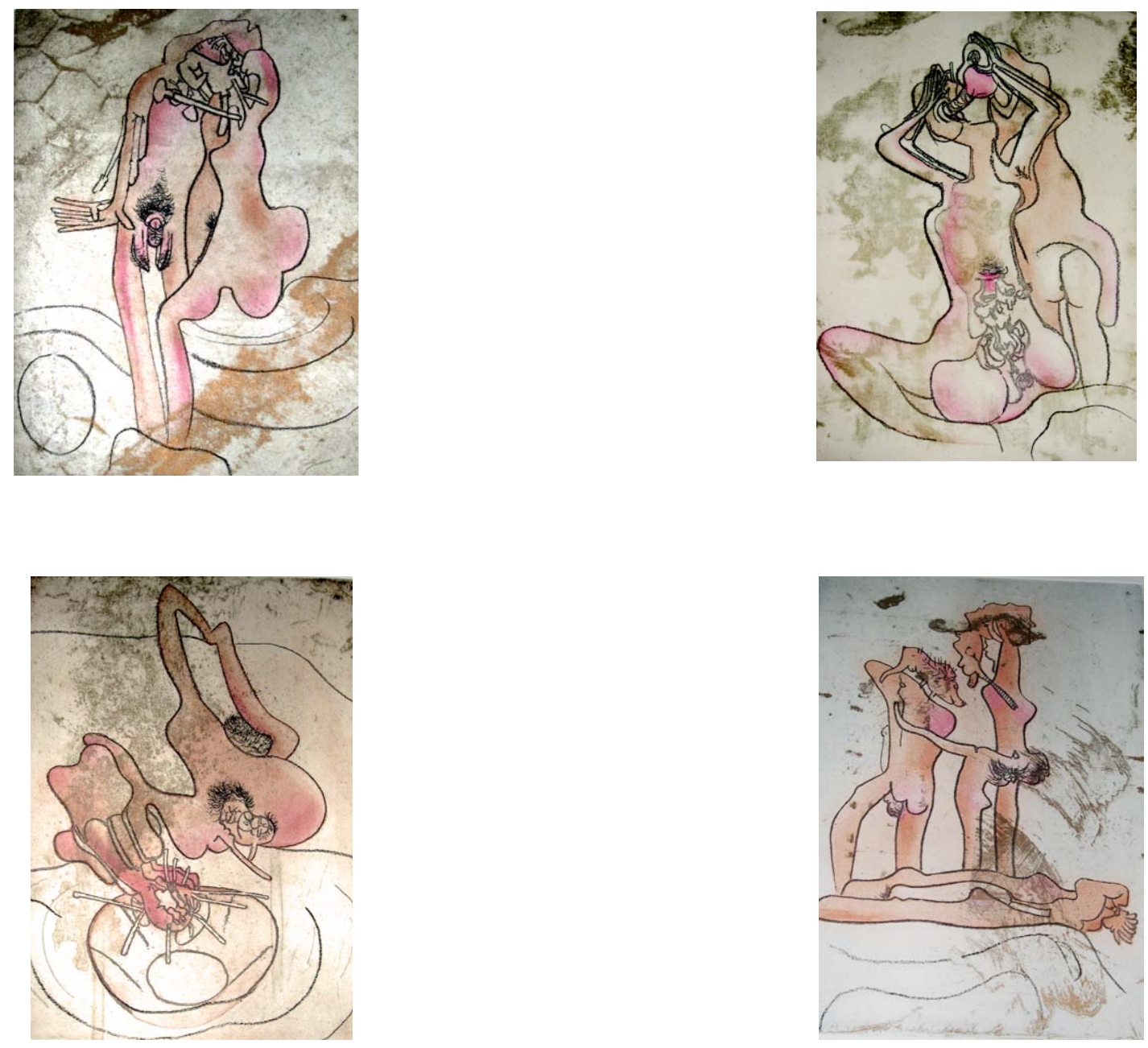

\section{Libros}

\section{Localización del libro o catalogo :}

Catalogo Razonado de G. Visat "L'oeuvre gravé de Matta”, editado por Sonet y George Visat, en 1975.

\section{Otros catologos que lo contengan :}

Se desconoce.

Registros gráficos obtenidos

Diapositiva

Imagén digital 


\section{Obra grafica Roberto Sebastian Matta Echaurren}

Ficha número : 8

Titulo de la obra : All Cosmicstrippers.

د د

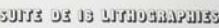

A 15

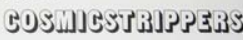

$7033-7923$

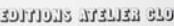
Paijs:

Tamaño del papel : Se desconoce.

Tamaño de la mancha : 50 x $65 \mathrm{~cm}$.

\section{Técnica}

Técnica : Litografia.

Procedimientos y recursos complementarios :

All Cosmicstrippers es un álbum que contiene 16 litografías a color realizadas por el artista, pero que fueron divididas en serie de cuatro en cuatro.

\section{Matriz}

Número de planchas : $\quad$ Se desconoce.

Material de las planchas : Piedra.

Datos complementarios :

No existen.

Estampación

En hueco

En relieve

Planigrafica

Permeografica

Número de tintas :

Entre 6 a 8 tintas.

Colores :

Amarillo, rojo, negro, celeste, crema, gris, verde y violeta.

Papel

Marca : $\quad$ Papel Arches vélin.

Gramaje : 250 gramos.

Color : Blanco. 


\section{Edición}

Número de ejemplares :

70 ejemplares, numerados y firmados del 1 al 60 sobre papel Arches mas X H.C., numerados y firmados.

$N^{\circ}$ de P.A. (Prueba de Artista): Se desconoce.

$\mathbf{N}^{\circ}$ de H.C. (Hors Commerce) : X H.C.

B.A.T. : $\quad$ Se desconoce.

Otras Pruebas : Se desconoce.

Taller en el que se realizó :

Impreso en atelier Bramsen et Georges en Paris en el anio 1975.

\section{Estampador}

Se desconoce.

Número de la estampa observada : Se desconoce.

\begin{tabular}{llll} 
Estampa observada directamente : & Si $X \quad$ No $X$ \\
\hline & & No
\end{tabular}

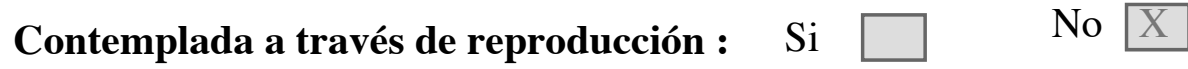

Colección

Colección en la que se encuentra : Coleccion particular en Paris.

Colección en la que se encuentra la plancha : Coleccion particular en Paris.

Otras colecciones que tengan ejemplares de este trabajo : 

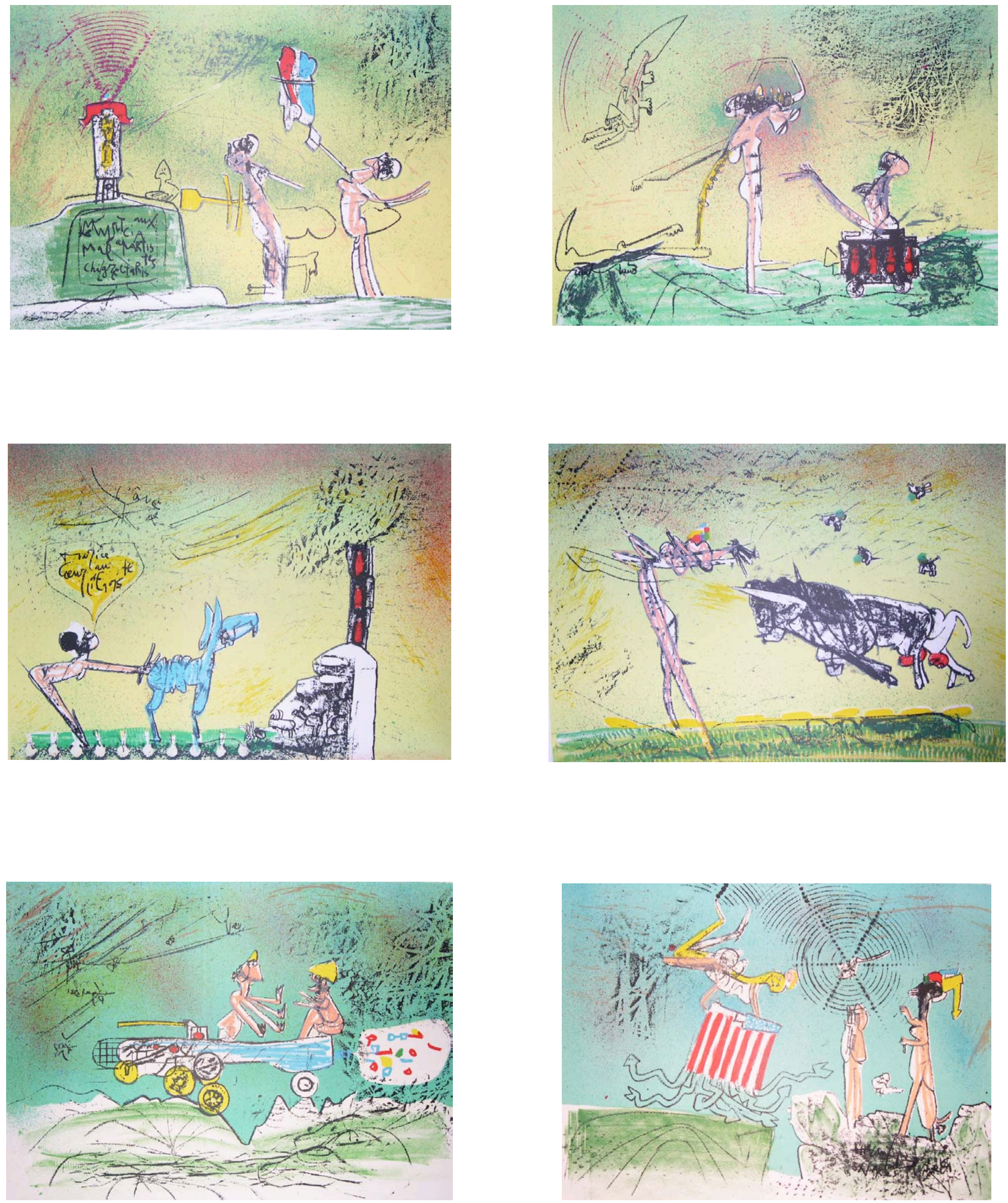

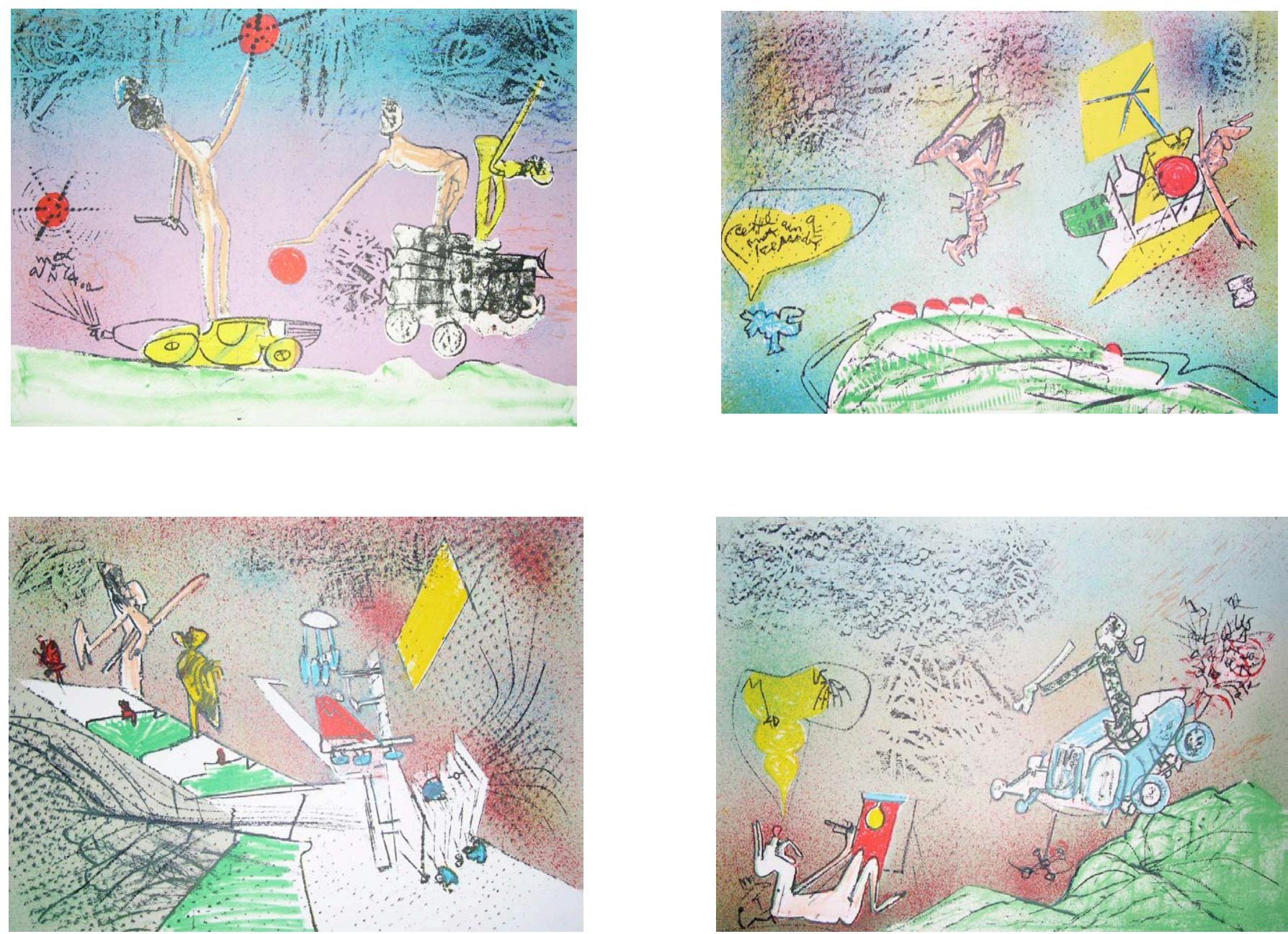

\section{Libros}

\section{Localización del libro o catalogo :}

Catalogo Razonado de G. Visat "L'oeuvre gravé de Matta”, editado por Sonet y George Visat, en 1975.

\section{Otros catologos que lo contengan :}

Se desconoce.

Registros gráficos obtenidos

Diapositiva

Imagén digital 


\section{Obra grafica Roberto Sebastian Matta Echaurren}

Ficha número : 9

Titulo de la obra : Hom'mère I "Chaosmos".

Fecha de realización : 1970- 1973.

\section{Dimensiones}

Tamaño del papel : $50 \times 66 \mathrm{~cm}$.

Tamaño de la mancha : 49 x $37.5 \mathrm{~cm}$.

\section{Técnica}

Técnica : Aguafuerte y aguatinta.

\section{Procedimientos y recursos complementarios :}

Hom'mère I "Chaosmos", es una carpeta artística compuesta por un poema inédito de Roberto Matta, mas 10 grabados del mismo artista realizados a través del aguafuerte y aguatinta.

Siendo “Chaosmos" el primer tomo de la serie Hom' mére.

\section{Matriz}

Número de planchas : $\quad$ Entre 6 y 12 placas.

Material de las planchas : Metal- Cobre.

\section{Datos complementarios :}

La cantidad de planchas utilizadas en cada obra, se refiere a la funcion que cumplen dentro de la misma, ya que Matta utilizaba una plancha para el fondo, otra plancha para los personajes y varias planchas mas para los colores utilizados en la(s) obra(s).

\section{Estampación}

En hueco

En relieve

Planigrafica

Permeografica

\section{Número de tintas :}

Dependiendo de cada una de las obras varia ente 6 a 12 tintas.

\section{Colores :}

Negro, verde, rojo, rosado, amarillo, gris, cafe, naranjo, azul, celeste, fucsia y violeta.

\section{Papel}

Marca : $\quad$ Papel Arches y Papel Japon Nacre tamano 50 x $65 \mathrm{~cm}$.

Gramaje : Se desconoce.

Color: Blanco. 


\section{Edición}

Número de ejemplares :

100 ejemplares para la suite sobre papel Arches, firmados y numerados del 1 al $100+$ XXV H.C. + 10 E.A. Mas 100 ejemplares para suite de papel Japón, firmados y numerados del 1 al $100+$ XXV H.C. + 10 E.A.

Presentándose en una caja de doble cubierta vertical forrada en tela de arpillera tamaño 54 x $70 \mathrm{~cm}$. Existiendo en el lomo un papel blanco pegado que dice "Sebastian Matta Chaosmos Hom'mère.

$\mathbf{N}^{\circ}$ de P.A. (Prueba de Artista) : Se desconoce.

$\mathbf{N}^{\circ}$ de H.C. (Hors Commerce) : XXV H.C.

B.A.T. : 10 B.A.T.

Otras Pruebas : Se desconoce.

Taller en el que se realizó :

La carpeta completa se realizo en el atelier de George Visat en Paris.

La tipografia en Elzévir Caslon es de Fequet y Baudier.

\section{Estampador}

George Visat.

Número de la estampa observada : 6/10 E.A.

$\begin{array}{llll}\text { Estampa observada directamente : } & \mathrm{Si} & \mathrm{X} & \text { No } \mathrm{X} \\ \end{array}$

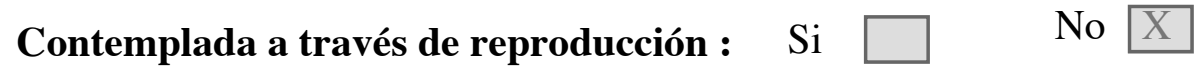

Colección

Colección en la que se encuentra : Coleccion particular en Paris.

Colección en la que se encuentra la plancha : Coleccion particular en Paris.

Otras colecciones que tengan ejemplares de este trabajo :

Se desconoce. 

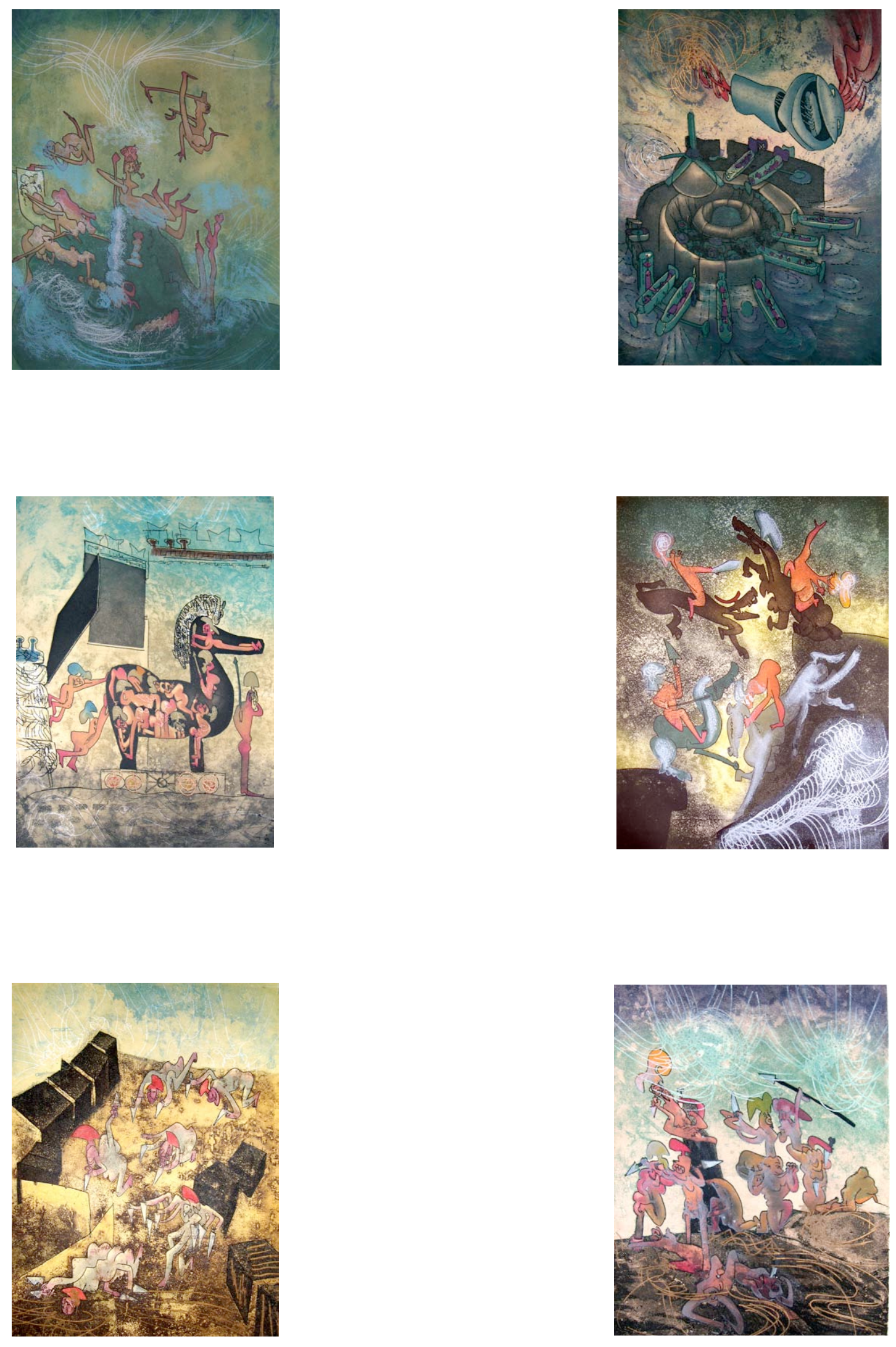

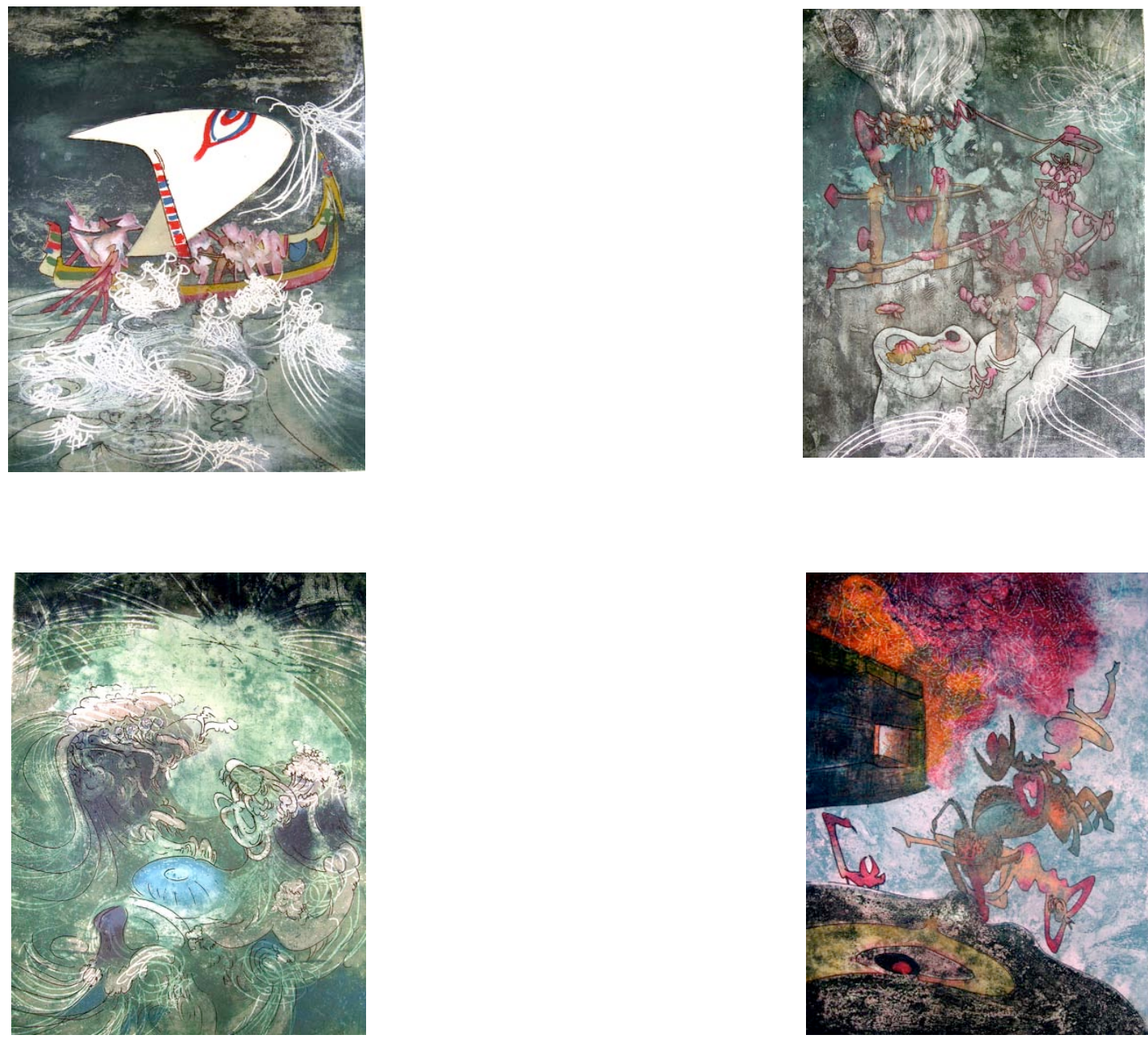

\section{Libros}

\section{Localización del libro o catalogo :}

Catalogo Razonado de G. Visat “L’oeuvre gravé de Matta”, editado por Sonet y George Visat, en 1975.

\section{Otros catologos que lo contengan :}

"Matta, Index dell'opera grafica dal 1969 al 1980", editado por Admministrazione Provinciali di Viterbo en 1980, realizado por Germana Ferrari.

"Matta: Estampas y poemas", editado por la casa de la Moneda para la exposicion realizada en el Museo Casa de la Moneda entre Diciembre 2001 hasta enero 2002.

Registros gráficos obtenidos

Diapositiva

Imagén digital 


\section{Obra grafica Roberto Sebastian Matta Echaurren}

Ficha número : 10

Titulo de la obra : Centre Noeuds.

Fecha de realización : 1974.

\section{Dimensiones}

Tamaño del papel : $70 \times 50 \mathrm{~cm}$.

Tamaño de la mancha : 36 × $26.5 \mathrm{~cm}$.

\section{Técnica}

Técnica : Aguafuerte y aguatinta.

\section{Procedimientos y recursos complementarios :}

Centre Noeuds es un libro artístico que se compone de un poema inédito de Antonin Artaud el cual es acompañado por 10 grabados de Roberto Matta.

\section{Matriz}

Número de planchas : $\quad$ Entre 4 a 8 planchas.

Material de las planchas : Metal- Cobre.

\section{Datos complementarios :}

La cantidad de planchas utilizadas en cada obra, se refiere a la funcion que cumplen dentro de la misma, ya que Matta utilizaba una plancha para el fondo, otra plancha para los personajes y varias planchas mas para los colores utilizados en la(s) obra(s).

\section{Estampación}

En hueco

En relieve

Planigrafica

Permeografica

\section{Número de tintas :}

Se utilizaron 8 tintas.

\section{Colores :}

Rojo, verde, fucsia, amarillo, negro, celeste, gris y blanco.

\section{Papel}

Marca : $\quad$ Papel Arches/Papel Japon nacre tamano 50 x $70 \mathrm{~cm}$

Gramaje : El de pael Arches 250 grm. y el papel japon nacre 180 grm.

Color : Blanco. 


\section{Edición}

\section{Número de ejemplares :}

125 ejemplares sobre papel Arches de tamaño 70 x $50 \mathrm{~cm}$. firmados y numerados del 1 al $125+$ XXX H.C. + 15 E.A. Mas 125 ejemplares sobre papel Japón de tamaño 50 x $70 \mathrm{~cm}$, firmados y numerados del 1 al $125+$ XXX H.C + 15 E.A.

$\mathbf{N}^{\circ}$ de P.A. (Prueba de Artista) : Se desconoce.

$\mathbf{N}^{\circ}$ de H.C. (Hors Commerce) : XXX H.C.

B.A.T.: 10 B.A.T.

Otras Pruebas : Se desconoce.

Taller en el que se realizó :

El presente libro artístico se realizo en una colaboración conjunta de dos atelieres que fueron Ediciones Alexander Kahan en New York y el atelier George Visat en Paris.

\section{Estampador}

George Visat.

Número de la estampa observada : 8/15 E.A.

Estampa observada directamente : $\quad \mathrm{Si} \quad \square \quad$ No $\mathrm{X}$

\begin{tabular}{lllll} 
Contemplada a través de reproducción : & $\mathrm{Si}$ & $\mathrm{X}$ & No & $\mathrm{X}$ \\
\hline
\end{tabular}

Colección

Colección en la que se encuentra : Coleccion particular en Paris.

Colección en la que se encuentra la plancha : Coleccion particular en Paris.

Otras colecciones que tengan ejemplares de este trabajo : 

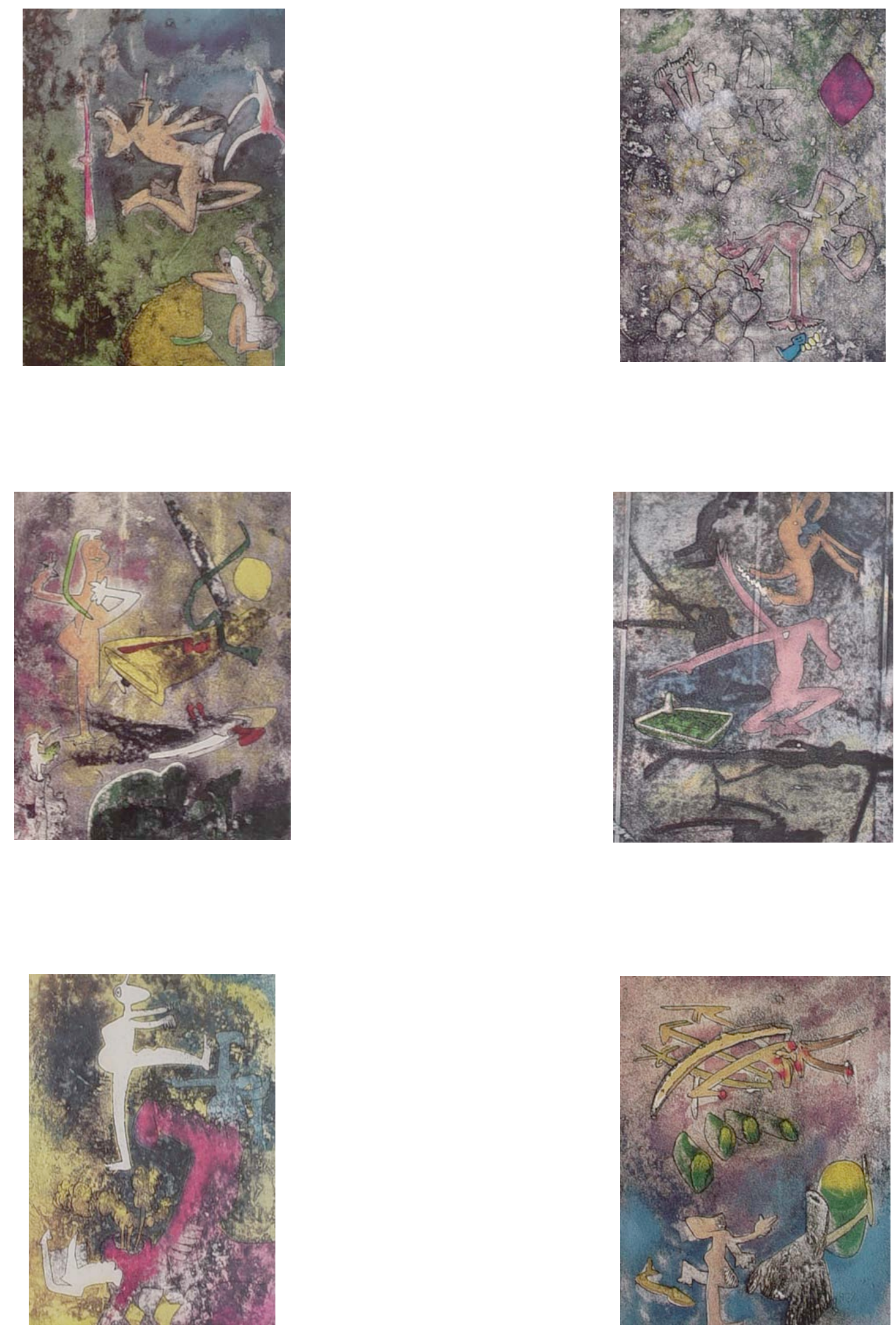

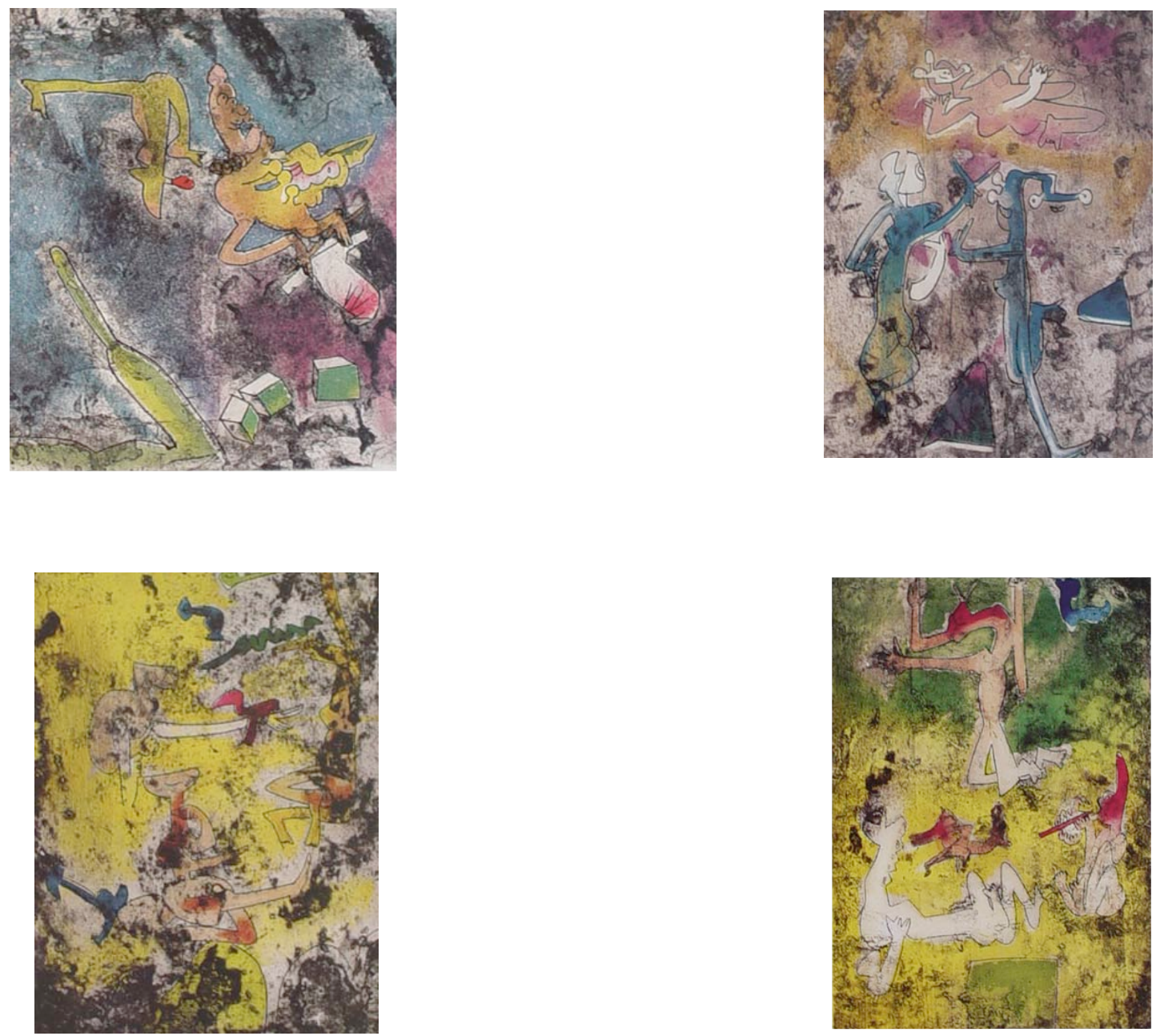

\section{Libros}

\section{Localización del libro o catalogo :}

"Matta, Index dell'opera grafica dal 1969 al 1980", editado por Admministrazione Provinciali di Viterbo en 1980, realizado por Germana Ferrari.

\section{Otros catologos que lo contengan :}

Se desconoce.

Registros gráficos obtenidos

Diapositiva

Imagén digital 
Ficha número : 11

Titulo de la obra : Los 5 Destacagados.

Fecha de realización : 1975

Dimensiones

Tamaño del papel : $\quad 50 \times 70 \mathrm{~cm}$.

Tamaño de la mancha : $38 \times 29.5 \mathrm{~cm}$.

\section{Técnica}

Técnica : Aguafuerte y aguatinta.

\section{Procedimientos y recursos complementarios :}

Los 5 destacagados es un álbum compuesto por un poema inédito de Rafael Alberti, acompañado por 5 grabados realizados por Roberto Matta a través del aguafuerte y el aguatinta.

Esta obra fue inspirada en el fresco de Matta que tiene el mismo titulo, los 5 destacagados realizado en 1974 y que mide 30 × 2 metros. Siendo la serie un homenaje de Matta a Jorge Zalamea.

Cada uno tiene por titulo: "Adefesia", "Jhonfixon burundu", "Pinosanguinochet", "Stroensburunnerda", "Burumbauzerda".

\section{Matriz}

Número de planchas : Se utilizaron 3 planchas.

\section{Material de las planchas : Metal- Cobre.}

\section{Datos complementarios :}

La cantidad de planchas utilizadas en cada obra, se refiere a la función que cumplen dentro de la misma, ya que Matta utilizaba una plancha para el fondo, otra plancha para los personajes y varias planchas mas para los colores utilizados en la(s) obra(s).

\section{Estampación}

En hueco

En relieve

Planigrafica

Permeografica

Número de tintas :

Entre 2 y 3 tintas para blanco y negro.

\section{Colores :}

Negro, blanco y gris, y existe una serie en color pero sin précision.

Papel

Marca : $\quad$ Papel Arches y Papel Japón Nacré.

Gramaje : Se desconoce. 
Color :

Se desconoce.

\section{Edición}

Número de ejemplares :

100 ejemplares sobre papel Arches de tamaño 50 x $70 \mathrm{~cm}$, firmado y numerado desde el 1 al $100+X X V$ H.C. firmado y numerado del I al XXV. Mas 100 ejemplares sobre papel Japón Nacré, de tamaño $50 \times 70 \mathrm{~cm}$, firmado y numerado desde el 1 al $100+$ XXV H.C. firmado y numerado del I al XXV.

$\mathbf{N}^{\circ}$ de P.A. (Prueba de Artista): Se desconoce.

$\mathbf{N}^{\circ}$ de H.C. (Hors Commerce) : XXV H.C.

B.A.T. :

Otras Pruebas : Se desconoce.

Taller en el que se realizó :

Estampador

Espalachi en Boulogne, según la información de Albert Dupont.

Número de la estampa observada : 
Estampa observada directamente :

Contemplada a través de reproducción :
$\mathrm{Si}$

$\mathrm{Si}$

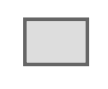

$\mathrm{X}$
No

No

\section{Colección}

Colección en la que se encuentra : Se desconoce.

Colección en la que se encuentra la plancha : Se desconoce.

Otras colecciones que tengan ejemplares de este trabajo :

Se desconoce.
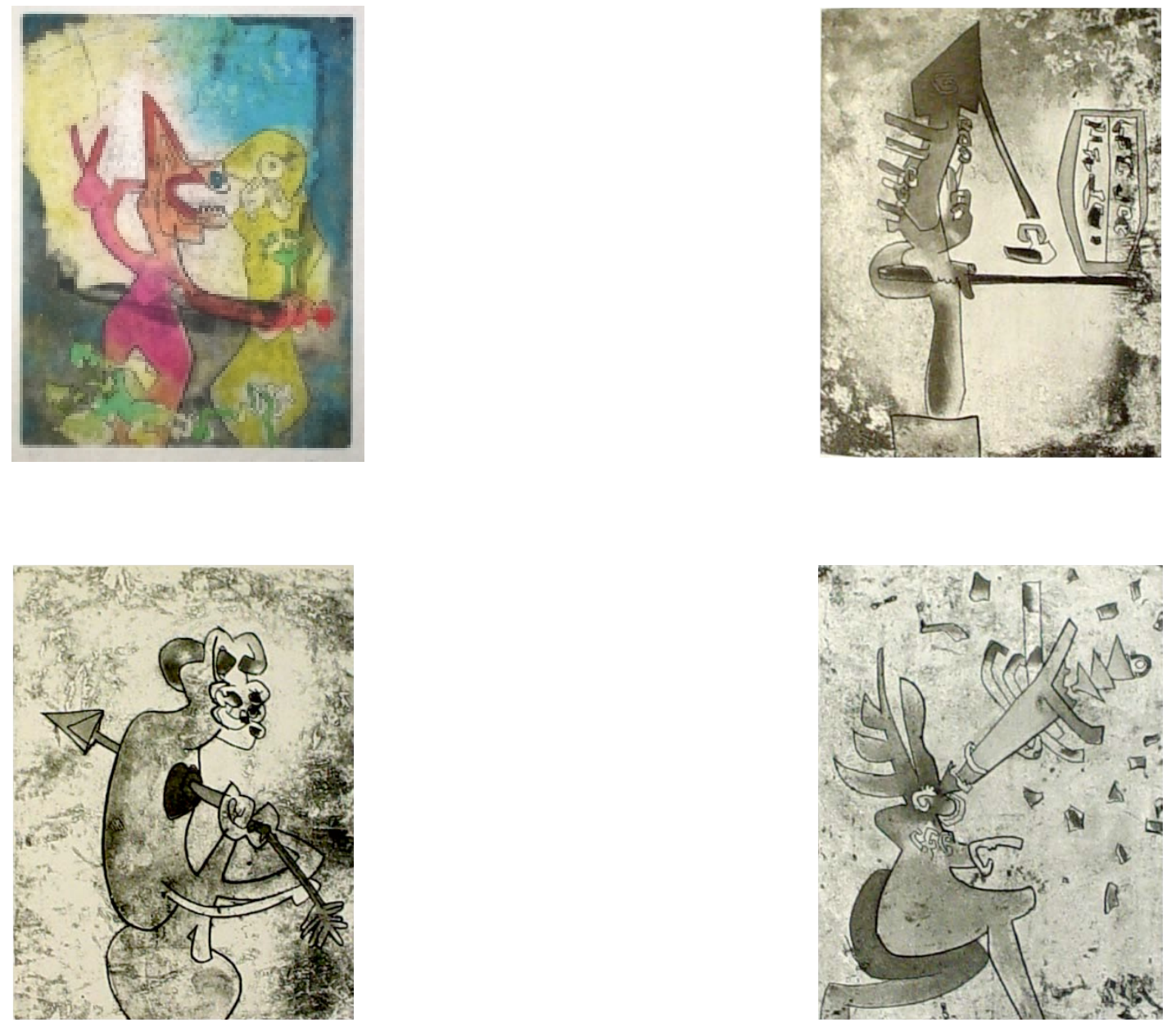


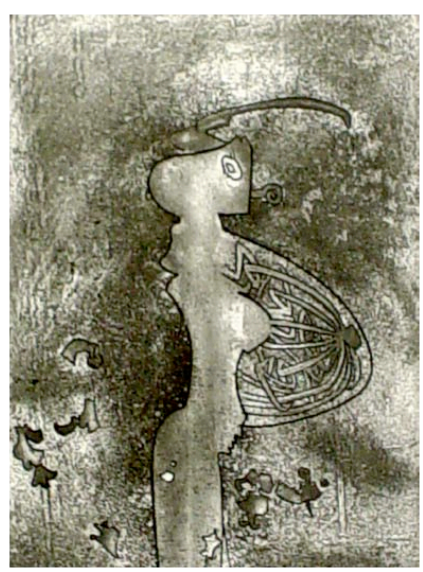

\section{Libros}

\section{Localización del libro o catalogo :}

"Matta, Index dell'opera grafica dal 1969 al 1980", editado por Admministrazione Provinciali di Viterbo en 1980, realizado por Germana Ferrari.

\section{Otros catologos que lo contengan :}

"Matta: Estampas y poemas", editado por la casa de la Moneda para la exposición realizada en el Museo Casa de la Moneda entre Diciembre 2001 hasta enero 2002.

Registros gráficos obtenidos Diapositiva $\quad \square \quad$ Imagén digital $\quad \mathrm{X}$ 


\section{Obra grafica Roberto Sebastian Matta Echaurren}

Ficha número : 12

Titulo de la obra : Hom'mère II "L'Eautre".

Fecha de realización : 1974-1975.

\section{Dimensiones}

Tamaño del papel : $50 \times 66 \mathrm{~cm}$.

Tamaño de la mancha : 49 x $37.5 \mathrm{~cm}$.

\section{Técnica}

Técnica : Aguafuerte y aguatinta.

\section{Procedimientos y recursos complementarios :}

Hom'mère II "L'Eautre" es una carpeta artística compuesta por un poema inédito de Roberto Matta, mas 10 grabados realizados por el mismo artista a través del aguafuerte y aguatinta.

Siendo "L'autre" el segundo tomo de la serie Hom'mére iniciada en 1973.

\section{Matriz}

Número de planchas : $\quad$ Entre 6 a 10 planchas.

Material de las planchas : Metal - Cobre.

\section{Datos complementarios :}

La cantidad de planchas utilizadas en cada obra, se refiere a la funcion que cumplen dentro de la misma, ya que Matta utilizaba una plancha para el fondo, otra plancha para los personajes y varias planchas mas para los colores utilizados en la(s) obra(s).

\section{Estampación}

En hueco

En relieve

Planigrafica

Permeografica

\section{Número de tintas :}

Se utilizaron 10 tintas en la totalidad de la serie.

\section{Colores :}

Amarillos, negro, azul, violetas, verde, cafe, rojo, rosado,blanco y naranjo.

\section{Papel}

Marca : Papel Arches vélin.

Gramaje : 250 grm.

Color: Blanco. 


\section{Edición}

Número de ejemplares :

100 ejemplares sobre papel Arches de 67.3 x $52 \mathrm{~cm}$. Según el catalogo elaborado por Germana Ferrari el tamaño es de 50 X $65 \mathrm{~cm}$., firmados y numerados del 1 al $100+$ XXV H.C.+10 E.A. Mas 100 ejemplares sobre papel Japón Nacre de 67.3 x 52 cm, firmados y numerados del 1 al $100+$ XXV H.C.+10 E.A.

Presentado en un contenedor de $56 \times 72 \mathrm{~cm}$.

$\mathrm{N}^{\circ}$ de P.A. (Prueba de Artista) : X P.A.

$\mathbf{N}^{\circ}$ de H.C. (Hors Commerce) : XXV H.C.

B.A.T.: $\quad$ X B.A.T.

Otras Pruebas : Se desconoce.

Taller en el que se realizó :

Atelier George Visat en Paris.

\section{Estampador}

George Visat.

Número de la estampa observada : 8/10 E.A.

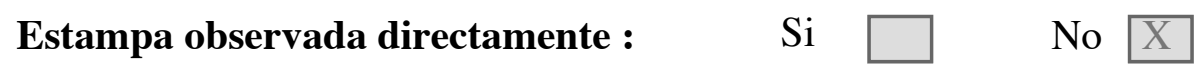

\begin{tabular}{lllll} 
Contemplada a través de reproducción : & $\mathrm{Si}$ & $\mathrm{X}$ & No & $\mathrm{X}$ \\
\hline
\end{tabular}

Colección

Colección en la que se encuentra : Coleccion particular en Paris.

Colección en la que se encuentra la plancha : Coleccion particular en Paris.

Otras colecciones que tengan ejemplares de este trabajo :

Se desconoce. 

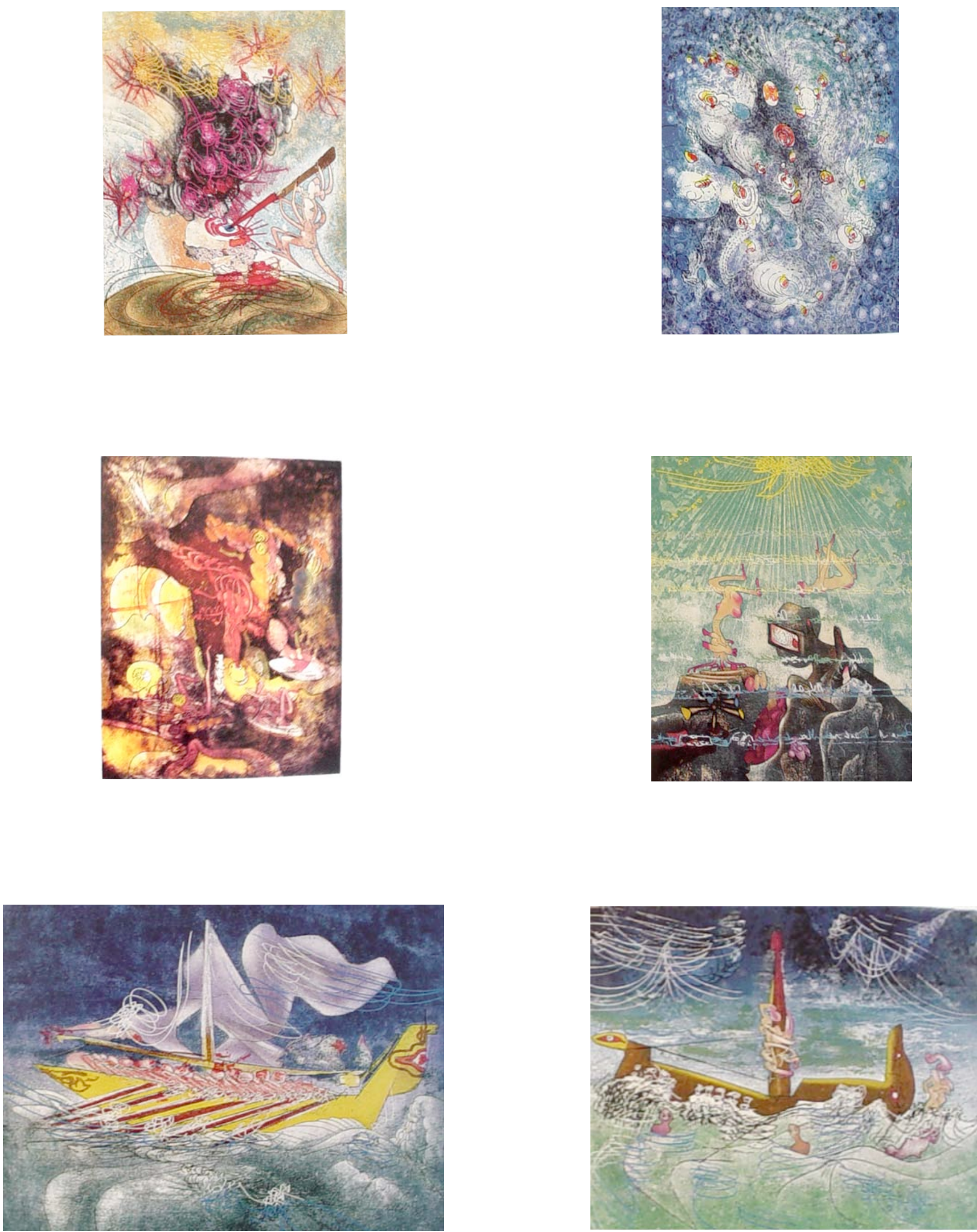

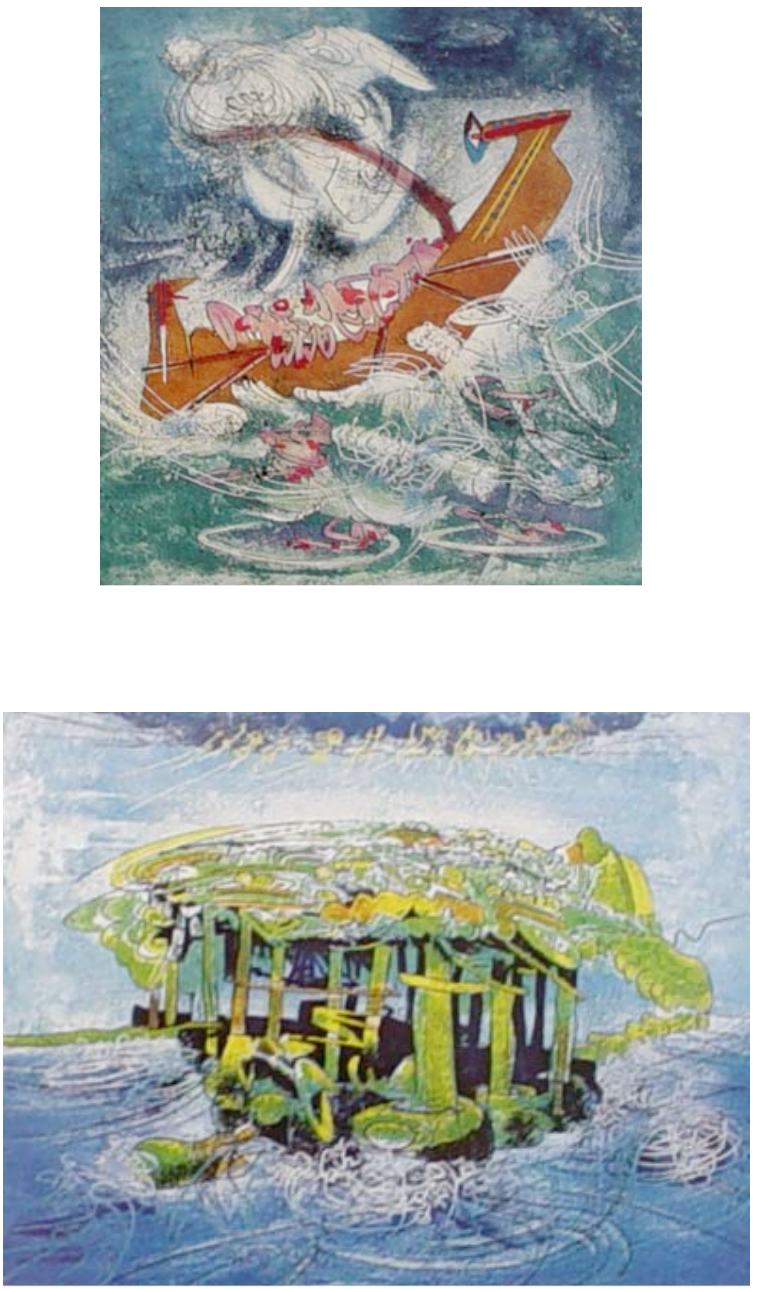
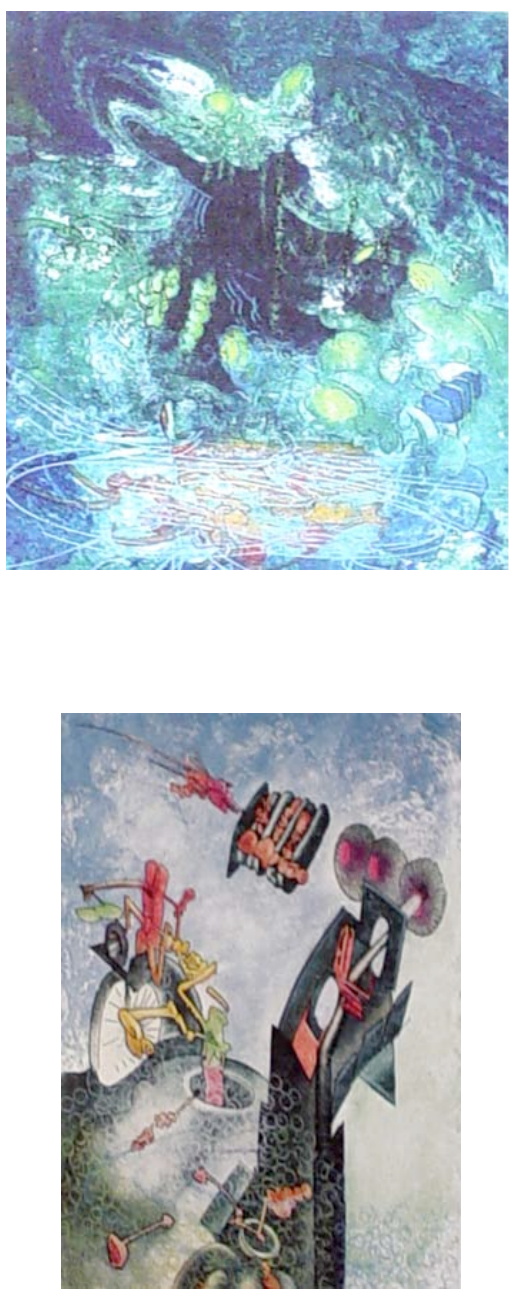

\section{Libros}

\section{Localización del libro o catalogo :}

"Matta, Index dell'opera grafica dal 1969 al 1980", editado por Admministrazione Provinciali di Viterbo en 1980, realizado por Germana Ferrari.

\section{Otros catologos que lo contengan :}

Se desconoce.

Registros gráficos obtenidos

Diapositiva

Imagén digital 


\section{Obra grafica Roberto Sebastian Matta Echaurren}

Ficha número : 13

Titulo de la obra : El gran Burundu-Burunda ha muerto.

Fecha de realización : 1975

Dimensiones

Tamaño del papel : $55 \times 75 \mathrm{~cm}$.

Tamaño de la mancha : 48 x $64 \mathrm{~cm}$.

\section{Técnica}

Técnica : Litografia

\section{Procedimientos y recursos complementarios :}

El gran Burundu-Burunda ha muerto es un libro de artista o carpeta litográfica(como se menciona en algunas bibliografías), compuesta por el texto inédito de José Zalamea titulado "El gran Burundu", el cual se presenta acompañado por 7 litografías realizadas por Roberto Matta.

\section{Matriz}

Número de planchas : $\quad$ Se desconoce.

Material de las planchas : Piedra.

\section{Datos complementarios :}

Se desconoccen.

Estampación

En hueco

En relieve

Planigrafica

Permeografica

Papel
Número de tintas :

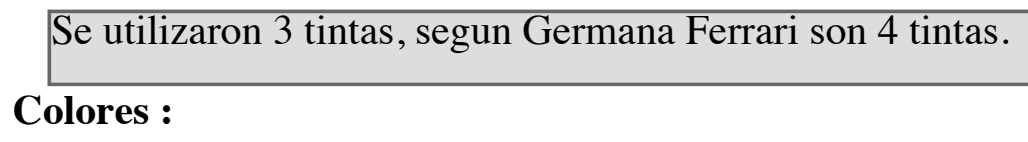

Negro, gris y crema.

Marca : Papel Arches.

Gramaje : Se desconoce.

Color : Crema. 


\section{Edición}

Número de ejemplares :

50 ejemplares sobre papel Arches de 50 x $77.5 \mathrm{~cm}$, firmados y numerados del 1 al $50+15$ pruebas de artista firmadas y numeradas del 1 al 15 .

$\mathbf{N}^{\circ}$ de P.A. (Prueba de Artista) : 15 P.A.

$\mathbf{N}^{\circ}$ de H.C. (Hors Commerce) : Se desconoce.

B.A.T. : Se desconoce.

Otras Pruebas : Se desconoce.

Taller en el que se realizó :

Ediciones Carmen Waugh en Madrid.

\section{Estampador}

Se desconoce.

Número de la estampa observada : 4 / 5 E.A.

Estampa observada directamente : $\quad S$

Contemplada a través de reproducción : $\mathrm{Si} X$

Colección

Colección en la que se encuentra : Coleccion particular en Paris.

Colección en la que se encuentra la plancha : Coleccion particular en Paris.

Otras colecciones que tengan ejemplares de este trabajo : Se desconoce.

\section{Libros}

\section{Localización del libro o catalogo :}

"Matta, Index dell4opera grafica dal 1969 al 1980", editado por Admministrazione Provinciali di Viterbo en 1980, realizado por Germana Ferrari.

\section{Otros catologos que lo contengan :}

"Matta: Verbo America", catalogo realizado para la exposicion organizada por la Junta de Andalucia, la conserjeria de cultura y Medio Ambiente, la caja de San Fernando y el Instituto Frances de Sevilla en 1991.

Registros gráficos obtenidos $\quad$ Diapositiva $\quad \square \quad$ Imagén digital $\quad X$ 


\section{Obra grafica Roberto Sebastian Matta Echaurren}

Ficha número : 14

Titulo de la obra : Hom'mère III "L'Ergonaute".

Fecha de realización : 1977.

\section{Dimensiones}

Tamaño del papel : $50 \times 66 \mathrm{~cm}$.

Tamaño de la mancha : 49 x $37.5 \mathrm{~cm}$

\section{Técnica}

Técnica : Aguafuerte y Aguatinta.

\section{Procedimientos y recursos complementarios :}

Hom'mère III “L'Ergonaute" es una carpeta artística compuesta por un poema inédito de Roberto Matta, mas 10 grabados realizados por el mismo artista a través del aguafuerte y aguatinta.

Siendo "L’ergonaute" el tercer tomo de la serie Hom’mére iniciada en 1973.

\section{Matriz}

Número de planchas : $\quad$ Entre 6 y 9 planchas.

Material de las planchas : Metal- Cobre.

\section{Datos complementarios :}

La cantidad de planchas utilizadas en cada obra, se refiere a la funcion que cumplen dentro de la misma, ya que Matta utilizaba una plancha para el fondo, otra plancha para los personajes y varias planchas mas para los colores utilizados en la(s) obra(s).

\section{Estampación}

En hueco

En relieve

Planigrafica

Permeografica

\section{Número de tintas :}

Entre 6 y 9 tintas.

\section{Colores :}

Negro, transparente blanco, verde, amarillo, burdeo fucsia, celeste, azul y violeta.

\section{Papel}

Marca : $\quad$ Papel Arches y Japon Nacre.

Gramaje : 250 grm.

Color: Blanco. 


\section{Edición}

Número de ejemplares :

100 ejemplares sobre papel Arches de 50 x $66 \mathrm{~cm}$, firmados y numerados del 1 al 100 mas XXV H.C. Mas 100 ejemplares sobre papel Japón de 52 x $67.5 \mathrm{~cm}$, firmados y numerados del 1 al $100+$ XXV H.C.

El que es presentado en un contenedor de $56 \times 72 \mathrm{~cm}$.

$\mathbf{N}^{\circ}$ de P.A. (Prueba de Artista) : Se desconoce.

Nº H.C. (Hors Commerce) : XXV H.C.

B.A.T.: $\quad$ Se desconoce.

Otras Pruebas : Se desconoce.

Taller en el que se realizó :

Atelier George Visat en Paris.

Estampador

George Visat.

Número de la estampa observada : 9/10 E.A.

Estampa observada directamente : $\quad$ Si $\square$ No $\mathrm{X}$

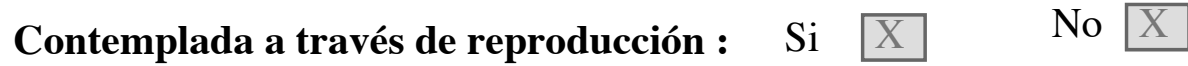

Colección

Colección en la que se encuentra : Coleccion particular en Paris.

Colección en la que se encuentra la plancha : Coleccion particular en Paris.

Otras colecciones que tengan ejemplares de este trabajo :

Se desconoce. 

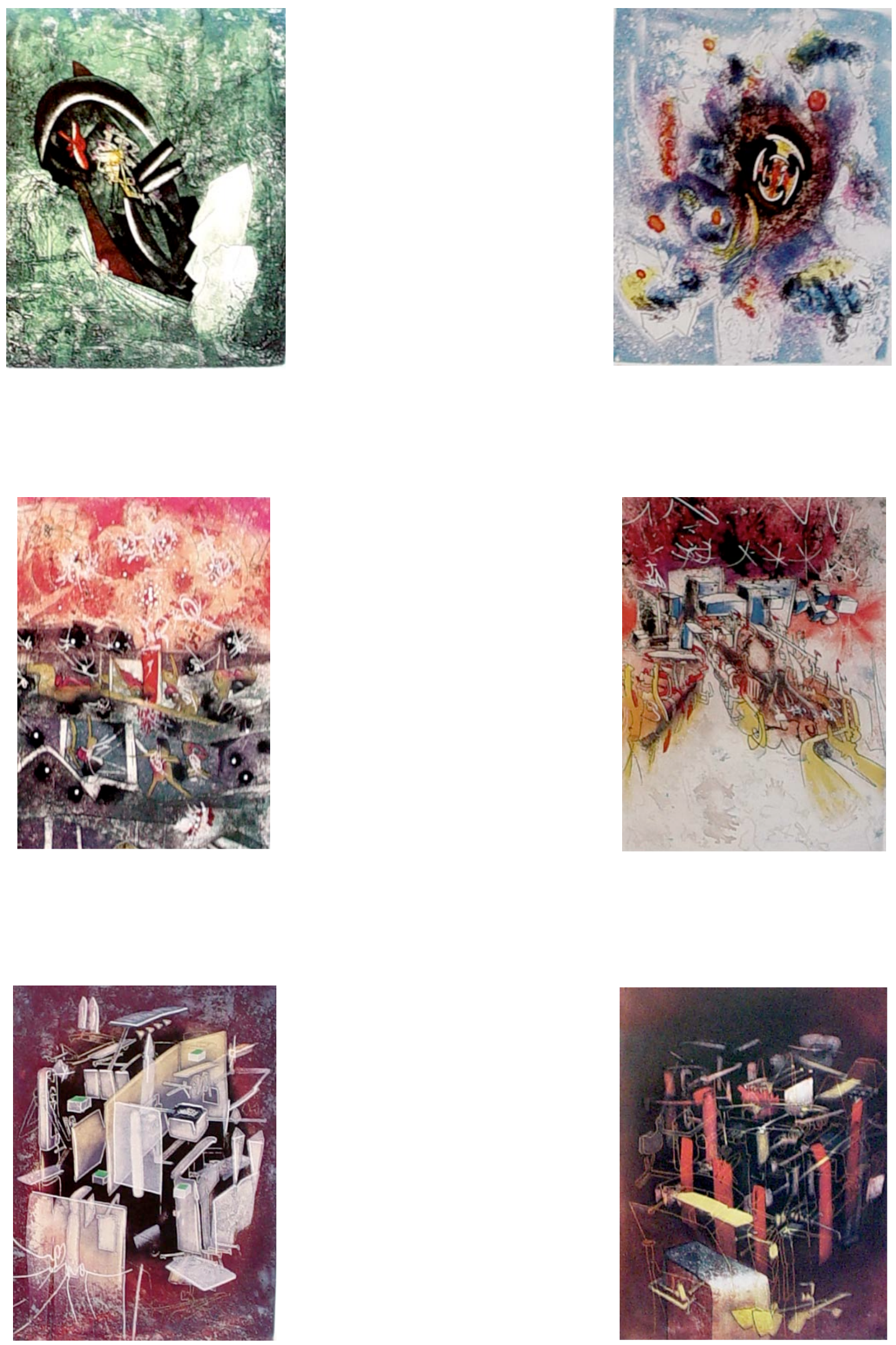

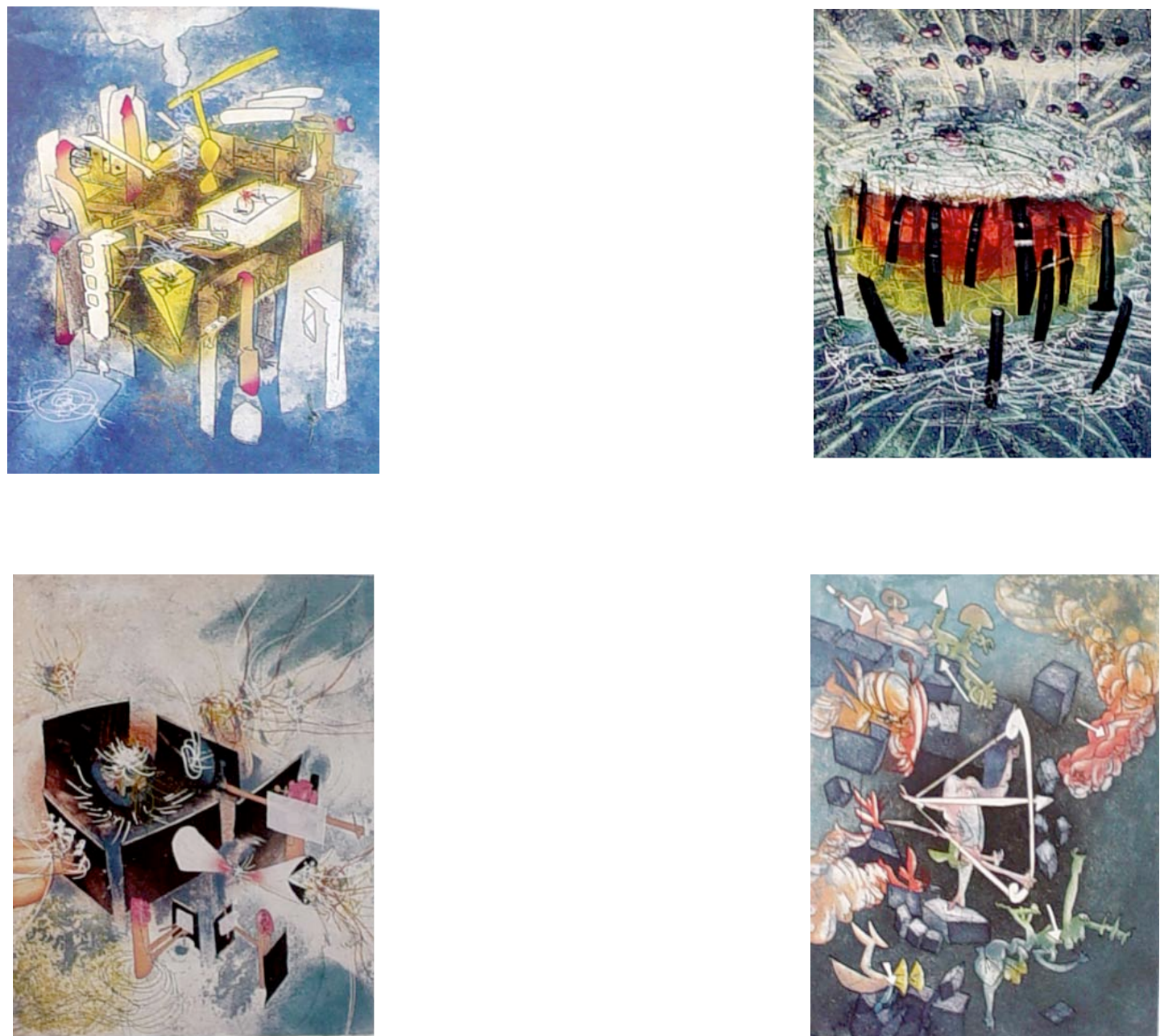

\section{Libros}

\section{Localización del libro o catalogo :}

"Matta, Index dell'opera grafica dal 1969 al 1980", editado por Admministrazione Provinciali di Viterbo en 1980, realizado por Germana Ferrari.

\section{Otros catologos que lo contengan :}

Se desconoce.

Registros gráficos obtenidos

Diapositiva

Imagén digital 


\section{Obra grafica Roberto Sebastian Matta Echaurren}

Ficha número : 15

Titulo de la obra : Une saison en enfer.

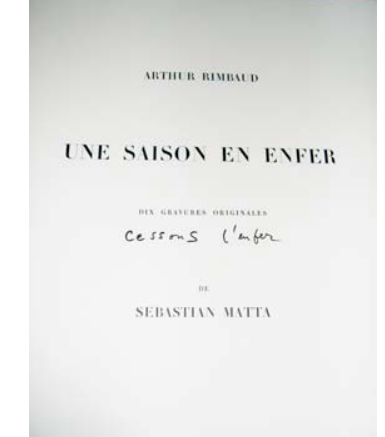

Tamaño del papel : 50 × $65 \mathrm{~cm}$.

Tamaño de la mancha : 47 x $36 \mathrm{~cm}$.

\section{Técnica}

Técnica : Aguafuerte y aguatinta.

\section{Procedimientos y recursos complementarios :}

Es un libro artístico compuesto por el texto Une saison en enfer de Arthur Rimbaud el que es acompañado por 10 grabados realizados por Roberto Matta a través del aguafuerte y aguatinta titulándose esta serie Cessons L'enfer.

\section{Matriz}

Número de planchas : $\quad$ Entre 6 y 9 planchas.

Material de las planchas : Metal- Cobre.

\section{Datos complementarios :}

La cantidad de planchas utilizadas en cada obra, se refiere a la funcion que cumplen dentro de la misma, ya que Matta utilizaba una plancha para el fondo, otra plancha para los personajes y varias planchas mas para los colores utilizados en la(s) obra(s).

\section{Estampación}

En hueco

En relieve

Planigrafica

Permeografica

Número de tintas :

Varia entre 6 y 9 tintas de colores.

\section{Colores :}

Negro, rojo, verde, amarillo, grises, blancos, violeta, rosados, cafe y naranjo. Algunos de estos colores fluorecentes.

\section{Papel}

Marca : $\quad$ Papel Atches/Papel Japon Nacre.

Gramaje : 250 grm.

Color : Blanco. 


\section{Edición}

\section{Número de ejemplares :}

100 ejemplares para la suite sobre papel Arches, firmados y numerados del 1 al $100+$ XXXVI H.C. Mas 100 ejemplares para la suite sobre papel Japón, firmados y numerados del 1 al 100 + XXXVI H.C. +10 E.A.

Nota: En algunos catálogos se menciona que las medidas del papel de este libro es de 65 x $50 \mathrm{~cm}$, variando entonces un centímetro en cada uno de los papeles lo que es incorrecto.

Presentándose en una caja forrada en tela de arpillera tamaño 15,5 . x $72 \mathrm{~cm}$. en el lomo se a pegado un papel blanco en el que se imprime con letras negras el titulo y los nombres de Matta y Rimbaud.

$N^{\circ}$ de P.A. (Prueba de Artista): Se desconoce.

$N^{\circ}$ de H.C. (Hors Commerce) : XXXVI H.C.

B.A.T. : 10 B.A.T.

Otras Pruebas : Se desconoce.

Taller en el que se realizó :

En el atelier George Visat en Paris donde se finalizo la impresión el 21 de marzo de 1978.

La edición se realizo por Ediciones Polígrafa y la tipografía fue realizada por Fequet - Baudier.

El contenedor donde se presenta la obra fue realizado por Duval.

\section{Estampador}

George Visat.

Número de la estampa observada : 62/100 - observada directamente 8/10 E.A.

Estampa observada directamente :

$\begin{array}{lll}\text { Contemplada a través de reproducción : } & \mathrm{Si} & \mathrm{X} \\ \end{array}$

Colección

Colección en la que se encuentra : Coleccion particular en Paris.

Colección en la que se encuentra la plancha : Coleccion particular en Paris.

Otras colecciones que tengan ejemplares de este trabajo :

Coleccion Museo Casa de la Moneda en Madrid. 

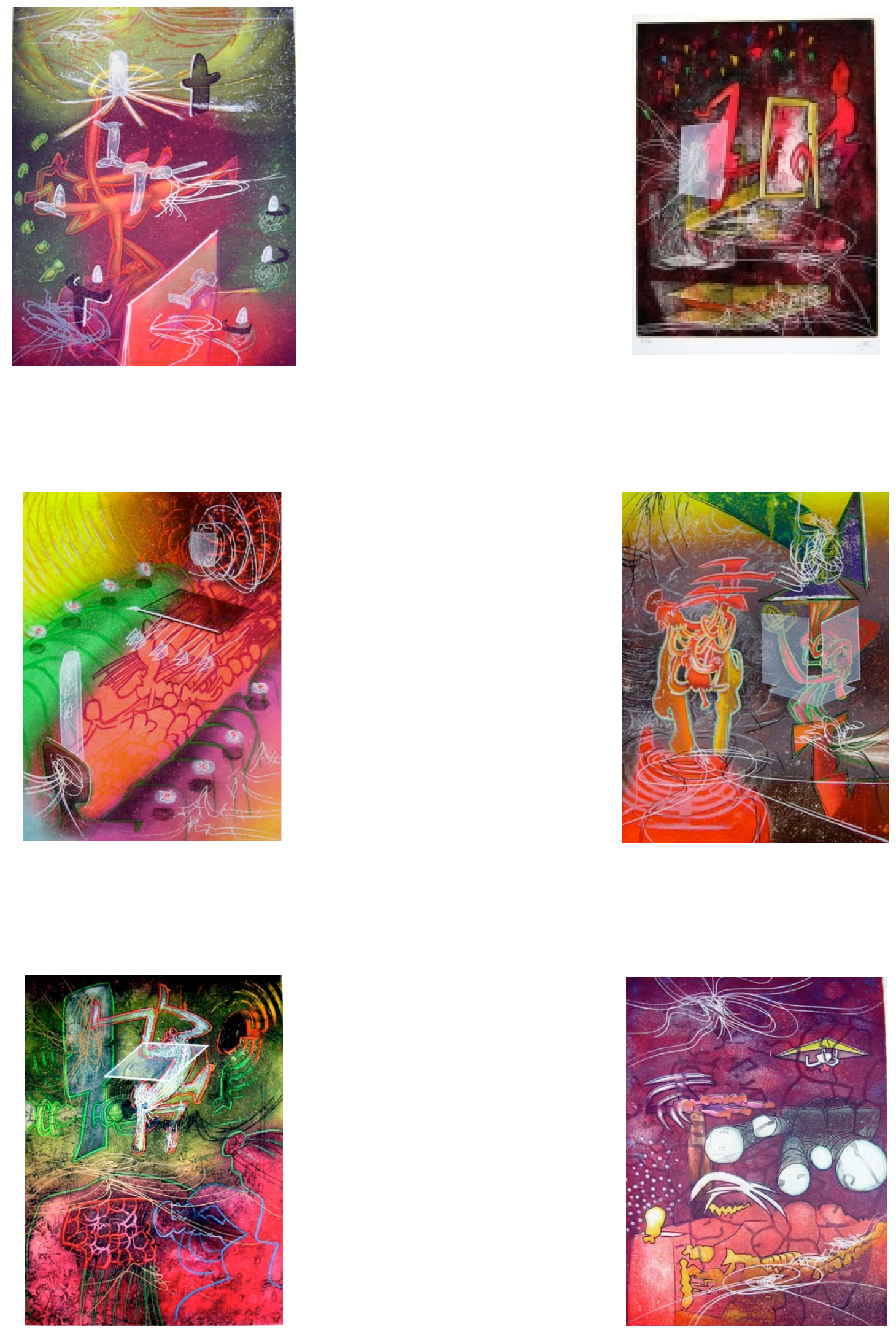

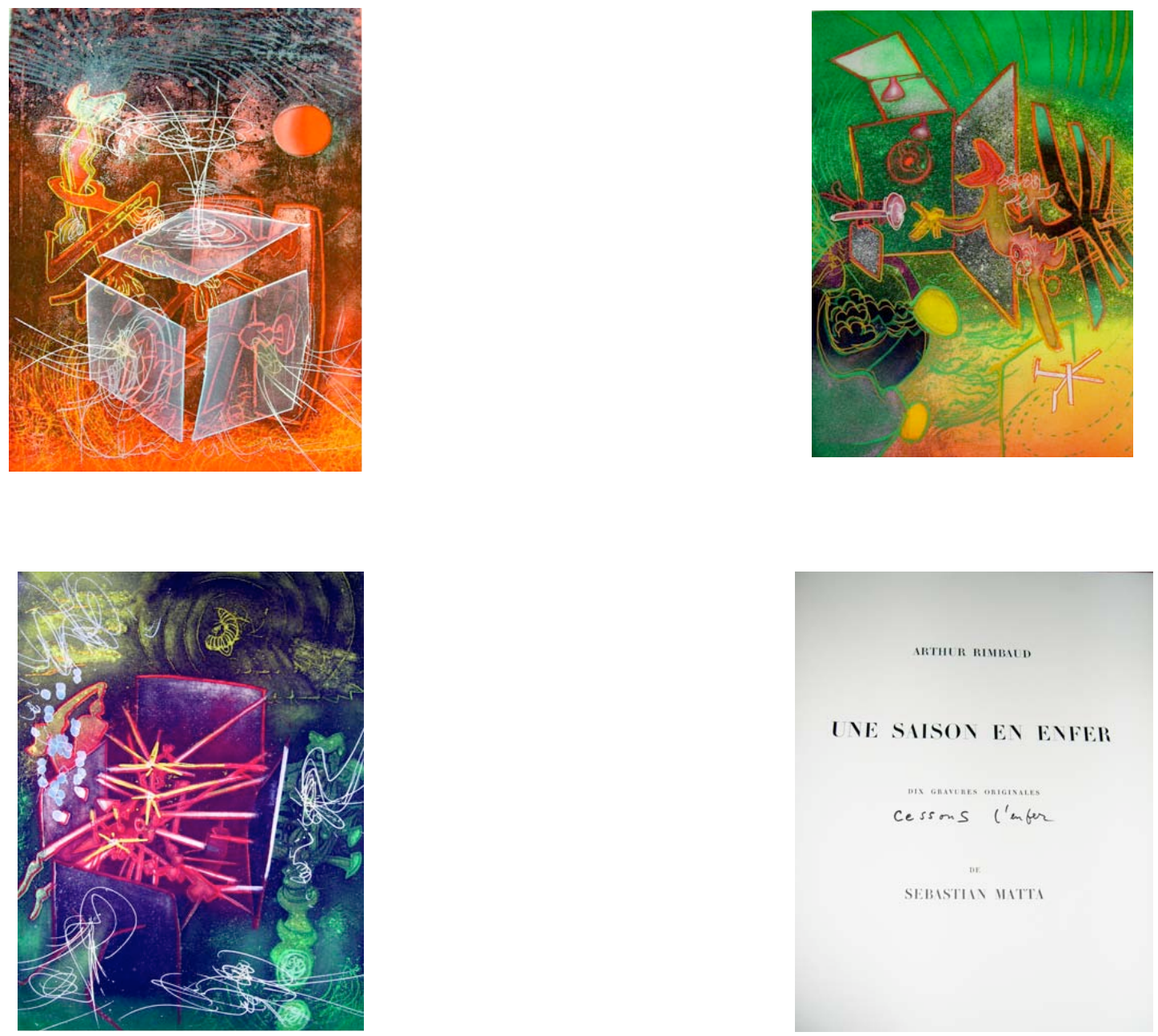

\section{Libros}

\section{Localización del libro o catalogo :}

"Ten original engravings by Sebastian Matta" Une saison en enfer, tex by A. Rimbaud. Ediciones Poligrafa, S. A.

\section{Otros catologos que lo contengan :}

"Matta, Index dell'opera grafica dal 1969 al 1980", editado por Admministrazione Provinciali di Viterbo en 1980, realizado por Germana Ferrari.

"Matta estampas y poemas", editado por Casa de la Moneda para la exposicion realizada en el museo Casa de la Moneda entre Diciembre 2001 hasta enero 2002.

"El anio de los tres 000"catalogo para la exposicion "El anio de los tres 000" en la sala de exposiciones del Centro Cultural las Claras en Murcia.

"Matta:Obra grafica"Coleccion Fundacion Pablo Picasso Museo-Casa Natal ayuntamiento de Malaga.

Registros gráficos obtenidos

Diapositiva

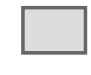

Imagén digital

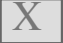


Ficha número : 16

Titulo de la obra : La Araucana.

Fecha de realización : 1979

Dimensiones

Tamaño del papel : $\quad$ Se desconoce.

Tamaño de la mancha : $50 \times 70 \mathrm{~cm}$.

\section{Técnica}

Técnica : Litografía.

\section{Procedimientos y recursos complementarios :}

La araucana es un libro artístico compuesto por un texto inédito de Roberto Matta basado en libro

"La araucana" de Alonso de Ercilla acompañado por litografías realizadas por Roberto Matta.

\section{Matriz}

Número de planchas : $\quad$ Se desconoce.

Material de las planchas : Piedra.

Datos complementarios :

Se desconocen.

\section{Estampación}

En hueco

En relieve

Planigrafica

Permeografica

Número de tintas :

Se utilizaron 7 tintas.

Colores :

Verde, amarillo, celeste, turquesa, naranjo negro y rojo.

Papel

Marca : Papel Magnani.

Gramaje : Se desconoce.

Color : Blanco. 


\section{Edición}

Número de ejemplares :

125 ejemplares numerados y firmados desde el 1 al 125 en papel Magnani.

$\mathbf{N}^{\circ}$ de P.A. (Prueba de Artista): Se desconoce.

$\mathbf{N}^{\circ}$ de H.C. (Hors Commerce) : Se desconoce.

B.A.T. : $\quad$ Se desconoce.

Otras Pruebas : Se desconoce.

Taller en el que se realizó :

Estamperia de la Bezuga en Florencia.

\section{Estampador}

Se desconoce.

Número de la estampa observada : Se desconoce.

$\begin{array}{llll}\text { Estampa observada directamente : } & \text { Si } \quad \mathrm{X} \quad \text { No } \square\end{array}$

$\begin{array}{llll}\text { Contemplada a través de reproducción : } & \mathrm{Si} & \mathrm{X} & \text { No } \\ \end{array}$

Colección

Colección en la que se encuentra : Coleccion particular en Paris.

Colección en la que se encuentra la plancha : Coleccion particular en Paris.

Otras colecciones que tengan ejemplares de este trabajo :

Se desconoce. 


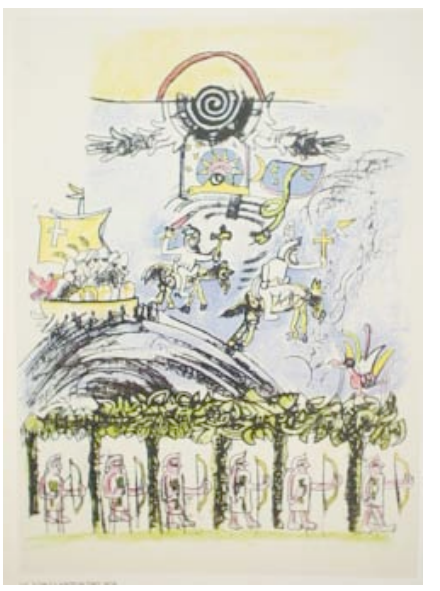

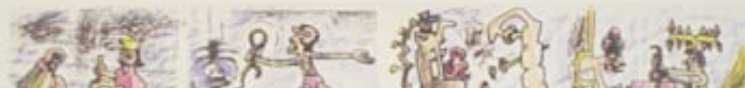
8-\{

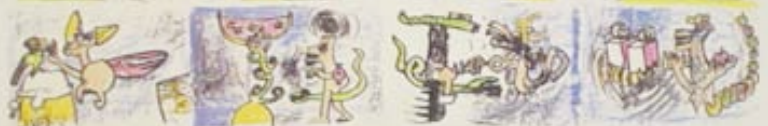

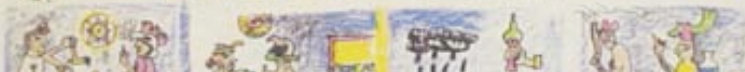

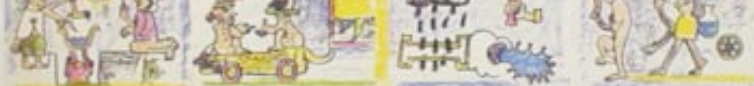

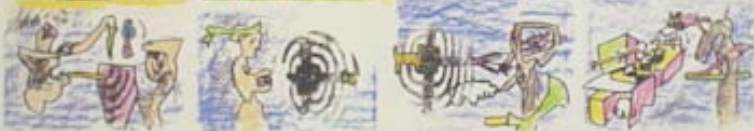

类

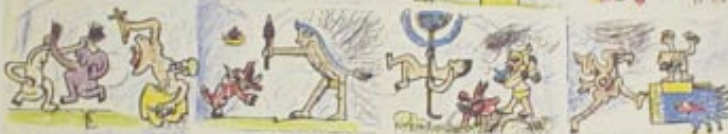

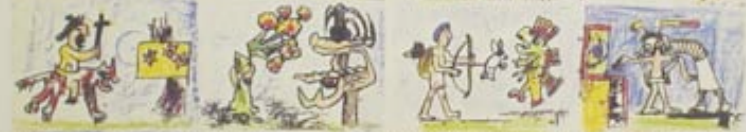

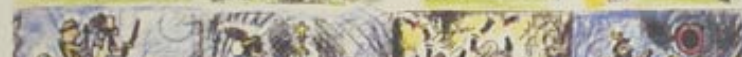

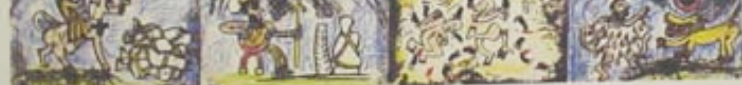

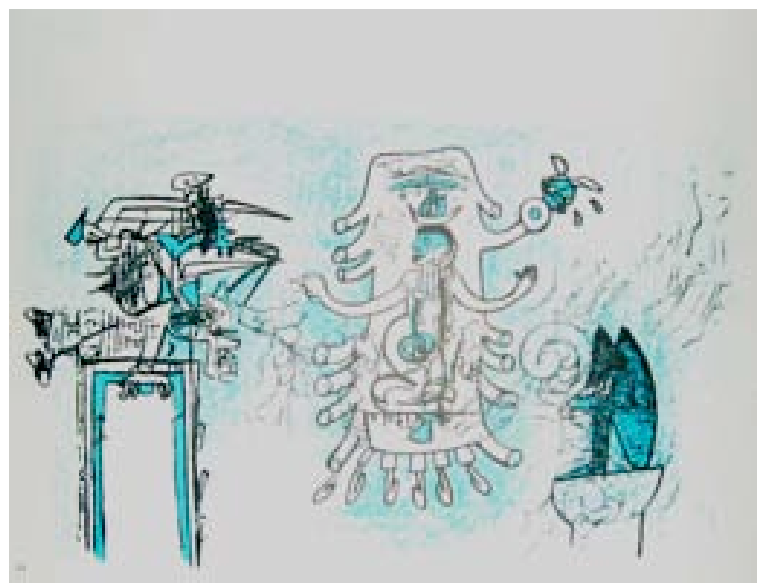

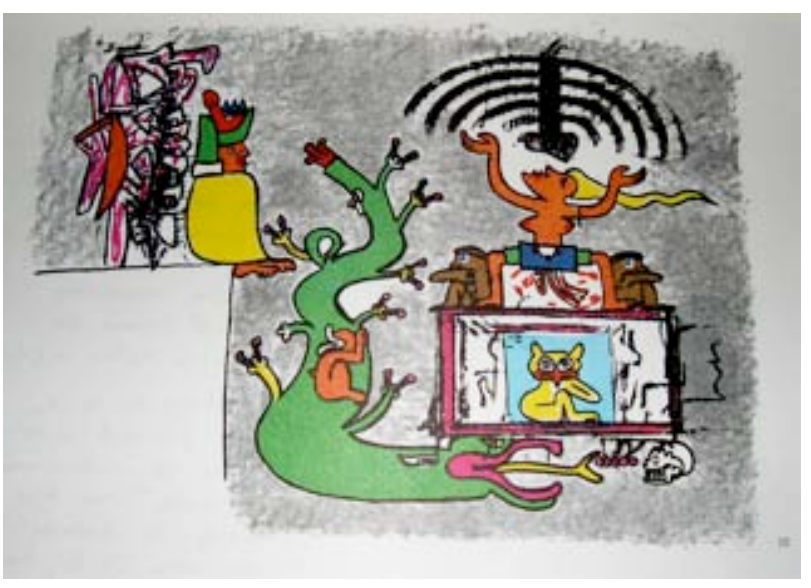

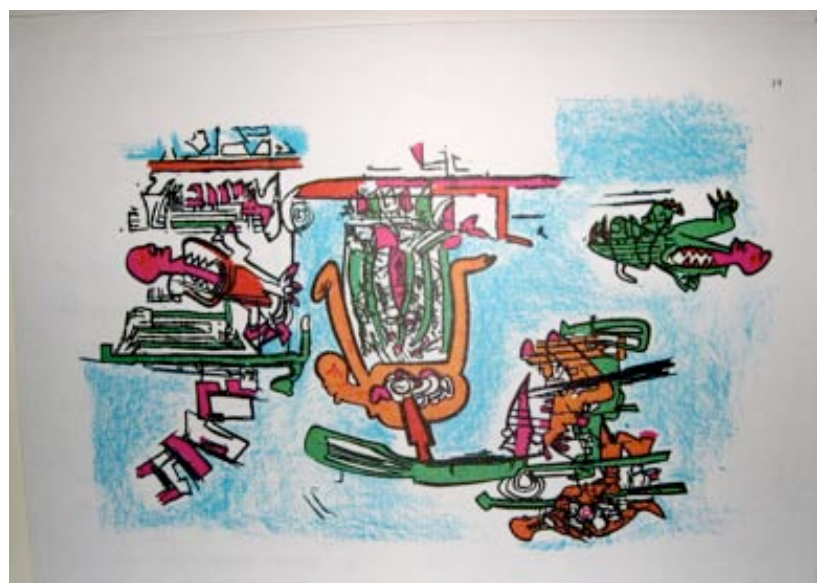



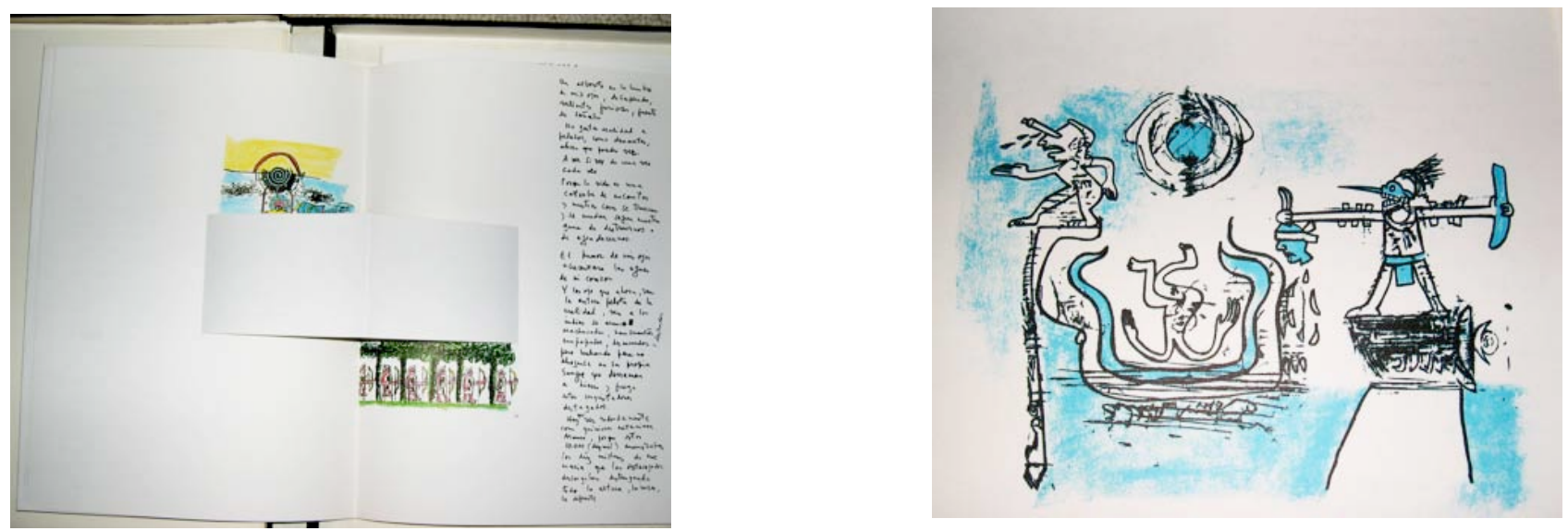

\section{Libros}

\section{Localización del libro o catalogo :}

"Matta, Index dell'opera grafica dal 1969 al 1980", editado por Admministrazione Provinciali di Viterbo en 1980, realizado por Germana Ferrari.

\section{Otros catologos que lo contengan :}

"Matta: Verbo America", catalogo realizado para la exposición organizada por la Junta de Andalucía, la conserjería de cultura y Medio Ambiente, la caja de San Fernando y el Instituto Frances de Sevilla en 1991. "Matta:Origenes/Arte en Caja" Oviedo Octubre-Noviembre 1992.Caja de Ahorros de Asturias. 


\section{Obra grafica Roberto Sebastian Matta Echaurren}

Ficha número : 17

Titulo de la obra : Don Q.

Fecha de realización : 1972-1980

\section{Dimensiones}

Tamaño del papel : Distinta en cada serie.

Tamaño de la mancha : Distinta en cada serie.

\section{Técnica}

Técnica : Litografía.

\section{Procedimientos y recursos complementarios :}

Don Q, es el titulo que reciben tres series litográficas compuestas por un texto inédito de Roberto Matta acompañado por litografías del artista.

teniendo estas tres series litográficas un formato distinto que es por lo cual se distinguen: formato pequeño entre $10 \times 8 \mathrm{~cm}$. formato medio entre $76 \times 57 \mathrm{~cm}$. y formato grande $1.20 \times 2.00 \mathrm{mts}$.

Asimismo todos los fondos de las litografías fueron realizados a partir de fotocopias de tramas geométricas lineales intervenidas por el artista.

\section{Matriz}

Número de planchas : $\quad$ Se desconoce.

Material de las planchas : Piedra.

\section{Datos complementarios :}

La serie Don Q en pequeño formato se presenta dentro de una cajetilla de cigarros. El formato medio se presenta como carpeta y el formato grande es solo una imagen reproducida 30 veces.

\section{Estampación}

En hueco

En relieve

Planigrafica

Permeografica

\section{Número de tintas :}

Se utilizaron mas de 7 tintas.

\section{Colores :}

Cafe, negro, blanco, azules, rosado fluorescente, amarillo fluorescente, verdes.

Papel

Marca : $\quad$ Papel Arches y un papel de color marron del que se desconoce su tipo de papel.

Gramaje : Se desconoce.

Color : $\quad$ La serie pequeña es de color blanco, la serie de formato mediano es de color café y la impresión grande de 30 eiemnlares es de color blanco 


\section{Edición}

\section{Número de ejemplares :}

Se desconoce la cantidad de ejemplares en formato pequeño. El formato medio tiene 100 ejemplares firmados y numerados del 1 al $100+$ XV H.C. El formato grande tiene 30 ejemplares firmados y numerados del 1 al 30 .

$\mathbf{N}^{\circ}$ de P.A. (Prueba de Artista) : Se desconoce.

$\mathbf{N}^{\circ}$ de H.C. (Hors Commerce) : XVH.C. en formato medio.

B.A.T.: $\quad$ Se desconoce.

Otras Pruebas : Se desconoce.

Taller en el que se realizó :

La realización de la serie formato pequeño y medio fue en el atelier de Michael Woolwort.

El formato grande se realizo en el atelier Franck Bordas.

\section{Estampador}

Michael Woolworth/Frank Bordas.

Número de la estampa observada : Se desconoce.

Estampa observada directamente :

$\mathrm{Si}$

No

Contemplada a través de reproducción : $\mathrm{Si} X$

No

Colección

Colección en la que se encuentra : Coleccion particular en Paris.

Colección en la que se encuentra la plancha : Coleccion particular en Paris.

Otras colecciones que tengan ejemplares de este trabajo :

Se deconoce. 

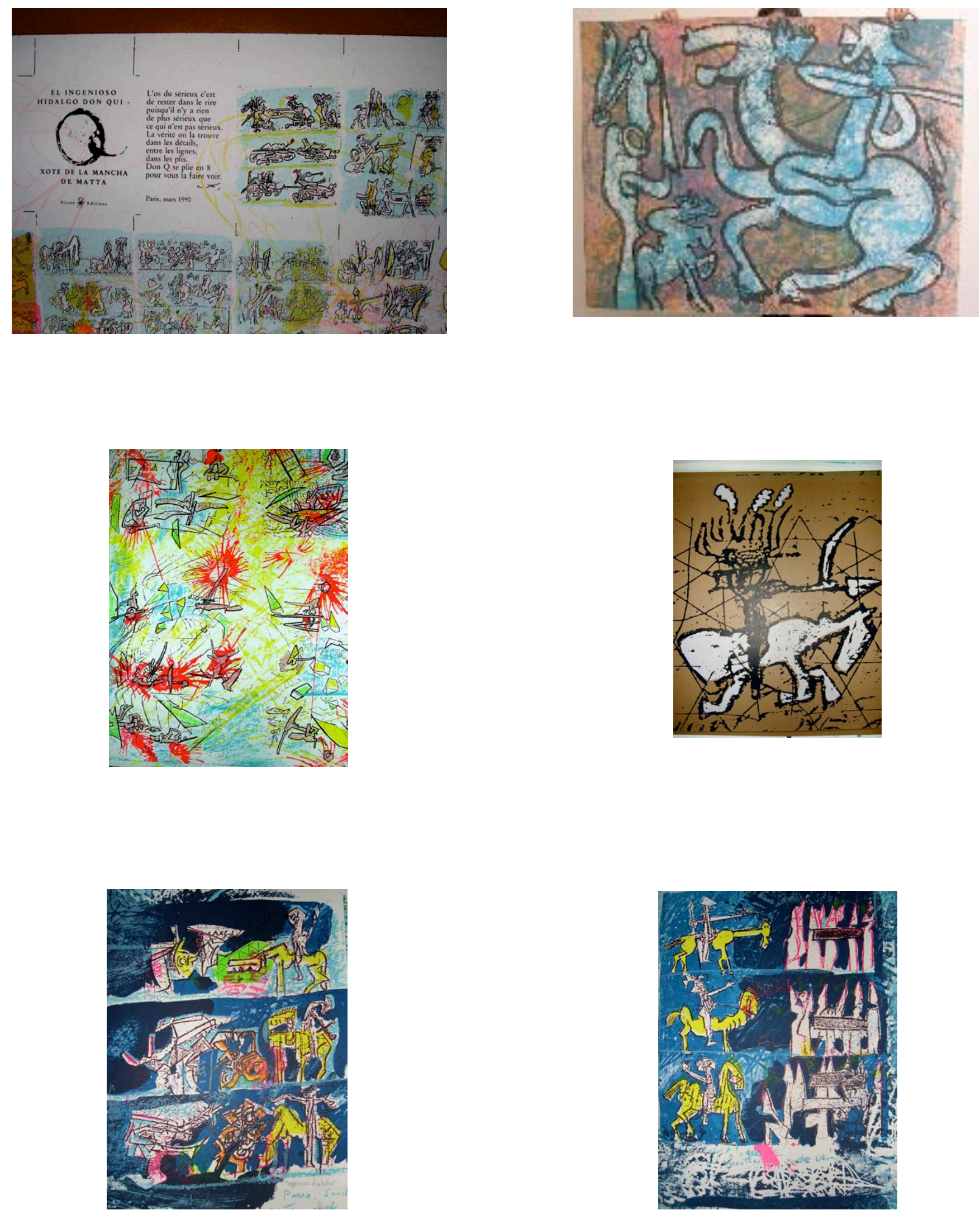

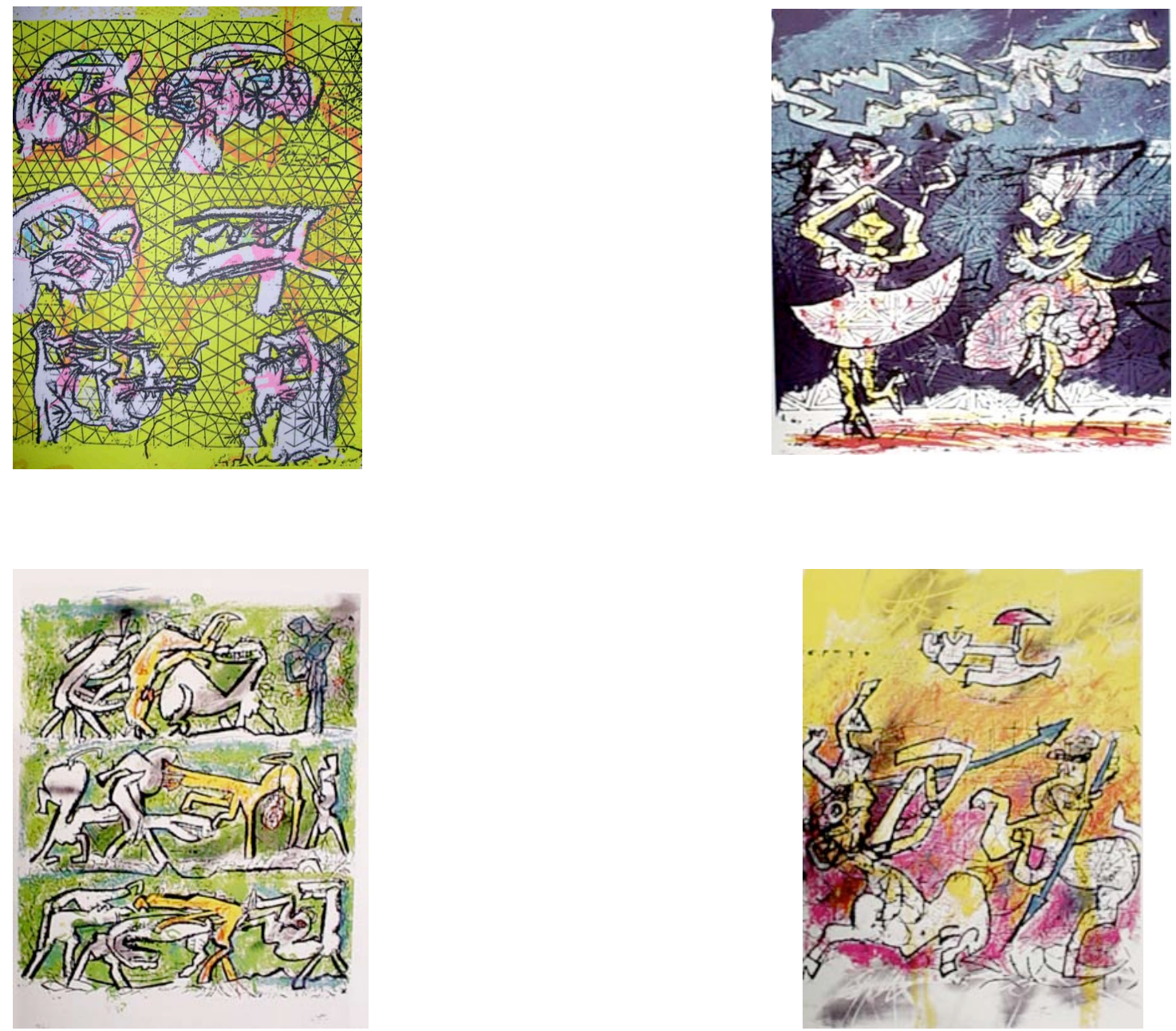

\section{Libros}

\section{Localización del libro o catalogo :}

"Matta, Index dell'opera grafica dal 1969 al 1980", editado por Admministrazione Provinciali di Viterbo en 1980, realizado por Germana Ferrari.

\section{Otros catologos que lo contengan :}

"Matta: Verbo America", catalogo realizado para la exposicion organizada por la Junta de Andalucia, la conserjeria de cultura y Medio Ambiente, la caja de San Fernando y el Instituto Frances de Sevilla en 1991.

Registros gráficos obtenidos

Diapositiva

Imagén digital 


\section{Obra grafica Roberto Sebastian Matta Echaurren}

Ficha número : 18

Titulo de la obra : Ubu Roi.

ALFRED JARRY

UBU ROI

Fecha de realización : 1982.

Dimensiones

Tamaño del papel : $42,5 \times 27 \mathrm{~cm}$.

Tamaño de la mancha : 33.2 x $13.9 \mathrm{~cm}$.

\section{Técnica}

Técnica : Aguafuerte.

Procedimientos y recursos complementarios :

Ubu Roi es u libro de artista compuesto por el texto de Alfred Jarry "Personnages", acompañado por 8 grabados en metal originales de Roberto Matta, los que se realizaron a través del aguafuerte.

\section{Matriz}

Número de planchas : Entre 5 y 8 planchas.

Material de las planchas : Metal- Cobre.

\section{Datos complementarios :}

La cantidad de planchas utilizadas en cada obra, se refiere a la función que cumplen dentro de la misma, ya que Matta utilizaba una plancha para el fondo, otra plancha para los personajes y varias planchas mas para los colores utilizados en la(s) obra(s).

\section{Estampación}

En hueco

En relieve

Planigrafica

Permeografica

\section{Número de tintas :}

Varia entre 5 a 8 tintas de colores.

\section{Colores :}

Negro, rojo, azul, cafe, naranjo, gris, amarillo fluorescente, verde, violeta, rosado, celeste.

Papel

Marca : Papel Arches Vélin.

Gramaje : $250 \mathrm{grm}$.

Color : Blanco. 


\section{Edición}

Número de ejemplares :

150 ejemplares sobre papel Arches de 40.7 x $51 \mathrm{~cm}$, firmados y numerados del 1 al $50+$ XV H.C. + 30 E.A. Presentándose en una caja forrada en tela de seda blanco tamaño de $42,5 \times 27 \mathrm{~cm}$. Impreso en el lomo el titulo y los nombres de los realizadores Matta y Alfred Jarry. La portada de este libro de artista fue grabada a aguafuerte y fue parte de un tiraje sobre hoja a plata que fue firmada y numerada no teniendo datos o registros anexos sobre este tiraje.

$\mathbf{N}^{\circ}$ de P.A. (Prueba de Artista): Se desconoce.

$\mathbf{N}^{\circ}$ de H.C. (Hors Commerce) : XV H.C.

B.A.T.: $\quad$ Se desconoce.

Otras Pruebas : Existen pruebas de estado las que se encuentran desaparecidas.

Taller en el que se realizó :

La realización y edición completa del libro fue realizada en el atelier de Albert Dupont- Visat en Paris. Siendo el contenedor en el que se presenta este libro, realizado por el atelier Bernard Duval, en Paris. La tipografía fueron impresas en las prensas de Fequet-Baudier. Terminado de imprimir el 20 septiembre de 1982.

\section{Estampador}

Albert Dupont.

Número de la estampa observada : $21 / 30$ de E.A.

Estampa observada directamente :

$\mathrm{Si}$

No

Contemplada a través de reproducción :

$\mathrm{Si}$

No

Colección

Colección en la que se encuentra : Colección particular en Paris.

Colección en la que se encuentra la plancha : Colección particular en Paris.

Otras colecciones que tengan ejemplares de este trabajo :

Se desconoce. 

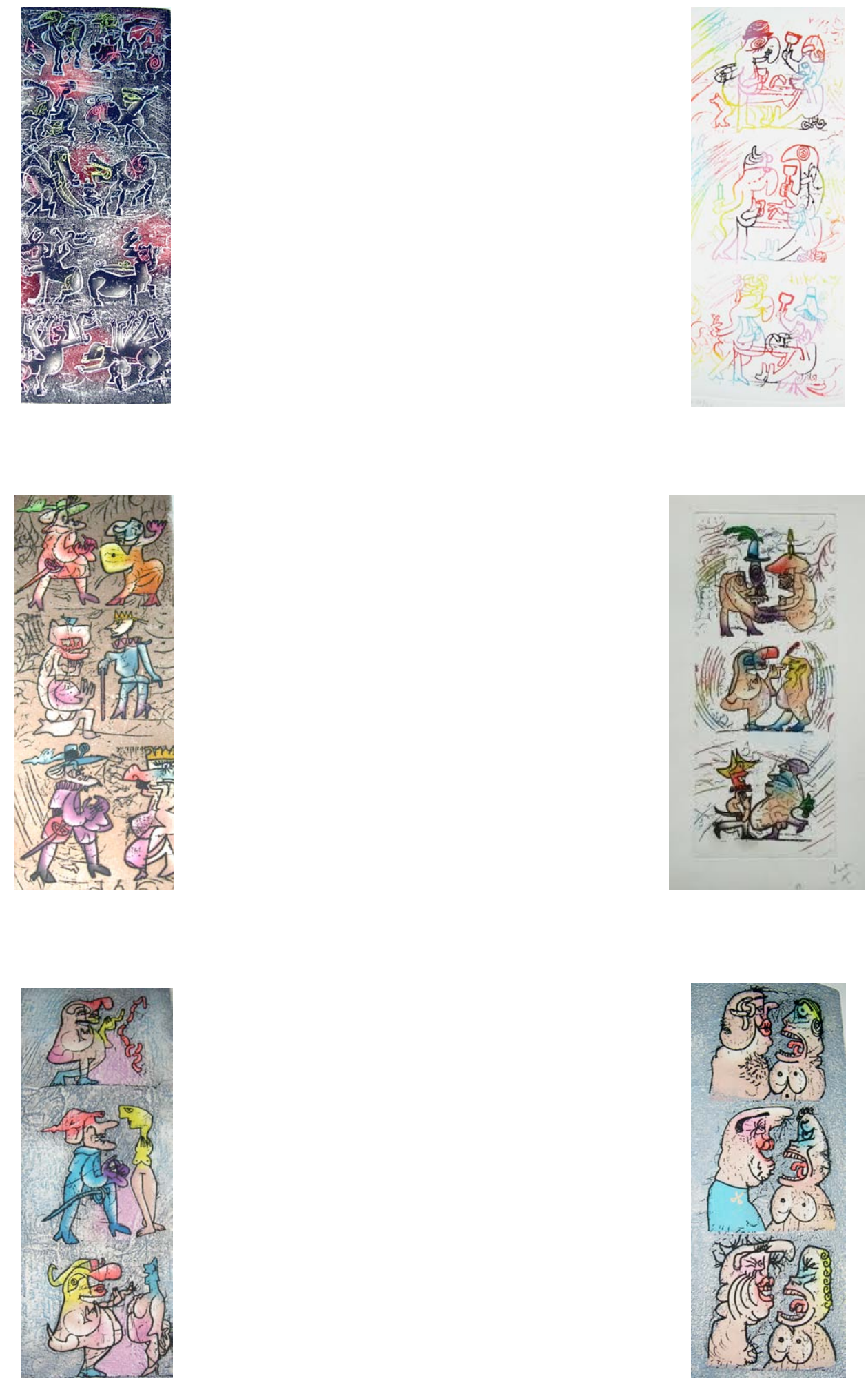

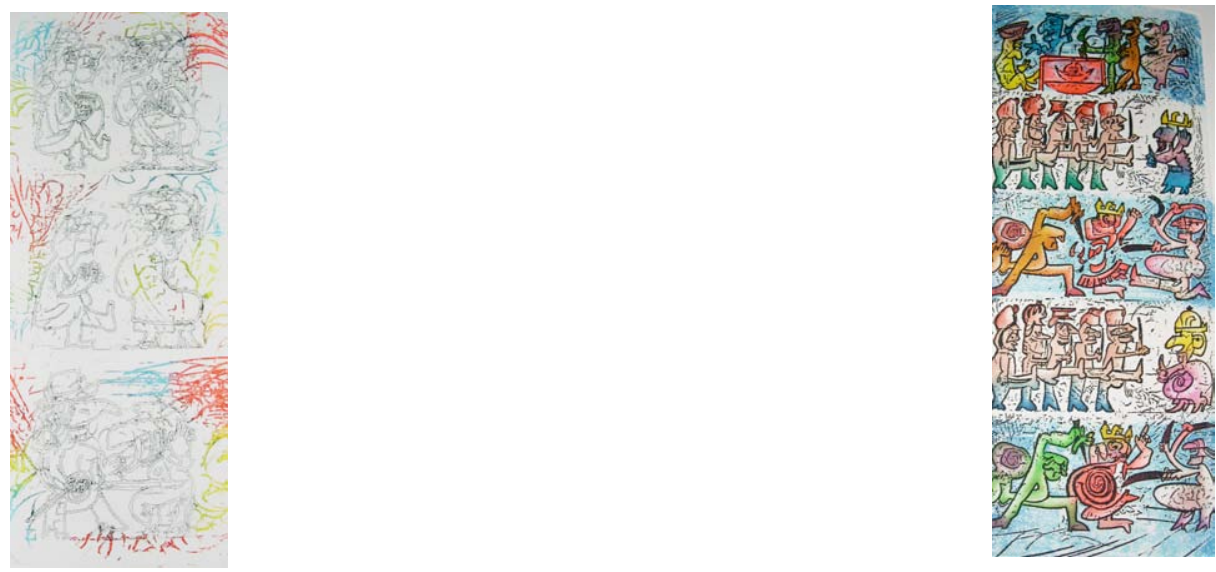

\section{Libros}

\section{Localización del libro o catalogo :}

"Matta: Estampas y poemas", editado por la casa de la Moneda para la exposicion realizada en el Museo Casa de la Moneda entre Diciembre 2001 hasta enero 2002.

\section{Otros catologos que lo contengan :}

Se desconoce.

Registros gráficos obtenidos

Diapositiva

Imagén digital 


\section{Obra grafica Roberto Sebastian Matta Echaurren}

Ficha número : 19

Titulo de la obra : Hom'mère IV "Point d'appui".

Fecha de realización : 1983

Dimensiones

Tamaño del papel : $\quad 67$ x $51 \mathrm{~cm}$.

Tamaño de la mancha : $50 \times 38 \mathrm{~cm}$.

\section{Técnica}

Técnica : Aguafuerte y aguatinta.

\section{Procedimientos y recursos complementarios :}

Hom'mère IV "Point d'appui" es una carpeta artística compuesta por un poema inédito de Roberto Matta, mas 10 grabados realizados por el mismo artista a través del aguafuerte y aguatinta.

Siendo "Ponit d'appui" el cuarto tomo de la serie Hom'mére iniciada en 1973.

\section{Matriz}

Número de planchas : $\quad$ Entre 6 y 12 planchas.

Material de las planchas : Metal-Cobre.

\section{Datos complementarios :}

La cantidad de planchas utilizadas en cada obra, se refiere a la función que cumplen dentro de la misma, ya que Matta utilizaba una plancha para el fondo, otra plancha para los personajes y varias planchas mas para los colores utilizados en la(s) obra(s).

\section{Estampación}

En hueco

En relieve

Planigrafica

Permeografica
Número de tintas :

Varia entre 7 a 14 tintas de colores diferentes.

Colores :

Negro, amarilo, naranjo, rojo, blanco, , cafe, verde, azul, celeste, rosado, violeta, dorado, burdeo mas transparencias.

Papel

Marca : $\quad$ Papel Arches y Papel Japón Nacré.

Gramaje : $250 \mathrm{grm}$. 
Color :

Blanco.

\section{Edición}

Número de ejemplares :

100 ejemplares para la suite sobre papel Arches de 67 x $51 \mathrm{~cm}$, firmados y numerados del 1 al $100+\mathrm{XXV} \mathrm{H}$. C. + 10 E.A. Mas 100 ejemplares para la suite sobre papel Japón Nacré de 68 x $52 \mathrm{~cm}$, firmados y numerados del 1 al $100+$ XXV H.C. + 10 E.A.

$\mathbf{N}^{\circ}$ de P.A. (Prueba de Artista): Se desconoce.

$\mathbf{N}^{\circ}$ de H.C. (Hors Commerce) : XXH.C.

B.A.T. : $\quad 10$ B.A.T.

Otras Pruebas : Se desconoce.

Taller en el que se realizó :

Ediciones Sistan a Lugano, finalizando su impresión el 22 de junio de 1983.

Las aguafuertes fueron impresas en el atelier George Visat y la tipografía fue compuesta en Elzévir Casmlon por Fequet-Baudier.

Estampador

Albert Dupont.

Número de la estampa observada : 
Estampa observada directamente :

Contemplada a través de reproducción :
$\mathrm{Si}$

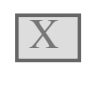

$\mathrm{Si}$

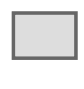

No $\mathrm{X}$

No $\mathrm{X}$

\section{Colección}

Colección en la que se encuentra : Colección particular en Paris.

Colección en la que se encuentra la plancha : Colección particular en Paris.

Otras colecciones que tengan ejemplares de este trabajo :

Colección Galería Almirante en Madrid.
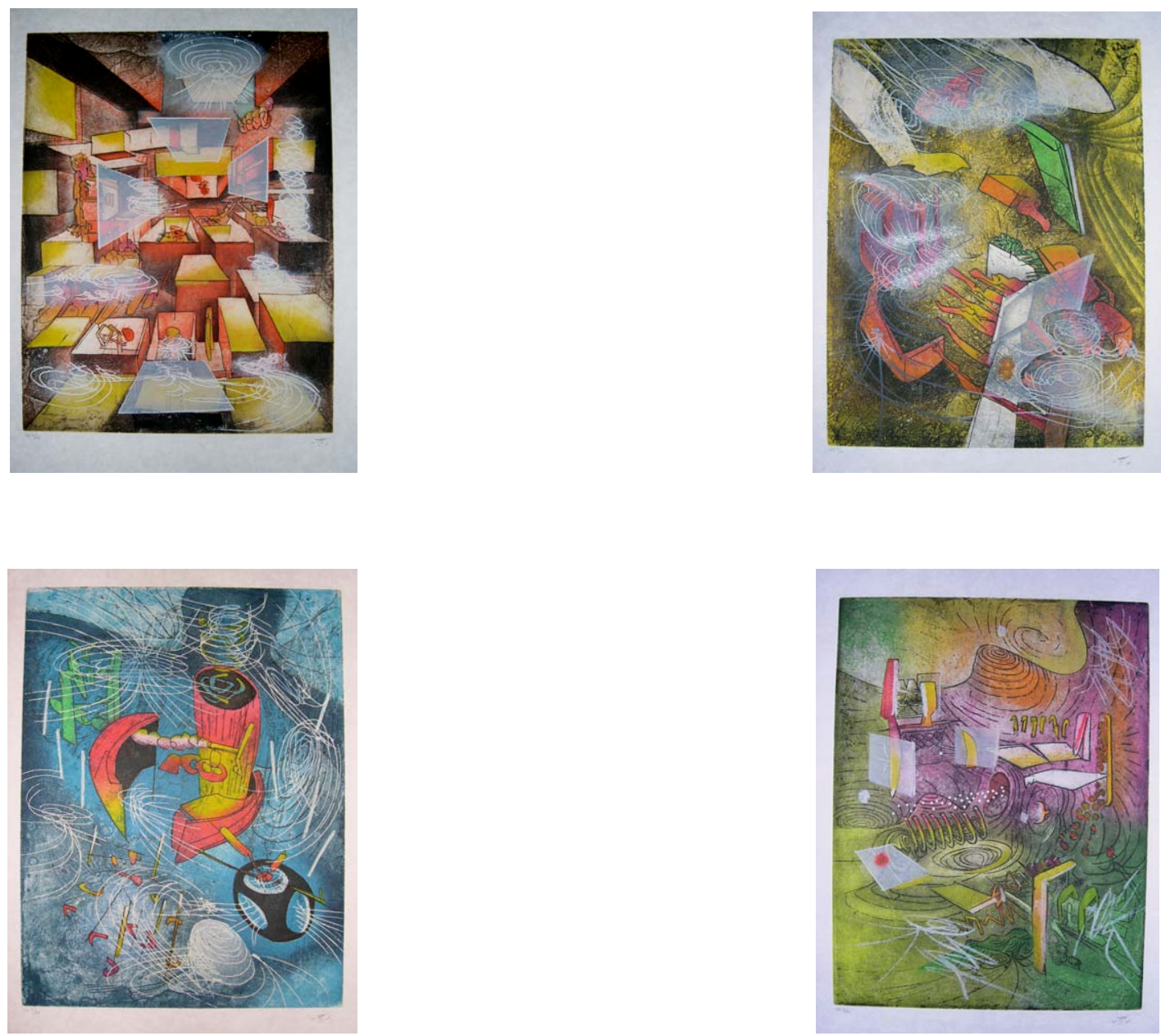

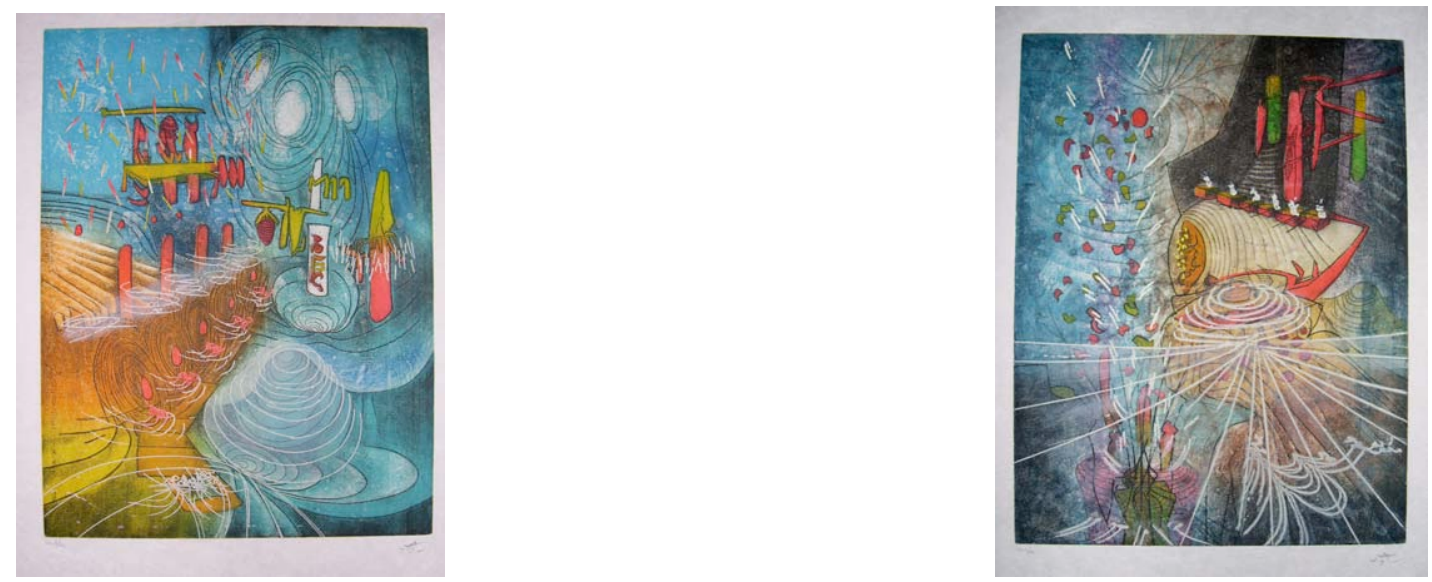

\section{Libros}

\section{Localización del libro o catalogo :}

"Matta: Estampas y poemas", editado por la casa de la Moneda para la exposicion realizada en el Museo Casa de la Moneda entre Diciembre 2001 hasta enero 2002.

\section{Otros catologos que lo contengan :}

"Matta: Verbo America", catalogo realizado para la exposición organizada por la Junta de Andalucía, la conserjería de cultura y Medio Ambiente, la caja de San Fernando y el Instituto Frances de Sevilla en 1991.

Registros gráficos obtenidos Diapositiva $\square$ Imagén digital $\quad \mathrm{X}$ 


\section{Obra grafica Roberto Sebastian Matta Echaurren}

Ficha número : 20

Titulo de la obra : Bachanal.

Fecha de realización : 1984

Dimensiones

Tamaño del papel : $\quad 77.3 \times 57.5 \mathrm{~cm}$

Tamaño de la mancha : 49 × $48 \mathrm{~cm}$.

\section{Técnica}

Técnica : Aguafuerte.

\section{Procedimientos y recursos complementarios :}

Bachanal es una carpeta artística compuesta por cuatro grabados realizados por Roberto Matta a través del aguafuerte.

\section{Matriz}

Número de planchas : Entre 5 y 8 planchas.

Material de las planchas : Metal- Cobre.

Datos complementarios :

La cantidad de planchas utilizadas en cada obra, se refiere a la función que cumplen dentro de la misma, ya que Matta utilizaba una plancha para el fondo, otra plancha para los personajes y varias planchas mas para los colores utilizados en la(s) obra(s).

\section{Estampación}

En hueco

En relieve

Planigrafica

Permeografica

Número de tintas :

Entre 5 y 10 tintas.

\section{Colores :}

Amarillo, naranjo, rojo, negro, azul, gris, variados tonos de verdes, y celeste.

Papel

Marca : Papel Arches.

Gramaje : Se desconoce. 
Color : $\quad$ Blanco.

Edición

Número de ejemplares :

100 ejemplares sobre papel Arches, firmados y numerados desde el 1 al $100+$ XXX H.C. + 20 P.A.

$\mathbf{N}^{\circ}$ de P.A. (Prueba de Artista) : 20 P.A.

$\mathbf{N}^{\circ}$ de H.C. (Hors Commerce) : XXX H.C.

B.A.T.: $\quad 4$ B.A.T.

Otras Pruebas : Se desconoce.

Taller en el que se realizó :

Ediciones Edicigno en Roma.

Estampador

Se desconoce.

Número de la estampa observada : 
Estampa observada directamente :

Contemplada a través de reproducción :
$\mathrm{Si}$

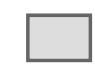

$\mathrm{Si}$
No

No

\section{Colección}

Colección en la que se encuentra : Colección privada en Madrid.

Colección en la que se encuentra la plancha : Colección privada en Madrid.

Otras colecciones que tengan ejemplares de este trabajo :

Se desconoce.
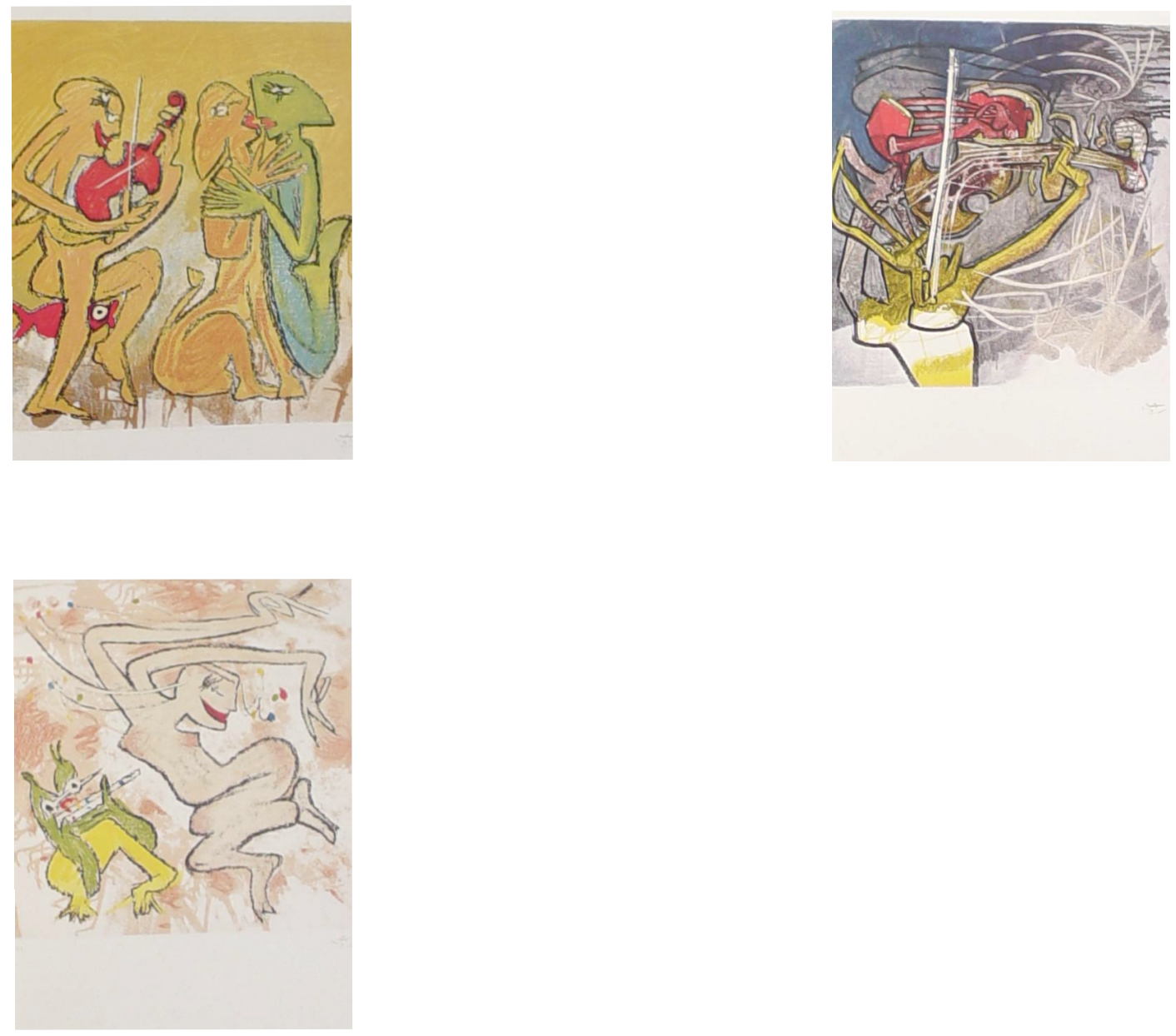


\section{Libros}

\section{Localización del libro o catalogo :}

"Matta: Estampas y poemas", editado por la casa de la Moneda para la exposición realizada en el Museo Casa de la Moneda entre Diciembre 2001 hasta enero 2002.

\section{Otros catologos que lo contengan :}

Se desconoce.

Registros gráficos obtenidos Diapositiva $\quad \square \quad$ Imagén digital $\quad X$ 


\section{Obra grafica Roberto Sebastian Matta Echaurren}

Ficha número : 21

Titulo de la obra : Verbo América.

Fecha de realización : 1987

Dimensiones

Tamaño del papel :

Tamaño de la mancha : 69.5 x $49.3 \mathrm{~cm}$.

Técnica

Técnica : Litografía.

Procedimientos y recursos complementarios :

Verbo America es una carpeta artística compuesta por 6 litografías.

Matriz

Número de planchas : Se desconoce.

Material de las planchas : Piedra.

Datos complementarios :

No existen.

\section{Estampación}

En hueco

En relieve

Planigrafica

Permeografica

Número de tintas :

Se utilizaron 9 tintas.

Colores :

Verde, amarillo, naranjo, rosado, negro, rojo, azul gris y celeste.

Papel

Marca : $\quad$ Papel Arches.

Gramaje : Se desconoce. 
Color : $\quad$ Blanco.

Edición

Número de ejemplares :

100 ejemplares sobre papel Arches firmados y numerados del 1 al $100+$ XXV H.C.

$\mathbf{N}^{\circ}$ de P.A. (Prueba de Artista) : Se desconoce.

$\mathbf{N}^{\circ}$ de H.C. (Hors Commerce) : XXV H.C.

B.A.T. : $\quad$ Se desconoce.

Otras Pruebas : Se desconoce.

Taller en el que se realizó :

Ediciones La Bezuga en Florencia.

Estampador

Se desconoce.

Número de la estampa observada : 
Estampa observada directamente :

Contemplada a través de reproducción :
$\mathrm{Si}$

$\mathrm{Si} \mathrm{X}$
No

No

\section{Colección}

Colección en la que se encuentra : Colección Galería Almirante en Madrid.

Colección en la que se encuentra la plancha : Colección Galería Almirante en Madrid.

Otras colecciones que tengan ejemplares de este trabajo :

Se desconoce.
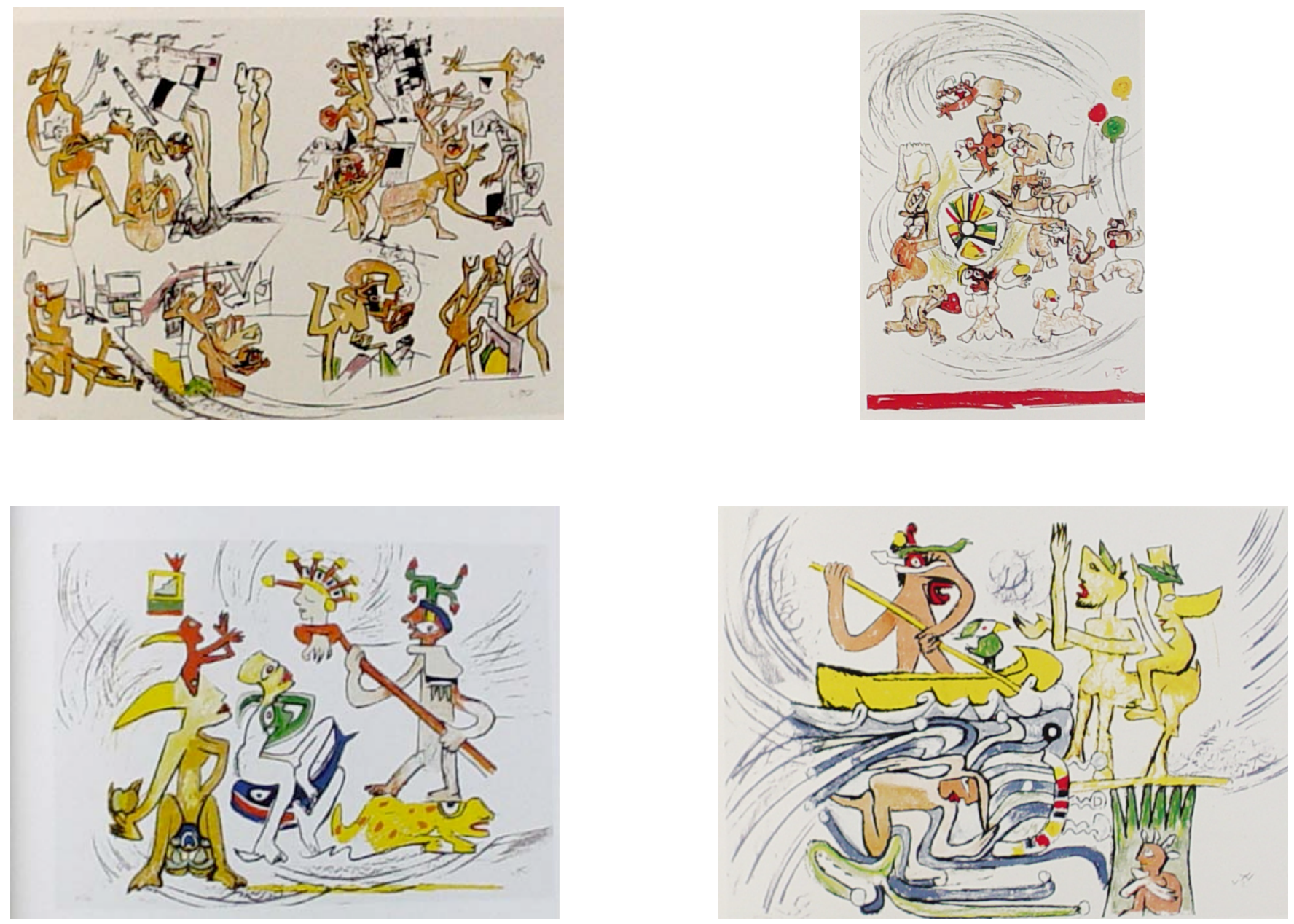


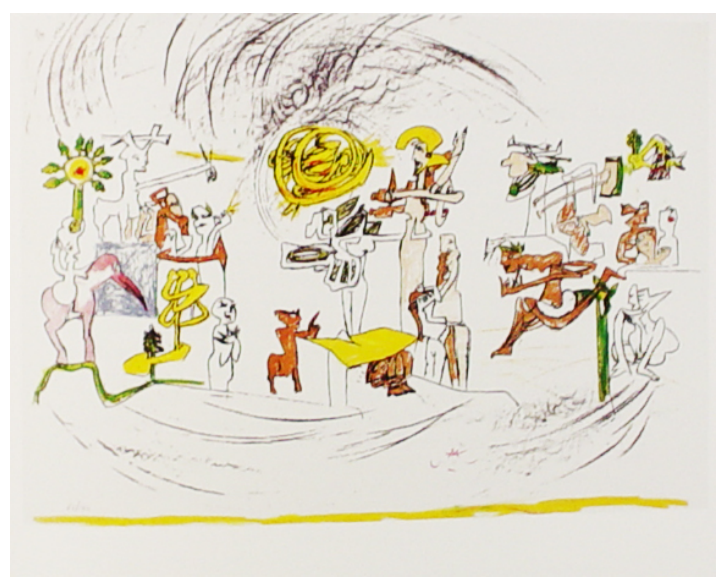

\section{Libros}

\section{Localización del libro o catalogo :}

"Matta: Estampas y poemas", editado por la casa de la Moneda para la exposición realizada en el Museo Casa de la Moneda entre Diciembre 2001 hasta enero 2002.

\section{Otros catologos que lo contengan :}

Se desconoce.

Registros gráficos obtenidos $\quad$ Diapositiva $\quad \square \quad$ Imagén digital $\quad X$ 


\section{Obra grafica Roberto Sebastian Matta Echaurren}

Ficha número : 22

Titulo de la obra : Entretiens Morphologiques.

Fecha de realización : 1987.

Dimensiones

Tamaño del papel : Se desconoce.

Tamaño de la mancha : 24 x $36 \mathrm{~cm}$.

\section{Técnica}

Técnica : Litografia.

Procedimientos y recursos complementarios :

Entretiens Morphologiques es una carpeta artística la que contiene 10 litografías realizadas por Roberto Matta.

\section{Matriz}

Número de planchas : $\quad$ Se desconoce.

Material de las planchas : Piedra.

Datos complementarios :

Se desconocen.

\section{Estampación}

En hueco

En relieve

Planigrafica

Permeografica

Número de tintas :

Entre 3 a 8 tintas.

\section{Colores :}

Rojo, crema, verde, gris, amarillo, negro, cafe y burdeo.

\section{Papel}

Marca : Papel Arches.

Gramaje : Se desconoce.

Color : Crema. 


\section{Edición}

Número de ejemplares :

Solo existe una edición especial de 10 ejemplares realizados sobre papel Arches firmados y numerados del I al $\mathrm{X}$.

$\mathbf{N}^{\circ}$ de P.A. (Prueba de Artista) : Se desconoce.

$\mathbf{N}^{\circ}$ de H.C. (Hors Commerce) : Se desconoce.

B.A.T.: $\quad$ Se desconoce.

Otras Pruebas : Se desconoce.

Taller en el que se realizó :

Se desconoce bibliograficamente.

\section{Estampador}

Frank Bordas.

Número de la estampa observada : IX/X

Estampa observada directamente :

$\begin{array}{lllll}\text { Contemplada a través de reproducción : } & \mathrm{Si} & \mathrm{X} & \text { No } \\ \end{array}$

Colección

Colección en la que se encuentra : Coleccion Galeria Almirante en Madrid.

Colección en la que se encuentra la plancha : Coleccion Galeria Almirante en Madrid.

Otras colecciones que tengan ejemplares de este trabajo :

Se desconoce. 

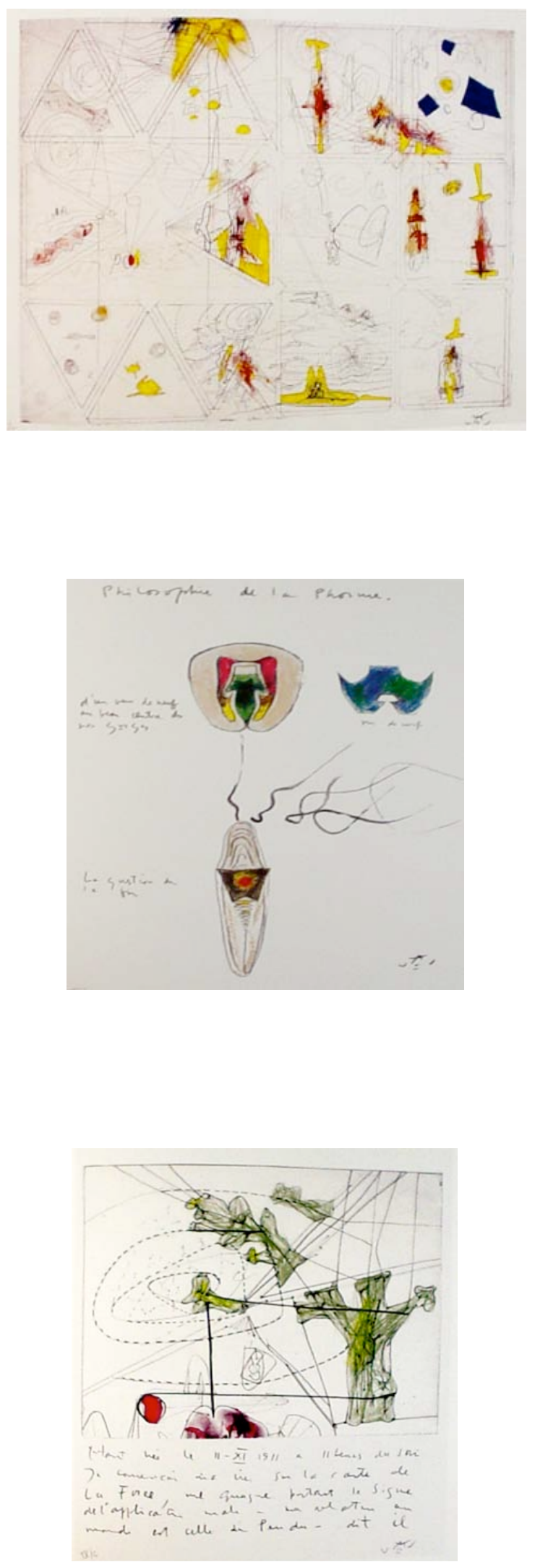
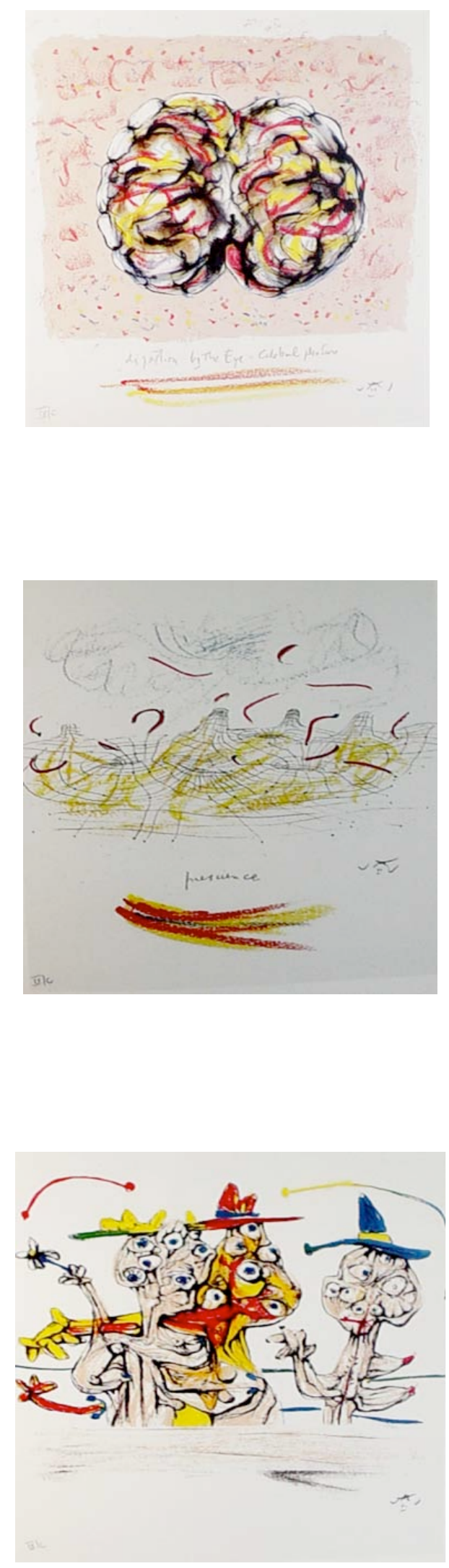

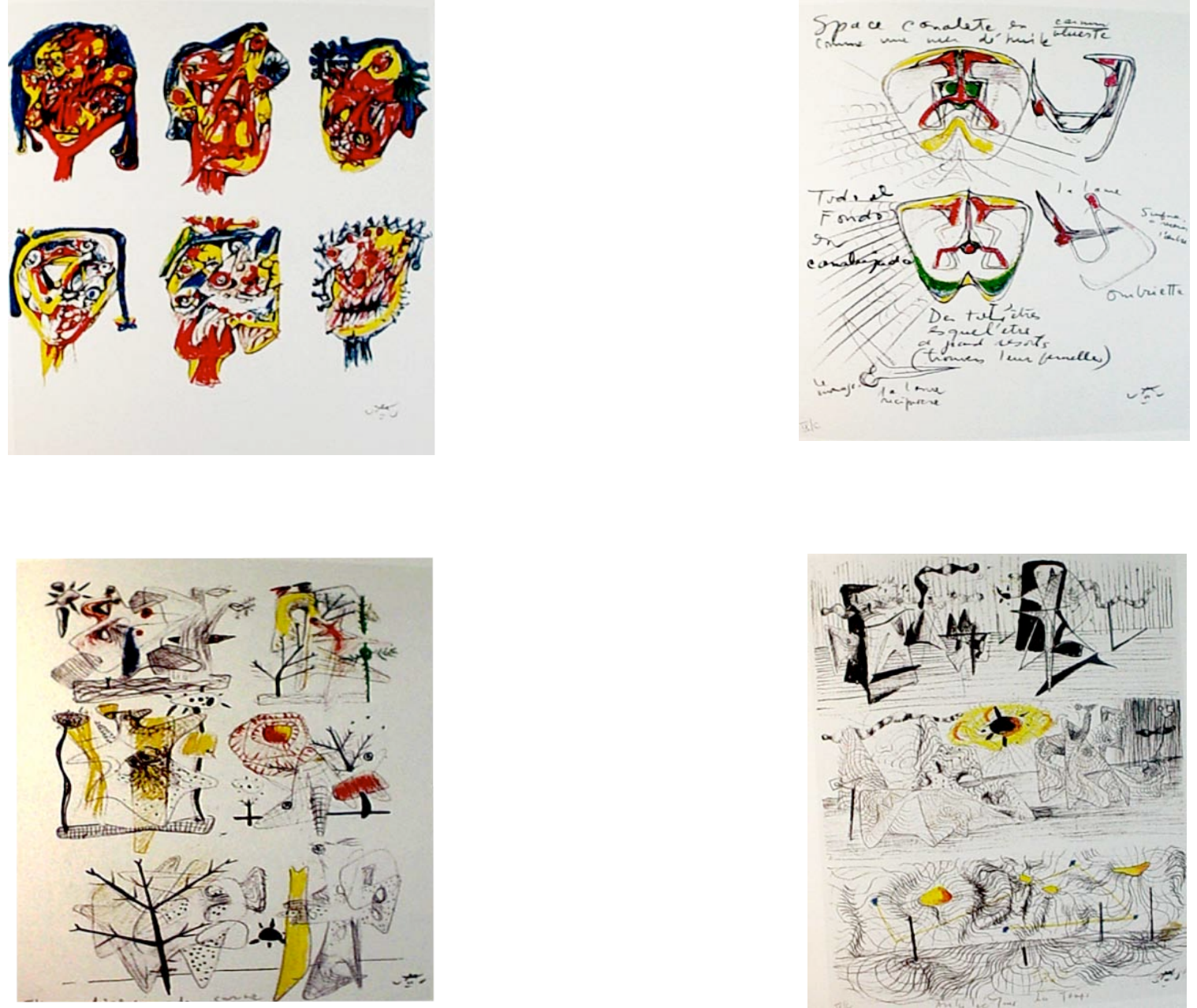

\section{Libros}

\section{Localización del libro o catalogo :}

"Matta: Estampas y poemas", editado por la casa de la Moneda para la exposicion realizada en el Museo Casa de la Moneda entre Diciembre 2001 hasta enero 2002.

\section{Otros catologos que lo contengan :}

Se desconoce.

Registros gráficos obtenidos

Diapositiva

Imagén digital 
Ficha número : 23

Titulo de la obra : Le verbo Hommérica.

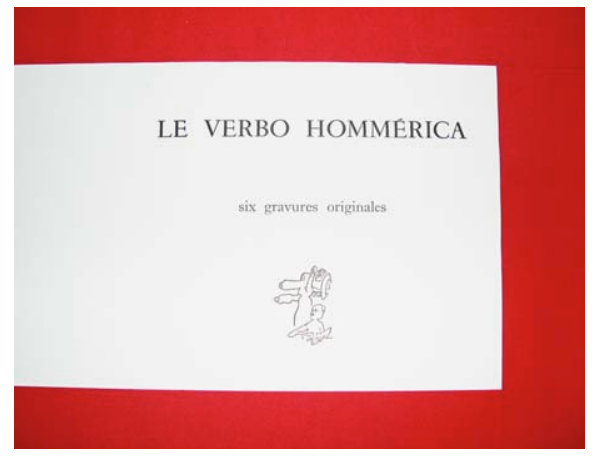

Fecha de realización : 1987.

\section{Dimensiones}

Tamaño del papel : $44.5 \times 63.5 \mathrm{~cm}$.

Tamaño de la mancha : 20.5 x $53 \mathrm{~cm} . / 3$ metros.

\section{Técnica}

Técnica : Aguafuerte.

Procedimientos y recursos complementarios :

Le verbo Hommérica es un libro de artista, que contiene un texto inédito de Roberto Matta acompañado por 6 grabados realizados por el mismo artista a través del aguafuerte.

Existen dos formatos, uno en forma de acordeón en papel Arches presentado dentro de un cofre.

\section{Matriz}

Número de planchas : $\quad$ Entre 2 y 3 planchas por cada una de las obras.

Material de las planchas : Metal- Cobre.

\section{Datos complementarios :}

La cantidad de planchas utilizadas en cada obra, se refiere a la función que cumplen dentro de la misma, ya que Matta utilizaba una plancha para el fondo, otra plancha para los personajes y varias planchas mas para los colores utilizados en la(s) obra(s).

\section{Estampación}

En hueco

En relieve

Planigrafica

Permeografica

\section{Número de tintas :}

Se utilizaron 2 tintas.

\section{Colores :}

\section{Blanco y Negro.}

Papel

Marca : Papel Japón Nacré.

Gramaje : $250 \mathrm{grm}$.

Color : Blanco. 


\section{Edición}

Número de ejemplares :

De cada versión existen 100 ejemplares sobre papel Japón de tamaño 44.5 x $63.5 \mathrm{~cm}$, firmados y numerados del 1 al $100+$ XXXV H.C. + 1 ejemplar para el deposito legal.

Presentándose la primera versión en una caja forrada en tela roja tamaño $25,5 \times 47 \mathrm{~cm}$. impreso en la portada con color dorado un grabado de Matta. la segunda versión se presenta en una carpeta forrada de tela roja tamaño 66,5 x $46,5 \mathrm{~cm}$. en la que también se presenta un grabado de Matta en color dorado. Existiendo además tres cintas rojas que atan esta carpeta.

$\mathbf{N}^{\circ}$ de P.A. (Prueba de Artista): Se desconoce.

$\mathbf{N}^{\circ}$ de H.C. (Hors Commerce) : XXXV H.C.

B.A.T. : 6 B.A.T.

Otras Pruebas : Se desconoce.

Taller en el que se realizó :

Estampador

Albert Dupont.

Número de la estampa observada : XVI/XXXV H.C.

$\begin{array}{llll}\text { Estampa observada directamente : } & \text { Si } \quad X \quad \text { No } \square\end{array}$

$\begin{array}{lllll}\text { Contemplada a través de reproducción : } & \mathrm{Si} & \mathrm{X} & \text { No } & \square\end{array}$

Colección

Colección en la que se encuentra : Colección particular en Paris.

Colección en la que se encuentra la plancha : Colección particular en Paris.

Otras colecciones que tengan ejemplares de este trabajo :

Colección particular en Madrid. 

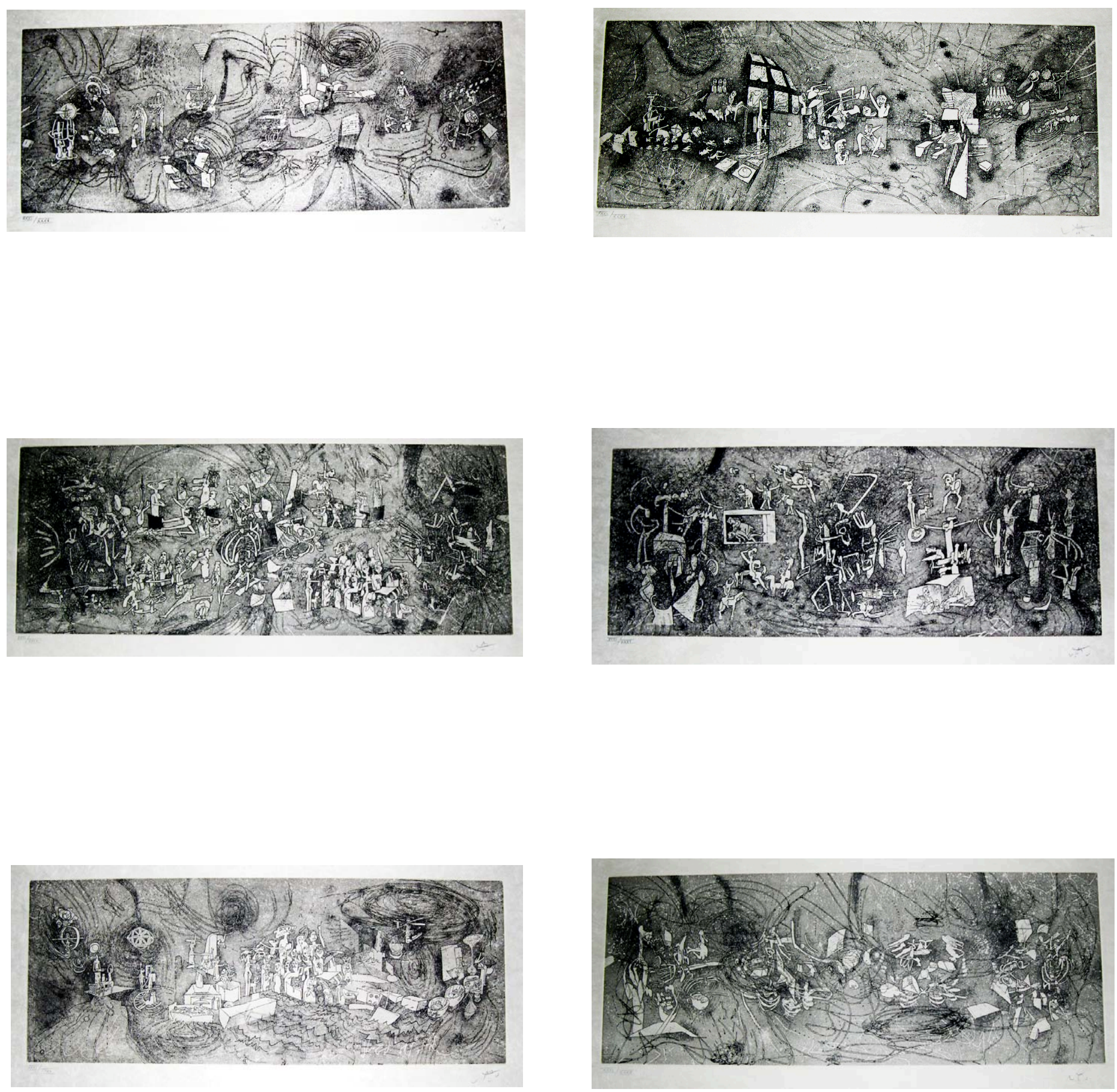

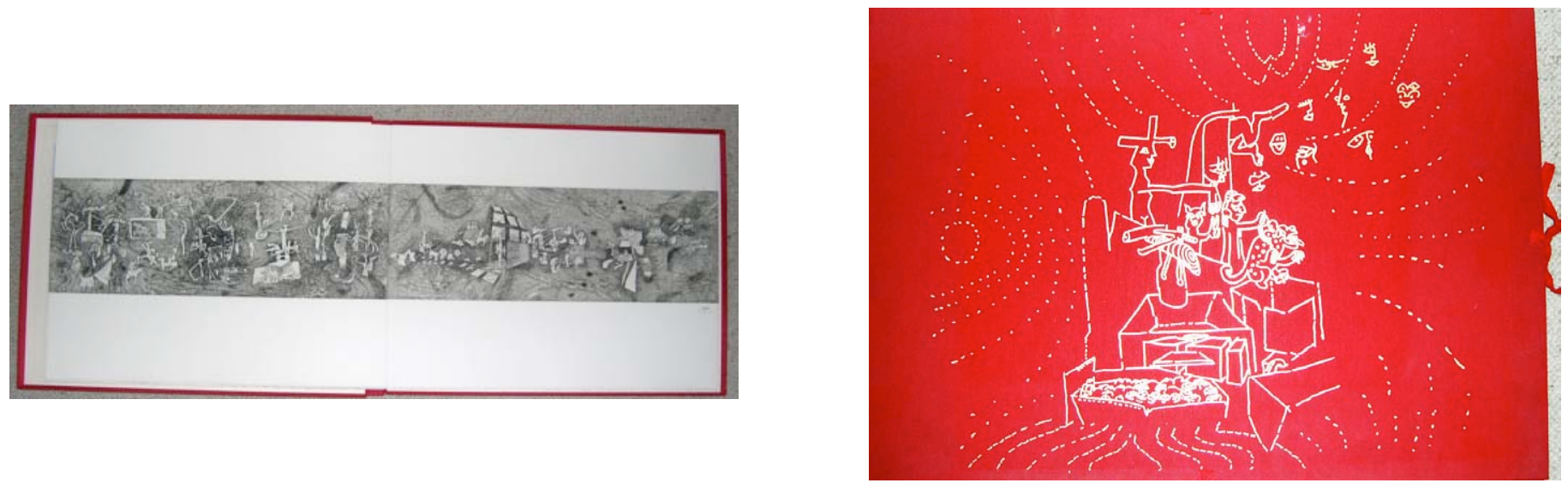

\section{Libros}

\section{Localización del libro o catalogo :}

"Matta: Verbo America", catalogo realizado para la exposición organizada por la Junta de Andalucía, la conserjería de cultura y Medio Ambiente, la caja de San Fernando y el Instituto Frances de Sevilla en 1991.

\section{Otros catologos que lo contengan :}

"Matta: Estampas y poemas", editado por la casa de la Moneda para la exposición realizada en el Museo Casa de la Moneda entre diciembre 2001 hasta enero 2002.

Registros gráficos obtenidos

Diapositiva

Imagén digital

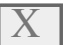




\section{Obra grafica Roberto Sebastian Matta Echaurren}

Ficha número : 24

Titulo de la obra : La terre est une Oignon (N'ou't'ou's).

Fecha de realización : 1995

Dimensiones

Tamaño del papel :

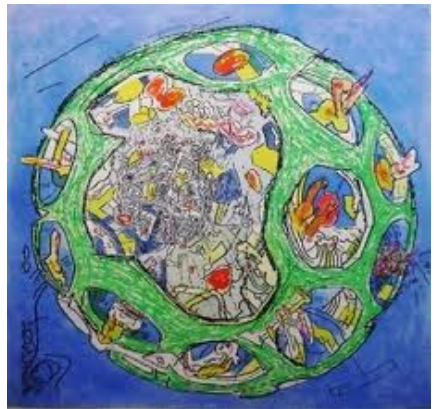

Tamaño de la mancha : 93.5 x $93.5 \mathrm{~cm}$.

\section{Técnica}

Técnica : Aguafuerte y aguatinta.

Procedimientos y recursos complementarios :

La terre est une Oignon es un solo grabado para el que utilizo la técnica del barniz blando para su realización.

\section{Matriz}

Número de planchas : $\quad$ Se utilizaron 5 planchas.

Material de las planchas : Metal- Cobre.

\section{Datos complementarios :}

La cantidad de planchas utilizadas en cada obra, se refiere a la función que cumplen dentro de la misma, ya que Matta utilizaba una plancha para el fondo, otra plancha para los personajes y varias planchas mas para los colores utilizados en la(s) obra(s).

\section{Estampación}

En hueco

En relieve

Planigrafica

Permeografica

Número de tintas :

Se utilizaron 5 tintas.
Colores :
Azul, amarillo, rojo, negro y verde.

Papel

Marca : Papel Arches.

Gramaje : Entre 300 y 400 grm. sin precisión por parte del impresor.

Color : Blanco. 


\section{Edición}

Número de ejemplares :

100 ejemplares de papel Arches 126 x $118 \mathrm{~cm}$, firmados y numerados del 1 al 100 .

$\mathbf{N}^{\circ}$ de P.A. (Prueba de Artista): Se desconoce.

$\mathbf{N}^{\circ}$ de H.C. (Hors Commerce) : Se desconoce.

B.A.T. : 5 B.A.T.

Otras Pruebas : No existen.

Taller en el que se realizó :

\section{Estampador}

Se desconoce.

Número de la estampa observada : 62/100

Estampa observada directamente :

$\mathrm{Si}$

No

Contemplada a través de reproducción : $\mathrm{Si}$

No

Colección

Colección en la que se encuentra : Colección Museo Nacional de arte Reina Sofía en Madrid.

Colección en la que se encuentra la plancha : Colección Museo Nacional de arte Reina Sofía en Madrid

Otras colecciones que tengan ejemplares de este trabajo : Se desconoce.

\section{Libros}

\section{Localización del libro o catalogo :}

"Matta: Estampas y poemas", editado por la casa de la Moneda para la exposicion realizada en el Museo Casa de la Moneda entre Diciembre 2001 hasta enero 2002.

\section{Otros catologos que lo contengan :}

Se desconoce.

Registros gráficos obtenidos

Diapositiva

Imagén digital 


\section{Obra grafica Roberto Sebastian Matta Echaurren}

Ficha número : 25

Titulo de la obra : Melodio, melodia.

Fecha de realización : 1996 algunos dicen 1995

Dimensiones

Tamaño del papel :

Tamaño de la mancha : 11.3 x $90.5 \mathrm{~cm}$.

\section{Técnica}

Técnica : Carborundo.

Procedimientos y recursos complementarios :

Se desconoce.

\section{Matriz}

Número de planchas : $\quad$ Se desconoce.

Material de las planchas : Se desconoce.

Datos complementarios :

Se desconoce.

Estampación

En hueco

En relieve

Planigrafica

Permeografica

Papel

Marca : Hecho a mano.

Gramaje : Se desconoce.

Color : $\quad$ Se desconoce.
Número de tintas :

Se utilizaron entre 5 tintas y ocho tintas.

Colores :

Diferentes tonalidades de rojos, amarillo, blanco, verde, negro y cafe.

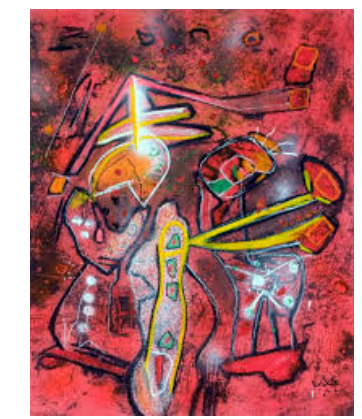




\section{Edición}

Número de ejemplares :

35 ejemplares firmados y numerados del I al XXXV.

$\mathbf{N}^{\circ}$ de P.A. (Prueba de Artista) : Se desconoce.

$\mathbf{N}^{\circ}$ de H.C. (Hors Commerce) : Se desconoce.

B.A.T. : $\quad$ Se desconoce.

Otras Pruebas : Se desconoce.

Taller en el que se realizó :

Se desconoce.

Estampador

Se desconoce.

Número de la estampa observada : $\mathrm{XXX/XXXV}$

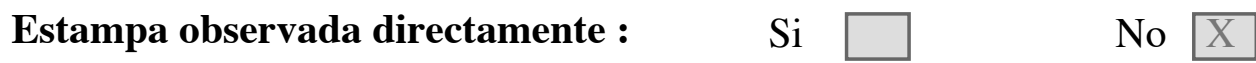

$\begin{array}{llll}\text { Contemplada a través de reproducción : Si } & \mathrm{X} \quad \text { No } & \mathrm{X}\end{array}$

Colección

Colección en la que se encuentra : Colección galería Almirante en Madrid.

Colección en la que se encuentra la plancha : Colección galería Almirante en Madrid.

Otras colecciones que tengan ejemplares de este trabajo : Se desconoce.

\section{Libros}

\section{Localización del libro o catalogo :}

"Matta: Estampas y poemas", editado por la casa de la Moneda para la exposicion realizada en el Museo Casa de la Moneda entre Diciembre 2001 hasta enero 2002.

\section{Otros catologos que lo contengan :}

Se desconoce.

Registros gráficos obtenidos

Diapositiva

Imagén digital 


\section{Obra grafica Roberto Sebastian Matta Echaurren}

Ficha número : 26

Titulo de la obra : Per ser L'invisible.

Fecha de realización : 1996.

Dimensiones

Tamaño del papel : $100 \times 100 \mathrm{~cm}$.

Tamaño de la mancha : Se desconoce.

\section{Técnica}

Técnica : Carborundo.

Procedimientos y recursos complementarios :

Se desconoce.

\section{Matriz}

Número de planchas : $\quad$ Se desconoce.

Material de las planchas : Se desconoce.

Datos complementarios :

Se desconoce.

Estampación

En hueco

En relieve

Planigrafica

Permeografica

Papel

Marca : Papel hecho.

Gramaje : Se desconoce.

Color : $\quad$ Se desconoce.
Número de tintas :

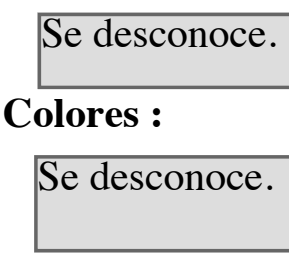

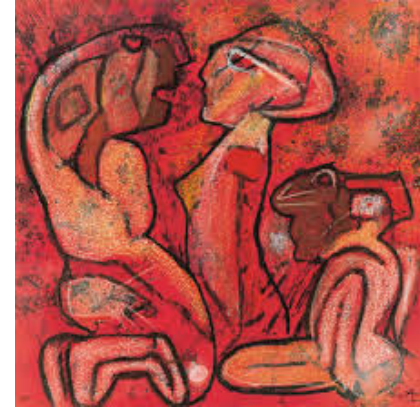




\section{Edición}

Número de ejemplares :

35 ejemplares firmados y numerados del I al XXXV.

$\mathbf{N}^{\circ}$ de P.A. (Prueba de Artista) : Se desconoce.

$\mathbf{N}^{\circ}$ de H.C. (Hors Commerce) : Se desconoce.

B.A.T. : $\quad$ Se desconoce.

Otras Pruebas : Se desconoce.

Taller en el que se realizó :

Se desconoce.

Estampador

Se desconoce.

Número de la estampa observada : XXXI/XXXV.

$\begin{array}{lll}\text { Estampa observada directamente : } & \mathrm{Si} \\ \square \quad \text { No } \mathrm{X}\end{array}$

$\begin{array}{llll}\text { Contemplada a través de reproducción : Si } & \mathrm{X} \quad \text { No } & \mathrm{X}\end{array}$

Colección

Colección en la que se encuentra : Colección galería Almirante en Madrid.

Colección en la que se encuentra la plancha : Colección galería Almirante en Madrid.

Otras colecciones que tengan ejemplares de este trabajo : Se desconoce.

\section{Libros}

\section{Localización del libro o catalogo :}

"Matta: Estampas y poemas", editado por la casa de la Moneda para la exposicion realizada en el Museo Casa de la Moneda entre Diciembre 2001 hasta enero 2002.

\section{Otros catologos que lo contengan :}

Se desconoce.

Registros gráficos obtenidos

Diapositiva

Imagén digital 


\section{Obra grafica Roberto Sebastian Matta Echaurren}

Ficha número : 27

Titulo de la obra : New View.

Fecha de realización : 1996.

Dimensiones

Tamaño del papel : $\quad$ Se desconoce.

Tamaño de la mancha : 110 x $98 \mathrm{~cm}$.

\section{Técnica}

Técnica : Carborundo.

Procedimientos y recursos complementarios :

Se desconocen.

\section{Matriz}

Número de planchas : $\quad$ Se desconoce.

Material de las planchas : Se desconoce.

Datos complementarios :

Se desconoce.

Estampación

En hueco

En relieve

Planigrafica

Permeografica

Número de tintas :

Se utilizaron mas de 5 tintas, se desconoce su totalidad.
Colores :
Violeta, cafes, blanco, negro, verde, amarillo, naranja, rosado, varias
tonalidades de rojo.

Papel

Marca : Es hecho a mano.

Gramaje : Se desconoce.

Color : $\quad$ Se desconoce. 


\section{Edición}

Número de ejemplares :

35 ejemplares firmados y numerados del I al XXXV.

$\mathbf{N}^{\circ}$ de P.A. (Prueba de Artista) : Se desconoce.

$\mathbf{N}^{\circ}$ de H.C. (Hors Commerce) : Se desconoce.

B.A.T. : $\quad$ Se desconoce.

Otras Pruebas : Se desconoce.

Taller en el que se realizó :

Se desconoce.

Estampador

Se desconoce.

Número de la estampa observada : $\mathrm{XXX/XXXV}$

Estampa observada directamente :

Contemplada a través de reproducción : Si X

Colección

Colección en la que se encuentra : Colección galería Almirante en Madrid.

Colección en la que se encuentra la plancha : Colección galería Almirante en Madrid.

Otras colecciones que tengan ejemplares de este trabajo : Se desconoce.

\section{Libros}

\section{Localización del libro o catalogo :}

"Matta: Estampas y poemas", editado por la casa de la Moneda para la exposicion realizada en el Museo Casa de la Moneda entre Diciembre 2001 hasta enero 2002.

\section{Otros catologos que lo contengan :}

Se desconoce.

Registros gráficos obtenidos $\quad$ Diapositiva $\quad \square \quad$ Imagén digital 


\section{Obra grafica Roberto Sebastian Matta Echaurren}

Ficha número : 28

Titulo de la obra : L`Altra Euridice.

Fecha de realización : 1969

Dimensiones

Tamaño del papel : $45 \times 75 \mathrm{~cm}$.

Tamaño de la mancha : 25 x $65 \mathrm{~cm}$.

\section{Técnica}

Técnica : Litografía.

\section{Procedimientos y recursos complementarios :}

L'altra Euridice es un cubo litográfico, es decir son cuatro litografías, dos utilizadas para realizar el cubo externo y otras dos que conforman el cubo interno. Es un cubo que se puede abrir y cerrar. A pesar de que L'astra Eurice es un texto oscuro en relación al mito de Orfeo y Euridice, Matta le da este carácter lúdico al presentarlo de esta forma, pero a la vez posee un significado mas relevante que es llegar o interno, al núcleo del núcleo, lo que se esconde y esta por descubrirse también podría ser un camino para lograr entender esta obra.

El texto de L'altra Euridice es inédito escrito por Italo Calvino.

\section{Matriz}

Número de planchas : $\quad$ Se desconoce.

Material de las planchas : Piedra

Datos complementarios :

\section{Estampación}

En hueco

En relieve

Planigrafica

Permeografica

Número de tintas :

Papel

Marca : Papel Fabriano.

Gramaje : Se desconoce.

Color : Blanco. 


\section{Edición}

Número de ejemplares :

Se desconoce, lo unico que sabemos es que no existe ninguna prueba de artista.

$\mathbf{N}^{\circ}$ de P.A. (Prueba de Artista) : Se desconoce.

$\mathbf{N}^{\circ}$ de H.C. (Hors Commerce) : Se desconoce.

B.A.T. : $\quad$ Se desconoce.

Otras Pruebas : Se desconoce.

Taller en el que se realizó :

Editado en la estamperia L'aldina en Roma. Se desconoce si la impresión se realizo en la misma estamperia o en algún otro atelier litográfico.

Estampador

Estamperia l`Aldina en Roma.

Número de la estampa observada : Se desconoce.

Estampa observada directamente :

$\mathrm{Si}$

No

Contemplada a través de reproducción : $\mathrm{Si} X$

No

Colección

Colección en la que se encuentra : Se desconoce.

Colección en la que se encuentra la plancha : Se desconoce.

Otras colecciones que tengan ejemplares de este trabajo : Se desconocen.

\section{Libros}

\section{Localización del libro o catalogo :}

"Matta, Index dell'opera grafica dal 1969 al 1980", editado por Admministrazione Provinciali di Viterbo en 1980, realizado por Germana Ferrari.

Pagina 1-4

Otros catologos que lo contengan :

Registros gráficos obtenidos $\quad$ Diapositiva $\quad \square \quad$ Imagén digital $\quad X$ 


\section{Obra grafica Roberto Sebastian Matta Echaurren}

Ficha número : 29

Titulo de la obra : Es-Erotica.

Fecha de realización : 1969

Dimensiones

Tamaño del papel : $50 \times 70 \mathrm{~cm}$.

Tamaño de la mancha : 70 x $50 \mathrm{~cm}$.

\section{Técnica}

Técnica : Litografía.

Procedimientos y recursos complementarios :

Es- Erótica son tres litografías realizadas en blanco y negro sobre el tema del erotismo donde se nos presentan dos personajes en diversas posiciones sexuales y eróticas. Por litografía veremos alrededor entre 10 hasta 18 escenas de estos personajes.

\section{Matriz}

Número de planchas : 3 planchas.

Material de las planchas : Piedra.

\section{Datos complementarios :}

Es interesante ver, que la posición dentro del formato de los personajes se estableció mediante una grilla cuadrada, la que se puede observar en dos de estas litografías.

\section{Estampación}

En hueco

En relieve

Planigrafica

Permeografica

Número de tintas :

Papel
Una tinta.
Colores :
Negro.

Marca : Papel Arches

Gramaje : Se desconoce.

Color : Blanco. 


\section{Edición}

Número de ejemplares :

Se desconoce.

$\mathbf{N}^{\circ}$ de P.A. (Prueba de Artista) : Se desconoce.

$\mathbf{N}^{\circ}$ de H.C. (Hors Commerce) : Se desconoce.

B.A.T. : $\quad$ Se desconoce.

Otras Pruebas : Se desconoce.

Taller en el que se realizó :

Se desconoce el taller donde se imprimió, solo sabemos que fue impreso y estampado en Florencia Italia.

Estampador

Se desconoce el estampador.

Número de la estampa observada : Se desconoce.

Estampa observada directamente :

$\mathrm{Si}$

No

Contemplada a través de reproducción : Si $X$

No

Colección

Colección en la que se encuentra : Se desconoce.

Colección en la que se encuentra la plancha : Se desconoce.

Otras colecciones que tengan ejemplares de este trabajo : Se desconoce.

\section{Libros}

\section{Localización del libro o catalogo :}

"Matta, Index dell'opera grafica dal 1969 al 1980", editado por Admministrazione Provinciali di Viterbo en 1980, realizado por Germana Ferrari.

Pagina 5-7.

\section{Otros catologos que lo contengan :}

Se desconoce.

Registros gráficos obtenidos

Diapositiva

Imagén digital 


\section{Obra grafica Roberto Sebastian Matta Echaurren}

Ficha número : $\quad 30$

Titulo de la obra : Antimondo.
Fecha de realización : 1969
Dimensiones
Tamaño del papel : $34 \times 39 \mathrm{~cm}$.

Titulo de la obra : Antimondo.
Fecha de realización : 1969
Dimensiones
Tamaño del papel : $34 \times 39 \mathrm{~cm}$.

Titulo de la obra : Antimondo.
Fecha de realización : 1969
Dimensiones
Tamaño del papel : $34 \times 39 \mathrm{~cm}$.

Titulo de la obra : Antimondo.
Fecha de realización : 1969
Dimensiones
Tamaño del papel : $34 \times 39 \mathrm{~cm}$.

Tamaño de la mancha : 16 x $16 \mathrm{~cm}$.

\section{Técnica}

Técnica : Aguafuerte y coloreada a mano por el artista.

Procedimientos y recursos complementarios :

Antimondo es una carpeta de cuatro grabados en los que interactúan dos personajes que van transformándose.

Cada grabado fue coloreado a mano por el propio Matta.

\section{Matriz}

Número de planchas :

Material de las planchas : Cobre.

Datos complementarios :

\section{Estampación}

En hueco

En relieve

Planigrafica

Permeografica

Papel

Marca : Papel Fabriano.

Gramaje : Se desconoce.

Color : $\quad$ Se desconoce.

\section{Número de tintas :}

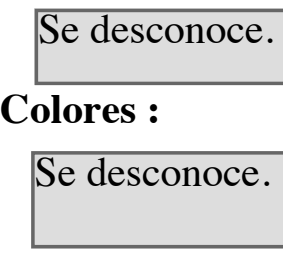

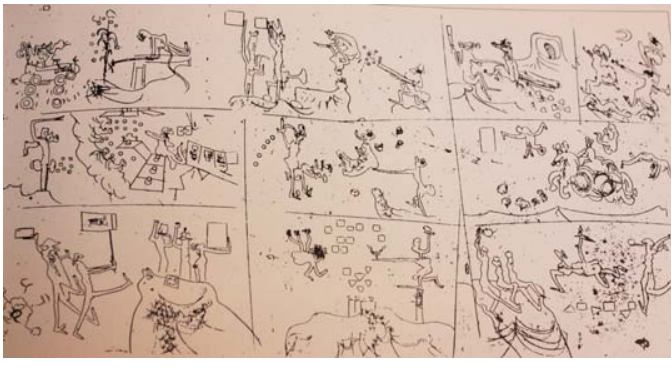

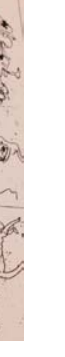




\section{Edición}

Número de ejemplares :

Existen 50 ejemplares sobre papel Fabriano, firmados y numerados del 1 al 50 mas X ejemplares de H.C. firmado y numerados del I al X.

$\mathbf{N}^{\circ}$ de P.A. (Prueba de Artista): Se desconoce, pero existen.

$\mathrm{N}^{\circ}$ de H.C. (Hors Commerce) : X H.C.

B.A.T. : Se desconoce.

Otras Pruebas : Se desconoce.

Taller en el que se realizó :

La edicion la realizo la Galeria S. Luca en Bolonia Italia.

\section{Estampador}

Se desconoce.

Número de la estampa observada : Prueba de artista.

Estampa observada directamente : $\quad \mathrm{Si}$

No

Contemplada a través de reproducción : Si X

No

Colección

Colección en la que se encuentra : Se desconoce.

Colección en la que se encuentra la plancha : Se desconoce.

Otras colecciones que tengan ejemplares de este trabajo : Se desconoce.

\section{Libros}

\section{Localización del libro o catalogo :}

“Matta, Index dell'opera grafica dal 1969 al 1980", editado por Admministrazione Provinciali di Viterbo en 1980, realizado por Germana Ferrari.

\section{Otros catologos que lo contengan :}




\section{Obra grafica Roberto Sebastian Matta Echaurren}

Ficha número : 31

Titulo de la obra : La Une a L`H pile.

Fecha de realización : 1969

Dimensiones

Tamaño del papel : $93 \times 176 \mathrm{~cm}$.

Tamaño de la mancha : 78 x $148 \mathrm{~cm}$.

\section{Técnica}

Técnica : Aguafuerte y Aguatinta

Procedimientos y recursos complementarios :

La Une a L 'H pile es un grabado realizado por Matta para el "Centro Genovés de grabado contemporáneo". Presentando nueve escenas que nos cuentan una historia como un cómics.

Es un grabado que no fue Editado existiendo solo dos impresiones de la presente estampa.

\section{Matriz}

Número de planchas : Dos planchas.

Material de las planchas : Se desconoce.

Datos complementarios :

Se desconocen.

\section{Estampación}

En hueco

En relieve

Planigrafica

Permeografica

Papel

Marca : Papel Arches.

Gramaje : 250 grm.

Color : Blanco.
Número de tintas :

Se utilizaron dos tintas.
Colores :
Gris y negro.

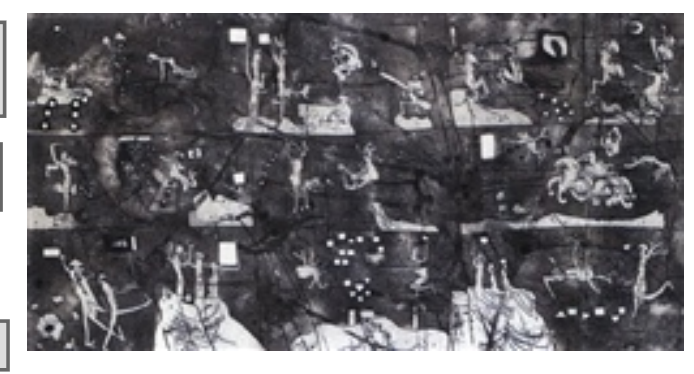




\section{Edición}

Número de ejemplares :

No existe tirage, ya que no fue editada.

$\mathbf{N}^{\circ}$ de P.A. (Prueba de Artista): Se desconoce.

$\mathbf{N}^{\circ}$ de H.C. (Hors Commerce) : $\quad$ No existe.

B.A.T. : No existe.

Otras Pruebas : Solo existen dos pruebas.

Taller en el que se realizó :

Se desconoce.

Estampador

Se desconoce.

Número de la estampa observada : Se desconoce.

Estampa observada directamente : $\quad \mathrm{Si} \square \quad$ No

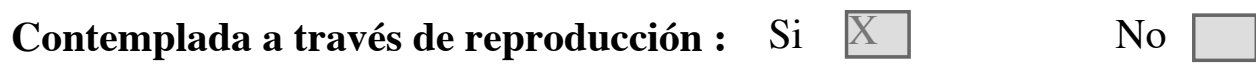

Colección

Colección en la que se encuentra : Se desconoce.

Colección en la que se encuentra la plancha : Se desconoce.

Otras colecciones que tengan ejemplares de este trabajo : Se desconocen.

\section{Libros}

\section{Localización del libro o catalogo :}

"Matta, Index dell'opera grafica dal 1969 al 1980", editado por Admministrazione Provinciali di Viterbo en 1980, realizado por Germana Ferrari.

Pagina 13

Otros catologos que lo contengan :

Registros gráficos obtenidos Diapositiva $\quad \square \quad$ Imagén digital $\quad X$ 


\section{Obra grafica Roberto Sebastian Matta Echaurren}

Ficha número : 32

Titulo de la obra : Eroterica.

Fecha de realización : $\quad 1969$ impreso 1970

Dimensiones

Tamaño del papel : $\quad 50 \times 70 \mathrm{~cm}$.

Tamaño de la mancha : $50 \times 70 \mathrm{~cm}$.

\section{Técnica}

Técnica : Litografía.

\section{Procedimientos y recursos complementarios :}

Eroterica es una carpeta de 6 litografías a color, donde nos presenta a través de diferentes personajes el culto al pene y diversas posiciones eróticas contadas de una manera graciosa, sutil y provocativa.

\section{Matriz}

Número de planchas : Se desconoce.

Material de las planchas : Piedra.

\section{Datos complementarios :}

Se desconoce.

\section{Estampación}

En hueco

En relieve

Planigrafica

Permeografica

Número de tintas :

Nueve tintas.

\section{Colores :}

Naranjo, negro, amarillo, rojo, verde, beige, gris, rosado y azul.

Papel

Marca : $\quad$ Papel Arches.

Gramaje : Se desconoce. 
Color :

Blanco.

\section{Edición}

Número de ejemplares :

60 ejemplares sobre papel arches, firmados y numerados del 1 al 60 mas X ejemplares de H.C. firmados y numerados del I al X.

$\mathbf{N}^{\circ}$ de P.A. (Prueba de Artista): Se desconoce.

$\mathbf{N}^{\circ}$ de H.C. (Hors Commerce) : X H.C.

B.A.T.: $\quad$ Se desconoce.

Otras Pruebas : Se desconoce.

Taller en el que se realizó :

En el taller "B" en Florencia Italia, realizándose también allí su edición.

Colección Galería Almirante en Madrid.

Estampador

Se desconoce.

Número de la estampa observada : 
Estampa observada directamente :

Contemplada a través de reproducción :
$\mathrm{Si}$

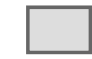

$\mathrm{Si} \mathrm{X}$
No

No

\section{Colección}

Colección en la que se encuentra : Se desconoce.

Colección en la que se encuentra la plancha : Se desconoce.

Otras colecciones que tengan ejemplares de este trabajo :

Se desconocen.
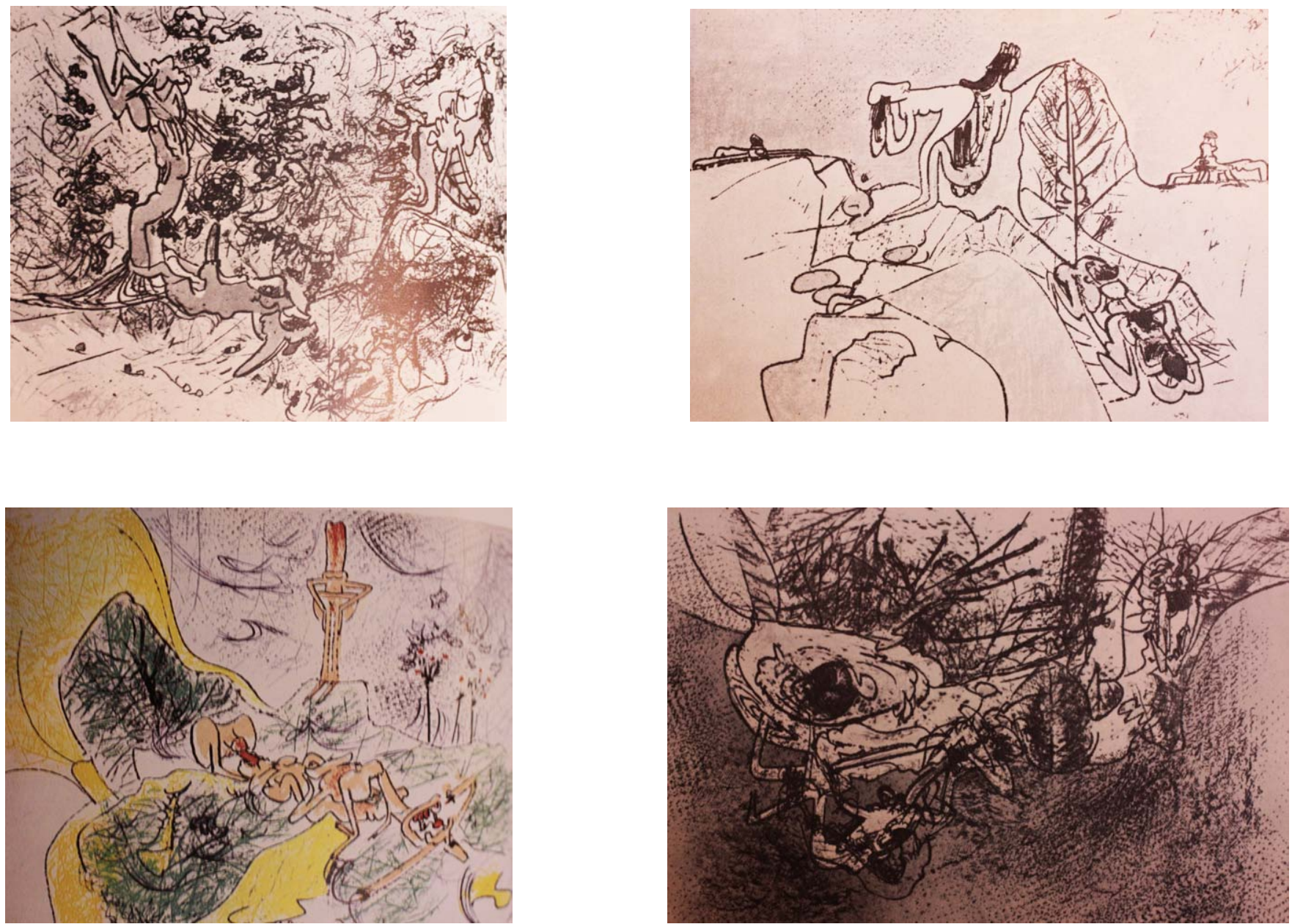


\section{Libros}

\section{Localización del libro o catalogo :}

"Matta, Index dell'opera grafica dal 1969 al 1980", editado por Admministrazione Provinciali di Viterbo en 1980, realizado por Germana Ferrari.

Pagina 14-19

\section{Otros catologos que lo contengan :}

Se desconoce.

Registros gráficos obtenidos Diapositiva $\quad \square \quad$ Imagén digital $\quad X$ 
Obra grafica Roberto Sebastian Matta Echaurren

Ficha número : 33

Titulo de la obra : Le Acque d`Arno.

Fecha de realización : $\quad 1967$ impreso 1970

Dimensiones

Tamaño del papel : $\quad 57,5 \times 78,5 \mathrm{~cm}$.

Tamaño de la mancha : $49,5 \times 74,5 \mathrm{~cm}$.

Técnica

Técnica : Litografía.

Procedimientos y recursos complementarios :

Le Acque d’Arno es una carpeta litográfica en blanco y negro que comprende seis litografías las que nos ilustran la inundación que sufrió la ciudad de Florencia en el año 1966 a causa de la salida del rio Arno, Matta lo expresa con fuerza, con tormento.

\section{Matriz}

Número de planchas : 6 planchas

Material de las planchas : Piedra.

Datos complementarios :

No existen.

\section{Estampación}

En hueco

En relieve

Planigrafica

Permeografica

Número de tintas :

Se utilizo solo una tinta.

Colores :

Negro.

Papel

Marca : $\quad$ Papel Arches

Gramaje : Se desconoce. 
Color :

Blanco.

\section{Edición}

Número de ejemplares :

Se realizaron 90 ejemplares numerados y firmados del 1 al 90 mas XX ejemplares de H.C. firmados y numerados del I al XX.

$\mathbf{N}^{\circ}$ de P.A. (Prueba de Artista): Se desconoce.

$\mathbf{N}^{\circ}$ de H.C. (Hors Commerce) : XX H.C.

B.A.T.: $\quad$ Se desconoce.

Otras Pruebas : Se desconocen.

Taller en el que se realizó :

En el taller "B" en Florencia Italia, realizándose también allí su edición en 1970.

Estampador

Se desconoce.

Número de la estampa observada : 
Estampa observada directamente :

Contemplada a través de reproducción :
$\mathrm{Si}$

$\mathrm{Si}$
No

No

\section{Colección}

Colección en la que se encuentra : Se desconoce.

Colección en la que se encuentra la plancha : Se desconoce.

Otras colecciones que tengan ejemplares de este trabajo :

Se desconoce.
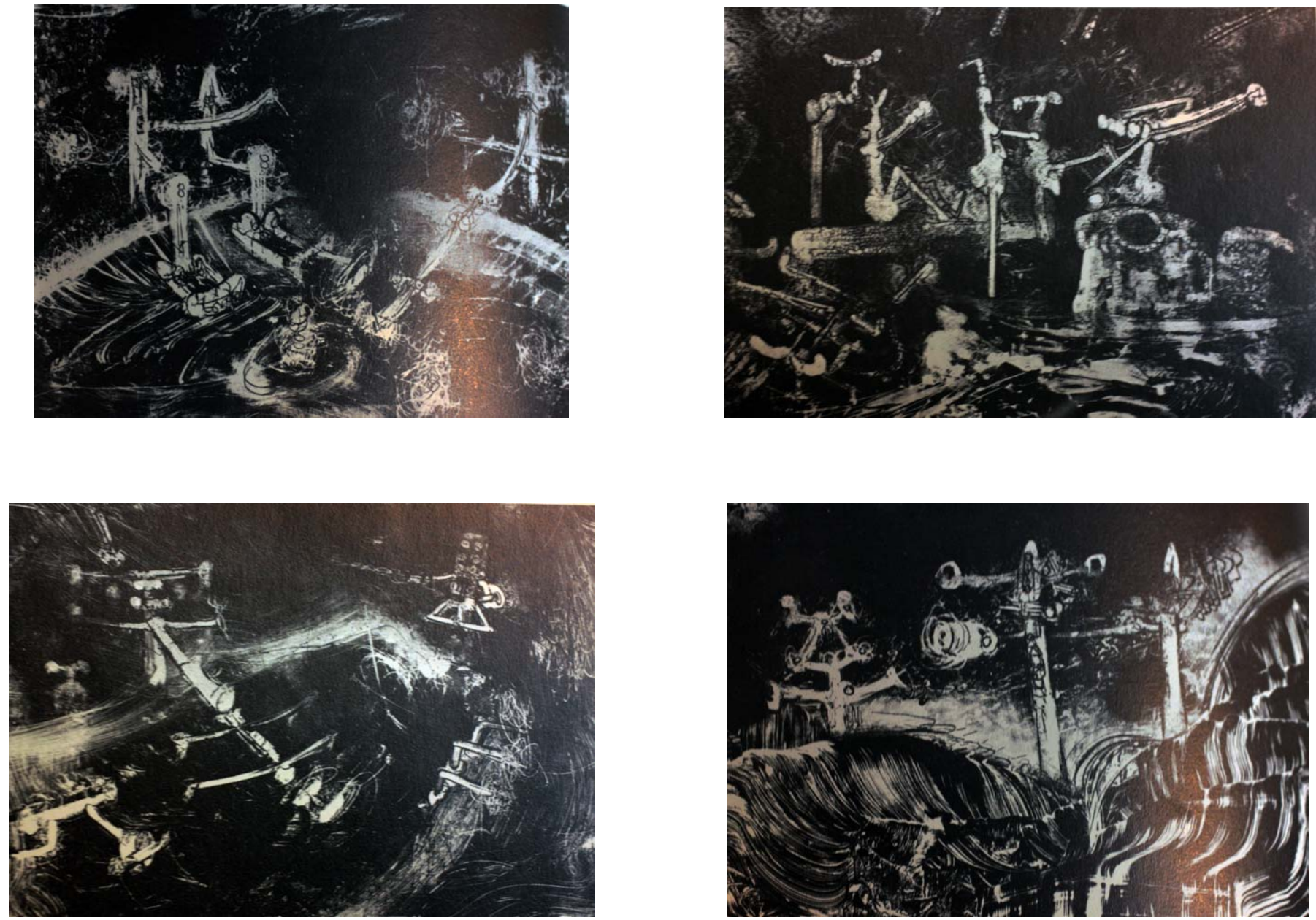


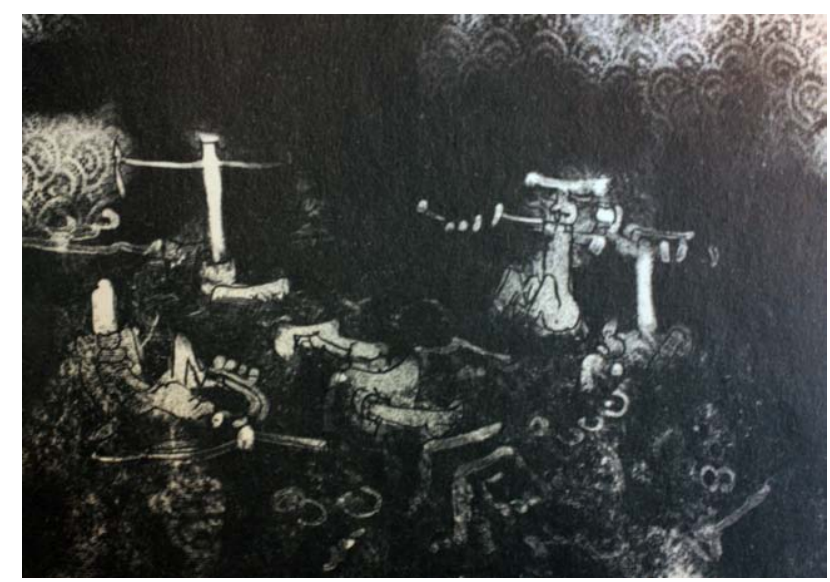

\section{Libros}

\section{Localización del libro o catalogo :}

"Matta, Index dell'opera grafica dal 1969 al 1980", editado por Admministrazione Provinciali di Viterbo en 1980, realizado por Germana Ferrari.

Pagina 20-25

\section{Otros catologos que lo contengan :}

Se desconoce.

Registros gráficos obtenidos Diapositiva $\square$ Imagén digital $\quad \mathrm{X}$ 


\section{Obra grafica Roberto Sebastian Matta Echaurren}

Ficha número : 34

Titulo de la obra : Anti Franco.

Fecha de realización : 1970

Dimensiones

Tamaño del papel : $\quad 49 \times 70 \mathrm{~cm}$.

Tamaño de la mancha : $37.5 \times 47 \mathrm{~cm}$.

Técnica

Técnica : Aguafuerte y en algunas publicaciones se escribe aguatinta.

Procedimientos y recursos complementarios :

Anti Franco carpeta que comprende 4 grabados.

\section{Matriz}

Número de planchas : Se desconoce.

Material de las planchas : cobre.

Datos complementarios :

Anti Franco fue un trabajo no terminado por Matta ya que fue prematuramente editado por la casa de edicion Bell'Antonio en Milano.

\section{Estampación}

En hueco

En relieve

Planigrafica

Permeografica

Número de tintas :

Se desconocen su totalidad.

Colores :

Crema, amarillo, negro y azul.

Papel

Marca : $\quad$ Papel Arches. No obstante en algunos escritos se menciona papel Vélin.

Gramaje : Se desconoce. 
Color :

Blanco.

\section{Edición}

Número de ejemplares :

No existe ningún ejemplar firmado o numerado.

Sin embargo a través de la Web podemos encontrar a la venta algunos de estos grabados y se menciona que si existió un tiraje firmado y numerado del 1 al 50.

$\mathbf{N}^{\circ}$ de P.A. (Prueba de Artista) : No existe.

$\mathbf{N}^{\circ}$ de H.C. (Hors Commerce) : No existe.

\section{B.A.T.: $\quad$ No existe.}

Otras Pruebas : No existe.

Taller en el que se realizó :

En el taller Bell'Antonio en Milano Italia.

\section{Estampador}

Se desconoce.

Número de la estampa observada : 
Estampa observada directamente :

Contemplada a través de reproducción :
$\mathrm{Si}$

$\mathrm{Si}$
No

No

\section{Colección}

Colección en la que se encuentra : Se desconoce

Colección en la que se encuentra la plancha : Se desconoce

Otras colecciones que tengan ejemplares de este trabajo :

Se desconocen.
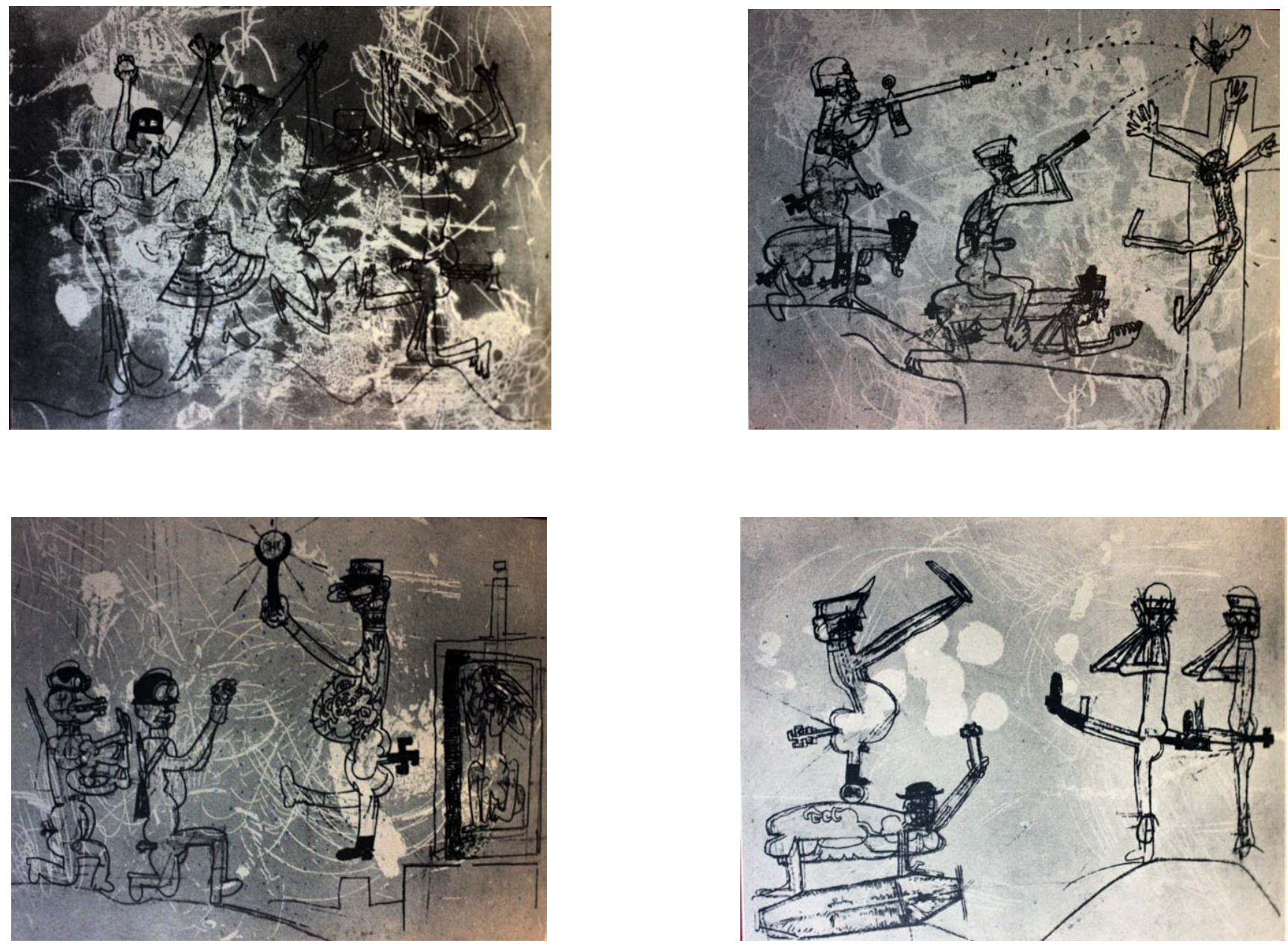


\section{Libros}

\section{Localización del libro o catalogo :}

"Matta, Index dell'opera grafica dal 1969 al 1980", editado por Admministrazione Provinciali di Viterbo en 1980, realizado por Germana Ferrari.

Pagina 27.

\section{Otros catologos que lo contengan :}

Se desconoce.

Registros gráficos obtenidos $\quad$ Diapositiva $\quad \square \quad$ Imagén digital $\quad \mathrm{X}$ 


\section{Obra grafica Roberto Sebastian Matta Echaurren}

Ficha número : 35

Titulo de la obra : Comme le doigt peut voir.

Fecha de realización : 1971.

Dimensiones

Tamaño del papel : $25 \times 18 \mathrm{~cm}$.

Tamaño de la mancha : No hay mancha.

\section{Técnica}

Técnica : Serigrafía en braile.

\section{Procedimientos y recursos complementarios :}

Comme le doigt peut voir, le nez fait gouter la couleur a l'oreille, reste le sens de l'inconnu, es la primera y la única hasta este momento conocida serigrafía en Braile que realizo Roberto Matta, sobre un papel Blanco en la parte superior solo vemos al parecer letras en Braile.

Esta obra se incluye en este catalogo, por ser tan particular en su obra y por que nos aleja de la forma plástica como él trabaja, pero también nos acerca a la profundidad humanidad de este artista.

\section{Matriz}

Número de planchas : No existen.

Material de las planchas : Tela.

\section{Datos complementarios :}

Se desconoce.

\section{Estampación}

En hueco

En relieve

Planigrafica

Permeografica

Número de tintas :

Papel

No hay tintas.
Colores :
No hay colores solo orificios.

Marca : Se desconoce.

Gramaje : Se desconoce.

Color : Blanco. 


\section{Edición}

Número de ejemplares :

Existen 100 ejemplares numerados y firmados del 1 al 100.

$\mathbf{N}^{\circ}$ de P.A. (Prueba de Artista): Se desconoce.

$\mathbf{N}^{\circ}$ de H.C. (Hors Commerce) : No existen.

B.A.T. : No existen.

Otras Pruebas : Se desconoce.

Taller en el que se realizó :

En la estamperia Ubiob italiana Cieci en Milano, y la edición fue privada.

Estampador

Se desconoce.

Número de la estampa observada : Se desconoce.

Estampa observada directamente : $\quad \mathrm{Si} \square$

No

Contemplada a través de reproducción : Si $\mathrm{X}$

No

Colección

Colección en la que se encuentra : Se desconoce.

Colección en la que se encuentra la plancha : Se desconoce.

Otras colecciones que tengan ejemplares de este trabajo : Se desconoce.

\section{Libros}

\section{Localización del libro o catalogo :}

"Matta, Index dell'opera grafica dal 1969 al 1980", editado por Admministrazione Provinciali di Viterbo en 1980, realizado por Germana Ferrari.

Pagina 32.

\section{Otros catologos que lo contengan :}

Se desconoce.

Registros gráficos obtenidos

Diapositiva

Imagén digital 


\section{Obra grafica Roberto Sebastian Matta Echaurren}

Ficha número : 36

Titulo de la obra : Le poing du jour.

Fecha de realización : 1971.

Dimensiones

Tamaño del papel : $56,5 \times 76 \mathrm{~cm}$.

Tamaño de la mancha : 46 x $68 \mathrm{~cm}$.

\section{Técnica}

Técnica : Aguafuerte y aguatinta en color.

Procedimientos y recursos complementarios :

Se desconoce.

\section{Matriz}

Número de planchas : $\quad$ Se puede deducir que se utilizaron de dos a tres planchas.

Material de las planchas : Cobre.

\section{Datos complementarios :}

Se desconoce.

\section{Estampación}

En hueco

En relieve

Planigrafica

Permeografica

Papel
Número de tintas :

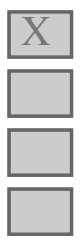

Cinco tintas.

Colores : esfumados.
Negro, amarillo, rosado, cafe, gris, celeste, casi todos se presentan

Marca : Papel Arches.

Gramaje : 250 grm.

Color : Blanco. 


\section{Edición}

Número de ejemplares :

90 ejemplares sobre papel arches tamaño 56.5 x 76 firmado y numerado del 1 al 90 mas XXX ejemplares de H.C. estampada en oro firmados y numerados del I al XXX; mas 30 P.A. a color firmados y numerados del 1 al 30.

$\mathbf{N}^{\circ}$ de P.A. (Prueba de Artista) : 30 P.A.

$\mathbf{N}^{\circ}$ de H.C. (Hors Commerce) : XXX H.C.

B.A.T. : $\quad$ Se desconoce.

Otras Pruebas : Se desconoce.

Taller en el que se realizó :

Atelier George Visat en Paris.

Estampador

Se desconoce.

Número de la estampa observada $: 3 / 10$

Estampa observada directamente :

$\mathrm{Si}$

No $\mathrm{X}$

Contemplada a través de reproducción : $\mathrm{Si} X$

No $\mathrm{X}$

Colección

Colección en la que se encuentra : Se desconoce.

Colección en la que se encuentra la plancha : Se desconoce.

Otras colecciones que tengan ejemplares de este trabajo : Se desconocen.

\section{Libros}

\section{Localización del libro o catalogo :}

"Matta, Index dell'opera grafica dal 1969 al 1980", editado por Admministrazione Provinciali di Viterbo en 1980, realizado por Germana Ferrari.

Pagina 33.

\section{Otros catologos que lo contengan :}

Se desconocen.

Registros gráficos obtenidos

Diapositiva

Imagén digital 


\section{Obra grafica Roberto Sebastian Matta Echaurren}

Ficha número : $\quad 37$

Titulo de la obra : Puro pueblo es tu cielo azulado.

Fecha de realización : 1971.

Dimensiones

Tamaño del papel : $75 \times 108 \mathrm{~cm}$.

Tamaño de la mancha : 75 x $108 \mathrm{~cm}$.

\section{Técnica}

Técnica : Serigrafía.

\section{Procedimientos y recursos complementarios :}

Puro pueblo es tu cielo azulado, es una serigrafía realizada con cinco colores y el titulo hace un relación a el himno nacional de Chile donde se canta "Puro Chile es tu cielo azulado...".

A modo de historieta nos expresa su visión sobre el periodo que se esta viviendo como el ser humano necesita de otro para avanzar y vivir dentro de la sociedad, apareciendo una bandera Chilena junto a una bandera Cubana.

Hay que mencionar que también existe una obra pictórica de Roberto Matta que posee el mismo titulo.

\section{Matriz}

Número de planchas : $\quad$ Se desconoce.

Material de las planchas : Se desconoce.

\section{Datos complementarios :}

Se desconocen.

\section{Estampación}

En hueco

En relieve

Planigrafica

Permeografica

Papel

Marca : Se desconoce.

Gramaje : Se desconoce.

Color : Blanco.

\section{Número de tintas :}

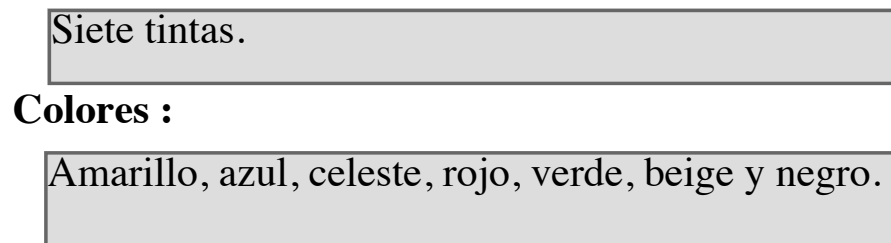




\section{Edición}

Número de ejemplares :

Tiraje indeterminado.

$\mathbf{N}^{\circ}$ de P.A. (Prueba de Artista): Se desconoce.

$\mathbf{N}^{\circ}$ de H.C. (Hors Commerce) : Se desconoce.

B.A.T. : $\quad$ Se desconoce.

Otras Pruebas : Se desconoce.

Taller en el que se realizó :

Taller privado en Santiago de Chile.

Estampador

Se desconoce.

Número de la estampa observada : Se desconoce.

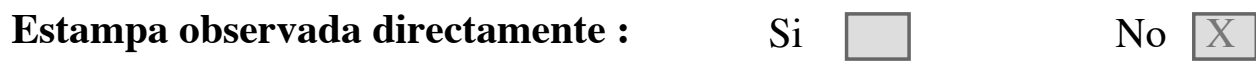

$\begin{array}{llll}\text { Contemplada a través de reproducción : Si } & X \quad \text { No } X\end{array}$

Colección

Colección en la que se encuentra : Se desconoce.

Colección en la que se encuentra la plancha : Se desconoce.

Otras colecciones que tengan ejemplares de este trabajo : Se desconocen.

\section{Libros}

\section{Localización del libro o catalogo :}

"Matta, Index dell'opera grafica dal 1969 al 1980", editado por Admministrazione Provinciali di Viterbo en 1980, realizado por Germana Ferrari.

Pagina 34

\section{Otros catologos que lo contengan :}

Se desconoce.

Registros gráficos obtenidos

Diapositiva

Imagén digital 


\section{Obra grafica Roberto Sebastian Matta Echaurren}

Ficha número : $\quad 38$

Titulo de la obra : Joriente.

Fecha de realización : 1971.

Dimensiones

Tamaño del papel : $75 \times 110 \mathrm{~cm}$.

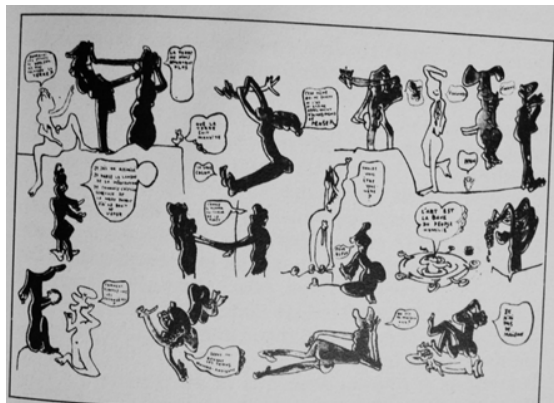

Tamaño de la mancha : 75 x $110 \mathrm{~cm}$.

\section{Técnica}

Técnica : Serigrafía.

Procedimientos y recursos complementarios :

Joriente es una serigrafía realizada en Martinica donde nos muestra en forma de historieta lo que el piensa y vive en ese momento en relación a la humanidad, al pueblo.

\section{Matriz}

Número de planchas : $\quad$ Se desconocen.

Material de las planchas : Se desconocen.

Datos complementarios :

No existen.

Estampación

En hueco

En relieve

Planigrafica

Permeografica

Papel

Marca : Se desconoce.

Gramaje : Se desconoce.

Color : $\quad$ Se desconoce.

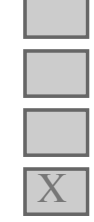

\section{Número de tintas :}

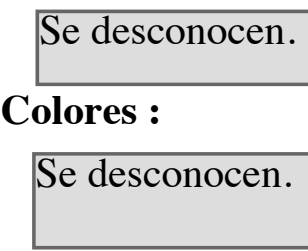

Colores :

Se desconocen. 


\section{Edición}

Número de ejemplares :

Tiraje indeterminado.

$\mathbf{N}^{\circ}$ de P.A. (Prueba de Artista): Se desconoce.

$\mathbf{N}^{\circ}$ de H.C. (Hors Commerce) : Se desconoce.

B.A.T.: $\quad$ Se desconoce.

Otras Pruebas : Se desconocen.

Taller en el que se realizó :

Edición en el taller Edouard Glissant en Martinica.

Estampador

Se desconoce.

Número de la estampa observada : Se desconoce.

$\begin{array}{llll}\text { Estampa observada directamente : } & \mathrm{Si} \\ \end{array} \quad$ No $\mathrm{X}$

$\begin{array}{llll}\text { Contemplada a través de reproducción : Si } & X \quad \text { No } X\end{array}$

Colección

Colección en la que se encuentra : Se desconoce.

Colección en la que se encuentra la plancha : Se desconoce.

Otras colecciones que tengan ejemplares de este trabajo : Se desconoce.

\section{Libros}

\section{Localización del libro o catalogo :}

"Matta, Index dell'opera grafica dal 1969 al 1980", editado por Admministrazione Provinciali di Viterbo en 1980, realizado por Germana Ferrari.

Pagina 34 bis.

\section{Otros catologos que lo contengan :}

Se desconoce.

Registros gráficos obtenidos

Diapositiva

Imagén digital 


\section{Obra grafica Roberto Sebastian Matta Echaurren}

Ficha número : $\quad 39$

Titulo de la obra : Les OH!! tomobiles.

Fecha de realización : 1972.

Dimensiones

Tamaño del papel : $51 \times 66 \mathrm{~cm}$.

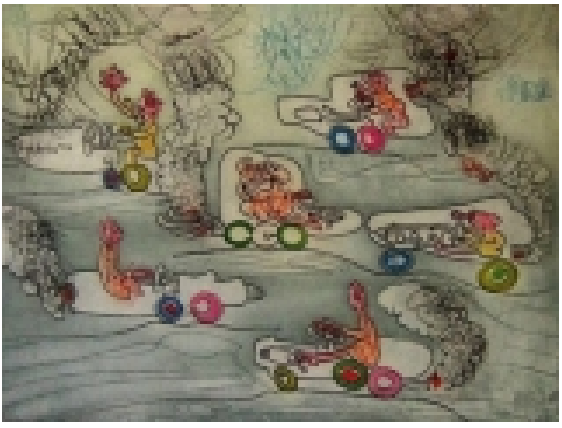

Tamaño de la mancha : 41.5 x $55 \mathrm{~cm}$.

\section{Técnica}

Técnica : Aguafuerte y Aguatinta.

\section{Procedimientos y recursos complementarios :}

Los OH tomobiles es un álbum compuesto por 10 grabados acompañados de un texto inédito de José Pierre. Es uno de los álbum mas completos de Matta, el tema elegido los autos y todo lo que puede suceder dentro y fuera de este vehiculo, es un álbum lleno de color, una explosión de movimientos y de formas dentro de un espacio que enriquece el movimiento de los autos.

El artista también realizo algunas de sus pinturas sobre el mismo tema.

\section{Matriz}

Número de planchas : Se desconoce.

Material de las planchas : Cobre.

Datos complementarios :

Uno de los álbum mas enriquecedores a nivel gestual, del trazo en libertad.

\section{Estampación}

En hueco

En relieve

Planigrafica

Permeografica

\section{Número de tintas :}

Se utilizaron 14 tintas.

\section{Colores :}

Verde, cafe, azul, rosado, fucsia, negro, gris, amarillo, ocres, rojo, celeste, beige, naranjo y violeta.

Papel

Marca : Papel Arches y Papel Japón Nacré.

Gramaje : 250 grm.

Color : Blanco. 


\section{Edición}

Número de ejemplares :

100 ejemplares sobre papel arches de tamaño 51 x 66 numerados y firmados del 1 al 100, mas XXV H.C. firmados y numerados del I al XXV.

100 ejemplares sobre papel Japón Nacré de tamaño 51 x 66 numerados y firmados del 1 al 100, mas XXV H.C. firmados y numerados del Ial XXV

Se presenta con un contenedor.

$\mathbf{N}^{\circ}$ de P.A. (Prueba de Artista): Se desconoce.

$\mathbf{N}^{\circ}$ de H.C. (Hors Commerce) : XXV H.C.

B.A.T.: $\quad$ Se desconoce.

Otras Pruebas : Se desconocen.

Taller en el que se realizó :

Atelier George Visat impresión y edición en Paris Francia.

\section{Estampador}

George Visat.

Número de la estampa observada : Se desconoce.

Estampa observada directamente :

$\mathrm{Si}$

No

Contemplada a través de reproducción :

$\begin{array}{lll}\mathrm{Si} & \mathrm{X} & \text { No }\end{array}$

\section{Colección}

Colección en la que se encuentra : Se desconoce.

Colección en la que se encuentra la plancha : Se desconoce.

Otras colecciones que tengan ejemplares de este trabajo :

Se desconocen. 

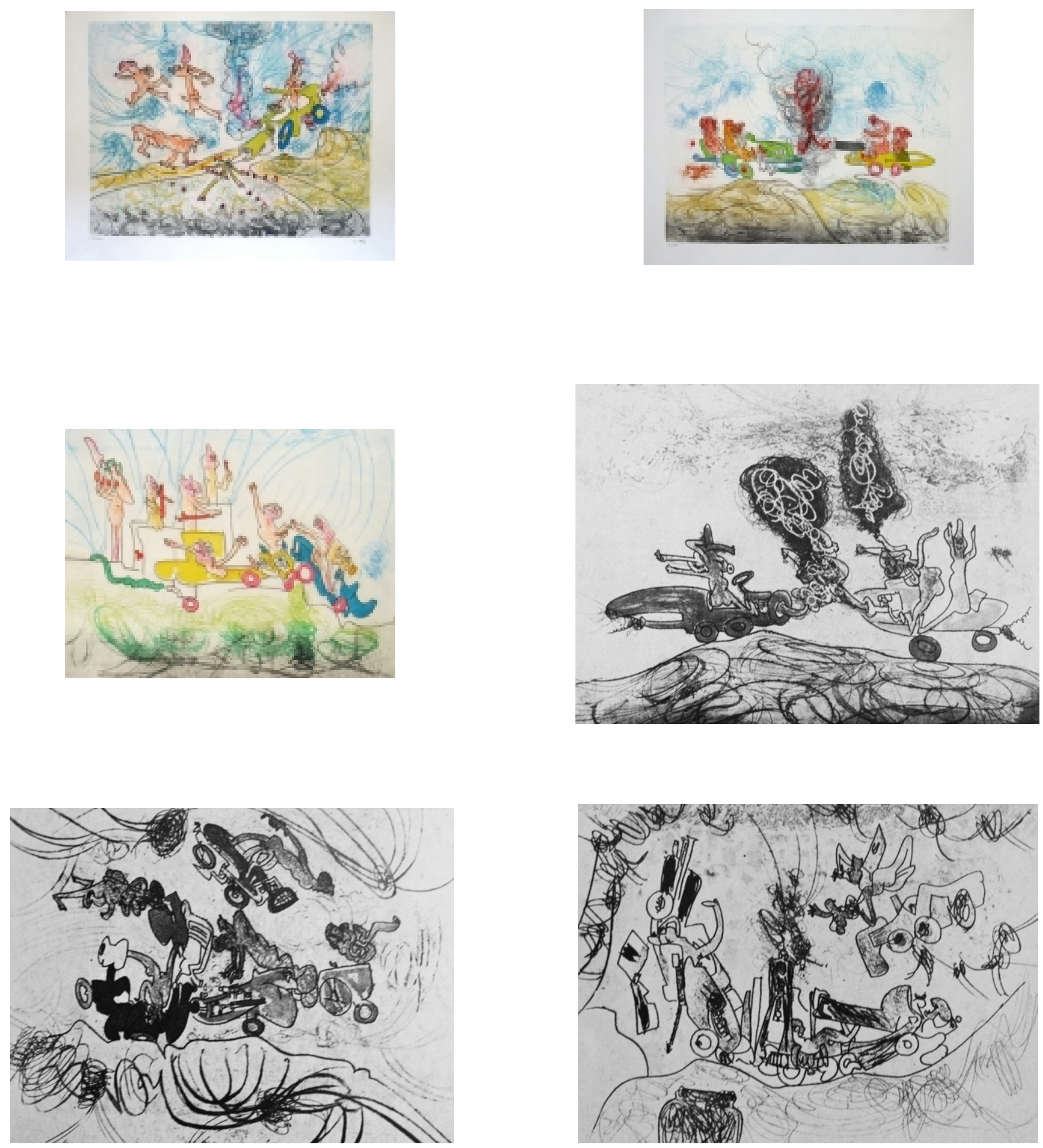

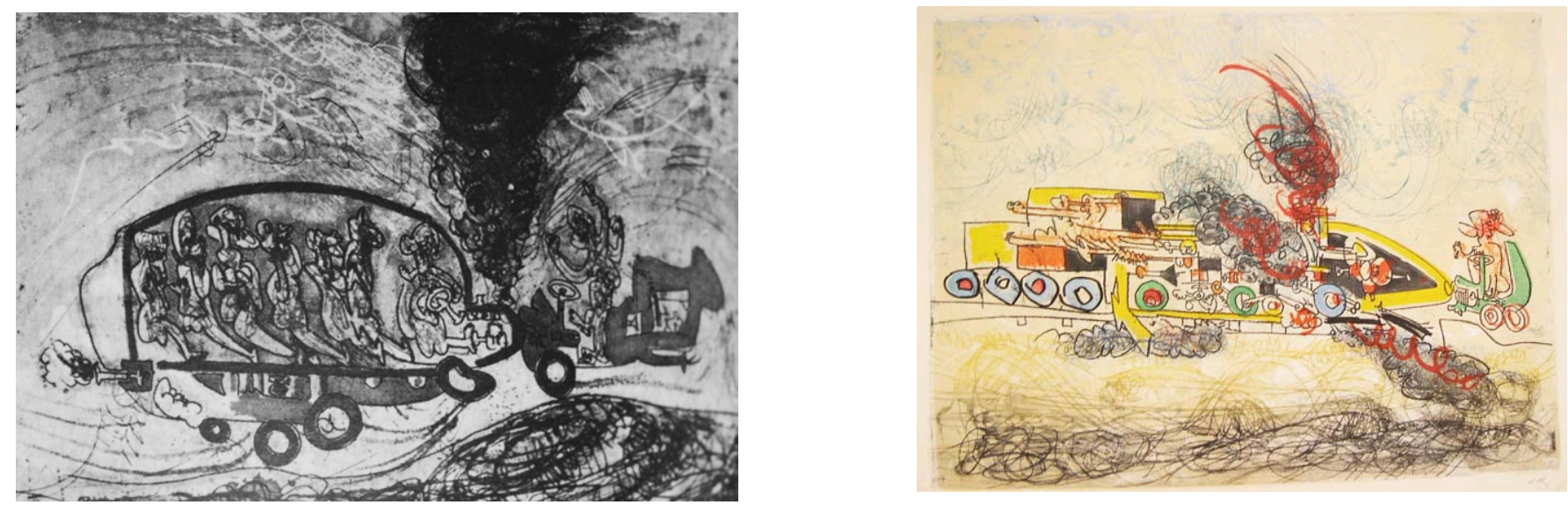

\section{Libros}

\section{Localización del libro o catalogo :}

"Matta, Index dell'opera grafica dal 1969 al 1980", editado por Admministrazione Provinciali di Viterbo en 1980, realizado por Germana Ferrari.

Pagina 60-69.

\section{Otros catologos que lo contengan :}

Se desconoce.

Registros gráficos obtenidos

Diapositiva

Imagén digital

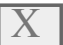




\section{Obra grafica Roberto Sebastian Matta Echaurren}

Ficha número : 40

Titulo de la obra : Morire per amore (Che Guevara).

Fecha de realización : 1973.

Dimensiones

Tamaño del papel : $200 \times 300 \mathrm{~cm} . / 69 \times 99 \mathrm{~cm}$.

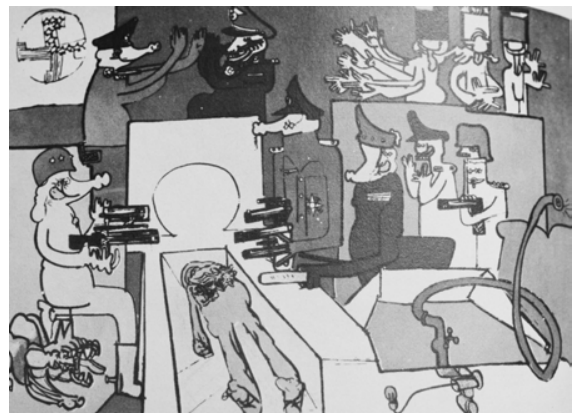

Tamaño de la mancha : 200 x $300 \mathrm{~cm} . / 66$ x $96 \mathrm{~cm}$.

\section{Técnica}

Técnica : Serigrafía.

\section{Procedimientos y recursos complementarios :}

Morire per amore (Che Guevara) son dos obras serigráficas impresas en dos formatos diferentes, uno sobre una tela de gran tamaño 200 x $300 \mathrm{~cm}$. y la segunda en formato carta 69 x $99 \mathrm{~cm}$.

Esta serigrafía muestra a el comandante Che Guevara dentro de su ataúd ya fallecido, a su alrededor lo acompañan solo militares jactándose de su muerte, riéndose, haciendo morisquetas y aplaudiendo a los costados del féretro. Una escena sin lugar a dudas dura y que refleja la postura del artista ante este horrible acontecimiento. Por ultimo los militares presentes poseen armas y en algunos de ellos sus rostros están ilustrados en formas de animales que se desfiguran.

\section{Matriz}

Número de planchas : $\quad$ Se desconoce.

Material de las planchas : Tela y Papel.

\section{Datos complementarios :}

Se desconocen.

\section{Estampación}

En hueco

En relieve

Planigrafica

Permeografica

Papel

Marca : $\quad$ No existe. Ya que esa tela y una carta.

Color : Blanco.

\section{Gramaje : No existe.}

Número de tintas :

Mas de seis tintas.
Colores :
Amarillo, naranja en diferentes tonalidades, cafe, negro, rojo, celeste-
turquesa y gris.

Color : Blanco. 


\section{Edición}

Número de ejemplares :

Serigrafía sobre tela: 16 ejemplares de tamaño 200 x 300 firmados y numerados del 1 al 16 .

Serigrafía sobre carta: 50 ejemplares sobre una carta tamaño 66 x 99 firmados y numerados del 1 al 50.

$\mathbf{N}^{\circ}$ de P.A. (Prueba de Artista) : Se desconoce.

$\mathbf{N}^{\circ}$ de H.C. (Hors Commerce) : Se desconoce.

B.A.T. : $\quad$ Se desconoce.

Otras Pruebas : Se desconocen.

Taller en el que se realizó :

Atelier de estampa Estudio Ammonite en Roma Italia, siendo la edicion privada.

Estampador

Se desconoce.

Número de la estampa observada : Se desconoce.

$\begin{array}{lll}\text { Estampa observada directamente : } & \mathrm{Si} \quad \mathrm{No} & \square\end{array}$

Contemplada a través de reproducción : $\mathrm{Si} X \quad$ No $\mathrm{X}$

Colección

Colección en la que se encuentra : Se desconoce.

Colección en la que se encuentra la plancha : Se desconoce.

Otras colecciones que tengan ejemplares de este trabajo : Se desconoce.

\section{Libros}

\section{Localización del libro o catalogo :}

"Matta, Index dell'opera grafica dal 1969 al 1980", editado por Admministrazione Provinciali di Viterbo en 1980, realizado por Germana Ferrari.

Pagina 70.

\section{Otros catologos que lo contengan :}

Se desconoce.

Registros gráficos obtenidos

Diapositiva

Imagén digital 


\section{Obra grafica Roberto Sebastian Matta Echaurren}

Ficha número : 41

Titulo de la obra : Il giudici di Norimberga.

Fecha de realización : 1973.

Dimensiones

Tamaño del papel : $62 \times 120 \mathrm{~cm}$.

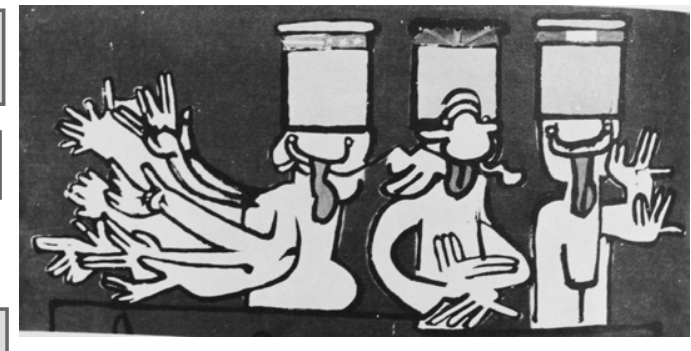

Tamaño de la mancha : $62 \times 120 \mathrm{~cm}$.

\section{Técnica}

Técnica : Serigrafía.

Procedimientos y recursos complementarios :

Il giudici di Norimberga es una serigrafía impresa sobre tela donde vemos tres personajes sacando su lengua riéndose y mostrándonos con sus manos diferentes señales y formas haciendo muecas.

La traducción de esta obra son "los jueves de Nuremberg" y es sobre el proceso realizado en Nuremberg a partir del año 1945 hasta el año 1946, donde se condeno a 21 nazis alemanes por haber cometido crímenes contra la paz, crímenes contra la humanidad y crímenes de guerra.

Quizás la obra de Matta de forma irónica se burla y se jacta de estos nazis que se creyeron con poder a todo, sin imaginar que serian procesados posteriormente.

\section{Matriz}

Número de planchas : Se desconoce.

Material de las planchas : Tela.

Datos complementarios :

Se desconoce.

\section{Estampación}

En hueco

En relieve

Planigrafica

Permeografica

Papel

Color : Blanco.

\section{Marca : No existe. \\ Gramaje : No existe.}

Número de tintas :

Se desconoce.
Colores :
Se desconoce.

Color : Blanco. 


\section{Edición}

Número de ejemplares :

30 ejemplares sobre tela firmados y numerados del 1 al 30 .

$\mathbf{N}^{\circ}$ de P.A. (Prueba de Artista) : No existe.

$\mathbf{N}^{\circ}$ de H.C. (Hors Commerce) : $\quad$ No existe.

B.A.T. : No existe.

Otras Pruebas : No existen.

Taller en el que se realizó :

Atelier de estampa Estudio Ammonite en Roma Italia, siendo la edición privada.

Estampador

Se desconoce.

Número de la estampa observada : Se desconoce.

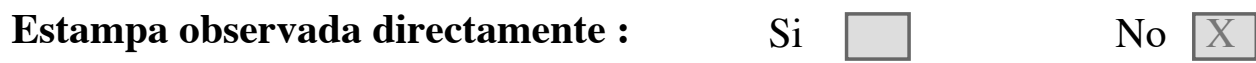

$\begin{array}{llll}\text { Contemplada a través de reproducción : Si } \quad \mathrm{X} & \text { No } \quad \mathrm{X}\end{array}$

Colección

Colección en la que se encuentra : Se desconoce.

Colección en la que se encuentra la plancha : Se desconoce.

Otras colecciones que tengan ejemplares de este trabajo : Se desconoce.

\section{Libros}

\section{Localización del libro o catalogo :}

"Matta, Index dell'opera grafica dal 1969 al 1980", editado por Admministrazione Provinciali di Viterbo en 1980, realizado por Germana Ferrari.

Pagina 71

\section{Otros catologos que lo contengan :}

Se desconoce.

Registros gráficos obtenidos

Diapositiva

Imagén digital 


\section{Obra grafica Roberto Sebastian Matta Echaurren}

Ficha número : 42

Titulo de la obra : De perro.

Fecha de realización : 1973.

Dimensiones

Tamaño del papel : $50 \times 70 \mathrm{~cm} / 50 \times 70 \mathrm{~cm}$.

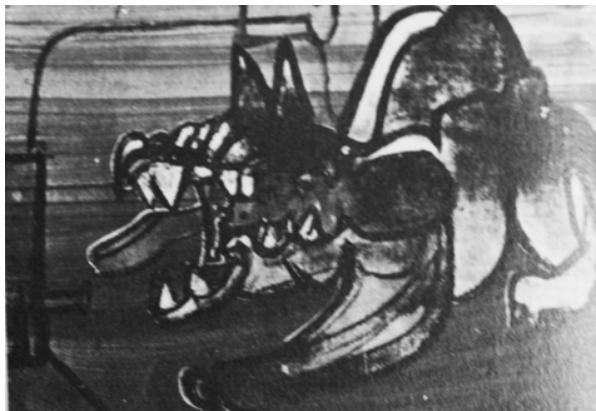

Tamaño de la mancha : $50 \times 70 \mathrm{~cm} / 50 \times 70 \mathrm{~cm}$.

\section{Técnica}

Técnica : Serigrafía.

Procedimientos y recursos complementarios :

De perro son dos obras serigráficas impresas en dos soportes diferentes, uno sobre una tela y la segunda en formato carta poseyendo ambas el mismo tamaño, donde se presenta un perro rabioso con el hocico abierto mostrando sus dientes, con la lengua afuera en posición de ataque, listo para lanzarse.

\section{Matriz}

Número de planchas : $\quad$ Se desconoce.

Material de las planchas : Tela / Papel.

Datos complementarios :

Se desconoce.

\section{Estampación}

En hueco

En relieve

Planigrafica

Permeografica

Papel

Marca : No existe.

Gramaje : Se desconoce.

Color : $\quad$ Se desconoce.
Número de tintas :

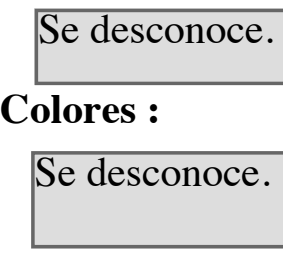




\section{Edición}

Número de ejemplares :

Serigrafía sobre tela de tamaño 50 x 70: 50 ejemplares firmados y numerados del 1 al 50 .

Serigrafía sobre carta de tamaño 50 x 70: 50 ejemplares firmados y numerados del 1 al 50.

$\mathbf{N}^{\circ}$ de P.A. (Prueba de Artista): No existe.

$\mathbf{N}^{\circ}$ de H.C. (Hors Commerce) : No existe.

B.A.T.: No existe.

Otras Pruebas : Se desconoce.

Taller en el que se realizó :

Atelier de estampa Estudio Ammonite en Roma Italia, siendo la edición privada.

Estampador

Se desconoce.

Número de la estampa observada : Se desconoce.

$\begin{array}{lll}\text { Estampa observada directamente : } & \mathrm{Si} \quad \mathrm{No} & \mathrm{X}\end{array}$

Contemplada a través de reproducción : $\mathrm{Si} X \quad$ No $\mathrm{X}$

Colección

Colección en la que se encuentra : Se desconoce.

Colección en la que se encuentra la plancha : Se desconoce.

Otras colecciones que tengan ejemplares de este trabajo : Se desconoce.

\section{Libros}

\section{Localización del libro o catalogo :}

"Matta, Index dell'opera grafica dal 1969 al 1980", editado por Admministrazione Provinciali di Viterbo en 1980, realizado por Germana Ferrari.

Pagina 72.

\section{Otros catologos que lo contengan :}

Se desconoce.

Registros gráficos obtenidos

Diapositiva

Imagén digital 


\section{Obra grafica Roberto Sebastian Matta Echaurren}

Ficha número : 43

Titulo de la obra : Azurosso.

Fecha de realización : 1973.

Dimensiones

Tamaño del papel : $70 \times 90 \mathrm{~cm}$.

Tamaño de la mancha : 80 × $65 \mathrm{~cm}$.

\section{Técnica}

Técnica : Serigrafía.

Procedimientos y recursos complementarios :

Azurosso es una serigrafía sobre tela donde se presenta un personaje femenino con un pájaro en la cabeza.

\section{Matriz}

Número de planchas : No existen.

Material de las planchas : Tela.

Datos complementarios :

Se desconoce.

Estampación

En hueco

En relieve

Planigrafica

Permeografica

Papel

Marca : No existen.

Gramaje : No existen.

Color : No existen.

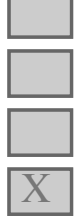

Número de tintas :

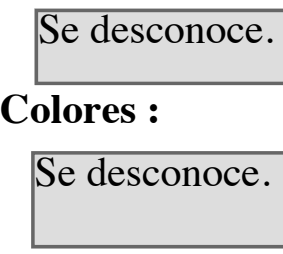

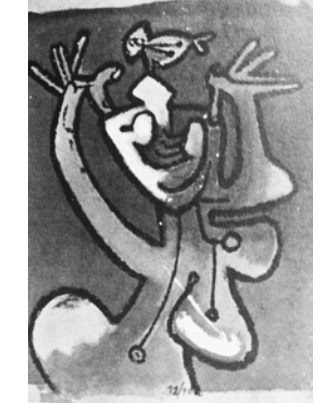




\section{Edición}

Número de ejemplares :

Serigrafía sobre tela de la cual existen 40 ejemplares numerados y firmados del 1 al 40.

$\mathbf{N}^{\circ}$ de P.A. (Prueba de Artista): Se desconoce.

$\mathbf{N}^{\circ}$ de H.C. (Hors Commerce) : Se desconoce.

B.A.T.: $\quad$ Se desconoce.

Otras Pruebas : Se desconoce.

Taller en el que se realizó :

Atelier de estampa Estudio Ammonite en Roma Italia, siendo la edición privada.

Estampador

Se desconoce.

Número de la estampa observada : $12 / 40$

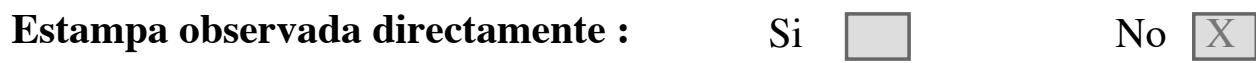

$\begin{array}{llll}\text { Contemplada a través de reproducción : Si } & \mathrm{X} \quad \text { No } & \mathrm{X}\end{array}$

Colección

Colección en la que se encuentra : Se desconoce.

Colección en la que se encuentra la plancha : Se desconoce.

Otras colecciones que tengan ejemplares de este trabajo : Se desconoce.

\section{Libros}

\section{Localización del libro o catalogo :}

"Matta, Index dell'opera grafica dal 1969 al 1980", editado por Admministrazione Provinciali di Viterbo en 1980, realizado por Germana Ferrari.

Pagina 73.

\section{Otros catologos que lo contengan :}

Se desconoce.

Registros gráficos obtenidos

Diapositiva

Imagén digital 


\section{Obra grafica Roberto Sebastian Matta Echaurren}

Ficha número : 44

Titulo de la obra : Uomo senza qualita.

Fecha de realización : 1973

Dimensiones

Tamaño del papel : $65 \times 60 \mathrm{~cm}$.

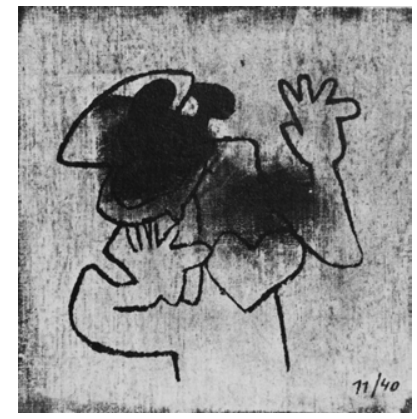

Tamaño de la mancha : $62 \times 50 \mathrm{~cm}$.

\section{Técnica}

Técnica : Serigrafía.

Procedimientos y recursos complementarios :

Uomo senza qualita es una serigrafía con un personaje central con dos grandes manchas y un corazón grande, sus brazos parecen defenderse a un ataque.

\section{Matriz}

Número de planchas : Se desconoce.

Material de las planchas : Tela

Datos complementarios :

Se desconoce.

\section{Estampación}

En hueco

En relieve

Planigrafica

Permeografica

Papel

Marca : No existe.

Gramaje : No existe.

Color : No existe.
Número de tintas :

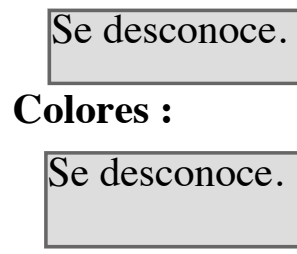




\section{Edición}

Número de ejemplares :

Serigrafía sobre tela tamaño 60 x 65, de la cual existen 40 ejemplares numerados y firmados del 1 al 40 .

$\mathbf{N}^{\circ}$ de P.A. (Prueba de Artista) : Se desconoce.

$\mathbf{N}^{\circ}$ de H.C. (Hors Commerce) : Se desconoce.

B.A.T. : Se desconoce.

Otras Pruebas : Se desconoce.

Taller en el que se realizó :

Atelier de estampa Estudio Ammonite en Roma Italia, siendo la edición privada.

Estampador

Se desconoce.

Número de la estampa observada : $11 / 40$

Estampa observada directamente :

$\mathrm{Si}$

No $\mathrm{X}$

Contemplada a través de reproducción : $\mathrm{Si} X$

No $\mathrm{X}$

Colección

Colección en la que se encuentra : Se desconoce.

Colección en la que se encuentra la plancha : Se desconoce.

Otras colecciones que tengan ejemplares de este trabajo : Se desconoce.

\section{Libros}

\section{Localización del libro o catalogo :}

"Matta, Index dell'opera grafica dal 1969 al 1980", editado por Admministrazione Provinciali di Viterbo en 1980, realizado por Germana Ferrari.

Pagina 74.

\section{Otros catologos que lo contengan :}

Se desconoce.

Registros gráficos obtenidos Diapositiva $\square$ Imagén digital $\mathrm{X}$ 


\section{Obra grafica Roberto Sebastian Matta Echaurren}

Ficha número : 45

Titulo de la obra : Delizio.

Fecha de realización : 1973.

Dimensiones

Tamaño del papel : $60 \times 65 \mathrm{~cm}$.

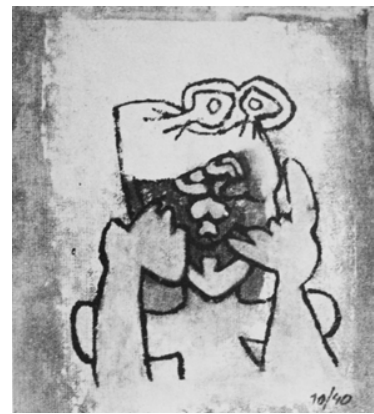

Tamaño de la mancha : 45 x $60 \mathrm{~cm}$.

\section{Técnica}

Técnica : Serigrafía.

Procedimientos y recursos complementarios :

Delizio es una serigrafía sobre tela donde un personaje central y en plano central nos hace una morisqueta sacando su lengua.

\section{Matriz}

Número de planchas : No existen.

Material de las planchas : Tela

Datos complementarios :

La tela elegida para el desarrollo de esta obra es el yute (jute).

Estampación

En hueco

En relieve

Planigrafica

Permeografica

Papel

Marca : No existe.

Gramaje : No existe.

Color : No existe.

\section{Número de tintas :}

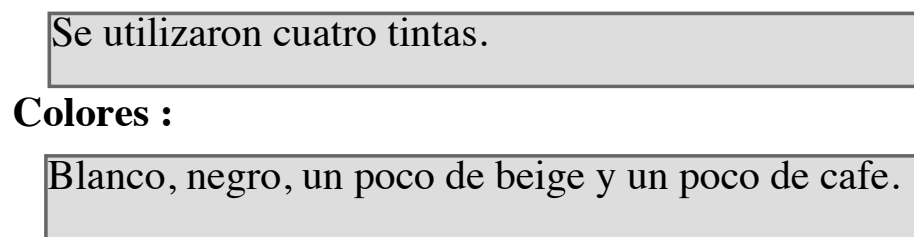




\section{Edición}

Número de ejemplares :

Serigrafía sobre tela, de la cual existen 40 ejemplares numerados y firmados del 1 al 40 .

$\mathbf{N}^{\circ}$ de P.A. (Prueba de Artista) : Se desconoce.

$\mathbf{N}^{\circ}$ de H.C. (Hors Commerce) : Se desconoce.

B.A.T. : $\quad$ Se desconoce.

Otras Pruebas : Se desconoce.

Taller en el que se realizó :

Atelier de estampa Estudio Ammonite en Roma Italia, siendo la edición privada.

Estampador

Se desconoce.

Número de la estampa observada : $10 / 40$

Estampa observada directamente : $\quad$ Si

$\begin{array}{llll}\text { Contemplada a través de reproducción : } & \mathrm{Si} & \mathrm{X} & \text { No }\end{array}$

Colección

Colección en la que se encuentra : Se desconoce.

Colección en la que se encuentra la plancha : Se desconoce.

Otras colecciones que tengan ejemplares de este trabajo : Se desconoce.

\section{Libros}

\section{Localización del libro o catalogo :}

"Matta, Index dell'opera grafica dal 1969 al 1980", editado por Admministrazione Provinciali di Viterbo en 1980, realizado por Germana Ferrari.

Pagina 75.

\section{Otros catologos que lo contengan :}

Se desconoce.

Registros gráficos obtenidos

Diapositiva

Imagén digital 


\section{Obra grafica Roberto Sebastian Matta Echaurren}

Ficha número : 46

Titulo de la obra : L`Ultima cena.

Fecha de realización : 1973.

Dimensiones

Tamaño del papel : $100 \times 300 \mathrm{~cm}$.

Tamaño de la mancha : $100 \times 300 \mathrm{~cm}$.

\section{Técnica}

Técnica : Serigrafía.

Procedimientos y recursos complementarios :

L`Ultima cena es una serigrafía que trata sobre la ultima cena de Jesucristo, lleno de personajes con variados movimientos.

Matriz

Número de planchas : No existen.

Material de las planchas : Tela.

Datos complementarios :

Se desconoce.

Estampación

Número de tintas :

En hueco

En relieve

Planigrafica

Permeografica

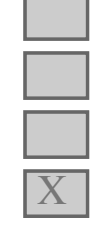

Se desconoce.

Colores :

Se desconoce.

Papel

Marca : No existen.

Gramaje : No existen.

Color : No existen. 


\section{Edición}

Número de ejemplares :

Serigrafía sobre tela de la cual existen 20 ejemplares numerados y firmados del 1 al 20.

$\mathbf{N}^{\circ}$ de P.A. (Prueba de Artista): Se desconoce.

$\mathbf{N}^{\circ}$ de H.C. (Hors Commerce) : Se desconoce.

B.A.T.: $\quad$ Se desconoce.

Otras Pruebas : Se desconoce.

Taller en el que se realizó :

Atelier de estampa Estudio Ammonite en Roma Italia, siendo la edición privada.

Estampador

Se desconoce.

Número de la estampa observada : Se desconoce.

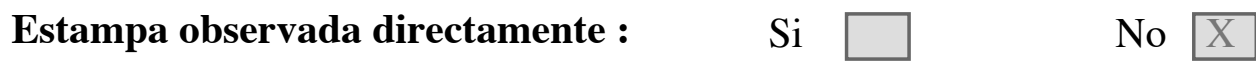

Contemplada a través de reproducción : Si $X \quad$ No $X$

Colección

Colección en la que se encuentra : Se desconoce.

Colección en la que se encuentra la plancha : Se desconoce.

Otras colecciones que tengan ejemplares de este trabajo : Se desconoce.

\section{Libros}

\section{Localización del libro o catalogo :}

"Matta, Index dell'opera grafica dal 1969 al 1980", editado por Admministrazione Provinciali di Viterbo en 1980, realizado por Germana Ferrari.

Pagina 76.

\section{Otros catologos que lo contengan :}

Se desconoce.

Registros gráficos obtenidos

Diapositiva

Imagén digital 


\section{Obra grafica Roberto Sebastian Matta Echaurren}

Ficha número : 47

Titulo de la obra : Fumetto.

Fecha de realización : 1973

Dimensiones

Tamaño del papel : $50 \times 70 \mathrm{~cm}$.

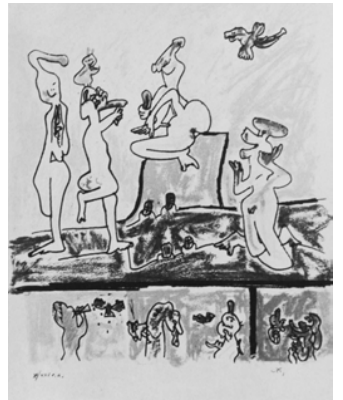

Tamaño de la mancha : 56 x $50 \mathrm{~cm}$.

\section{Técnica}

Técnica : Litografía.

Procedimientos y recursos complementarios :

Se desconoce.

\section{Matriz}

Número de planchas : $\quad$ Se desconoce.

Material de las planchas : Piedra.

Datos complementarios :

Se desconoce.

Estampación

En hueco

En relieve

Planigrafica

Permeografica

Papel

Marca : Papel Arches.

Gramaje : Se desconoce.

Color : Blanco.
Número de tintas :

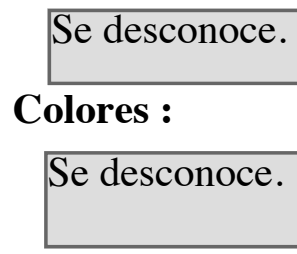




\section{Edición}

Número de ejemplares :

99 ejemplares firmados y numerados sobre carta, sobre papel tamaño 50 x $70 \mathrm{~cm}$. mas XXV P.A. firmados y numerados del I al XXV.

$\mathbf{N}^{\circ}$ de P.A. (Prueba de Artista) : Se desconoce.

$\mathbf{N}^{\circ}$ de H.C. (Hors Commerce) : Se desconoce.

B.A.T. : $\quad$ Se desconoce.

Otras Pruebas : Se desconoce.

Taller en el que se realizó :

Se desconoce. Edición privada.

Estampador

Se desconoce.

Número de la estampa observada : X/XXV E.A.

\begin{tabular}{llll} 
Estampa observada directamente : & $\mathrm{Si}$ & $\square$ & No \\
\hline
\end{tabular}

Contemplada a través de reproducción : $\mathrm{Si} X$ No $\mathrm{X}$

Colección

Colección en la que se encuentra : Se desconoce.

Colección en la que se encuentra la plancha : Se desconoce.

Otras colecciones que tengan ejemplares de este trabajo : Se desconoce.

\section{Libros}

\section{Localización del libro o catalogo :}

"Matta, Index dell'opera grafica dal 1969 al 1980", editado por Admministrazione Provinciali di Viterbo en 1980, realizado por Germana Ferrari.

Pagina 77

\section{Otros catologos que lo contengan :}

Se desconoce.

Registros gráficos obtenidos

Diapositiva

Imagén digital 


\section{Obra grafica Roberto Sebastian Matta Echaurren}

Ficha número : 48

Titulo de la obra : Chateau situationiste.

Fecha de realización : 1973.

Dimensiones

Tamaño del papel : $54 \times 75 \mathrm{~cm}$.

Tamaño de la mancha : 39 x $62 \mathrm{~cm}$.

\section{Técnica}

Técnica : Litografía.

Procedimientos y recursos complementarios :

Chateau situationiste es una litografía perteneciente al álbum de homenaje "Pour Jorn", hacia el artista Asger Jorn muerto en el año 1973 y creador del grupo COBRA y de la INTERNACIONAL SITUCIONISTA.

Este álbum contiene 14 litografías a color, realizadas por 14 artistas entre ellos Roberto Matta, Wilfredo Lam, Pierre Alechinsky y Henri Michaux.

\section{Matriz}

Número de planchas : $\quad$ Se desconoce.

Material de las planchas : Piedra.

Datos complementarios :

Se desconoce.

Estampación

En hueco

En relieve

Planigrafica

Permeografica

Papel

Marca : Papel Arches.

Gramaje : Se desconoce.

Color : Blanco.
Número de tintas :

Se utilizaron alrededor de 5 tintas.
Colores :
Negro, rojo, beige, naranjo, y celeste turquesa.




\section{Edición}

Número de ejemplares :

99 ejemplares sobre papel Arches, firmado y numerado del 1 al 99 mas XXV H.C. firmados y numerados del I al XXV. En algunas publicaciones se menciona que esta litografía posee un tiraje de 100 ejemplares.

$\mathbf{N}^{\circ}$ de P.A. (Prueba de Artista) : Se desconoce.

$\mathbf{N}^{\circ}$ de H.C. (Hors Commerce) : XXV H.C.

B.A.T. : $\quad$ Se desconoce.

Otras Pruebas : Se desconoce.

Taller en el que se realizó :

Atelier de Fernand Mourlot Paris Francia y la edición en el museo de Silkeborg.

Estampador

Fernand Mourlot- Frank Bordas.

Número de la estampa observada : Se desconoce.

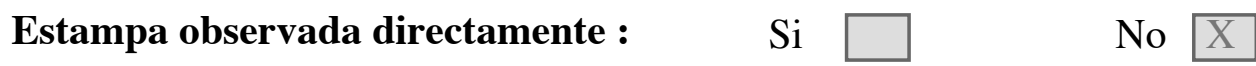

Contemplada a través de reproducción : $\mathrm{Si} X \quad$ No $\mathrm{X}$

Colección

Colección en la que se encuentra : Se desconoce.

Colección en la que se encuentra la plancha : Se desconoce.

Otras colecciones que tengan ejemplares de este trabajo : Se desconoce.

\section{Libros}

\section{Localización del libro o catalogo :}

"Matta, Index dell'opera grafica dal 1969 al 1980", editado por Admministrazione Provinciali di Viterbo en 1980, realizado por Germana Ferrari.

Pagina 81

\section{Otros catologos que lo contengan :}

Se desconoce.

Registros gráficos obtenidos

Diapositiva

Imagén digital 


\section{Obra grafica Roberto Sebastian Matta Echaurren}

Ficha número : 49

Titulo de la obra : $\mathrm{OH}$ ! l’as de pique.

Fecha de realización : 1974.

Dimensiones

Tamaño del papel : Se desconoce.

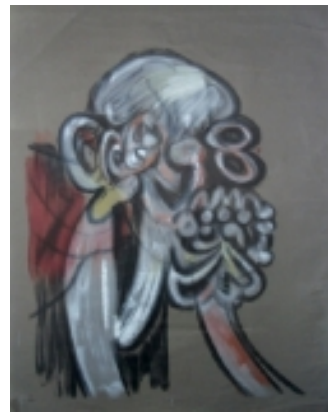

Tamaño de la mancha : 65 x $50 \mathrm{~cm}$.

\section{Técnica}

Técnica : Litografia.

Procedimientos y recursos complementarios :

$\mathrm{OH}$ ! I as de pique es un homenaje realizado por Roberto Matta para el artista Pablo Picasso cuando cumplió noventa años.

\section{Matriz}

Número de planchas : $\quad$ Se desconoce.

Material de las planchas : Piedra.

\section{Datos complementarios :}

Se desconoce.

\section{Estampación}

En hueco

En relieve

Planigrafica

Permeografica

Número de tintas :

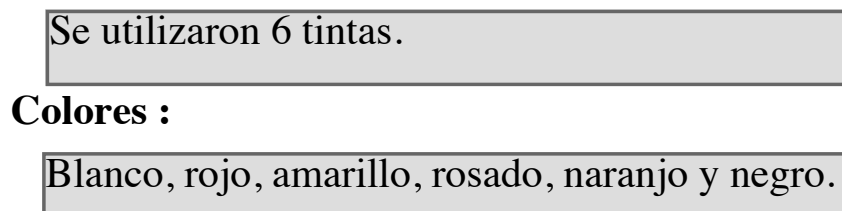

Papel

Marca : Papel Canson grigia.

Gramaje : Se desconoce.

Color : Marron grisacio. 


\section{Edición}

Número de ejemplares :

125 ejemplares sobre canson firmados y numerados del 1 al 125 mas XXV P.A. firmadas pero no numeradas.

$\mathbf{N}^{\circ}$ de P.A. (Prueba de Artista) : XXV P.A.

$\mathbf{N}^{\circ}$ de H.C. (Hors Commerce) : Se desconoce.

B.A.T. : Se desconoce.

Otras Pruebas : Se desconoce.

Taller en el que se realizó :

Atelier Fernand Mourlot en Paris Francia y la edición fue privada en Paris.

Estampador

Fernand Mourlot

Número de la estampa observada : Se desconoce.

Estampa observada directamente : $\mathrm{Si} X$

No

Contemplada a través de reproducción : $\mathrm{Si} X$

No

Colección

Colección en la que se encuentra : Se desconoce.

Colección en la que se encuentra la plancha : Se desconoce.

Otras colecciones que tengan ejemplares de este trabajo : Se desconoce.

\section{Libros}

\section{Localización del libro o catalogo :}

"Matta, Index dell'opera grafica dal 1969 al 1980", editado por Admministrazione Provinciali di Viterbo en 1980, realizado por Germana Ferrari.

Pagina 82.

\section{Otros catologos que lo contengan :}

Se desconoce.

Registros gráficos obtenidos Diapositiva $\square$ Imagén digital 


\section{Obra grafica Roberto Sebastian Matta Echaurren}

Ficha número : 50

Titulo de la obra : Architetre.

Fecha de realización : 1974.

Dimensiones

Tamaño del papel : $56 \times 71 \mathrm{~cm}$.

Tamaño de la mancha : 49 x $65 \mathrm{~cm}$.

\section{Técnica}

Técnica : Litografía.

Procedimientos y recursos complementarios :

Architetre es una litografía bastante inusual en el mundo grafico de Matta es una obra donde nos presenta un paisaje arquitectónico con influencias romanas, presentándonos una rigidez pocas veces existente en su obra.

\section{Matriz}

Número de planchas : $\quad$ Se desconoce.

Material de las planchas : Piedra.

Datos complementarios :

Se desconoce.

\section{Estampación}

En hueco

En relieve

Planigrafica

Permeografica

Papel
Número de tintas :

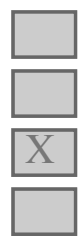

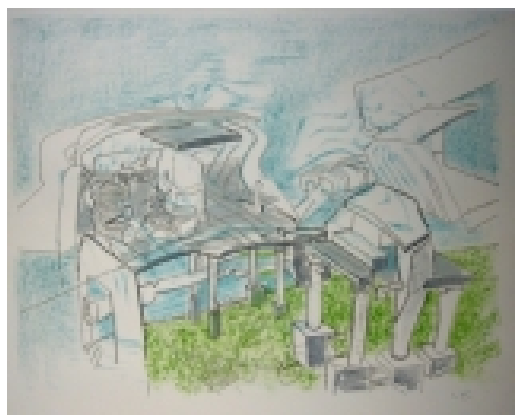

$49 \times 105$. 


\section{Edición}

Número de ejemplares :

50 ejemplares sobre papel Arches firmados y numerados del 1 al 50 mas XXV

H.C. firmado y numerado del I al XXV.

$\mathbf{N}^{\circ}$ de P.A. (Prueba de Artista) : Se desconoce.

$\mathbf{N}^{\circ}$ de H.C. (Hors Commerce) : Se desconoce.

B.A.T. : $\quad$ Se desconoce.

Otras Pruebas : Se desconoce.

Taller en el que se realizó :

Atelier Fernand Mourlot en Paris Francia y la edición fue realizada en Kessner-Gesellschaft, Hannover Alemania.

Estampador

Fernand Mourlot.

Número de la estampa observada : Se desconoce.

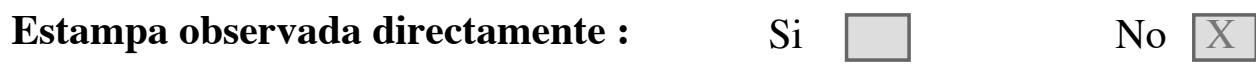

Contemplada a través de reproducción : $\mathrm{Si} X \quad$ No $\mathrm{X}$

Colección

Colección en la que se encuentra : Se desconoce.

Colección en la que se encuentra la plancha : Se desconoce.

Otras colecciones que tengan ejemplares de este trabajo : Se desconoce.

\section{Libros}

\section{Localización del libro o catalogo :}

"Matta, Index dell'opera grafica dal 1969 al 1980", editado por Admministrazione Provinciali di Viterbo en 1980, realizado por Germana Ferrari.

Pagina 87.

\section{Otros catologos que lo contengan :}

Se desconoce.

Registros gráficos obtenidos Diapositiva $\quad \square \quad$ Imagén digital $\quad X$ 


\section{Obra grafica Roberto Sebastian Matta Echaurren}

Ficha número : 51

Titulo de la obra : Baden -Baden (bad, worst, often).

Fecha de realización : 1974.

Dimensiones

Tamaño del papel : $56 \times 71 \mathrm{~cm}$.

Tamaño de la mancha : 49 x $65 \mathrm{~cm}$.

\section{Técnica}

Técnica : Litografía.

Procedimientos y recursos complementarios :

No se posee información sobre esta obra.

\section{Matriz}

Número de planchas : $\quad$ Se desconoce.

Material de las planchas : Piedra.

Datos complementarios :

Se desconoce.

\section{Estampación}

En hueco

En relieve

Planigrafica

Permeografica

Papel

Marca : Papel Arches.

Gramaje : Se desconoce.

Color : Blanco.
Número de tintas :

Se utilizaron 7 tintas.
Colores :
Amarillo, gris, celeste, naranjo, beige, rosado, ocre.

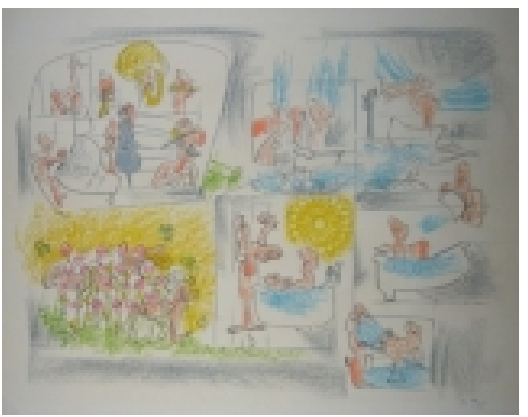




\section{Edición}

Número de ejemplares :

50 ejemplares sobre papel Arches los que están numerados y firmados del

1 al 50 mas XXV H.C. firmados y numerados del I al XXV.

$\mathbf{N}^{\circ}$ de P.A. (Prueba de Artista) : Se desconoce.

$\mathbf{N}^{\circ}$ de H.C. (Hors Commerce) : Se desconoce.

B.A.T. : $\quad$ Se desconoce.

Otras Pruebas : Se desconoce.

Taller en el que se realizó :

Atelier Fernand Mourlot en Paris Francia y la edición fue realizada en Kessner-Gesellschaft, Hannover Alemania.

Estampador

Fernand Mourlot.

Número de la estampa observada : Se desconoce.

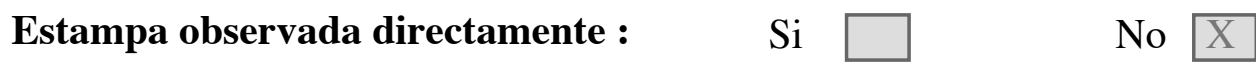

Contemplada a través de reproducción : $\mathrm{Si} X \quad$ No $\mathrm{X}$

Colección

Colección en la que se encuentra : Se desconoce.

Colección en la que se encuentra la plancha : Se desconoce.

Otras colecciones que tengan ejemplares de este trabajo : Se desconoce.

\section{Libros}

\section{Localización del libro o catalogo :}

"Matta, Index dell'opera grafica dal 1969 al 1980", editado por Admministrazione Provinciali di Viterbo en 1980, realizado por Germana Ferrari.

Pagina 98.

\section{Otros catologos que lo contengan :}

Se desconoce.

Registros gráficos obtenidos

Diapositiva

Imagén digital 


\section{Obra grafica Roberto Sebastian Matta Echaurren}

Ficha número : 52

Titulo de la obra : Per Giovanni Marini.

(dimentica di esse un uomo)

Fecha de realización : 1974

Dimensiones

Tamaño del papel : $\quad 50 \times 70 \mathrm{~cm}$.

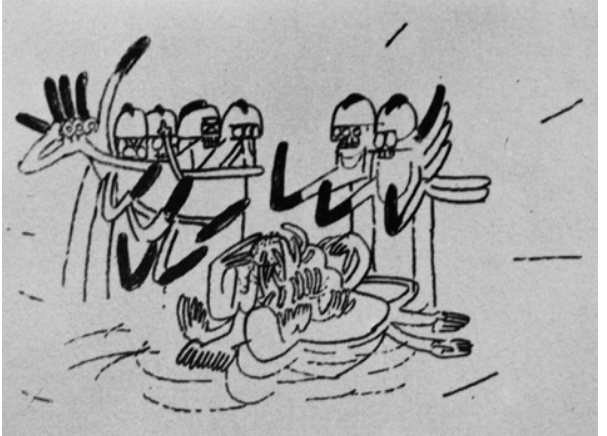

Tamaño de la mancha : $23 \times 28 \mathrm{~cm}$.

Técnica

Técnica : Litografía.

Procedimientos y recursos complementarios :

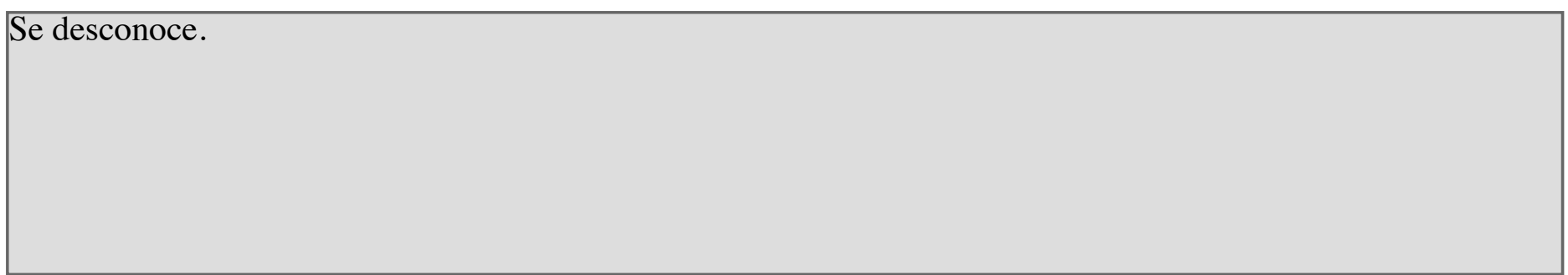

Matriz

Número de planchas : Se desconoce.

Material de las planchas : Piedra.

Datos complementarios :

Se desconoce.

Estampación

En hueco

En relieve

Planigrafica

Permeografica

Número de tintas :

Una sola tinta.

Colores :

Negro.

Papel

Marca : Papel Arches.

Gramaje : Se desconoce. 
Color : $\quad$ Blanco.

Edición

Número de ejemplares :

100 ejemplares sobre papel Arches, firmado y numerado del 1 al 100.

$\mathbf{N}^{\circ}$ de P.A. (Prueba de Artista) : Se desconoce.

$\mathbf{N}^{\circ}$ de H.C. (Hors Commerce) : Se desconoce.

B.A.T. : $\quad$ Se desconoce.

Otras Pruebas : Se desconoce.

Taller en el que se realizó :

Edicion Dario Fo en Milan Italia.

Estampador

Se desconoce.

Número de la estampa observada : 
Estampa observada directamente :

Contemplada a través de reproducción :
$\mathrm{Si}$

$\mathrm{Si}$

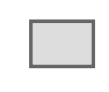

$\mathrm{X}$
No

No

\section{Colección}

Colección en la que se encuentra : Se desconoce.

Colección en la que se encuentra la plancha : Se desconoce.

Otras colecciones que tengan ejemplares de este trabajo :

Se desconoce.
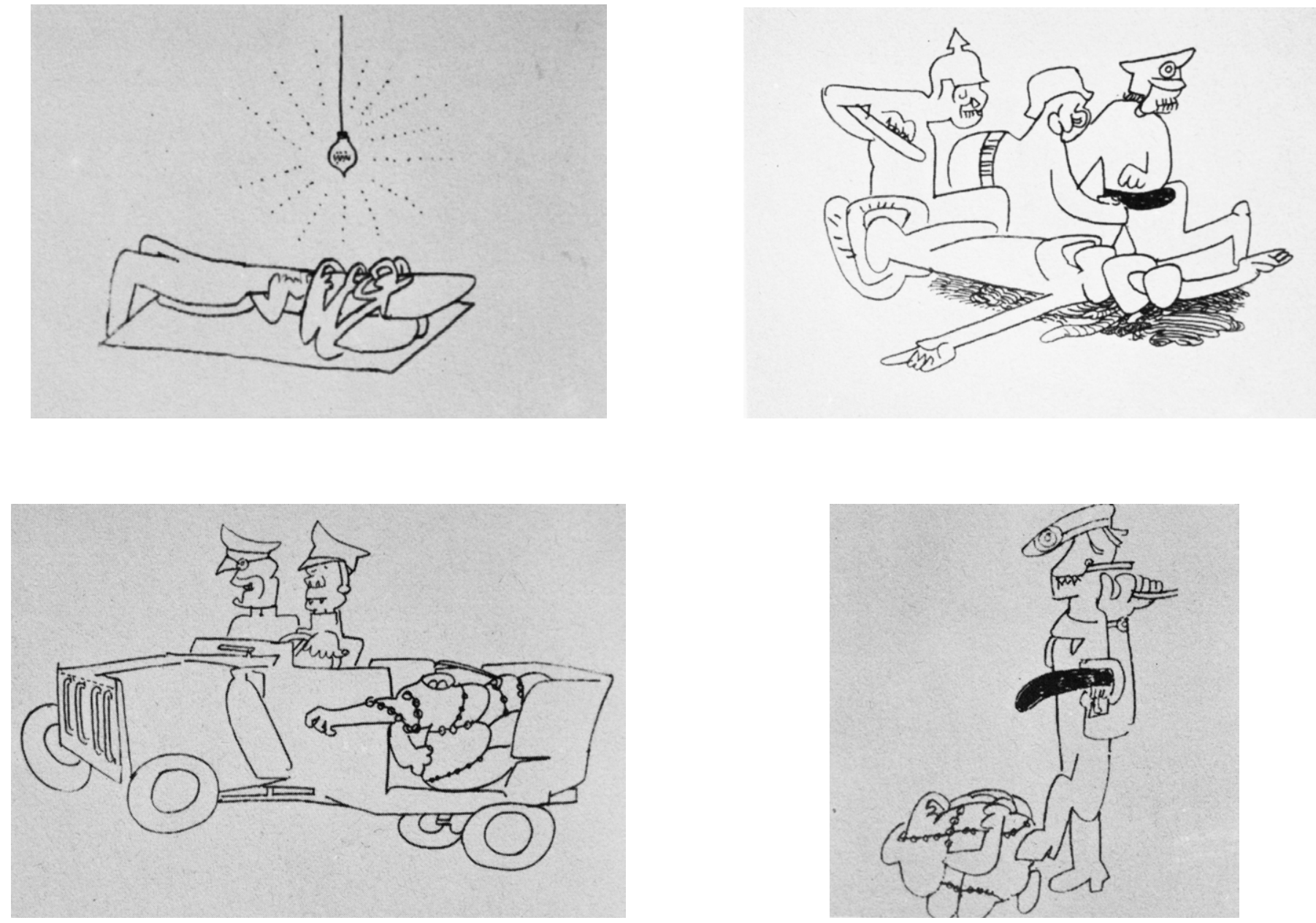

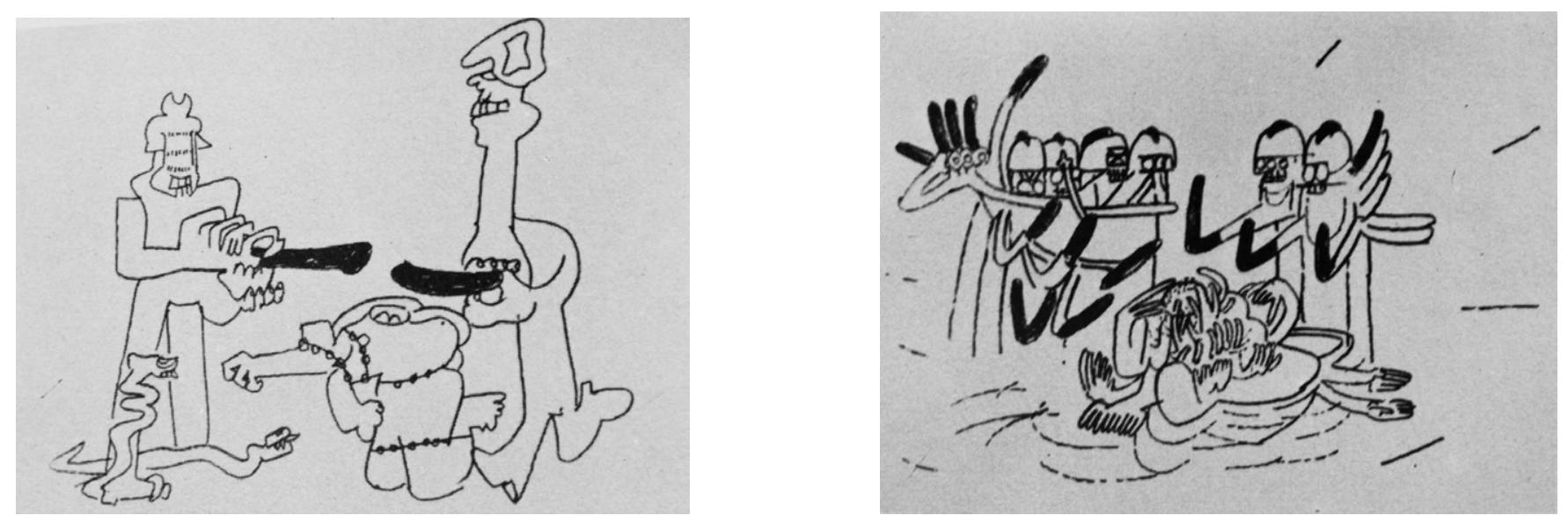

\section{Libros}

\section{Localización del libro o catalogo :}

"Matta, Index dell'opera grafica dal 1969 al 1980", editado por Admministrazione Provinciali di Viterbo en 1980, realizado por Germana Ferrari.

Pagina 99-100.

\section{Otros catologos que lo contengan :}

Se desconoce.

Registros gráficos obtenidos Diapositiva

Imagén digital $\mathrm{X}$ 


\section{Obra grafica Roberto Sebastian Matta Echaurren}

Ficha número : 53

Titulo de la obra : L’Arc Obscur des heures.

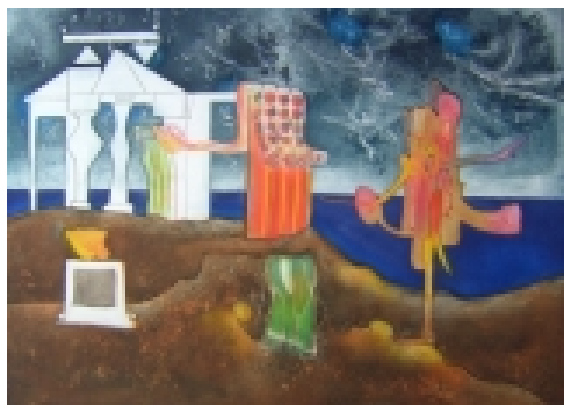

Tamaño del papel : $\quad 90 \times 120 \mathrm{~cm}$.

Tamaño de la mancha : $46 \times 68 \mathrm{~cm}$.

\section{Técnica}

Técnica : Aguafuerte.

Procedimientos y recursos complementarios :

L `Arc Obscur des heures es un álbum de 10 aguafuertes a color y cada una tiene el titulo de un horario preciso comenzando desde las 2 a.m. hasta las 12 p.m. Nos presenta un paisaje que cambia su atmósfera en relación a el horario, un paisaje donde se encuentran edificaciones romanas, y basando este trabajo en un escrito de Heráclito.

\section{Matriz}

Número de planchas : $\quad$ Se desconoce.

Material de las planchas : Cobre.

Datos complementarios :

Se desconoce.

\section{Estampación}

En hueco

En relieve

Planigrafica

Permeografica

Número de tintas :

Se utilizaron alrededor de 11 tintas.

\section{Colores :}

Negro, azul, cafes, beige, verde, amarillo, rosado, naranjo, ocre, grises y violeta.

Papel

Marca : Papel Arches y Papel Japón Nacré.

Gramaje : Se desconoce.

Color : Blanco. 


\section{Edición}

Número de ejemplares :

100 ejemplares sobre papel Arches de tamaño 90 x 120 firmados y numerados del 1 al 100 mas XXV H.C. firmados y numerados del I al XXV.

100 ejemplares sobre papel Japón Nacré de tamaño 90 x 120 firmados y numerados del 1 al 100 mas XXV H. C. firmados y numerados del I al XXV.

Ambas series poseen un contenedor.

$\mathbf{N}^{\circ}$ de P.A. (Prueba de Artista): Se desconoce.

$\mathbf{N}^{\circ}$ de H.C. (Hors Commerce) : Se desconoce.

B.A.T.: $\quad$ Se desconoce.

Otras Pruebas : Se desconoce.

Taller en el que se realizó :

Atelier George Visat en Paris y la Edición en Multiplicata S.A. en Chiasso.

\section{Estampador}

No se sabe si fue George Visat o Albert Dupont.

Número de la estampa observada : Se desconoce.

Estampa observada directamente :

$\mathrm{Si}$

No

Contemplada a través de reproducción :

$\mathrm{Si}$

No

\section{Colección}

Colección en la que se encuentra : Se desconoce.

Colección en la que se encuentra la plancha : Se desconoce.

Otras colecciones que tengan ejemplares de este trabajo :

Se desconoce. 

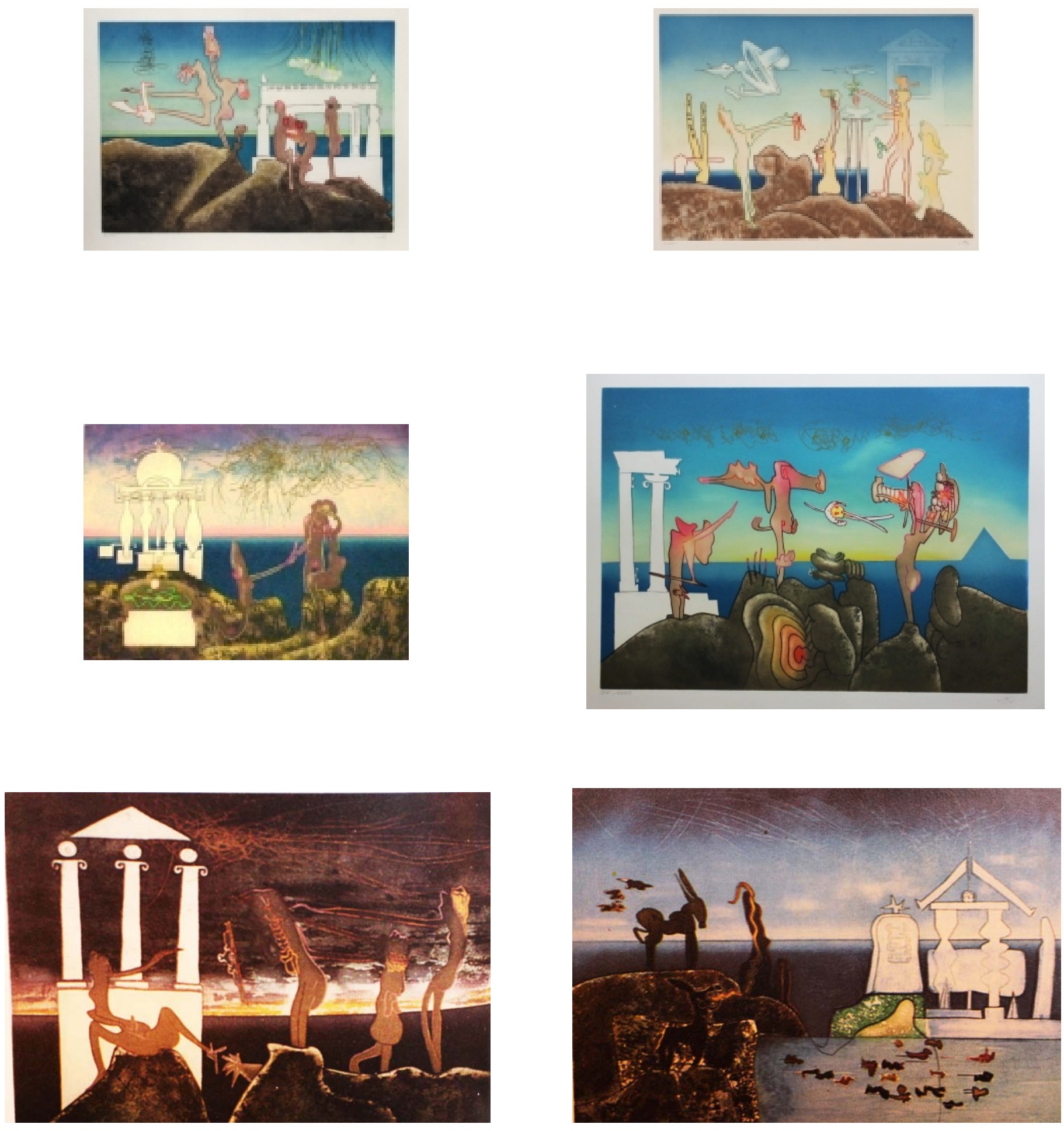

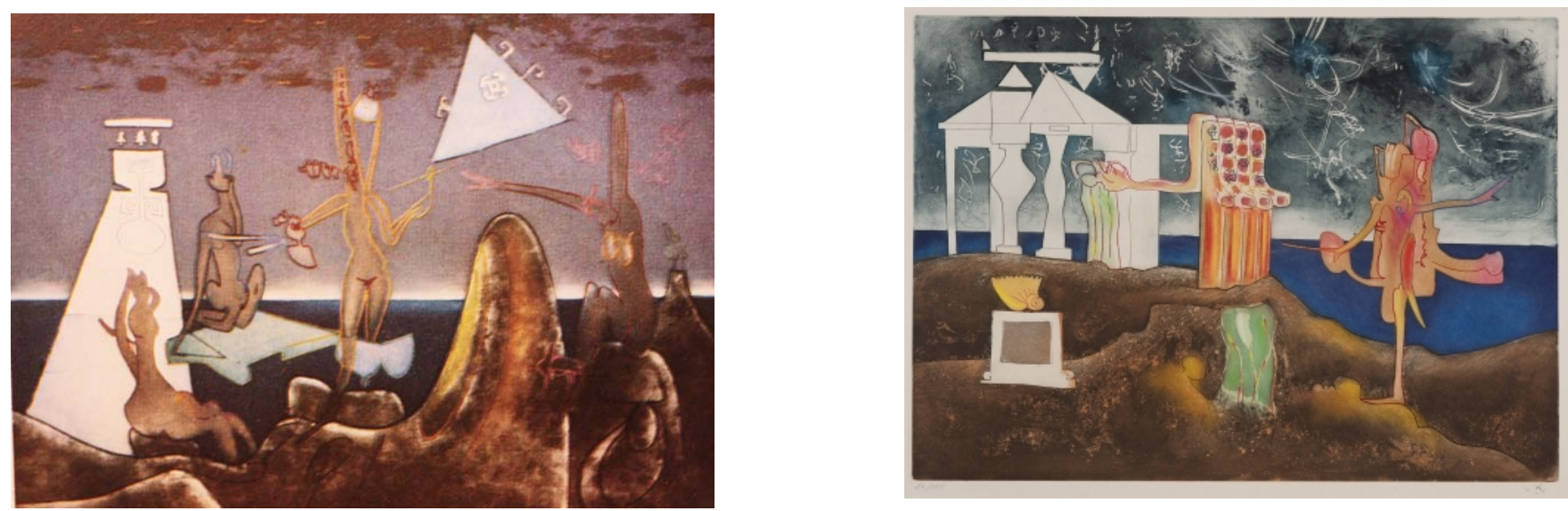

\section{Libros}

\section{Localización del libro o catalogo :}

"Matta, Index dell'opera grafica dal 1969 al 1980", editado por Admministrazione Provinciali di Viterbo en 1980, realizado por Germana Ferrari.

Pagina $105-114$.

\section{Otros catologos que lo contengan :}

Se desconoce.

Registros gráficos obtenidos

Diapositiva

Imagén digital

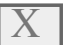




\section{Obra grafica Roberto Sebastian Matta Echaurren}

Ficha número : 54

Titulo de la obra : Cittadino d onore.

Fecha de realización : 1975

Dimensiones

Tamaño del papel : $50 \times 65 \mathrm{~cm}$.

Tamaño de la mancha : $46 \times 36 \mathrm{~cm}$.

\section{Técnica}

Técnica : Litografía.

Procedimientos y recursos complementarios :

Se desconoce.

\section{Matriz}

Número de planchas : $\quad$ Se desconoce.

Material de las planchas : Piedra.

Datos complementarios :

Se desconoce.

Estampación

Número de tintas :

En hueco

En relieve

Planigrafica

Permeografica

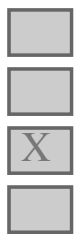

Se desconoce.

Colores :

Se desconoce.

Papel

Marca : Papel Fabriano.

Gramaje : Se desconoce.

Color : Blanco. 


\section{Edición}

Número de ejemplares :

100 ejemplares en papel Fabriano tamaño 50 x 65 firmados y numerados del 1 al 100 .

$\mathbf{N}^{\circ}$ de P.A. (Prueba de Artista): No existe.

$\mathbf{N}^{\circ}$ de H.C. (Hors Commerce) : Se desconoce.

B.A.T. : $\quad$ Se desconoce.

Otras Pruebas : Se desconoce.

Taller en el que se realizó :

Lo único que se sabe es que fue editado por la comuna de Tarquinia Italia.

Estampador

Se desconoce.

Número de la estampa observada : Se desconoce.

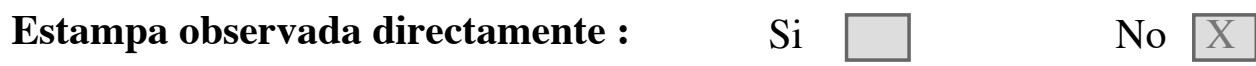

$\begin{array}{llll}\text { Contemplada a través de reproducción : Si } & \mathrm{X} \quad \text { No } & \mathrm{X}\end{array}$

Colección

Colección en la que se encuentra : Se desconoce.

Colección en la que se encuentra la plancha : Se desconoce.

Otras colecciones que tengan ejemplares de este trabajo : Se desconoce.

\section{Libros}

\section{Localización del libro o catalogo :}

"Matta, Index dell'opera grafica dal 1969 al 1980", editado por Admministrazione Provinciali di Viterbo en 1980, realizado por Germana Ferrari.

Pagina 116.

\section{Otros catologos que lo contengan :}

Se desconoce.

Registros gráficos obtenidos

Diapositiva

Imagén digital 


\section{Obra grafica Roberto Sebastian Matta Echaurren}

Ficha número : 55

Titulo de la obra : Perche le vittime vincano.

Fecha de realización : 1975.

Dimensiones

Tamaño del papel : 200 x $500 \mathrm{~cm}$. Tela.

Tamaño de la mancha : 200 x $500 \mathrm{~cm}$.

\section{Técnica}

Técnica : Serigrafía.

Procedimientos y recursos complementarios :

Se desconoce.

\section{Matriz}

Número de planchas : $\quad$ Se desconoce.

Material de las planchas : Tela.

Datos complementarios :

Se desconoce.

Estampación

En hueco

En relieve

Planigrafica

Permeografica

Papel

Marca : No existe.

Gramaje : No existe.

Color : No existe.
Número de tintas :

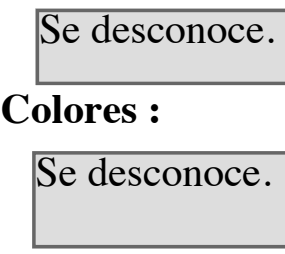

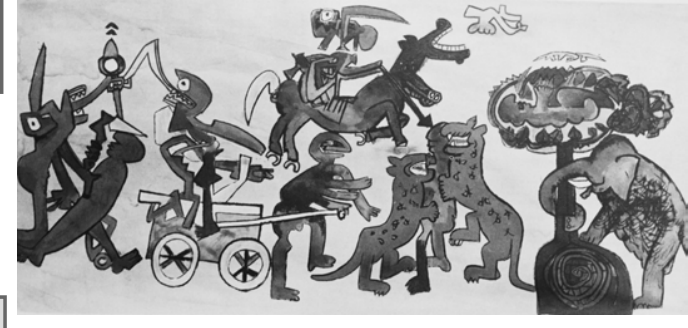




\section{Edición}

Número de ejemplares :

Ejemplar único.

$\mathbf{N}^{\circ}$ de P.A. (Prueba de Artista): No existe.

$\mathbf{N}^{\circ}$ de H.C. (Hors Commerce) : $\quad$ No existe.

B.A.T.: No existe.

Otras Pruebas : No existe.

Taller en el que se realizó :

Lo único que se sabe es que fue editado por la comuna de Tarquinia Italia.

Estampador

Se desconoce.

Número de la estampa observada : La única existente.

Estampa observada directamente : $\quad \mathrm{Si} \square \quad$ No

$\begin{array}{llll}\text { Contemplada a través de reproducción : } & \mathrm{Si} \quad \mathrm{X} \quad \text { No }\end{array}$

Colección

Colección en la que se encuentra : Se desconoce.

Colección en la que se encuentra la plancha : Se desconoce.

Otras colecciones que tengan ejemplares de este trabajo : Se desconoce.

\section{Libros}

\section{Localización del libro o catalogo :}

"Matta, Index dell'opera grafica dal 1969 al 1980", editado por Admministrazione Provinciali di Viterbo en 1980, realizado por Germana Ferrari.

Pagina 117.

\section{Otros catologos que lo contengan :}

Se desconoce.

Registros gráficos obtenidos

Diapositiva

Imagén digital 
Ficha número : 56

Titulo de la obra : La magma de los perros.

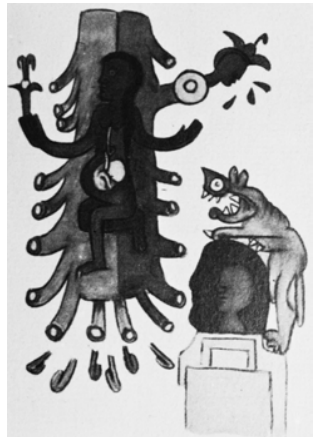

Tamaño del papel : $\quad$ Se desconoce.

Tamaño de la mancha : $28 \times 100 \mathrm{~cm}$.

Técnica

Técnica : Litografía.

Procedimientos y recursos complementarios :

Se desconoce.

\section{Matriz}

Número de planchas : $\quad$ Se desconoce.

Material de las planchas : Piedra.

Datos complementarios :

Se desconoce.

\section{Estampación}

En hueco

En relieve

Planigrafica

Permeografica

Número de tintas :

Se desconoce.

\section{Colores :}

Se desconoce.

Papel

Marca : $\quad$ Se desconoce.

Gramaje : Se desconoce.

Color : Se desconoce. 


\section{Edición}

Número de ejemplares :

Tiraje indeterminado, publicado en el catalogo " $L$ `homme descend du signe" no firmado no numerado.

$\mathbf{N}^{\circ}$ de P.A. (Prueba de Artista): Se desconoce.

$\mathbf{N}^{\circ}$ de H.C. (Hors Commerce) : Se desconoce.

B.A.T.: $\quad$ Se desconoce.

Otras Pruebas : Se desconoce.

Taller en el que se realizó :

Se desconoce.

\section{Estampador}

Se desconoce.

Número de la estampa observada : Se desconoce.

Estampa observada directamente :

$\mathrm{Si}$

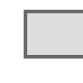

No

Contemplada a través de reproducción :

$\mathrm{Si}$

No

\section{Colección}

Colección en la que se encuentra : Se desconoce.

Colección en la que se encuentra la plancha : Se desconoce.

Otras colecciones que tengan ejemplares de este trabajo :

Se desconoce. 

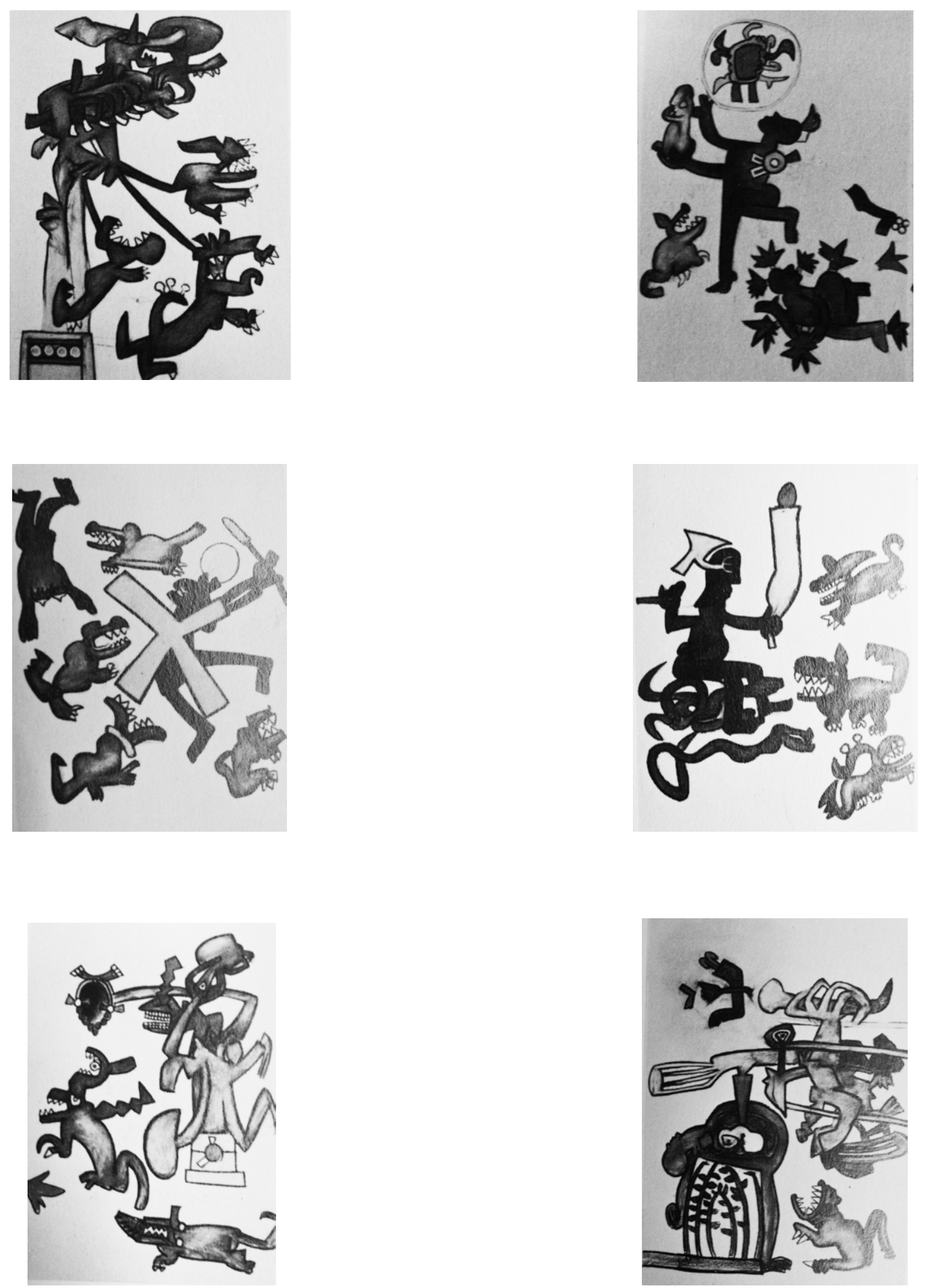

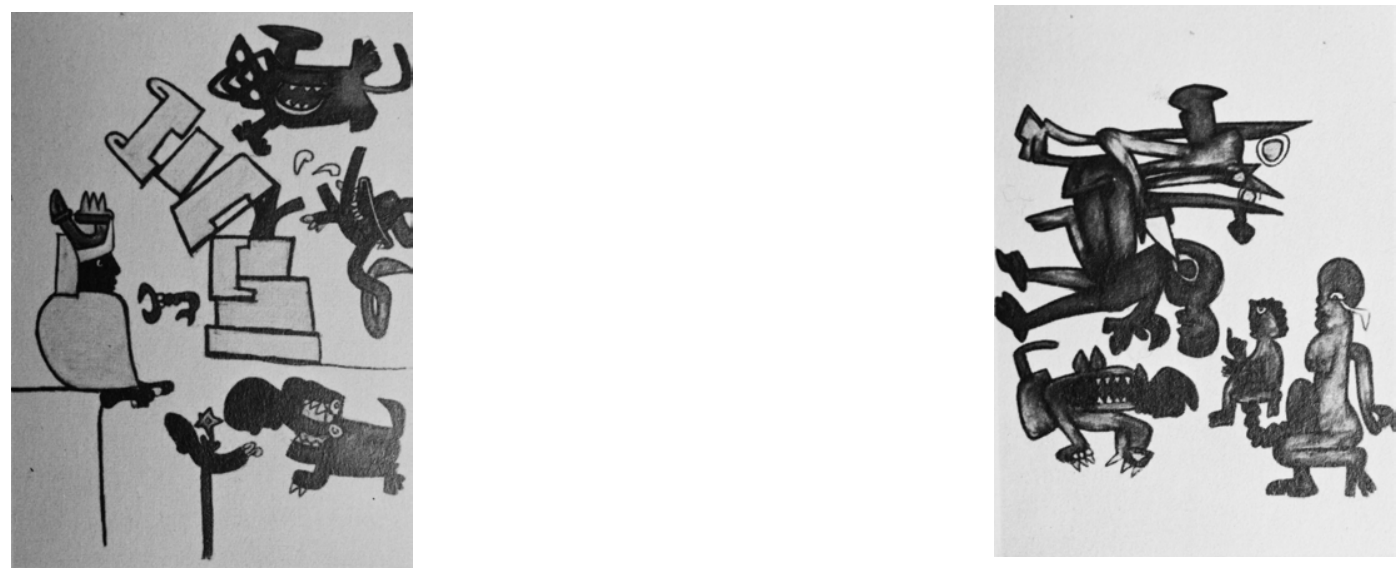

\section{Libros}

\section{Localización del libro o catalogo :}

"Matta, Index dell'opera grafica dal 1969 al 1980", editado por Admministrazione Provinciali di Viterbo en 1980, realizado por Germana Ferrari.

Pagina 118.

\section{Otros catologos que lo contengan :}

Se desconoce.

Registros gráficos obtenidos

Diapositiva

Imagén digital 


\section{Obra grafica Roberto Sebastian Matta Echaurren}

Ficha número : 57

Titulo de la obra : Asesinaron Cristian en la madre visible.

Fecha de realización : 1975.

Dimensiones

Tamaño del papel : $\quad$ Se desconoce.

Tamaño de la mancha : $28 \times 80 \mathrm{~cm}$.

\section{Técnica}

Técnica : Litografía.

Procedimientos y recursos complementarios :

Se desconoce.

\section{Matriz}

Número de planchas : $\quad$ Se desconoce.

Material de las planchas : Se desconoce.

Datos complementarios :

Se desconoce.

\section{Estampación}

En hueco

En relieve

Planigrafica

Permeografica

Papel

Marca : Se desconoce.

Gramaje : Se desconoce.

Color : $\quad$ Se desconoce.
Número de tintas :

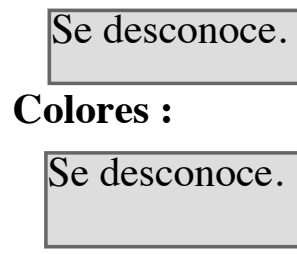




\section{Edición}

Número de ejemplares :

Tiraje indeterminado, publicado en el catalogo "L`homme descend du signe" no firmado no numerado.

$\mathbf{N}^{\circ}$ de P.A. (Prueba de Artista) : Se desconoce.

$\mathbf{N}^{\circ}$ de H.C. (Hors Commerce) : Se desconoce.

B.A.T. : Se desconoce.

Otras Pruebas : Se desconoce.

Taller en el que se realizó :

Editado en la galería del Oca en Roma Italia.

Estampador

Se desconoce.

Número de la estampa observada : Se desconoce.

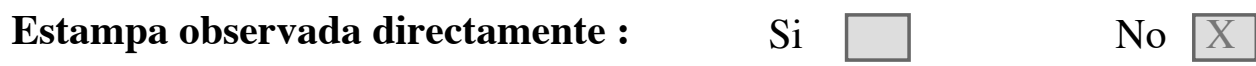

Contemplada a través de reproducción : $\mathrm{Si} X \quad$ No $\mathrm{X}$

Colección

Colección en la que se encuentra : Se desconoce.

Colección en la que se encuentra la plancha : Se desconoce.

Otras colecciones que tengan ejemplares de este trabajo : Se desconoce.

\section{Libros}

\section{Localización del libro o catalogo :}

"Matta, Index dell'opera grafica dal 1969 al 1980", editado por Admministrazione Provinciali di Viterbo en 1980, realizado por Germana Ferrari.

Pagina 119

\section{Otros catologos que lo contengan :}

Se desconoce.

Registros gráficos obtenidos $\quad$ Diapositiva $\quad \square \quad$ Imagén digital 


\section{Obra grafica Roberto Sebastian Matta Echaurren}

Ficha número : 58

Titulo de la obra : Coigitum.

Fecha de realización : 1975

Dimensiones

Tamaño del papel : $39.5 \times 54 \mathrm{~cm}$.

Tamaño de la mancha : $31.5 \times 31.5 \mathrm{~cm}$.

\section{Técnica}

Técnica : Aguafuerte y aguatinta.

\section{Procedimientos y recursos complementarios :}

Coigitum es un grabado realizado para la exposición de Roberto Matta realizada en Atenas en el año 1975.

Es muy interesante este grabado ya que es uno de los pocos donde Matta no va delinear el dibujo en negro sino que los colores son puestos directamente sobre la plancha, lo que da una sensación de tranquilidad, de dulzura con la abstención del color negro.

\section{Matriz}

Número de planchas : Una sola.

Material de las planchas : Cobre.

Datos complementarios :

Se desconoce.

\section{Estampación}

En hueco

En relieve

Planigrafica

Permeografica

\section{Papel}

Marca : Papel Arches.

Gramaje : Se desconoce.

Color : Blanco.
Número de tintas :

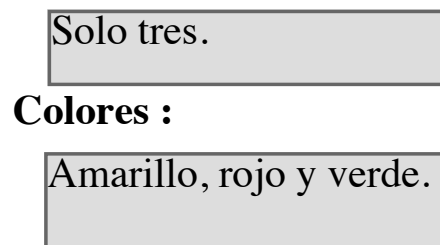




\section{Edición}

Número de ejemplares :

100 ejemplares sobre papel Arches tamaño 39.5 x $54 \mathrm{~cm}$. firmados y numerados del 1 al 100 mas XXV H. C. firmados y numerados del I al XXV.

$\mathbf{N}^{\circ}$ de P.A. (Prueba de Artista) : Se desconoce.

$\mathbf{N}^{\circ}$ de H.C. (Hors Commerce) : XXV H.C.

B.A.T. : $\quad$ Se desconoce.

Otras Pruebas : Se desconoce.

Taller en el que se realizó :

Atelier George Visat y edición galería A. Jolas en Paris.

Estampador

No se sabe si fue George Visat o Albert Dupont.

Número de la estampa observada : No se sabe si fue George Visat o Albert Dupont.

\begin{tabular}{llll} 
Estampa observada directamente : & $\mathrm{Si}$ & $\square$ & No \\
\hline
\end{tabular}

Contemplada a través de reproducción : $\mathrm{Si} X \quad$ No $\mathrm{X}$

Colección

Colección en la que se encuentra : Se desconoce.

Colección en la que se encuentra la plancha : Se desconoce.

Otras colecciones que tengan ejemplares de este trabajo : Se desconoce.

\section{Libros}

\section{Localización del libro o catalogo :}

"Matta, Index dell'opera grafica dal 1969 al 1980", editado por Admministrazione Provinciali di Viterbo en 1980, realizado por Germana Ferrari.

Pagina 120

\section{Otros catologos que lo contengan :}

Se desconoce.

Registros gráficos obtenidos $\quad$ Diapositiva $\quad \square \quad$ Imagén digital 


\section{Obra grafica Roberto Sebastian Matta Echaurren}

Ficha número : 59

Titulo de la obra : Reorganimation de la liberté.

Fecha de realización : 1975.

Dimensiones

Tamaño del papel : $22 \times 22 \mathrm{~cm}$.

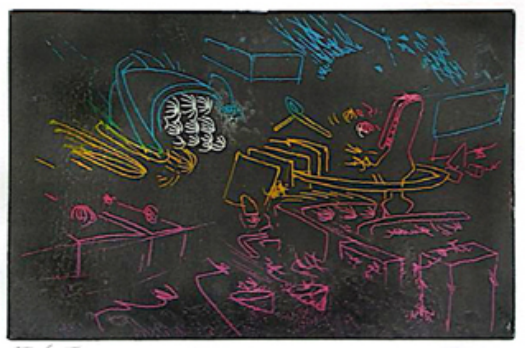

Tamaño de la mancha : 12.5 x $19 \mathrm{~cm}$.

\section{Técnica}

Técnica : Aguafuerte y Aguatinta.

Procedimientos y recursos complementarios :

Reorganimation de la liberté es un grabado que se realiza con motivo de la exposición de Matta "Ojoser" en la galería A. Jolas.

\section{Matriz}

Número de planchas : Se utilizaron dos planchas.

Material de las planchas : Cobre.

Datos complementarios :

Se desconoce.

\section{Estampación}

En hueco

En relieve

Planigrafica

Permeografica

Número de tintas :
Se utilizaron 4 tintas.
Colores :
Negro, rosado fuerte, amarillo, azul y blanco.

\section{Papel}

Marca : Papel Arches.

Gramaje : Se desconoce.

Color : Blanco. 


\section{Edición}

Número de ejemplares :

100 ejemplares sobre papel Arches tamaño 22 × $22 \mathrm{~cm}$. firmados y numerados del 1 al 100 mas XXV H. C. firmados y numerados del I al XXV.

$\mathbf{N}^{\circ}$ de P.A. (Prueba de Artista) : Se desconoce.

$\mathbf{N}^{\circ}$ de H.C. (Hors Commerce) : XXV H.C.

B.A.T. : $\quad$ Se desconoce.

Otras Pruebas : Se desconoce.

Taller en el que se realizó :

Atelier George Visat y Edicion galeria A. Jolas en Paris.

Estampador

No se sabe si fue George Visat o Albert Dupont.

Número de la estampa observada : Se desconoce.

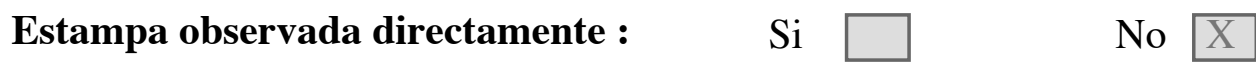

Contemplada a través de reproducción : $\mathrm{Si} X \quad$ No $\mathrm{X}$

Colección

Colección en la que se encuentra : Se desconoce.

Colección en la que se encuentra la plancha : Se desconoce.

Otras colecciones que tengan ejemplares de este trabajo : Se desconoce.

\section{Libros}

\section{Localización del libro o catalogo :}

"Matta, Index dell'opera grafica dal 1969 al 1980", editado por Admministrazione Provinciali di Viterbo en 1980, realizado por Germana Ferrari.

Pagina 121.

\section{Otros catologos que lo contengan :}

Se desconoce.

Registros gráficos obtenidos $\quad$ Diapositiva $\quad \square \quad$ Imagén digital 


\section{Obra grafica Roberto Sebastian Matta Echaurren}

Ficha número : 60

Titulo de la obra : D`or Ling.

Fecha de realización : 1975.

Dimensiones

Tamaño del papel : $37.5 \times 48 \mathrm{~cm}$.

Tamaño de la mancha : $32 \times 24 \mathrm{~cm}$.

\section{Técnica}

Técnica : Litografía.

Procedimientos y recursos complementarios :

D`or Ling fue una litografía editada para la revista XX siecle.

\section{Matriz}

Número de planchas : $\quad$ Se desconoce.

Material de las planchas : Piedra.

Datos complementarios :

Se desconoce.

Estampación

En hueco

En relieve

Planigrafica

Permeografica

Papel

Marca : Papel Arches.

Gramaje : Se desconoce.

Color : Blanco.
Número de tintas :

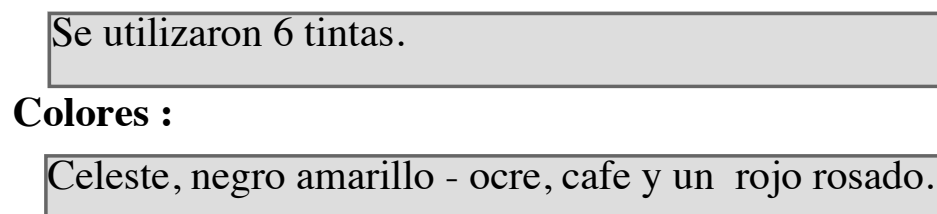




\section{Edición}

Número de ejemplares :

99 ejemplares sobre papel Arches tamaño 37.5 x $48 \mathrm{~cm}$. firmados y numerados del 1 al 99 .

$\mathbf{N}^{\circ}$ de P.A. (Prueba de Artista) : Se desconoce.

$\mathbf{N}^{\circ}$ de H.C. (Hors Commerce) : Se desconoce.

B.A.T. : $\quad$ Se desconoce.

Otras Pruebas : Se desconoce.

Taller en el que se realizó :

Atelier Fernand Mourlot en Paris y Edición en siglo XX en Paris.

Estampador

No se sabe si fue Fernand Mourlot o Franck Bordas.

Número de la estampa observada : Se desconoce.

Estampa observada directamente : $\quad \mathrm{Si} \square \quad$ No $\mathrm{X}$

Contemplada a través de reproducción : $\mathrm{Si} X \quad$ No $\mathrm{X}$

Colección

Colección en la que se encuentra : Se desconoce.

Colección en la que se encuentra la plancha : Se desconoce.

Otras colecciones que tengan ejemplares de este trabajo : Se desconoce.

\section{Libros}

\section{Localización del libro o catalogo :}

"Matta, Index dell'opera grafica dal 1969 al 1980", editado por Admministrazione Provinciali di Viterbo en 1980, realizado por Germana Ferrari.

Pagina 122.

\section{Otros catologos que lo contengan :}

Se desconoce.

Registros gráficos obtenidos $\quad$ Diapositiva $\quad \square \quad$ Imagén digital 


\section{Obra grafica Roberto Sebastian Matta Echaurren}

Ficha número : 61

Titulo de la obra : XX siecle.

Fecha de realización : 1975.

Dimensiones

Tamaño del papel : $32 \times 24.5 \mathrm{~cm}$.

Tamaño de la mancha : $32 \times 24.5 \mathrm{~cm}$.

\section{Técnica}

Técnica : Litografía.

Procedimientos y recursos complementarios :

XX siecle fue una litografía editada para la revista XX siecle.

\section{Matriz}

Número de planchas : $\quad$ Se desconoce.

Material de las planchas : Piedra.

Datos complementarios :

Se desconoce.

Estampación

En hueco

En relieve

Planigrafica

Permeografica

Papel

Marca : Papel Arches.

Gramaje : Se desconoce.

Color : Blanco.

\section{Número de tintas :}
Se utilizaron 7 tintas.
Colores :
Celeste, gris, amarillo, rosado fluor, negro y verde. 


\section{Edición}

Número de ejemplares :

99 ejemplares sobre papel Arches tamaño 36 x $44.5 \mathrm{~cm}$. firmados y numerados del 1 al 99 .

$\mathbf{N}^{\circ}$ de P.A. (Prueba de Artista) : Se desconoce.

$\mathbf{N}^{\circ}$ de H.C. (Hors Commerce) : Se desconoce.

B.A.T. : $\quad$ Se desconoce.

Otras Pruebas : Se desconoce.

Taller en el que se realizó :

Atelier Fernand Mourlot en Paris y Edición en siglo XX en Paris.

Estampador

No se sabe si fue Fernand Mourlot o Franck Bordas.

Número de la estampa observada : Se desconoce.

Estampa observada directamente : $\quad \mathrm{Si} \square \quad$ No $\mathrm{X}$

Contemplada a través de reproducción : $\mathrm{Si} X \quad$ No $\mathrm{X}$

Colección

Colección en la que se encuentra : Se desconoce.

Colección en la que se encuentra la plancha : Se desconoce.

Otras colecciones que tengan ejemplares de este trabajo : Se desconoce.

\section{Libros}

\section{Localización del libro o catalogo :}

"Matta, Index dell'opera grafica dal 1969 al 1980", editado por Admministrazione Provinciali di Viterbo en 1980, realizado por Germana Ferrari.

Pagina 123.

\section{Otros catologos que lo contengan :}

Se desconoce.

Registros gráficos obtenidos $\quad$ Diapositiva $\quad \square \quad$ Imagén digital 


\section{Obra grafica Roberto Sebastian Matta Echaurren}

Ficha número : 62

Titulo de la obra : Per il Cile.

Fecha de realización : 1972 impresa en 1975

Dimensiones

Tamaño del papel : $\quad 50 \times 70 \mathrm{~cm}$.

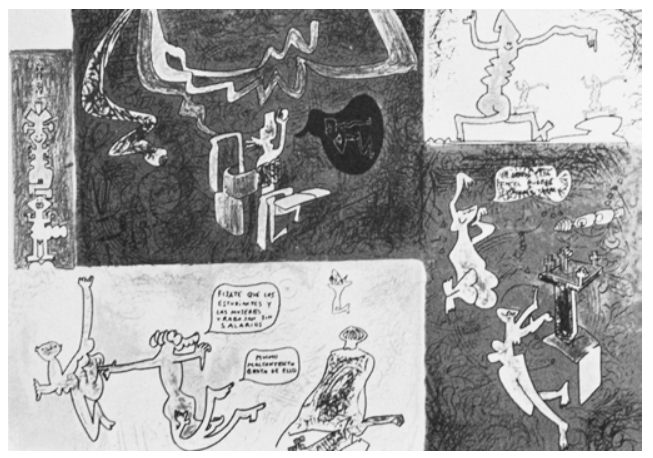

Tamaño de la mancha : 46 × $67 \mathrm{~cm}$.

Técnica

Técnica : Litografía.

Procedimientos y recursos complementarios :

Per il Cile es una carpeta litográfica que posee 7 litografías a color, esta serie litográfica fue realizada en el año 1972 para el periódico chileno "El siglo" un periódico de izquierda. Tristemente a causa del golpe militar en 1973 no pudo ser impreso por este diario, luego cuando se pudieron recuperar las litografías estas fueron impresas por “l'unita” en 1974 y en seguido en 1975 fue editada por la galería del Oca en Roma Italia.

\section{Matriz}

Número de planchas : Se desconoce.

Material de las planchas : Se desconoce.

Datos complementarios :

\section{Estampación}

En hueco

En relieve

Planigrafica

Permeografica

Número de tintas :

Se desconoce.

Colores :

Se desconoce.

Papel

Marca : $\quad$ Se desconoce.

Gramaje : Se desconoce. 
Color :

Se desconoce.

Edición

Número de ejemplares :

80 ejemplares sobre una carta " uso mano", firmados y numerados del 1 al 80 mas XXH.C. firmados y numerados del I al XX.

$\mathbf{N}^{\circ}$ de P.A. (Prueba de Artista): Se desconoce.

$\mathbf{N}^{\circ}$ de H.C. (Hors Commerce) : Se desconoce.

B.A.T.: $\quad$ Se desconoce.

Otras Pruebas : Se desconoce.

Taller en el que se realizó :

Estamperia Il globo en Bolonia Italia y Edicion Galeria dell ‘Oca en Roma Italia.

Estampador

Se desconoce.

Número de la estampa observada : 
Estampa observada directamente :

Contemplada a través de reproducción :
$\mathrm{Si}$

$\mathrm{Si}$
No

No

\section{Colección}

Colección en la que se encuentra : Se desconoce.

Colección en la que se encuentra la plancha : Se desconoce.

Otras colecciones que tengan ejemplares de este trabajo :

Se desconoce.
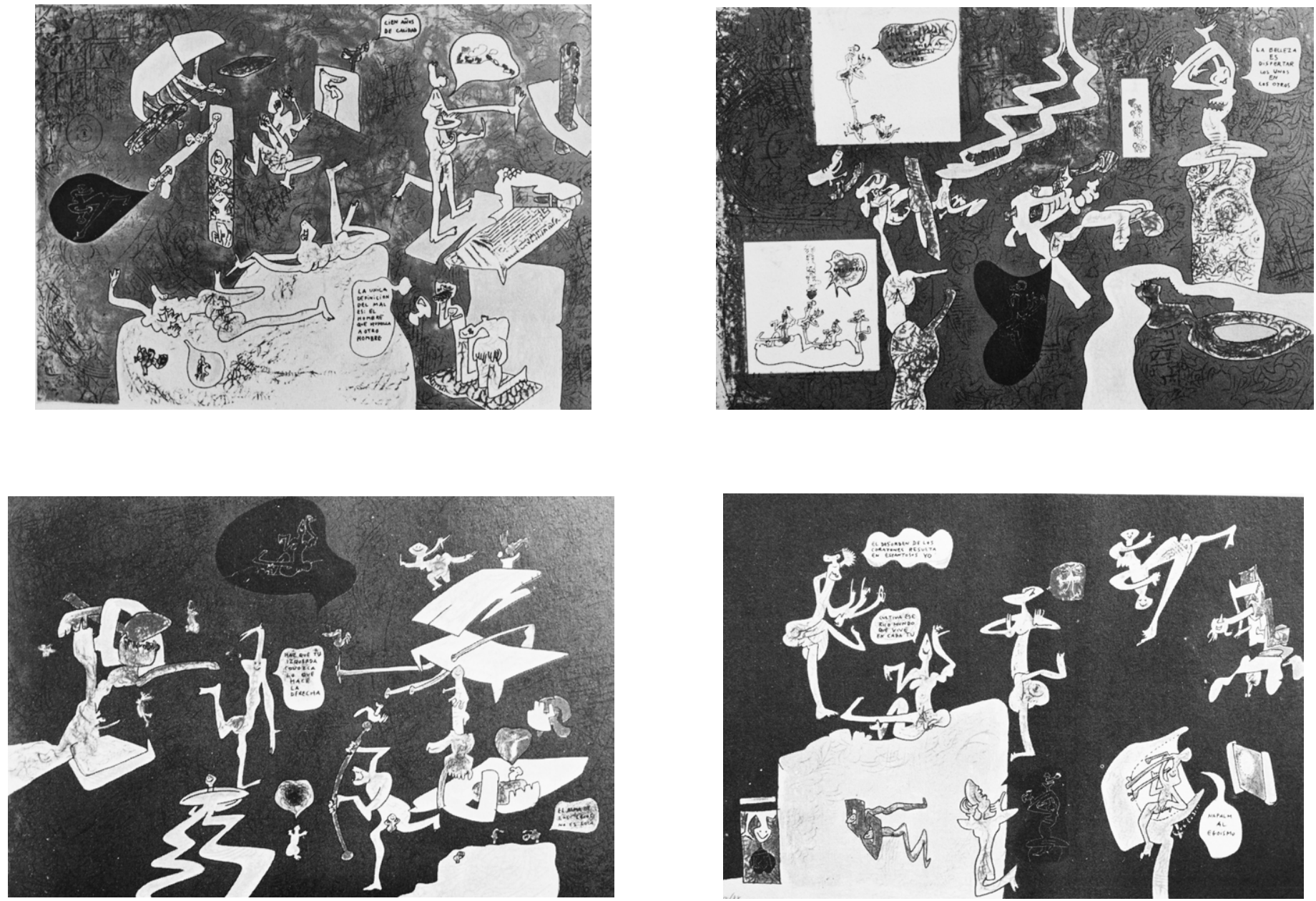

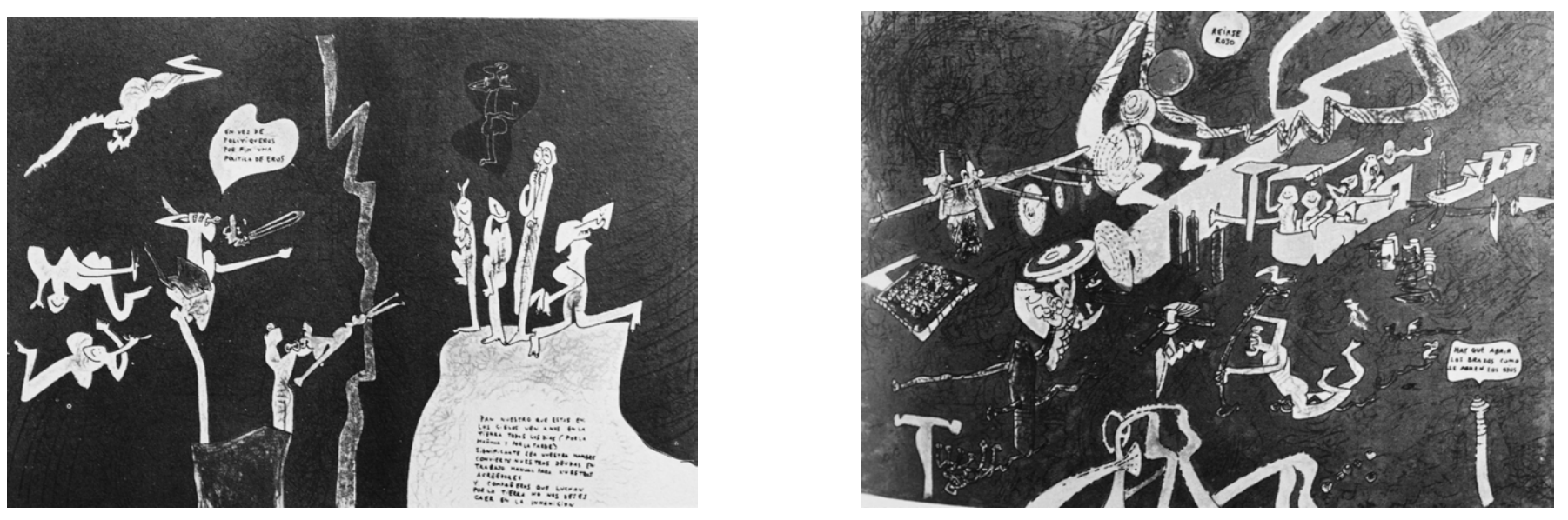

\section{Libros}

\section{Localización del libro o catalogo :}

"Matta, Index dell'opera grafica dal 1969 al 1980", editado por Admministrazione Provinciali di Viterbo en 1980, realizado por Germana Ferrari.

Pagina $124-130$.

\section{Otros catologos que lo contengan :}

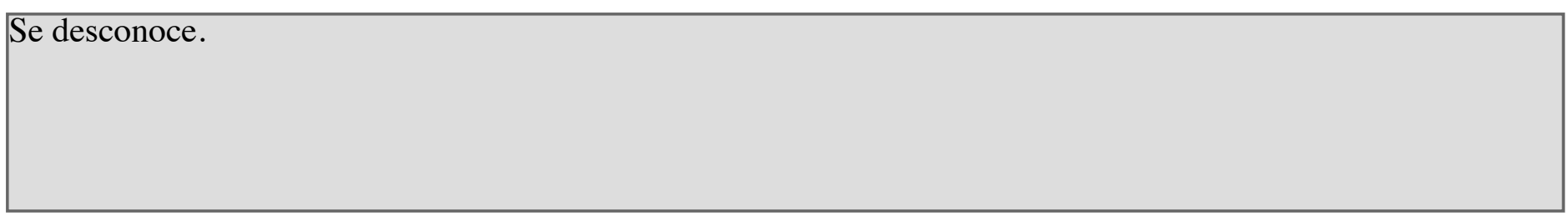

Registros gráficos obtenidos $\quad$ Diapositiva $\quad \square \quad$ Imagén digital $\quad X$ 


\section{Obra grafica Roberto Sebastian Matta Echaurren}

Ficha número : 63

Titulo de la obra : Los engulleran.

Fecha de realización : 1973 impreso 1975

Dimensiones

Tamaño del papel : $\quad 56 \times 70 \mathrm{~cm}$.

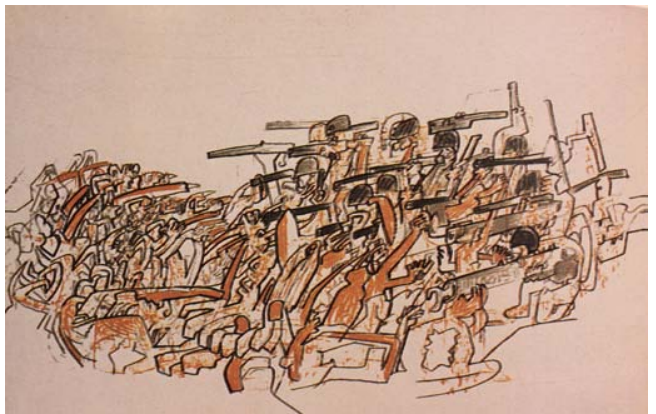

Tamaño de la mancha : $50 \times 65 \mathrm{~cm}$.

Técnica

Técnica : Litografía.

Procedimientos y recursos complementarios :

Es una serie litográfica de tres litografías. Dibujado en 1973 e impreso en 1975.

Matriz

Número de planchas : Se desconoce.

Material de las planchas : Piedra.

Datos complementarios :

Se desconoce.

Estampación

En hueco

En relieve

Planigrafica

Permeografica

Número de tintas :

Se utilizaron tres tintas.

Colores :

Beige, gris y negro.

Papel

Marca : $\quad$ Papel Arches.

Gramaje : Se desconoce. 
Color : $\quad$ Blanco.

Edición

Número de ejemplares :

50 ejemplares H.C sobre papel Arches tamaño 56 x $70 \mathrm{~cm}$. numerados del 1 al 50.

$\mathbf{N}^{\circ}$ de P.A. (Prueba de Artista) : Se desconoce.

$\mathbf{N}^{\circ}$ de H.C. (Hors Commerce) : 50 H.C.

B.A.T.: $\quad$ Se desconoce.

Otras Pruebas : Se desconoce.

Taller en el que se realizó :

Atelier Fernand Mourlot en Paris.

Estampador

No se sabe si fue Fernand Mourlot o Franck Bordas.

Número de la estampa observada : 
Estampa observada directamente :

Contemplada a través de reproducción :
$\mathrm{Si}$

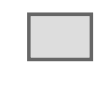

$\mathrm{Si}$
No

No

\section{Colección}

Colección en la que se encuentra : Se desconoce.

Colección en la que se encuentra la plancha : Se desconoce.

Otras colecciones que tengan ejemplares de este trabajo :

Se desconoce.
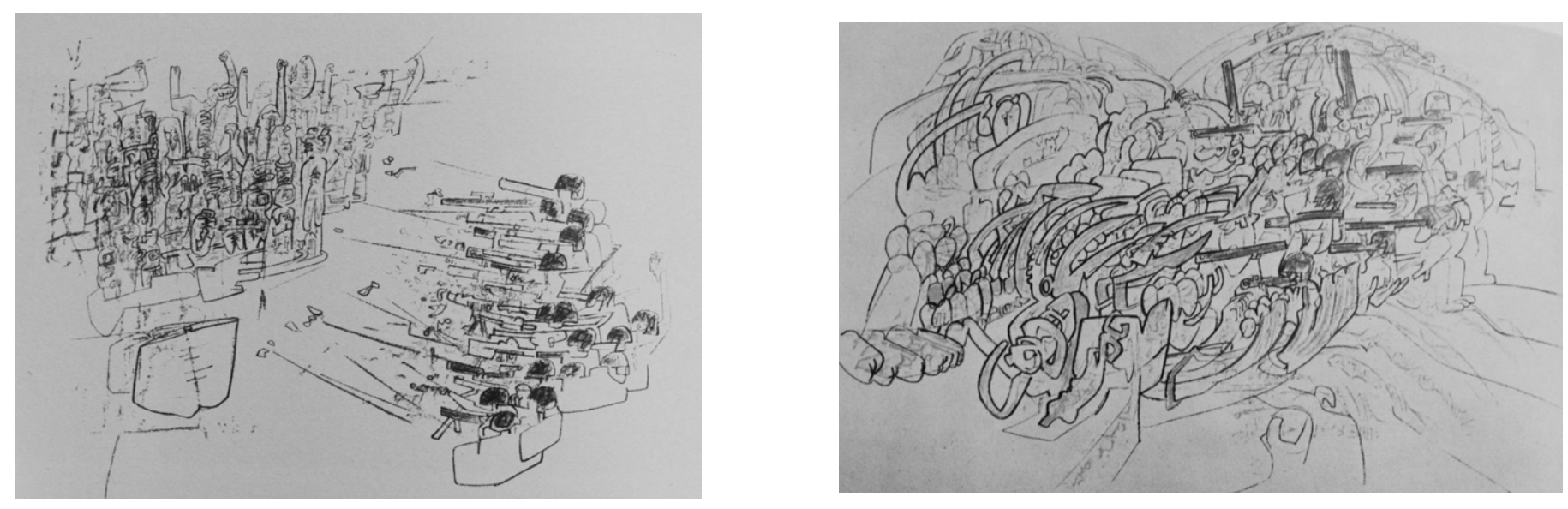


\section{Libros}

\section{Localización del libro o catalogo :}

"Matta, Index dell'opera grafica dal 1969 al 1980", editado por Admministrazione Provinciali di Viterbo en 1980, realizado por Germana Ferrari.

Pagina $131-133$.

\section{Otros catologos que lo contengan :}

Se desconoce.

Registros gráficos obtenidos Diapositiva $\square$ Imagén digital $\quad \mathrm{X}$ 


\section{Obra grafica Roberto Sebastian Matta Echaurren}

Ficha número : 64

Titulo de la obra : United Snakes of America.

Fecha de realización : dibujo 1973 / impreso 1975-1976

Dimensiones

Tamaño del papel : $56 \times 70 \mathrm{~cm}$.

Tamaño de la mancha : 50 x $65 \mathrm{~cm}$.

\section{Técnica}

Técnica : Litografía.

Procedimientos y recursos complementarios :

United Snakes of America es una litografía impresa en 1975 pero su dibujo se creo en 1973, la creación de esta obra se genero a partir del golpe militar en Chile.

\section{Matriz}

Número de planchas : $\quad$ Se desconoce.

Material de las planchas : Piedra.

\section{Datos complementarios :}

Se desconoce.

\section{Estampación}

En hueco

En relieve

Planigrafica

Permeografica

Papel
Número de tintas :

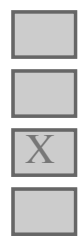

Se utilizaron 5 tintas.

Colores :

Negro, gris, beige, rojo y narango

Marca : Papel Arches.

Gramaje : Se desconoce.

Color : Blanco. 


\section{Edición}

Número de ejemplares :

100 ejemplares sobre papel Arches tamaño 56 x $70 \mathrm{~cm}$. firmados y numerados del 1 al 100 mas XXV H. C. firmados y numerados del I al XXV.

$\mathbf{N}^{\circ}$ de P.A. (Prueba de Artista) : Se desconoce.

$\mathbf{N}^{\circ}$ de H.C. (Hors Commerce) : Se desconoce.

B.A.T.: $\quad$ Se desconoce.

Otras Pruebas : Se desconoce.

Taller en el que se realizó :

Atelier Fernand Mourlot en Paris y la edición en Chile Democrático en Nueva York.

Estampador

No se sabe si fue Fernand Mourlot o Franck Bordas.

Número de la estampa observada : Se desconoce.

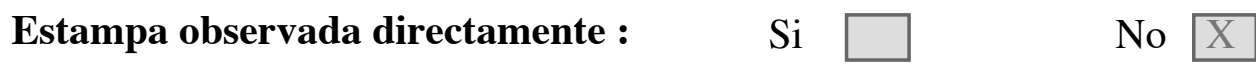

Contemplada a través de reproducción : $\mathrm{Si} X \quad$ No $\mathrm{X}$

Colección

Colección en la que se encuentra : Se desconoce.

Colección en la que se encuentra la plancha : Se desconoce.

Otras colecciones que tengan ejemplares de este trabajo : Se desconoce.

\section{Libros}

\section{Localización del libro o catalogo :}

"Matta, Index dell'opera grafica dal 1969 al 1980", editado por Admministrazione Provinciali di Viterbo en 1980, realizado por Germana Ferrari.

Pagina 134.

\section{Otros catologos que lo contengan :}

Se desconoce.

Registros gráficos obtenidos

Diapositiva

Imagén digital 


\section{Obra grafica Roberto Sebastian Matta Echaurren}

Ficha número : 65

Titulo de la obra : La commune de Paris est la revolution francaise.

Fecha de realización : 1975.

Dimensiones

Tamaño del papel : $60 \times 80 \mathrm{~cm}$.

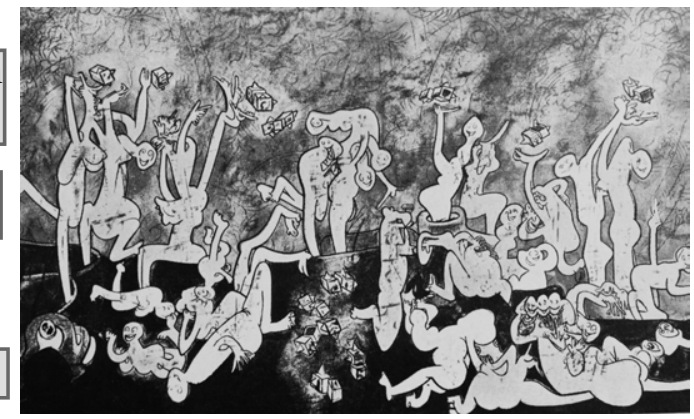

Tamaño de la mancha : $47 \times 76 \mathrm{~cm}$.

\section{Técnica}

Técnica : Serigrafía.

Procedimientos y recursos complementarios :

Se desconoce.

\section{Matriz}

Número de planchas : No existen.

Material de las planchas : Tela.

Datos complementarios :

Se desconoce.

Estampación

Número de tintas :

En hueco

En relieve

Planigrafica

Permeografica

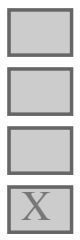

Cinco tintas.

\section{Colores :}

Azul, amarillo fluor, rosado, negro y verde.

Papel

Marca : Papel Fabriano.

Gramaje : Se desconoce.

Color : Blanco. 


\section{Edición}

Número de ejemplares :

99 ejemplares en papel Fabriano tamaño 60 × $80 \mathrm{~cm}$. firmados y numerados del 1 al 99 mas XXV H.C. firmados y numerados del I al XXV.

$\mathbf{N}^{\circ}$ de P.A. (Prueba de Artista) : Se desconoce.

$\mathbf{N}^{\circ}$ de H.C. (Hors Commerce) : XXV H.C.

B.A.T. : $\quad$ Se desconoce.

Otras Pruebas : Se desconoce.

Taller en el que se realizó :

Edición privada en Roma Italia.

Estampador

Se desconoce.

Número de la estampa observada : Se desconoce.

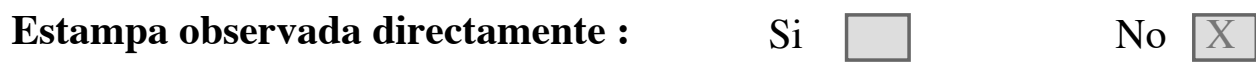

Contemplada a través de reproducción : $\mathrm{Si} X \quad$ No $\mathrm{X}$

Colección

Colección en la que se encuentra : Se desconoce.

Colección en la que se encuentra la plancha : Se desconoce.

Otras colecciones que tengan ejemplares de este trabajo : Se desconoce.

\section{Libros}

\section{Localización del libro o catalogo :}

"Matta, Index dell'opera grafica dal 1969 al 1980", editado por Admministrazione Provinciali di Viterbo en 1980, realizado por Germana Ferrari.

Pagina 135

\section{Otros catologos que lo contengan :}

Se desconoce.

Registros gráficos obtenidos $\quad$ Diapositiva $\quad \square \quad$ Imagén digital 


\section{Obra grafica Roberto Sebastian Matta Echaurren}

Ficha número : 66

Titulo de la obra : El guatasso.

Fecha de realización : 1975.

Dimensiones

Tamaño del papel : $60 \times 80 \mathrm{~cm}$.

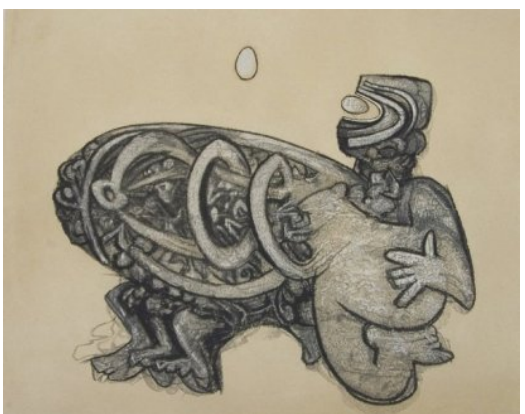

Tamaño de la mancha : 47 x $59 \mathrm{~cm}$.

\section{Técnica}

Técnica : Serigrafía.

Procedimientos y recursos complementarios :

El guatasso es una serigrafía impresa en un formato carta.

\section{Matriz}

Número de planchas : $\quad$ No existe.

Material de las planchas : Tela.

Datos complementarios :

Se desconoce.

Estampación

En hueco

En relieve

Planigrafica

Permeografica

Papel

Marca : $\quad$ No existe es una hoja de carta, muy parecido al papel craft.

Gramaje : Se desconoce.

Color : Marron.

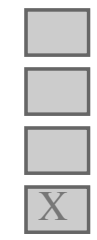

Número de tintas :

Se utilizaron tres tintas.
Colores :
Negro, gris y blanco.
Manton. 


\section{Edición}

Número de ejemplares :

99 ejemplares sobre carta tamaño 60 x 80 firmados y numerados del 1 al 99 mas XXV H.C. firmados y numerados del I al XXV.

$\mathbf{N}^{\circ}$ de P.A. (Prueba de Artista) : Se desconoce.

$\mathbf{N}^{\circ}$ de H.C. (Hors Commerce) : XXV H.C.

B.A.T. : Se desconoce.

Otras Pruebas : Se desconoce.

Taller en el que se realizó :

Edición privada en Roma Italia.

Estampador

Se desconoce.

Número de la estampa observada : Se desconoce.

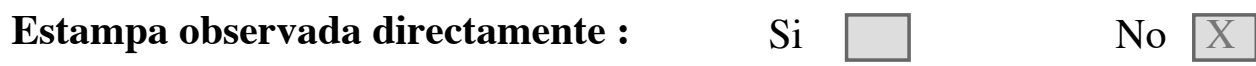

Contemplada a través de reproducción : $\mathrm{Si} X \quad$ No $\mathrm{X}$

Colección

Colección en la que se encuentra : Se desconoce.

Colección en la que se encuentra la plancha : Se desconoce.

Otras colecciones que tengan ejemplares de este trabajo : Se desconoce.

\section{Libros}

\section{Localización del libro o catalogo :}

"Matta, Index dell'opera grafica dal 1969 al 1980", editado por Admministrazione Provinciali di Viterbo en 1980, realizado por Germana Ferrari.

Pagina 144.

\section{Otros catologos que lo contengan :}

Se desconoce.

Registros gráficos obtenidos $\quad$ Diapositiva $\quad \square \quad$ Imagén digital 
Ficha número : 67

Titulo de la obra : Trompetuya.

Fecha de realización : 1975

Dimensiones

Tamaño del papel : $60 \times 80 \mathrm{~cm}$.

Tamaño de la mancha : 47 x $53 \mathrm{~cm}$.

\section{Técnica}

Técnica : Serigrafía.

Procedimientos y recursos complementarios :

Trompetuyaes una serigrafía impresa en un formato carta.

\section{Matriz}

Número de planchas : No existe.

Material de las planchas : Tela.

Datos complementarios :

Se desconoce.

Estampación

En hueco

En relieve

Planigrafica

Permeografica

Papel

Marca : No existe es una hoja de carta.

Gramaje : Se desconoce.

Color : Blanco.
Número de tintas :

\section{Se utilizaron tres tintas. \\ Colores :}

Negro, blanco y marron claro.

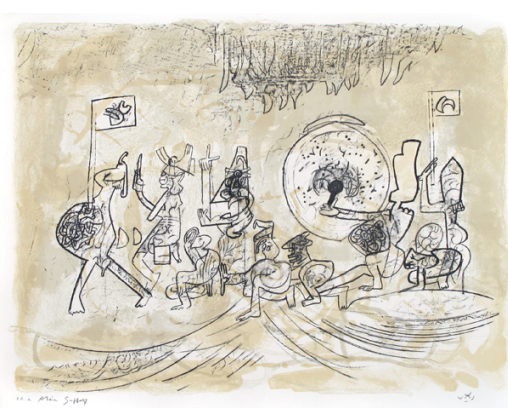




\section{Edición}

Número de ejemplares :

99 ejemplares sobre carta tamaño 60 x 80 firmados y numerados del 1 al 99 .

$\mathbf{N}^{\circ}$ de P.A. (Prueba de Artista): Se desconoce.

$\mathbf{N}^{\circ}$ de H.C. (Hors Commerce) : Se desconoce.

B.A.T. : $\quad$ Se desconoce.

Otras Pruebas : Se desconoce.

Taller en el que se realizó :

Edición privada en Roma Italia.

Estampador

Se desconoce.

Número de la estampa observada : Se desconoce.

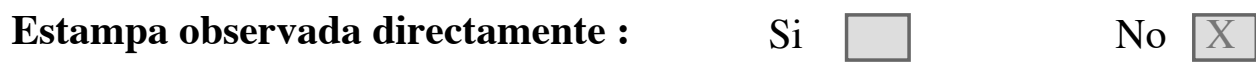

$\begin{array}{llll}\text { Contemplada a través de reproducción : Si } & \mathrm{X} \quad \text { No } & \mathrm{X}\end{array}$

Colección

Colección en la que se encuentra : Se desconoce.

Colección en la que se encuentra la plancha : Se desconoce.

Otras colecciones que tengan ejemplares de este trabajo : Se desconoce.

\section{Libros}

\section{Localización del libro o catalogo :}

"Matta, Index dell'opera grafica dal 1969 al 1980", editado por Admministrazione Provinciali di Viterbo en 1980, realizado por Germana Ferrari.

Pagina 145

\section{Otros catologos que lo contengan :}

Se desconoce.

Registros gráficos obtenidos

Diapositiva

Imagén digital 


\section{Obra grafica Roberto Sebastian Matta Echaurren}

Ficha número : 68

Titulo de la obra : La chasse aux papillons.

Fecha de realización : 1975.

Dimensiones

Tamaño del papel : $\quad$ Se desconoce.

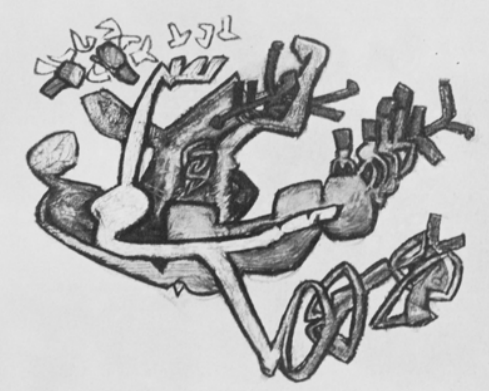

Tamaño de la mancha : 47 x $61 \mathrm{~cm}$.

\section{Técnica}

Técnica : Serigrafía.

Procedimientos y recursos complementarios :

Se desconoce.

\section{Matriz}

Número de planchas : No existe.

Material de las planchas : Tela.

Datos complementarios :

Se desconoce.

Estampación

Número de tintas :

En hueco

En relieve

Planigrafica

Permeografica

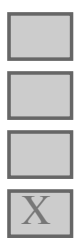

Se desconoce.

\section{Colores :}

Se desconoce.

\section{Papel}

Marca : No existe es una hoja de carta.

Gramaje : Se desconoce.

Color : $\quad$ Se desconoce. 


\section{Edición}

Número de ejemplares :

99 ejemplares sobre carta tamaño 60 x $80 \mathrm{~cm}$. firmada y numerada del 1 al 99 mas XXV H.C. firmada y numerada del 1 al XXV.

$\mathbf{N}^{\circ}$ de P.A. (Prueba de Artista) : Se desconoce.

$\mathbf{N}^{\circ}$ de H.C. (Hors Commerce) : Se desconoce.

B.A.T.: $\quad$ Se desconoce.

Otras Pruebas : Se desconoce.

Taller en el que se realizó :

Edición privada en Roma Italia.

Estampador

Se desconoce.

Número de la estampa observada : Se desconoce.

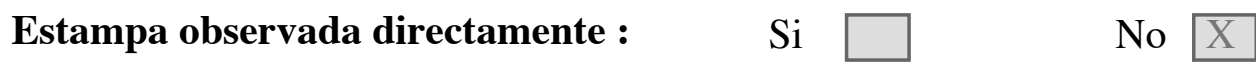

Contemplada a través de reproducción : $\mathrm{Si} X \quad$ No $\mathrm{X}$

Colección

Colección en la que se encuentra : Se desconoce.

Colección en la que se encuentra la plancha : Se desconoce.

Otras colecciones que tengan ejemplares de este trabajo : Se desconoce.

\section{Libros}

\section{Localización del libro o catalogo :}

"Matta, Index dell'opera grafica dal 1969 al 1980", editado por Admministrazione Provinciali di Viterbo en 1980, realizado por Germana Ferrari.

Pagina 151.

\section{Otros catologos que lo contengan :}

Se desconoce.

Registros gráficos obtenidos $\quad$ Diapositiva $\quad \square \quad$ Imagén digital 


\section{Obra grafica Roberto Sebastian Matta Echaurren}

Ficha número : 69

Titulo de la obra : Les convaincus.

Fecha de realización : 1952- 1976.

Dimensiones

Tamaño del papel : $54 \times 76 \mathrm{~cm}$.

Tamaño de la mancha : $48 \times 70 \mathrm{~cm}$.

\section{Técnica}

Técnica : Litografía.

Procedimientos y recursos complementarios :

Les convaincus es una litografía impresa en 1976 la que se dibujo en el año 1952.

\section{Matriz}

Número de planchas : Se desconoce.

Material de las planchas : Piedra.

Datos complementarios :

Se desconoce.

\section{Estampación}

En hueco

En relieve

Planigrafica

Permeografica

Papel

\section{Número de tintas :}

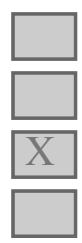

Se utilizaron cuatro tintas.

\section{Colores :}

Beige, crema, negro y celeste.

Marca : Papel Arches.

Gramaje : Se desconoce.

Color : Blanco. 


\section{Edición}

Número de ejemplares :

99 ejemplares sobre papel Arches tamaño 54 x $76 \mathrm{~cm}$. firmados y numerados del 1 al 99 mas X P.A. numerada del I al X.

$\mathrm{N}^{\circ}$ de P.A. (Prueba de Artista) : X P.A.

$\mathbf{N}^{\circ}$ de H.C. (Hors Commerce) : Se desconoce.

B.A.T. : $\quad$ Se desconoce.

Otras Pruebas : Se desconoce.

Taller en el que se realizó :

Atelier Fernand Mourlot en Paris Edicion Helion en Paris Francia.

Estampador

No se sabe si fue Fernand Mourlot o Franck Bordas.

Número de la estampa observada : Se desconoce.

Estampa observada directamente : $\quad \mathrm{Si} \square \quad$ No $\mathrm{X}$

Contemplada a través de reproducción : $\mathrm{Si} X \quad$ No $\mathrm{X}$

Colección

Colección en la que se encuentra : Se desconoce.

Colección en la que se encuentra la plancha : Se desconoce.

Otras colecciones que tengan ejemplares de este trabajo : Se desconoce.

\section{Libros}

\section{Localización del libro o catalogo :}

"Matta, Index dell'opera grafica dal 1969 al 1980", editado por Admministrazione Provinciali di Viterbo en 1980, realizado por Germana Ferrari.

Pagina 152.

\section{Otros catologos que lo contengan :}

Se desconoce.

Registros gráficos obtenidos $\quad$ Diapositiva $\quad \square \quad$ Imagén digital 


\section{Obra grafica Roberto Sebastian Matta Echaurren}

Ficha número : 70

Titulo de la obra : Le doute des trois mondes.

Fecha de realización : $1958-1976$.

Dimensiones

Tamaño del papel : $54 \times 76 \mathrm{~cm}$.

Tamaño de la mancha : 49 x $72 \mathrm{~cm}$.

\section{Técnica}

Técnica : Litografía.

Procedimientos y recursos complementarios :

Le doute des trois mondes es una litografía impresa en 1976 la que se dibujo en el año 1958.

\section{Matriz}

Número de planchas : $\quad$ Se desconoce.

Material de las planchas : Piedra.

Datos complementarios :

Se desconoce.

\section{Estampación}

En hueco

En relieve

Planigrafica

Permeografica

Número de tintas :

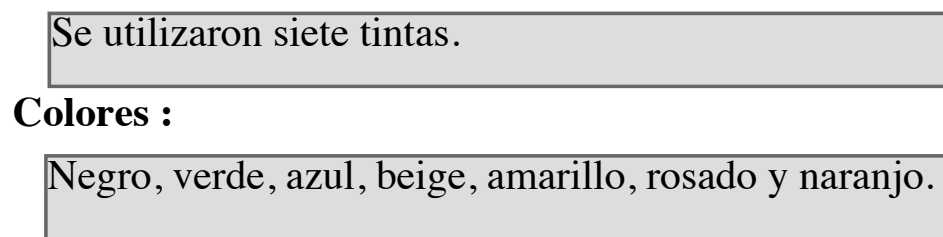

\section{Papel}

Marca : Papel Arches.

Gramaje : Se desconoce.

Color : Blanco. 


\section{Edición}

Número de ejemplares :

99 ejemplares sobre papel Arches tamaño 54 x $76 \mathrm{~cm}$. firmados y numerados del 1 al 99 mas X P.A. numerada del I al X.

$N^{\circ}$ de P.A. (Prueba de Artista) : X P.A.

$\mathbf{N}^{\circ}$ de H.C. (Hors Commerce) : Se desconoce.

B.A.T. : $\quad$ Se desconoce.

Otras Pruebas : Se desconoce.

Taller en el que se realizó :

Atelier Fernand Mourlot en Paris Edicion Helion en Paris Francia.

Estampador

No se sabe si fue Fernand Mourlot o Franck Bordas.

Número de la estampa observada : Se desconoce.

Estampa observada directamente : $\quad \mathrm{Si} \square \quad$ No $\mathrm{X}$

Contemplada a través de reproducción : $\mathrm{Si} X \quad$ No $\mathrm{X}$

Colección

Colección en la que se encuentra : Se desconoce.

Colección en la que se encuentra la plancha : Se desconoce.

Otras colecciones que tengan ejemplares de este trabajo : Se desconoce.

\section{Libros}

\section{Localización del libro o catalogo :}

"Matta, Index dell'opera grafica dal 1969 al 1980", editado por Admministrazione Provinciali di Viterbo en 1980, realizado por Germana Ferrari.

Pagina 153.

\section{Otros catologos que lo contengan :}

Se desconoce.

Registros gráficos obtenidos Diapositiva $\quad \square \quad$ Imagén digital $\quad X$ 


\section{Obra grafica Roberto Sebastian Matta Echaurren}

Ficha número : 71

Titulo de la obra : La promenade de venus.

Fecha de realización : $1965-1976$.

Dimensiones

Tamaño del papel : $54 \times 76 \mathrm{~cm}$.

Tamaño de la mancha : 48 x $70 \mathrm{~cm}$.

\section{Técnica}

Técnica : Litografía.

Procedimientos y recursos complementarios :

La promenade de Venus es una litografía impresa en 1976 la que se dibujo en el año 1965.

\section{Matriz}

Número de planchas : $\quad$ Se desconoce.

Material de las planchas : Piedra

Datos complementarios :

Se desconoce.

\section{Estampación}

En hueco

En relieve

Planigrafica

Permeografica

Papel

\section{Número de tintas :}

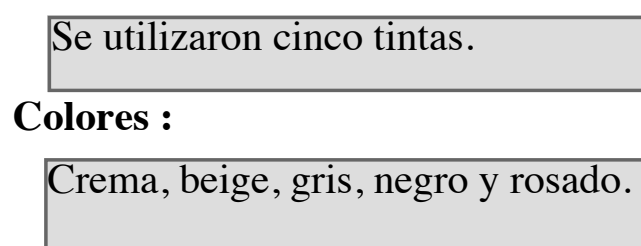

Marca : Papel Arches.

Gramaje : Se desconoce.

Color : Blanco. 


\section{Edición}

Número de ejemplares :

99 ejemplares sobre papel Arches tamaño 54 x $76 \mathrm{~cm}$. firmados y numerados del 1 al 99 mas X P.A. numerada del I al X.

$N^{\circ}$ de P.A. (Prueba de Artista) : X P.A

$\mathbf{N}^{\circ}$ de H.C. (Hors Commerce) : Se desconoce.

B.A.T. : $\quad$ Se desconoce.

Otras Pruebas : Se desconoce.

Taller en el que se realizó :

Atelier Fernand Mourlot en Paris Edicion Helion en Paris Francia.

Estampador

No se sabe si fue Fernand Mourlot o Franck Bordas.

Número de la estampa observada : Se desconoce.

Estampa observada directamente : $\quad \mathrm{Si} \square \quad$ No $\mathrm{X}$

Contemplada a través de reproducción : $\mathrm{Si} X \quad$ No $\mathrm{X}$

Colección

Colección en la que se encuentra : Se desconoce.

Colección en la que se encuentra la plancha : Se desconoce.

Otras colecciones que tengan ejemplares de este trabajo : Se desconoce.

\section{Libros}

\section{Localización del libro o catalogo :}

"Matta, Index dell'opera grafica dal 1969 al 1980", editado por Admministrazione Provinciali di Viterbo en 1980, realizado por Germana Ferrari.

Pagina 154.

\section{Otros catologos que lo contengan :}

Se desconoce.

Registros gráficos obtenidos Diapositiva $\quad \square \quad$ Imagén digital $\quad X$ 


\section{Obra grafica Roberto Sebastian Matta Echaurren}

Ficha número : 72

Titulo de la obra : O`nain de venus.

Fecha de realización : Dibujo 1969/ impreso 1976.

Dimensiones

Tamaño del papel : $54 \times 76 \mathrm{~cm}$.

Tamaño de la mancha : $48 \times 68 \mathrm{~cm}$.

\section{Técnica}

Técnica : Litografía.

Procedimientos y recursos complementarios :

O`nain de Venus es una litografía impresa en 1976 la que se dibujo en el año 1969.

\section{Matriz}

Número de planchas : $\quad$ Se desconoce.

Material de las planchas : Piedra.

Datos complementarios :

Se desconoce.

Estampación

En hueco

En relieve

Planigrafica

Permeografica

Papel

Marca : Papel Arches.

Gramaje : Se desconoce.

Color : Blanco.

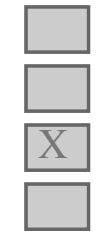

Número de tintas :

Se utilizaron cinco tintas.
Colores :
Amarillo, azul, celeste, verde y negro.

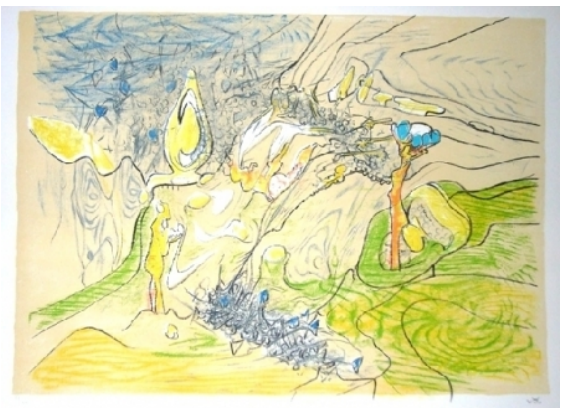




\section{Edición}

Número de ejemplares :

99 ejemplares sobre papel Arches tamaño 54 x $76 \mathrm{~cm}$. firmados y numerados del 1 al 99 mas X P.A. numerada del I al X.

$\mathrm{N}^{\circ}$ de P.A. (Prueba de Artista) : X P.A.

$\mathbf{N}^{\circ}$ de H.C. (Hors Commerce) : Se desconoce.

B.A.T. : $\quad$ Se desconoce.

Otras Pruebas : Se desconoce.

Taller en el que se realizó :

Atelier Fernand Mourlot en Paris Edicion Helion en Paris Francia.

Estampador

No se sabe si fue Fernand Mourlot o Franck Bordas.

Número de la estampa observada : Se desconoce.

Estampa observada directamente : $\quad \mathrm{Si} \square \quad$ No $\mathrm{X}$

Contemplada a través de reproducción : $\mathrm{Si} X \quad$ No $\mathrm{X}$

Colección

Colección en la que se encuentra : Se desconoce.

Colección en la que se encuentra la plancha : Se desconoce.

Otras colecciones que tengan ejemplares de este trabajo : Se desconoce.

\section{Libros}

\section{Localización del libro o catalogo :}

"Matta, Index dell'opera grafica dal 1969 al 1980", editado por Admministrazione Provinciali di Viterbo en 1980, realizado por Germana Ferrari.

Pagina 155.

\section{Otros catologos que lo contengan :}

Se desconoce.

Registros gráficos obtenidos Diapositiva $\quad \square \quad$ Imagén digital $\quad X$ 


\section{Obra grafica Roberto Sebastian Matta Echaurren}

Ficha número : 73

Titulo de la obra : Eugenio C.

Fecha de realización : $1970-1976$

Dimensiones

Tamaño del papel : $56 \times 76 \mathrm{~cm}$.

Tamaño de la mancha : 50 × $65 \mathrm{~cm}$.

\section{Técnica}

Técnica : Litografía.

Procedimientos y recursos complementarios :

Eugenio C es una litografía impresa en 1976 la que se dibujo en el año 1970.

\section{Matriz}

Número de planchas : $\quad$ Se desconoce.

Material de las planchas : Piedra.

\section{Datos complementarios :}

Se desconoce.

Estampación

En hueco

En relieve

Planigrafica

Permeografica

Papel

Marca : Papel Arches.

Gramaje : Se desconoce.

Color : Blanco.
Número de tintas :

Se utilizaron 6 tintas.
Colores :
Gris, crema, beige, celeste, azul y negro.

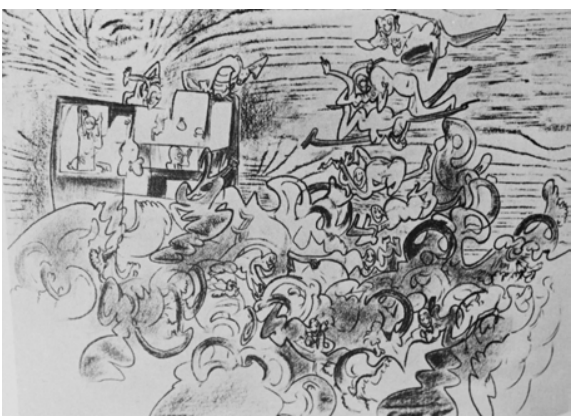




\section{Edición}

Número de ejemplares :

99 ejemplares sobre papel Arches tamaño 54 x $76 \mathrm{~cm}$. firmados y numerados del 1 al 99 mas X P.A. numerada del I al X.

$\mathbf{N}^{\circ}$ de P.A. (Prueba de Artista) : Se desconoce.

$\mathbf{N}^{\circ}$ de H.C. (Hors Commerce) : Se desconoce.

B.A.T. : $\quad$ Se desconoce.

Otras Pruebas : Se desconoce.

Taller en el que se realizó :

Atelier Fernand Mourlot en Paris Edicion privada en Paris Francia.

Estampador

No se sabe si fue Fernand Mourlot o Franck Bordas.

Número de la estampa observada : Se desconoce.

Estampa observada directamente : $\quad \mathrm{Si} \square \quad$ No $\mathrm{X}$

Contemplada a través de reproducción : $\mathrm{Si} X \quad$ No $\mathrm{X}$

Colección

Colección en la que se encuentra : Se desconoce.

Colección en la que se encuentra la plancha : Se desconoce.

Otras colecciones que tengan ejemplares de este trabajo : Se desconoce.

\section{Libros}

\section{Localización del libro o catalogo :}

"Matta, Index dell'opera grafica dal 1969 al 1980", editado por Admministrazione Provinciali di Viterbo en 1980, realizado por Germana Ferrari.

Pagina 156.

\section{Otros catologos que lo contengan :}

Se desconoce.

Registros gráficos obtenidos $\quad$ Diapositiva $\quad \square \quad$ Imagén digital 


\section{Obra grafica Roberto Sebastian Matta Echaurren}

Ficha número : 74

Titulo de la obra : Ca ira.

Fecha de realización : $1972-1976$.

Dimensiones

Tamaño del papel : $54 \times 76 \mathrm{~cm}$.

Tamaño de la mancha : 50 x $68 \mathrm{~cm}$.

\section{Técnica}

Técnica : Litografía.

Procedimientos y recursos complementarios :

Ca ira es una litografía impresa en 1976 la que se dibujo en el año 1972.

\section{Matriz}

Número de planchas : $\quad$ Se desconoce.

Material de las planchas : Piedra.

Datos complementarios :

Se desconoce.

Estampación

En hueco

En relieve

Planigrafica

Permeografica

Papel

Marca : Papel Arches.

Gramaje : Se desconoce.

Color : Blanco.
Número de tintas :

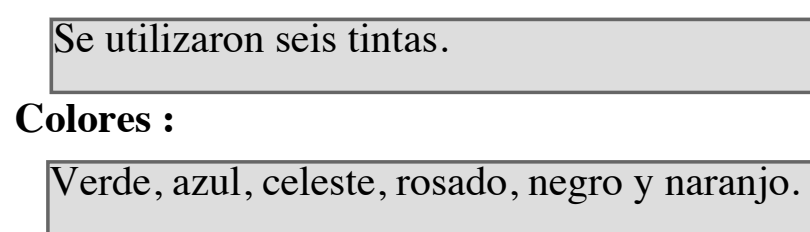




\section{Edición}

Número de ejemplares :

99 ejemplares sobre papel Arches tamaño 54 x $76 \mathrm{~cm}$. firmados y numerados del 1 al 99 mas X P.A. numerada del I al X.

$N^{\circ}$ de P.A. (Prueba de Artista) : X P.A.

$\mathbf{N}^{\circ}$ de H.C. (Hors Commerce) : Se desconoce.

B.A.T. : Se desconoce.

Otras Pruebas : Se desconoce.

Taller en el que se realizó :

Atelier Fernand Mourlot en Paris Edicion privada en Paris Francia.

Estampador

No se sabe si fue Fernand Mourlot o Franck Bordas.

Número de la estampa observada : Se desconoce.

Estampa observada directamente : $\quad \mathrm{Si} \square \quad$ No $\mathrm{X}$

Contemplada a través de reproducción : $\mathrm{Si} X \quad$ No $\mathrm{X}$

Colección

Colección en la que se encuentra : Se desconoce.

Colección en la que se encuentra la plancha : Se desconoce.

Otras colecciones que tengan ejemplares de este trabajo : Se desconoce.

\section{Libros}

\section{Localización del libro o catalogo :}

"Matta, Index dell'opera grafica dal 1969 al 1980", editado por Admministrazione Provinciali di Viterbo en 1980, realizado por Germana Ferrari.

Pagina 158.

\section{Otros catologos que lo contengan :}

Se desconoce.

Registros gráficos obtenidos $\quad$ Diapositiva $\quad \square \quad$ Imagén digital 


\section{Obra grafica Roberto Sebastian Matta Echaurren}

Ficha número : 75

Titulo de la obra : ça A.

Fecha de realización : $1971-1976$.

Dimensiones

Tamaño del papel : $56 \times 76 \mathrm{~cm}$.

Tamaño de la mancha : $50 \times 68 \mathrm{~cm}$.

\section{Técnica}

Técnica : Litografía.

Procedimientos y recursos complementarios :

ça A es una litografía impresa en 1976 la que se dibujo en el año 1971.

\section{Matriz}

Número de planchas : $\quad$ Se desconoce.

Material de las planchas : Piedra.

Datos complementarios :

Se desconoce.

Estampación

En hueco

En relieve

Planigrafica

Permeografica

Papel

Marca : Papel Arches.

Gramaje : Se desconoce.

Color : $\quad$ Se desconoce.

\section{Número de tintas :}

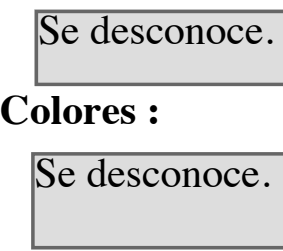

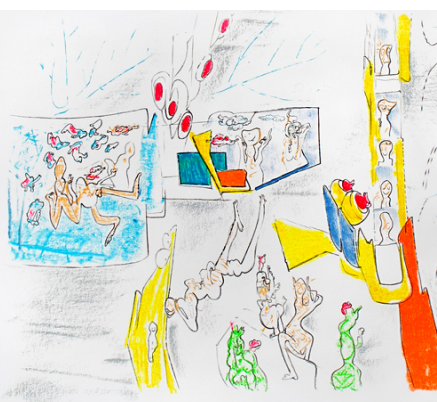




\section{Edición}

Número de ejemplares :

99 ejemplares sobre papel Arches tamaño 54 x $76 \mathrm{~cm}$. firmados y numerados del 1 al 99 mas X P.A. numerada del I al X.

$N^{\circ}$ de P.A. (Prueba de Artista) : X P.A.

$\mathbf{N}^{\circ}$ de H.C. (Hors Commerce) : Se desconoce.

B.A.T. : Se desconoce.

Otras Pruebas : Se desconoce.

Taller en el que se realizó :

Atelier Fernand Mourlot en Paris Edicion privada en Paris Francia.

Estampador

No se sabe si fue Fernand Mourlot o Franck Bordas.

Número de la estampa observada : Se desconoce.

Estampa observada directamente : $\quad \mathrm{Si} \square \quad$ No $\mathrm{X}$

Contemplada a través de reproducción : $\mathrm{Si} X \quad$ No $\mathrm{X}$

Colección

Colección en la que se encuentra : Se desconoce.

Colección en la que se encuentra la plancha : Se desconoce.

Otras colecciones que tengan ejemplares de este trabajo : Se desconoce.

\section{Libros}

\section{Localización del libro o catalogo :}

"Matta, Index dell'opera grafica dal 1969 al 1980", editado por Admministrazione Provinciali di Viterbo en 1980, realizado por Germana Ferrari.

Pagina 157.

\section{Otros catologos que lo contengan :}

Se desconoce.

Registros gráficos obtenidos Diapositiva $\quad \square \quad$ Imagén digital $\quad X$ 


\section{Obra grafica Roberto Sebastian Matta Echaurren}

Ficha número : 76

Titulo de la obra : Fluxant.

Fecha de realización : Dibujo 1972/ impreso 1976

Dimensiones

Tamaño del papel : $54 \times 76 \mathrm{~cm}$.

Tamaño de la mancha : $50 \times 70 \mathrm{~cm}$.

\section{Técnica}

Técnica : Litografía.

Procedimientos y recursos complementarios :

Fluxant es una litografía impresa en 1976 la que se dibujo en el año 1972.

\section{Matriz}

Número de planchas : $\quad$ Se desconoce.

Material de las planchas : Piedra.

Datos complementarios :

Se desconoce.

Estampación

En hueco

En relieve

Planigrafica

Permeografica

Papel

Marca : Papel Arches.

Gramaje : Se desconoce.

Color : $\quad$ Se desconoce.
Número de tintas :

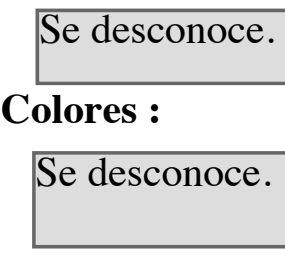

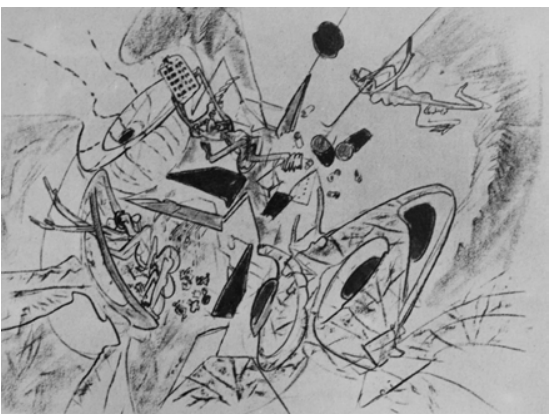




\section{Edición}

Número de ejemplares :

99 ejemplares sobre papel Arches tamaño 54 x $76 \mathrm{~cm}$. firmados y numerados del 1 al 99 mas X P.A. numerada del I al X.

$\mathrm{N}^{\circ}$ de P.A. (Prueba de Artista) : X P.A.

$\mathbf{N}^{\circ}$ de H.C. (Hors Commerce) : Se desconoce.

B.A.T. : $\quad$ Se desconoce.

Otras Pruebas : Se desconoce.

Taller en el que se realizó :

Atelier Fernand Mourlot en Paris Edicion privada en Paris Francia.

Estampador

No se sabe si fue Fernand Mourlot o Franck Bordas.

Número de la estampa observada : Se desconoce.

Estampa observada directamente : $\quad \mathrm{Si} \square \quad$ No $\mathrm{X}$

Contemplada a través de reproducción : $\mathrm{Si} X \quad$ No $\mathrm{X}$

Colección

Colección en la que se encuentra : Se desconoce.

Colección en la que se encuentra la plancha : Se desconoce.

Otras colecciones que tengan ejemplares de este trabajo : Se desconoce.

\section{Libros}

\section{Localización del libro o catalogo :}

"Matta, Index dell'opera grafica dal 1969 al 1980", editado por Admministrazione Provinciali di Viterbo en 1980, realizado por Germana Ferrari.

Pagina 159.

\section{Otros catologos que lo contengan :}

Se desconoce.

Registros gráficos obtenidos $\quad$ Diapositiva $\quad \square \quad$ Imagén digital 


\section{Obra grafica Roberto Sebastian Matta Echaurren}

Ficha número : 77

Titulo de la obra : Le veau d’or.

Fecha de realización : 1976.

Dimensiones

Tamaño del papel : $50 \times 65 \mathrm{~cm}$.

Tamaño de la mancha : 50 x $65 \mathrm{~cm}$. Sin margen.

\section{Técnica}

Técnica : Litografía.

Procedimientos y recursos complementarios :

Se desconoce.

\section{Matriz}

Número de planchas : $\quad$ Se desconoce.

Material de las planchas : Piedra.

\section{Datos complementarios :}

Se desconoce.

\section{Estampación}

En hueco

En relieve

Planigrafica

Permeografica

Papel

Marca : $\quad$ Papel Arches y papel Japon Nacre.

Color : Blanco.

\section{Gramaje : Se desconoce.}

Número de tintas :

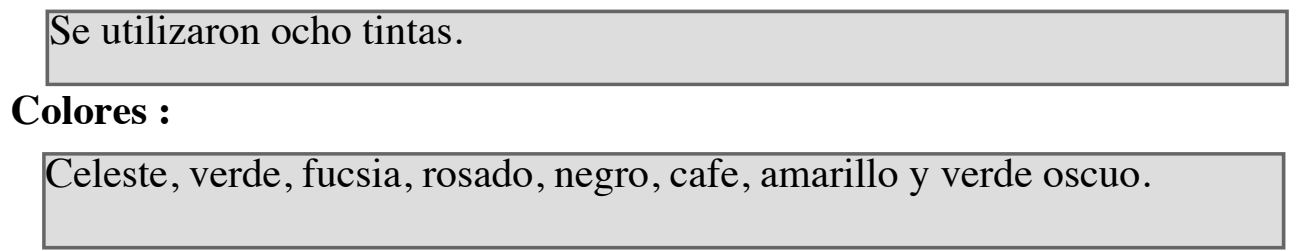

Color : Blanco. 


\section{Edición}

Número de ejemplares :

125 ejemplares sobre papel Arches tamaño 50 × 65 cm. firmados y numerados del 1 al 125 mas XXV H.C. sobre papel Japón Nacre firmado y numerado del I al XXV y alguna P.A. no numerada.

$\mathbf{N}^{\circ}$ de P.A. (Prueba de Artista) : Se desconoce.

$\mathbf{N}^{\circ}$ de H.C. (Hors Commerce) : XXV H.C.

B.A.T. : $\quad$ Se desconoce.

Otras Pruebas : Se desconoce.

Taller en el que se realizó :

Atelier Fernand Mourlot en Paris Edición Rosenberg Nueva York.

Estampador

No se sabe si fue Fernand Mourlot o Franck Bordas.

Número de la estampa observada : Se desconoce.

\begin{tabular}{llll} 
Estampa observada directamente : & $\mathrm{Si}$ & $\square$ & No \\
\hline
\end{tabular}

Contemplada a través de reproducción : $\mathrm{Si} X \quad$ No $\mathrm{X}$

Colección

Colección en la que se encuentra : Se desconoce.

Colección en la que se encuentra la plancha : Se desconoce.

Otras colecciones que tengan ejemplares de este trabajo : Se desconoce.

\section{Libros}

\section{Localización del libro o catalogo :}

"Matta, Index dell'opera grafica dal 1969 al 1980", editado por Admministrazione Provinciali di Viterbo en 1980, realizado por Germana Ferrari.

Pagina 160

\section{Otros catologos que lo contengan :}

Se desconoce.

Registros gráficos obtenidos

Diapositiva

Imagén digital 


\section{Obra grafica Roberto Sebastian Matta Echaurren}

Ficha número : 78

Titulo de la obra : No lo sabia.

Fecha de realización : 1976.

Dimensiones

Tamaño del papel : $45 \times 60 \mathrm{~cm}$.

Tamaño de la mancha : $41 \times 48 \mathrm{~cm}$.

\section{Técnica}

Técnica : Litografía.

Procedimientos y recursos complementarios :

Se desconoce.

\section{Matriz}

Número de planchas : $\quad$ Se desconoce.

Material de las planchas : Se desconoce.

Datos complementarios :

Se desconoce.

Estampación

En hueco

En relieve

Planigrafica

Permeografica

Papel

Marca : $\quad$ Se desconoce.

Gramaje : Se desconoce.

Color : $\quad$ Se desconoce.
Número de tintas :

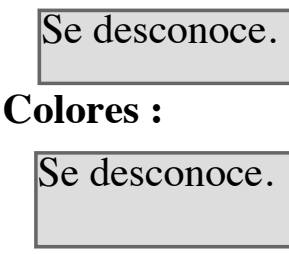

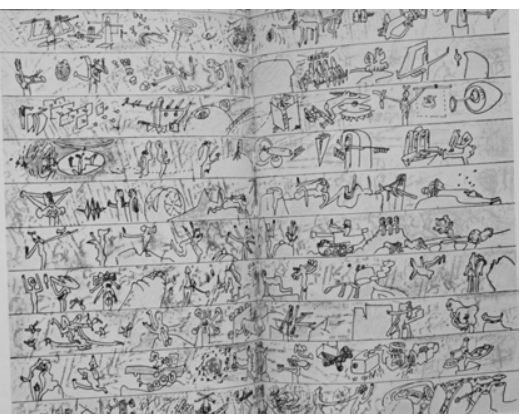




\section{Edición}

Número de ejemplares :

20 P.A. tamaño $45 \times 60 \mathrm{~cm}$. no numerada.

$\mathbf{N}^{\circ}$ de P.A. (Prueba de Artista) : 20 P.A.

$\mathbf{N}^{\circ}$ de H.C. (Hors Commerce) : Se desconoce.

B.A.T.: $\quad$ Se desconoce.

Otras Pruebas : Se desconoce.

Taller en el que se realizó :

Estampa y edición en La catedral Cuba.

Estampador

Se desconoce.

Número de la estampa observada : Se desconoce.

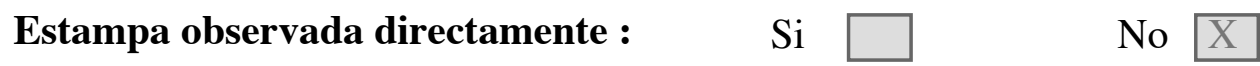

$\begin{array}{llll}\text { Contemplada a través de reproducción : } & \text { Si } \quad X \quad \text { No } & X\end{array}$

Colección

Colección en la que se encuentra : Se desconoce.

Colección en la que se encuentra la plancha : Se desconoce.

Otras colecciones que tengan ejemplares de este trabajo : Se desconoce.

\section{Libros}

\section{Localización del libro o catalogo :}

"Matta, Index dell'opera grafica dal 1969 al 1980", editado por Admministrazione Provinciali di Viterbo en 1980, realizado por Germana Ferrari.

Pagina 164;

\section{Otros catologos que lo contengan :}

Se desconoce.

Registros gráficos obtenidos

Diapositiva

Imagén digital 


\section{Obra grafica Roberto Sebastian Matta Echaurren}

Ficha número : 79

Titulo de la obra : Cicatriciel.

Fecha de realización : 1976.

Dimensiones

Tamaño del papel : 34 x $44 \mathrm{~cm}$.

Tamaño de la mancha : $24 \times 17.5 \mathrm{~cm}$.

\section{Técnica}

Técnica : Aguafuerte y aguatinta

Procedimientos y recursos complementarios :

Se desconoce.

\section{Matriz}

Número de planchas : $\quad$ Se desconoce.

Material de las planchas : Se desconoce.

Datos complementarios :

Se desconoce.

Estampación

En hueco

En relieve

Planigrafica

Permeografica

Papel

Marca : Papel Arches.

Gramaje : Se desconoce.

Color : $\quad$ Se desconoce.

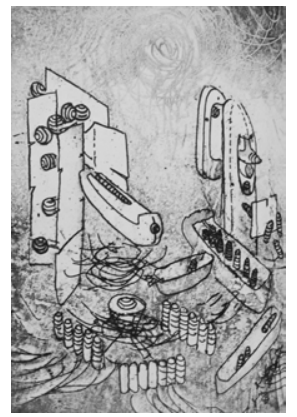




\section{Edición}

Número de ejemplares :

100 ejemplares sobre papel Arches tamaño 34 x $44 \mathrm{~cm}$. firmados y numerados del 1 al 100 mas XXV H.C. firmados y numerados del I al XXV.

$\mathbf{N}^{\circ}$ de P.A. (Prueba de Artista) : Se desconoce.

$\mathbf{N}^{\circ}$ de H.C. (Hors Commerce) : XXV H.C.

B.A.T. : $\quad$ Se desconoce.

Otras Pruebas : Se desconoce.

Taller en el que se realizó :

Atelier George Visat y edición privada en Paris Francia.

Estampador

No se sabe si es George Visat o Albert Dupont.

Número de la estampa observada : Se desconoce.

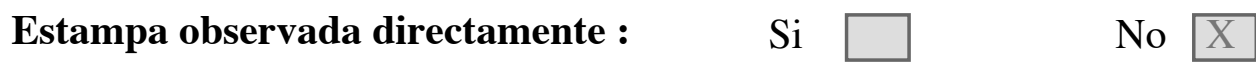

Contemplada a través de reproducción : $\mathrm{Si} X \quad$ No $\mathrm{X}$

Colección

Colección en la que se encuentra : Se desconoce.

Colección en la que se encuentra la plancha : Se desconoce.

Otras colecciones que tengan ejemplares de este trabajo : Se desconoce.

\section{Libros}

\section{Localización del libro o catalogo :}

"Matta, Index dell'opera grafica dal 1969 al 1980", editado por Admministrazione Provinciali di Viterbo en 1980, realizado por Germana Ferrari.

Pagina 165

\section{Otros catologos que lo contengan :}

Se desconoce.

Registros gráficos obtenidos

Diapositiva

Imagén digital 


\section{Obra grafica Roberto Sebastian Matta Echaurren}

Ficha número : 80

Titulo de la obra : Douze Heures.

Fecha de realización : 1976.

Dimensiones

Tamaño del papel : $54 \times 70 \mathrm{~cm}$.

Tamaño de la mancha : 48 x $63 \mathrm{~cm}$.

\section{Técnica}

Técnica : Litografía.

Procedimientos y recursos complementarios :

Se desconoce.

\section{Matriz}

Número de planchas : $\quad$ Se desconoce.

Material de las planchas : Se desconoce.

Datos complementarios :

Se desconoce.

Estampación

En hueco

En relieve

Planigrafica

Permeografica

Papel

Marca : $\quad$ Papel Arches y papel Japon Nacre.

Gramaje : Se desconoce.

Color : Blanco.

\section{Número de tintas :}

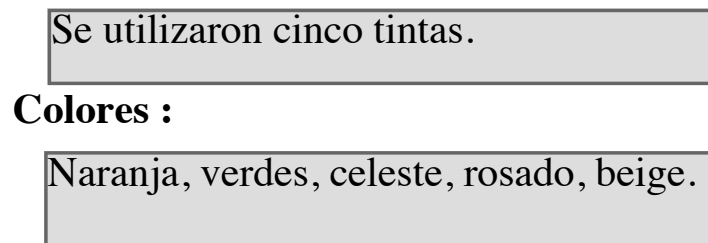

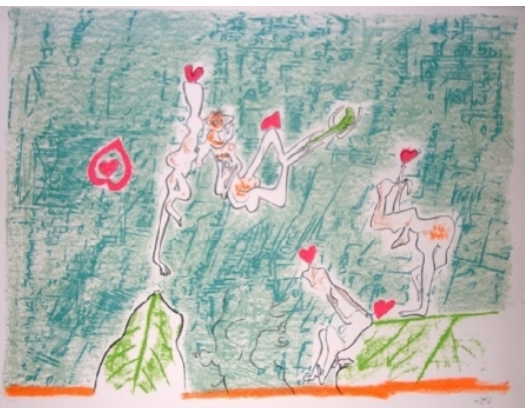




\section{Edición}

Número de ejemplares :

99 ejemplares sobre papel Arches firmados y numerados del 1 al 99 mas X ejemplares sobre papel Japón Nacre firmados y numerados del I al X mas alguna prueba de artista no numerada.

Esta litografía se utilizo para un manifiesto del partido comunista del cual hubieron 500 ejemplares de $58 \mathrm{x}$ $70 \mathrm{~cm}$. no firmados.

$\mathbf{N}^{\circ}$ de P.A. (Prueba de Artista) : Se desconoce.

$\mathbf{N}^{\circ}$ de H.C. (Hors Commerce) : Se desconoce.

B.A.T. : $\quad$ Se desconoce.

Otras Pruebas : Se desconoce.

Taller en el que se realizó :

Atelier Fernand Mourlot en Paris. Mas una edición del Partido Comunista en Tours Francia.

Estampador

No se sabe si fue Fernand Mourlot o Franck Bordas.

Número de la estampa observada : Se desconoce.

Estampa observada directamente : $\quad \mathrm{Si} X$

Contemplada a través de reproducción : $\mathrm{Si} X$

Colección

Colección en la que se encuentra : Se desconoce.

Colección en la que se encuentra la plancha : Se desconoce.

Otras colecciones que tengan ejemplares de este trabajo : Se desconoce.

\section{Libros}

\section{Localización del libro o catalogo :}

"Matta, Index dell'opera grafica dal 1969 al 1980", editado por Admministrazione Provinciali di Viterbo en 1980, realizado por Germana Ferrari.

Pagina 166

\section{Otros catologos que lo contengan :}

Se desconoce.

Registros gráficos obtenidos

Diapositiva

Imagén digital 


\section{Obra grafica Roberto Sebastian Matta Echaurren}

Ficha número : 81

Titulo de la obra : Bande a jazz.

Fecha de realización : 1976.

Dimensiones

Tamaño del papel : $63 \times 85 \mathrm{~cm}$.

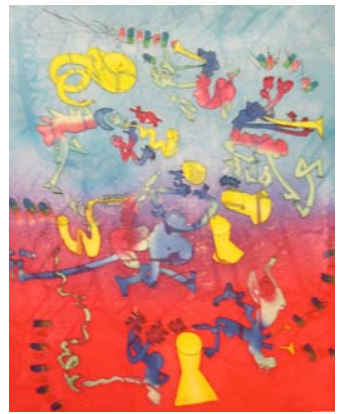

Tamaño de la mancha : 63.5 x $50 \mathrm{~cm}$.

\section{Técnica}

Técnica : Aguafuerte y aguatinta

Procedimientos y recursos complementarios :

Se desconoce.

\section{Matriz}

Número de planchas : $\quad$ Se desconoce.

Material de las planchas : Se desconoce.

Datos complementarios :

Se desconoce.

Estampación

Número de tintas :

En hueco

En relieve

Planigrafica

Permeografica

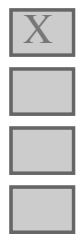

Alrededor de diez tintas.

Colores :

Rosado, violeta, amarillo, azul, verde, celeste, verde oscuro, rosado oscuro, turqueza.

Papel

Marca : $\quad$ Papel Arches y papel Japon Nacre.

Gramaje : Se desconoce.

Color : $\quad$ Blanco. 


\section{Edición}

Número de ejemplares :

75 ejemplares sobre papel arches tamaño $63 \times 85 \mathrm{~cm}$. firmados y numerados del 1 al 75 mas XXV ejemplares sobre papel Japón Nacre firmados y numerados del I al XXV mas 30 ejemplares sobre papel Arches firmados y numerados del 1 al 30 firmados E.A.

$\mathbf{N}^{\circ}$ de P.A. (Prueba de Artista) : Se desconoce.

$\mathbf{N}^{\circ}$ de H.C. (Hors Commerce) : Se desconoce.

B.A.T.: $\quad$ Se desconoce.

Otras Pruebas : Se desconoce.

Taller en el que se realizó :

Atelier George Visat en Paris Francia y Edición Sonet en Estocolmo suecia.

Estampador

Albert Dupont.

Número de la estampa observada : Se desconoce.

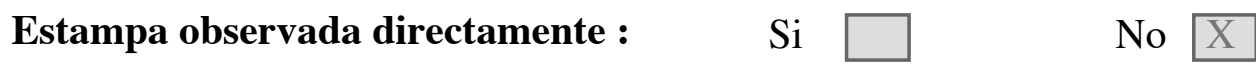

Contemplada a través de reproducción : $\mathrm{Si} X \quad$ No $\mathrm{X}$

Colección

Colección en la que se encuentra : Se desconoce.

Colección en la que se encuentra la plancha : Se desconoce.

Otras colecciones que tengan ejemplares de este trabajo : Se desconoce.

\section{Libros}

\section{Localización del libro o catalogo :}

"Matta, Index dell'opera grafica dal 1969 al 1980", editado por Admministrazione Provinciali di Viterbo en 1980, realizado por Germana Ferrari.

Pagina 168.

\section{Otros catologos que lo contengan :}

Se desconoce.

Registros gráficos obtenidos

Diapositiva

Imagén digital 


\section{Obra grafica Roberto Sebastian Matta Echaurren}

Ficha número : 82

Titulo de la obra : Jazz-Session.

Fecha de realización : 1975-1976.

Dimensiones

Tamaño del papel : Se desconoce.

Tamaño de la mancha : 50 × $67 \mathrm{~cm}$.

\section{Técnica}

Técnica : Litografía.

Procedimientos y recursos complementarios :

Se desconoce.

\section{Matriz}

Número de planchas : $\quad$ Se desconoce.

Material de las planchas : Piedra.

Datos complementarios :

Se desconoce.

Estampación

En hueco

En relieve

Planigrafica

Permeografica

Papel

Marca : Papel Arches.

Gramaje : Se desconoce.

Color : $\quad$ Se desconoce.

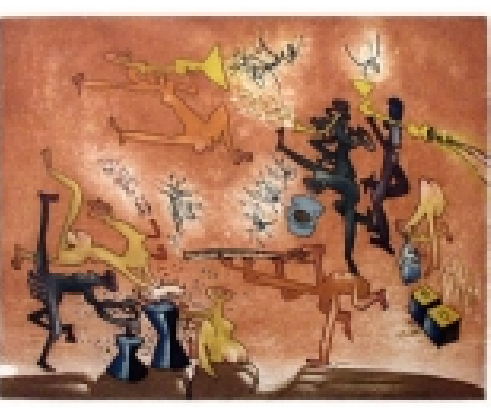

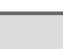




\section{Edición}

Número de ejemplares :

10 P.A. sobre papel Arches.

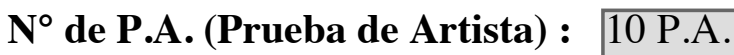

$\mathbf{N}^{\circ}$ de H.C. (Hors Commerce) : Se desconoce.

B.A.T. : $\quad$ Se desconoce.

Otras Pruebas : Se desconoce.

Taller en el que se realizó :

Estamperia Arte al Borgo en Palermo Italia.

Estampador

Se desconoce.

Número de la estampa observada : Se desconoce.

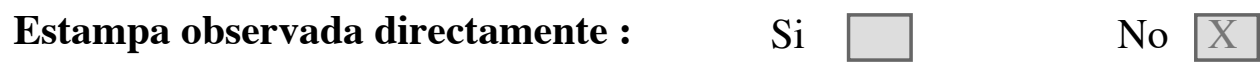

$\begin{array}{llll}\text { Contemplada a través de reproducción : Si } & \mathrm{X} \quad \text { No } \mathrm{X}\end{array}$

Colección

Colección en la que se encuentra : Se desconoce.

Colección en la que se encuentra la plancha : Se desconoce.

Otras colecciones que tengan ejemplares de este trabajo : Se desconoce.

\section{Libros}

\section{Localización del libro o catalogo :}

"Matta, Index dell'opera grafica dal 1969 al 1980", editado por Admministrazione Provinciali di Viterbo en 1980, realizado por Germana Ferrari.

Pagina 169

\section{Otros catologos que lo contengan :}

Se desconoce.

Registros gráficos obtenidos Diapositiva $\quad \square \quad$ Imagén digital $\quad X$ 


\section{Obra grafica Roberto Sebastian Matta Echaurren}

Ficha número : 83

Titulo de la obra : Le sot a la perche.

Fecha de realización : 1976.

Dimensiones

Tamaño del papel : 45 x $57 \mathrm{~cm}$.

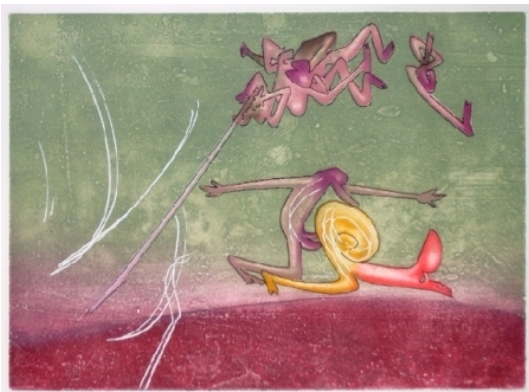

Tamaño de la mancha : $27 \times 36.5 \mathrm{~cm}$.

\section{Técnica}

Técnica : Aguafuerte y aguatinta

Procedimientos y recursos complementarios :

Le sot a la perche es un grabado con goffrados con una simpleza en el trazo y en el espacio.

\section{Matriz}

Número de planchas : $\quad$ Se desconoce.

Material de las planchas : Cobre.

Datos complementarios :

Se desconoce.

\section{Estampación}

En hueco

En relieve

Planigrafica

Permeografica

Número de tintas :

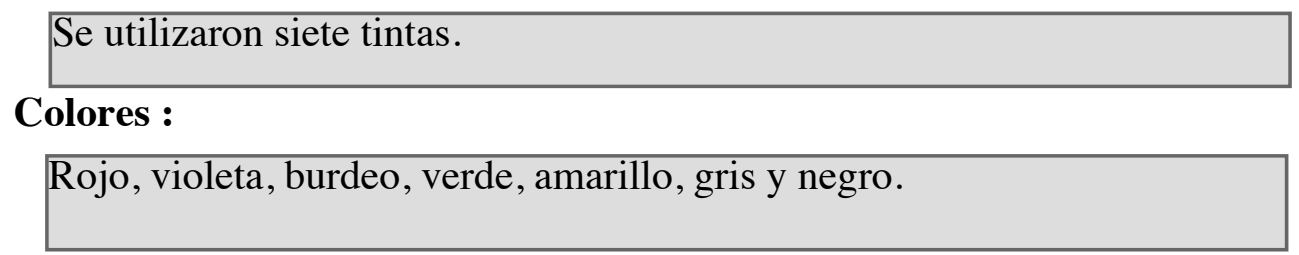

Papel

Marca : $\quad$ Papel Arches tamano $45 \times 57 \mathrm{~cm}$.

Gramaje : Se desconoce.

Color : Blanco. 


\section{Edición}

Número de ejemplares :

100 ejemplares sobre papel Arches tamaño 45 x $57 \mathrm{~cm}$ firmados y numerados del 1 al 100 mas XXV H.C. firmados y numerados del I al XXV.

$\mathbf{N}^{\circ}$ de P.A. (Prueba de Artista) : Se desconoce.

$\mathbf{N}^{\circ}$ de H.C. (Hors Commerce) : XXV H.C.

B.A.T. : $\quad$ Se desconoce.

Otras Pruebas : Se desconoce.

Taller en el que se realizó :

Atelier George Visat en Paris Francia y Edición Sonet en Estocolmo suecia.

Estampador

No se sabe si es George Visat o Albert Dupont.

Número de la estampa observada : Se desconoce.

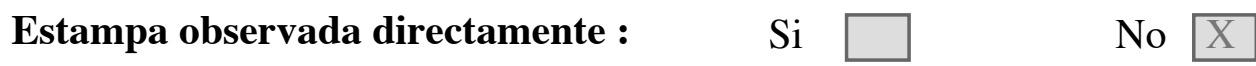

Contemplada a través de reproducción : $\mathrm{Si} X \quad$ No $\mathrm{X}$

Colección

Colección en la que se encuentra : Se desconoce.

Colección en la que se encuentra la plancha : Se desconoce.

Otras colecciones que tengan ejemplares de este trabajo : Se desconoce.

\section{Libros}

\section{Localización del libro o catalogo :}

"Matta, Index dell'opera grafica dal 1969 al 1980", editado por Admministrazione Provinciali di Viterbo en 1980, realizado por Germana Ferrari.

Pagina 170.

\section{Otros catologos que lo contengan :}

Se desconoce.

Registros gráficos obtenidos

Diapositiva

Imagén digital 


\section{Obra grafica Roberto Sebastian Matta Echaurren}

Ficha número : 84

Titulo de la obra : Les transesport.

Fecha de realización : 1976 impreso 1977

Dimensiones

Tamaño del papel : $45.5 \times 58 \mathrm{~cm}$.

Tamaño de la mancha : 26.5 x $37 \mathrm{~cm}$.

\section{Técnica}

Técnica : Aguafuerte y aguatinta.

\section{Procedimientos y recursos complementarios :}

Les transesport es un álbum de 10 grabados acompañados de un texto inédito de Roberto Matta.Contiene gofrados. Sus títulos son: les cyclistes, footballeur, la fleur du cheval, le filet cytoplasmique, la cible y S" ytoplanet.

\section{Matriz}

Número de planchas : Se desconoce.

Material de las planchas : Cobre.

\section{Datos complementarios :}

Se desconoce.

\section{Estampación}

En hueco

En relieve

Planigrafica

Permeografica
Número de tintas :

Se utilizaron entre entre 5 a 10 tintas.

Colores :

Cafe, ocre, amarillo, verde, burdeo, rosado, beige, naranja y negro.

Papel

Marca : $\quad$ Papel Arches y Papel Japón Nacré.

Gramaje : Se desconoce. 
Color :

Blanco.

\section{Edición}

Número de ejemplares :

100 ejemplares sobre papel Arches tamaño 45.5 x $58 \mathrm{~cm}$. firmado y numerado del 1 al 100 mas XXV H.C. firmados y numerados del Ial XXV

100 ejemplares sobre papel Japón Nacré tamaño 45.5 x $58 \mathrm{~cm}$. firmado y numerado del 1 al 100 mas XXV H. C. firmados y numerados del I al XXV.

$\mathbf{N}^{\circ}$ de P.A. (Prueba de Artista): Se desconoce.

$\mathbf{N}^{\circ}$ de H.C. (Hors Commerce) : XXV H.C.

B.A.T.: $\quad$ Se desconoce.

Otras Pruebas : Se desconoce.

Taller en el que se realizó :

Atelier George Visat impresión y edición en Paris Francia.

Estampador

No se sabe si es George Visat o Albert Dupont.

Número de la estampa observada : 
Estampa observada directamente :

Contemplada a través de reproducción :
$\mathrm{Si}$

$\mathrm{Si}$
No

No

\section{Colección}

Colección en la que se encuentra : Se desconoce.

Colección en la que se encuentra la plancha : Se desconoce.

Otras colecciones que tengan ejemplares de este trabajo :

Se desconoce.
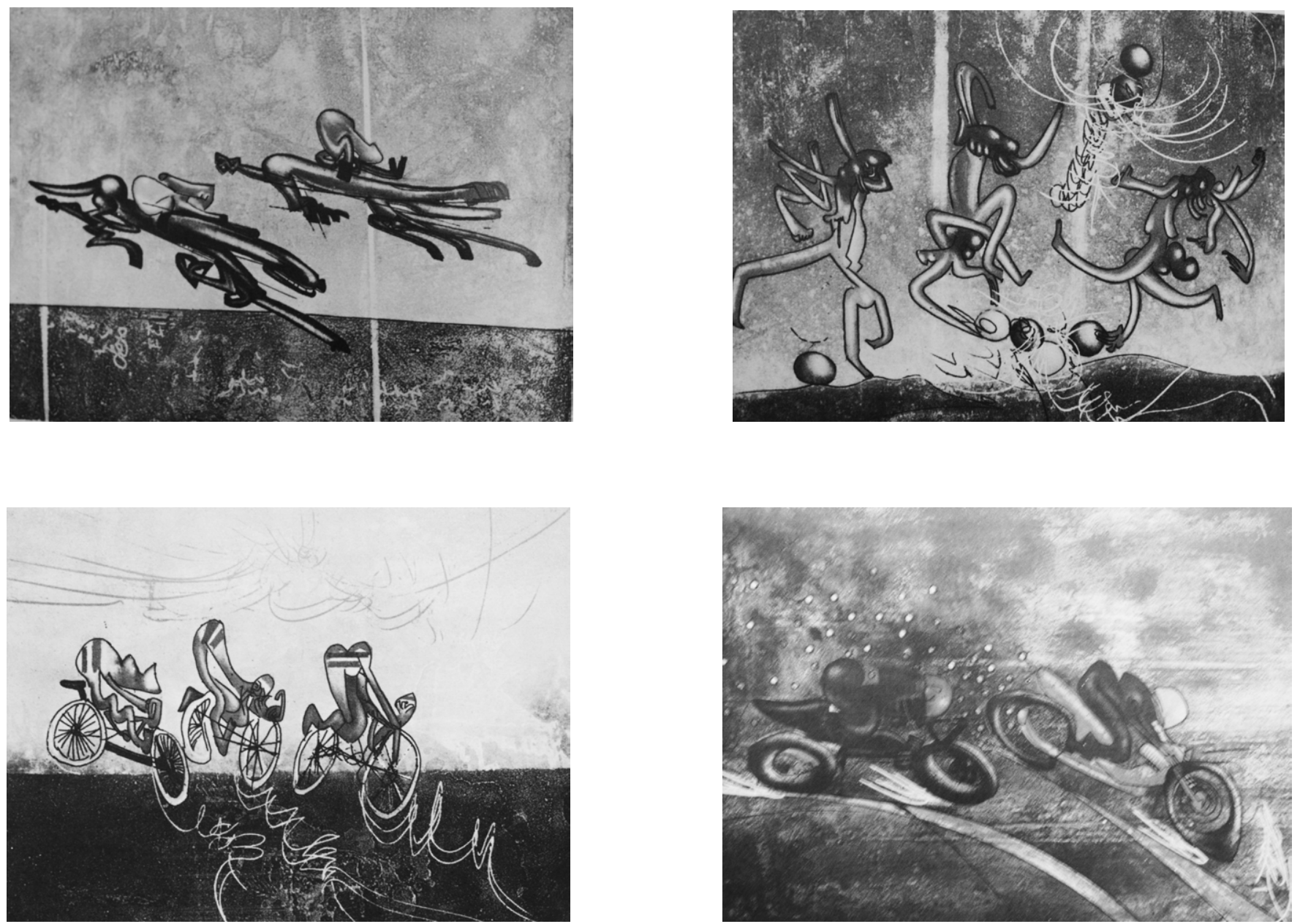


\section{Obra grafica Roberto Sebastian Matta Echaurren}

Ficha número : 85

Titulo de la obra : Gesu Bambini.

Fecha de realización : 1977.

Dimensiones

Tamaño del papel : $80 \times 62 \mathrm{~cm}$.

Tamaño de la mancha : 80 × $62 \mathrm{~cm}$.

\section{Técnica}

Técnica : Serigrafía.

Procedimientos y recursos complementarios :

Es una serigrafía como pocas que vemos de Roberto Matta en ella aparece el Niño Jesús acostado sobre la hierba amarilla y con un personaje a su lado que no podríamos definir bien si es María ya que no posee atuendos femeninos, no obstante a esto el Niño Jesús se ve tranquilo, feliz, contento, placido, y el personaje a su lado le entrega esa paz esa tranquilidad como si estuviese cantando a su lado y diciéndole que es hora del silencio, de dormir.

\section{Matriz}

Número de planchas : $\quad$ Se desconoce.

Material de las planchas : Tela.

Datos complementarios :

Se desconoce.

\section{Estampación}

En hueco

En relieve

Planigrafica

Permeografica

Número de tintas :

Se utilizaron 5 tintas.
Colores :
Negro, amarillo, azul, rojo y rosado.

Papel

Marca : Se desconoce.

Gramaje : Se desconoce.

Color : Beige. 


\section{Edición}

Número de ejemplares :

50 ejemplares firmados y numerados y alguna P.A.

$\mathbf{N}^{\circ}$ de P.A. (Prueba de Artista) : Se desconoce.

$\mathbf{N}^{\circ}$ de H.C. (Hors Commerce) : Se desconoce.

B.A.T. : $\quad$ Se desconoce.

Otras Pruebas : Se desconoce.

Taller en el que se realizó :

Se desconoce el taller en que se realizo pero fue editado por la Provincia de Viterbo en Italia a la ocasión de la muestra de Matta en 1977.

Estampador

Número de la estampa observada : Se desconoce.

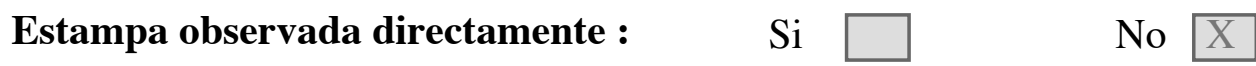

$\begin{array}{llll}\text { Contemplada a través de reproducción : Si } & \mathrm{X} \quad \text { No } \mathrm{X}\end{array}$

Colección

Colección en la que se encuentra : Se desconoce.

Colección en la que se encuentra la plancha : Se desconoce.

Otras colecciones que tengan ejemplares de este trabajo : Se desconoce.

\section{Libros}

\section{Localización del libro o catalogo :}

"Matta, Index dell'opera grafica dal 1969 al 1980", editado por Admministrazione Provinciali di Viterbo en 1980, realizado por Germana Ferrari.

Pagina 180

\section{Otros catologos que lo contengan :}

Se desconoce.

Registros gráficos obtenidos

Diapositiva

Imagén digital 


\section{Obra grafica Roberto Sebastian Matta Echaurren}

Ficha número : 86

Titulo de la obra : La revanche des etrusques.

Fecha de realización : 1977

Dimensiones

Tamaño del papel : $57 \times 76 \mathrm{~cm}$.

Tamaño de la mancha : $47 \times 70 \mathrm{~cm}$.

\section{Técnica}

Técnica : Serigrafia.

Procedimientos y recursos complementarios :

Se desconocen.

\section{Matriz}

Número de planchas : $\quad$ Se desconoce.

Material de las planchas : Tela.

Datos complementarios :

Se desconoce.

Estampación

Número de tintas :

En hueco

En relieve

Planigrafica

Permeografica

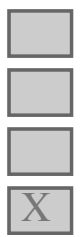

Se desconocen.

Colores :

Se desconocen.

Papel

Marca : $\quad$ Papel Fabriano.

Gramaje : Se desconoce.

Color : $\quad$ Se desconoce. 


\section{Edición}

Número de ejemplares :

99 ejemplares sobre papel Fabriano tamaño 57 x $76 \mathrm{~cm}$. firmados y numerados del 1 al 99 mas XXV H.C. firmados y numerados del I al XXV.

$\mathbf{N}^{\circ}$ de P.A. (Prueba de Artista) : Se desconocen.

$\mathbf{N}^{\circ}$ de H.C. (Hors Commerce) : Se desconocen.

B.A.T. : $\quad$ Se desconoce.

Otras Pruebas : Se desconoce.

Taller en el que se realizó :

Su realizacion y edicion fue en un taller privado en Roma.

Estampador

Se desconoce.

Número de la estampa observada : Se desconoce.

Estampa observada directamente : $\quad \mathrm{Si} \square \quad$ No $\mathrm{X}$

Contemplada a través de reproducción : $\mathrm{Si} X \quad$ No $\mathrm{X}$

Colección

Colección en la que se encuentra : Se desconoce.

Colección en la que se encuentra la plancha : Se desconoce.

Otras colecciones que tengan ejemplares de este trabajo : Se desconoce.

\section{Libros}

\section{Localización del libro o catalogo :}

"Matta, Index dell'opera grafica dal 1969 al 1980", editado por Admministrazione Provinciali di Viterbo en 1980, realizado por Germana Ferrari.

Pagina 182.

\section{Otros catologos que lo contengan :}

Se desconoce.

Registros gráficos obtenidos

Diapositiva

Imagén digital 


\section{Obra grafica Roberto Sebastian Matta Echaurren}

Ficha número : 87

Titulo de la obra : Ouvre l `instant.

Fecha de realización : 1977.

Dimensiones

Tamaño del papel : $63 \times 82 \mathrm{~cm}$.

Tamaño de la mancha : 62 x $57 \mathrm{~cm}$.

\section{Técnica}

Técnica : Aguafuerte y aguatinta.

Procedimientos y recursos complementarios :

Se desconocen.

\section{Matriz}

Número de planchas : $\quad$ Se desconoce.

Material de las planchas : Cobre.

Datos complementarios :

Se desconoce.

\section{Estampación}

En hueco

En relieve

Planigrafica

Permeografica

Número de tintas :
Se utilizaron 9 tintas.
Colores :
Verde, amarillo, azul, blanco, naranjo, rosado, violeta, negro, gris.

\section{Papel}

Marca : Papel Arches.

Gramaje : Se desconoce.

Color : Blanco. 


\section{Edición}

Número de ejemplares :

100 ejemplares sobre papel Arches tamaño 63 x $82 \mathrm{~cm}$. firmado y numerado del 1 al 100 mas XXV H.C. firmado y numerado del I al XXV.

$\mathbf{N}^{\circ}$ de P.A. (Prueba de Artista) : Se desconoce.

$\mathbf{N}^{\circ}$ de H.C. (Hors Commerce) : XXV H.C.

B.A.T. : $\quad$ Se desconoce.

Otras Pruebas : Se desconoce.

Taller en el que se realizó :

Atelier George Visat en Paris Francia y Edicion Poligrafa en Barcelona Espania.

Estampador

No se sabe si es George Visat o Albert Dupont.

Número de la estampa observada : Se desconoce.

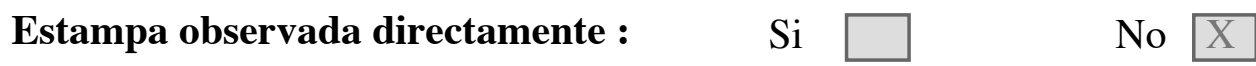

Contemplada a través de reproducción : $\mathrm{Si} X \quad$ No $\mathrm{X}$

Colección

Colección en la que se encuentra : Se desconoce.

Colección en la que se encuentra la plancha : Se desconoce.

Otras colecciones que tengan ejemplares de este trabajo : Se desconoce.

\section{Libros}

\section{Localización del libro o catalogo :}

"Matta, Index dell'opera grafica dal 1969 al 1980", editado por Admministrazione Provinciali di Viterbo en 1980, realizado por Germana Ferrari.

Pagina 183

\section{Otros catologos que lo contengan :}

Se desconoce.

Registros gráficos obtenidos

Diapositiva

Imagén digital 


\section{Obra grafica Roberto Sebastian Matta Echaurren}

Ficha número : 88

Titulo de la obra : La Storia è rotonda.

Fecha de realización : 1979.

Dimensiones

Tamaño del papel : $70 \times 100 \mathrm{~cm}$.

Tamaño de la mancha : 70 x $100 \mathrm{~cm}$.

\section{Técnica}

Técnica : Litografía.

\section{Procedimientos y recursos complementarios :}

Se desconocen. Aunque podemos decir que cuenta una historia sobre los indígenas de Latinoamérica o Centroamérica a través de 16 imágenes, diferentes, rectangulares que están dentro del formato de su papel, y se expresa en formato de historieta.

\section{Matriz}

Número de planchas : $\quad$ Se desconoce.

Material de las planchas : Se desconoce.

\section{Datos complementarios :}

Se desconoce.

Estampación

En hueco

En relieve

Planigrafica

Permeografica

Papel

Marca : Papel fabriano.

Color : Blanco.

\section{Gramaje : Se desconoce.}

Número de tintas :

Se utilizaron 7 tintas.
Colores :
Azul, amarillo, rosado, negro, beige, gris, crema.

Color : Blanco. 


\section{Edición}

Número de ejemplares :

99 ejemplares sobre papel Fabriano tamaño 70 x $100 \mathrm{~cm}$. firmados y numerados del 1 al 99, mas XV H.C. firmados y numerados del I al XV.

$\mathbf{N}^{\circ}$ de P.A. (Prueba de Artista) : Se desconoce.

$\mathbf{N}^{\circ}$ de H.C. (Hors Commerce) : XV H.C.

B.A.T.: $\quad$ Se desconoce.

Otras Pruebas : Se desconoce.

Taller en el que se realizó :

Taller de estampa la Bezuga en Florencia, Italia y su edición fue privada en Milano Italia.

Estampador

Se desconoce.

Número de la estampa observada : Se desconoce.

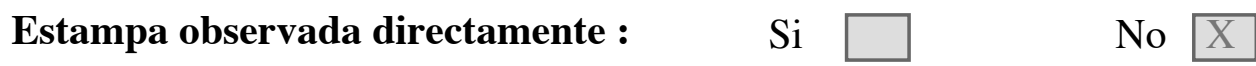

Contemplada a través de reproducción : $\mathrm{Si} X \quad$ No $\mathrm{X}$

Colección

Colección en la que se encuentra : Se desconoce.

Colección en la que se encuentra la plancha : Se desconoce.

Otras colecciones que tengan ejemplares de este trabajo : Se desconoce.

\section{Libros}

\section{Localización del libro o catalogo :}

"Matta, Index dell'opera grafica dal 1969 al 1980", editado por Admministrazione Provinciali di Viterbo en 1980, realizado por Germana Ferrari.

Pagina 235.

\section{Otros catologos que lo contengan :}

Se desconoce.

Registros gráficos obtenidos $\quad$ Diapositiva $\quad \square \quad$ Imagén digital 


\section{Obra grafica Roberto Sebastian Matta Echaurren}

Ficha número : 89

Titulo de la obra : XX ans de Cuba.

Fecha de realización : 1979.

Dimensiones

Tamaño del papel : $50 \times 70 \mathrm{~cm}$.

Tamaño de la mancha : 50 x $70 \mathrm{~cm}$.

\section{Técnica}

Técnica : Serigrafía.

\section{Procedimientos y recursos complementarios :}

XX ans de Cuba es una serigrafía que fue realizada en dos formatos diferentes, el primero es un formato de $50 \times 70 \mathrm{~cm}$. sobre papel y el segundo es un formato carta, la que utilizamos comúnmente.

Esta serigrafía se presenta como narrando una historia a través de 6 imágenes diferentes que se relacionan entre ellas. Y en la parte inferior encontramos un escrito realizado por el mismo artista a mano.

\section{Matriz}

Número de planchas : $\quad$ Se desconoce.

Material de las planchas : Tela.

\section{Datos complementarios :}

Se desconoce.

\section{Estampación}

En hueco

En relieve

Planigrafica

Permeografica

Número de tintas :

\section{Se desconocen. \\ Colores :}

Se desconocen.

Papel

Marca : La marca tanto del papel como del sobre se desconocen.

Gramaje : Se desconoce.

Color : $\quad$ Se desconoce. 


\section{Edición}

Número de ejemplares :

99 ejemplares sobre papel carta "uso mano" firmados y numerados del 1 al 99 mas

XXV H.C. firmados y numerados del I al XXV.

$\mathbf{N}^{\circ}$ de P.A. (Prueba de Artista) : Se desconoce.

$\mathbf{N}^{\circ}$ de H.C. (Hors Commerce) : XXV H.C.

B.A.T. : $\quad$ Se desconoce.

Otras Pruebas : Se desconoce.

Taller en el que se realizó :

Edición privada en Roma, Italia.

\section{Estampador}

Se desconoce.

Número de la estampa observada : Se desconoce.

\begin{tabular}{llll} 
Estampa observada directamente : & $\mathrm{Si}$ & $\square$ & No \\
\hline
\end{tabular}

Contemplada a través de reproducción : $\mathrm{Si} X \quad$ No $\mathrm{X}$

Colección

Colección en la que se encuentra : Se desconoce.

Colección en la que se encuentra la plancha : Se desconoce.

Otras colecciones que tengan ejemplares de este trabajo : Se desconoce.

\section{Libros}

\section{Localización del libro o catalogo :}

"Matta, Index dell'opera grafica dal 1969 al 1980", editado por Admministrazione Provinciali di Viterbo en 1980, realizado por Germana Ferrari.

Pagina 236.

\section{Otros catologos que lo contengan :}

Se desconoce.

Registros gráficos obtenidos

Diapositiva

Imagén digital 


\section{Obra grafica Roberto Sebastian Matta Echaurren}

Ficha número : 90

Titulo de la obra : L`amore utopico e l’amore scientifico.

Fecha de realización : 1979

Dimensiones

Tamaño del papel : $50 \times 70 \mathrm{~cm}$.

Tamaño de la mancha : 50 x $70 \mathrm{~cm}$.

\section{Técnica}

Técnica : Litografía.

Procedimientos y recursos complementarios :

L`amore utópico e lamore scientifico es una Litografía que fue realizada en dos formatos diferentes, el primero es un formato de $50 \times 70 \mathrm{~cm}$. sobre papel y el segundo es un formato carta, la que utilizamos comúnmente.

\section{Matriz}

Número de planchas : $\quad$ Se desconoce.

Material de las planchas : Se desconoce.

Datos complementarios :

Se desconoce.

\section{Estampación}

En hueco

En relieve

Planigrafica

Permeografica

Número de tintas :

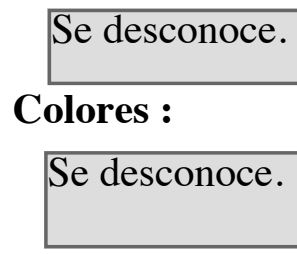

Papel

Marca : $\quad$ Se desconoce la marca del papel, aunque sabemos que existen P. A en Japón Nacré.

Gramaje : Se desconoce.

Color : Se desconoce. 


\section{Edición}

Número de ejemplares :

99 ejemplares sobre papel carta "uso mano" ( sin margen) firmados y numerados del 1 al 99 mas XXV H. C. firmados y numerados del Ial XXV. Y algunas P.A. sobre papel Japón Nacré.

$\mathbf{N}^{\circ}$ de P.A. (Prueba de Artista) : Se desconoce su cantidad, pero existen.

$\mathbf{N}^{\circ}$ de H.C. (Hors Commerce) : XXV H.C.

B.A.T.: $\quad$ Se desconoce.

Otras Pruebas : Se desconoce.

Taller en el que se realizó :

Taller de estampa la Bezuga en Florencia, Italia y su edición fue en Rinascita en Roma Italia.

Estampador

Se desconoce.

Número de la estampa observada : Se desconoce.

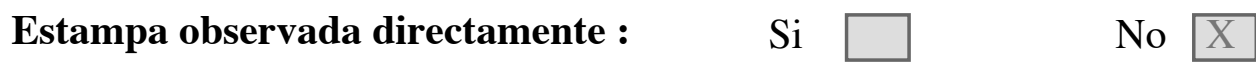

Contemplada a través de reproducción : $\mathrm{Si} X \quad$ No $\mathrm{X}$

Colección

Colección en la que se encuentra : Se desconoce.

Colección en la que se encuentra la plancha : Se desconoce.

Otras colecciones que tengan ejemplares de este trabajo : Se desconoce.

\section{Libros}

\section{Localización del libro o catalogo :}

"Matta, Index dell'opera grafica dal 1969 al 1980", editado por Admministrazione Provinciali di Viterbo en 1980, realizado por Germana Ferrari.

Pagina 238.

\section{Otros catologos que lo contengan :}

Se desconoce.

Registros gráficos obtenidos

Diapositiva

Imagén digital 


\section{Obra grafica Roberto Sebastian Matta Echaurren}

Ficha número : 91

Titulo de la obra : Les roses de la violence.

Fecha de realización : 1979.

Dimensiones

Tamaño del papel : $50 \times 70 \mathrm{~cm}$.

Tamaño de la mancha : $50 \times 70 \mathrm{~cm}$.

\section{Técnica}

Técnica : Litografía.

Procedimientos y recursos complementarios :

Les roses de la violence es una Litografía que fue realizada en dos formatos diferentes, el primero es un formato de $50 \times 70 \mathrm{~cm}$. sobre papel y el segundo es un formato carta, la que utilizamos comúnmente, no obstante la impresión sobre el formato carta no posee margen.

La obra cuenta en formato historia con 6 imágenes diferentes lo que va pasando con dos personajes y a veces interviene un personaje animalesco podría pensarse un perro.

\section{Matriz}

Número de planchas : $\quad$ Se desconoce.

Material de las planchas : Se desconoce.

Datos complementarios :

Se desconoce.

\section{Estampación}

En hueco

En relieve

Planigrafica

Permeografica

Número de tintas :

Se utilizaron 6 tintas.
Colores :
Celeste, rosado, amarillo, verde, negro y beige.

Papel

Marca : $\quad$ Se desconoce la marca del papel, aunque sabemos que existen P. A en Japón Nacré.

Gramaje : Se desconoce.

Color : Blanco. 


\section{Edición}

Número de ejemplares :

99 ejemplares sobre papel carta "uso mano" (sin margen) firmados y numerados del 1 al 99 mas XXV H. C. firmados y numerados del Ial XXV. Y alguna P.A. sobre papel Japón Nacré.

$\mathbf{N}^{\circ}$ de P.A. (Prueba de Artista): Se desconoce su cantidad, pero existen.

$\mathbf{N}^{\circ}$ de H.C. (Hors Commerce) : XXV H.C.

B.A.T. : $\quad$ Se desconoce.

Otras Pruebas : Se desconoce.

Taller en el que se realizó :

Taller de estampa la Bezuga en Florencia, Italia y su edición fue en Rinascita en Roma Italia.

Estampador

Se desconoce.

Número de la estampa observada : Se desconoce.

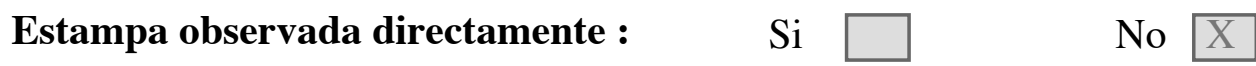

Contemplada a través de reproducción : $\mathrm{Si} X \quad$ No $\mathrm{X}$

Colección

Colección en la que se encuentra : Se desconoce.

Colección en la que se encuentra la plancha : Se desconoce.

Otras colecciones que tengan ejemplares de este trabajo : Se desconoce.

\section{Libros}

\section{Localización del libro o catalogo :}

"Matta, Index dell'opera grafica dal 1969 al 1980", editado por Admministrazione Provinciali di Viterbo en 1980, realizado por Germana Ferrari.

Pagina 239.

\section{Otros catologos que lo contengan :}

Se desconoce.

Registros gráficos obtenidos $\quad$ Diapositiva $\quad \square \quad$ Imagén digital 


\section{Obra grafica Roberto Sebastian Matta Echaurren}

Ficha número : 92

Titulo de la obra : Cruleaut elle.

Fecha de realización : 1979.

Dimensiones

Tamaño del papel : $56 \times 76 \mathrm{~cm}$.

Tamaño de la mancha : $50 \times 65 \mathrm{~cm}$.

\section{Técnica}

Técnica : Litografía.

Procedimientos y recursos complementarios :

Se desconocen.

\section{Matriz}

Número de planchas : $\quad$ Se desconoce.

Material de las planchas : Se desconoce.

Datos complementarios :

Se desconoce.

Estampación

En hueco

En relieve

Planigrafica

Permeografica

Papel

Marca : Papel Arches.

Gramaje : Se desconoce.

Color : Blanco.

\section{Número de tintas :}

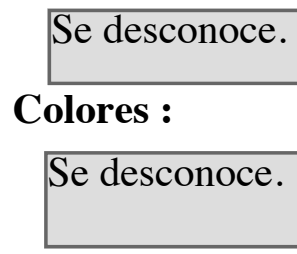

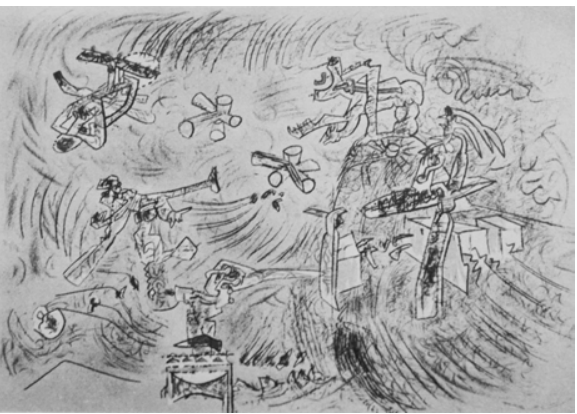




\section{Edición}

Número de ejemplares :

100 ejemplares sobre papel Arches tamaño 56 x $76 \mathrm{~cm}$. firmados y numerados del 1 al 100 mas X H.C. firmados y numerados del I al X. mas 10 P.A. firmados y numerados del 1 al 10.

$N^{\circ}$ de P.A. (Prueba de Artista): X P.A.

$\mathbf{N}^{\circ}$ de H.C. (Hors Commerce) : X H.C.

B.A.T. : $\quad$ Se desconoce.

Otras Pruebas : Se desconoce.

Taller en el que se realizó :

Taller Grapholith en Paris Francia y la Edición en Galería Grafica en Suiza.

Estampador

Se desconoce.

Número de la estampa observada : Se desconoce.

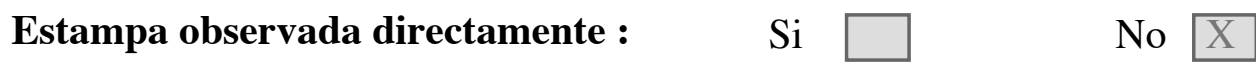

Contemplada a través de reproducción : $\mathrm{Si} X \quad$ No $\mathrm{X}$

Colección

Colección en la que se encuentra : Se desconoce.

Colección en la que se encuentra la plancha : Se desconoce.

Otras colecciones que tengan ejemplares de este trabajo : Se desconoce.

\section{Libros}

\section{Localización del libro o catalogo :}

"Matta, Index dell'opera grafica dal 1969 al 1980", editado por Admministrazione Provinciali di Viterbo en 1980, realizado por Germana Ferrari.

Pagina 240.

\section{Otros catologos que lo contengan :}

Se desconoce.

Registros gráficos obtenidos

Diapositiva

Imagén digital 


\section{Obra grafica Roberto Sebastian Matta Echaurren}

Ficha número : 93

Titulo de la obra : La vitesse du sort.

Fecha de realización : 1979.

Dimensiones

Tamaño del papel : $56 \times 76 \mathrm{~cm}$.

Tamaño de la mancha : $50 \times 70 \mathrm{~cm}$.

\section{Técnica}

Técnica : Litografía.

Procedimientos y recursos complementarios :

Se desconocen.

\section{Matriz}

Número de planchas : $\quad$ Se desconoce.

Material de las planchas : Se desconoce.

Datos complementarios :

Se desconoce.

Estampación

En hueco

En relieve

Planigrafica

Permeografica

Papel

Marca : Papel Arches.

Gramaje : Se desconoce.

Color : Blanco.

\section{Número de tintas :}

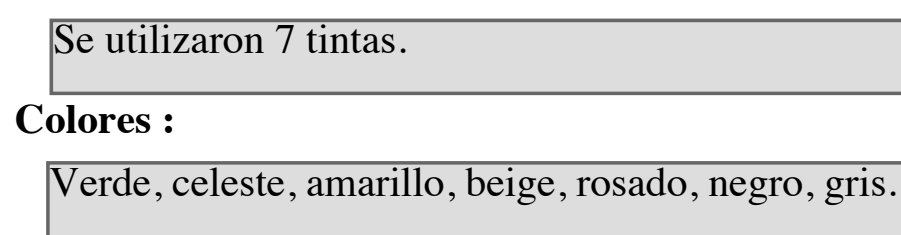




\section{Edición}

Número de ejemplares :

100 ejemplares sobre papel Arches tamaño 56 x $76 \mathrm{~cm}$. firmados y numerados del 1 al 100 mas X H.C. firmados y numerados del Ial X. mas 10 P.A. firmados y numerados del 1 al 10.

$N^{\circ}$ de P.A. (Prueba de Artista) : X P.A.

$\mathbf{N}^{\circ}$ de H.C. (Hors Commerce) : X H.C.

B.A.T.: $\quad$ Se desconoce.

Otras Pruebas : Se desconoce.

Taller en el que se realizó :

Taller Grapholith en Paris Francia y la Edición en Galería Grafica en Suiza.

Estampador

Se desconoce.

Número de la estampa observada : Se desconoce.

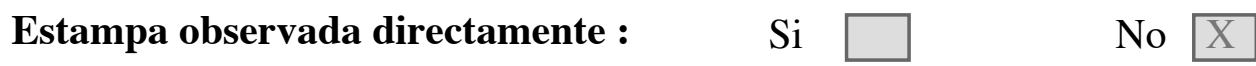

Contemplada a través de reproducción : $\mathrm{Si} X \quad$ No $\mathrm{X}$

Colección

Colección en la que se encuentra : Se desconoce.

Colección en la que se encuentra la plancha : Se desconoce.

Otras colecciones que tengan ejemplares de este trabajo : Se desconoce.

\section{Libros}

\section{Localización del libro o catalogo :}

"Matta, Index dell'opera grafica dal 1969 al 1980", editado por Admministrazione Provinciali di Viterbo en 1980, realizado por Germana Ferrari.

Pagina 241.

\section{Otros catologos que lo contengan :}

Se desconoce.

Registros gráficos obtenidos $\quad$ Diapositiva $\quad \square \quad$ Imagén digital 


\section{Obra grafica Roberto Sebastian Matta Echaurren}

Ficha número : 94

Titulo de la obra : Maintenant.

Fecha de realización : 1958-1979

Dimensiones

Tamaño del papel : 34 x $40 \mathrm{~cm}$.

Tamaño de la mancha : 17.5 × $28 \mathrm{~cm}$

\section{Técnica}

Técnica : Aguafuerte y aguatinta.

\section{Procedimientos y recursos complementarios :}

Maintenant es una obra creada en el año 1958 no sabemos si fue directamente creada sobre una plancha o a través de un dibujo, posteriormente en el año 1979 fue realizada sobre una plancha de cobre.

\section{Matriz}

Número de planchas : $\quad$ Se desconoce.

Material de las planchas : Cobre.

Datos complementarios :

Se desconocen.

Estampación

En hueco

En relieve

Planigrafica

Permeografica

Papel

Marca : Papel Arches.

Gramaje : Se desconoce.

Color : $\quad$ Se desconoce.

\section{Número de tintas :}

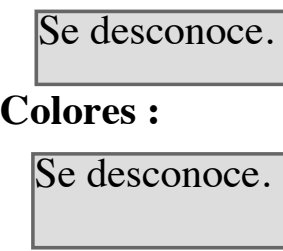

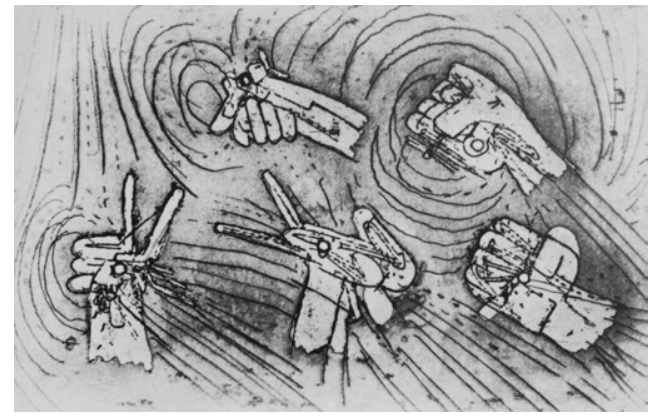




\section{Edición}

Número de ejemplares :

XXX ejemplares sobre papel Arches, firmados y numerados del I al XXX mas 10 P.A. firmados y numerados del 1 al 10.

$N^{\circ}$ de P.A. (Prueba de Artista): X P.A.

$\mathbf{N}^{\circ}$ de H.C. (Hors Commerce) : Se desconoce.

B.A.T. : $\quad$ Se desconoce.

Otras Pruebas : Se desconoce.

Taller en el que se realizó :

Atelier George Visat en Paris Francia y la Edición en la Galería du Dragón en Paris Francia.

Estampador

No se sabe si es George Visat o Albert Dupont.

Número de la estampa observada : Se desconoce.

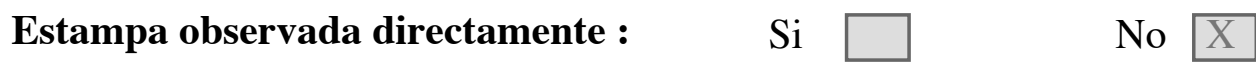

Contemplada a través de reproducción : $\mathrm{Si} X \quad$ No $\mathrm{X}$

Colección

Colección en la que se encuentra : Se desconoce.

Colección en la que se encuentra la plancha : Se desconoce.

Otras colecciones que tengan ejemplares de este trabajo : Se desconoce.

\section{Libros}

\section{Localización del libro o catalogo :}

"Matta, Index dell'opera grafica dal 1969 al 1980", editado por Admministrazione Provinciali di Viterbo en 1980, realizado por Germana Ferrari.

Pagina 242.

\section{Otros catologos que lo contengan :}

Se desconoce.

Registros gráficos obtenidos Diapositiva $\quad \square \quad$ Imagén digital $\quad X$ 


\section{Obra grafica Roberto Sebastian Matta Echaurren}

Ficha número : 95

Titulo de la obra : L`impensable.

Fecha de realización : $1958-1979$.

Dimensiones

Tamaño del papel : 34 x $40 \mathrm{~cm}$.

Tamaño de la mancha : $20 \times 28 \mathrm{~cm}$.

\section{Técnica}

Técnica : Aguafuerte y aguatinta.

Procedimientos y recursos complementarios :

L`impensable es una obra creada en el año 1958 no sabemos si fue directamente creada sobre una plancha o a través de un dibujo, posteriormente en el año 1979 fue realizada sobre una plancha de cobre.

\section{Matriz}

Número de planchas : Se desconoce.

Material de las planchas : Cobre.

Datos complementarios :

En esta obra se realizaron ciertos gofrados.

\section{Estampación}

En hueco

En relieve

Planigrafica

Permeografica

Número de tintas :

\section{Se utilizaron 3 tintas. \\ Colores :}

Negro, gris y rosado.

\section{Papel}

Marca : Papel Arches.

Gramaje : Se desconoce.

Color : Blanco. 


\section{Edición}

Número de ejemplares :

XXX ejemplares sobre papel Arches, firmados y numerados del I al XXX mas 10 P.A. firmados y numerados del 1 al 10.

$N^{\circ}$ de P.A. (Prueba de Artista) : X P.A.

$\mathbf{N}^{\circ}$ de H.C. (Hors Commerce) : Se desconoce.

B.A.T. : Se desconoce.

Otras Pruebas : Se desconoce.

Taller en el que se realizó :

Atelier George Visat en Paris Francia y la Edición en la Galería du Dragón en Paris Francia.

Estampador

No se sabe si es George Visat o Albert Dupont.

Número de la estampa observada : Se desconoce.

Estampa observada directamente : $\quad \mathrm{Si} \square \quad$ No $\mathrm{X}$

Contemplada a través de reproducción : $\mathrm{Si} X \quad$ No $\mathrm{X}$

Colección

Colección en la que se encuentra : Se desconoce.

Colección en la que se encuentra la plancha : Se desconoce.

Otras colecciones que tengan ejemplares de este trabajo : Se desconoce.

\section{Libros}

\section{Localización del libro o catalogo :}

"Matta, Index dell'opera grafica dal 1969 al 1980", editado por Admministrazione Provinciali di Viterbo en 1980, realizado por Germana Ferrari.

Pagina 243.

\section{Otros catologos que lo contengan :}

Se desconoce.

Registros gráficos obtenidos Diapositiva $\quad \square \quad$ Imagén digital $\quad X$ 


\section{Obra grafica Roberto Sebastian Matta Echaurren}

Ficha número : 96

Titulo de la obra : Achille e la tartaruga.

Fecha de realización : 1979.

Dimensiones

Tamaño del papel : $25 \times 34 \mathrm{~cm}$.

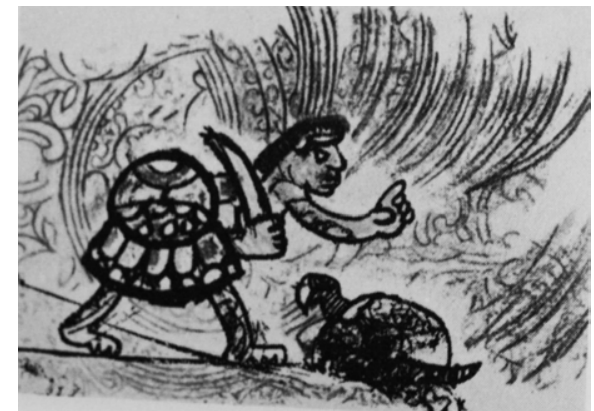

Tamaño de la mancha : 25 x $34 \mathrm{~cm}$.

\section{Técnica}

Técnica : Litografía.

Procedimientos y recursos complementarios :

Se desconocen, pero la obra presenta a un hombre indígena inclinado, con una mano llevando un puñal y con la otra queriendo como dar un cariño, o una indicación a la tortuga que esta frente de él.

\section{Matriz}

Número de planchas : $\quad$ Se desconoce.

Material de las planchas : Se desconoce.

Datos complementarios :

Se desconoce.

Estampación

En hueco

En relieve

Planigrafica

Permeografica

Papel

Marca : Papel Fabriano.

Gramaje : Se desconoce.

Color : $\quad$ Se desconoce.

\section{Número de tintas :}

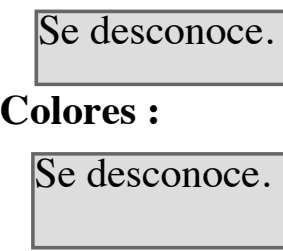




\section{Edición}

Número de ejemplares :

99 ejemplares sobre papel Fabriano tamaño 25 x $34 \mathrm{~cm}$. firmados y numerados del 1 al 99, mas XXV H.C. firmados y numerados del I al XXV.

$\mathbf{N}^{\circ}$ de P.A. (Prueba de Artista) : Se desconoce.

$\mathbf{N}^{\circ}$ de H.C. (Hors Commerce) : XXV H.C.

B.A.T. : $\quad$ Se desconoce.

Otras Pruebas : Se desconoce.

Taller en el que se realizó :

La estampa y la edición en el taller la Bezuga en Florencia, Italia.

Estampador

Se desconoce.

Número de la estampa observada : Se desconoce.

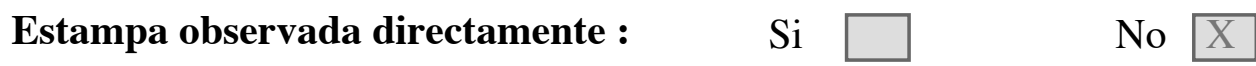

Contemplada a través de reproducción : $\mathrm{Si} X \quad$ No $\mathrm{X}$

Colección

Colección en la que se encuentra : Se desconoce.

Colección en la que se encuentra la plancha : Se desconoce.

Otras colecciones que tengan ejemplares de este trabajo : Se desconoce.

\section{Libros}

\section{Localización del libro o catalogo :}

"Matta, Index dell'opera grafica dal 1969 al 1980", editado por Admministrazione Provinciali di Viterbo en 1980, realizado por Germana Ferrari.

Pagina 232.

\section{Otros catologos que lo contengan :}

Se desconoce.

Registros gráficos obtenidos

Diapositiva

Imagén digital 


\section{Obra grafica Roberto Sebastian Matta Echaurren}

Ficha número : 97

Titulo de la obra : Chupa el tepec.

Fecha de realización : 1978 .

Dimensiones

Tamaño del papel : $55 \times 76 \mathrm{~cm}$.

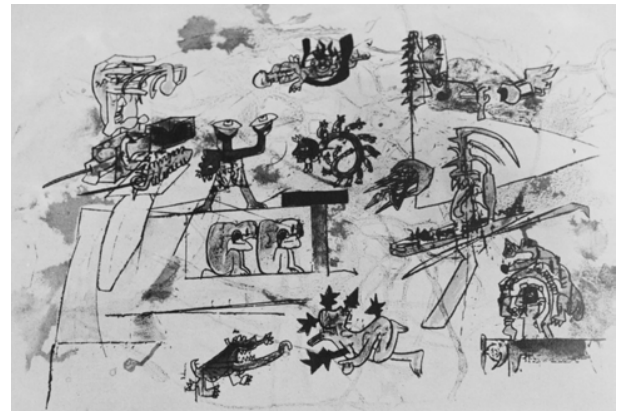

Tamaño de la mancha : $55 \times 76 \mathrm{~cm}$.

\section{Técnica}

Técnica : Litografía.

Procedimientos y recursos complementarios :

Se desconoce.

\section{Matriz}

Número de planchas : $\quad$ Se desconoce.

Material de las planchas : Se desconoce.

Datos complementarios :

Se desconoce.

Estampación

En hueco

En relieve

Planigrafica

Permeografica

Papel

Marca : Papel Arches.

Gramaje : Se desconoce.

Color : $\quad$ Se desconoce.
Número de tintas :

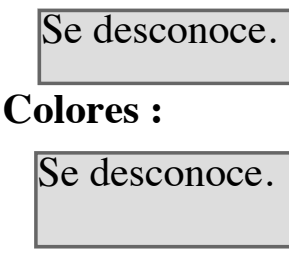




\section{Edición}

Número de ejemplares :

100 ejemplares sobre papel Arches, firmados del 1 al 100.

$\mathbf{N}^{\circ}$ de P.A. (Prueba de Artista): Se desconoce.

$\mathbf{N}^{\circ}$ de H.C. (Hors Commerce) : Se desconoce.

B.A.T. : $\quad$ Se desconoce.

Otras Pruebas : Se desconoce.

Taller en el que se realizó :

Se desconoce.

Estampador

Se desconoce.

Número de la estampa observada : Se desconoce.

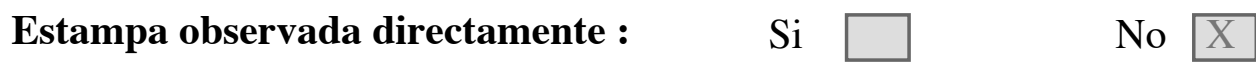

$\begin{array}{llll}\text { Contemplada a través de reproducción : Si } & \mathrm{X} \quad \text { No } & \mathrm{X}\end{array}$

Colección

Colección en la que se encuentra : Se desconoce.

Colección en la que se encuentra la plancha : Se desconoce.

Otras colecciones que tengan ejemplares de este trabajo : Se desconoce.

\section{Libros}

\section{Localización del libro o catalogo :}

"Matta, Index dell'opera grafica dal 1969 al 1980", editado por Admministrazione Provinciali di Viterbo en 1980, realizado por Germana Ferrari.

Pagina 225.

\section{Otros catologos que lo contengan :}

Se desconoce.

Registros gráficos obtenidos

Diapositiva

Imagén digital 


\section{Obra grafica Roberto Sebastian Matta Echaurren}

Ficha número : $\quad 98$

Titulo de la obra : Morphologia dell autoapocalipse.

Fecha de realización : 1978.

Dimensiones

Tamaño del papel : $50 \times 70 \mathrm{~cm}$.

Tamaño de la mancha : $50 \times 70 \mathrm{~cm}$.

\section{Técnica}

Técnica : Litografía.

\section{Procedimientos y recursos complementarios :}

Morphologia dell autoapocalipse es una litografía donde se presentan cuatro imágenes de la posible morfología del autocalipsis, son de dos a tres personajes que se persiguen, que se buscan, que se hieren.

\section{Matriz}

Número de planchas : $\quad$ Se desconoce.

Material de las planchas : Se desconoce.

Datos complementarios :

Se desconoce.

Estampación

En hueco

En relieve

Planigrafica

Permeografica

Papel

Marca : Papel Fabriano.

Gramaje : Se desconoce.

Color : $\quad$ Se desconoce.

\section{Número de tintas :}

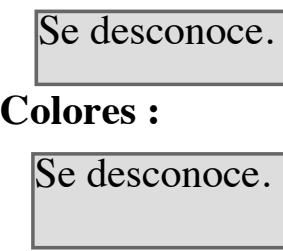

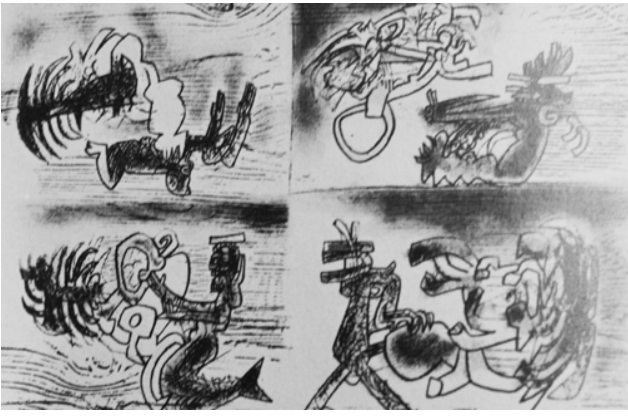




\section{Edición}

Número de ejemplares :

99 ejemplares sobre papel Fabriano tamaño 50 x $70 \mathrm{~cm}$. firmados y numerados del 1 al 99 mas XXV H.C. firmados y numerados del I al XXV.

$\mathbf{N}^{\circ}$ de P.A. (Prueba de Artista) : Se desconoce.

$\mathbf{N}^{\circ}$ de H.C. (Hors Commerce) : XXV H.C

B.A.T.: $\quad$ Se desconoce.

Otras Pruebas : Se desconoce.

Taller en el que se realizó :

Edicion privada en Roma.

\section{Estampador}

Se desconoce.

Número de la estampa observada : Se desconoce.

\begin{tabular}{llll} 
Estampa observada directamente : & $\mathrm{Si}$ & $\square$ & No \\
\hline
\end{tabular}

Contemplada a través de reproducción : $\mathrm{Si} X \quad$ No $\mathrm{X}$

Colección

Colección en la que se encuentra : Se desconoce.

Colección en la que se encuentra la plancha : Se desconoce.

Otras colecciones que tengan ejemplares de este trabajo : Se desconoce.

\section{Libros}

\section{Localización del libro o catalogo :}

"Matta, Index dell'opera grafica dal 1969 al 1980", editado por Admministrazione Provinciali di Viterbo en 1980, realizado por Germana Ferrari.

Pagina 227.

\section{Otros catologos que lo contengan :}

Se desconoce.

Registros gráficos obtenidos

Diapositiva

Imagén digital 


\section{Obra grafica Roberto Sebastian Matta Echaurren}

Ficha número : 99

Titulo de la obra : L`organo di berberia.

Fecha de realización : 1978.

Dimensiones

Tamaño del papel : 27 x $23 \mathrm{~cm}$.

Tamaño de la mancha : 27 x $23 \mathrm{~cm}$.

\section{Técnica}

Técnica : Litografía.

Procedimientos y recursos complementarios :

L`organo di berberia es una litografía que pertenece a una carpeta litográfica realizada por diferentes artistas.

Es una de las pocas litografías tan claras a nivel de ilustración como si estuviésemos frente a una banda de músicos, estilizados y con movimiento.

\section{Matriz}

Número de planchas : Se desconoce.

Material de las planchas : Se desconoce.

Datos complementarios :

Se desconoce.

\section{Estampación}

En hueco

En relieve

Planigrafica

Permeografica

Papel

\section{Número de tintas :}

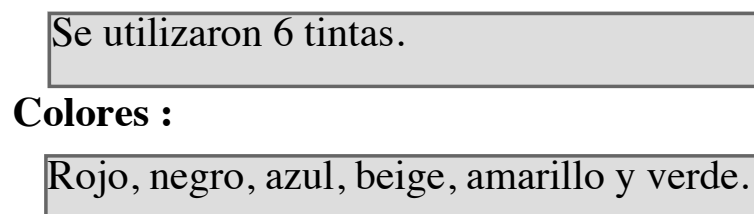

Marca : Papel Arches.

Gramaje : Se desconoce.

Color : Blanco. 


\section{Edición}

Número de ejemplares :

125 ejemplares sobre papel Arches $27 \times 23 \mathrm{~cm}$. firmados y numerados del 1 al 125 mas XXV H.C. firmados y numerados del Ial XXV.

$\mathbf{N}^{\circ}$ de P.A. (Prueba de Artista) : Se desconoce.

$\mathbf{N}^{\circ}$ de H.C. (Hors Commerce) : XXV H.C.

B.A.T.: $\quad$ Se desconoce.

Otras Pruebas : Se desconoce.

Taller en el que se realizó :

Atelier de Franck Bordas en Paris Francia y la Edición en Polígrafa Barcelona España.

Estampador

Franck Bordas.

Número de la estampa observada : Se desconoce.

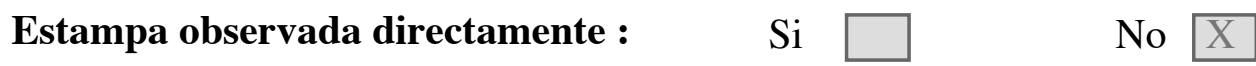

Contemplada a través de reproducción : $\mathrm{Si} X \quad$ No $\mathrm{X}$

Colección

Colección en la que se encuentra : Se desconoce.

Colección en la que se encuentra la plancha : Se desconoce.

Otras colecciones que tengan ejemplares de este trabajo : Se desconoce.

\section{Libros}

\section{Localización del libro o catalogo :}

"Matta, Index dell'opera grafica dal 1969 al 1980", editado por Admministrazione Provinciali di Viterbo en 1980, realizado por Germana Ferrari.

Pagina 230.

\section{Otros catologos que lo contengan :}

Se desconoce.

Registros gráficos obtenidos $\quad$ Diapositiva $\quad \square \quad$ Imagén digital 


\section{Obra grafica Roberto Sebastian Matta Echaurren}

Ficha número : 100

Titulo de la obra : Requiem pour la fin des temps.

Fecha de realización : $1978-1979$.

Dimensiones

Tamaño del papel : $50 \times 65 \mathrm{~cm}$.

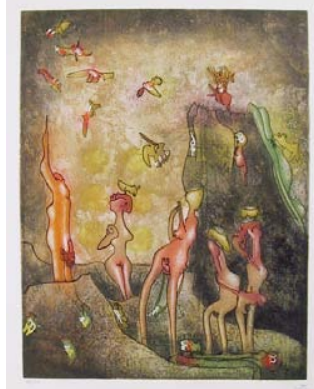

Tamaño de la mancha : 50 x $65 \mathrm{~cm}$.

\section{Técnica}

Técnica : Aguafuerte.

Procedimientos y recursos complementarios :

Réquiem pour la fin des temps es un álbum que posee 8 aguafuertes, realizadas por 4 artistas Bacon, Hartung, H. Moore y Roberto Matta, cada uno creo 2 obras para este álbum.

Las obras de Matta tienen como titulo: "Nids de noeds" y "Ma cher rie".

\section{Matriz}

Número de planchas : $\quad$ Se desconoce.

Material de las planchas : Cobre.

Datos complementarios :

Se desconoce.

\section{Estampación}

En hueco

En relieve

Planigrafica

Permeografica

Papel
Número de tintas :

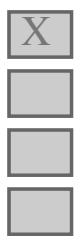

Se desconoce.

Colores :

Se desconoce.

Marca : Papel Arches.

Gramaje : Se desconoce.

Color : $\quad$ Se desconoce. 


\section{Edición}

Número de ejemplares :

100 ejemplares sobre papel Arches 50 x $65 \mathrm{~cm}$. firmados y numerados del 1 al 100 mas XLVI H.C. firmados y numerados del I al XLVI.

Y cada obra esta marcada(firmada) en seco.

$\mathbf{N}^{\circ}$ de P.A. (Prueba de Artista) : Se desconoce.

$\mathbf{N}^{\circ}$ de H.C. (Hors Commerce) : XLVI H.C.

B.A.T. : $\quad$ Se desconoce.

Otras Pruebas : Se desconoce.

Taller en el que se realizó :

Estampación y Edición en el Atelier de George Visat en Paris Francia.

Estampador

No se sabe si es George Visat o Albert Dupont.

Número de la estampa observada : Se desconoce.

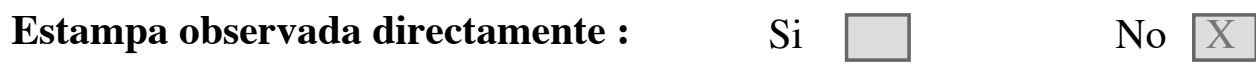

Contemplada a través de reproducción : $\mathrm{Si} X \quad$ No $\mathrm{X}$

Colección

Colección en la que se encuentra : Se desconoce.

Colección en la que se encuentra la plancha : Se desconoce.

Otras colecciones que tengan ejemplares de este trabajo : Se desconoce.

\section{Libros}

\section{Localización del libro o catalogo :}

"Matta, Index dell'opera grafica dal 1969 al 1980", editado por Admministrazione Provinciali di Viterbo en 1980, realizado por Germana Ferrari.

Paginas 244-245.

\section{Otros catologos que lo contengan :}

Se desconoce.

Registros gráficos obtenidos

Diapositiva

Imagén digital 


\section{Obra grafica Roberto Sebastian Matta Echaurren}

Ficha número : $\quad 101$

Titulo de la obra : Sex-uberant.

Fecha de realización : 1979.

Dimensiones

Tamaño del papel : $44 \times 33 \mathrm{~cm}$.

Tamaño de la mancha : 24.5 x $19 \mathrm{~cm}$.

\section{Técnica}

Técnica : Aguafuerte y aguatinta

\section{Procedimientos y recursos complementarios :}

Sex-uberant es un grabado donde se presentan dos personajes enormes que ocupan casi todo el formato del papel, podríamos distinguir que son un hombre y una mujer y que la mujer le sostiene el enorme pene a su hombre quien la sostiene por su trasero y le muestra con la otra mano una especie de circulo de globo, podríamos pensar que es allí donde esta la fecundación, la vida.

\section{Matriz}

Número de planchas : 3 planchas

Material de las planchas : Cobre

Datos complementarios :

Se desconoce.

\section{Estampación}

En hueco

En relieve

Planigrafica

Permeografica

Papel
Número de tintas :

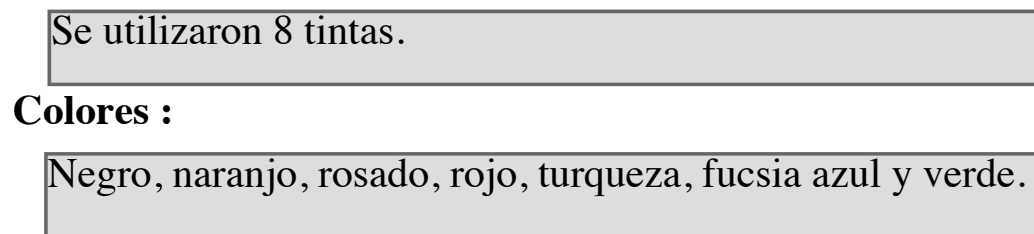

Marca : Papel Arches.

Gramaje : 250 grm.

Color: Blanco. 


\section{Edición}

Número de ejemplares :

100 ejemplares sobre papel Arches tamaño 32.5 x $43 \mathrm{~cm}$. firmados y numerados del 1 al 100 mas XLVI H. C. firmados y numerados dem I al XLVI.

$\mathbf{N}^{\circ}$ de P.A. (Prueba de Artista) : Se desconoce.

$\mathbf{N}^{\circ}$ de H.C. (Hors Commerce) : XLVI H.C.

B.A.T. : $\quad$ Se desconoce.

Otras Pruebas : Se desconoce.

Taller en el que se realizó :

Atelier George Visat en Paris Francia.

Estampador

George Visat.

Número de la estampa observada : Se desconoce.

\begin{tabular}{llll} 
Estampa observada directamente : & $\mathrm{Si}$ & $\mathrm{X}$ & No \\
\hline
\end{tabular}

Contemplada a través de reproducción : $\mathrm{Si} X \quad$ No $\mathrm{X}$

Colección

Colección en la que se encuentra : Privada en Paris.

Colección en la que se encuentra la plancha : Privada en Paris.

Otras colecciones que tengan ejemplares de este trabajo : Se desconocen.

\section{Libros}

\section{Localización del libro o catalogo :}

"Matta, Index dell'opera grafica dal 1969 al 1980", editado por Admministrazione Provinciali di Viterbo en 1980, realizado por Germana Ferrari.

Pagina 246

\section{Otros catologos que lo contengan :}

Se desconoce.

Registros gráficos obtenidos

Diapositiva

Imagén digital 


\section{Obra grafica Roberto Sebastian Matta Echaurren}

Ficha número : 102

Titulo de la obra : Etre en soi.

Fecha de realización : 1979.

Dimensiones

Tamaño del papel : $56 \times 76 \mathrm{~cm}$.

Tamaño de la mancha : 66 x $51 \mathrm{~cm}$.

\section{Técnica}

Técnica : Aguafuerte y aguatinta

Procedimientos y recursos complementarios :

Se desconoce.

\section{Matriz}

Número de planchas : $\quad$ Se desconoce.

Material de las planchas : Cobre.

Datos complementarios :

Se desconoce.

Estampación

En hueco

En relieve

Planigrafica

Permeografica

Papel

Marca : Papel Arches.

Color : Blanco.

\section{Gramaje : Se desconoce.}

Número de tintas :
Se utilizaron 9 tintas.
Colores :
Azul, negro, verde, amarillo, nzaranjo, rojo, beige, gris y violeta. 


\section{Edición}

Número de ejemplares :

50 ejemplares sobre papel Arches, firmados y numerados del 1 al 50 mas XV H.C. firmados y numerados del I al XV.

$\mathbf{N}^{\circ}$ de P.A. (Prueba de Artista) : Se desconoce.

$\mathbf{N}^{\circ}$ de H.C. (Hors Commerce) : XV H.C.

B.A.T.: $\quad$ Se desconoce.

Otras Pruebas : Se desconoce.

Taller en el que se realizó :

Atelier George Visat en Paris Francia y la edición fue en J. tasende, La Jolla en Estados unidos de Norteamérica.

Estampador

No se sabe si es George Visat o Albert Dupont.

Número de la estampa observada : Se desconoce.

Estampa observada directamente : $\quad \mathrm{Si} \square \quad$ No $\mathrm{X}$

Contemplada a través de reproducción : $\mathrm{Si} X \quad$ No $\mathrm{X}$

Colección

Colección en la que se encuentra : Se desconoce.

Colección en la que se encuentra la plancha : Se desconoce.

Otras colecciones que tengan ejemplares de este trabajo : Se desconoce.

\section{Libros}

\section{Localización del libro o catalogo :}

"Matta, Index dell'opera grafica dal 1969 al 1980", editado por Admministrazione Provinciali di Viterbo en 1980, realizado por Germana Ferrari.

Pagina 247

\section{Otros catologos que lo contengan :}

Se desconoce.

Registros gráficos obtenidos $\quad$ Diapositiva $\quad \square \quad$ Imagén digital 


\section{Obra grafica Roberto Sebastian Matta Echaurren}

Ficha número : 103

Titulo de la obra : Etre au monde.

Fecha de realización : 1979.

Dimensiones

Tamaño del papel : $56 \times 76 \mathrm{~cm}$.

Tamaño de la mancha : 66 x $51 \mathrm{~cm}$.

\section{Técnica}

Técnica : Aguafuerte y aguatinta

Procedimientos y recursos complementarios :

Se desconoce.

\section{Matriz}

Número de planchas : $\quad$ Se desconoce.

Material de las planchas : Cobre

Datos complementarios :

Se desconoce.

\section{Estampación}

En hueco

En relieve

Planigrafica

Permeografica

Papel
Número de tintas :

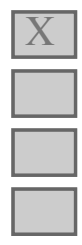

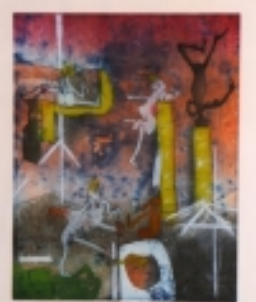

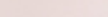




\section{Edición}

Número de ejemplares :

50 ejemplares sobre papel Arches tamaño 56 x $76 \mathrm{~cm}$. firmados y numerados del 1 al 50 mas XV H.C. firmados y numerados del I al XV.

$\mathbf{N}^{\circ}$ de P.A. (Prueba de Artista) : Se desconoce.

$\mathbf{N}^{\circ}$ de H.C. (Hors Commerce) : XV H.C.

B.A.T.: $\quad$ Se desconoce.

Otras Pruebas : Se desconoce.

Taller en el que se realizó :

Atelier George Visat en Paris Francia y la edición fue en J. tasende, La Jolla en Estados unidos de Norteamérica.

Estampador

No se sabe si es George Visat o Albert Dupont.

Número de la estampa observada : Se desconoce.

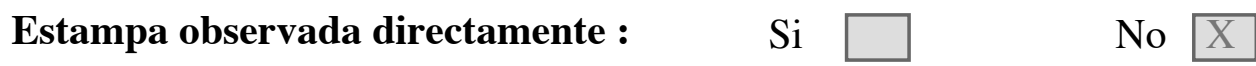

Contemplada a través de reproducción : $\mathrm{Si} X \quad$ No $\mathrm{X}$

Colección

Colección en la que se encuentra : Se desconoce.

Colección en la que se encuentra la plancha : Se desconoce.

Otras colecciones que tengan ejemplares de este trabajo : Se desconoce.

\section{Libros}

\section{Localización del libro o catalogo :}

"Matta, Index dell'opera grafica dal 1969 al 1980", editado por Admministrazione Provinciali di Viterbo en 1980, realizado por Germana Ferrari.

\section{Otros catologos que lo contengan :}

Se desconoce.

Registros gráficos obtenidos

Diapositiva

Imagén digital 


\section{Obra grafica Roberto Sebastian Matta Echaurren}

Ficha número : $\quad 104$

Titulo de la obra : Nymphee.

Fecha de realización : 1979.

Dimensiones

Tamaño del papel : $50 \times 65 \mathrm{~cm}$.

Tamaño de la mancha : 41.5 x $32 \mathrm{~cm}$.

\section{Técnica}

Técnica : Aguafuerte y aguatinta

Procedimientos y recursos complementarios :

Se desconoce.

\section{Matriz}

Número de planchas : $\quad$ Se desconoce.

Material de las planchas : Cobre

Datos complementarios :

Se desconoce.

Estampación

En hueco

En relieve

Planigrafica

Permeografica

Papel

\section{Número de tintas :}

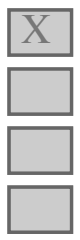

Se desconoce.

Colores :

Se desconoce.

Marca : Papel Arches y Papel Japon Nacré.

Gramaje : Se desconoce.

Color : $\quad$ Se desconoce. 


\section{Edición}

Número de ejemplares :

100 ejemplares sobre papel Arches tamaño 50 x $65 \mathrm{~cm}$. firmados y numerados del 1 al 100 mas XXXV H. C. firmados y numerados del I al XXXV.

100 ejemplares sobre papel Japón Nacré tamaño 50 x $65 \mathrm{~cm}$. firmados y numerados del 1 al 100 mas XXXV H.C. firmados y numerados del I al XXXV.

$\mathbf{N}^{\circ}$ de P.A. (Prueba de Artista) : Se desconoce.

$N^{\circ}$ de H.C. (Hors Commerce) : XXXV H.C.

B.A.T. : $\quad$ Se desconoce.

Otras Pruebas : Se desconoce.

Taller en el que se realizó :

Atelier George Visat en Paris Francia y la edición fue la Galería de la Incisiones en Milano Italia.

Estampador

No se sabe si es George Visat o Albert Dupont.

Número de la estampa observada : Se desconoce.

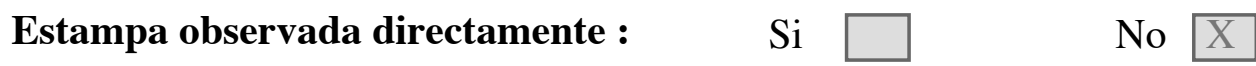

Contemplada a través de reproducción : $\mathrm{Si} X \quad$ No $\mathrm{X}$

Colección

Colección en la que se encuentra : Se desconoce.

Colección en la que se encuentra la plancha : Se desconoce.

Otras colecciones que tengan ejemplares de este trabajo : Se desconoce.

\section{Libros}

\section{Localización del libro o catalogo :}

"Matta, Index dell'opera grafica dal 1969 al 1980", editado por Admministrazione Provinciali di Viterbo en 1980, realizado por Germana Ferrari.

\section{Otros catologos que lo contengan :}

Se desconoce.

Registros gráficos obtenidos

Diapositiva

Imagén digital 


\section{Obra grafica Roberto Sebastian Matta Echaurren}

Ficha número : 105

Titulo de la obra : Carnamont.

Fecha de realización : 1979.

Dimensiones

Tamaño del papel : $50 \times 65 \mathrm{~cm}$.

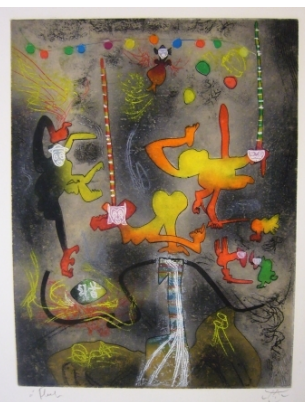

Tamaño de la mancha : $48 \times 36 \mathrm{~cm}$.

\section{Técnica}

Técnica : Aguafuerte y aguatinta

Procedimientos y recursos complementarios :

Carnamont es un album compuesto por 6 grabados y cada uno posee como titulo "Lastra I", "Lastra II", "Lastra III" "Lastra IV”,"Lastra V”,"Lastra VI".

\section{Matriz}

Número de planchas : $\quad$ Se desconoce.

Material de las planchas : Cobre.

Datos complementarios :

Se desconoce.

\section{Estampación}

En hueco

En relieve

Planigrafica

Permeografica

Número de tintas :

Papel

Marca : Papel Arches.

Gramaje : Se desconoce.

Color : $\quad$ Se desconoce. 


\section{Edición}

Número de ejemplares :

100 ejemplares sobre papel Arches tamaño 50 x $65 \mathrm{~cm}$. firmados y numerados del 1 al 100 mas XV H.C. firmados y numerados del I al XV.

Y cada obra esta marcada(firmada) en seco.

$\mathbf{N}^{\circ}$ de P.A. (Prueba de Artista) : Se desconoce.

$\mathbf{N}^{\circ}$ de H.C. (Hors Commerce) : XV H.C.

B.A.T. : $\quad$ Se desconoce.

Otras Pruebas : Se desconoce.

Taller en el que se realizó :

Atelier George Visat en Paris Francia, estampación y edición.

Estampador

No se sabe si es George Visat o Albert Dupont.

Número de la estampa observada : Se desconoce.

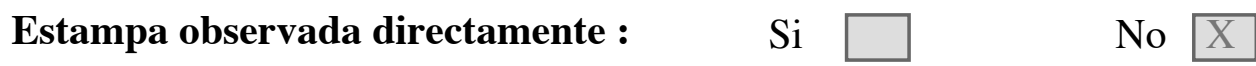

Contemplada a través de reproducción : $\mathrm{Si} X \quad$ No $\mathrm{X}$

Colección

Colección en la que se encuentra : Se desconoce.

Colección en la que se encuentra la plancha : Se desconoce.

Otras colecciones que tengan ejemplares de este trabajo : Se desconoce.

\section{Libros}

\section{Localización del libro o catalogo :}

"Matta, Index dell'opera grafica dal 1969 al 1980", editado por Admministrazione Provinciali di Viterbo en 1980, realizado por Germana Ferrari.

\section{Otros catologos que lo contengan :}

Se desconoce.

Registros gráficos obtenidos

Diapositiva

Imagén digital 


\section{Obra grafica Roberto Sebastian Matta Echaurren}

Ficha número : $\quad 106$

Titulo de la obra : Antologia.

Fecha de realización : 1938 - 1979.

Dimensiones

Tamaño del papel : $54 \times 76 \mathrm{~cm}$.

Tamaño de la mancha : Varia en cada obra.

\section{Técnica}

Técnica : Litografía.

Procedimientos y recursos complementarios :

Antología es una carpeta de 10 litografías, cada una fue creada a partir de un dibujo realizado entre los años 1938 y 1944 con la información que poseemos.

Los títulos de algunas de ellas son: D'Yeux (dibujo realizado en 1938), Cristifixion (dibujo realizado en 1938), Le coq (dibujo realizado en 1941), Sois bastión et Cristóbal (dibujo realizado en 1944), Nuie Bu (dibujo realizado en 1944).

\section{Matriz}

Número de planchas : $\quad$ Se desconoce.

Material de las planchas : Se desconoce.

Datos complementarios :

Se desconoce.

\section{Estampación}

En hueco

En relieve

Planigrafica

Permeografica

Número de tintas :

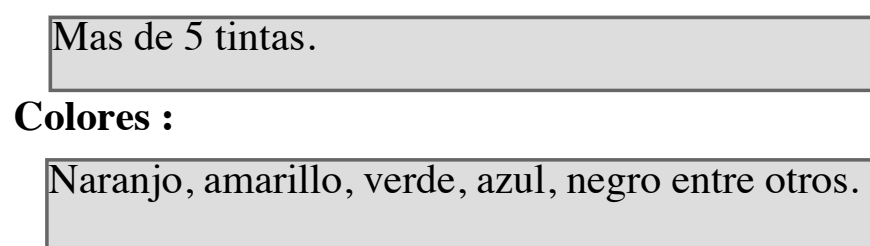

Papel

Marca : Papel Arches tamano 54 x $76 \mathrm{~cm}$.

Gramaje : Se desconoce.

Color : Beige. 


\section{Edición}

Número de ejemplares :

100 ejemplares sobre papel Arches tamaño 54 x $76 \mathrm{~cm}$. firmados y numerados del 1 al 100 mas V H.C. firmados y numerados del I al V mas alguna P.A.

$\mathbf{N}^{\circ}$ de P.A. (Prueba de Artista) : Ninguna prueba de artista.

$\mathbf{N}^{\circ}$ de H.C. (Hors Commerce) : V H.C.

B.A.T.: $\quad$ Se desconoce.

Otras Pruebas : Se desconoce.

Taller en el que se realizó :

Edizione in corso. Estamperia Grapholith, Paris Francia, y la edición en Polígrafa Barcelona España.

Estampador

Se desconoce.

Número de la estampa observada : Se desconoce.

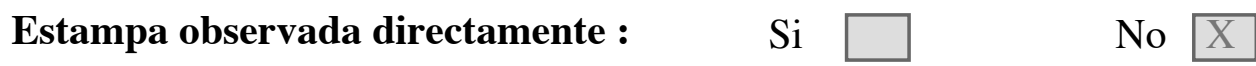

Contemplada a través de reproducción : $\mathrm{Si} X \quad$ No $\mathrm{X}$

Colección

Colección en la que se encuentra : Se desconoce.

Colección en la que se encuentra la plancha : Se desconoce.

Otras colecciones que tengan ejemplares de este trabajo : Se desconoce.

\section{Libros}

\section{Localización del libro o catalogo :}

"Matta, Index dell'opera grafica dal 1969 al 1980", editado por Admministrazione Provinciali di Viterbo en 1980, realizado por Germana Ferrari.

Pagina 256-260

\section{Otros catologos que lo contengan :}

Se desconoce.

Registros gráficos obtenidos $\quad$ Diapositiva $\quad \square \quad$ Imagén digital 


\section{Obra grafica Roberto Sebastian Matta Echaurren}

Ficha número : 107

Titulo de la obra : Bonnie and Clyde.

Fecha de realización : $1979-1980$.

Dimensiones

Tamaño del papel : $50 \times 66 \mathrm{~cm}$.

Tamaño de la mancha : 37.5 x $49 \mathrm{~cm}$.

\section{Técnica}

Técnica : Aguafuerte y aguatinta.

\section{Procedimientos y recursos complementarios :}

Bonnie and Clyde trata la historia de estos dos ladrones, contadas en cuatro escenas diferentes que se entrelazan en formato historia, se ve como asaltan, como la policía los busca y como logran fugarse.

\section{Matriz}

Número de planchas : $\quad$ Se desconoce.

Material de las planchas : Cobre.

Datos complementarios :

Se desconoce.

\section{Estampación}

En hueco

En relieve

Planigrafica

Permeografica

Papel
Número de tintas :

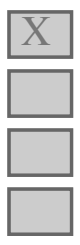

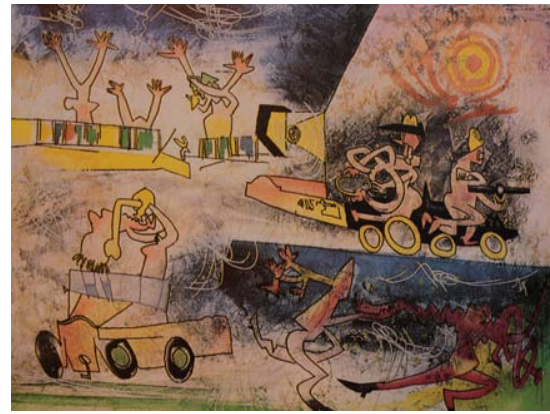




\section{Edición}

Número de ejemplares :

100 ejemplares sobre papel Arches tamaño 50 x $66 \mathrm{~cm}$ firmados y numerados del 1 al 100 mas XXV H.C. firmados y numerados del I al XXV.

$\mathbf{N}^{\circ}$ de P.A. (Prueba de Artista) : Se desconoce.

$\mathbf{N}^{\circ}$ de H.C. (Hors Commerce) : XXV H.C.

B.A.T. : $\quad$ Se desconoce.

Otras Pruebas : Se desconoce.

Taller en el que se realizó :

Atelier George Visat en Paris Francia y su edición fue privada en Paris.

Estampador

No se sabe si es George Visat o Albert Dupont.

Número de la estampa observada : Se desconoce.

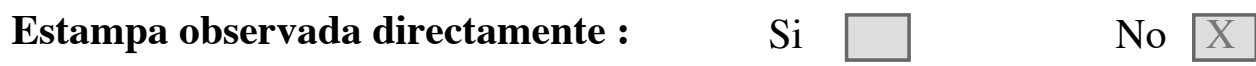

Contemplada a través de reproducción : $\mathrm{Si} X \quad$ No $\mathrm{X}$

Colección

Colección en la que se encuentra : Se desconoce.

Colección en la que se encuentra la plancha : Se desconoce.

Otras colecciones que tengan ejemplares de este trabajo : Se desconoce.

\section{Libros}

\section{Localización del libro o catalogo :}

"Matta, Index dell'opera grafica dal 1969 al 1980", editado por Admministrazione Provinciali di Viterbo en 1980, realizado por Germana Ferrari.

Pagina 265

\section{Otros catologos que lo contengan :}

Se desconoce.

Registros gráficos obtenidos

Diapositiva

Imagén digital 


\section{Obra grafica Roberto Sebastian Matta Echaurren}

Ficha número : 108

Titulo de la obra : Hommage a Man Ray.

Fecha de realización : 1978-1980.

Dimensiones

Tamaño del papel : $52,5 \times 37,2 \mathrm{~cm}$.

Tamaño de la mancha : 43 x $30.5 \mathrm{~cm}$.

\section{Técnica}

Técnica : Aguafuerte y aguatinta.

Procedimientos y recursos complementarios :

Hommage a Man Ray es el homenaje que Roberto Matta le hizo a este artista, retratándolo y entregándonos a través de su mirada toda una profundidad en su espíritu, una obra muy potente solo al verla y sobre su rostro coloco ciertas figuras de él, como si volasen sobre Man Ray.

\section{Matriz}

Número de planchas : Dos

Material de las planchas : Cobre

Datos complementarios :

Se desconoce.

\section{Estampación}

En hueco

En relieve

Planigrafica

Permeografica

Número de tintas :

Papel

Marca : Papel Arches.

Gramaje : 250 grm.

Color : $\quad$ Crema - beige. 


\section{Edición}

Número de ejemplares :

85 ejemplares sobre papel Arches tamaño 47 x $52 \mathrm{~cm}$. firmados y numerados del 1 al 85 mas X H.C. firmados y numerados del I al X.

$\mathbf{N}^{\circ}$ de P.A. (Prueba de Artista) : Se desconoce.

$\mathbf{N}^{\circ}$ de H.C. (Hors Commerce) : XH.C.

B.A.T.: $\quad$ Se desconoce.

Otras Pruebas : Se desconoce.

Taller en el que se realizó :

Atelier George Visat en Paris.

Estampador

George Visat.

Número de la estampa observada : Se desconoce.

\begin{tabular}{llll} 
Estampa observada directamente : & $\mathrm{Si}$ & $\mathrm{X}$ & No \\
\hline
\end{tabular}

Contemplada a través de reproducción : $\mathrm{Si} X \quad$ No $\mathrm{X}$

Colección

Colección en la que se encuentra : Privada en Paris.

Colección en la que se encuentra la plancha : Privada en Paris.

Otras colecciones que tengan ejemplares de este trabajo : Se desconoce.

\section{Libros}

\section{Localización del libro o catalogo :}

"Matta, Index dell'opera grafica dal 1969 al 1980", editado por Admministrazione Provinciali di Viterbo en 1980, realizado por Germana Ferrari.

Pagina 266.

\section{Otros catologos que lo contengan :}

Se desconoce.

Registros gráficos obtenidos $\quad$ Diapositiva $\quad \square \quad$ Imagén digital 


\section{Obra grafica Roberto Sebastian Matta Echaurren}

Ficha número : $\quad 109$

Titulo de la obra : Pyrocentre.

Fecha de realización : 1980.

Dimensiones

Tamaño del papel : $62 \times 84 \mathrm{~cm}$.

Tamaño de la mancha : $62 \times 57 \mathrm{~cm}$.

\section{Técnica}

Técnica : Aguafuerte y aguatinta

Procedimientos y recursos complementarios :

Se desconoce.

\section{Matriz}

Número de planchas : $\quad$ Se desconoce.

Material de las planchas : Cobre.

Datos complementarios :

Se desconoce.

Estampación

En hueco

En relieve

Planigrafica

Permeografica

Papel

Marca : Papel Arches.

Gramaje : Se desconoce.

Color : Blanco.
Número de tintas :

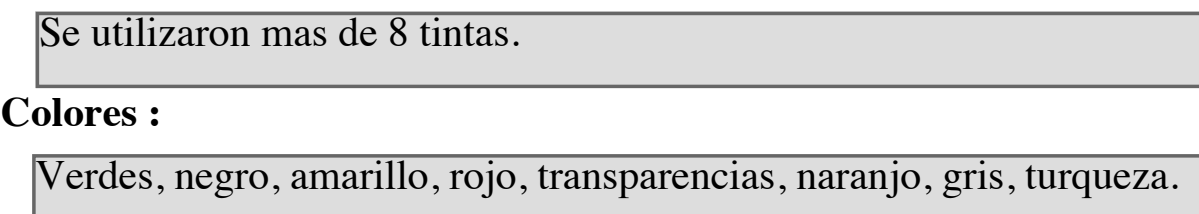




\section{Edición}

Número de ejemplares :

100 ejemplares sobre papel Arches tamaño 62 x $84 \mathrm{~cm}$. firmados y numerados del 1 al 100 mas X H.C. firmados y numerados del I al X.

$\mathbf{N}^{\circ}$ de P.A. (Prueba de Artista) : Se desconoce.

$\mathbf{N}^{\circ}$ de H.C. (Hors Commerce) : X H.C.

B.A.T. : $\quad$ Se desconoce.

Otras Pruebas : Se desconoce.

Taller en el que se realizó :

Atelier George Visat en Paris Francia y su edición fue privada en Paris.

Estampador

No se sabe si es George Visat o Albert Dupont.

Número de la estampa observada : Se desconoce.

Estampa observada directamente :

$\mathrm{Si}$

No

Contemplada a través de reproducción : $\mathrm{Si}$

No

Colección

Colección en la que se encuentra : Se desconoce.

Colección en la que se encuentra la plancha : Se desconoce.

Otras colecciones que tengan ejemplares de este trabajo : Se desconoce.

\section{Libros}

\section{Localización del libro o catalogo :}

"Matta, Index dell'opera grafica dal 1969 al 1980", editado por Admministrazione Provinciali di Viterbo en 1980, realizado por Germana Ferrari.

Pagina 267.

\section{Otros catologos que lo contengan :}

Se desconoce.

Registros gráficos obtenidos

Diapositiva

Imagén digital 
Obra grafica Roberto Sebastian Matta Echaurren

Ficha número : 110

Titulo de la obra : Mathematique Sensible.

Fecha de realización : $1938-1980$.

Dimensiones

Tamaño del papel : $\quad 50 \times 66 \mathrm{~cm}$.

Tamaño de la mancha : $37,5 \times 49 \mathrm{~cm}$.

\section{Técnica}

Técnica : Aguafuerte y aguatinta.

Procedimientos y recursos complementarios :

Mathematique Sensible es un texto de Roberto Matta publicado por la revista minotauro nr. 11 en 1938. Contiene 10 grabados los cuales se titulan "bedroom", "livingroom", "withdrawinroom", "lovingroom".

\section{Matriz}

Número de planchas : $\quad$ Se desconoce

Material de las planchas : Cobre

Datos complementarios :

Se desconoce

\section{Estampación}

En hueco

En relieve

Planigrafica

Permeografica

Número de tintas :

Se desconoce.

Colores :

Se desconoce.

Papel

Marca : $\quad$ Se desconoce.

Gramaje : Se desconoce. 
Color : $\quad$ Se desconoce.

Edición

Número de ejemplares :

Se desconoce.

$\mathbf{N}^{\circ}$ de P.A. (Prueba de Artista): Se desconoce.

$\mathbf{N}^{\circ}$ de H.C. (Hors Commerce) : Se desconoce.

B.A.T. : $\quad$ Se desconoce.

Otras Pruebas : Se desconoce.

Taller en el que se realizó :

Se desconoce.

Estampador

Se desconoce.

Número de la estampa observada : 
Estampa observada directamente :

$\mathrm{Si}$

No $\square$

Contemplada a través de reproducción :

$\mathrm{Si} \square \quad$ No

Colección

Colección en la que se encuentra : Se desconoce.

Colección en la que se encuentra la plancha : Se desconoce.

Otras colecciones que tengan ejemplares de este trabajo :

Se desconoce.
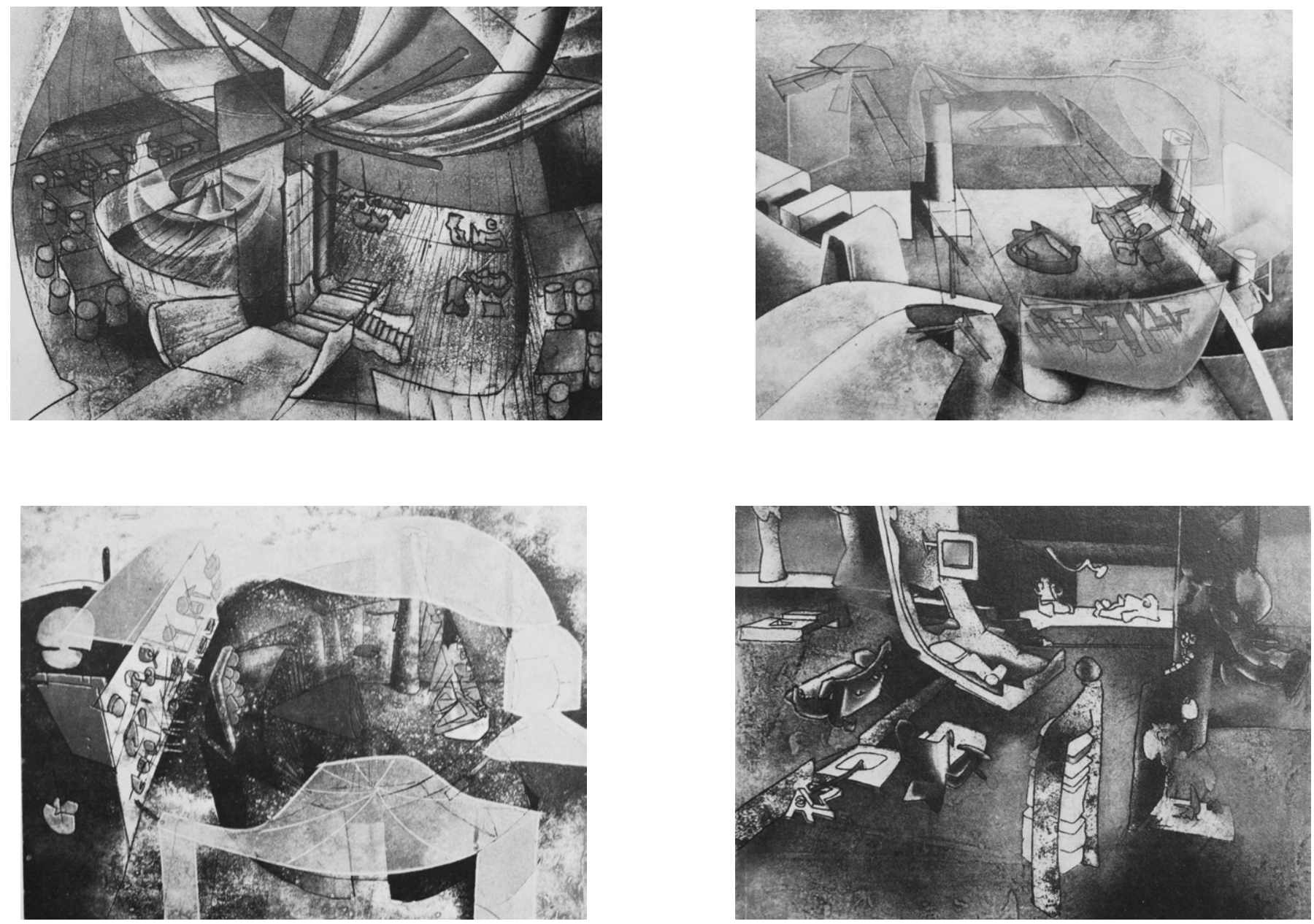


\section{Libros}

\section{Localización del libro o catalogo :}

"Matta, Index dell'opera grafica dal 1969 al 1980", editado por Admministrazione Provinciali di Viterbo en 1980, realizado por Germana Ferrari.

Pagina 261-264.

\section{Otros catologos que lo contengan :}

Se desconoce.

\section{Registros gráficos obtenidos Diapositiva $\square$ Imagén digital $X$}




\section{Cronología de la vida y obra de Roberto Matta IX.1.Introducción}

$\mathrm{L}$

a cronología que se presenta sobre Roberto Matta menciona los aspectos más importantes acontecidos en la vida y obra del artista. Donde se establece una relación entre cada hito personal de Matta, con hechos históricos relevantes de su país natal, Chile, y con hechos relevantes a nivel mundial, los que a partir de 1943 se irán relacionando con su obra grafica.

Se considera hacer una cronología de esta índole porque se cree que son de suma significación las influencias que consciente o inconscientemente han provocado efectos sobre el artista y sus obras, entendiendo este término como "causar una cosa ciertos efectos en otra"75. Las influencias que se desea mencionar corresponden a tipos de acontecimientos en la vida de Matta, queriendo decir con esto que los hechos personales algunas veces produjeron un efecto en su obra, y su obra muchas veces fue un dialogo, un medio de comunicación con los acontecimientos especialmente históricos y políticos en los que él se encontraba inmerso. Es por esto que el realizar una cronología en esta línea, abre caminos hacia un aprendizaje más global de la vida del artista y enriquece el conocimiento.

Para facilitar la lectura de esta cronología, se ha escrito en letra negra oscura los acontecimientos relacionados con Roberto Matta, bajo esto, con letra normal (lucida grande), se presentará la cronología de su obra gráfica, con letra cursiva los acontecimientos relacionados con la historia de Chile, y con letra gris los acontecimientos mundiales que han marcado un hito en la historia universal. Escribiéndose estos cuatro puntos en el siguiente orden a) Vida y Obra Roberto Matta, b) obras realizadas por Matta

\footnotetext{
75 Diccionario Sopena Aristos 3. Editorial Ramón Sopena, S.A., Barcelona, Novena Edición 1992.p.355.
} 
en el campo del grabado y la estampación c) Historia de Chile y d) Historia Universal. Existiendo en el centro de cada una de las páginas los años numerados en color negro.

Cabe mencionar que esta cronología se hace como un anexo a la Biografía específica presentada en la primera parte de esta tesis, la que trata única y exclusivamente la vida y obra de Roberto Matta. En cambio, la cronología de la vida y obra de Roberto Matta se presenta con la intención de que el lector conozca y participe de la vida y obra de Matta a través de los hechos históricos o culturales que, de cierta manera, han influenciado el trabajo plástico de este artista. Pudiendo en alguna forma sentirse cercano a los acontecimientos que esta cronología menciona.

IX.2.Cronología vida y obra de Roberto Matta

1911

Roberto Sebastián Antonio Matta Echaurren, nace el día once de noviembre de mil novecientos once, es decir 11/11/1911 en Santiago de Chile, siendo el mayor de cuatro hermanos, de una familia de origen Vasco-Francés.

En Chile en esos instantes gobernaba Ramón Barros Luco, desde 1910 hasta 1915, quien en su gobierno dio un impulso a las obras públicas, entre las que destacan: la construcción del ferrocarril de Arica a la Paz Bolivia, la cual se inicia en 1906 y se termina en 1913, la continuación de las obras de alcantarillado y agua potable, el inicio de la construcción del edificio de la Biblioteca Nacional de Santiago, la creación del puerto artificial de San Antonio.

En este mismo año el explorador noruego Roald Amundsen logra la hazaña de alcanzar el polo sur geográfico por primera vez, llegando al polo el día 14 de diciembre. 
Roberto Matta E. finaliza sus estudios secundarios en el Colegio Sagrado Corazón de Jesús y María, Congregación de Jesuitas Marianos, ubicado en Santiago (la capital chilena), siendo en este establecimiento donde aprende el idioma francés.

Un año antes en Chile, en 1927, asumiría como Presidente de la Republica el señor Carlos Ibáñez del Campo, durando su periodo hasta 1931. Caracterizándose por llevar una política personal, equidistante de los comunistas, a quienes perseguía, y de los conservadores, con quienes no compartió su gobierno. Solo su política económica tuvo una inclinación izquierdista.

En España, José María Escrivá de Balaguer, funda la orden religiosa del Opus Dei.

\section{9}

Durante este año Matta comienza a estudiar arquitectura en la Pontificia Universidad Católica de Santiago en Chile.

En Chile seguía ejerciendo su etapa política, Carlos Ibáñez del campo. Realizándose en su periodo la firma de el Tratado de Lima en el que se destaca entre varios puntos el que Arica queda bajo la soberanía chilena.

Asimismo el gobierno de Ibáñez afronta una inestabilidad política iniciada en 1931 que durará hasta 1932 en el país.

En EE.UU., comienza un derrumbe bursátil, producido por el colapso de la bolsa de Nueva York, generándose perdidas de hasta un 40\% en un mes, tres años después habrá 5.000 bancos en quiebra. 
Matta en este periodo, egresa de la Pontificia Universidad Católica del Chile, con el proyecto de fin de carrera titulado "La Liga de las religiones-Valle de Jeaspeat, la isla del elefante" el cual consistía en un templo donde estaban representadas en dibujos 147 religiones.

En Chile 1932 comienza el segundo periodo del Gobierno de Arturo Alessandri Palma el que durará hasta 1938. Caracterizándose por la variadas creaciones empresariales y de ayuda como COVENSA, (corporación de ventas del salitre y yodo) y CAJA DE LA HABITACIÓN POPULAR (fomento a la construcción de viviendas para la clase más pobre). Asimismo se otorgó en su periodo de gobierno el voto municipal a las mujeres y la construcción del estadio nacional entre 1938-1939.

En Alemania, en enero de 1933, asumirá el cargo de canciller Adolfo Hitler. Comenzando a registrarse un mes más tarde las restricciones a los derechos civiles, se forma la elite de las SS y las juventudes Hitlerianas que organizadas queman y destruyen los libros considerados antialemanes.

1934

Roberto Matta, a principio de este año parte rumbo a Europa con su amigo Manuel Marchant, en el barco trasatlántico Merchant Marine Compagnie Trasatlantique, con él estaría en varios puertos de Italia, España, Alemania, Yugoslavia, Grecia, e Inglaterra, rumbo a Francia.

En Chile, se otorga el voto a las mujeres para las elecciones municipales.

En EE.UU., se aprueba la ley de reserva del oro estableciendo un precio de $35 \mathrm{u} \$$ la onza y reduciendo el contenido de oro del dólar. 
Matta pasa las navidades de 1934 en Madrid en la casa de su tía apodada Bebé y su tío, Carlos Morla Linch, siendo esta actividad familiar una reunión donde Matta conoce y ve por primera vez a Rafael Alberti, Maruja Mallo, Manuel Ángeles Ortiz, Pablo Neruda y Federico García Lorca.

En Chile: Pablo Neruda publica "Residencia en mi tierra" (I y II) y María Luisa Bombal pública "La Amortajada".

En Rusia el régimen de Stalin realiza sangrientas purgas políticas en defensa del consumismo.

El físico escocés Robert Watson-Watt, (1892-1973) obtiene una patente relacionada con la localización de objetos a distancia por medio de ondas de radio, el sistema se conocerá por sus siglas como Radar.

1936

Roberto Matta, decide cambiar de residencia trasladándose a Londres, lugar donde conocerá y trabajará con los profesores de la Bauhaus, Walter Groupius, Moholy-Nagy y los artistas Henry Moore y Roland Penrose. Visitando durante el verano de ese mismo año en Lisboa, (Portugal) a la poetisa Gabriela Mistral, quien le introduce el interés de los postulados de las Brigadas culturales en México.

En España comienza la Guerra civil (1936-1939) a partir de la rebelión militar iniciada desde Marruecos por el general Francisco Franco, durante los primeros meses del conflicto, es fusilado en Granada el poeta y dramaturgo español Federico García Lorca.

Se crea la terrorífica GESTAPO, policía política liderada por Heinrich Himmler. 
Durante este año el artista, escribe y dibuja definiendo su vocación artística, quizás motivada u originada por el joven oficial de marina inglés Gordon Onslow Ford, quien al ver sus dibujos lo incita a pintar. Durante ese mismo año es contratado por Josep Lluis Sert, para el pabellón español en la Feria Mundial de París, donde tiene la oportunidad de ver el montaje de “Guernica” de Picasso y donde conocerá a Picasso.

1938

El grupo surrealista invita a Matta a participar como miembro activo del conjunto, del cual será miembro formalmente hasta 1948, participando en este año en la Exposición Internacional del Surrealismo en la galería de Bellas Artes de París.

En Chile se inicia el gobierno de Pedro Aguirre Cerda, hasta el año 1941. El programa del gobierno de Aguirre Cerda se sintetiza en esta frase "Pan, Techo y Abrigo".

En Europa, en la conferencia de paz de Munich, Inglaterra, Francia e Italia convienen, frente al expansionismo alemán, que Checoslovaquia ceda la región del sudeste a Alemania. Estas concesiones no evitarán que un año mas tarde estalle la guerra. Hitler ordena la anexión de Austria luego de sucesivos ultimátum al gobierno del canciller Schuschnigg, jaqueado por los nazis austriacos.

1939

Se inicia la Segunda Guerra Mundial, y a consecuencia de ello Matta decide partir a EE.UU. con su esposa Ann Clark e Yves Tanguy, por invitación de Marcel Duchamp. Llega a Nueva York a finales de 1939, y es allí donde comenzará a trabajar. 
En Chile en este año se produce el 24 de enero de 1939 uno de los mayores terremotos de la historia del país, el sismo es de magnitud 8.3 en la escala de Richter, el cual deja más de 3.000 muertos en la zona afectada entre Talca y Bíobío.

En Europa comienza la segunda guerra mundial, en septiembre de 1939.

1940

Roberto Matta E. realiza su primera exposición individual en Julien Levi Gallery de Nueva York. Asimismo participa en muestras colectivas del arte surrealista: Exposición Internacional del Surrealismo, en la Galería de Arte Mexicano, y en Surrealism Today, en la Zwemmer Gallery, en Londres.

En Chile se dicta el decreto que fija los limites del territorio chileno antártico; los meridianos $53^{\circ}$ y $90^{\circ}$ de longitud oeste. Los que se habían comenzado a realizar un año antes.

En EE.UU. comienzan a interesarse por el proyecto de la bomba atómica a partir de un informe presentado por un grupo de físicos encabezados por Albert Einstein.

En Europa, durante ese mismo año, comienza la batalla de Inglaterra, la cual será una guerra aérea entre ingleses y alemanes, en la que al final vence el ejército británico gracias al uso del radar.

1941

Matta durante este tiempo visita México acompañado por los pintores Baziotes, David Hare, María Ferrero, Motherwell y su esposa, Bárbara Reis y Ann Clark; coinciden con Wolfgang Paalen, pintor surrealista afincado en México. 
El 25 de noviembre de este año en Chile, muere a causa de una tuberculosis aguda Pedro Aguirre Cerda, quien en ese entonces era el presidente de gobierno.

Francisco Coloane publica "El ultimo grumete de la Baquedano" y "Cabo de hornos".

EE.UU. se involucra en la segunda guerra mundial, lo que se inicia por el hecho provocado por Japón quien ataca sorpresivamente con una fuerza aeronaval el 7 de diciembre a la base naval de Pearl Harbour, en el Pacífico, provocando que EE.UU. ingresara en la guerra.

El 11 de diciembre Alemania declara la guerra a EE.UU.; los aliados contarían desde entonces con el apoyo directo de la principal potencia industrial del planeta.

1942

En la Galería Pierre Matisse de Nueva York, Roberto Matta realiza la exposición "La tierra es un hombre", con posterioridad participa en la exposición colectiva "Artists in exile" ambas muestras realizadas en la Galería Pierre Matisse. Durante este mismo año participa como integrante en el estudio de Stanley William Hayter, reconocido grabador.

En Chile durante este mismo periodo gobierna el señor Juan Antonio Ríos desde febrero de 1942 hasta enero de 1946.

Augusto D’halman obtiene el Premio Nacional de Literatura.

En EE.UU. Enrico Fermi y sus colaboradores construyen en Chicago la primera pila atómica, este acontecimiento determina la primera reacción nuclear controlada en la historia de la humanidad y servirá de modelo para centrales electro-nucleares futuras. 
Matta, Participa en importantes exposiciones de arte contemporáneo. Nacen sus hijos gemelos Sebastián (batan) y Gordon Matta Clark en Nueva York. Meses más tarde Ann y Roberto se separan.

Crea durante este periodo la serie "The New School”. (catálogo página 1 )

En Chile, bajo el gobierno de Juan Antonio Ríos, se crea por iniciativa de la CORFO, la Empresa Nacional de Electricidad S.A., ENDESA.

En estos momentos en África los nazis son derrotados, los aliados invaden Sicilia iniciando la liberación de Italia, los nazis ocupan Roma al mando del mariscal Albert Kesserling, durante los meses de julio y agosto la aviación aliada bombardea Roma.

Durante este mismo año es destituido Mussolini.

1944

Este año Matta, expone en la Galería Pierre Matisse de Nueva York, ocasión en la cual André Bretón escribe "Le perle est gatee à mes yeux", texto que será publicado en 1950. El artista crea una serie de personajes míticos inspirándose en formas del arte primitivo.

Crea a la vez el grabado "Acane 17".

Durante este periodo en Francia, comienza la invasión de Normandía. Los aliados desembarcan en Normandía, Londres sufre bombardeos masivos y París es liberado; en el Pacífico los americanos desembarcan en GUAM. 
Expone "Le poete" en Galería Pierre Matisse y exhibe sus esculturas por primera vez en la exposición "Imagery of Chess".

La poetisa chilena Lucila Godoy Alcayaga, más conocida como Gabriela Mistral, recibe el premio Nóbel de literatura y Pablo Neruda obtiene el Premio Nacional de Literatura.

En el mundo, finaliza la segunda guerra mundial con la rendición del Japón, luego del bombardeo atómico aliado a Hiroshima.

En Nagasaki se devasta la ciudad mediante una bomba atómica de plutonio. Comenzando entonces la era atómica.

1946

Roberto Matta E., presenta muestra individual en la Galería Pierre Matisse de Nueva York. En los Cahiers d'arts se reproducen varias de sus obras.

Crea los grabados "Par la Bait Naitre", "El Poète de Notre Connaissance" y "Le vitreur ou non".

En Chile comienza el gobierno de Gabriel Gonzáles Videla que durará hasta 1952. Este año Amanda Labarca es nombrada representante de las mujeres frente a las naciones unidas.

En Nuremberg, Alemania, el tribunal militar internacional que un año antes ha empezado a juzgar a los principales lideres nazis por crímenes contra la humanidad y crímenes de guerra, dicta sentencias, 12 de entre los 22 acusados son condenados a la pena de muerte en la horca, una de las sentencias no llegará a cumplirse ya que Martín Bormann quien continúa prófugo ha sido condenado en ausencia. 
Matta participa en diversas exposiciones colectivas entre las que destacan: la exposición internacional del surrealismo en la Galería Maeght, París, donde expone un “Altar” dedicado a Marcel Duchamp; Presenta su primera muestra individual en París, en la Galería Rene Drouin.

Crea las litografías "Preliminaires sur Matta" y "I want to see it to believe it" realizado para la Carpeta artística Bruñidor portafolio.

En Chile se funda la Universidad Técnica del Estado en Santiago, la capital chilena. Se revindica la soberanía de 200 millas marinas en el mes de junio de este año.

Marcela Paz publica "Papelucho".

En medio oriente durante este año trasciende el descubrimiento por parte de beduinos de antiguos rollos manuscritos en la zona de Qumram. Estos manuscritos son los más antiguos encontrados, los que serán conocidos como los rollos del mar muerto y serán considerados uno de los mayores hallazgos arqueológicos del siglo.

1948

Después de 14 años Roberto Matta vuelve a Santiago de Chile exponiendo en la Galería Dédalo en el centro de la capital, y la revista Proarte publica su texto "Reorganimación de la afectividad". Decide regresar a finales de este año definitivamente a Europa. Siendo expulsado en Francia por el grupo surrealista, el cual 11 años más tarde le recibiría (readmitiéndolo) y excluido de la escuela de Nueva York y de las Galerías Pierre Matisse, Sydney, Janis, Maeght, etc. Después de estos acontecimientos decide marcharse a Roma.

En Chile se promulga la ley contra el comunismo.

Se inaugura en la antártica la base Arturo Prat, en la bahía de la Isla Greenwich. 
Israel logra su independencia en Palestina al culminar el protectorado británico.

En EE.UU., se formula el plan Marshall.

1949

Matta se establece durante este año en Roma donde permanecerá hasta 1954. Viajará frecuentemente a París. Por primera vez Matta pinta el concepto del cubo abierto que venía desarrollando desde 1942, con el cual intenta expresar el espacio múltiple en una superficie bidimensional.

Crea las litografías "Cessation d'etat et at it", y "Affiche".

En Europa en este mismo tiempo, 10 naciones europeas conjuntamente con EE.UU. y Canadá forman el pacto del atlántico norte conocido como NATO.

División de Alemania en dos repúblicas: RDA y la RFA.

1950

Presenta sus primeras exposiciones individuales en Italia: "Matta. fostore sciamo" en la Galería del Obelisco y en la Galería del Secolo, en Roma. Luego expone en Milán y en Venecia. Siendo este año cuando nace su hijo Pablo.

Crea la litografía "Nommeur des nommeurs".

En Asia, mientras tanto, comienza la guerra de Corea (1950-1951); Corea del sur apoyada por los EE.UU. y sus aliados se enfrenta a Corea del norte apoyada por el bloque comunista.

El Consejo Mundial de la Paz dicta una prohibición de todas las armas atómicas.

Stalin y Mao firman un pacto de amistad. 
Roberto Matta, expone en Institut of Contemporany Art de Londres. Esta muestra se exhibe luego en la Galería Sydney Janis, en Nueva York, ocasión en que se publican algunos textos artísticos.

En Chile se realiza el primer vuelo aéreo a la Isla de Pascua desde el continente.

En Jordania es asesinado el Rey Abdullah, lo sucede Tala I pero es reemplazado por el parlamento quien designa como sucesor a su hijo Hussein.

1952

Matta realiza numerosas muestras colectivas en el Museo Nacional de Arte Moderno en París y Pittsburg International evento en el que participará regularmente. Termina durante este año "Les roses son belles" (una alusión al proceso Rosenberg), su primera obra dedicada a un hecho histórico.

En Chile en este mismo año comienza el segundo gobierno de Carlos Ibáñez del Campo que durará hasta 1958. Definiéndose su periodo por la creación de puertos libres en Arica y Magallanes, por la fundación de la base Antártica Pedro Aguirre Cerda, la creación del Banco del Estado, la ley de asignación familiar obrera y salario mínimo campesino, la ley de asignación familiar prenatal y la fundación de Puerto Williams, siendo estos cambios lo mas sobresalientes en su periodo.

EE.UU., efectúa en las islas Marshall en el pacífico, el 31 de octubre, la detonación de la primera bomba de hidrógeno, basada en la fusión nuclear, bajo el gobierno de Dwight Eisenhower. 
Roberto Matta E. presenta dos exposiciones individuales: en Galería Iolas, Nueva York, y en la Sala Napoleónica, Venecia. Se publican varios textos que analizan el espacio en la obra de Matta: "Le réalisme ouvert de Matta", de Alain Jouffroy, en Cahiers d arts; "El espacio de Matta" de Stanley William Hayter, en la revista italiana Número; y "Espace xontinu espace vécu", de Max Clarac Sérou, en la revista parisina Position.

Se inicia la Guerra de Indochina.

En Inglaterra, Isabel II es coronada reina, sucediendo a su padre Jorge VI. En esos instantes en Rusia muere Stalin durante el mes de marzo, lo sucederá como presidente G. Malenkov.

Los británicos crearon la Federación de Nyasalandia y Rhodesia del Norte y del Sur, en África Central, donde los blancos adquirieron una posición preponderante hasta 1960.

1954

Matta viaja a Perú y Chile. Presenta exposiciones individuales en la Galería Lima en Lima y en el Museo Nacional de Bellas Artes, en Santiago. Participa por primera vez en el Salón de mayo, en Paros, donde expondrá regularmente. Se establece nuevamente en París pero viajará continuamente a Roma.

Vietnam libera su territorio septentrional de manos francesas; el sur queda en estado beligerante, mientras Mao-Tse-Tung es elegido presidente de la República Popular China. La Conferencia de Ginebra: Divide a Vietnam en dos estados. 
Matta, recibe un premio en el Pittsburg International con el óleo titulado "Interrogation". Con los artistas del grupo Cobra, Karel Appel, Corneilli y Jorn, expone esculturas en cerámica.

Nace su hija Federica.

Crea los grabados "Torototo (coup de pied par terre)" y "Affiche". Para la exposición en conjunto con Appel, Corneille, Jorn, en donde exponen obras realizadas en cerámica, en la Galería Mazzotti.

Se crea el Pacto de Varsovia, para la defensa militar, la seguridad y colaboración política entre sus miembros.

El científico Jonas Salk hace pública la obtención de una vacuna efectiva contra la poliomielitis.

Invasión de Hungría por el ejercito Soviético.

1956

Pintará para la UNESCO el mural "Las dudas de tres mundos". Colabora con Víctor Brauner en pinturas y dibujos y exponen juntos en la Galería del Dragón, (París) sobre el tema de la televisión. Tele-invitation es de los primeros cuadros retransmitidos en la televisión francesa en París, ocasión en la que Edouard Glissant escribe un texto sobre la obra reciente del artista.

Crea las litografías "Les quatre observateurs ou l'objet du dialogue”, “Le Pianiste”. Más el grabado "Matta terres nouvelles".

Estalla la Guerra de Suez, en el Medioriente. Debido a las restricciones impuestas por Egipto a Israel para la navegación en el canal, el conflicto involucra a los países árabes e 
Israel con la participación militar de Francia e Inglaterra la que será neutralizada por la intervención de EE.UU. y Rusia.

1957

Roberto Matta realiza su primera retrospectiva en el Museum of Modern Art (M.O.M.A.), Nueva York coordinada por William Rubin. Se presentan exposiciones de su trayectoria en el dibujo desde 1937 hasta 1957 en la Galería Ruth Moskin, en Nueva York, y en la Galería del Dragón, en Paris.

Crea la litografía "L'exitateur" y el grabado "L'emploi du temps".

Se inicia la Guerra de Vietnam.

Rusia pone en orbita el primer satélite artificial, lo que impacta fuertemente a EE.UU. acelerando sus energías en la investigación tecnológica y espacial.

Con estos hechos comienza la carrera espacial.

1958

Presenta exposiciones individuales en la Galería Iolas en Nueva York y en la Galería del Dragón en París. Entre los textos publicados sobre el artista destacan "La questión" de Alain Jouffroy y "Matta, l'aube et le vertigue" de Patrick Waldberg. Pinta "La cuestion de djamila", en respuesta al libro “Cuestion" de Henri Alleg, sobre la tortura en la guerra de independencia en Argelia.

Crea la serie "Vigies sur cibles" obra de Henri Michaux. Y el grabado "Voeux galerie du dragón". Durante este mismo año crea el libro de artista "Droites libérées", que será impreso en 1971.

Comienza en Chile, el gobierno de Jorge Alessandri Rodríguez, que durará hasta 1964. Su gobierno se caracteriza por el desarrollo de las obras públicas, destacando la 
construcción de casi un centenar de hospitales, reconstrucciones de viviendas, 1.000 escuelas primarias, 40 liceos y 39 instituciones de Enseñanza Superior.

Comienza en Italia el pontificado del Papa Juan XXIII, sucediendo a Pío XII. Su pontificado se caracterizara por sus transformaciones progresistas, durante este siglo.

\section{9}

Matta expone en Fráncfort, en la Galería de Daniel Cordier. Se organiza en Europa la primera retrospectiva del artista, por Pontus Hultenen el Moderna Museet de Estocolmo, bajo el título "Quince formas de dudas", "15 formes du doute". Es reincorporado al movimiento surrealista y participa en la octava edición de la obra “ El espacio de la especie" que culminara en 1963. Y expone en la XII Documenta de Kassel.

Matta colabora en "Paroles peintes" obra de Alain Bosquet, junto a Max Ernst, Jacques Hérold, Wilfredo Lam et Dorotea Tanning, presentando el grabado "Paroles peintes", además crea la serie de "Onze formes du doute".

En Cuba triunfa la revolución de Fidel Castro, que depone al dictador Batista. Fidel Castro impondrá luego un giro hacia el comunismo.

1960

Expone por primera vez sus esculturas en la Galería del Dragón en París. Presenta una muestra individual en la Galería Frumkin, en Nueva York. Alain Jouffroy publica un artículo en la revista Combat, en París, en el cual plantea la revolucionaria postura política del artista.

Nace su hijo Ramuntcho.

Crea los grabados "Le sel noir", "Les avoeux de cordier", "The mooner" y "The moon shoker". 
En Chile, se producen varios sismos, el primero en Concepción y el segundo al día siguiente en Valdivia, donde se produce un segundo sismo seguido con un gran maremoto. La magnitud del terremoto fue de 8.75 en la escala de Richter.

La población mundial llega a los 3.000 millones de personas. Durante los 14 años siguientes llegará a 4.000, aunque ha pasado más de un siglo para duplicarse de 1.000 a 2.000 millones.

Entre 1960 y 1965 se independiza gran parte del África negra.

1961

Roberto Matta viaja a Chile y da inicio a un mural para la Universidad Técnica del Estado (actual Universidad Santiago de Chile) en Santiago titulado "Vivir enfrentando las flechas" y que será culminado en 1971, el cual mide 7 metros. Entre las colectivas en que participa este año se destaca la exposición "Abstract expressionist imagists", en el Guggenheim Museum de Nueva York.

Matta crea los grabados "Le catalyseur" y "Le mur".

Rusia pone en órbita terrestre al primer astronauta de la historia, el militar Yuri Gagarin en la Vostok I; poco más tarde EE.UU. lanza en su primer vuelo suborbital al astronauta Alan Sherpard a bordo de una cápsula Mercury.

1962

En este año Matta presenta una exposición de sus grabados en la Galería Point Cardinal, en París. Recibe en ese mismo año el premio Mazotto.

Crea simultáneamente los grabados "Come detta dentro vo significando", "Le miroir du merveilleux" y la serie de 8 aguafuertes en colores titulada "Scenes familières". 
China rompe relaciones con la URSS.

En Cuba la presencia de mísiles nucleares rusos culmina con una grave crisis, lo que genera el retiro de estos mísiles por parte de Rusia tras un tenso bloqueo naval de los EE.UU.

En octubre de este año, se inauguraba el concilio Vaticano II, que declaró que la Guerra tiene un carácter inmoral, considerándola un crimen contra Dios y la humanidad. La paz debe ser, en este sentido, la aspiración de todos los espíritus.

1963

Durante este periodo se organizan más de 12 exposiciones del artista en diferentes ciudades europeas. Entre ellas destaca una gran retrospectiva que presenta el Museo Cívico de Bolonia, que luego itineraria por Viena y Dusseldorf.

Crea el grabado "Scogliatole", el cual nunca fue editado, y de la cual existe una sola prueba de ensayo. Crea, simultáneamente, las litografías "Affiche", "Quatre formes de doute" y "Affiche".

En EE.UU., en la ciudad de Dallas, Texas, es asesinado a balazos el presidente John F. Kennedy, las sospechas sobre un complot se mantendrán durante más de 30 años.

1964

La retrospectiva de Bolonia se presenta en Ámsterdam, Bruselas y Mannheim. Matta viaja nuevamente a Cuba con el motivo de presentar una exposición en la Casa de las Américas. Su estadía en la Habana inspira una serie de pinturas que exhibirá en la Galería Ático, en Roma. Participa en la XXXII Bienal de Venecia, la tercera edición de la Documenta en Kassel y la muestra de 10 años de arte actual, en el Museo de Arte Moderno de la Villa de París. 
Crea durante este periodo las litografías "Le robinet de Guantánamo", "Fruta bomberos", "Los conchanchos ou un sans parole" y "Los cochinos ou l'eau a Guantánamo", "Affiche” y "Les Voix”; más la creación de una serie de 6 grabados a color titulados "Pasaje et sage du couple".

Durante este mismo año, Matta crea un libro de arte titulado "Voix" con un texto inédito de Michel Fardoulis Lagrange ilustrado con 10 grabados del artista.

En Chile comienza el gobierno de Eduardo Freí Montalva que durara hasta 1970.

En el Sudeste Asiático un ataque con torpedos por parte de lanchas rápidas vietnamitas en el Golfo de Tonkin a los destructores de EE.UU., Maddox y Turner Joy provoca una grave escalada en la guerra conduciendo al inicio bombardeos aéreos sobre Vietnam del Norte.

En URSS Kruschev fue destituido de su cargo y en su reemplazo se alzó la figura de Leonidas Brezner quien era partidario del comunismo ortodoxo.

Roberto Matta E., presenta la exposición “Cubo Abierto” en el Kunstmuseum en Lucerna, Suiza, ocasión en la cual publica dos textos que plantean en rasgos generales su concepción estética: "L’espace de l'espace” y “Cosa è la cosa mentale”. Participa asimismo en diversas colectivas entre las cuales destaca la XI Exposición Internacional del surrealismo, en la Galería Loeil, en Paris.

Crea los grabados "F.S.A.V.”, “Herring-harangue”, "La fin et la manière”, “Intronautes” y "Castronautes", más la "Serie de Or" y la litografía "Had a great fall".

En Chile nuevamente se produce un terremoto, afectando a la zona central del país. 
En Centroamérica desaparece un avión de la fuerza aérea Argentina con los cadetes de la promoción de ese año en viaje hacia los EE.UU.

1966

Expone en Milán, Nueva York, París, Lima y Minneapolis.

F. C. Toussaint realiza una extensa entrevista a Matta sobre "El surrealismo y la revolución” publicada en Les lettres françaises en París.

Crea la serie de grabados "Les Damnations" obra compuesta por un texto inédito de Joyce Mansour, ilustrado por 11 grabados de Matta. Creando también los grabados "Personaje 1" y "Personajes 2" realizados ambos en aguafuerte con aguatinta a colores.

La Unión Soviética logra, por primera vez desde el inicio de la carrera espacial, que una nave se pose en un descenso controlado sobre la Luna. La nave se llama Lunik IX.

1967

Durante este año Roberto Matta viaja a la Habana y expone en la Galería Latinoamericana. En esta ocasión realiza un mural junto a los estudiantes de la Escuela de Bellas Artes titulado "Para que la libertad no se convierta en estatua". Muere Bretón y Matta escribe como homenaje póstumo "L'illumination", publicado en la Nouvelle Revue Française, en París. Adquiere un viejo convento en Tarquinia (Italia) que se convierte en su casa- estudio.

Crea los grabados "Les Parnnos" y las litografías "Les venusiennes", "Les voleurs volés par leurs volants" y "Les jupitiens" y el álbum "Judgments" compuesto por 7 grabados de Matta.

Estalla la Guerra de los 6 días entre árabes y judíos cuyo desenlace le otorga a Israel importante ventajas territoriales. 
Ernesto Che Guevara líder guerrillero comunista es capturado y fusilado en Bolivia.

1968

Roberto Matta expone en la muestra Totems et Tabous, presentada en el Museo de Arte Moderno de la Villa de París. Esta exposición se traslada luego a la fábrica de la Nord Aviation, ocupada entonces por la huelga general.

Crea las litografías "Pan, ton io" y "Utopiens au soleil", "Les freins d'Hippolyte", "La perche”, “D’hui le drapeau a l'etoile”, “Demain” y "L'or en suisse”, "Planifatur", "Affiche Auschwitz 1941-1945/ Palestine 1948-1968". Más “Morphèmes” un álbum compuesto por 6 grabados, y "Aimera bien qui aimera le dernier", "Se tordre d'amour", "Se marrer d'amour", "Figure I", “Personajes III", "Pouffer l'amour" y “Amour aux eclats".

Visita Chile Isabel II de Gran Bretaña, acompañada por el duque de Edimburgo príncipe consorte.

En París se desarrolló uno de los movimientos sociales más importantes de la historia de Francia del siglo XX. Siendo una revuelta social, cultural y política en contra la sociedad tradicional, el capitalismo, y el imperialismo lo que desencadena una oposición fuerte contra Charles De Gaulle.

En EE.UU., es asesinado en la localidad de Menphis el pastor Martín Luther King.

1969

Entre las exposiciones en que participa este año, destaca "La revolución y la arquitectura”, presentada en el Centro Cultural de Villa de París.

Crea durante este periodo la litografía "Es erótica", la serigrafía "D’io", y "Antimundo" , además de los grabados "Flute et flutistes", "La une a I'h pile" y "Histoire de l'huitre", "Les mots dans la peinture". 
En Chile se comienza a chilenizar el cobre, gracias a las iniciativas puestas en marcha a partir de 1965.

En Europa, el grupo musical británico llamado "The Beatles", coloca al tope de ventas su primer disco titulado "Love me do". Los Beatles iniciaran un cambio en el ritmo musical de la época, harán dinero e historia por más de dos décadas imponiendo la "Beatlemania”. En EE.UU. Richard Nixon ocupaba la presidencia.

\section{0}

Matta realiza una retrospectiva en la National galerie de Berlín. Visita Chile donde se encuentra con Salvador Allende y Fidel Castro, por dos días, y es invitado por la Universidad de Concepción a participar en un "Diálogo sobre la tradición del futuro". En este mismo año fue invitado por el periódico Al Arma en Egipto donde se reunió con intelectuales Árabes.

Nace su hija Alisee, acontecimiento que motiva la realización de su obra "Dar a la vida una luz".

Crea durante este año dos carpetas cada una de ellas con 6 litografías, tituladas "Erótica" y "Le acque d'arno", además crea la serigrafía "Eros humor Tarquinia", la carpeta "Anti-franco", los grabados "The sea-salt pathway", "Les helvements", "Les suicides", "Sur-Matta" obra de Michel Fardoulis en la que Matta participa con dos aguafuertes originales, mas las litografías "Le cube”, “La guerre”, "L’Hecatombe de toros, agnelli”, el "Vivere a clair de terre", y el álbum compuesto por 10 grabados titulados "Cosi fan tutte".

Comienza en Chile el Gobierno de Salvador Allende Gossens, que durará hasta 1973. Su gobierno posee un amplio programa el cual tiene como prioridad la aplicación de las llamadas "40 medidas básicas" que se dividen en las siguientes 4 categorías: 1. las referentes al orden institucional y al manejo de la administración pública; 2. las relativas al 
funcionamiento de una nueva economía; 3. las de carácter social; y 4. las de orden cultural y educacional.

EE.UU., envía la misión lunar Apolo 13 la cual debe abortar imprevistamente su misión por un desperfecto en la nave realizando un dramático regreso a la tierra.

1971

Roberto Matta participa activamente en diversas acciones de la Brigada Ramona Parra, entre las cuales destaca la elaboración del mural "Primer gol del pueblo chileno", en la Municipalidad de la Granja de Santiago de Chile. Durante ese mismo año es considerado uno de los 10 mejores pintores del mundo sobre la base de una encuesta realizada a 104 personalidades artísticas internacionales, y que publicó la revista francesa Connaissance des Arts.

Neftalí Reyes Basoalto, más conocido como Pablo Neruda, quien es embajador durante ese año en Francia, recibe Premio Nóbel de Literatura por su extensa obra literaria.

Crea las serigrafías "Comme le doigt peut voir, le nez fait gouter la couleur a l'oreille, reste le sens de l'inconnu", “l'oriente", “la tradición del futuro" y "Puro pueblo es tu cielo azulado" más los grabados "Le poing du jour", "FMR", "Episstil et pistelle?", "Pankinorama", "Cherche eve”, "Feuilles ouvertes", “Franq-isme”, “Droites liberées”. Además de la realización de una plancha en offset titulada "Dramatisation (sur plan cosmique) des emotions de L'enfance" y las litografías "Les anus d'une pomme", "Les annales du son", "Composition pour berggruen", "Hecatombe de toros", "La mort eautoro" y "Fog gog magog".

La República Popular China ingresa en la ONU, provocando así la eliminación de Taiwán de este organismo.

La Unión Soviética lanza la primera estación espacial en orbita terrestre llamada Salyut-1, entretanto la misión de su sonda Mars 3 a Marte falla misteriosamente. 
Matta sigue desarrollando el concepto espacial del Cubo Abierto y realiza una serie de obras que expone en la Galería de Nueva York. Entre las exhibiciones colectivas en que participa destaca el surrealismo, presentada en Haus der Kunst de Munich y en el Museo de Artes Decorativas de París. Dona al pueblo chileno las obras "Hagámonos la guerrilla interior para parir el hombre nuevo" y "Ojo con los desarrolladores".

Durante este año realiza varios grabados entre los que destacan "Les oh! Tomobiles", "Omnimal”, "Sexplication suffisante”, “Fou riez", “loessa”, "Les escrobates”, "Personnage brune", "Personnage verte", las litografías "Langage animal”, "Lithographie pour Visat", “L'austerite des robustes", “La temperature de la tete”, “L'espace del viva”, "Un premier goal au Chili", y los álbumes "La danse de la mort" álbum compuesto por 8 grabados de Matta, junto a la obra de Strindberg, "Les oh! Tomobiles" álbum compuesto por textos inéditos de José Pierre ilustrado por 10 grabados y "Mots desserre freins" obra compuesta de un texto inédito de Robert Valancay ilustrado por 6 grabados de Matta.

En Munich, Alemania, donde se realizan los Juegos Olímpicos, un grupo extremista palestino denominado Septiembre Negro secuestra y asesina a 11 atletas israelíes provocando consternación mundial.

Se crea el Estado de Bangladesh, (antiguo Pakistán Oriental).

1973

Luego del Golpe de Estado del 11 de septiembre en Chile, las municipalidades italianas de Livorno, Bolonia y Rávena, en solidaridad con el pueblo chileno, organizan la exposición "Por Chile con Matta”. Presenta posteriormente Roberto Matta una gran muestra de sus obras recientes en la Galería Cívica de Arte Moderno, en Ferrara. 
Durante este año realiza serigrafías sobre tela en las que destacan "Morire per amore" (Che guevara) ,"I guidici di norimberga", "Etrusculudens Tarquinia", "Index- Volver", "De Perro", “Azurosso", “Uomo senza qualità", “Delizio”, “L’ultima cena”, las litografías “Fumetto”, “Lieberos”, “Orbis yeux”, “Fete couchee”, “Falbala”, “Le visage inferieur”, “L'anti proces", "Les voix en conserve”, “ United snakes of América”, "Los engulleran”. Los grabados “Un autre aprés”, “Devoir dans le hasard”, “L’angle mére”, “Frappe le marteau qui frappe”, "La grande invariante”, “Voir dans le hassard”, "Un pourquoi final”, "Son my”, “Tromp’homme”, “Contropbasse”, “Flute”, “Jazz bande”, “Les avoeux de Visat”, “Visión dechirante", "Emospheral", y el álbum "Vivante mortalite" obra compuesta por un texto inédito ilustrado por 7 aguafuertes de Matta, más el álbum "Hom'mére Chaosmos" compuesto por un poema inédito y 10 grabados de Matta.

En Chile comienza el régimen militar con el Golpe de Estado en contra Salvador Allende. El golpe militar genera que en Chile durante 16 años esté en el poder una junta militar presidida por Augusto Pinochet, la cual durará desde 1973 hasta 1989.

En medioriente estalla la Guerra del Yon Kipur encabezada por Egipto al frente de sus aliados árabes, Israel sufre pérdidas territoriales en Sinai aunque por razón de una enérgica contraofensiva forzara un rápido armisticio 15 días mas tarde.

Roland Sabatier y George Visat publican El catálogo razonado de la obra gráfica de Matta 1943-1974. Se organiza la muestra del artista "El gran burundún burundá ha muerto". Homenaje a Jorge Zalamea, en la Galería Aele de Madrid. Durante el año siguiente esta muestra itineraria por varias ciudades latinoamericanas: el Museo de Arte Moderno de Bogota y el Museo de Bellas Artes, en Caracas. Participa en los eventos de la Bienal de Venecia. 
Crea varias litografías entre las que destacan "Pas perdus", "Architetre", "BadenBaden”, “Declin ressu-erection”, “La bonne dance”, "L’effet Gabriel (saint sprimatozoides)", "Oh l'as de pique", "Press on art" y "Per giovanni marini", y los grabados "Centre Noeds", "Al capone", "Va-riante”, “Un critere du temps perdu", "Mallarme l'or", "On se lasse de tout sauf du contraire", "Il se livre", "Il se delivre", "Si non ti tumbo ti maso", "Bonjour Max Ernst", "Landru" y termina el álbum "All comicstrippers" compuesto por 16 litografías en colores.

La población mundial asciende a 4.000 millones de personas.

EE.UU. y Rusia firman el primer tratado de Limitación de Armas Estratégicas, conocido como SALT I.

Participa en la exposición itinerante del "El gran Burundú-Burundá ha muerto” para apoyar la declaración del tribunal Russel sobre los crímenes de la junta militar en Chile.

Crea los grabados "Non ci si bagna mai due volte nello stesso Heráclito", "Coigitum", "Reorganimation de la liberté", "Grand circus", "Les escargots" y "Los 5 destacagados" y las litografías "La magma de los perros", "Cittadino dònore", "XX siecle", "Asesinaron Cristian en la madre visible" y "D’or ling" más la serie litográfica "El gran BurunduBurunda ha muerto" y serigrafías entre las que destacan "Perché le vittime vincano", "La commune de Paris est la revolution francaise", "El guatasso", "Trompetuya" y "Lachasse aux papillons", y el álbum "Hom'mére l'eautre".

Consolidación en Chile del régimen militar, auge y caída de la DINA. Se crea durante este año la Vicaría de la solidaridad, la que ejerce principalmente la labor de la defensa y la promoción de los derechos humanos. 
En los EE.UU. Gerald Ford ejerce el cargo de presidente. Durante este año cae finalmente en manos de los comunistas norvietnamitas Saigón, la capital de Vietnam del sur, poniendo fin de la guerra Asiática luego de haber obligado a los estadounidenses a retirarse del conflicto.

1976

Acaba la construcción iniciada en 1973 con un colectivo de obreros y artesanos de Tarquinia, de "L’autoapocalypse", una casa construida con componentes de la fábrica Fiat. No es una máquina para habitar, sino un intento de humanizar la máquina.

Durante este año realiza las litografías: "Les convaincus", "Le doute des tríos mondes", “Le promenade de venus", "O'nain de venus”, "Eugenio C”, “CA A”, “CA ira”, "Fluxant”, más "Le veau D’or", "No lo sabía- non lo sapevo", "Douuze heures", "Jazz-session”, y los grabados "Cicatriciel", "Bande a jazz", "Le sot a la perche", y "Les transesport". Más la serigrafía "Le sport primo passo verso l'uomo collectivo".

EE.UU., logra posar en Marte las naves exploradoras de las misiones Viking I y II transmitiendo las primeras imágenes desde su superficie en las planicies Chryse y Utopía. Las naves realizan experimentos en la superficie marciana para determinar la posible existencia de microorganismos en busca de señales de vida, sus resultados aun años más tarde no resultarán concluyentes aunque sí polémicos.

Argentina sufre del Golpe de Estado.

1977

Durante este año, Matta ilustra el poema de Rimbaud "Une saison en enfer", editado por Ediciones Polígrafa, en Barcelona. 
Crea la litografía "Festival d'avignon", las serigrafías "Gesú bambini”, "La revanche des etrusques" y los grabados "Ouvre l'instant", "Hom'mére l'ergonaute".

En Chile la Vicaría de la solidaridad entrega una detallada cuenta de 613 casos comprobados de detenidos desaparecidos.

EE.UU., lanza en este mismo periodo las naves espaciales Voyaguer I y II, para explorar nuestro sistema solar, sus trayectorias finales las llevarán luego a un viaje sin fin por el universo, serán los primeros ingenios humanos en hacerlo.

Bajo los auspicios de los presidentes Jimmy Carter de EE.UU., Anwar el Sadat de Egipto y Menahem Begin de Israel, se firman los Acuerdos de Camp David que establecieron la paz entre El Cairo y Tel. Aviv, junto a la devolución del Sinaí a Egipto.

\section{8}

\section{Matta expone en la Galería Minotauro en Caracas Venezuela.}

En Chile se institucionaliza el régimen militar, comienza el boom económico.

Durante este año, crea las litografías "Chupa el tepec", "Semáforo", "Morphologia dell'autoapocalipse”, "L’organo di berberia” y “Antología”, además de la serigrafía "Miss en bouteille", la fotolitografía "55 dessins depuis 1937", más los grabados "Réquiem pour la fins des temps", "Nid de noeds" y "Machair rie", más "Sex-uberant", "Etre au monde", "Nymphee" y "Carnamont", el álbum de diez aguafuertes y aguatintas titulado “Mathematique sensible" publicado en 1938, siendo su proyecto desde 1938 al 1980.

El Papa Juan Pablo I, sucesor de Pablo VI muere tan solo 33 días después de asumir, es uno de los pontificados más cortos de la historia; lo sucede Juan Pablo II, el primer Papa no italiano elegido en más de cuatro siglos quien regirá los destinos de la iglesia por más de 20 años. 
Roberto Matta E., ilustra una serie de litografías de el canto I de "La Araucana", escrito por Alonso de Ercilla en 1500. Esta edición de 125 ejemplares se presenta en el Palazzo Vecchio de Florencia.

Durante este mismo año realiza diversas litografías en las que destacan "Lumacoso", "Historia e rotonda", "L’amore Utópico e l’amore científico", "Les roses de la violence", “Cruleaut'elle”, “La vitesse du sport”, “Achille e la tartaruga”, "L’Araucana” y "L'índice dell'indice", la serigrafía "XX ans de Cuba" y "Ai confini dell'io" más los grabados “Maintenant”, “L’impensable” y "Blanc de blanc" realizados los tres en aguafuerte.

En Teherán, miles de fanáticos religiosos asaltan la embajada de EE.UU. tomando rehenes, los que estarán en cautiverio por más de 400 días.

1980

Se realiza la presentación del libro “MATTA: Index dell'Opera Grafica dal 1969 al 1980" dirigido por Germana Ferrari, en la Exposición "El corazón es un ojo", en el Palazzo degli Alessandri, en Viterbo.

Crea los grabados "Bonnie and clyde", "Hommage a Man Ray", "Pyrocentre". Las litografías "Don Q" a colores con tres formatos distintos y la serigrafía "Il cuore è un occhio".

En Chile se realiza la votación para la aprobación de la constitución de 1980, la que se mantendrá hasta nuestros días.

En EE.UU., se elige presidente al republicano y ex gobernador de California a Ronald Reagan. 
En Sudamérica, Argentina y Chile superan el tenso conflicto de límites por el canal de Beagle, gracias a la mediación del cardenal Samoré realizada por encargo del Papa Juan Pablo II, lo que evita la guerra.

Matta expone en el Palazzo Reale, en Nápoles, ocasión en que se publican dos textos inéditos. Entre las exhibiciones colectivas en que participa, destaca "Un nuevo espíritu de pintura", en la Real Academia de Londres.

En Florencia presenta la muestra "Gargantatua" como interpretación gráfica del cuento “Gargantúa” de Rabelais.

Asesinato del presidente Egipcio. Anwar El Sadat.

En Roma, el Papa Juan Pablo II es baleado mientras realiza un breve recorrido en un vehículo descubierto saludando a la concurrencia entre la cual se encuentra su agresor. El pontífice sobrevive con graves heridas. El agresor es detenido e identificado como Mehmet Ali Agca, de origen turco.

Comienza guerra entre Irán e Irak.

1982

Roberto Matta viaja a Nicaragua con ocasión del Congreso Interamericano donde participa con Gabriel García Márquez y Julio Cortázar. Sobre “Autonomía cultural de nuestra América", ocasión en que se publica su texto "Reorganización de la razón", porque la historia es redonda como la tierra. En Cuba colabora con la formación del Museo de Arte del Hombre Latinoafricano, con la donación de una serie de esculturas africanas. 
Crea 8 grabados para el libro de artista "Ubu Roy" que está compuesto con el texto de Alfred Jarry "Personnages".

Argentina invade el archipiélago de Malvinas, el envío de una poderosa fuerza de tareas inglesa, causa la redición de las fuerzas argentinas luego de 74 días de ocupación.

1983

Matta realiza estudios en Riverside, en Londres, presenta durante ese año una exposición de pasteles y grabados inspirados en la tempestad de Shakespeare, que intenta crear un paralelismo con la epopeya precolombina. Se organiza una gran retrospectiva del artista titulada "Mediterráneo Verbo América" en Valencia y Barcelona, España.

Crea el grabado “Hom'mére Point d'appui”.

En Chile desde 1983 hasta 1985 comienza una reacción de la sociedad opositora al régimen militar. Protestas nacionales, siendo el año de la reactivación de la sociedad civil chilena.

En Francia, en el Instituto Pasteur el Dr. Luc Montagnier logra aislar finalmente el virus del Sida desatándose una polémica con el Dr. Robert Gallo de EE.UU., quien durante más de 10 años le disputará el hallazgo.

1984

Matta expone una muestra de pasteles titulada "Verbo América", el que se exhibe en el Museo de Bellas Artes de la Habana.

Crea el grabado "Bachanal". 
En India es asesinada la primera ministra Indira Gandhi por miembros de su guardia personal del palacio.

1985

Se realiza una gran retrospectiva de la obra de Roberto Matta en el Centro de Arte Georges Pompidou-Museo de Arte Moderno, en París. Recibe en este mismo periodo la medalla de oro de las Bellas Artes españolas. Esta condecoración le fue entregada por el Rey Juan Carlos de España, en un acto celebrado en el Museo del Prado en Madrid.

El 3 de marzo de este año, se produce un gran terremoto en Chile afectando principalmente a la zona central del país.

La convención de Viena confirma oficialmente la existencia del fenómeno del agujero de ozono en el polo sur, para comenzar su protección.

1986

Exhibe en la Galería Totah-Stelling y en el Instituto Hispánico en Nueva York.

En Florida EE.UU., se produce la mayor tragedia de la astronáutica hasta el presente al estallar en vuelo a pocos segundos de su lanzamiento el trasbordador espacial Challenger provocando la muerte de sus 7 tripulantes.

1987

Durante este año Matta expone en Chile en la Galería de Arte el Caballo Verde en Concepción y en el Museo Nacional de Bellas Artes de Santiago con motivo de la IV Bienal de Arquitectura. En Santiago se publica el Libro "Matta-conversaciones" de Eduardo Carrasco. 
Crea la serie de grabados "El verbo Hommérica" más las litografías "Entretiens Morphologiques" y "Verbo América".

En Chile se produce la primera y única visita del Papa Juan Pablo II.

En Palestina la OLP inicia una rebelión Árabe, inicialmente pasiva, en los territorios ocupados por Israel que se conocerá como Intifada.

1988

Presenta una exposición en el Palasso Venecia, Italia.

En Chile se realiza el plebiscito del si y el no, para decidir seguir con el poder político militar o para cambiar a un gobierno democrático. Ganando en estas elecciones el no, lo que quiere decir que la sociedad chilena opta por cambiar su gobierno a una democracia.

El Instituto Goddard de Investigaciones Espaciales de la NASA anuncia que el calentamiento global del planeta ha comenzado, 1988 es el año más caluroso de la década, comprobándose su tendencia creciente desde el siglo pasado.

Comienza la política de la Perestroika en URSS.

1989

En el Museo Nacional de Bellas Artes de Santiago cambia el nombre de la Sala Matta por Sala Chile, por solicitud expresa del artista. Al año siguiente se le restituirá el nombre original, en honor a Matta, cuando Nemesio Antúnez asuma la dirección del Museo.

En Chile se realizan las elecciones Presidenciales.

En Alemania, es derribado el muro de Berlín que desde la década de los 60 divide la ciudad, anticipando la pronta reunificación del país, la caída del régimen comunista de Alemania Oriental y el fin del comunismo. 
Hungría abrió sus puertas con Austria a fin de favorecer un mayor flujo comercial, esta apertura económica fue seguida por la apertura política.

1990

El 27 de agosto Matta recibe el Premio Nacional de Arte, en Chile, a los setenta y nueve años de edad. Se organiza una exposición en el Palazzo Reale, en Milán.

En Chile comienza la Democracia con el Gobierno de Patricio Aylwin Azocar.

En el Golfo Pérsico divisiones militares iraquíes cruzan en una acción relámpago su frontera sur y en pocas horas ocupan cruentamente Kuwait concretando la amenaza de reivindicación territorial anticipada por su líder.

1991

En agosto de este año se inaugura el mural alegórico al "Descubrimiento de América", en San Salvador. Esta obra pertenece a la serie titulada "Verbo América", en la cual también se incluye el mural que realizará en la entrada de la Exposición Universal de Sevilla, programada para 1992. El Museo Nacional de Bellas Artes de Santiago y el Museo de Bellas Artes de Caracas se organizan la exposición Matta UniVerso 11-11-11 como homenaje a los 50 años de vida artística y a los ochenta años de existencia del pintor.

Comienza la Guerra del Golfo, en medio oriente, en la que Irak es atacado y derrotado por una coalición multinacional en represalia por su invasión a Kuwait.

Se crea el MERCOSUR. 
La Junta de Andalucía le encarga a Roberto Matta un Mural de cerámica para la Exposición Universal, de Sevilla. En esta misma ciudad se realiza la exposición Verbo América, en la Caja San Fernando de Sevilla. La cual itineraria por 7 ciudades españolas. Matta recibe este mismo año el Premio Príncipe de Asturias de las Artes y realiza una exposición de Escultura y Pintura, patrocinada por la Caja de Ahorros de Asturias Oviedo.

Rusia y EE.UU. firman un acuerdo conjunto de cooperación para la exploración del espacio.

Roberto Matta realiza una exposición individual, en el Yokohoma Museum of Art., en Japón.

En enero de este año, Checoslovaquia se divide en Republica Checa y Republica Eslovaca.

Comienza, luego de casi 500 años, la nueva versión del catecismo presentado por la iglesia católica conteniendo la fe de la iglesia y la doctrina católica a la luz de la época actual.

Asume la presidencia de EE.UU. Bill Clinton hasta 1996.

1994

Matta realiza una exposición en el Museo de Arte e Historia, de Belfort constituida por pintura, escultura, y cerámica.

En Chile comienza el Gobierno de Eduardo Frei Ruiz Tagle. 
Nelson Mándela es presidente de Sudáfrica.

El Vaticano e Israel establecen por primera vez relaciones diplomáticas plenas.

Roberto Matta E., Gana el Premium Imperiale for life time achievement in the arts, Japón.

Crea el grabado “La terre est une oignon (N'ou's t'ou's)

Asesinan en TEL Aviv a Yitzhak Rabin, primer ministro de Israel.

Elección de Netanyahu en Israel.

1996

Expone en la Galería Artespacio y Galería AMS bajo él titulo "Matta hoy".

Crea los grabados "Melodio, melodía", "Per ser l'invisible” y "New view".

En Inglaterra se origina el mal de las vacas locas, que es la enfermedad provocada al comer carne y derivados de animales afectados por la enfermedad de Creutzfeld-Jakob

1997

Exposición Matta: Die elemente, etc. Gli elementi, etc, Museion fur Moderna Kunst, Bozen; Museo d'arte moderno, Bolzano. Invierno en Florida y las Bahamas.

La princesa Lady Di, Diana Spencer, muere trágicamente en Francia. 
Artista de Honor en Art Miami 98.

Centroamérica es devastada por el huracán Mitch, los países más afectados son: Guatemala, Honduras, El Salvador y Nicaragua.

1999

Retrospectiva de Roberto Matta en el Museo Nacional Centro de Arte Reina Sofía. Exposición Retrospectiva MNCARS. Galería Almirante, Madrid.

La OTAN interviene militarmente y por primera vez en Kosovo atacando por aire a Yugoslavia durante 79 días.

2002

Roberto Sebastián Antonio Matta, muere en Italia el sábado 26 de noviembre del 2002 a los 91 años, en un convento de Padres Pasionistas del siglo XVIII, en la localidad de Tarquinia a 100 kilómetros de Roma, acompañado durante en estos últimos instantes por su última esposa de origen italiano Germana Ferrari. 


\section{$\mathrm{X}$. Conclusiones}

$\mathrm{S}$

e cree que no se podría llegar nunca a una conclusión definitiva del trabajo que se presenta, ya que no se posee toda la obra gráfica de Roberto Sebastián Matta Echaurren, por los motivos que se mencionaron en la introducción de esta tesis. No obstante, se pueden concluir varios puntos interesantes propuestos en este trabajo: uno, si se entiende o se pudiese ver a Roberto Matta como un grabador, que es lo mas relevante y la motivación de esta tesis y dos, si Matta recibe influencias desde la pintura y sus ayudantes para el desarrollo de su obra gráfica.

Si se entiende al artista grabador-estampador como el que se implica en todo el proceso de creación, compenetrándose, no tan solo con la creación de su obra y el resultado que espera obtener, sino que fundamentalmente, se implica con la evolución que va a generar, desarrollar y transcurrir en la obra por sí misma, nutriéndose de este proceso, el cual quizás llevara al artista y persona a sustentar su obra, con las riquezas de este transcurso, en forma práctica y teórica, estaremos un poco alejados de lo que hizo Matta. Ya que en su caso este aspecto del artista grabador-estampador se cumple muy poco, pues existen, como mencionamos en esta tesis, los colaboradores, que son los que otorgan soluciones a los azares que se van generando en el grabado. Por lo tanto podría pensarse que, dentro de esta posición, Matta sigue siendo un artista externo al grabado, ya que él, por sí mismo, no realizó nunca en forma completa el proceso de grabado, a excepción de las series Don $Q$ y The new school. Sin embargo, se sabe que el artista, y los grandes artistas, todos, tienen a su lado colaboradores, como algo intrínsicamente práctico, correcto y normal. Entonces, se pudiese pensar en ese caso que Matta sí es un grabador, ya que él genera una obra y va seleccionando lo que considera bien o mal en uno u otro momento, cuando los colaboradores le entregan las opciones, o los amplios resultados a que podría llegar su obra. 
Por lo tanto, dependiendo de cómo se entiende a un artista grabador, es como se entenderá a Matta. Eso quiere decir, que si se entiende al grabador como el que trabaja todo el transcurso de su creación por sí mismo, nutriéndose de los azares técnicos y valorándolos en la proyección de su obra, se aleja bastante de lo que se ve a Matta dentro del grabado, pero si optamos por entender al grabador como el que posee la idea inicial y la trata de ir proyectando en el transcurso, nutriéndose igualmente de los azares técnicos gráficos, pero sin ser parte en la práctica del proceso de su obra, se estará cercano a como se ve a Matta dentro del grabado.

No importando cual de las dos opciones como grabador se opte, se sabe que hubo algo que probablemente fue inconsciente en Matta, que lo llevase a impulsarse al grabado. Sin embargo se supone que por la personalidad del artista, activa y rápida, las técnicas gráficas quedaban atrás, a las exigencias en tiempo que el administraba, siendo ésta la posible justificación del por qué Matta opta por la pintura antes de el grabado. Y es allí, en la pintura, donde Matta se enfrenta, se involucra en todo el proceso, sin terceros, logrando quizás un trabajo más íntimo y mas cercano a él, a lo que fueron a mi parecer el desarrollo de sus grabados.

Como segundo punto de conclusión se plantea si Matta recibió influencias desde la pintura hacia al grabado, en este sentido se cree fundamentalmente que un artista es una sola persona, entonces no es alguien que se divida en dos, para crear de manera u forma diferente en un área u otra, por consiguiente siempre veremos tanto en la pintura y el grabado, como así mismo en escultura y cerámica, que existirá siempre el mismo estilo, la misma marca que vemos en todos los trabajos de Matta. No obstante, creo que no hubo influencias explicitas, es decir, nunca hizo una pintura que se reflejase de igual forma en el grabado, aunque de cierto modo sí lo hizo inversamente, desde el grabado hacia la pintura, como he mencionado en la Página 10 del catalogo, con la obra Centre Noeuds, donde nos encontramos con una obra que posee el mismo título en ambas áreas pero creada en diferentes años, en 1974 en grabado y en 1978 en pintura, pero que no es una 
copia de lo realizado en grabado, me atrevo a decir que es como una elongación de un trabajo, una parte que quizás faltaba desarrollar para Matta y así poder poner punto final a este "Centre Noeuds" (centro nudo) que tenía en su cabeza.

Asimismo en esta tesis se afirma que Matta pudiese ser un grabador frustrado, entendiéndose el acto de la frustración como "Fracaso en una esperanza o deseo", ya que como supimos en al menos dos entrevistas Matta quiso desarrollar sus creaciones en el grabado, deseó poder aprender aún más de lo que ya sabía, le interesaba el proceso, pero fueron personajes anexos quienes frustraron este desarrollo personal en los grabados que Matta pudiese haber emprendido.

Del mismo modo, hay que mencionar que la obra gráfica de Matta no desmerece en ningún punto de su transcurso. Siendo, eso sí, innegable el escribir que una gran parte de su obra gráfica se localizó en la realización de libros de artista, de lujo, cosa que de alguna u otra forma, se destinaba a un selecto grupo de lectores/espectadores. Siendo la gran mayoría de estos libros realizados sobre la base de escritos, textos y/o poemas de escritores o poetas anteriores y contemporáneos del propio Matta. Se piensa entonces, que la elección de Matta por realizar libros de lujo, respondía principalmente a una primera razón que era la amistad, ya que, el realizar este tipo de libros le permitía estar constantemente con los amigos, conversando y trabajando, cosa que a Matta le encantaba, según se nos reveló en las entrevistas, porque era una instancia en la que se sentía libre sin ataduras emocionales, que le quitaban tiempo y que le exigían organizar su trabajo. Y en relación a esto, la segunda razón del por qué Matta realizaba este tipo de libros, puede estar muy ligada a su vida personal, ya que las ganancias que obtuvo de estas creaciones, probablemente producían una seguridad en el círculo cercano al artista, lo que desafortunadamente se corrobora hoy, ya que se pueden ver y palpar, una no menor parte de las estampas pertenecientes a libros creados por el artista, que se exponen y venden individualmente por todo el mundo, lo que hace concluir que hasta hoy económicamente 
es un asunto relevante para ciertas personas, que estuvieron cercanas a Matta, explotar todo este material, que en conjunto imagino que debe tener un valor económico altísimo.

Entonces se cree que Matta realizó estos libros de artista de lujo para por una parte importante disfrutar y liberarse quizás sin ningún cargo de conciencia, ya que esto le permitió dar tranquilidad a su entorno vigente en ese entonces.

No obstante, a todo lo anteriormente mencionado seguramente hubo una profunda motivación de Matta diferente a las que se han descrito, o quizás fueron varias las motivaciones para la creación de estos libros. Hasta hoy esta tesis solo puede llegar a este tipo de conclusiones descritas, en base a lo investigado, lo que por cierto no cierra la posibilidad de encontrar en un futuro, otras motivaciones del artista por realizar este tipo de libros.

Se desea aclarar, en base a las entrevistas realizadas, sobre el tema de los libros de artista, que en Francia se le otorga la denominación "de lujo", cuando son realizados por artistas y/o escritores relevantes, asimismo son ediciones limitadas, numeradas y firmadas que han sido realizadas en grandes e importantes atelieres y talleres, lo que significaba además que Matta estuviese en contacto con diferentes artistas y artesanos para la organización y elección del cómo se iba a llevar a cabo el libro, desde el tipo de tela hasta la tipografía que se deseaba utilizar, realizándose todo ello en un clima de camaradería del que Matta disfrutaba muchísimo.

Otro aspecto que es relevante mencionar como conclusión, es su aporte hacia el grabado, ya que Matta es un grabador innovador y precursor. Esto se puede afirmar y corroborar porque Matta utilizó fotocopias, gofrados y exigió utilizar a sus colaboradores libremente y sin prejuicios colores, que él mismo predefinía e iba indicando con anticipación. Para la época de realización era absolutamente diferente al de las obras gráficas que se exhibían, y me atrevo a decir que hasta hoy es innovador, especialmente en la utilización de colores que sobresalen en su obra, impactan, atraen y se envuelven en ella. Como ejemplo se puede mencionar la serie de grabados FMR (véase página 7 del 
catalogo) donde la utilización de los dorados sobre y en los gofrados sobresale con fuerza dentro de los personajes y el espacio. En la misma línea del uso del color, pero en otro sentido, la serie litográfica All Comicstrippers (véase página 8 del catalogo) nos presenta un juego de colores alegres sobre la piedra, y por último habría que destacar Une saison en enfer (véase página 15 del catalogo) donde los colores fluorescentes llenan la obra. Respecto al uso de fotocopias, hasta finales de la década de los 80, tener una maquina fotocopiadora era algo difícil y no muy común, sin embargo para ese tiempo Matta ya poseía una y trabajaba con las fotocopias de algunas formas o dibujos, las que utilizaba luego como fondos de algunas de sus series en grabado como por ejemplo en la serie Don $Q$ (véase página 17 del catalogo). Se desea dilucidar que a pesar de que Matta no trabajó en el proceso de la realización de sus grabados, en forma práctica al cien por ciento, sí se puede decir que participó en ella, ya que era él quien decidía e indicaba a sus colaboradores qué era lo él tenía en su cabeza. Y es gracias a estos colaboradores, que he obtenido esta información, sobre su aporte al mundo del grabado.

Asimismo se desea mencionar que a pesar de todo lo que se ha investigado sobre Matta siempre habrá mucho más que investigar y recabar de información, porque Matta fue un artista sumamente productivo en el ámbito artístico, lo que genera que a pesar de toda la información que se posee sobre sus grabados, ésta sea aún incompleta, sobre todo cuando nos enfrentamos a límites claramente impuestos para no seguir investigando. No poseyendo aún esta tesis información clara de todas las obras gráficas existentes, de las cuales se deseó y se comenzó en un primer momento, hacer un catastro completo, el que traté de ir perfeccionando con el tiempo, y del que lamentablemente no he podido concluir por la amenaza recibida, por una integrante de la familia Matta, sobre los derechos de autor de las imágenes que presentó y por no poseer las autorizaciones para realizar esta investigación. Lo que generó que mi tesis presente alrededor de un 75 \% de los grabados de Matta, en forma clasificada. Siendo quizás este $75 \%$ un número mayor a lo encontrado, y que tristemente nunca sabremos cuál es la cantidad de obra gráfica realizada por Matta, ya que existe una parte que se me prohibió conocer y ver, pero de la 
cual poseo algunos datos y hay otra parte a la que no he tenido acceso, porque es un secreto que se esconde en un apartamento de París, donde sé que están guardados algunos grabados de Matta de los que no poseo información, ni tampoco sé la cantidad que allí se guardan, y menos sé si son o no los mismos que yo ya he investigado. Para mi este lugar secreto es un enigma por completo.

No obstante quiero escribir que se contó con el sustento de una gran parte de la familia del artista, que aún sigue apoyando esta tesis y es por su ayuda, y el interés nuestro en finalizar de la mejor forma esta investigación, como se pudo recabar numerosos detalles que no poseía anteriormente cuando entregué el proyecto de investigación.

Finalmente deseo agregar algo más personal como conclusión, que es el ir descubriendo el mundo de Matta, el revivirlo para muchos, reconocerlo y aceptarlo como artista del mundo, lo que me sirvió no tan solo para comprender la vida de Matta, sino algo más profundo que es difícil de describir, que es la magia, las palabras, el modo de vida, la poesía que tienen los verdaderos artistas y no algunos de los que hoy pasan por la moda, las ventas, el todo superfluo que lleva más que un concepto, trae consigo la estupidez de pensarse divos, y que es justamente eso, ese estar, sin el corazón, sin el alma, viviendo y aprovechando el mundo que se tiene, el que nos hace perder el norte de quienes somos verdaderamente, el para dónde vamos y el cómo lo expresamos. Con Matta he aprendido que soy válida, que mi discurso es válido si estoy sintiendo, si estoy viviendo la imagen, mi imagen como poesía. 


\section{Bibliografía}

\section{Libros y Catálogos}

- ALIX, Josefina, y otros: Matta, Barcelona, Fundació Caixa Catalunya, 1999.

- BASUALTO, Manuel: El corazón es un ojo, editado Fundación BankBoston, para la exposición realizada en el año 2003 en la Fundación BankBoston en Santiago de Chile.

- BURGOS, Elizabet y ALFAGEME RUANO Pedro, Verbo América: Matta, edición Junta de Andalucía. Para la exposición Matta Verbo América realizada en 1991.

-CARRASCO, Eduardo: Autorretrato, nuevas conversaciones con Matta, Santiago de Chile, editorial Lom, 2002.

- CARRASCO, Eduardo: Matta conversaciones, Santiago de Chile, editorial Cesoc-ceneca, 1987.

- FERRARI, Germana: Matta, index dell'opera grafica dal 1969 al 1980, Viterbo, Amministrazione Provinciale di Viterbo, 1980.

. FERRARI, Germana y ROJAS Gonzalo: Duotto canto a dos voces editado por el Fondo de Cultura Económica en México 2005.

- FRANCÉS Fernando: El año de los tres 000, edición Caja de Ahorros de Murcia, para la exposición en el Centro Cultural las Claras de Murcia, realizada desde noviembre del 2000 hasta enero del 2001.

- FRIAS VALENZUELA Francisco, Manual de historia de Chile desde la prehistoria hasta el 2000, editado por Zig-Zag 2006.

- J.J. Mathias, Y.M. Le Roux- C. Morel, Baron Rivieres y Associés, Roberto Matta et les surrealistes d'aprés guerre, la collection Jean Bernard, editado por centre aux enchéres publiques, Paris- Drouot Richelieu, Paris 2006.

·JOUFFROY, Alain: Matta, Paris, Galerie du Dragón, 1958, 1958.

- MATTA, Roland SABATIER: Matta: catalogue raisonné de l'oeuvre gravé (1943-1974), Stockholm, Sonet, 1975. 
• MATTA, Sebastián: Une saison en enfer, Barcelona, Ediciones Polígrafa, 1978.

- OYARZUN, P., G. Álvarez, M.E. Muñoz, y S. Accatino: Tentativas sobre Matta, Santiago de Chile, editorial Delirio Poético, 2002.

- SAYAG, A, D. Bozo, O. Paz, y otros: Matta, Paris, Centre Georges Pompidou, 1985.

- ULIBARRI Luisa y otros: “Matta, el año de los tres 000” edición Fundación Telefónica, para la exposición realizada entre abril y julio del año 2000 en la Sala Arte Fundación Telefónica en Santiago de Chile.

- VV.AA.: Matta-Dessins 1937-1989, Nîmes, Carré d'art-Musée d'art contemporain, 1990.

- VV.AA: "Matta uni-verso" Edición Ministerio de Educación de Chile. Realizado para las exposiciones Matta Uni-Verso 11-11-11 en el Museo Nacional de Bellas Artes de Santiago de Chile. Entre noviembre y diciembre 1991, y para el Museo de Bellas Artes de Caracas, Venezuela entre febrero y abril de 1992.

- VV.AA: Orígenes: Matta, arte en la Caja. Edición Caja de Ahorros de Asturias en 1992. Para la exposición realizada en la obra social y cultural de la Caja de Ahorros de Asturias, en Oviedo entre octubre y noviembre del año 1992.

- VV.AA: Matta, edición Fundación Caixa Catalunya en 1999.

- VV.AA: Matta: Ceres Ceresa, heres la tierra, editado por la Galería Almirante, para la exposición realizada entre mayo-julio del año 1999.

- VV.AA.: Matta: Estampas y poemas, editado por la Casa de la Moneda para la exposición realizada en el Museo Casa de la Moneda entre diciembre 2001 hasta enero 2002.

- ZACCARELLI SICHEL, Humberto, Estética de la Imagen método de análisis de la pintura, editado por Lom ediciones 2001.

\section{Diccionarios}

- A. Ghio D., Sinónimos y antónimos, Calderon y Cia. Ltda., Santiago de Chile 1978.

- VIDAL, Jean Paul, Harrap's Esencial Dictionnaire Francais-espagnol/ Espagnol- Francais, editado por Larousse Bordas Paris 1998. 
- VIDAL, Jean Paul, Hispano Bordas Dictionnaire Francais-espagnol/ Espagnol- Francais, editado por Larousse Bordas Paris 1989.

- Diccionario Sopena Aristos 3. Editorial Ramón Sopena, S.A., Barcelona, Novena Edición 1992.

\section{Sitios web}

- Pagina creada por el sitio Web el poder de la palabra. Biografía Rafael Alberti en http://www.epdlp.com/alberti.html, 1998. Visitada en junio 2004, revisitada en agosto 2006.

- Pagina creada por el sitio Web Ciudad Universitaria de Caracas. Biografía AlexanderCalderenhttp://www.centenariovillanueva.web.ve/CUC/Sinte_Artes/Artistas_Extranjero/Arp/F rames_Arp.htm, 2004. Visitada en junio 2004, revisitada en agosto 2004.

- Pagina creada por el sitio Web de la Caixa de Galicia, Biografía de Maruja Mallo en http://www.caixagalicia.es/fundación/ColecArte/96_98/Mallo.htm. Visitada en junio 2004.

- Pagina creada por el sitio Web de la Universidad de Chile. Biografía Hernán Gazmuri en http://www.uchile.cl/cultura/mac/virtual/g2/. Visitada en mayo 2004, revistada en agosto 2006.

- Pagina creada por el sitio Web Chile vive. Biografía Pablo Neruda en http://www.chilevive.cl/homenaje/neruda/biografía.html. Visitada en mayo 2004.

- Pagina creada por el sitio Web Mi pagina. Biografía Wilfredo Lam en http://mipagina.cantv.net/artsales/artistas.htm. Visitada en mayo 2004.

- Pagina creada por el sitio Web Portal-local. Biografía Alejo Carpentier en http://www.portal-local.com/occu_cer_carp_vid.asp. Visitada en junio 2004.

- Pagina creada por el sitio Web Portal-local. Biografía Jackson Pollock en http://www.xtec.es/jarrimad/contemp/pollock.html. Visitada en junio 2004.

- Biografía Arshile Gorky. Escrito por Albarracín, María de la Paz en http://www.transoxiana.com.ar/0101/gorky.html. Visitada en mayo 2004. 
- Biografía Gordon Matta Clark. Escrito por Arévalo, Antonio en http://laventana.casa.cult.cu/modules.php?name=News\&file=article\&sid=735. Visitada en junio 2004.

- Biografías y artículos sobre Roberto Matta. Visitadas entre diciembre 2003 hasta agosto 2006.

http://clubdelgrabado.com/index.mv?portada_fam1.txt +37

http://www.rionegro.com.ar/arch200307/c30p23.html

http://mujer.latercera.cl/2003/11/16/matta4.htm

http://www.unavuelta.com/Santiago/Plastica/Biografias/Matta/Principal.htm

http://www.mujereshoy.com/secciones/817.shtml

http:/ $/$ www.editorialoceano.cl $/$ modules.php?name $=$ News\& file $=$ article $\&$ sid $=50$

http:/ $/$ www.portaldenegocios.cl $/$ modules.php?name $=$ Name\&file $=$ print $\&$ sid $=2596$

http://www.quepasa.cl/revista/2000/04/15/t-14.04.QP.SOC.GUIAPLASTICA.html

http://www.iadb.org/idbamerica/Archive/stories/1999/esp/c1099k1.htm

http://www.quepasa.cl/revista/1455/33.html

http://www.vertice2000.cl/nacion29.html

http://www.elsur.cl/gen/25102002/A_CULTURA/

http://www-eha.boj.org/repositorio/biografias/m/msg00100.html

http://www.quepasa.cl/revista/2002/11/29/t-29.11.QP.CYT.MATTA.html

Caso Rosenberg. Escrito por Ceron, Pablo en

http://old.clarin.com/diario/2003/06/19/i-02501.htm. Visitada en junio 2004, revistada en agosto 2006.

Los situacionistas.

http://artcontemporain.eu.org/base/chronologie/1298.html

http://geocities.com/CapitolHill/Lobby/4867/paris.html. Visitadas en mayo 2004.

Guernica.http://www.el-mundo.es/larevista/num91/textos/guerni1.html. Visitada en mayo 2004, revisitada en agosto 2006. 


\section{Entrevistas}

- Frank Bordas, conversaciones realizadas entre septiembre de 2003 hasta enero 2004, Paris.

- Albert Dupont, conversaciones realizadas entre noviembre de 2003 hasta febrero 2004, Paris.

- Gino Diomaiuto, conversaciones realizadas entre noviembre de 2003 hasta febrero 2004, Paris.

- Michael Woolwort, conversaciones realizadas entre diciembre 2003 hasta enero 2004, Paris.

\section{Imágenes}

Las imágenes presentadas, son de propiedad privada. Obtenidas de libros y de colecciones en las que se hace mención dentro de sus respectivas fichas de catalogación.

\section{Direcciones impresores y dibujantes}

Atelier Frank Bordas: 2, rue de la roquete F-75011 Paris, Tel.: 0147003161.

Atelier Albert Dupont L'Inéditeur: 13, rue du Dragón 75006 Paris (cuando trabajo con Roberto Matta) posteriormente en el año 2007 cambia su atelier a 25 rue Vavin 75006 Paris, Tel.: 0146331435.

Atelier Michael Woolworth: 6, Gallieni 92240 Malakoff, Tel.: 0146569041.

Atelier Gino Diomaiuto: 50, rue Hallé primer piso, Tel.:0143219628.

Nota: Se desea aclarar, que todas las afirmaciones, descripciones tanto de hechos como de relatos con, de y para Roberto Matta, asimismo los juicios de valor que pudiesen ser universalizantes, se han realizado bajo una estricta rigurosidad. Por lo tanto si existiese alguna duda sobre este rigor en los escritos, se solicita informarlo para aclarar así debidamente la información. 